University of Louisville

ThinkIR: The University of Louisville's Institutional Repository

$12-2014$

\title{
Project management and its relation to long-term project success : an empirically based theoretical framework.
}

Youssef Ait Boudlal 1969-

University of Louisville

Follow this and additional works at: https://ir.library.louisville.edu/etd

Part of the Engineering Commons

\section{Recommended Citation}

Boudlal, Youssef Ait 1969-, "Project management and its relation to long-term project success : an empirically based theoretical framework." (2014). Electronic Theses and Dissertations. Paper 1730. https://doi.org/10.18297/etd/1730

This Doctoral Dissertation is brought to you for free and open access by ThinkIR: The University of Louisville's Institutional Repository. It has been accepted for inclusion in Electronic Theses and Dissertations by an authorized administrator of ThinkIR: The University of Louisville's Institutional Repository. This title appears here courtesy of the author, who has retained all other copyrights. For more information, please contact thinkir@louisville.edu. 


\title{
PROJECT MANAGEMENT AND ITS RELATION TO LONG-TERM PROJECT SUCCESS: AN EMPIRICALLY BASED THEORETICAL FRAMEWORK
}

\author{
By \\ Youssef Ait Boudlal \\ Dipl. -Ing. (FH), University of Applied Science Bielefeld, 1999 \\ M.S., University of Applied Science Berlin, 2008 \\ A Dissertation \\ Submitted to the Faculty of the \\ J. B. Speed School of Engineering of the University of Louisville \\ in Partial Fulfillment of the Requirements \\ for the Degree of
}

Doctor of Philosophy

Department of Industrial Engineering

University of Louisville

Louisville, Kentucky

December 2014 
(C) Copyright 2014 by Youssef Ait Boudlal

All Rights Reserved 



\title{
PROJECT MANAGEMENT AND ITS RELATION TO LONG-TERM PROJECT SUCCESS: AN EMPIRICALLY BASED THEORETICAL FRAMEWORK
}

\author{
By \\ Youssef Ait Boudlal \\ Dipl. -Ing. (FH), University of Applied Science Bielefeld, 1999 \\ M.S., University of Applied Science Berlin, 2008 \\ A Dissertation Approved on
}

August 6, 2014

by the following Dissertation Committee:

Dr. Gerald W. Evans, Committee Chair

\begin{tabular}{c}
\hline Dr. Suraj M. Alexander \\
\hline Dr. Mahesh C. Gupta \\
\hline Dr. Jon H. Rieger
\end{tabular}




\section{DEDICATION}

This dissertation is dedicated to my mother

Miftah El Faraj Jmiaa, my aunt Miftah El Raraj Rabiaa,

and

my wife

Miftah El Faraj Hanan

who have supported me achieving my educational objectives. 


\section{ACKNOWLEDGMENTS}

I would like to thank my professors, Dr. Gerald W. Evans and Dr. Mahesh C. Gupta, for their guidance and helpful recommendations. I would also like to thank Dr. Suraj M. Alexander, Dr. William E. Biles and Dr. Jon H. Rieger, for their assistance. I would also like to express my thanks to my wife, Hanan, for her understanding and patience during the last years. Also, many thanks to my children Soufian and Yasmin.

Youssef Ait Boudlal 


\begin{abstract}
PROJECT MANAGEMENT AND ITS RELATION TO LONG-TERM PROJECT SUCCESS: AN EMPIRICALLY BASED THEORETICAL FRAMEWORK
\end{abstract}

Youssef Ait Boudlal

August 6, 2014

Companies implement effective project management to successfully operate in turbulent market cycles and ensure the success of their endeavors. Project management is indispensable for most industrial sectors and is employed in a variety of for-profit and non-profit organizations. It can be considered as a management method that contributes value to a variety of organizations.

Many practitioners and researchers have attempted to identify the causes of project failure, the factors of project success, and the criteria to gauge this success. There has been little agreement on what constitutes project success. In response to the widespread debate surrounding project success, several lists dealing with factors related to project success have been published. The lack of agreement on the definition of project success renders the quest to identify the factors that contribute to successful project implementation moot. Without knowing what constitutes success, we cannot know what contributes to it.

Practitioners are interested in recommendations for implementing project success factors and the corrective or preventative actions that should be taken if 
the project fails to meet one or more project success criteria. Project management and related research are, therefore facing severe criticism for not fulfilling their contributory expectations within the management discipline.

The purpose of this research is to identify relationships between the project management body of knowledge and short- and long-term project success. The project management body of knowledge includes nine knowledge areas: integration, scope, time, cost, quality, communication, risk, human resources, and procurement management and five project management process groups (initiating, planning, executing, monitoring, controlling, and closing process groups) (PMBoK, 2004), while project success is related to budget/cost, schedule, customer satisfaction, user satisfaction, stakeholder satisfaction, project team satisfaction, strategic contribution of the project, financial objectives, technical objectives, performance objectives, commercial benefit for contractors, commercial benefit for customer, scope, personal growth, customer approval, profitability, and sales.

This study is based on a self-conducted survey of 163 members of the Project Management Institute / German Chapter from October 8, 2013 to January $31^{\text {st }}, 2014$, who are project managers, project coordinators, or project team members. The business areas included in the survey are computers / information technology, construction, engineering, education, government, health care, manufacturing, software development, and telecommunications.

Pearson chi-square tests and Fisher's exact tests were performed to examine whether relationships exist between the project management body of 
knowledge and project success (short-term and long-term project success). The study revealed significant evidence of relationships between the outputs of the project management body of knowledge and short- and long-term project success. The study revealed also that project success depends on the project type, project size and project business area.

The main contributions of this dissertation are: (a) an empirically based investigation of the relationship between outputs of the management processes and the project judgment criteria; (b) a closing of the existing gap in the literature regarding the link between factors that contribute to project success and ways to measure it (in previous studies project success criteria and success factors have been investigated in isolation); (c) a holistic analysis of the project management body of knowledge by providing an organized view of the outputs of each project management process that could influence short- and long-term project resulting outcomes; and (d) a framework for the analysis and improvement of project outcomes by using the theory of constraints.

\section{Key words:}

Project success criteria; Project success factors; Short-term project success; Long-term project success; Project management body of knowledge; Project management knowledge areas; Project management process groups. 
TABLE OF CONTENTS

PAGE

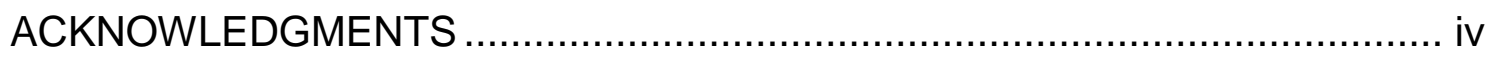

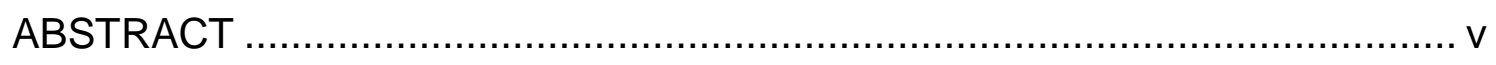

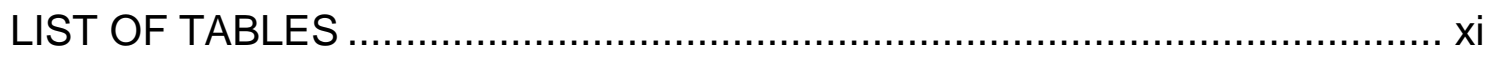

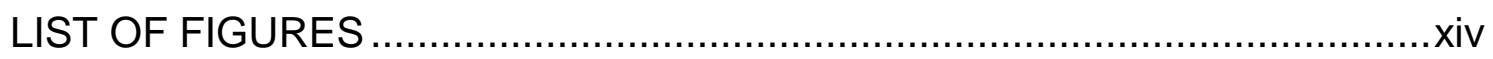

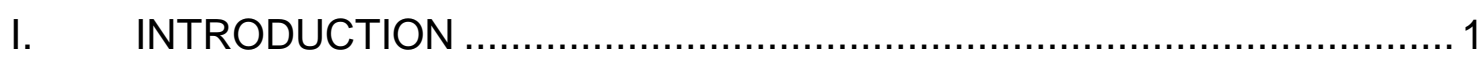

Background and Relevance of the Research...................................... 1

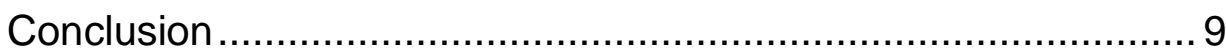

Research Questions and Model....................................................... 11

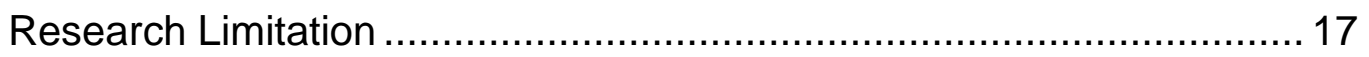

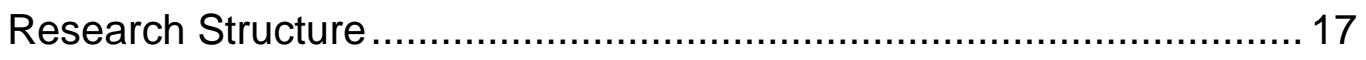

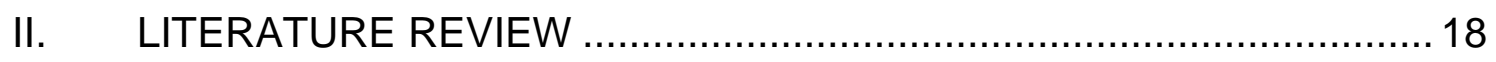

Projects and Project Management .................................................... 18

Project Management Knowledge Areas.............................................. 19

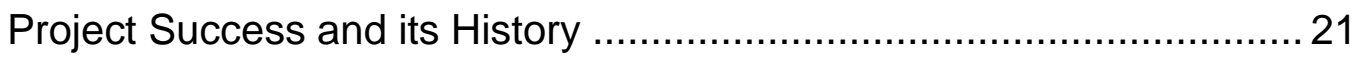

Project Success Criteria.............................................................. 26

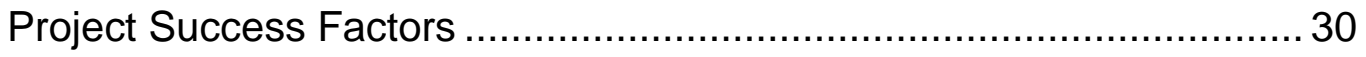

Project Management Application of the Theory of Constraints ............... 38

The Five Focusing Steps...................................................... 38 
Resource Constrained Project Scheduling................................. 40

The TOC Thinking Processes .................................................... 47

III. RESEARCH METHODOLOGY AND DESIGN ..................................51

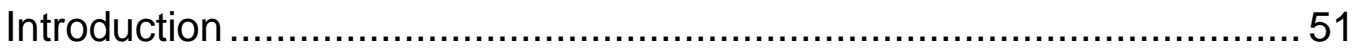

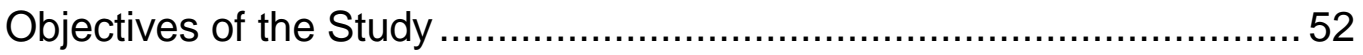

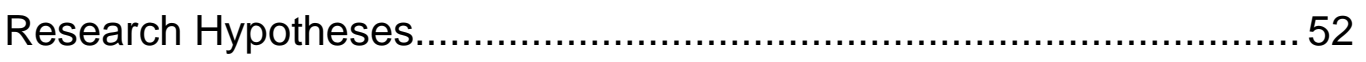

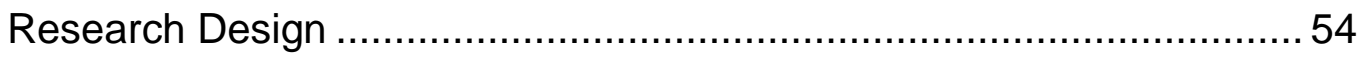

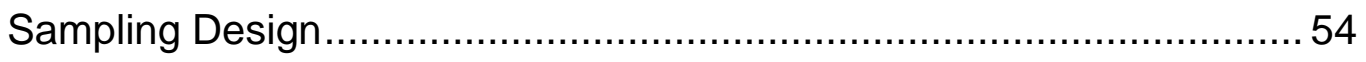

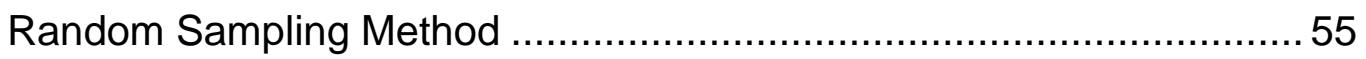

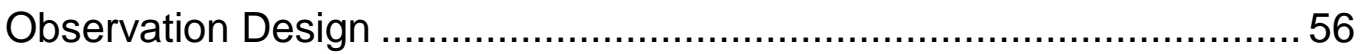

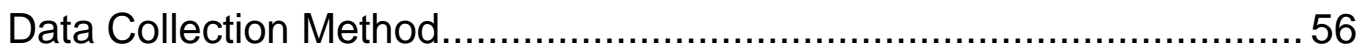

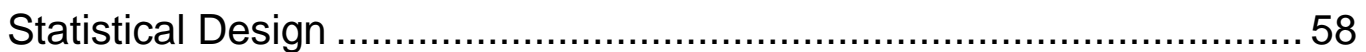

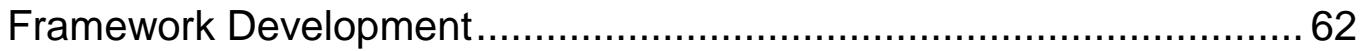

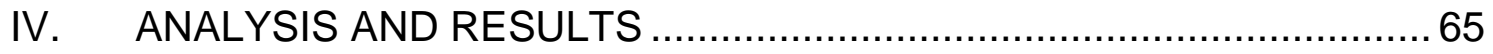

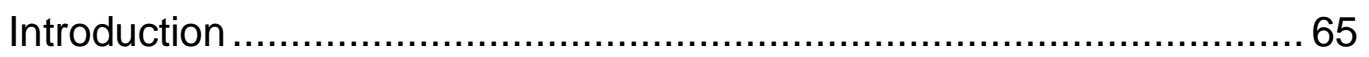

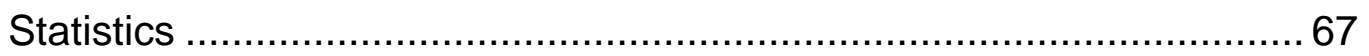

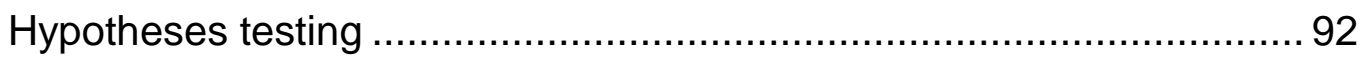

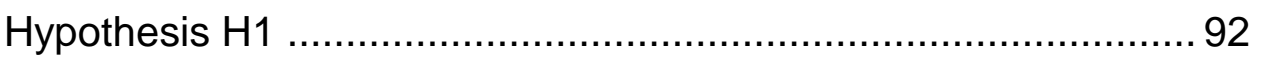

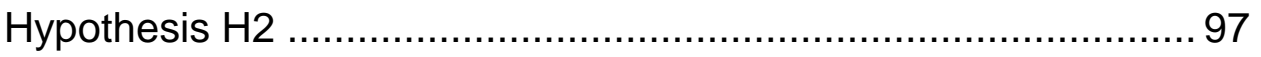

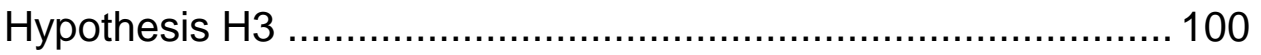

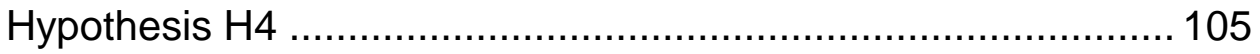

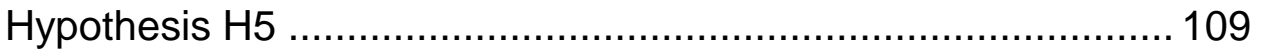

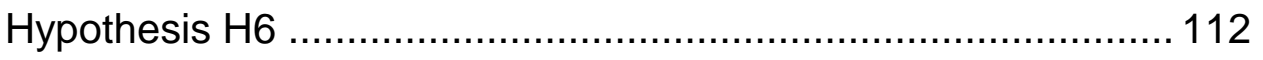

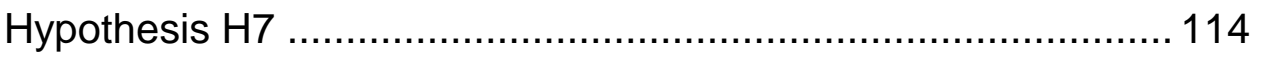

Hypothesis H8 ……...................................................... 117 


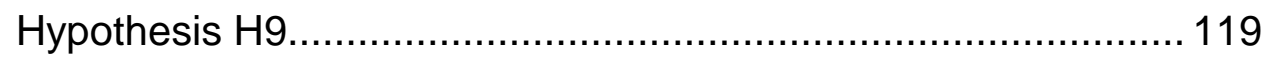

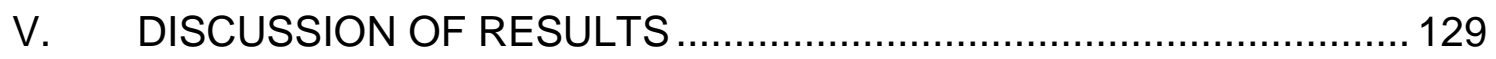

VI. CONCLUSIONS AND FUTURE RESEARCH..................................146

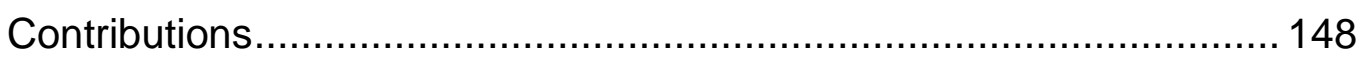

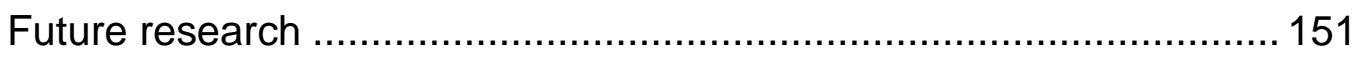

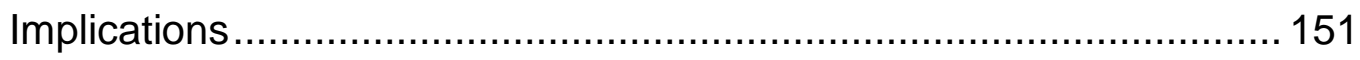

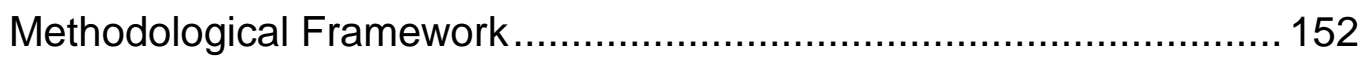

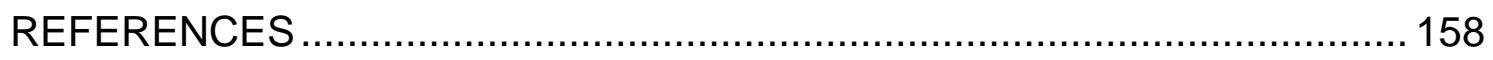

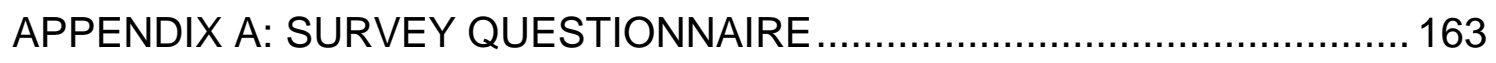

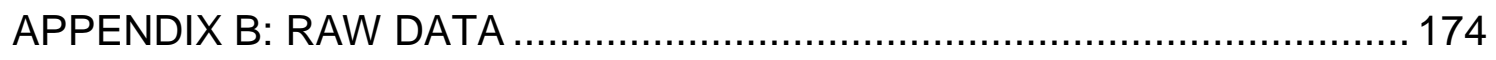

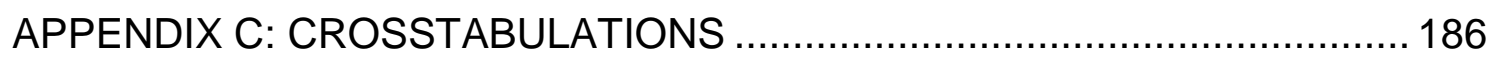

APPENDIX D: $p$ - AND CHI-SQUARE VALUES OF ALL TESTS ....................237

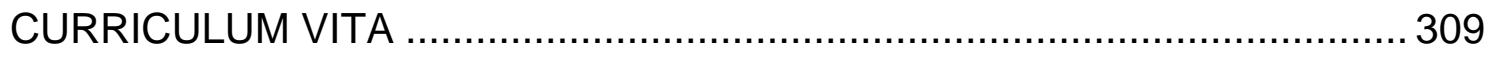




\section{LIST OF TABLES}

\section{TABLE}

PAGE

1. Standish Group findings over the years ............................................... 4

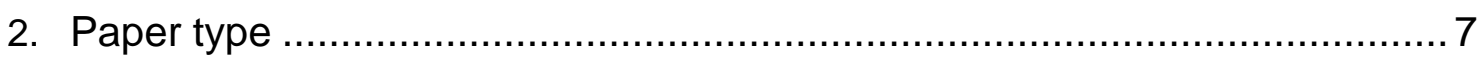

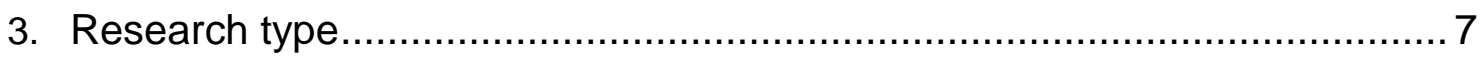

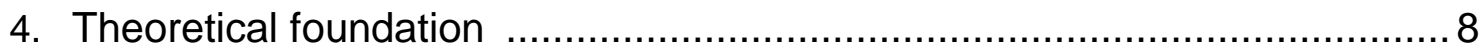

5. Methods used for solution development ............................................... 8

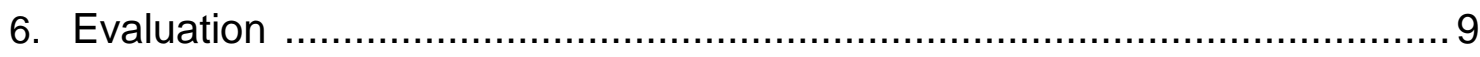

7. Measuring success across the project and product life cycle ...................22

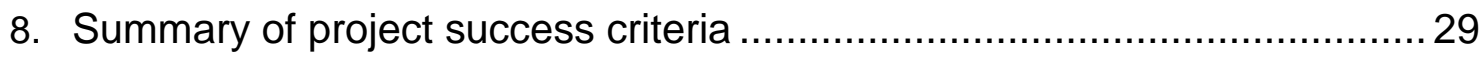

9. Summary of project success factors .................................................... 36

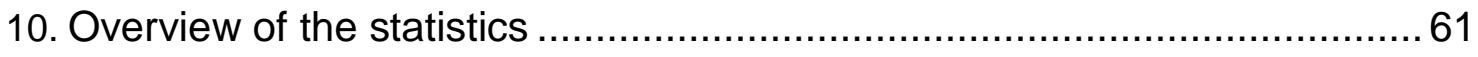

11. Project success criteria: Chi square test of goodness-of-fit ......................78

12. KMO Measure of Sampling Adequacy and Bartlett's Test of Sphericity ..... 79

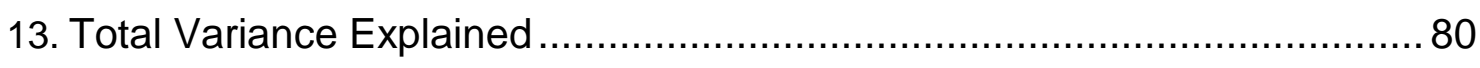

14. PM initiating processes: hypothesis test summary ................................ 83

15. PM planning processes: hypothesis test summary ................................. 85

16. PM executing processes: hypothesis test summary .............................. 89

17. PM controlling and monitoring processes: hypothesis test summary..........91 
18. Crosstab H1-2 Project scope statement * Stakeholder satisfaction ............93

19. Crosstab H1-4 Project management plan* Stakeholder satisfaction........... 95

20. Summary hypothesis testing: $\mathrm{H} 1$ integration management.......................96

21. Crosstab H2-5 Scope baseline * Project team satisfaction ........................ 98

22. Crosstab H2-5 Scope baseline * Profitability ............................................99

23. Summary hypothesis testing: $\mathrm{H} 2$ project scope management ................. 100

24. Crosstab H3-1 Activity list * Customer satisfaction .................................. 102

25. Crosstab H3-6 Resource breakdown structure * Customer satisfaction ... 103

26. Crosstab H3-9 Project schedule * Customer satisfaction........................ 104

27. Summary hypothesis testing; H3 project time management .................... 105

28. Crosstab H4-2 Activity cost estimates supp. detail * Cust. satisfaction..... 107

29. Crosstab H4-4 Cost baseline * Customer satisfaction ............................ 108

30. Summary hypothesis testing; H4 project cost management ................... 109

31. Crosstab H5-1 Quality management plan * Customer satisfaction ........... 111

32. Summary hypothesis testing: $\mathrm{H} 5$ project quality management ............... 112

33. Crosstab H6-1 Roles and responsibilities * Stakeholder satisfaction ........ 113

34. Summary hypothesis testing: $\mathrm{H} 6$ project human resource management.. 114

35. Crosstab H7-1 Communication management plan * Cust. satisfaction..... 116

36. Summary hypothesis testing: H7 project communication management.... 117

37. Crosstab H8-1 Risk management plan * Profitability ..............................118

38. Summary hypothesis testing: H8 project risk management …................ 119

39. Crosstab H9-1 Procurement management plan * Customer satisfaction .. 121

40. Crosstab H9-8 Proposals * Customer satisfaction ................................. 122 
41. Crosstab H9-9 Selected sellers * Customer satisfaction......................... 124

42. Crosstab H9-10 Contract * Customer satisfaction ................................ 125

43. Crosstab H9-11 Contract management plan * Customer satisfaction ....... 126

44. Summary hypothesis testing: H9 project procurement management....... 127

45. Demographic characteristics of the respondents (1) ............................ 132

46. Demographic characteristics of the respondents (2) ............................ 133

47. Demographic characteristics of the respondents (3) ............................ 134 


\section{LIST OF FIGURES}

FIGURE

PAGE

1. Implementation projects with and without PM (Hab \& Wagner, 2006) ............. 2

2. Typical Sequence of Phases in Project Life Cycle (PMI, 2004) .................... 10

3. Relationship between the Product and Project Life Cycles (PMI, 2004) ......... 11

4. Research model …........................................................................ 14

5. The Five Focusing Steps and Application of the Critical Chain ......................39

6. Comparison between Critical Chain and PERT/CPM ................................. 44

7. The TOC thinking process application tools (Watson et al., 2007) ................ 48

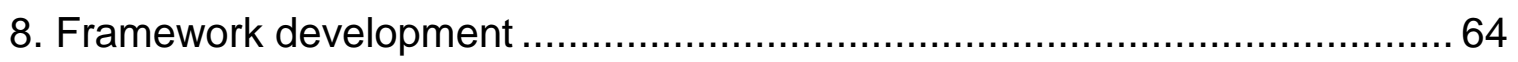

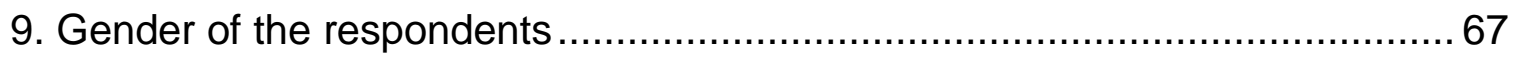

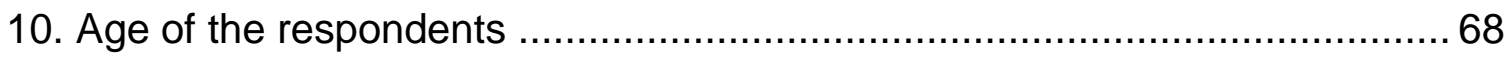

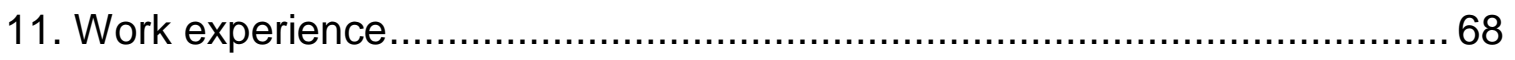

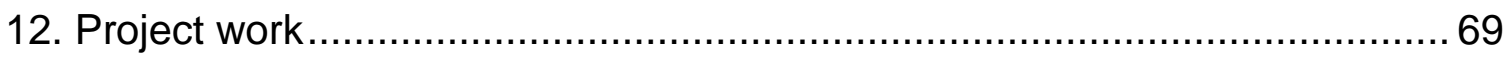

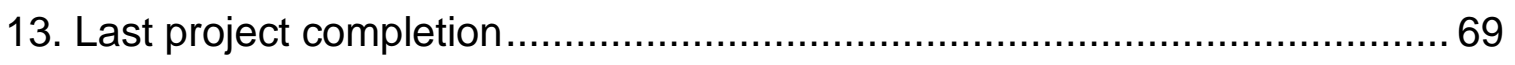

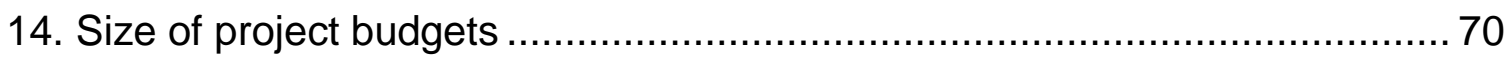

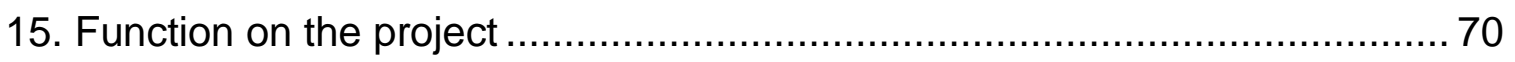

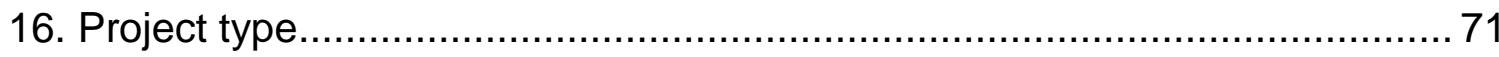

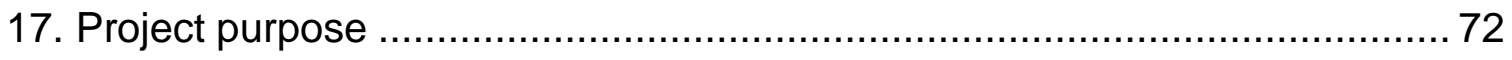

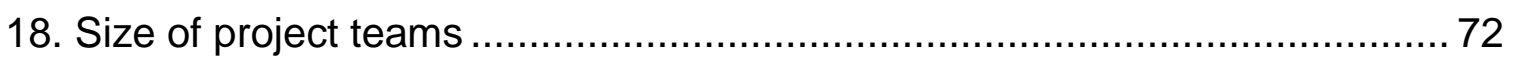




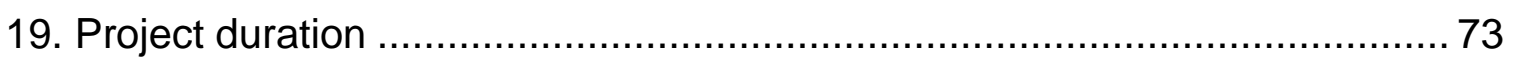

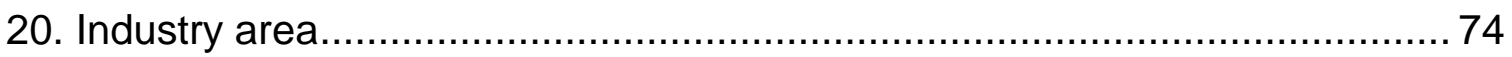

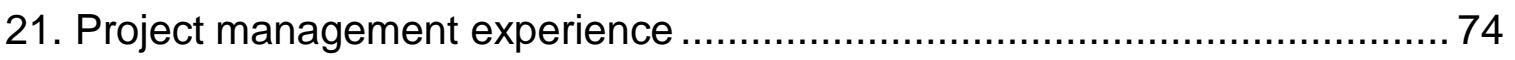

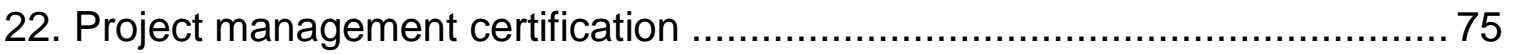

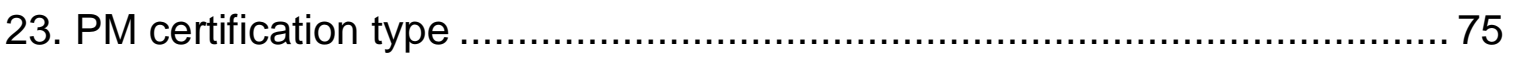

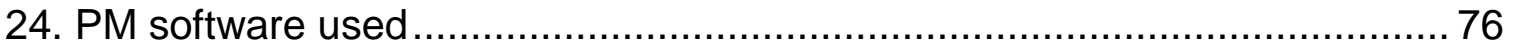

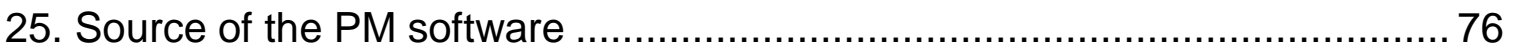

26. Project success criteria: Observed frequencies..................................... 77

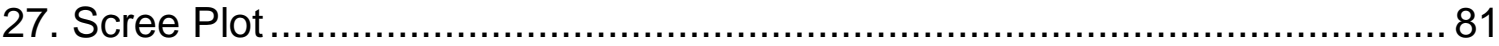

28. PM initiating processes: chi-square test of goodness-of-fit......................... 82

29. PM planning processes: chi-square test of goodness-of-fit ....................... 84

30. PM executing processes: chi-square test of goodness-of-fit ...................... 88

31. PM C \& M processes: chi-square test of goodness-of-fit ............................ 90

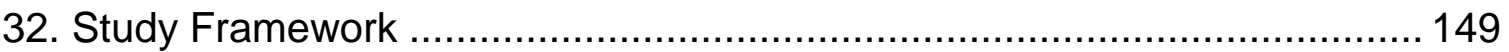

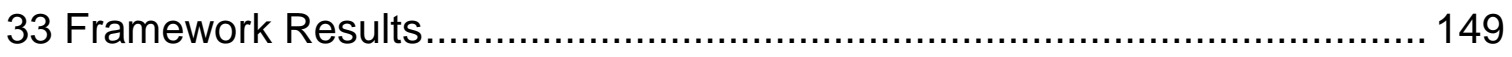

34. Theory of constraints applied to customer satisfaction ............................ 157 


\section{INTRODUCTION}

\section{Background and Relevance of the Research}

As a result of significant economic pressure as well as the growth of globalized markets, many companies are faced with the challenge of reducing both the development time and price of products or services while simultaneously improving their quality. Clearly, there are notable advantages to being the first company to bring a new product, innovation, or service to the market. However, doing so requires an effective and efficient development and realization process. By developing such a process, the product life cycle shortens, thus allowing the first firm in the market to earn money on that product for a longer period of time.

Because of these issues, markets are becoming more competitive. Competition has led some firms to squeeze others out of the market. Some firms cease to be economically viable, thereby making room for other firms to secure a greater number of market shares. Others feel compelled to react to these circumstances in the short term and increase both the effectiveness and efficiency of each business-related activity in the longer term. To do so, firms are forced to undergo a strategic and operational transformation; otherwise, their ability to compete and to survive will be compromised. Companies that are able to successfully implement these changes, therefore, tend to achieve an advantage over the companies that fail in this regard. This competitive advantage 
could be in the form of cost leadership or innovative products or services.

Given this, the main objective of every firm should be to survive and to gain a competitive advantage in the market in which they operate. This can only be achieved through continuous product improvement, optimization of applied technologies and organizational processes, and effective and efficient realization of changes combined with a maximum level of flexibility in implementing these changes.

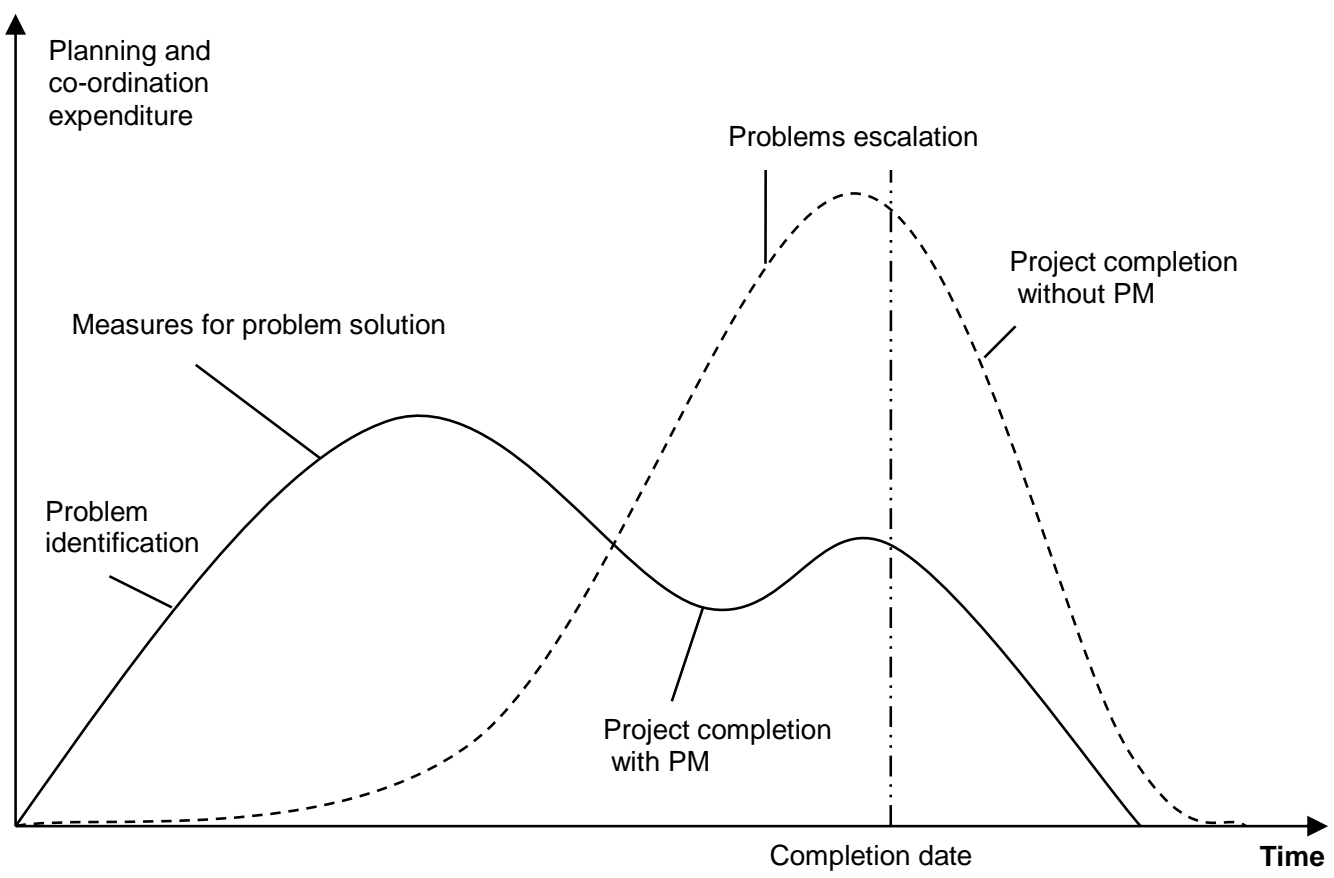

Figure 1. Implementation projects with and without PM (Hab \& Wagner, 2006)

To successfully operate in such turbulent market cycles, companies must implement effective project management to ensure the success of their endeavors (see Figure 1). Kerzner emphasized the importance of project management, stating that "success in project management is often a reflection of the organization's ability to respond quickly and effectively to changes in the 
marketplace" (Kerzner, 1987, p. 36). The response to which Kerzner referred could be, for example, a shorter time for project realization or organizational flexibility in reacting when characteristics of the business environment change As a result of these strengths, project management is indispensable for most industrial sectors and is employed in a variety of for-profit and non-profit organizations. The necessity of implementing project management to succeed in the highly competitive business environment is recognized by most companies (Sherman et al., 1996). Once project management is adopted and correctly implemented, the efficiency, effectiveness, and productivity of the organization increases (Kerzner, 1987). Because of the positive outcomes associated with it, some companies invest large amounts of money and resources into employee training and adaptation of its existing organizational structure to a project management system. In companies that successfully adapt to this system, project management is used to achieve the objectives that are derived from the company or organization strategy. Jugdev and Müller emphasized the strategic role of project management, stating that "project management can have strategic value when a clear connection is made between how efficiently and effectively a project is done and how the project's products and services provide business value" (Jugdev and Müller, 2005, p. 19). Therefore, project management can be considered a management method that contributes value to the organizations in which it is implemented.

In parallel to challenges posed by increased project complexity, academics and practitioners are likewise facing a challenge associated with 
maintaining a sound base of corresponding management knowledge. To this end, several studies have been conducted in this field to explore the link between theory and practice of project management. This has been performed to identify the gaps between the two and to initiate further research. Academics and practitioners have thus analyzed how to successfully manage projects. The results of these efforts have resulted in regular publications in the International Journal of Project Management by IPMA (International Project Management Association) and the Project Management Journal by the Project Management Institute (PMI). Some organizations publish their findings in independent reports. One such organization, called The Standish Group, publishes its findings in reports named "Chaos Reports" (Table 1). According to the 2009 Chaos Report, $32 \%$ of IT-projects have been judged to be successful (The Standish Group, 2009). This survey aimed to investigate the factors that lead projects to fail and how these failures can be reduced or eliminated. The Standish Group classified projects into three categories:

Table 1. The Standish Group findings over the years

\begin{tabular}{cccc}
\hline Year & Successful (\%) & Challenged (\%) & Failed (\%) \\
\hline 1994 & 16 & 53 & 31 \\
1996 & 27 & 33 & 40 \\
1998 & 26 & 46 & 28 \\
2000 & 28 & 49 & 23 \\
2004 & 29 & 53 & 18 \\
2006 & 35 & 46 & 19 \\
2009 & 32 & 44 & 24 \\
\hline
\end{tabular}

- Successful project: a project that is completed within time and budget constraints and meets all predetermined requirements, 
- Challenged project: a project that is completed and operational but over budget, over the time estimate, and offers fewer features and functions than originally specified, and

- Failed project: a project is canceled during the development phase.

In response to these reports as well as other previous studies, many practitioners and researchers have attempted to identify the causes of project failure, the factors that contribute to project success, and which criteria are appropriate to gauge this success. Atkinson found, for example, that "[p]rojects continue to be described as failing, despite management. Why should this be if both the factors and the criteria for success are believed to be known?" (Atkinson, 1999, p. 337). He further claimed that no considerable amelioration of project success criteria have been realized in the last half century.

Because the use of projects to achieve organizational outcomes is integral for organizational success, the search for factors that contribute to project success is likewise critical (Söderlund, 2004). In spite of this, some researchers, academics, and practitioners have argued that there has been little agreement on what constitutes project success. In response to the widespread debate surrounding project success, several lists dealing with factors related to project success have been published. The lack of agreement on the definition of project success renders the quest to identify the factors that contribute to successful project implementation moot. Without knowing what constitutes success, we cannot know what contributes to it. 
Regardless of these debates, there is a marked lack of research linking project success factors and project success criteria. Practitioners are interested in recommendations for implementing project success factors and the corrective or preventative actions that should be taken if the project fails to meet one or more project success criteria. Project management and the research related to it are therefore, facing severe criticism for not fulfilling their contributory expectations within the management discipline. Packendorff (1995), for example, claimed that there has not been sufficient empirical research in the project management field to determine (a) what project success is, or (b) how to gauge it.

A recent study conducted by Ahlemann et al. (2012) investigated the status of project management research in the last five years through a survey of the International Journal of Project Management from 2006 to October 2010. The goal of this study was to find answers to the following questions:

1. What is the nature of the project-related body of knowledge that can serve as a foundation for prescriptive project management research?

2. What types of solutions are proposed and enacted for problems related to projects?

3. What are the methods used to develop solutions for project-related problems?

4. What evaluative approaches have been proven useful with respect to method design and testing?

In this study, 422 project management papers were reviewed and classified into five categories (see Table 2). The majority of the reviewed papers 
were descriptive (216 papers, $51.18 \%), 120$ papers $(28.43 \%)$ were classified as prescriptive, and only 10 papers $(2.37 \%)$ dealt with theories in the project management field. With respect to research types, 57 papers $(47.50 \%)$ were method-based, 42 papers (35\%) explored conceptual models, and 18 papers (15\%) were geared towards developing a framework (see Table 3). Only 23 papers (19.17\%) of the 120 prescriptive papers had a sound theoretical foundation (see Table 4). The study also showed that 32 papers $(26.66 \%)$ did not contain information about the solution development process (Table 5) and 62 (49.2\%) papers reported on research results by utilizing one or more evaluation methods (Table 6).

Table 2. Paper type (Ahlemann et al., 2012)

\begin{tabular}{lccc}
\hline Paper type & & \\
\hline Descriptive & 216 & $51.18 \%$ \\
Prescriptive & 120 & $28.43 \%$ \\
Other & 39 & $9.24 \%$ \\
Conceptual & 37 & $8.76 \%$ \\
Theory & 10 & $2.37 \%$ \\
Total & 422 & $100 \%$ \\
\hline
\end{tabular}

Table 3. Research type (Ahlemann et al., 2012)

Prescriptive papers: Research type

\begin{tabular}{lcc}
\hline Method & 57 & $47.50 \%$ \\
Model & 42 & $35.00 \%$ \\
Framework & 18 & $15.00 \%$ \\
Ontology & 1 & $0.83 \%$ \\
Reference model & 1 & $0.83 \%$ \\
System & 1 & $0.83 \%$ \\
Total & 120 & $100 \%$ \\
\hline
\end{tabular}


Ahlemann et al. criticized the maturity of project management, stating that the "review of the IJPM papers confirms that theoretical work in project management research is underdeveloped." and that "[a]lthough project management practices have been known for centuries, PM research is still in its infancy compared to the natural sciences" (Ahlemann et al., 2013, p. 45).

Table 4. Theoretical foundation (Ahlemann et al., 2012)

\begin{tabular}{lcc}
\hline Prescriptive papers: Theoretical foundation & & \\
\hline No foundation: No theory is used to justify the design decisions & 97 & $80.83 \%$ \\
Fuzzy set theory & 2 & $4.16 \%$ \\
Organization theory & 2 & $1.66 \%$ \\
Theory of constraints & 1 & $0.83 \%$ \\
Arbitrage pricing theory & 1 & $0.83 \%$ \\
Theory of social constructivism & 1 & $0.83 \%$ \\
Contingency theory & 1 & $0.83 \%$ \\
Evidence theory & 1 & $0.83 \%$ \\
Game theory & 1 & $0.83 \%$ \\
Graph theory & 1 & $0.83 \%$ \\
Lifecycle management theory & 1 & $0.83 \%$ \\
Management control theory & 1 & $0.83 \%$ \\
Negotiation analysis theory & 1 & $0.83 \%$ \\
Organizational psychology theory of job performance & 1 & $0.83 \%$ \\
Porter's generic strategies & 1 & $0.83 \%$ \\
Pragmatic theory of knowledge & 1 & $0.83 \%$ \\
Stakeholder theory & 1 & $0.83 \%$ \\
Theory of convention & 120 & $100 \%$ \\
Total & 120 \\
\hline
\end{tabular}

Table 5. Methods used for solution development (Ahlemann et al., 2012)

Prescriptive papers: Methods used for solution development

\begin{tabular}{lll}
\hline No details: No details on the solution development process & 32 & $26.66 \%$ \\
Literature analysis & 54 & $45.00 \%$ \\
Mathematical and logical deductions & 28 & $23.33 \%$ \\
Empirical data analysis & 25 & $20.83 \%$ \\
\hline
\end{tabular}


As a result of the efforts of academics and practitioners to improve the project management field through the development of theories, frameworks, and models, the project success rate increased from 16\% in 1994 to $32 \%$ in 2009 . Still, it could be argued that there remains a need for more extensive and practice-oriented research.

Table 6. Evaluation (Ahlemann et al., 2012)

\begin{tabular}{lcc}
\hline Prescriptive papers: Evaluation & & \\
\hline No evaluation: No evaluation method is used to assess the effectiveness & 58 & $48.33 \%$ \\
Case study (single or multiple) & 24 & $20.00 \%$ \\
Simulation & 19 & $15.83 \%$ \\
Survey & 10 & $8.33 \%$ \\
Expert opinion & 9 & $7.50 \%$ \\
Meta analysis & 3 & $2.50 \%$ \\
Literature review & 2 & $1.66 \%$ \\
Text analysis & 1 & $0.83 \%$ \\
\hline
\end{tabular}

\section{$\underline{\text { Conclusion }}$}

Several studies have dealt with the identification of project success criteria or causal antecedents to project success. Unfortunately, success criteria and causal factors have been investigated in isolation; there has been no conceptual link between the causes of project success and ways to gauge that success. Therefore, there is little reason to implement assumed factors that contribute to project success without knowing the intended outputs. Given this, practitioners are interested in determining which success factors (activities, process output, behaviors, etc.) will improve particular project outcomes. Little attention has been paid to the relationship between project success criteria and project success factors and to how project success factors can be improved to achieve better project outcomes. In addition, there has been no empirical differentiation of past- 
oriented criteria (POC; related to corrective action plans) and future-oriented criteria (FOC; related to preventive action plans). For instance, many researchers have stated that the execution of a project is successful when it is performed within budget, on time, and with predetermined specification. In this case, there are three project success criteria that are considered indicative of project success: cost, time, and specification. Other authors link these three criteria to the main objectives of project management and argue for their measurement directly following product handover (Figue. 2).

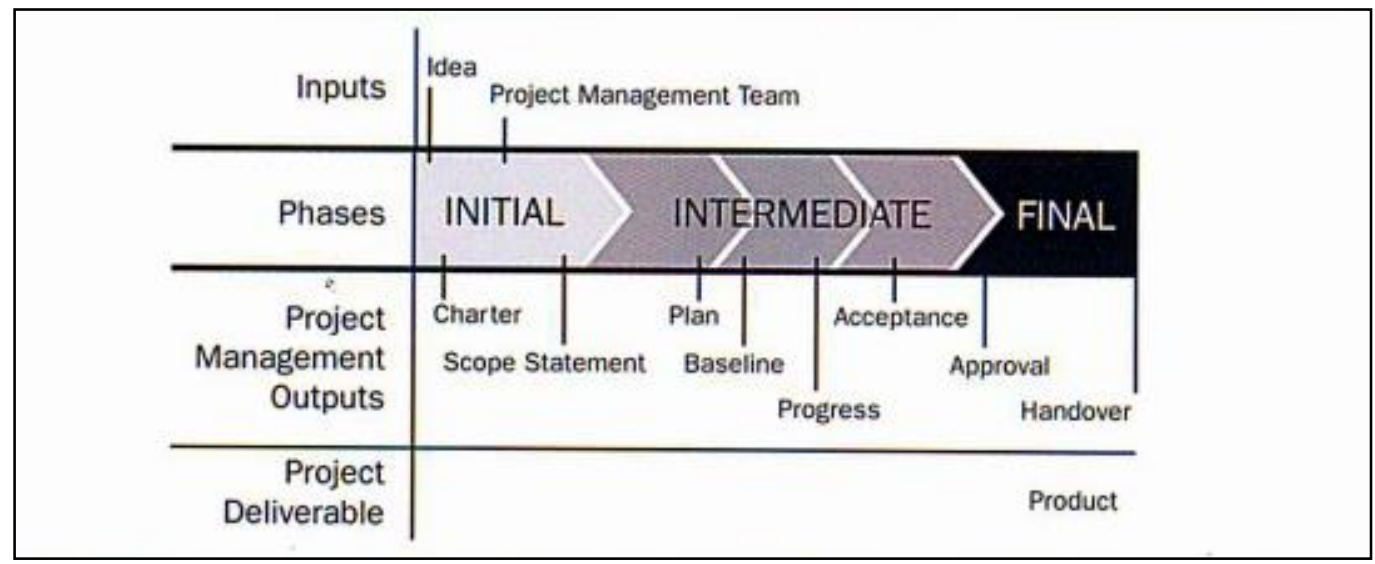

Figure 2. Typical Sequence of Phases in Project Life Cycle (PMI, 2004)

Despite their use for theorizing about project management, all these criteria are past-oriented. For instance, customer satisfaction, end-user satisfaction, and long-term objectives, which are all future-oriented, are not considered. Customer satisfaction must be continuously measured during the project and the product's life cycle (Figure 3) to effectively determine how to positively affect it. End-user satisfaction represents how happy the user is with the final product or service, so this criterion should also be measured regularly during the product life cycle. Given all this, it could be argued that there exists a general lack of applicable 
project management knowledge for practitioners. This can be resolved by coordinating with researchers, but academics and practitioners acting in the project management field do not speak the same language. Bridging the gap between theory and practice is integral for improving not only how projects are managed but also how the success of that management is gauged.

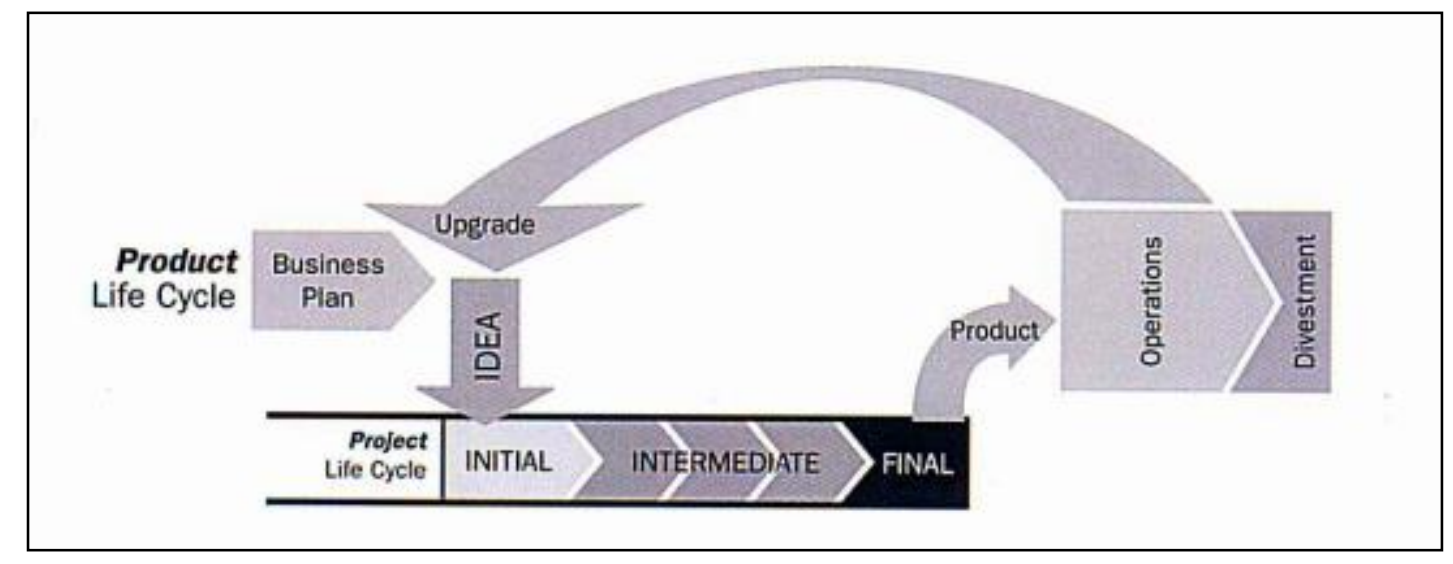

Figure 3. Relationship between the Product and Project Life Cycles (PMI, 2004)

\section{Research Questions and Model}

This study explores the maturity of project management both as a discipline and as an applicable instrument to facilitate competition in a highly competitive business environment. It draws on prescriptive research, empirical data related to project success factors and success criteria, and the theoretical and methodological project management corpus of literature to: 
1. systematically describe the current situation regarding the project management body of research and its impact on the long-term project objectives;

2. discover and/or establish the existence of interdependence among project success factors in salient project management knowledge areas (integration management, scope management, time management, cost management, quality management, communication management, risk management, human resources management, and procurement management), project management process groups (initiating, planning, executing, monitoring, and controlling), and project success criteria;

3. examine the relationship between project success factors and project success criteria; and

4. develop a framework that deals with the operational link between the success factors identified in project management knowledge areas, project management process groups, and project success criteria (past-oriented criteria: POC, and future-oriented criteria: FOC).

Therefore, this study addresses the following questions:

1. What is the role of project management research in helping organizations to achieve short- and long-term project success?

2. What are the factors of the project management body of knowledge that contribute to project success?

3. What is the link between project success factors and the short- and long-term project success criteria? 
4. How can project failure be prevented through preventive FOC and how can possible project failures measured with POC be corrected through problem solving tools like TOC (Theory of Constraints)?

The guiding research question in this study is the following: Is there a significant relationship between project management body of knowledge and long-term project success?. As known testable research questions begin with one of the two phrases, (a) is there a significant difference between the variable or attributes of interest; (b) is there a significant relationship between the variable or attributes of interest. Therefore, the research question mentioned above is testable.

A research hypothesis is a testable statement of opinion. It is created from the research question by replacing the words "Is there" with the words "There is", and replacing the question mark with a period. The hypothesis for the research questions is:

There is a significant relationship between project management body of knowledge and long-term project success.

This so-called alternative hypothesis could not be tested directly, because it cannot be rejected, one may only accept that a relationship exists. Instead, the hypothesis must be turned into a null hypothesis. The null hypothesis is created from the hypothesis by adding the words "no" to the statement. Therefore, the null hypothesis for this study is:

There is no significant relationship between project management body of knowledge and long-term project success. 
The independent factors in this study have been conceptualized as those elements of project management knowledge areas and the related project management process groups that can be influenced or implemented to increase the chance of project success. These factors are described in the PMBoK Guide 2004. The dependent items in this study were those project outcomes (project success criteria) that are influenced by the outputs of the process groups (independent factors) in each subject area within the knowledge base of project management. These criteria were established according to researcher experiences in project management and previous research on the topic.

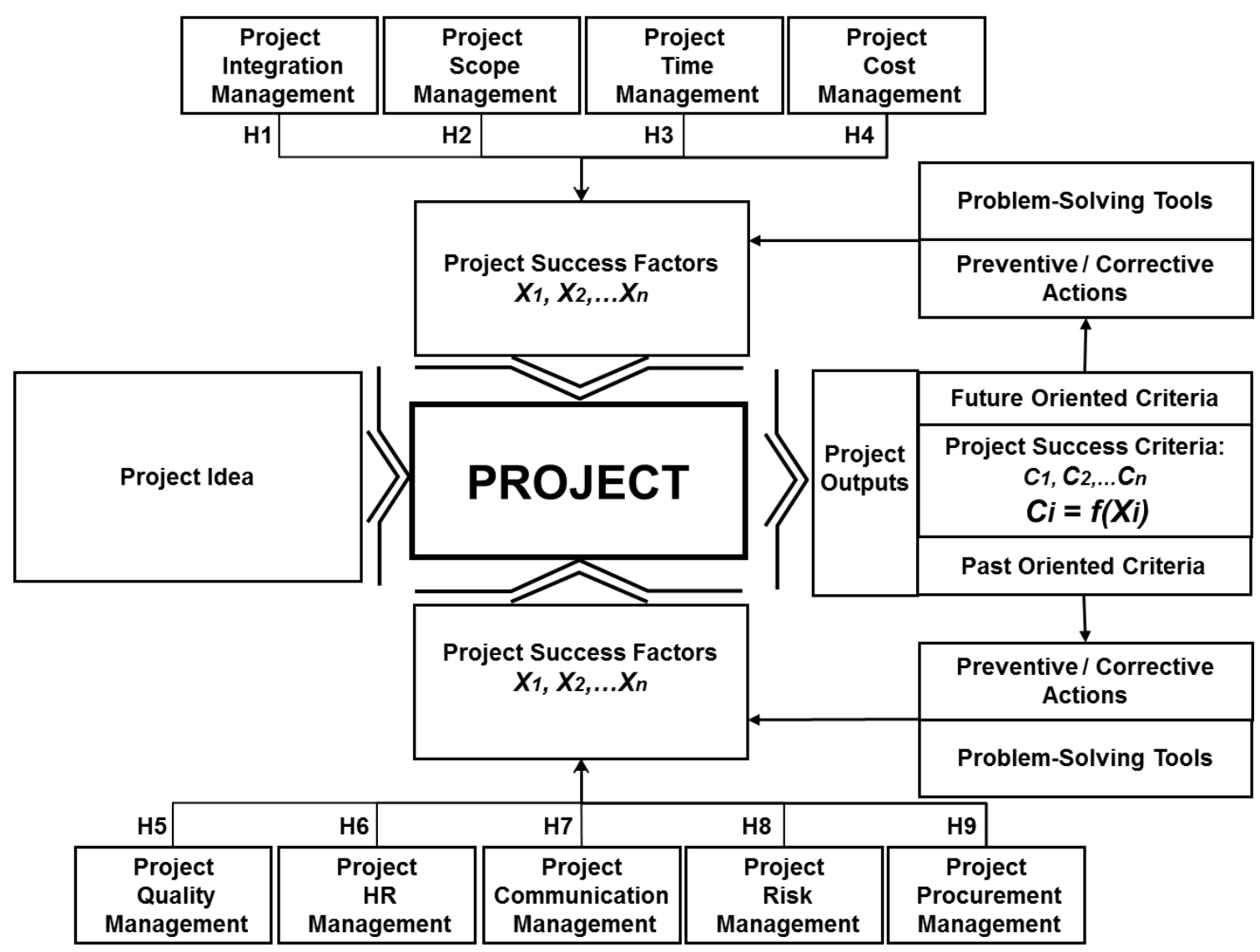

Figure 4. Research model 
Independent Factors: Project Success Factors:

H1-1 Project charter, H1-2 Preliminary project scope statement, H1-3 Updates, H1-4 Project management plan, H1-5 Deliverables, H1-6 Requested changes, H1-7 Implemented change requests, H1-8 Implemented corrective actions, H1-9 Implemented preventive actions, H1-10 Implemented defect repair, H1-11 Work performance information, H1-12 Recommended corrective actions, H1-13 Recommended preventive actions, H1-14 Forecasts, H1-15 Recommended defect repair, H1-16 Requested changes, H1-17 Approved change requests, H1-18 Rejected change requests, H1-19 Approved corrective actions, H1-20 Approved preventive actions, H1-21 Approved defect repair, H1-22 Validated defect repair, H1-23 Deliverables, H2-1 Project scope management plan, H2-2 Project scope statement, H2-3 Work breakdown structure, H2-4 WBS dictionary, H2-5 Scope baseline, H2-6 Accepted deliverables, H3-1 Activity list, H3-2 Activity attributes, H3-3 Milestones list, H3-4 Project schedule network diagrams, H3-5 Activity resource requirements, H3-6 Resource breakdown structure, H3-7 Resource calendar, H3-8 Activity duration estimates, H3-9 Project schedule, H3-10 Schedule model data, H3-11 Schedule baseline, H3-12 Performance measurements, H4-1 Activity cost estimates, H4-2 Activity cost estimates supporting detail, H4-3 Cost management plan, H4-4 Cost baseline, H4-5 Project funding requirements, H4-6 Forecasted completion, H5-1 Quality management plan, H5-2 Quality metrics, H5-3 Quality checklists, H5-4 Process improvement plan, H5-5 Quality baseline, H5-6 Recommended corrective actions, H5-7 Organizational 
process assets, H5-8 Quality control measurements, H5-9 Validated deliveries, H6-1 Roles and responsibilities, H6-2 Project organization chart, H6-3 Staffing management plan, H6-4 Project staff assignments, H6-5 Resource availability, H6-6 Team performance assessment, H7-1 Communication management plan, H7-2 Performance reports, H7-3 Resolved issues, H8-1 Risk management plan, H8-2 Risk register, H8-3 Risk-related contractual agreements, H9-1 Procurement management plan, H9-2 Contract statement of work, H9-3 Make-or-buy decisions, H9-4 Procurement documents, H9-5 Supplier evaluation criteria, H9-6 Updates, H9-7 Procurement document package, H9-8 Proposals, H9-9 Selected sellers, H910 Contract, H9-11 Contract management plan, H9-12 Procurement management plan (update) and H9-13 Contract documentation

The measurement level of the independent PM process outputs mentioned above is categorical (ordinal) that use the numeric value from 1 to 5 according to the Likert scale: (1: strongly agree, 2: agree, 3: neither agree nor disagree, 4: disagree, 5 :strongly disagree).

Dependent Project Outcomes - Project Success Criteria:

Budget/cost, schedule, customer, user, stakeholder and project team satisfaction, strategic contribution of the project, financial, technical and performance objectives, commercial benefit for contractors and customer, scope, personal growth, customer approval, profitability, and sales. 
The dependent project outcomes mentioned above are categorical (nominal) that use the numeric value 0 and 1 to stand for No and Yes.

\section{Research Limitation}

In this study, the literature review and analysis of existing empirical data related to project success factors criteria considers all project types (i.e., IS/IT projects, construction, new product development). There is a growing recognition among researchers that most seminal studies on project success criteria and project success factors use projects in information systems and information technology (IS/IT) as data. The factors and criteria for project success strongly depend on project type and industry. Therefore, to explore the application of problem solving tools like TOC in a more comprehensive manner, this study pays greater attention to new product development projects.

\section{Research Structure}

The remainder of this paper is structured as follows. Chapter Two provides an overview of the literature dealing with the project management body of knowledge. Chapter Three discuss the research methodology and solution design utilized in this study. Following this, Chapter Four verifies the research objectives presented in Chapter One through a presentation of the analysis results. Chapter Five provides an interpretation of these results. Finally, Chapter Six summarizes the findings of this study and concludes with recommendations for future research. 


\section{LITERATURE REVIEW}

\section{Projects and Project Management}

In recent years, several definitions of the term "project" have been proposed. Turner defined a project as "an endeavor in which human, material and financial resources are organized in a novel way, to achieve a unique scope of work, of given specification, with constraints of cost and time, so as to achieve a purpose defined by quantitative and qualitative objectives" (Turner, 1993, p. 8). Turner's definition does not consider external constraints such as the cultural, political, and social environments in which a project is carried out. Thus, this definition isolates the project's external factors that could have an important impact on the project's implementation. Furthermore, the "quantitative and qualitative objectives" referenced by Turner leave much room for interpretation. Similar to Turner, Andersen et al. defined a project as "unique task; is designed to attain a specific result; requires a variety of resources; and is limited in time" (Andersen et al., 2009, p. 10).

While several authors conceptualize project as an endeavor, others view a project as a collective of individuals. Steiner (1969), for example, defined a project as "an organization of people dedicated to specific purpose or objective."

Furthermore, the term "project management" also has a number of definitions in the literature. The simplest, and arguably the most meaningful, 
definition was proposed by Widemann (1995). He stated that "[t]he underpinning of project management can be characterized as 'getting things done'." (Widemann, 1995, p. 72). However, he added that project management is also about the "manner of how people do it." He also stated that project management involves sub-skills that integrate both "things" and "people" (Widemann, 1995). This definition also incorporates interpersonal skill, which is missing in many other definitions.

The Project Management Institute PMI defined project management as "the application of knowledge, skills, tools and techniques to project activities to meet project requirements. Project management is accomplished through the application and integration of the project management processes of initiating, planning, executing, monitoring and controlling, and closing" (PMI, 2004, p. 8). PMI also noted that "managing a project includes identifying requirements, establishing clear and achievable objectives, balancing the competing demands for quality, scope, time and cost, and adapting the specification, plans, and approach to the different concerns and expectations of the various stakeholders" (PMI, 2004, p. 8).

\section{Project Management Knowledge Areas}

The PMI identified nine significant knowledge areas in its Project Management Body of Knowledge (PMBoK, 2004). These nine knowledge areas and the related project management process groups are fundamental to the 
development of the survey questionnaire used in the research described here. These knowledge areas are as follows:

1. Project Integration Management includes the processes related to developing of the project charter, the preliminary project scope statement, and the project management plan, directing and managing project execution, monitoring and controlling project work, integrating change control, and the project closure process (PMI, 2004).

2. Project Scope Management includes the processes related to scope planning, scope definition, creating work-break-down structure, scope verification, and scope control processes (PMI, 2004).

3. Project Time Management includes the processes related to defining project activities, setting the sequencing of project activities, estimating the needed resources for each activity, estimating the duration that each activity will take, and creating a time schedule and controlling it (PMI, 2004).

4. Project Cost Management includes the processes of estimating, budgeting, and controlling the project cost (PMI, 2004).

5. Project Quality Management includes the processes of quality planning and performing quality assurance and control (PMI, 2004).

6. Project Human Resource Management includes the processes of organizing and planning the required human resources for project execution (PMI, 2004).

7. Project Communication Management includes the processes of communication planning, information sharing, performance reporting, and managing stakeholders (PMI, 2004). 
8. Project Risk Management includes the processes of risk management planning, risk identification, qualitative and quantitative risk analysis, risk response planning, and risk monitoring and control (PMI, 2004).

9. Project Procurement Management includes the processes of planning the scope to be purchased and acquired, contract management, getting supplier responses, and supplier selection (PMI, 2004).

\section{Project Success and its History}

In their retrospective look at project management success, Jugdev and Müller argued that "our views on project success have changed over the years from definitions that were limited to the implementation phase of the project life cycle to definitions that reflect an appreciation of success over the entire project and product life cycle" (Jugdev and Müller, 2005, p. 19) (see Table 7).

During Period 1, only the time, cost, and specifications were used to judge whether a project was successful (Jugdev \& Müller 2005). They also claimed that little attention has been paid to customer contact and long-term follow-up and troubleshooting (Jugdev \& Müller 2005). In this period, the literature was focused on theory and not on the empirical investigation of issues related to project management (Belassi \& Tukel, 1996). 
Table 7. Measuring success across the project and product life cycles (Jugdev and Müller, 2005)

\begin{tabular}{|l|l|l|l|l|l|}
\hline \multicolumn{5}{|c|}{ PROJECT LIFE CYCLE } & \multicolumn{2}{l|}{} \\
\hline \multicolumn{5}{|c|}{ PROJECT LIFE CYCLE } & Close Down \\
\hline Conception & Planning & $\begin{array}{l}\text { Production / } \\
\text { Implementation }\end{array}$ & Handover & Utilization & \\
\hline \multicolumn{2}{|l|}{} & $\begin{array}{l}\text { Period 1: Project } \\
\text { Implementation and } \\
\text { Handover (1960s - 1980s) }\end{array}$ & & \\
\hline \multicolumn{2}{|c|}{ Period 2: CSF Lists (1980s - 1990s) } & & \\
\hline Period 4: Strategic Project Management (21st century) & \\
\hline
\end{tabular}

In Period 2, an additional criterion was included to judge project success: stakeholder satisfaction. In addition, several lists related to critical success factors were published during this period. Unfortunately, these studies were not organized in a coherent fashion (Jugdev \& Müller 2005).

In Period 3, the focus of research related to project management was on the development and realization of project success-related frameworks. In this period, it was argued that project success depends on stakeholders and the collaboration among the involved organizations (Jugdev \& Müller, 2005).

During Period 4, the critical success factors lists that had emerged in Period 2 were enhanced by further integrating criteria like management support (Jugdev \& Müller, 2005). Some of those lists will be discussed in later chapters.

In the past few decades, project success has been the most widely discussed topic within the literature on project management. Despite its 
popularity, the concept of project success is not a tangible one. Hyväri noted that "in the project management literature, it is still somewhat unclear what makes a successful project in general, and, in particular, in the terms of organizational context of the company or companies involved" (Hyväri, 2006, p. 31). Remenyi and Sherwood-Smith (1999) made a similar remark, arguing that project success remains a poorly understood concept and concluded that projects are often undertaken without defining how the success of these projects will be judged. As a result of the difficulties associated with conceptualizing project success, it remains subjective and variable from one person or group to another. Succinctly stated by Freeman and Beale (1992), "an architect may consider success in terms of aesthetic appearance, an engineer in terms technical competence, an accountant in terms of dollars spent under budget, and chief executive officers rate their success in the stock market". That which is not defined can be not measured, and that which can be not measured cannot be monitored, controlled, or improved.

McCoy (1986) observed that there is neither a generally accepted definition for project success nor guidelines to measure it. Similarly, Wateridge (1995) found that there was no agreement on the criteria for judging project success. Despite these inconsistencies, extant research indicates that most metrics for success depend on completing the project on time, within budget, and with the predetermined user requirements and functionality incorporated into it. Extant research has also indicated that projects perceived to have failed have used time and budget as the primary criteria for judging success. Wateridge 
noted these inconsistencies in determining project success and concluded that "[t]here does not appear to be a consensus of opinion among researchers and authors on the criteria for judging project success and the factors that influence that success" (Wateridge, 1995, p. 171). To resolve this, prior to the start of a project, the individuals involved should determine the criteria with which the project will be judged and identify and implement factors that will contribute to the project's success (Wateridge, 1995).

Several researchers have argued that the completion of a project on time, within budget, and to the customer's specification may not be sufficient in determining project success. As such, many have attempted to identify other criteria that could be used to judge project success as well as factors relevant to achieving that success. Thus, other lists of project success criteria and project success factors have been published since the 1980s. Cleland (1986), for example, suggested a consideration of two views related to project success: 1) the fulfillment of predetermined technical requirements on time and within budget, and 2) the achievement of the strategic objectives. Morris and Hough (1987) similarly argued that although the completion of a project on time and within budget is important, a project can still be considered a success if it is completed late or goes over budget. Correspondingly, when a project meets its time and budget constraints, it does not automatically indicate success (Anderson \& Merna, 2003). Therefore, time, budget, and specification are only three criteria among many for judging project success. 
Widemann (1995) stated that success is closely related to effective communication and the quality of the resulting product. Bounds (1998) argued that a successful project involves staff training and education; dedicated resources; good tools; strong leadership and management; and concurrent development of the individual, team, and organization. Given Widemann's (1995) and Bounds's (1998) perspectives, it can be concluded that project success is also related to cost management, time management, scope management, quality management, communication management, and human resources management. These represent six of the nine project management knowledge areas indicated by the PMI.

Some authors (e.g., Cooke-Davies, 2002; Munns \& Bjeirmi, 1996) question the relationship between project management and project success. Specifically, they differentiate the objectives of project management that include the monitoring and controlling of cost, time and progress, and project objectives, which are oriented towards long-term outputs like return on investment and market share. Baccarini (1999) echoed this perspective, arguing that project management success should be secondary to project success.

One of the objectives of this study is to identify empirically the elements of project management knowledge areas and related project management process groups that affect short and long-term project objectives, and thus, overall project success. The role of project management is more than controlling of cost, time, and progress. According to Jugdev and Müller, "if project success is limited to the variables of time, cost, and scope- and the links to product/service value are 
missing- then project management is perceived as providing tactical (operational) value and not strategic value" (Jugdev and Müller, 2005, p. 19). To avoid this pitfall, this study will explore the relationships between predictor variables beyond timeliness, budgetary conformity, and product specificity and incorporate some of the project management knowledge areas outlined above.

\section{Project Success Criteria}

Cooke-Davies described success criteria as "the measures by which the success or failures of a project or business will be judged" (Cooke-Davies, 2002, p. 185). Lim and Mohammed defined success criteria as "the set of principles or standards by which judgment is made and are considered to be the rule of the game" (Lim and Mohammed, 1999, p. 243). Each company, enterprise, or organization has its own principles and standards. The latter of these are developed and implemented by individuals within those organizations, enterprises, or companies. Each individual has a unique perspective on things within an organization. Therefore, the judgment of a project success may differ not only from organization to organization, but also from project to project and even from one person to another. Because of these differential perspectives within and between organizations, Freeman and Beale (1992) proposed that project success be evaluated through different perspectives or expectations. These expectations can include the achievement of a predetermined technical performance within time and on budget, the level of internal or external 
satisfaction with the project, or the commercial benefit generated from it (Freeman \& Beale, 1992).

In addition to project management constraints (budget, schedule, and specifications), Morris and Hough (1987) identified another criteria that contain financial and technical requirements, and contractor's commercial performance by which a project success can be judged. However the list associates project management with meeting budget, schedule, and specification. Project management consists of nine knowledge areas. Schedule, cost, and scope management represent just three knowledge areas of these nine. This begs the question - what are the respective roles of the remaining areas in achieving project objectives? The answer to this question will become evident below.

Kerzner defined a successful project as "one which has been accomplished within time, within cost or budget, at the desired performance or quality level, within the original scope or mutually agreed upon scope changes, without disturbing the corporate culture or corporate values, and with welldocumented post-audit analysis" (Kerzner, 1987, p. 30). Although this definition is also based on the "iron triangle" of timeliness, cost, and specificity, new criteria such as performance, quality, and scope are addenda to these original three. Similarly, Pinto (1989) enhanced the iron triangle by adding customer satisfaction. He argued that because a project is normally carried out for an internal or external customer, it is logical to consider customer satisfaction when judging whether a project is successful. 
Shenhar et al. (1997) identified four dimensions for assessing project success: time, specification, customer requirements fulfillment, and business performance/future opportunities. Through this definition, Shenhar et al. extended Pinto's (1989) widely accepted definition by adding direct economic and strategic impacts that the project may have on the organization.

Further, Baccarini (1999) proposed a Logical Framework Method (FM) for defining project success. He identified four levels of project objectives: goal, purpose, output, and input. According to Baccarini, project success consists of two principal components. First, Baccarini argued that a successful project is managed well by assessing inputs and outputs as well as focusing on cost, budget, and quality. The second component of project considers the final product. In this way, project success has predetermined goals and purposes. With this statement, Baccarini, similar to Munns et al., linked the focus of project management to the achievement of cost, time, and quality goals.

In their study on IT-projects, Agarwal and Rathold (2006) found that project scope has been identified as the most agreed upon criterion for determining project success. In fact, it has been described as equal in importance to cost, time, quality, and customer when judging project success.

Finally, Thomas and Fernández (2008) conducted an exploratory study to investigate how 36 companies operating in three Australian industries define and measure successful IT projects. Their findings highlighted success criteria like sponsor satisfaction, business continuity, project team satisfaction, and steering committee satisfaction as important for project success. 


\section{Table 8. Summary of project success criteria}

\begin{tabular}{ll}
\hline Authors & Project Success Criteria \\
\hline Cleland (1986) & $\begin{array}{l}\text { attain technical performance objective on time and within budget; } \\
\text { contribution that the project made to the strategic mission of the enterprise }\end{array}$
\end{tabular}

Morris and

Hough (1987)

Kerzner (1987)

Pinto (1989)

Freeman and

Beale (1992)

Turner (1993)

Widemann (1995)

Wateridge (1995)

Munns and

Bjeirmi (1996) meet financial and technical requirements, meet the budget, schedule, and specifications, commercial benefit for contractors, in the event that the project had to be cancelled, was this decision made reasonably and efficiently

been accomplished within time, within cost or budget, at the desired performance or quality level, within the original scope or mutually agreed upon scope changes, without disturbing the corporate culture or corporate values, and with well-documented post-audit analysis

on-schedule (time criterion), comes in-on budget (monetary criterion), achieves basically al the goals originally set for it (effectiveness criterion), and is accepted and used by the client for whom the project is intended (client satisfaction criterion)

Technical performance, Efficiency of the project execution, Managerial and organizational implications, Personal growth, Project termination, Technical innovations, Manufacturability and business performance

achieve its stated business purpose, provides satisfactory benefit to the owner, satisfy the needs of the owner, users and stakeholders, meet its pre-stated objectives to produce the facility, The facility is produced to specification, within budget and on time and the project should satisfy the needs of the project team and supporters

stated that success is closely associated with effective communication and the quality of the resulting product

meet the user requirements and functionality, on time and to budget

long-term goals - return on investment, profitability, competition and market ability); short-term goals - completion to budget, satisfy the project schedule, adequate quality standards, and meeting the project goal

Shenhar, Levy and Dvir (1997) on time and within the specified budget, impact on the customer and/or the user of the end result, sales, income, and profits, business results and market share, organizational and technological infrastructure for the future 


\begin{tabular}{ll}
\hline Authors & Project Success Criteria \\
\hline Bounds (1998) & $\begin{array}{l}\text { staff training and education, dedicated resources, good tools, strong } \\
\text { leadership and management, concurrent development of the individual, } \\
\text { team, and organization }\end{array}$ \\
$\begin{array}{l}\text { Lim and } \\
\text { Mohamed (1999) }\end{array}$ & $\begin{array}{l}\text { macro viewpoint (used by users and stakeholders), "does the original } \\
\text { concept tick" and the micro viewpoint used by developer and contractor }\end{array}$ \\
Baccarini (1999) & $\begin{array}{l}\text { successful accomplishment of cost, time, and quality objectives, effect of } \\
\text { the project's final product }\end{array}$ \\
Agarwal and & $\begin{array}{l}\text { scope, functionality, customer happiness and satisfaction, project specific } \\
\text { priorities }\end{array}$ \\
Rathold (2006) & $\begin{array}{l}\text { sponsor satisfaction, business continuity, project team satisfaction, and } \\
\text { steering group satisfaction }\end{array}$
\end{tabular}

\section{Project Success Factors}

Cooke-Davies (2002) described success factors as those which contribute to achieving success on a project. According to Kerzner (1987), success factors are those elements that must exist within the organization to create an environment in which projects are consistently managed with excellence.

Researchers and practitioners in the field of project management have developed several lists of project success factors and frameworks. Morris (1998), for example, suggested that the implementation of factors like communication, conflict, cost, schedule, stakeholders, life cycle, and technical and risk management could increase the likelihood of a project's success.

Although the above three studies are most well-known for defining project success, several other studies have also attempted to codify these factors. Below, I review the history of such research in chronological order. 
Sayles and Chandler (1971) developed a list of project success factors. Their list included project manager's competence, scheduling, control systems and responsibilities, monitoring and feedback, and continued involvement in the project.

For Martin (1976), project success depends on the definition of goals, the selection of a proper project organizational philosophy, the organization and delegation of authority, the selection of an effective project team, the allocation of sufficient resources, the provision for control and a mechanism for information dissemination, and the support of general management.

Cleland and King (1983) considered project summary, operational concept, top management support, financial support, the successful implementation of logistics, market intelligence (i.e., successful identification of customers), project schedules, executive development and training, manpower, information and communication channels, and project review as contributory factors of successful project implementation.

In contrast, Baker et al. (1983) identified completely different project success factors. These included goal clarity and commitment, an on-site project manager, adequate funding for completion of the project, adequate project team capability, accurate initial cost estimates, a minimum of start-up difficulties, adequate techniques for planning and control, and the absence of bureaucracy.

One year later, Locke (1984) published a list of project success factors that seemed to be a combination of the findings of Sayles and Chandler (1971), Cleland and King (1983), Marin (1976), and Murphy and Fischer (1983). This 
included making project commitments known, project authority derived from the top organization level, the appointment of a competent project manager, established communications, procedures, and control mechanisms; and regular progress meetings.

Although the above-mentioned lists indicate the variety of perspectives related to project success, one of the widely cited and accepted lists was produced by Pinto and Slevin (1987). This list includes project mission, top management support, project scheduling, client consultation, competent personnel, technical tasks, client acceptance, monitoring and feedback, communication, and troubleshooting as factors integral for successful project implementation.

Another extensive list of project success factors developed by Kerzner (1987) includes corporate understanding of project management at the employee, middle management, and top management levels; commitment by top management to support the project through appropriate managerial strategies; organizational adaptability that enables companies to react quickly to the changes in the political, cultural, social, or economic environments; a resultoriented project manager possessing strong interpersonal skills; strong commitment to corporate values; appropriate project manager leadership style; and commitment to planning and continuous follow-ups of project activities.

The original CHAOS study (1994) identified 10 success factors: executive support, user involvement, the presence of an experienced project manager, clear business objectives, a minimized scope, standard software infrastructure, 
basic firm requirements, formal methodology, reliable estimates, and other miscellaneous criteria.

Unlike the aforementioned studies, Belassi and Tukel (1996) argued that judging a project as a success or failure is not as simple as compiling a list. Instead, they classified and clustered former published success factors into four groups to investigate their impact on project outcomes. These groups included factors related to the project, project personnel, organization, and external environment.

In her study, Clarke (1999) investigated the changes in projects observed in a variety of organizations. Through her analyses, she identified four factors critical to the success of those projects: communication throughout the project, clear objectives and scope, Breaking large projects down into sub-projects or work packages and using project plans as working documents.

Further, Cooke-Davies (2002) also investigated the factors that are critical to project management success. He identified eight factors: knowledge of risk management concepts, the assignment of ownership of risks, a visible risk register, an up-to-date risk management plan, documentation of organizational responsibilities on the project, a short duration (fewer than three years), a mature control process for allowing changes in scope, and the maintenance of the integrity of the performance measurement baseline. Cooke-Davies (2002) also identified one criterion that contributes to project success - effective benefits delivery and management process - and three other criteria that lead to consistently successful projects - portfolio and program management, clear 
metrics for gauging portfolio and project management, and effective means for experiential learning.

White and Fortune (2002) also conducted empirical research to identify success factors. They conducted a survey to capture the "real world" experiences of project managers in order to identify common criteria used for defining project success and to establish a common list of critical success factors. In this way, while previous work in this domain simply listed potential success factors, White and Fortune (2002) sought to summarize this literature as a means to identify common factors across extant research. Their findings demonstrated that the classic criteria of timeliness, staying within budget, and staying within the specification of the customer were the most referenced criteria to judge a project's success. However, the authors also found that a fit between the project and the organization and the influence of the project on business performance were often cited as important criteria.

Similarly, Westerveld (2003) developed a Project Excellence Model (EFQM-model) to link project success criteria with project success factors using extant research. The model consists of six results areas covering project success criteria, six organizational areas covering project success factors, and five project types. Each of the areas in Westerveld's (2003) model is detailed below.

- Results areas: Project results (budget, schedule, and quality), appreciation by the client, appreciation by project personnel, appreciation by users, appreciation by contracting partners, and appreciation by stakeholders. 
- Organizational areas: emphasis on leadership and team, appropriate policy and strategy, stakeholder management, resources, contracting, and competent project management (i.e., effective scheduling, budget, organization, quality, information, and risks).

- Project types: product orientation, tool orientation, system orientation, strategy orientation, and total project management. 


\section{Table 9. Summary of project success factors}

\begin{tabular}{|c|c|}
\hline Authors & Project Success Factors \\
\hline $\begin{array}{l}\text { Sayles and } \\
\text { Chandler (1971) }\end{array}$ & $\begin{array}{l}\text { project manager's competence, scheduling, control systems and } \\
\text { responsibilities, monitoring and feedback, continuing involvement and } \\
\text { the project }\end{array}$ \\
\hline Martin (1976) & $\begin{array}{l}\text { define goals, select project organizational philosophy, organize and } \\
\text { delegate authority, select project team, allocate sufficient resources, } \\
\text { provide for control and information mechanism, require planning and } \\
\text { review and get support from general management }\end{array}$ \\
\hline $\begin{array}{l}\text { Cleland and } \\
\text { King (1983) }\end{array}$ & $\begin{array}{l}\text { project summary, operational concept, top management support, } \\
\text { financial support, logistic requirements, facility support market } \\
\text { intelligence, project schedule, executive development and training, } \\
\text { manpower and organization, acquisition, information and communication } \\
\text { channels and project review }\end{array}$ \\
\hline $\begin{array}{l}\text { Baker, Murphy and } \\
\text { Fischer (1983) }\end{array}$ & $\begin{array}{l}\text { clears goals, goal commitment of project team, on-site project manager, } \\
\text { adequate funding to completion, adequate project team capability, } \\
\text { accurate initial cost estimate, minimum start-up difficulties, planning and } \\
\text { control techniques, Task (vs. orientation ) and absence of bureaucracy }\end{array}$ \\
\hline Locke (1984) & $\begin{array}{l}\text { make project commitments known, project authority from the top, } \\
\text { appoint competent project manager, set up communications and } \\
\text { procedures, set up control mechanism (schedules, etc.) and progress } \\
\text { meetings }\end{array}$ \\
\hline $\begin{array}{l}\text { Pinto and } \\
\text { Slevin (1987). }\end{array}$ & $\begin{array}{l}\text { project mission, top management support, project schedule / plan, client } \\
\text { consultation, personnel, technical tasks, client acceptance, monitoring } \\
\text { and feedback, communication and troubleshooting }\end{array}$ \\
\hline Kerzner (1987) & $\begin{array}{l}\text { corporate understanding of project management, commitment by } \\
\text { executive management, organizational adaptability, project managers } \\
\text { selection criteria, leadership style of the project manager, project } \\
\text { committed to planning }\end{array}$ \\
\hline $\begin{array}{l}\text { Morris and } \\
\text { Hough (1987) }\end{array}$ & $\begin{array}{l}\text { project objectives, technical uncertainty, politics, community involvement } \\
\text { Implement problems. }\end{array}$ \\
\hline Clarke (1995) & $\begin{array}{l}\text { Communication throughout the project, clear objectives and scope, } \\
\text { Breaking the project into "bite sized chunks, using project plans as } \\
\text { working documents }\end{array}$ \\
\hline
\end{tabular}




\begin{tabular}{|c|c|}
\hline Authors & Project Success Factors \\
\hline $\begin{array}{l}\text { Belassi and } \\
\text { Tukel (1996) }\end{array}$ & $\begin{array}{l}\text { project size and value, uniqueness of project activities, density of } \\
\text { project, life cycle and urgency; ability to delegate authority, ability to } \\
\text { trade-off, ability to coordinate, perception of project manager roles and } \\
\text { responsibilities, competence and commitment (project manager); } \\
\text { technical background, communication skills, trouble shooting and } \\
\text { commitment (project team members); top management support, project } \\
\text { organizational structure, functional managers' support and project } \\
\text { champion; political environment, economical environment, social } \\
\text { environment, technological environment, nature, client, competitors and } \\
\text { subcontractors. }\end{array}$ \\
\hline Morris (1998) & $\begin{array}{l}\text { controlling, directing, team building, communicating, cost and schedule } \\
\text { management, technical and risk management, conflict and stakeholders } \\
\text { management and life-cycle management, among others }\end{array}$ \\
\hline Bounds (1998) & $\begin{array}{l}\text { staff training and education, dedicated resources, good tools, strong } \\
\text { leadership and management, concurrent development of the individual, } \\
\text { team, and organization }\end{array}$ \\
\hline Standish Group (2000) & $\begin{array}{l}\text { executive support, user involvement, experienced project manager, clear } \\
\text { business objectives, minimized scope, standard software infrastructure, } \\
\text { firm basic requirements, formal methodology, reliable estimates, other } \\
\text { criteria }\end{array}$ \\
\hline Cooke-Davies (2002) & $\begin{array}{l}\text { education on the concepts risk management, assigning ownership of } \\
\text { risks, visible risk register is maintained, up-to-date risk management } \\
\text { plan, documentation of organizational responsibilities on the project, } \\
\text { keep project (or project stage duration) as far blow } 3 \text { years as possible } \\
\text { ( } 1 \text { year is better), allow changes to scope only through a mature scope } \\
\text { change control process, maintain the integrity of the performance } \\
\text { measurement baseline, effective benefits delivery and management } \\
\text { process, portfolio- and program management, project, program and } \\
\text { portfolio metrics, effective means of "learning from experience" }\end{array}$ \\
\hline $\begin{array}{l}\text { White and } \\
\text { Fortune (2002) }\end{array}$ & $\begin{array}{l}\text { on time, to budget and specification, fit between the project and the } \\
\text { organization, the consequences of the project for the performance of the } \\
\text { business }\end{array}$ \\
\hline Westerveld (2003) & $\begin{array}{l}\text { Project results (budget, schedule and quality); appreciation by the client; } \\
\text { appreciation by project personnel; appreciation by users; appreciation by } \\
\text { contracting partners; appreciation by stakeholders; leadership and team; } \\
\text { policy and strategy; stakeholder management; resources; contracting; } \\
\text { project management: (scheduling, budget, organization, quality, } \\
\text { information and risks), product orientation, tool orientation, system } \\
\text { orientation, strategy orientation and total project management. }\end{array}$ \\
\hline
\end{tabular}


Project Management Application of the Theory of Constraints

With the advent of optimized production timetables scheduling software in 1979, the basis for Goldratt and Cox's Theory of Constraints (TOC) emerged. Since its inception, TOC has been developing and has been integrated into different fields like project management and problem solving. Watson et al. (2007) segmented the evolution of TOC into five eras:

1. 1979-1984: The Optimized Production Technology Era - the secret algorithm

2. 1984-1990: The Goal Era - articulating drum-buffer-rope scheduling

3. 1990-1994: The Haystack Syndrome Era - articulating the TOC measures

4. 1994-1997: The It's Not Luck Era - thinking process applied to various topic

5. 1997-2004: The Critical Chain Era - TOC project management

\section{The Five Focusing Steps}

According to Goldratt (1990), the Theory of Constraints is based on five steps:

1. Identify the system's constraints: In this step, an individual should determine the constraints that have a negative impact on system performance. In discussing project schedules, the primary constraint is the completion of the longest chain of dependent project activities that would fulfill both precedence and resource constraints. This also refers to bottlenecking resources that are assigned to different projects or project activities.

2. Decide how to exploit the system's constraint: With respect to time management, this step implies that the primary objective should be to 
increase the efficiency of project execution on the whole as a means to ensure that the activities in the critical chain are well performed and without delay.

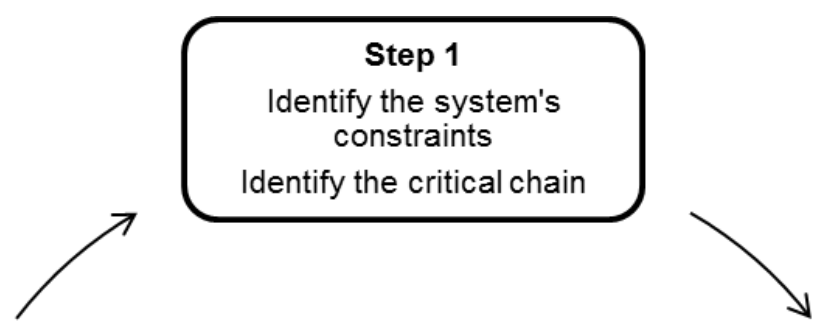

\section{Step 5}

Go back to Step 1 and do not allow inertia to cause a system's constraint

Monitoring and performance

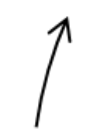

Step 4

Elevate the system's constraints

Change participants' behaviors

\section{Step 2}

Decide how to exploit the system's constraints Condense activity duration

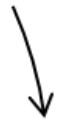

Step 3

Subordinate everything else to the decision in Step 2 Insert buffers

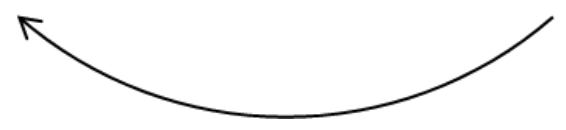

Figure 5. The Five Focusing Steps and Application of the Critical Chain

3. Subordinate: This step refers to the avoidance of allowing non-critical project activities to negatively influence critical activities for the project. Non-critical resources should be made available when they are needed. 
4. Elevate the system's constraints: If the intended performance is not fully achieved after executing the steps outlined above, additional resource must be allocated.

5. Go back to step1: If intended performance is achieved, return to step 1 to improve the process further.

\section{Resource Constrained Project Scheduling}

Resource scheduling includes the assignment of resources to project activities or project activities to resources. This process supports schedulers making decisions about the workload and available resources. There are two different aspects to be considered in the scheduling process. The constraint could be time or resources or both.

Time-constrained project: The project must be accomplished in a fixed time line, using reasonable and justifiable level of resources. In this case the time is critical and not the resources. "Time-constrained resource scheduling assumes that time constraints are fixed, and seeks to resolve capacity overloads by manipulating the timing of activities within their total float, and without affecting the initial project completion time." (Abeyasinghe et al., 2001).

Resource-constrained project: The project must be accomplished in a reasonable and justifiable time line, using predefined and fixed level of resources. In this case the resources are critical and not the time. "Resource-constrained scheduling accepts the priority of fixed resource availability, and permits not only sequencing and float times to be altered, but (if necessary) the 
project duration to be increased beyond the initial non-constrained project duration." (Abeyasinghe et al., 2001).

Critical Path Method (CPM) and Project Evaluation and Review Technique (PERT) are doubtless the most popular scheduling procedures used since 1959. CPM scheduling helps project managers and project schedulers to ensure the project completion in time and on budget. However these Techniques are activities-time-based and do not consider the resources required to execute those project activities. In others words these scheduling methods are not appropriate for addressing issues related of resources utilization and availability. Thus, they consider the existence of infinite resources and therefore the possibility of adding resources to activities to reduce their duration. Yet in real project environment, resources are limited. For this reason, scheduling projects without considering resources requirements is out of touch with project reality. The shortcoming of these two techniques has been discussed in several previous studies (e.g. Wiest 1967, Cooper 1976). Researchers have recognized this limitation and therefore they are spending lot of efforts in developing others methods and approaches to solve the project scheduling under consideration of resources constraints. The most known two approaches are (a) optimization by mathematical programming techniques, and (b) heuristic techniques.

Mathematical optimization methods define the resource-constrained project scheduling problem as a mathematical programming problem (linear programming, enumeration, tree search, and branch and bound) to identify the 
best solution. Yet, this approach is not applicable for large-scale projects. Heuristic methods are the most used and applicable methods for solving the resource-constrained project scheduling problems. Based on the PERT/CPM schedule analysis heuristics examine the project activities in periods in which the resource level is exceeded and allocated the scarce resource to them according the following rules among others:

- Earliest start prioritization: As soon as possible

- Latest start prioritization: As late as possible

- $\quad$ Earliest finish prioritization: Finish as soon as possible

- $\quad$ Latest finish prioritization: Finish as late as possible

- $\quad$ Activity duration: Shortest task first

- $\quad$ Activity duration: Longest task first

- Greatest resource utilization: Most resources first

- Job slack: Minimum slack first

- Most critical followers

- Most successors

Critical chain project management (CCPM) distinguishes between critical and non-critical resources assigned to projects. Therefore, CCPM focuses on the effective and efficient management of critical resources during the planning of projects. Watson and his associates (2007) stated that there are three main differences between CPM, PERT, and CCPM in terms of assigning task durations, the utilization of buffers, and the avoidance of resource conflict. 
For the manufacturing sector, task duration estimates depend on several factors. The availability of materials, workers, and tools, for example, can drastically alter how long the task will take. The insertion of a margin for error into the estimate seems to be a general practice; estimates typically reflect a $90 \%$ $95 \%$ confidence rate at which the task will be executed within the suggested time frames (Watson et al., 2007). As such, a safety time is built into each project activity (Figure 5). In reference to the CPM or PERT approach, Jyh-Bin stated that "[o]ne of the pitfalls is the unrealistic activity duration that combines proper duration and redundant safety time. With inflated duration, a project manager cannot control the schedule because project participants are reserving their safety time" (Jyh-Bin, 2007, p. 25). Unfortunately, this redundancy has yet to be resolved. In fact, since the introduction of the critical path method, no significant improvements have been made to it (Shou \& Yeo, 2000). Shou and Yeo (2000) further argued that existing problems like late project completion, cost overruns, and the need to cut specification are the principal reasons for the development of the critical chain project management approach.

The critical chain approach is more geared towards changing the behavior of project members so that realistic estimates of activity durations are made. To ensure meeting the project completion date, the critical chain method typically uses an activity duration estimate with $50 \%$ confidence with margins for error placed at the end of the project (Figure 5). 


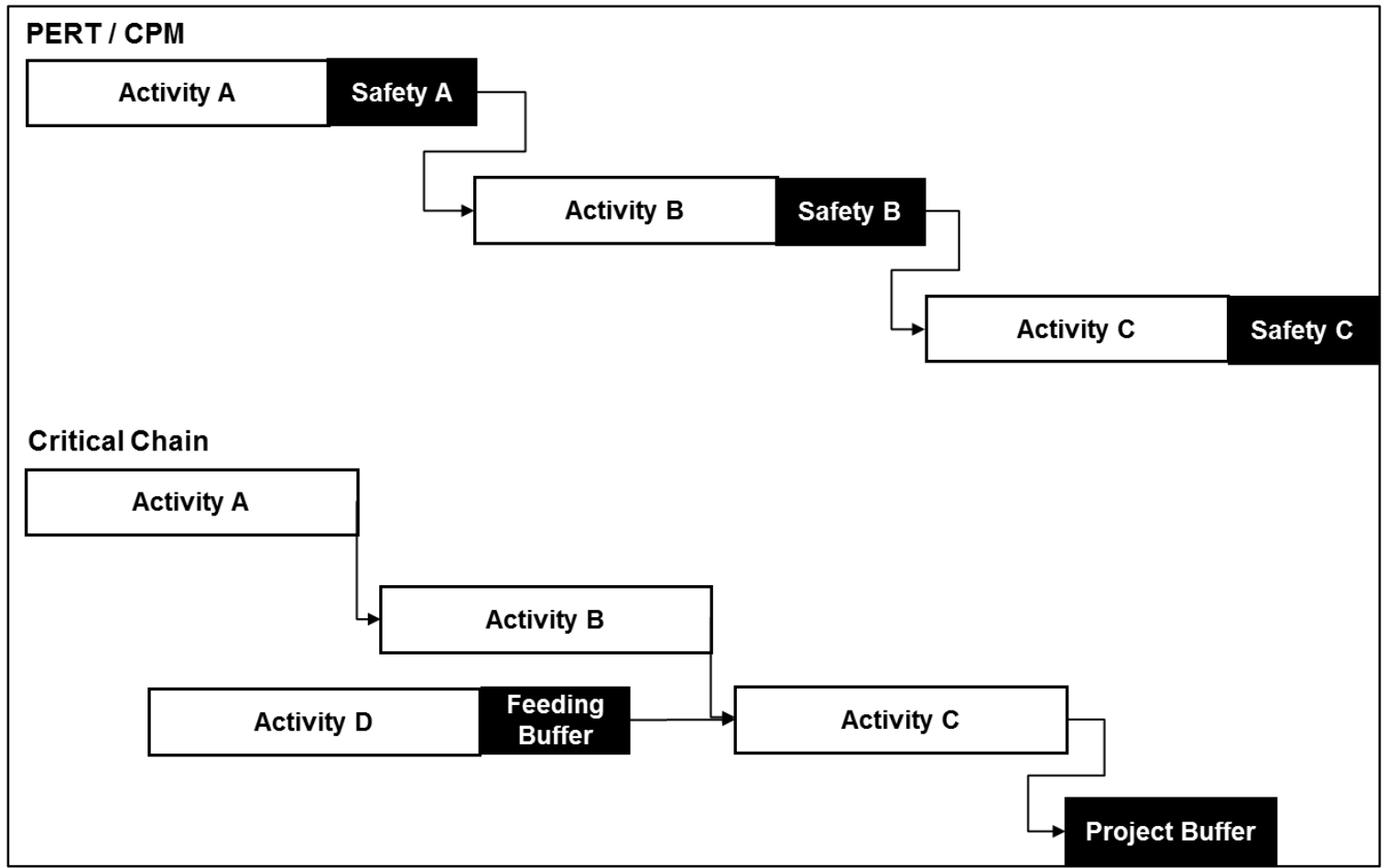

Figure 6. Comparison between Critical Chain and PERT/CPM

The critical chain project management approach is designed to reduce project duration time by accounting for constraints on resources. It considers not only the overall project but also the component projects that are likewise constrained by time, cost, and scope. This CCPM approach, thus, uses three different buffers. First, CCPM incorporates a project buffer to ensure the project's completion date. Second, it incorporates a feeding buffer to protect the critical chain against negative influences of other activities or non-critical chains. Finally, it uses a resource buffer to protect the project's completion time in the event of resource conflicts (see Figure 5).

In his book, Critical Chain, Goldratt (1997) argued for the application of the Theory of Constraints to project management. He stated that the root cause of 
failure to meet project completion dates is the inefficient utilization of the margin time built into the activities' duration estimates. He further argued that the estimates used in CPM and PERT to cover uncertainties in projects are overdrawn. Both PERT and CPM have been criticized by several authors because of the integration of safety times into each project activity, regardless of whether the activities are on the critical path or not. In contrast, critical chain project management allows for the aggregation of safety times at the end of the project, resulting in not only on-time completion of the project but also a reduction in the time it takes to complete.

Another pitfall associated with CPM or PERT is referred to as "Student Syndrome" (Goldratt, 1997). With CPM or PERT, the knowledge that safety times are built into each project activity provides incentive for the worker to avoid starting his/her assigned activities on time. With critical chain project management, however, project personnel and the customer agree and commit to only the project completion date. Due dates of single activities (and in some cases, milestones) are removed. Another issue that has been addressed by CCPM is the reduction of the work in process (WIP). In the field of project management, WIP reduction involves scheduling the execution of some activities in a project as late as possible.

By adopting a CCPM approach, a project manager or scheduler can identify activities that require more attention and avoid delays in project completion. Therefore, the project manager should keep a track of the project as a complete system and not as a series of singular activities. This makes the 
completion date the most important date related to the project. Milestone achievements should be considered only if mandated by the customer.

Given the clear benefits of CCPM, Newbold (1998) offered several steps for its successful implementation. These steps include first setting clear project objectives, including the development of a project plan. This also includes deducing the project completion date from the master plan provided by the customer and disseminating it to project personnel. Second, a project manager should determine the customer requirements and define the activities designed to meet them. These activities should then be delegated. Third, it is imperative to identify the logical relationship between activities and requirements, such as start-to-start, start-to-finish, finish-to-start, and finish-to-finish activities. This will facilitate the reduction or elimination of simultaneous activities. Fourth, a project manager should estimate the resources that are required, the duration of the activities to be performed, and the costs based on his/her experience on previous projects. Fifth, one should calculate the critical chain schedule, accounting for time buffers. Sixth, the project manager should evaluate the schedule according to the project objectives set in step one. Finally, if the schedule meets the internal and external requirements, the process is complete. If not, the manager must revisit this process to improve project performance. 


\section{The TOC Thinking Processes}

The second TOC approach that will be discussed in this chapter is entitled "TOC: Thinking Process." It includes logical guidelines on how to manage changes in a firm's operational environment. The main points to be addressed include what to change, what to change into, and how to bring about this change.

The TOC thinking process is based on two logical levels (see Figure 7): 1) sufficient cause or effect-cause-effect logic, which includes the current reality tree (CRT), future reality tree (FRT), and transition tree (TT); and 2) necessary condition logic, which is used by the evaporating cloud $(\mathrm{EC})$ and prerequisite tree (PRT) to identify all obstacles that prevent the system from achieving the objectives (Scheinkopf, 1999).

According to Dettmer (1997), the Current Reality Tree CRT logically represents the current state of a given system, organization, or process as a means to:

- $\quad$ clarify thought and allow for the understanding of complex systems;

- $\quad$ identify non-conformities, which are called undesirable effects (UDEs);

- $\quad$ execute a root cause effect analysis and identify the major factors that cause UDEs;

- $\quad$ identify which factors are controllable and which are not;

- $\quad$ separate uncontrollable factors and address them to improve the system; and identify quick changes that have a significant impact on the system as a whole. 


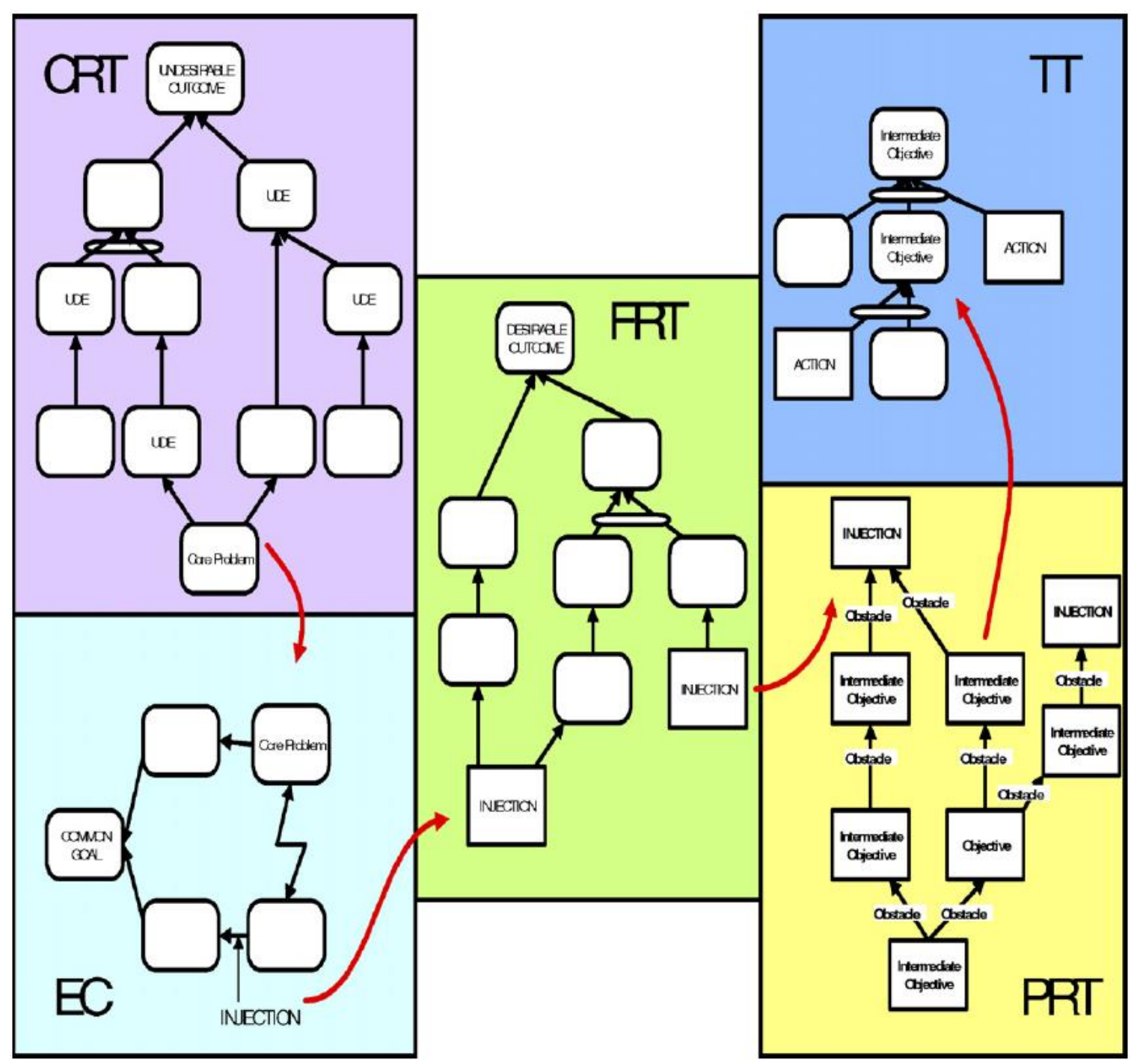

Figure 7. The TOC thinking process application tools (Watson et al., 2007)

The evaporating cloud EC addresses the second question (i.e., what to change to) and can be used to reduce or eliminate of the impact of UDEs. According to Dettmer (1997), the evaporating cloud EC intends to:

- $\quad$ confirm the existing non-conformities;

- $\quad$ identify the non-conformity or conflict that causes a major problem;

- eliminate this non-conformity or conflict without compromise; 
- $\quad$ define solutions, including a "win-win" approach; and

- define new solutions to problems and explain their existence and the related conflicting relationship.

The Future Reality Tree FRT represents the next step of the TOC thinking process and focuses on the effectiveness of solutions to be implemented. According to Dettmer (1997), the FRT is designed to:

- justify the effectiveness of the new solution before its implementation;

- identify any negative side-effects that could be produced after its implementation;

- investigate any additional problems or side effects caused by the implementation of the new change and define new preventive actions accordingly;

- $\quad$ support the decision making process; and

- facilitate initial planning.

The fourth step in the thinking process is the prerequisite tree (PRT). It deals with the process of implementing solutions that are developed in the previous steps. Dettmer (1997) explained that the PRT is used to:

- identify any hindrances that could have a negative effect on the achievement of the objectives;

- investigate how to overcome these hindrances or minimize their impact;

- structure the actions to be implemented for the achievement of the objectives; and 
- $\quad$ support localization of actions even if the steps to achieve an objective are unknown.

The Transition Tree TT has nine basic purposes (Dettmer, 1997). These purposes are to:

- $\quad$ serve as a detailed structure method for the implementation process;

- $\quad$ ease orientation through the change process;

- $\quad$ identify deviation during the implementation process;

- $\quad$ integrate modifications if necessary;

- communicate the purpose of each action;

- $\quad$ realize the ideas generated in the EC or FRT;

- $\quad$ achieve the subordinate targets defined in the PRT;

- develop tactical action plans; and

- ensure that no undesirable effects occur. 


\title{
III. RESEARCH METHODOLOGY AND DESIGN
}

\author{
Introduction
}

According to Clifford Woody, research involves defining and redefining problems, formulating hypothesis or suggested solutions, collecting, organizing and evaluating data, making deductions and reaching conclusions, and finally, carefully testing those conclusions to determine how they relate to the formulated hypotheses. Given this, a well-designed research methodology is a powerful, multi-phase tool for exploring research questions. To conduct a strenuous, empirical investigation of the issues described in the previous chapters, I considered several options for conducting my research.

Given the utility of primary data for examining the hypotheses described above, this study includes a web survey in addition to archival research. To be familiar with effective methods for developing and conducting a survey, the researcher took part in several webinars on the topic. For the statistical data evaluation methods (described below), the researcher participated in several statistics courses at the University of Louisville and underwent training in the use of SPSS software (Statistical Package for the Social Sciences). 


\section{Objectives of the Study}

To achieve the project objectives, predetermined long and short-term purposes, and the business sustainability of an organization the utilization of project management is indispensable. Several studies have concluded that project management contributes only to the achievement of short-term project objectives like cost, schedule, and quality. These three criteria represent just a small part of the goals that companies intend to achieve though the execution of their projects. In addition to cost, time, and quality management, this project incorporates another six knowledge areas that were described in Chapter One. Therefore, the main objectives of this study were to (a) identify the role of project management body of knowledge in achieving long-term project success; (b) identify factors of the project management body of knowledge that contribute to long-term project success; (c) identify the link between project success factors and long-term project success criteria, and (d) develop a framework that could prevent project failure through preventative FOC (Future-Oriented Criteria), measure possible project failure through POC (Past-Oriented Criteria), and correct the failure using problem solving tools like TOC (Theory of Constraints).

\section{Research Hypotheses}

The guiding research question for the proposed study was: What is the relationship between long-term success and the project management body of knowledge represented in nine knowledge areas: integration management, scope management, time management, cost management, quality management, 
communication management, risk management, human resources management, and procurement management? The following hypotheses have been used to test the research question:

H1: There is no significant relationship between long-term project success and project integration management.

H2: There is no significant relationship between long-term project success and project scope management.

H3: There is no significant relationship between long-term project success and project time management.

H4: There is no significant relationship between long-term project success and project cost management.

H5: There is no significant relationship between long-term project success and project quality management.

H6: There is no significant relationship between long-term project success and project human resources management.

H7: There is no relationship between long-term project success and project communication management.

H8: There is no significant relationship between long-term project success and project risk management.

H9: There is no significant relationship between long-term project success and project procurement management. 


\section{Research Design}

A research design refers to the controlled organization of conditions for data collection and analysis in a way that aims to combine relevance to the research purpose with economy in procedure (Selltiz et al., 1962). This study is a quantitative descriptive inquiry designed to explore whether a relationship exists between long-term project success and the project management body of knowledge. According to Kothari (2004), descriptive research can include surveys as well as other forms of empirical inquiry. Ultimately, the goal of such research is to describe a situation as it currently exists. He further argued that the researcher has little control over the variables in this method; he is only able to report what has happened. Descriptive research, then, includes comparative and correlational methods."

In the following section, the research design for this study is summarized. First the sampling methods and the observation conditions are discussed, following that; the statistical methods and tools used for the data analysis are described.

\section{Sampling Design}

The study population consists of members of the German Chapter of the Project Management Institute, a finite sampling pool. Each member represents a sampling unit. random sampling technique have been used to select those members of the German Chapter of the PMI that (a) have PMI certification, or (b) are involved with projects, (c) have a particular function (project manager, project 
team member, project coordinator, steering committee member, etc.), and (d) belong to a particular industry (information technology, construction, engineering, etc.)

This way a sample of people involved in projects in different business areas and different industry sectors has been selected. The data about factors of the project management knowledge areas and the related project management process groups that contribute to project success were gathered from project managers, team members, and people that were or are involved in project work.

\section{Random Sampling Method}

PMI is the world's leading not-for-profit membership association for the project management profession, with 450,713 PMI-members and 239,965 chapter members and credential holders in more than 185 countries. Four main chapters, Munich, Frankfurt, Berlin /Brandenburg and Cologne, represent the PMI in Germany that includes 6,524 PMI-members in which 2,931 are chapter members (PMI, 2013). The survey could not be posted directly on the PMl.org site because of changed policies. Therefore, the researcher contacted members via Xing / PMI-Forum.

Random sampling has been used to select the participants because doing so eliminates bias, thereby allowing sampling error to be estimated (Kothari, 2004). Further, this method ensures that each member of the German Chapters of the PMI has an equal chance of being used in the sample. The link to the survey was sent to 1,047 PMI-members via the Xing-Forum/PMI, who are 
involved in project management and/or earned a project management certification

\section{Observation Design}

A survey has been used as the primary tool for data collection (see Appendix A)

\section{Data Collection Method}

Generally speaking, two types of data can be collected to answer research questions: primary data and secondary data. According to Kothari (2004), primary data is original information collected for the first time. Secondary data, in contrast, is information that has been previously statistically analyzed. In this study, secondary data have been obtained through a review of journals, books, magazines, dissertations, and other sources. These data were discussed in Chapter Two.

Although secondary data can be used to explore a number of research questions, Kothari (2004) and others have proposed questionnaires, interviews, and direct observation as integral means for collecting data. Therefore, in addition to the secondary data used for this study, primary data were collected via questionnaires placed on Qualtrics.com. Qualtrics is a web based researchsurveying software. It enables users to do any kind of online data collection and analysis including market research, customer satisfaction and loyalty, product and concept testing, employee evaluations and website feedback. The Qualtrics 
Research Suite is a top choice of academics. Therefore, quantitative statistical analysis performed with Qualtrics is cited in a number of professional and academic journals and books. Qualtrics.com complies with the United States (U.S.) and European Union (E.U.) Safe Harbor Framework and the U.S. and Swiss Safe Harbor Framework, set forth by the U.S. Department of Commerce. This ensures the protection of any primary source data collected for this study.

The questionnaire (Appendix A) included statements and questions on the following topics. For all project-related demographic questions the researcher assumes that the repondents are referring to their last project:

- Gender and age of the respondent

- Work and project management experience and the last project completed

- Average budget size of the respondent's projects

- Project functions

- Project types and industries

- Project durations and customer types (i.e., internal or external)

- Size of the project teams

- Types of project management certification

- Types of project management software used

- Respondent's opinion regarding criteria for project success measurement

- The frequency of specified project-related symptoms at the respondent's organization

- Respondent's opinion regarding the contribution of the PM-initiating process outputs to project success 
- Respondent's opinion of agreement regarding the contribution of the planning-processes outputs to project success

- Respondent's opinion regarding the contribution of the executing-processes outputs to project success

- Respondent's opinion regarding the contribution of the monitoring- and controlling-processes outputs to project success

\section{Statistical Design}

IBM SPSS Statistics Package was used for data analysis. The Qualtric.com program allows data exportation to SPSS, so transfer of data from the data collection tool to the data analysis tool was a relatively easy endeavor. The collected data have been edited, coded, classified, and tabulated prior to quantitative analysis (Table 10). The data analysis itself includes descriptive analysis. The hypotheses have been tested to indicate whether a relationship exists between the long-term project success (i.e., project success criteria: dependent project outcomes) and the project management body of knowledge (i.e., project success factors: independent factors) using chi-square tests and Fisher's exact tests. This study seeks to reject those hypotheses at the $(p<.05)$ level. The chi-square metric has been chosen to test the hypotheses based on the fact that (a) the non-parametric test is based on frequencies and not on parameters like mean and standard deviation that are unavailable, (b) there is no need for assumptions regarding the type of the population and parametric values, and (c) non-parametric tests are appropriate for application to ordinal or nominal 
scales. In cases where the chi-square assumptions were not met, thus more than $20 \%$ of the cells have expected count less than five, Fisher's exact test has been used for the independence investigation.

The basic computation of Chi-Square is as follows:

$$
x^{2}=\sum_{i=1}^{\text {columnsrows }} \sum_{j=1}^{\left(\text {observed }_{i j}-\text { expected }_{i j}\right)^{2}}
$$

where observed $d_{i j}$ is the observed frequency of the cell in the ith row and jth column and expected ${ }_{i j}$ is the expected frequency of the cell in the ith row and jth column.

The tables used in the test within the chi-square tests are contingency table or a three by two tables because its relate two categories of data. The rows include respondent's opinion regarding the contribution of the PM - processes outputs to project success (1: strongly agree, 2:agree, 3:neither agree nor disagree, 4: disagree, 5: strongly disagree). The columns include their opinion regarding criteria for project success measurement (1: selected, 0: not selected). Each box in the tables is referred to as a cell. Each cell contains the frequency of the category.

In order to increase the number of cells with expected count more than five, the categories 1 and 2 have been group to a new category "1: strongly agree/ agree" and 4 and 5 to "3: disagree/ strongly disagree". Category 3: neither agree nor disagree becomes category 2 
Limitations of the hypothesis testing:

- Hypothesis testing is useful aids for decision-making, but result should not be used as decision.

- Hypothesis testing do not provide the reasons why does a relation or association exist between the variables or attributes in consideration.

- The sample size must be large enough in order to increase the reliability of the drawn statistical inferences based on the independence tests.

- The results of independence tests are based on probabilities and include uncertainties. When the chi-square or Fisher's exact test shows that a relationship is statistically significant, then it simply suggest that, the relationship is probably not due to the chance.

- Doubtless chi-square test of independence is useful for testing a relationship or association between the attributes of interest, but it suffers from several limitations. The test is not a measure of the degree or the form of relationship between the attributes considered, it indicates only the significance of the relationship or association between those attributes. 


\section{Table 10. Overview of the statistics}

\begin{tabular}{|c|c|c|}
\hline Questions & $\begin{array}{l}\text { Measurement } \\
\text { level }\end{array}$ & Statistics \\
\hline Q1. Gender & Nominal & Frequencies \\
\hline Q2. Age & Scale & Frequencies \\
\hline Q3. Total years' work experience & Scale & Frequencies \\
\hline Q4. Project work & Nominal & Frequencies \\
\hline Q5. Last project completion & Scale & Frequencies \\
\hline Q6. Average size of project budgets & Scale & Frequencies \\
\hline Q7. Function on the project & Nominal & Frequencies \\
\hline Q8. Project type & Nominal & Frequencies \\
\hline Q9. Project purpose & Nominal & Frequencies \\
\hline Q10. Size of project teams & Scale & Frequencies \\
\hline Q11. Average duration of projects & Scale & Frequencies \\
\hline Q12. Business area & Nominal & Frequencies \\
\hline Q13. PM experience & Scale & Frequencies \\
\hline Q14. PM Certification & Nominal & Frequencies \\
\hline Q15. PM-Certification type & Nominal & Frequencies \\
\hline Q16. Project Management software & Nominal & Frequencies \\
\hline Q17. Source of the PM-software & Nominal & Frequencies \\
\hline Q18. Project success criteria & Nominal & $\begin{array}{l}\text { Chi-square test of goodness-of-fit } \\
\text { / Frequencies }\end{array}$ \\
\hline Q19. Symptoms at the organization & Ordinal & Exploratory factor analysis \\
\hline Q20. PM Initiating Processes & Ordinal & $\begin{array}{l}\text { Chi-square test and Fisher's exact } \\
\text { test of independence / } \\
\text { Frequencies }\end{array}$ \\
\hline Q21. PM Planning Processes & Ordinal & $\begin{array}{l}\text { Chi-square test and Fisher's exact } \\
\text { test of independence / } \\
\text { Frequencies }\end{array}$ \\
\hline Q22. PM Executing Processes & Ordinal & $\begin{array}{l}\text { Chi-square test and Fisher's exact } \\
\text { test of independence / } \\
\text { Frequencies }\end{array}$ \\
\hline Q23. PM M\&C Processes & Ordinal & $\begin{array}{l}\text { Chi-square test and Fisher's exact } \\
\text { test of independence / } \\
\text { Frequencies }\end{array}$ \\
\hline
\end{tabular}




\section{Framework Development}

A number of papers dealing with the application of the theory of constraints to project management have been published. These papers focused only on the critical chain and thus time management as knowledge area in the project management field. None of these papers addressed the application of the theory of constraints to the other knowledge areas like communication management, cost management, quality management, procurement management and so one.

The following model has been used for the framework development (see Figure 8).

\section{What to change?}

- Identify the core conflict which is responsible for the undesired project outcomes.

- Identify the core conflict causing the symptoms, or undesired project outcomes.

- The relationship between the project success factors (elements of the project management knowledge area and the related project management process groups) and the project success criteria (project outcomes) will be investigated empirically.

- $\quad$ Localize the project management knowledge areas.

- Localize the project management process group (initiation, planning, executing, monitoring and controlling or closing). 
- And finally identify the element(s) of the process (factors) causing the undesired project results.

- $\quad$ Build a current reality tree that confirms the existence of the core conflict. This will help to understand the existing cause-and-effect-relationship (Figure 8).

\section{What to change to?}

- Identify and break the assumptions that allow the Core Conflict to persist.

- $\quad$ Construct a Future Reality Tree that lays out the complete solution.

- Resolves all of the undesired project outcomes by making their opposites, the desired project outcomes.

- Ensures alignment with the project and organization objectives.

- Ensures that no new negative side-effects (Negative Branches) will occur from implementing the solution.

- Leverages the existing TOC applications that are needed to make the solution work.

\section{How to cause the change?}

- $\quad$ Build a Tactical Objectives Map that charts the overall course for getting from the current reality to the future reality, where the solution is fully implemented.

- $\quad$ Create detailed task interdependency diagram, using Transition Trees (TRTs) when necessary to flesh out crucial actions. 
- Transform action plans into a complete project network that can be effectively managed using project management techniques like Critical Chain project management.

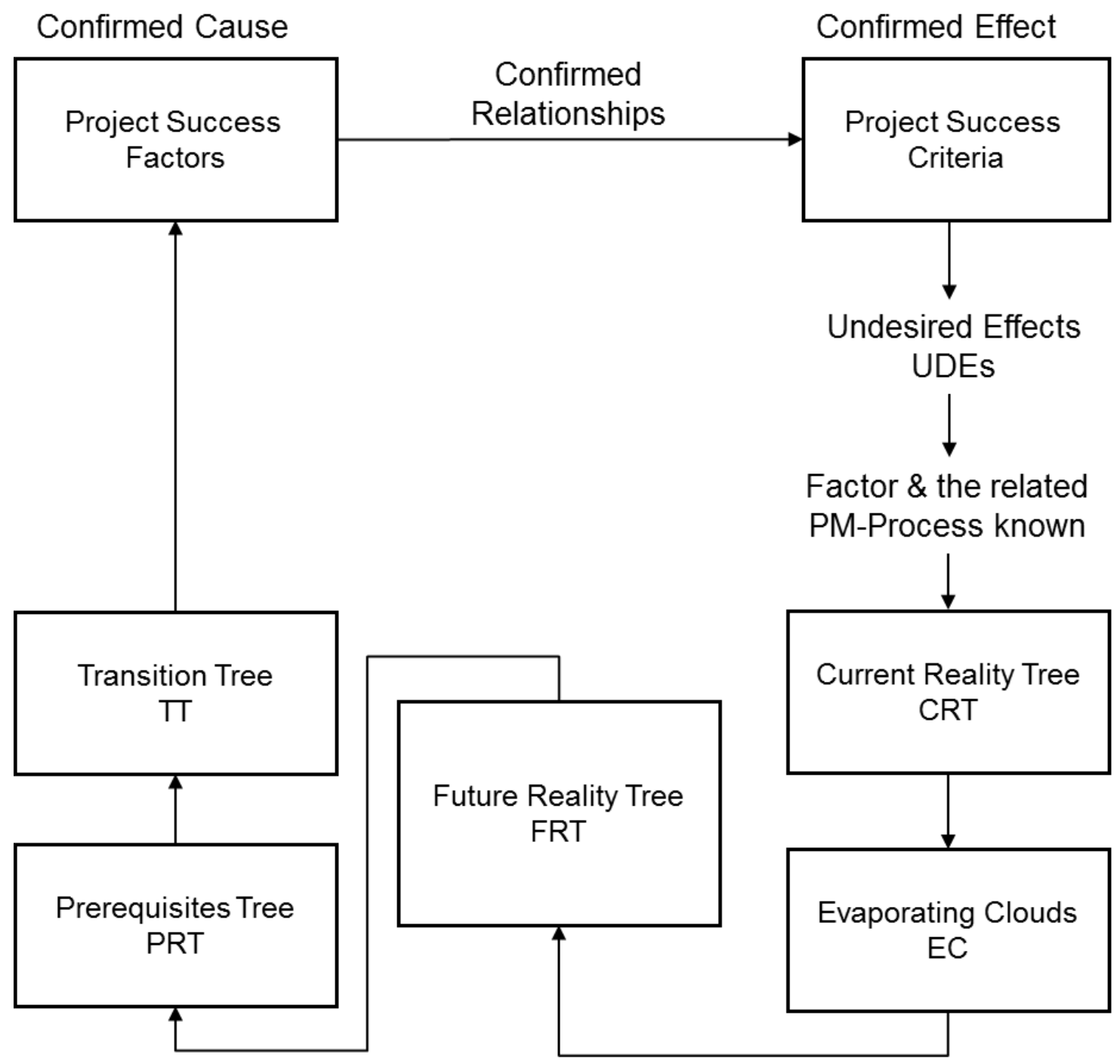

Figure 8. Framework development 


\section{ANALYSIS AND RESULTS}

\section{Introduction}

The focus of this chapter is analyzing the collected data to determine whether a relationship exists between long-term project success and the project management body of knowledge represented in the nine knowledge areas of integration management, scope management, time management, cost management, quality management, communication management, risk management, human resources management, and procurement management.

This study aims to add to the body of knowledge concerning project management, specifically project success factors and criteria. The study used a quantitative descriptive approach, and SPSS (Statistical Package for the Social Sciences) was used to analyze the survey data.

The survey consisted of a random sample of 163 PMI-members with knowledge of and experience in project management. Random sampling ensured that each PMI-member had an equal probability of being selected. All responses to the survey were kept anonymous to protect the respondents' confidentiality, and, per the University Of Louisville's Institutional Review Board (IRB) rules for research ethics compliance, no identifiable information was collected from the survey instrument, and all data were analyzed in aggregate with no individual survey respondent identified. The survey instrument posed questions on the 
following topics:

- Gender and age of the respondent

- Work and project management experience and the last project completed

- Average budget size of the respondent's projects

- Project functions

- Project types and industries

- Project durations and customer types (i.e., internal or external)

- Size of the project teams

- Types of project management certification

- Types of project management software used

- Respondent's opinion regarding criteria for project success measurement

- The frequency of specified project-related symptoms at the respondent's organization

- Respondent's opinion regarding the contribution of the PM-initiating process outputs to project success

- Respondent's opinion regarding the contribution of the planning-processes outputs to project success

- Respondent's opinion regarding the contribution of the executing-processes outputs to project success

- Respondent's level of agreement regarding the contribution of the monitoringand controlling-processes outputs to project success

The link to the survey was sent on October 8, 2013, to 1,047 PMI-members via the Xing-Forum/PMI. The survey concluded on January 31, 2014, by which time 
199 people had responded, a response rate of $19 \%$. One hundred and nighty nine (199) participants accessed the survey; one hundred and sixty three (163) participants completed the survey. Thirty-six (36) of the respondents who accessed the survey were excluded because their responses were incomplete. Therefore, 163 completed surveys were included in the study.

Statistics

\section{Question 1: Gender of the respondents}

Of the 163 respondents, $145(89.0 \%)$ were male and 18 (11.0\%) female (see Figure 9).

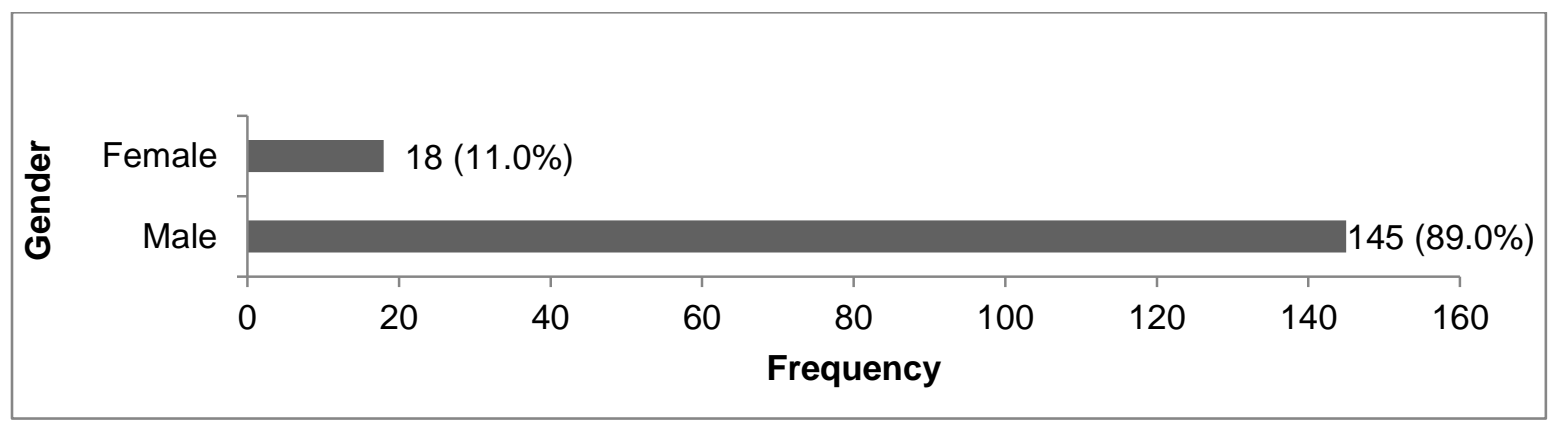

Figure 9. Gender of the respondents

\section{Question 2: Age of the respondents}

Respondents were asked to provide their age. The responses were slotted into four age groups. As shown in Figure 10, nine (5.5\%) respondents were 20 to 30 years old, 60 (36.8\%) were 31 to 40 years old, 75 (46.0\%) were 41 to 50 years old, and 19 (11.7\%) were 50 or older. 


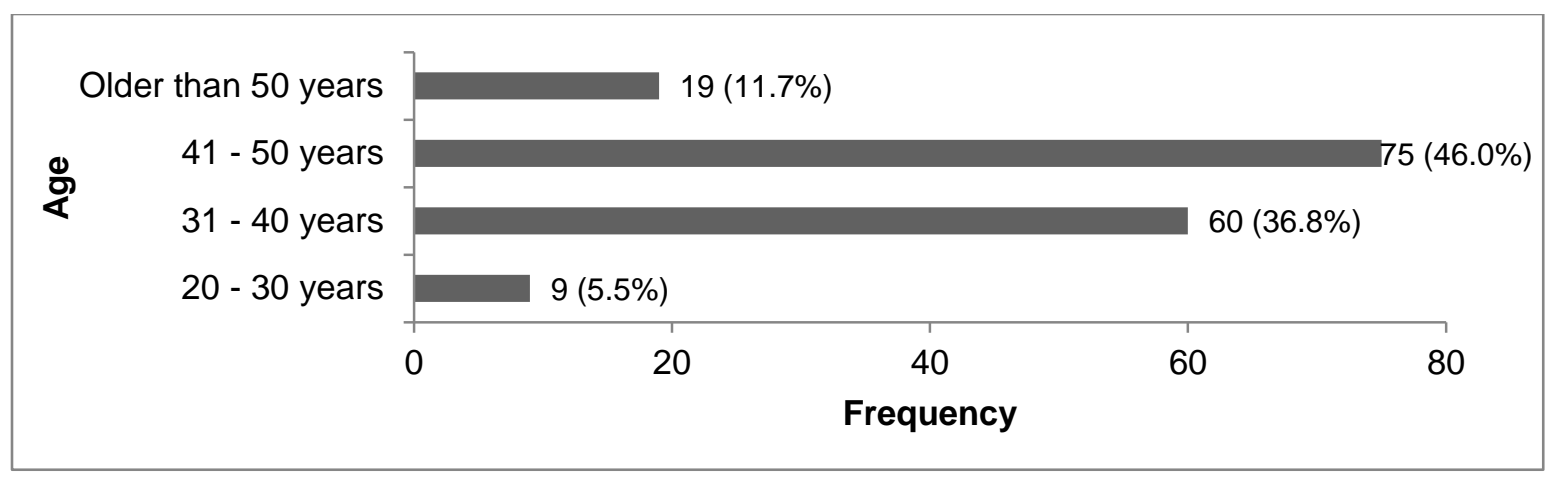

Figure 10. Age of the respondents

\section{Question 3: Work experience}

As shown in Figure 11, the largest contingent of respondents $(84 ; 51.5 \%)$ had worked for between 11 and 20 years, followed by the 41 (25.2\%) who had worked for more than 20 years. Respondents with five or fewer years' work experience represented less than $5.0 \%$ of the total.

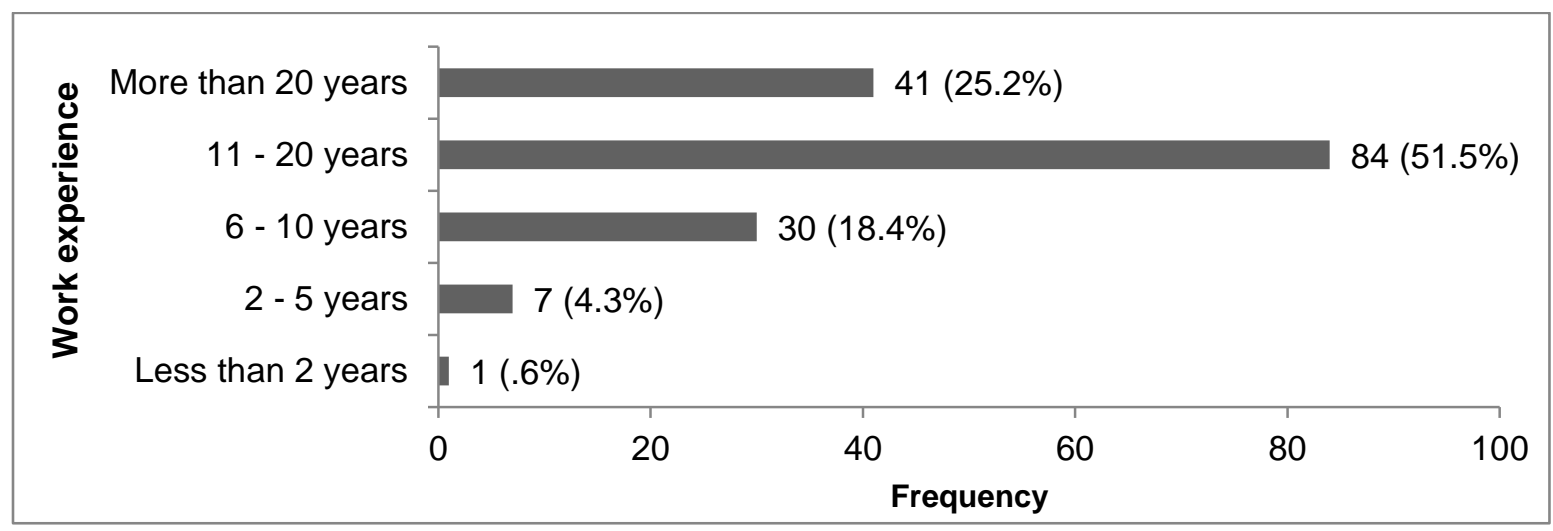

Figure 11. Work experience

\section{Question 4: Project work}

As demonstrated in Figure 12 all respondents (163; 100\%) confirmed their involvement in project work. 


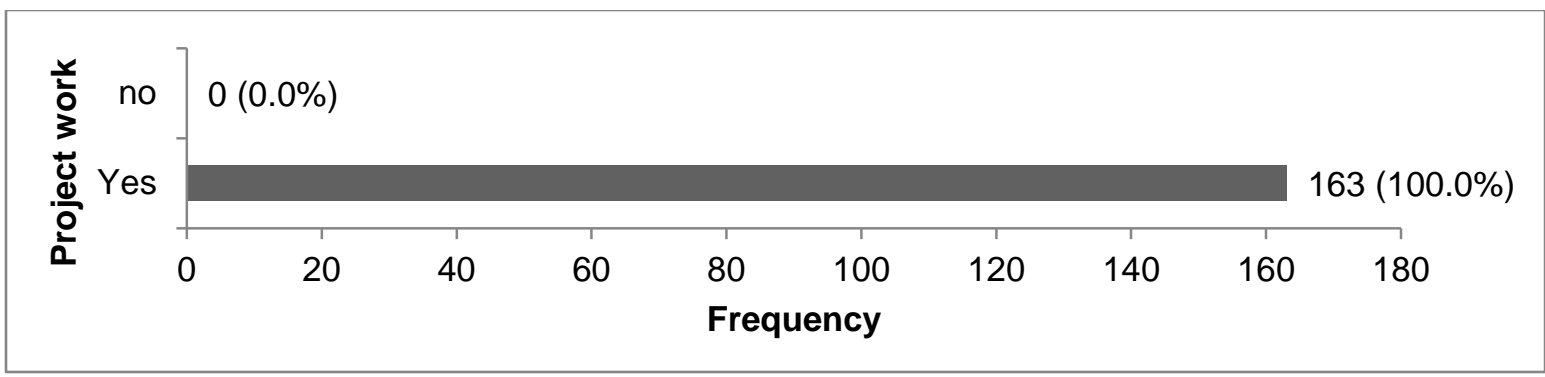

Figure 12. Project work

\section{Question 5: Last project completion}

The respondents were asked to provide the time when the last project was completed. As shown in Figure 13, the majority of the respondents 161 (98.8\%) reported that their last project was finished five years ago or less.

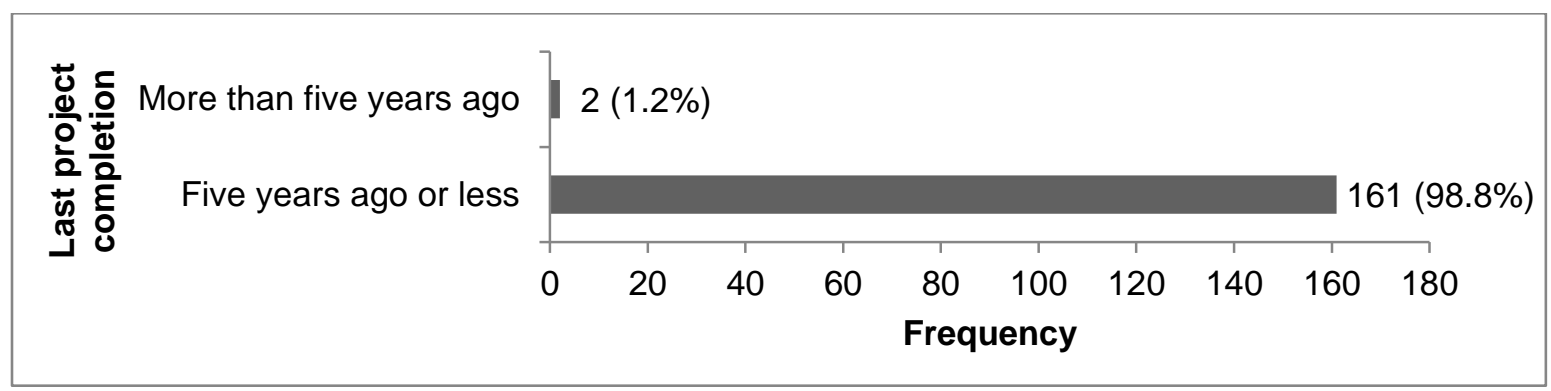

Figure 13. Last project completion

\section{Question 6: Size of project budgets}

Respondents were asked to provide the budgets of the projects they have worked with. As can be seen in Figure 14, the largest group 67 (41.1\%) reported project budgets of more than $\$ 1$ million and less than $\$ 10$ million, followed closely by the 66 (40.5\%) with more than $\$ 100,000$ and less than $\$ 1$ million. Only $12.3 \%$ of projects had budgets of more than $\$ 10$ million and less than $\$ 50$ million, $4.3 \%$ had budgets of less than $\$ 100,000$, and $1.8 \%$ had budgets of more than $\$ 50$ million. 


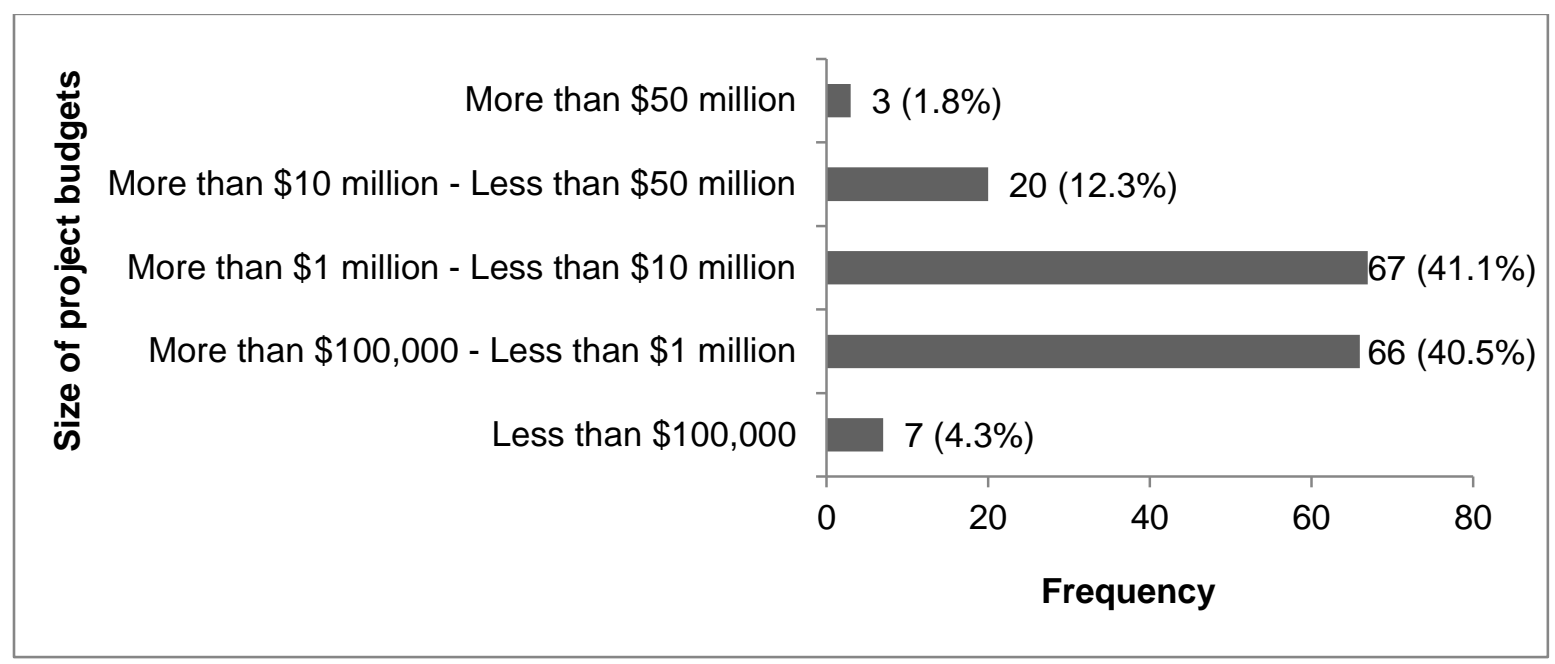

Figure 14. Size of project budgets

\section{Question 7: Function on the project}

As shown in Figure 15, most respondents $(85.3 \%)$ were project managers, followed by the $4.9 \%$ who were project coordinators, and the $4.3 \%$ who were team members. Seven responses (4.3\%) were reported as "Other," including the program manager, project executive, and consultant. Of the total, one was a steering committee member, and another was an advisor.

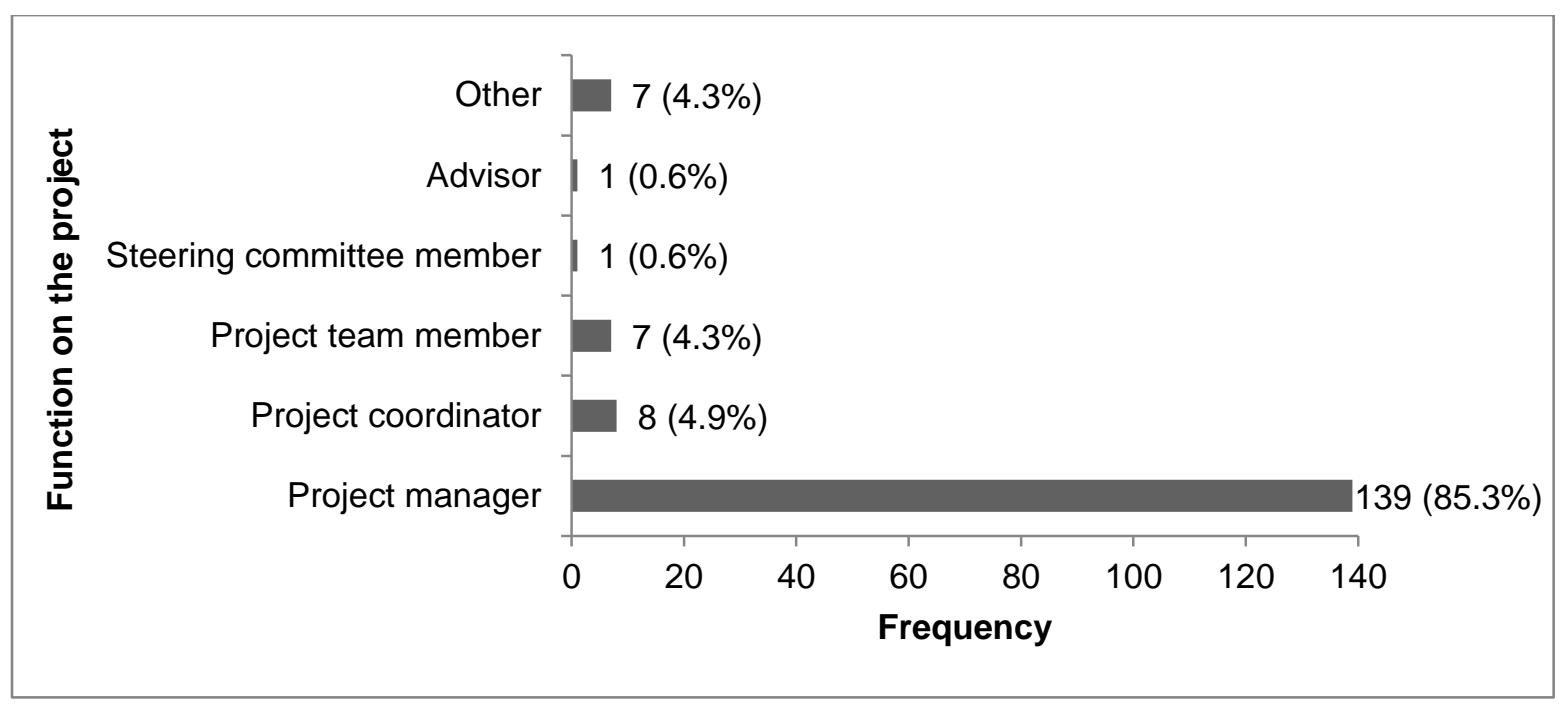

Figure 15. Function on the project 


\section{Question 8: Project type}

Most respondents worked in information technology 112 (68.7\%) and engineering (14.1\%; see Figure 16). The "Other" category, representing 8.6\%, included consulting/implementation, education, product development in telecommunication, consulting, product marketing management, business application, outsourcing, public infrastructure, publicity agency projects, capital market IT, and logistics.

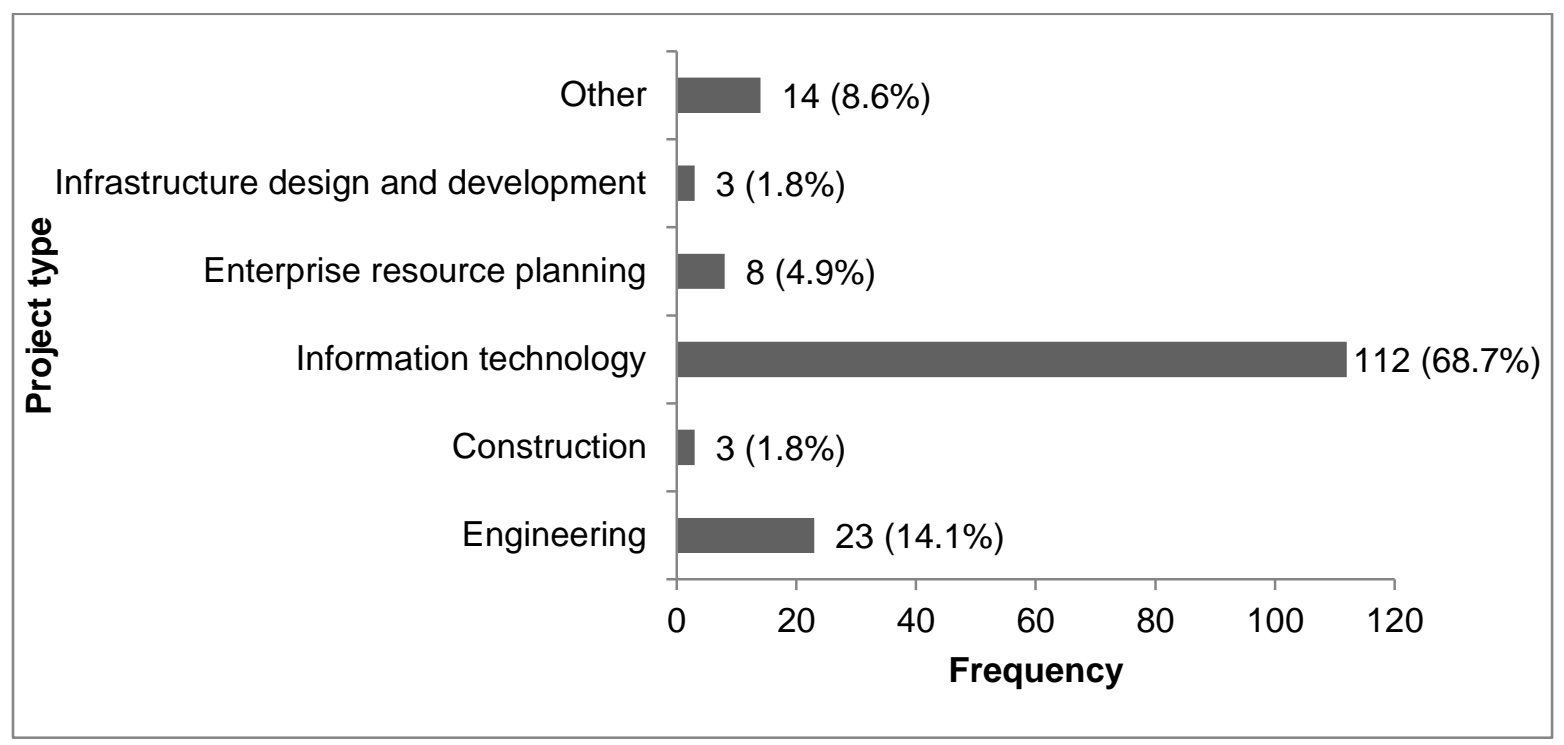

Figure 16. Project type

\section{Question 9: Project purpose}

The participants were asked to provide the client type for their projects. Approximately one half $(49.7 \%)$ of the respondents reported working for external clients, $25.8 \%$ worked for internal clients, and $24.5 \%$ worked for a combination of both (see Figure 17). 


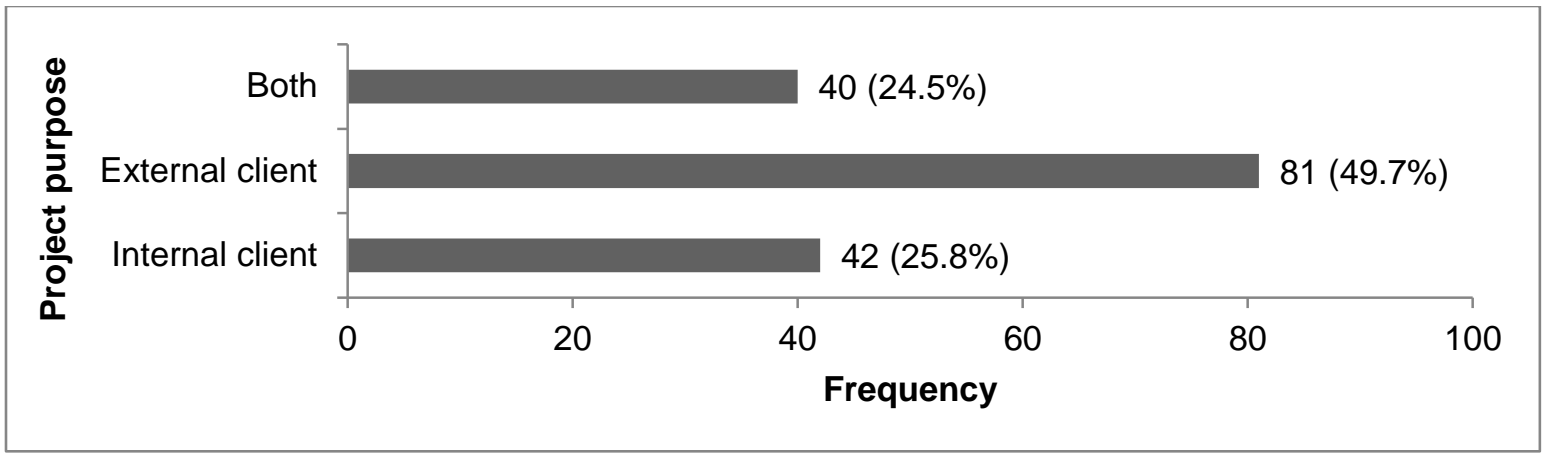

Figure 17. Project purpose

\section{Question 10: Size of project teams}

The respondents were asked to provide the average size of their project teams. As can be seen in Figure 18, the largest group (52, or 31.9\%) reported a project team size of 21 to 50 , followed closely by those (46, or $28.2 \%$ ) with 11 to 20 members; 38 respondents (23.3\%) had 5 to 10 project team members. Projects with more than 51 team members represented $12.3 \%$ of the total, and those with less than 5 members, $4.3 \%$.

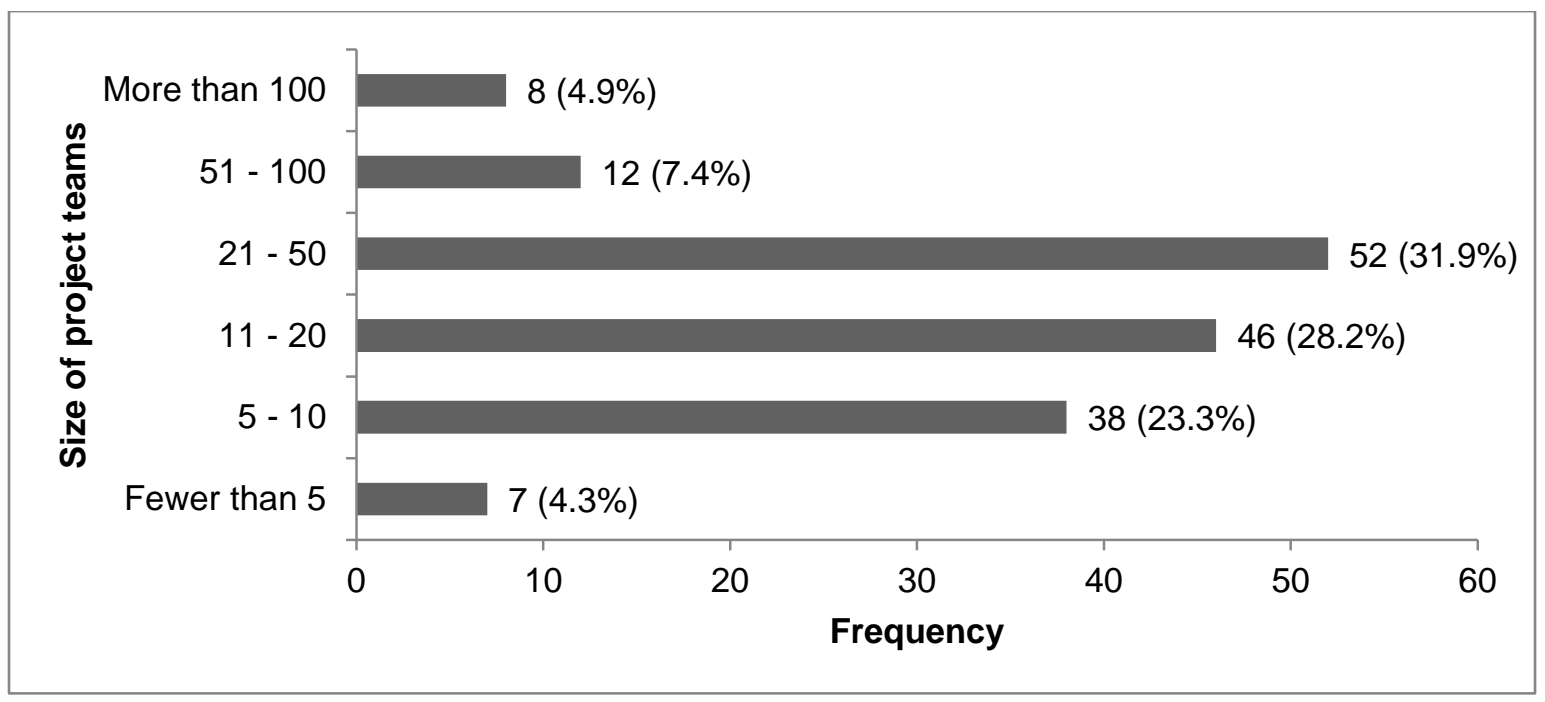

Figure 18. Size of project teams 


\section{Question 11: Project duration}

The respondents were asked to provide the average duration of the last project. As Figure 19 shows, the largest group (63, or 38.7\%) reported a project duration of 13 to 24 months, followed closely by those $(60,36.8 \%)$ reporting a duration of 7 to 12 months. Durations of fewer than six months and between 25 and 36 months both represented $9.8 \%$ of the total, and durations more than 36 months represented $4.9 \%$.

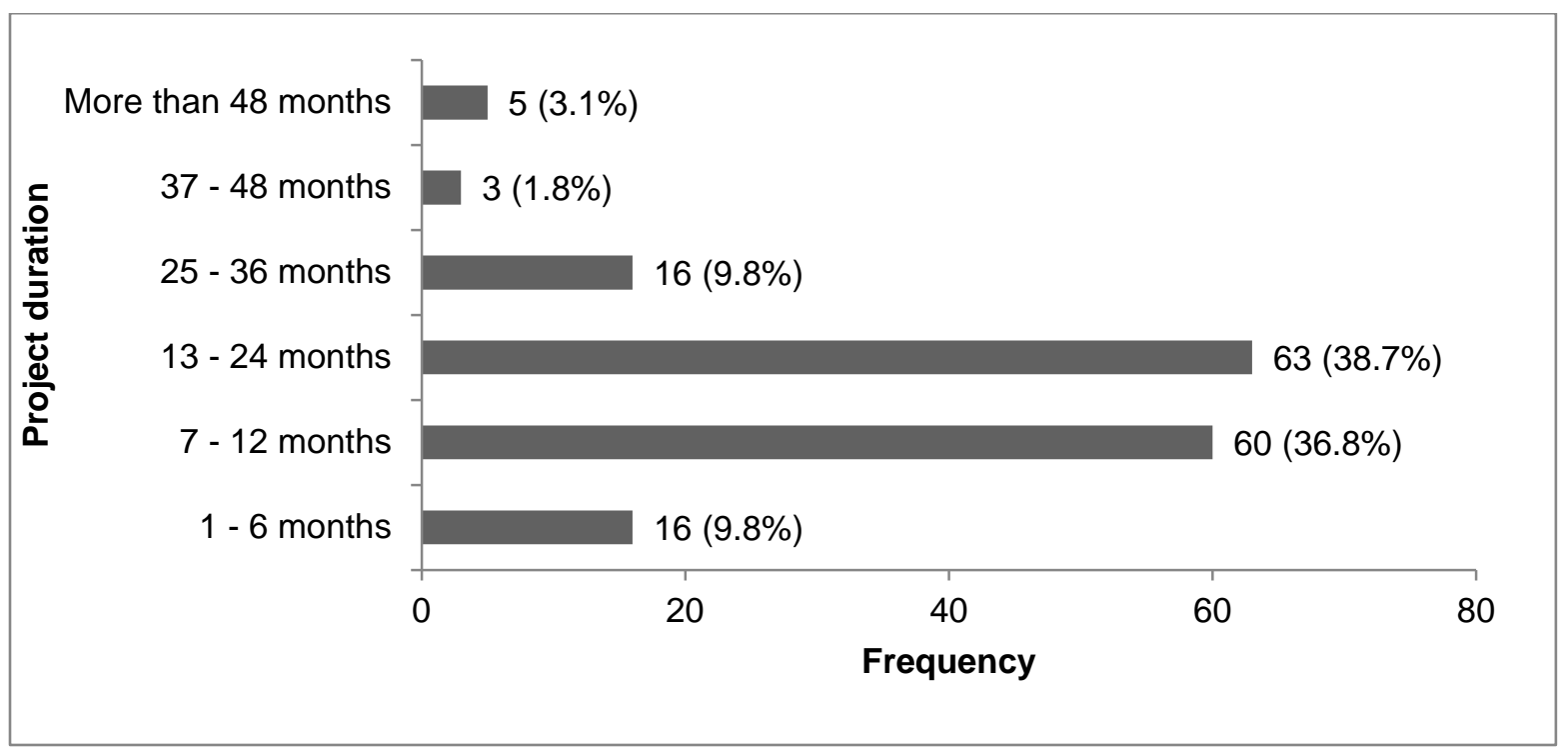

Figure 19. Project duration

\section{Question 12: Industry area}

Computers and information technology is the most common industry sector in this sample, as shown in Figure 20, followed by telecommunications, software development, engineering, and manufacturing. 


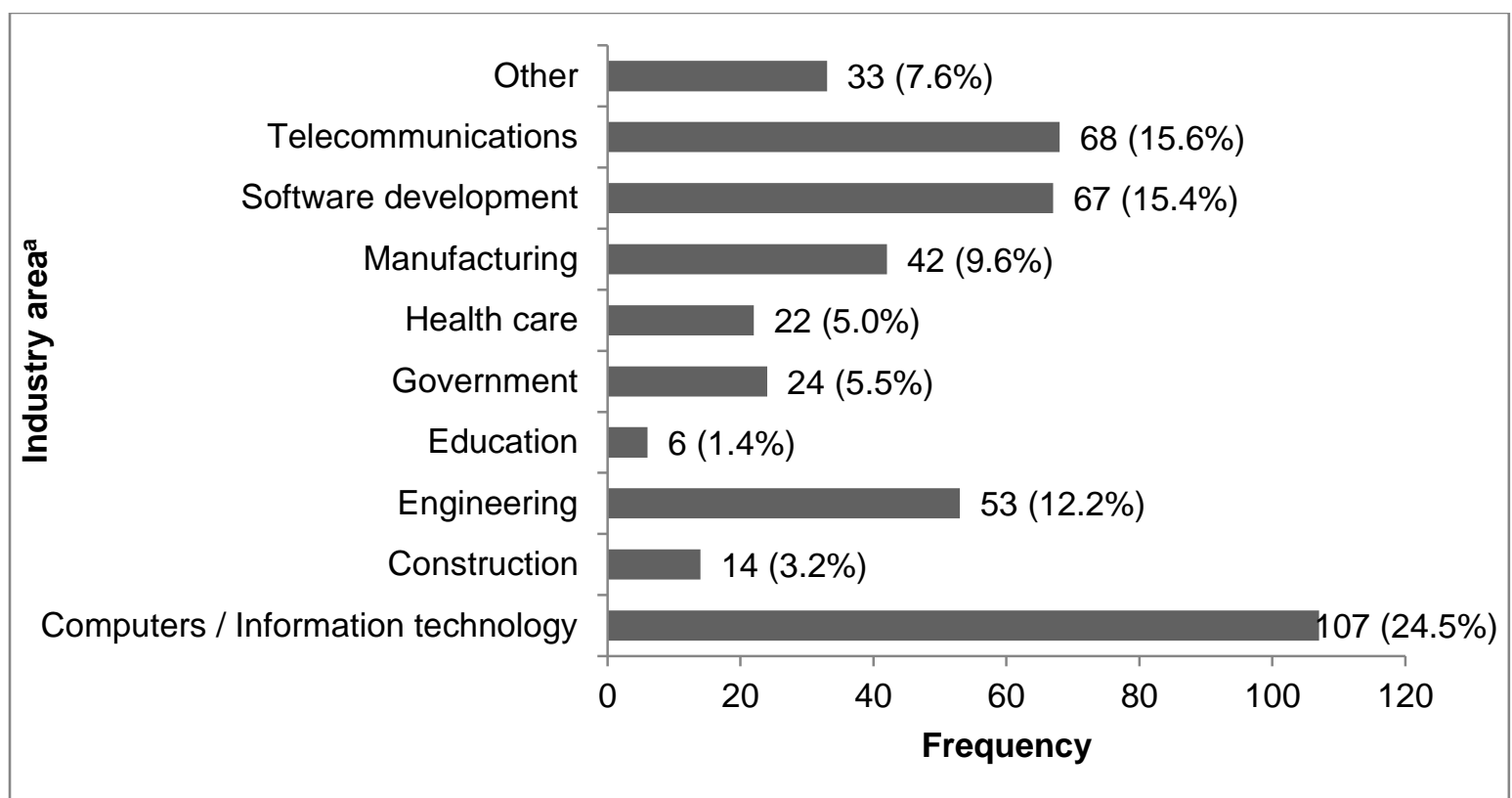

a. Dichotomy group tabulated at value 1 .

Figure 20. Industry area

\section{Question 13: Project management experience}

The respondents were asked to provide their level of experience in project management (in years). Figure 21 shows that the largest group (62, or $38.0 \%$ ) reported a project management experience of 6 to 10 years, followed closely by those (59, or $36.2 \%)$ with 11 to 20 years. Respondents with fewer than five years' experience represented $19.6 \%$ of the total, and those with more than 20 years, $6.1 \%$.

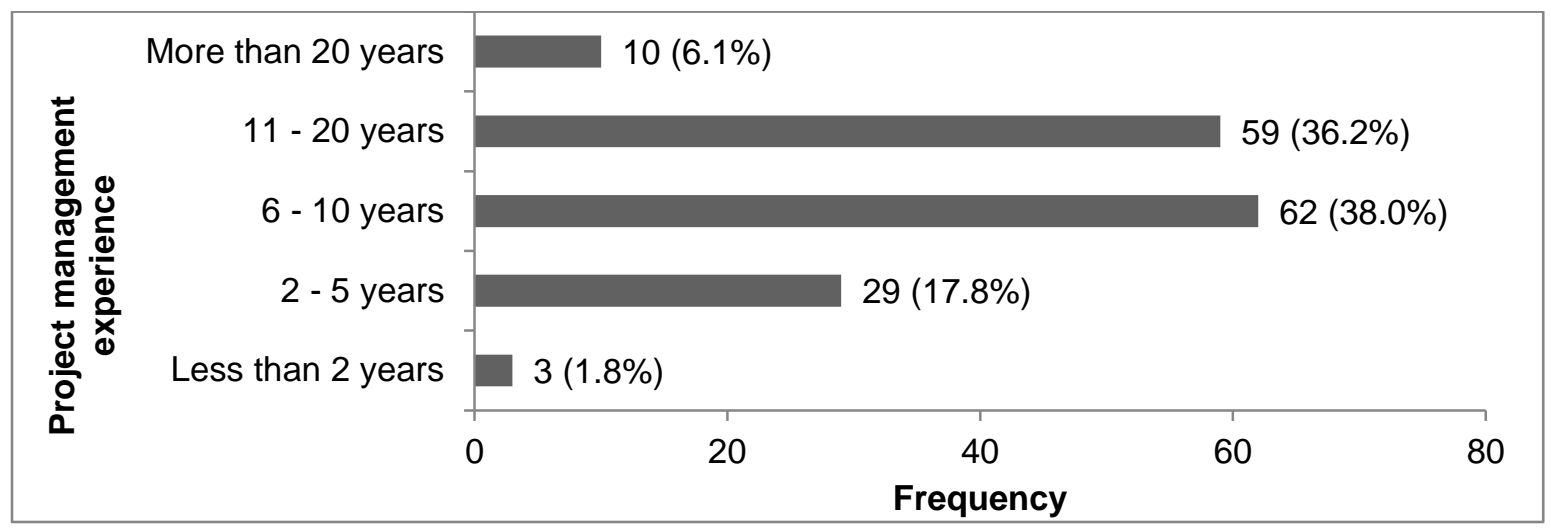

Figure 21. Project management experience 


\section{Question 14: Project management certification}

As shown in Figure 22, $86.5 \%$ of the respondents had earned a project management certification, and $13.5 \%$ had not.

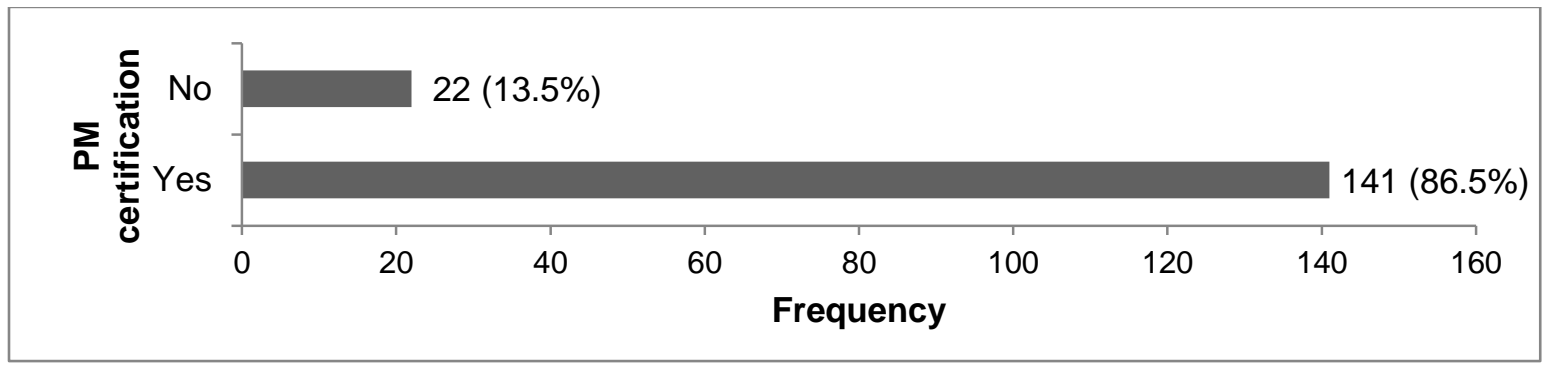

Figure 22. Project management certification

\section{Question 15: PM certification type}

Figure 23 shows that most (137, or $76.1 \%$ ) reported having earned Project Management Professional (PMP) certification. The "Other" category included certifications such as PRINCE2 Practitioner, Certified Scrum Master, PSM I, PRINCE2 Foundation, IPMA Level C, PMA-Germany, PRINCE1 Foundation Level, GPM Level D, MSP program management, Prince2, Management of Successful Programs (MSP), IPMA D+C+B, PRINCE2, CSM, and P3O.

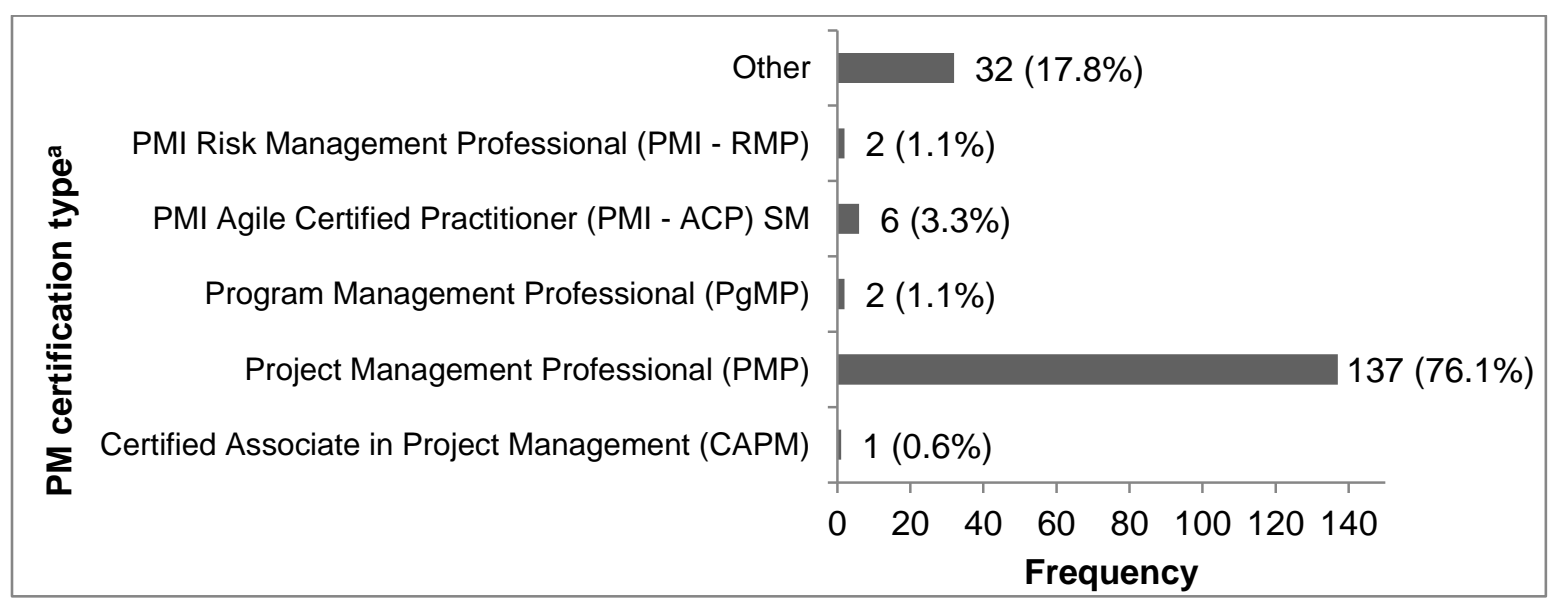

a. Dichotomy group tabulated at value 1 .

\section{Figure 23. PM certification type}




\section{Question 16: PM software used}

Most respondents (146, or 63.5\%) used Microsoft Project as their PM software (Figure 24). The "Other" category includes software such as ePM, JIRA, con10, Projektron, Actano RPlan, Primavera, CanDo, Excel, Visio, Merlin, OmniPlan, and OpenProj.

\begin{tabular}{|c|c|c|c|c|c|c|c|c|}
\hline \multirow{8}{*}{ 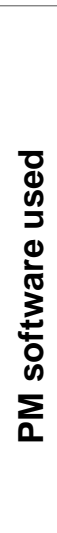 } & \multirow{2}{*}{$\begin{array}{l}\text { Other } \\
\text { 2-plan }\end{array}$} & \multicolumn{7}{|c|}{$66(28.7 \%)$} \\
\hline & & \multicolumn{7}{|l|}{$2(0.9 \%)$} \\
\hline & PLANTA Project & \multicolumn{7}{|l|}{$2(0.9 \%$} \\
\hline & Projectplace & \multicolumn{7}{|l|}{$7(3.0 \%)$} \\
\hline & Smartsheet & \multicolumn{7}{|l|}{$4(1.7)$} \\
\hline & Microsoft Project & \multicolumn{7}{|c|}{$146(63.5 \%)$} \\
\hline & Basecamp & \multicolumn{7}{|l|}{$3(1.3 \%)$} \\
\hline & & 20 & 40 & 60 & Frequency 100 & 120 & 140 & 160 \\
\hline
\end{tabular}

a. Dichotomy group tabulated at value 1 .

Figure 24. PM software used

\section{Question 17: Source of the PM software used}

As shown in Figure 25, 56.4\% of respondents used commercial software, and $7.4 \%$ used their company's own software. Using a combination of both was reported by $34.4 \%$. The "Other" category includes self-made and self-developed software.

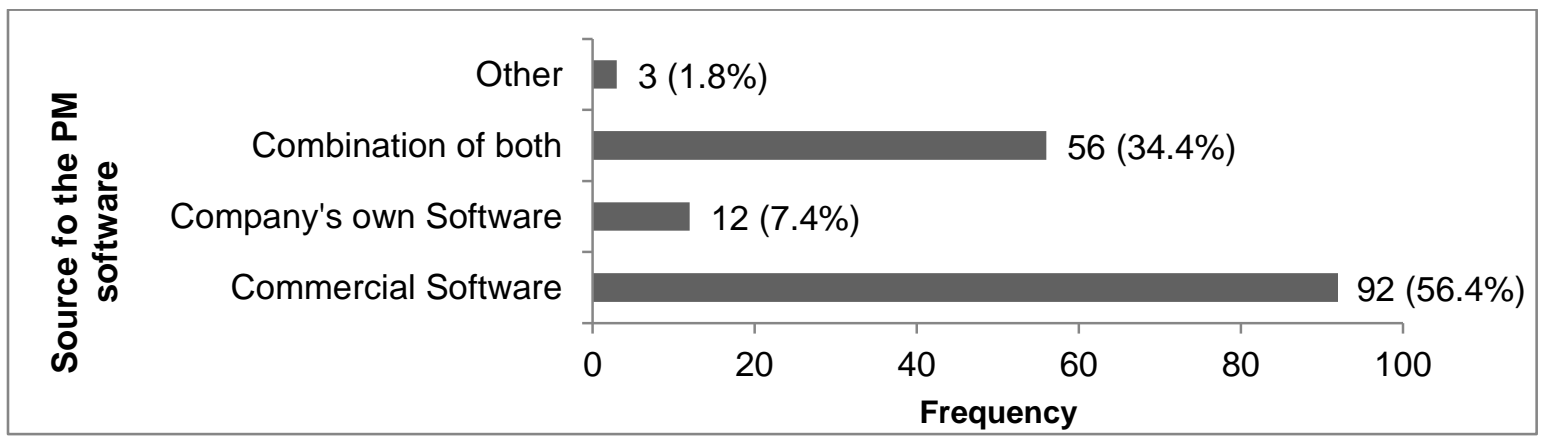

Figure 25. Source of the PM software 


\section{Question 18: Project success criteria}

A chi-square test of goodness-of-fit was performed to determine whether the project success criteria for judging projects were equally used. Usage of project success criteria was not equally distributed in the sample (see Figure 26 and Table 11).

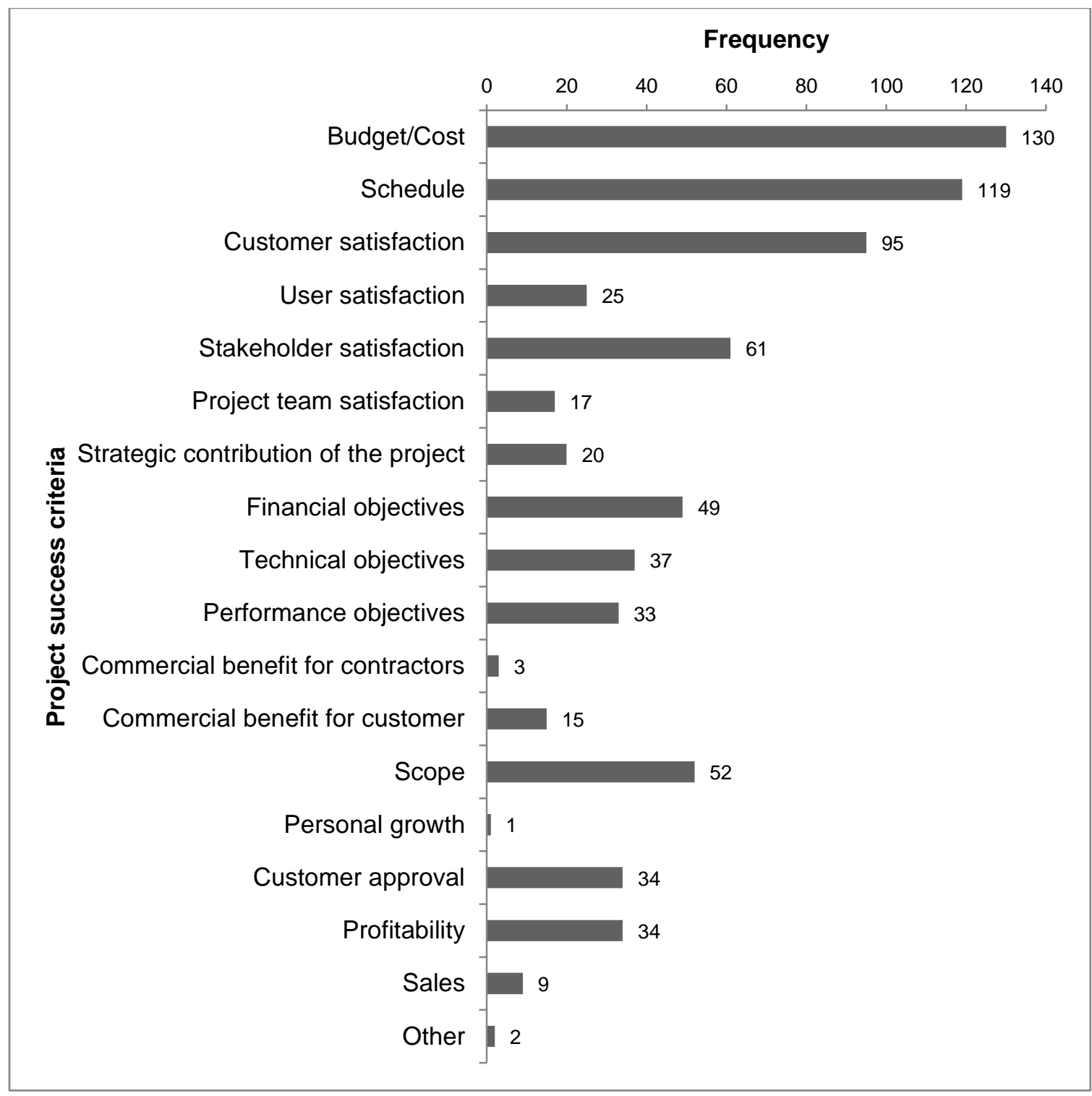

Figure 26. Project success criteria: Observed frequencies 


\section{Table 11. Project success criteria: Chi square test of goodness-of-fit}

\begin{tabular}{|c|c|c|c|c|c|}
\hline & & 0 & 1 & Total & Chi-square test \\
\hline \multirow[t]{2}{*}{ Budget / Cost } & Count & 33 & 130 & 163 & \multirow{2}{*}{$\chi^{2}(1, N=163)=57.724, p<.05$} \\
\hline & Expected Count & 81.5 & 81.5 & 163.0 & \\
\hline \multirow[t]{2}{*}{ Schedule } & Count & 44 & 119 & 163 & \multirow{2}{*}{$\chi^{2}(1, N=163)=34.509, p<.05$} \\
\hline & Expected Count & 81.5 & 81.5 & 163.0 & \\
\hline \multirow[t]{2}{*}{ Customer satisfaction } & Count & 68 & 95 & 163 & \multirow{2}{*}{$\chi^{2}(1, N=163)=4.472, p<.05$} \\
\hline & Expected Count & 81.5 & 81.5 & 163.0 & \\
\hline \multirow[t]{2}{*}{ Use satisfaction } & Count & 138 & 125 & 163 & \multirow{2}{*}{$\chi^{2}(1, N=163)=78.337, p<.05$} \\
\hline & Expected Count & 81.5 & 81.5 & 163.0 & \\
\hline \multirow[t]{2}{*}{ Stakeholder satisfaction } & Count & 102 & 61 & 163 & \multirow{2}{*}{$\chi^{2}(1, N=163)=10.313, p<.05$} \\
\hline & Expected Count & 81.5 & 81.5 & 163.0 & \\
\hline Project team & Count & 146 & 17 & 163 & \multirow{2}{*}{$\chi^{2}(1, N=163)=102.092, p<.05$} \\
\hline satisfaction & Expected Count & 81.5 & 81.5 & 163.0 & \\
\hline \multirow{2}{*}{$\begin{array}{l}\text { Strategic contribution of } \\
\text { the project }\end{array}$} & Count & 143 & 20 & 163 & \multirow{2}{*}{$\chi^{2}(1, N=163)=92.816, p<.05$} \\
\hline & Expected Count & 81.5 & 81.5 & 163.0 & \\
\hline \multirow[t]{2}{*}{ Financial objectives } & Count & 119 & 49 & 163 & \multirow{2}{*}{$\chi^{2}(1, N=163)=25.920, p<.05$} \\
\hline & Expected Count & 81.5 & 81.5 & 163.0 & \\
\hline \multirow[t]{2}{*}{ Technical objectives } & Count & 126 & 37 & 163 & \multirow{2}{*}{$\chi^{2}(1, N=163)=48.595, p<.05$} \\
\hline & Expected Count & 81.5 & 81.5 & 163.0 & \\
\hline \multirow[t]{2}{*}{ Performance objectives } & Count & 130 & 33 & 163 & \multirow{2}{*}{$\chi^{2}(1, N=163)=57.724, p<.05$} \\
\hline & Expected Count & 81.5 & 81.5 & 163.0 & \\
\hline \multirow{2}{*}{$\begin{array}{l}\text { Commercial benefit for } \\
\text { contractors }\end{array}$} & Count & 160 & 3 & 163 & \multirow{2}{*}{$\chi^{2}(1, N=163)=151.221, p<.05$} \\
\hline & Expected Count & 81.5 & 81.5 & 163.0 & \\
\hline \multirow{2}{*}{$\begin{array}{l}\text { Commercial benefit for } \\
\text { customer }\end{array}$} & Count & 148 & 15 & 163 & \multirow{2}{*}{$\chi^{2}(1, N=163)=108.521, p<.05$} \\
\hline & Expected Count & 81.5 & 81.5 & 163.0 & \\
\hline \multirow[t]{2}{*}{ Scope } & Count & 111 & 51 & 163 & \multirow{2}{*}{$\chi^{2}(1, N=163)=21.356, p<.05$} \\
\hline & Expected Count & 81.5 & 81.5 & 163.0 & \\
\hline \multirow[t]{2}{*}{ Personal growth } & Count & 162 & 1 & 163 & \multirow{2}{*}{$\chi^{2}(1, N=163)=159.025, p<.05$} \\
\hline & Expected Count & 81.5 & 81.5 & 163.0 & \\
\hline \multirow[t]{2}{*}{ Customer approval } & Count & 129 & 34 & 163 & \multirow{2}{*}{$\chi^{2}(1, N=163)=55.368, p<.05$} \\
\hline & Expected Count & 81.5 & 81.5 & 163.0 & \\
\hline Profitability & Count & 139 & 34 & 163 & $\gamma^{2}(1-N=163)=55368 n<05$ \\
\hline & Expected Count & 81.5 & 81.5 & 163.0 & $X(1, N=100)=50.000, p<.05$ \\
\hline Sales & Count & 154 & 9 & 163 & $\gamma^{2}(1 N=163)=12898$ \\
\hline & Expected Count & 81.5 & 81.5 & 163.0 & $\chi(1, N=103)=128.988, p<.05$ \\
\hline
\end{tabular}




\section{Question 19: Symptoms at the organization}

Exploratory factor analysis was used to measure the symptoms of organizational or personal factors hampering the proper execution of projects in the participants' project environment. Before factor extraction, the data gathered from 163 respondents were tested for their suitability for the exploratory factor analysis. As shown in Table 12, the Kaiser-Meyer-Olkin Measure of Sampling Adequacy was .846 , above the recommended .6 , and the Bartlett's Test of Sphericity was significant at $p<.05$. Principal component analysis was used for the factor extraction, and a varimax with Kaiser normalization was employed for the rotation of the 33 items.

Table 12. Kaiser-Meyer-Olkin Measure of Sampling Adequacy and Bartlett's Test of Sphericity

\section{KMO and Bartlett's Test}

Kaiser-Meyer-Olkin Measure of Sampling Adequacy.

Bartlett's Test of Sphericity

Approx. Chi-Square

$1,790.125$

Df

528

Sig.

.000

As shown in Table 13, the cumulative percentage of the variance was $63.4 \%$, and 10 components (factors) had an eigenvalue $>1$. Thus, the 33 questionnaire items were loaded onto those 10 factors. 
Table 13. Total Variance Explained

Total Variance Explained

\begin{tabular}{|c|c|c|c|c|c|c|}
\hline \multirow[t]{3}{*}{ Component } & \multicolumn{3}{|c|}{ Initial Eigenvalues } & \multicolumn{3}{|c|}{ Rotation Sums of Squared Loadings } \\
\hline & & $\%$ of & & & $\%$ of & \\
\hline & Total & Variance & Cumulative \% & Total & Variance & Cumulative \% \\
\hline 1 & 8.279 & 25.086 & 25.086 & 3.375 & 10.227 & 10.227 \\
\hline 2 & 1.932 & 5.856 & 30.942 & 2.558 & 7.752 & 17.979 \\
\hline 3 & 1.815 & 5.500 & 36.442 & 2.455 & 7.438 & 25.417 \\
\hline 4 & 1.601 & 4.850 & 41.293 & 2.389 & 7.240 & 32.657 \\
\hline 5 & 1.491 & 4.517 & 45.809 & 2.354 & 7.134 & 39.791 \\
\hline 6 & 1.391 & 4.214 & 50.024 & 1.961 & 5.944 & 45.735 \\
\hline 7 & 1.162 & 3.521 & 53.545 & 1.901 & 5.762 & 51.497 \\
\hline 8 & 1.134 & 3.437 & 56.982 & 1.346 & 4.077 & 55.574 \\
\hline 9 & 1.100 & 3.334 & 60.316 & 1.298 & 3.932 & 59.506 \\
\hline 10 & 1.023 & 3.099 & 63.414 & 1.290 & 3.908 & 63.414 \\
\hline 11 & .947 & 2.870 & 66.284 & & & \\
\hline 12 & .915 & 2.774 & 69.059 & & & \\
\hline 13 & .856 & 2.593 & 71.651 & & & \\
\hline 14 & .806 & 2.444 & 74.095 & & & \\
\hline 15 & .761 & 2.306 & 76.401 & & & \\
\hline 16 & .684 & 2.073 & 78.473 & & & \\
\hline 17 & .635 & 1.925 & 80.399 & & & \\
\hline 18 & .613 & 1.857 & 82.256 & & & \\
\hline 19 & .589 & 1.784 & 84.040 & & & \\
\hline 20 & .556 & 1.686 & 85.725 & & & \\
\hline 21 & .549 & 1.662 & 87.388 & & & \\
\hline 22 & .466 & 1.413 & 88.800 & & & \\
\hline 23 & .459 & 1.392 & 90.192 & & & \\
\hline 24 & .431 & 1.305 & 91.498 & & & \\
\hline 25 & .411 & 1.246 & 92.744 & & & \\
\hline 26 & .384 & 1.164 & 93.909 & & & \\
\hline 27 & .363 & 1.100 & 95.009 & & & \\
\hline 28 & .321 & .972 & 95.981 & & & \\
\hline 29 & .319 & .967 & 96.948 & & & \\
\hline 30 & .285 & .864 & 97.812 & & & \\
\hline 31 & .265 & .804 & 98.616 & & & \\
\hline 32 & .231 & .700 & 99.316 & & & \\
\hline 33 & .226 & .684 & 100.000 & & & \\
\hline
\end{tabular}

Extraction Method: Principal Component Analysis. 


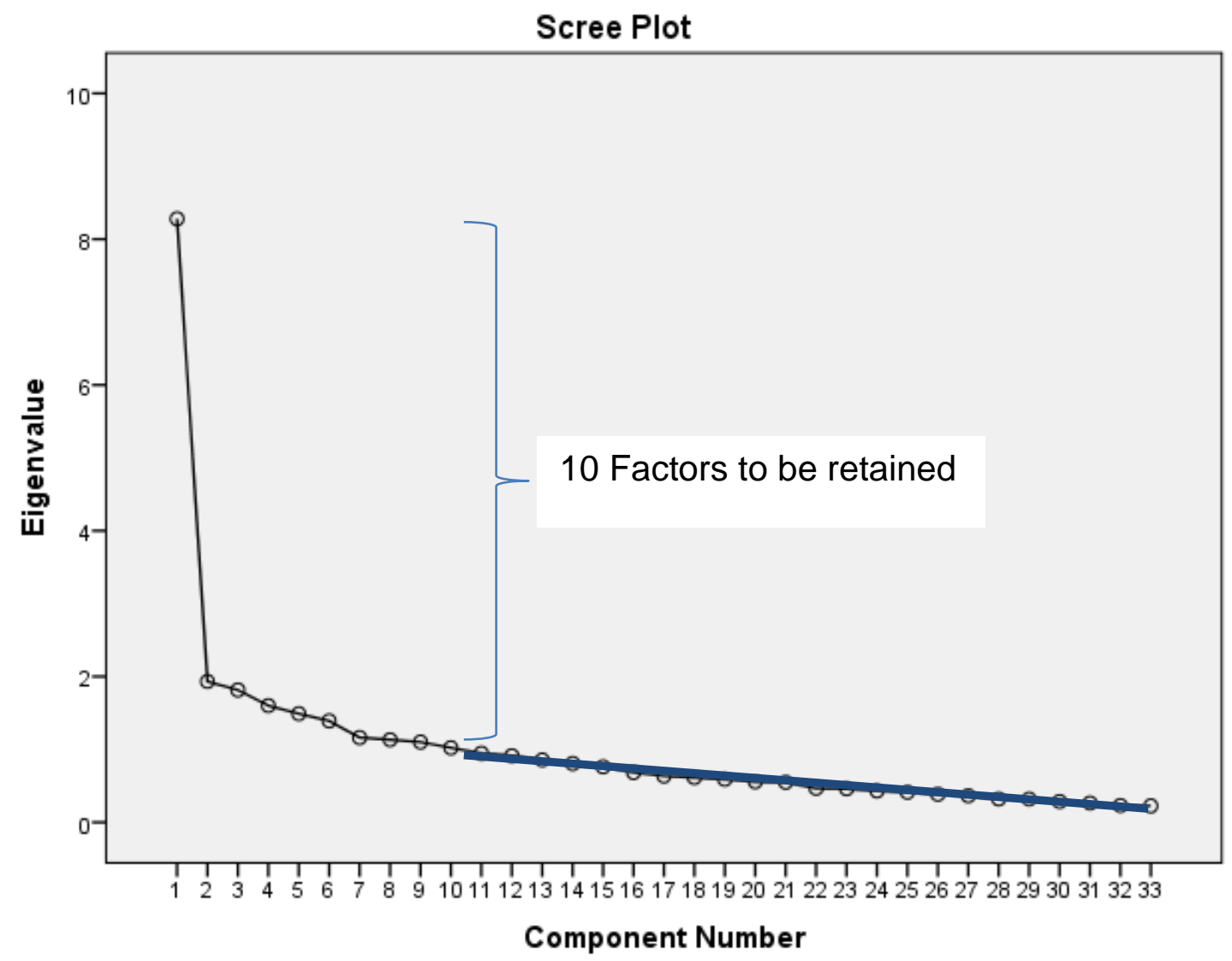

Figure 27. Scree Plot

Seven items loaded onto Factor 1. All these items are related to behavior and consequences on the project (see Rotated Component Matrix in Appendix B). This factor was labeled "Project-oriented behavior of people involved in projects." Six items loaded onto Factor 2, all related to project difficulties such as incomprehensible project measurement systems and self-impeding procedures and policies. This factor was labeled "Self-impeding organization." Three items loaded onto Factor 3, all related to the leadership team and their perceptions of the symptoms that may put the project at risk. This factor was labeled "Problemsolving oriented leadership." Five items loaded onto Factor 4, all related to team 
accountability and teamwork. This factor was labeled "Project team related project constraints." Three items loaded onto Factor 5; all were related to the project outcomes, cost, scope, quality, and schedule. This factor was labeled "Project outcomes." Three items loaded onto Factor 6, all related to the customer and to missing inputs for successful project execution. This factor was labeled "Customer-related project constraints."

Three items loaded onto Factor 7, all related to the non-availability of resources such as experts in relevant fields and/or equipment capacities. This factor was labeled "Resources-related project constraints."

\section{Question 20: PM initiating processes: contribution to project success}

A chi-square test of goodness-of-fit was performed to determine whether agreement regarding how the outputs of project management initiating processes contributed to project success was equally distributed. The level of agreement was not equally distributed in the sample (see Figure 28 and Table 14).

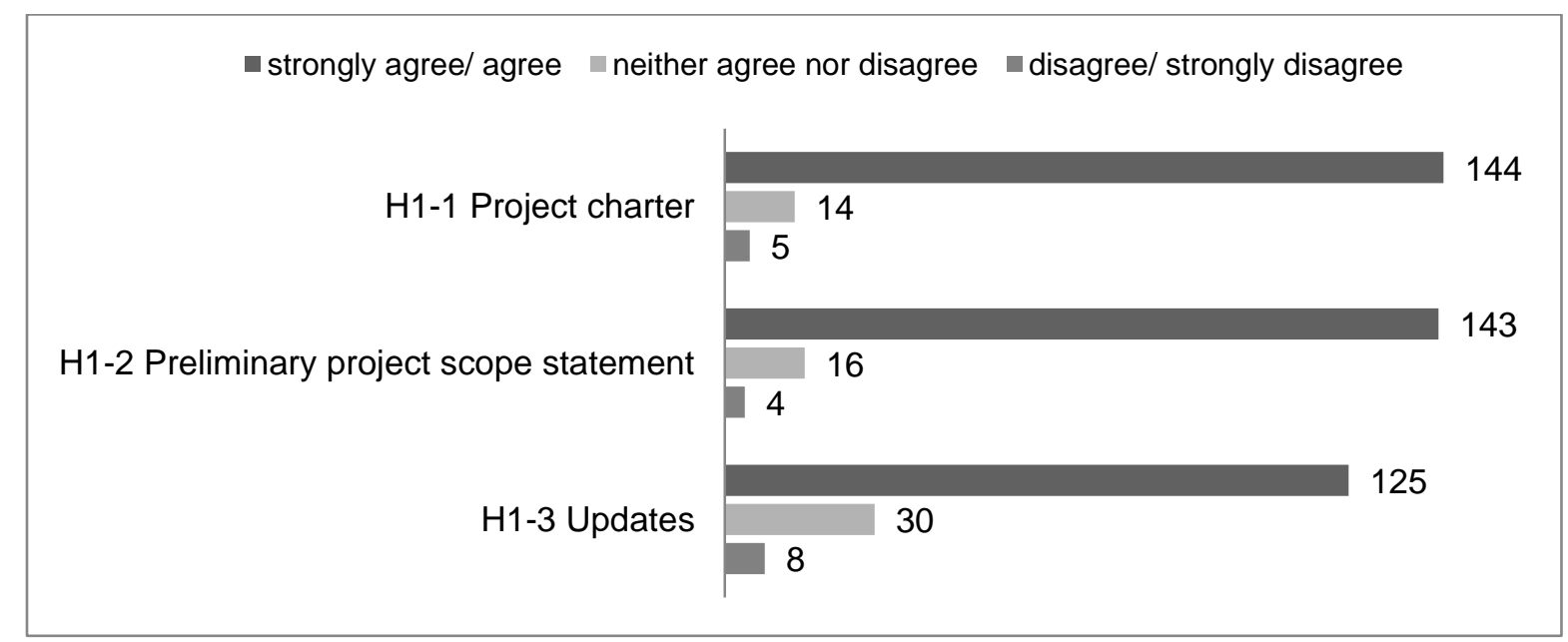

Figure 28. PM initiating processes: chi-square test of goodness-of-fit 
Table 14. PM initiating processes: hypothesis test summary

\begin{tabular}{|c|c|c|c|c|}
\hline \multicolumn{5}{|c|}{ Hypothesis Test Summary } \\
\hline & Null Hypothesis & Test & Sig. & Decision \\
\hline 1 & $\begin{array}{l}\text { The categories of } \mathrm{H} 1-1 \text { Project charter occur with } \\
\text { equal probabilities. }\end{array}$ & $\begin{array}{l}\text { One-Sample Chi- } \\
\text { Square Test }\end{array}$ & .000 & $\begin{array}{l}\text { Reject the null } \\
\text { hypothesis. }\end{array}$ \\
\hline 2 & $\begin{array}{l}\text { The categories of } \mathrm{H} 1-2 \text { Preliminary project scope } \\
\text { statement occur with equal probabilities. }\end{array}$ & $\begin{array}{l}\text { One-Sample Chi- } \\
\text { Square Test }\end{array}$ & .000 & $\begin{array}{l}\text { Reject the null } \\
\text { hypothesis. }\end{array}$ \\
\hline 3 & $\begin{array}{l}\text { The categories of } \mathrm{H} 1-3 \text { Updates occur with equal } \\
\text { probabilities. }\end{array}$ & $\begin{array}{l}\text { One-Sample Chi- } \\
\text { Square Test }\end{array}$ & .000 & $\begin{array}{l}\text { Reject the null } \\
\text { hypothesis. }\end{array}$ \\
\hline
\end{tabular}

\section{Question 21: PM planning processes: contribute to project success}

A chi-square test of goodness-of-fit was performed to determine whether agreement on how the outputs of project management planning processes contribute to project success was equally distributed. The level of agreement was not equally distributed in the sample (see Figure 29 and Table 15). 


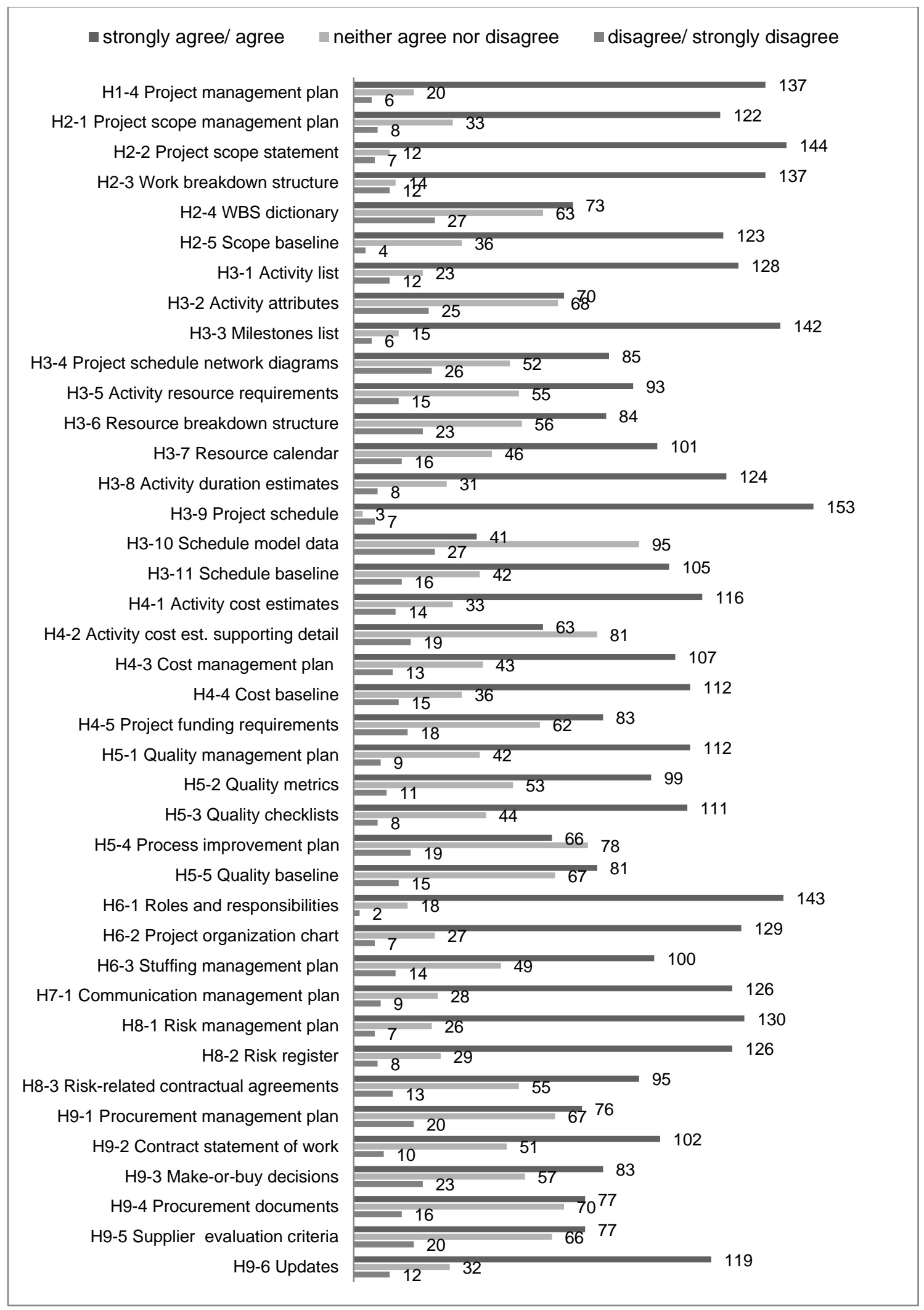

Figure 29. PM planning processes: chi-square test of goodness-of-fit 


\section{Table 15. PM planning processes: hypothesis test summary}

\begin{tabular}{|c|c|c|c|c|}
\hline \multicolumn{5}{|c|}{ Hypothesis Test Summary } \\
\hline & Null Hypothesis & Test & Sig. & Decision \\
\hline 1 & $\begin{array}{l}\text { The categories of } \mathrm{H} 1-4 \text { Project } \\
\text { Management plan occur with equal } \\
\text { probabilities. }\end{array}$ & $\begin{array}{l}\text { One-Sample } \\
\text { Chi-Square } \\
\text { Test }\end{array}$ & .000 & $\begin{array}{l}\text { Reject the null } \\
\text { hypothesis. }\end{array}$ \\
\hline 2 & $\begin{array}{l}\text { The categories of } \mathrm{H} 2-1 \text { Project scope } \\
\text { management plan occur with equal } \\
\text { probabilities. }\end{array}$ & $\begin{array}{l}\text { One-Sample } \\
\text { Chi-Square } \\
\text { Test }\end{array}$ & .000 & $\begin{array}{l}\text { Reject the null } \\
\text { hypothesis. }\end{array}$ \\
\hline 3 & $\begin{array}{l}\text { The categories of } \mathrm{H} 2-2 \text { Project scope } \\
\text { statement occur with equal probabilities. }\end{array}$ & $\begin{array}{l}\text { One-Sample } \\
\text { Chi-Square } \\
\text { Test }\end{array}$ & .000 & $\begin{array}{l}\text { Reject the null } \\
\text { hypothesis. }\end{array}$ \\
\hline 4 & $\begin{array}{l}\text { The categories of } \mathrm{H} 2-3 \text { Work breakdown } \\
\text { structure occur with equal probabilities. }\end{array}$ & $\begin{array}{l}\text { One-Sample } \\
\text { Chi-Square } \\
\text { Test }\end{array}$ & .000 & $\begin{array}{l}\text { Reject the null } \\
\text { hypothesis. }\end{array}$ \\
\hline 5 & $\begin{array}{l}\text { The categories of } \mathrm{H} 2-4 \text { WBS dictionary } \\
\text { occur with equal probabilities. }\end{array}$ & $\begin{array}{l}\text { One-Sample } \\
\text { Chi-Square } \\
\text { Test }\end{array}$ & .000 & $\begin{array}{l}\text { Reject the null } \\
\text { hypothesis. }\end{array}$ \\
\hline 6 & $\begin{array}{l}\text { The categories of } \mathrm{H} 2-5 \text { Scope baseline } \\
\text { occur with equal probabilities. }\end{array}$ & $\begin{array}{l}\text { One-Sample } \\
\text { Chi-Square } \\
\text { Test }\end{array}$ & .000 & $\begin{array}{l}\text { Reject the null } \\
\text { hypothesis. }\end{array}$ \\
\hline 7 & $\begin{array}{l}\text { The categories of H3-1 Activity list occur } \\
\text { with equal probabilities. }\end{array}$ & $\begin{array}{l}\text { One-Sample } \\
\text { Chi-Square } \\
\text { Test }\end{array}$ & .000 & $\begin{array}{l}\text { Reject the null } \\
\text { hypothesis. }\end{array}$ \\
\hline 8 & $\begin{array}{l}\text { The categories of } \mathrm{H} 3-2 \text { Activity attributes } \\
\text { occur with equal probabilities. }\end{array}$ & $\begin{array}{l}\text { One-Sample } \\
\text { Chi-Square } \\
\text { Test }\end{array}$ & .000 & $\begin{array}{l}\text { Reject the null } \\
\text { hypothesis. }\end{array}$ \\
\hline 9 & $\begin{array}{l}\text { The categories of } \mathrm{H} 3-3 \text { Milestones list occur } \\
\text { with equal probabilities. }\end{array}$ & $\begin{array}{l}\text { One-Sample } \\
\text { Chi-Square } \\
\text { Test }\end{array}$ & .000 & $\begin{array}{l}\text { Reject the null } \\
\text { hypothesis. }\end{array}$ \\
\hline 10 & $\begin{array}{l}\text { The categories of H3-4 Project schedule } \\
\text { network diagram occur with equal } \\
\text { probabilities. }\end{array}$ & $\begin{array}{l}\text { One-Sample } \\
\text { Chi-Square } \\
\text { Test }\end{array}$ & .000 & $\begin{array}{l}\text { Reject the null } \\
\text { hypothesis. }\end{array}$ \\
\hline 11 & $\begin{array}{l}\text { The categories of } \mathrm{H} 3-5 \text { Activity resources } \\
\text { requirements occur with equal probabilities. }\end{array}$ & $\begin{array}{l}\text { One-Sample } \\
\text { Chi-Square } \\
\text { Test }\end{array}$ & .000 & $\begin{array}{l}\text { Reject the null } \\
\text { hypothesis. }\end{array}$ \\
\hline 12 & $\begin{array}{l}\text { The categories of H3-6 Resource } \\
\text { breakdown structure occur with equal } \\
\text { probabilities. }\end{array}$ & $\begin{array}{l}\text { One-Sample } \\
\text { Chi-Square } \\
\text { Test }\end{array}$ & .000 & $\begin{array}{l}\text { Reject the null } \\
\text { hypothesis. }\end{array}$ \\
\hline 13 & $\begin{array}{l}\text { The categories of H3-7 Resource calendar } \\
\text { occur with equal probabilities. }\end{array}$ & $\begin{array}{l}\text { One-Sample } \\
\text { Chi-Square } \\
\text { Test }\end{array}$ & .000 & $\begin{array}{l}\text { Reject the null } \\
\text { hypothesis. }\end{array}$ \\
\hline 14 & $\begin{array}{l}\text { The categories of } \mathrm{H} 3-8 \text { Activity duration } \\
\text { estimates occur with equal probabilities. }\end{array}$ & $\begin{array}{l}\text { One-Sample } \\
\text { Chi-Square } \\
\text { Test }\end{array}$ & .000 & $\begin{array}{l}\text { Reject the null } \\
\text { hypothesis. }\end{array}$ \\
\hline 15 & $\begin{array}{l}\text { The categories of H3-9 Project schedule } \\
\text { occur with equal probabilities. }\end{array}$ & $\begin{array}{l}\text { One-Sample } \\
\text { Chi-Square } \\
\text { Test }\end{array}$ & .000 & $\begin{array}{l}\text { Reject the null } \\
\text { hypothesis. }\end{array}$ \\
\hline
\end{tabular}


16

17 egries of occur with equal probabilities.

18

The categories of H4-1 Activity cost estimates occur with equal probabilities.

The categories of H4-2 Activity cost tegories of $\mathrm{H} 4-5$ Project funding requirements occur with equal probabilities.

The categories of H5-1 Quality

23 management plan occur with equal probabilities.

24 The categories of H5-2 Quality metrics occur with equal probabilities.

25 The categories of H5-3 Quality checklists occur with equal probabilities.

The categories of H5-4 Process

26 improvement plan occur with equal probabilities.

27 The categories of H5-5 Quality baseline occur with equal probabilities.

The categories of H6-1 Roles and

28 responsibilities occur with equal probabilities.

29 The categories of $\mathrm{H6}$-2 Project organization chart occur with equal probabilities.

The categories of $\mathrm{H} 6-3$ Staffing

30 management plan occur with equal probabilities.

The categories of H7-1 Communication

31 management plan occur with equal probabilities.
One-Sample

Test

One-Sample

Chi-Square

Test

One-Sample

Chi-Square

Test

One-Sample

Chi-Square

Test

One-Sample

Chi-Square

Test

One-Sample

Chi-Square

Test

One-Sample

Chi-Square

Test

One-Sample

Chi-Square

Test

One-Sample

Chi-Square

Test

One-Sample

Chi-Square

Test

One-Sample

Chi-Square

Test

One-Sample

Chi-Square

Test

One-Sample

Chi-Square

Test

One-Sample

Chi-Square

Test

One-Sample

Chi-Square

Test

One-Sample

Chi-Square

Test

32 The categories of H8-1 Risk management

One-Sample

.000 Reject the null hypothesis.

Reject the null hypothesis.

.000

Reject the null hypothesis.

, 000

Reject the null hypothesis.

Reject the null hypothesis.

Reject the null hypothesis.

.000

Reject the null hypothesis.

.000

Reject the null hypothesis.

Reject the null hypothesis.

Reject the null hypothesis.

.000

Reject the null hypothesis.

Reject the null hypothesis.

Reject the null hypothesis.

Reject the null hypothesis.

Reject the null hypothesis.

Reject the null hypothesis. 


\begin{tabular}{|c|c|c|c|c|}
\hline & plan occur with equal probabilities. & $\begin{array}{l}\text { Chi-Square } \\
\text { Test }\end{array}$ & & hypothesis. \\
\hline 33 & $\begin{array}{l}\text { The categories of H8-2 Risk register occur } \\
\text { with equal probabilities. }\end{array}$ & $\begin{array}{l}\text { One-Sample } \\
\text { Chi-Square } \\
\text { Test }\end{array}$ & .000 & $\begin{array}{l}\text { Reject the null } \\
\text { hypothesis. }\end{array}$ \\
\hline 34 & $\begin{array}{l}\text { The categories of H8-3 Risk-related } \\
\text { contractual agreements occur with equal } \\
\text { probabilities. }\end{array}$ & $\begin{array}{l}\text { One-Sample } \\
\text { Chi-Square } \\
\text { Test }\end{array}$ & .000 & $\begin{array}{l}\text { Reject the null } \\
\text { hypothesis. }\end{array}$ \\
\hline 35 & $\begin{array}{l}\text { The categories of } \mathrm{H} 9-1 \text { Procurement } \\
\text { management plan occur with equal } \\
\text { probabilities. }\end{array}$ & $\begin{array}{l}\text { One-Sample } \\
\text { Chi-Square } \\
\text { Test }\end{array}$ & .000 & $\begin{array}{l}\text { Reject the null } \\
\text { hypothesis. }\end{array}$ \\
\hline 36 & $\begin{array}{l}\text { The categories of H9-2 Contract statement } \\
\text { of work occur with equal probabilities. }\end{array}$ & $\begin{array}{l}\text { One-Sample } \\
\text { Chi-Square } \\
\text { Test }\end{array}$ & .000 & $\begin{array}{l}\text { Reject the null } \\
\text { hypothesis. }\end{array}$ \\
\hline 37 & $\begin{array}{l}\text { The categories of H9-3 Make-or-buy } \\
\text { decisions occur with equal probabilities. }\end{array}$ & $\begin{array}{l}\text { One-Sample } \\
\text { Chi-Square } \\
\text { Test }\end{array}$ & .000 & $\begin{array}{l}\text { Reject the null } \\
\text { hypothesis. }\end{array}$ \\
\hline 38 & $\begin{array}{l}\text { The categories of H9-4 Procurement } \\
\text { documents occur with equal probabilities. }\end{array}$ & $\begin{array}{l}\text { One-Sample } \\
\text { Chi-Square } \\
\text { Test }\end{array}$ & .000 & $\begin{array}{l}\text { Reject the null } \\
\text { hypothesis. }\end{array}$ \\
\hline 39 & $\begin{array}{l}\text { The categories of H9-5 Supplier evaluation } \\
\text { criteria occur with equal probabilities. }\end{array}$ & $\begin{array}{l}\text { One-Sample } \\
\text { Chi-Square } \\
\text { Test }\end{array}$ & .000 & $\begin{array}{l}\text { Reject the null } \\
\text { hypothesis. }\end{array}$ \\
\hline 40 & $\begin{array}{l}\text { The categories of } \mathrm{H} 9-6 \text { Updates occur with } \\
\text { equal probabilities. }\end{array}$ & $\begin{array}{l}\text { One-Sample } \\
\text { Chi-Square } \\
\text { Test }\end{array}$ & .000 & $\begin{array}{l}\text { Reject the null } \\
\text { hypothesis. }\end{array}$ \\
\hline
\end{tabular}

\section{Question 22: PM executing processes: contribution to project success}
A chi-square test of goodness-of-fit was performed to determine whether agreement on how project management executing process outputs contribute to project success was equally distributed. The level of agreement was not equally distributed in the sample (see Figure 30 and Table 16). 


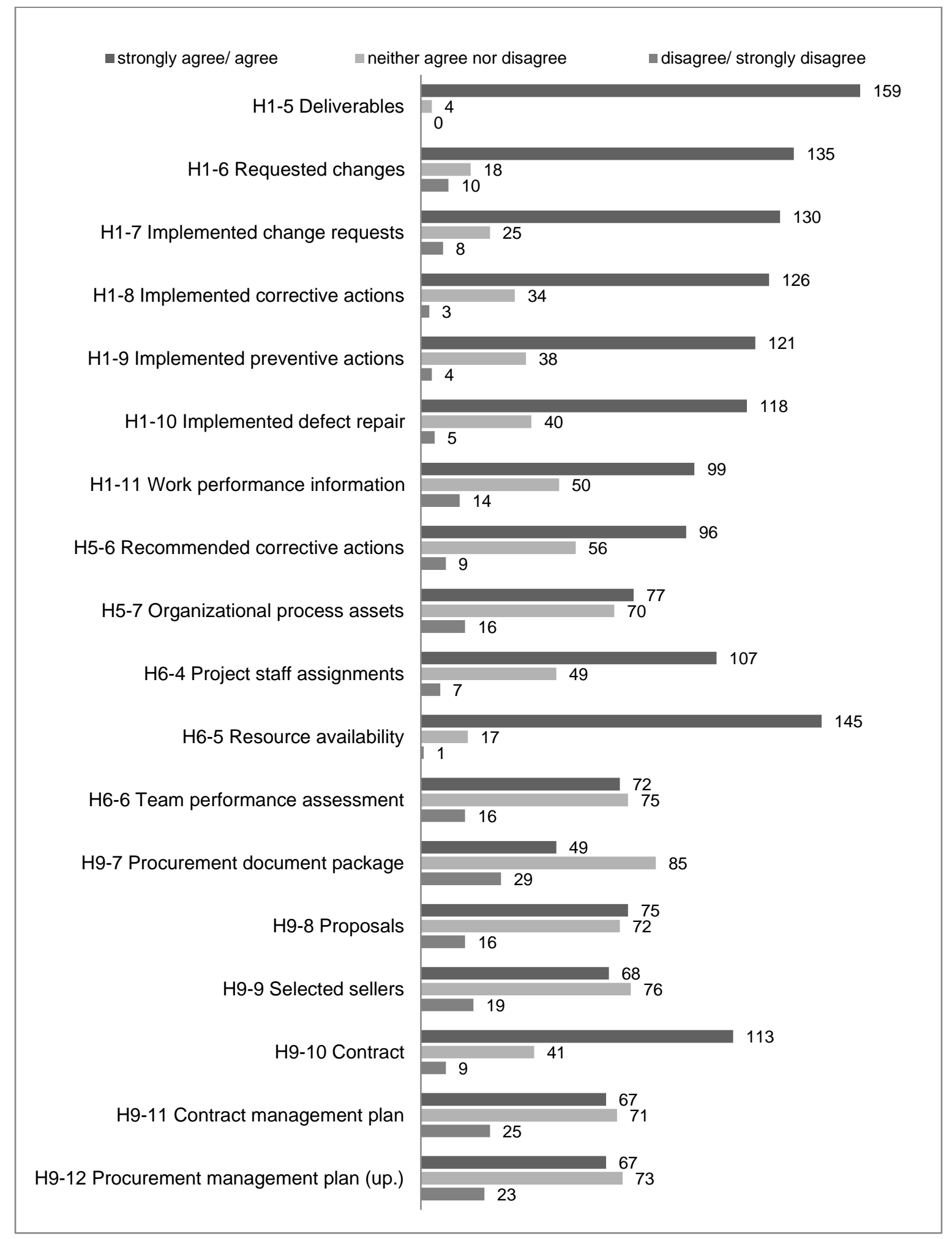

Figure 30. PM executing processes: chi-square test of goodness-of-fit 


\section{Table 16. PM executing processes: hypothesis test summary}

\begin{tabular}{|c|c|c|c|c|}
\hline \multicolumn{5}{|c|}{ Hypothesis Test Summary } \\
\hline & Null Hypothesis & Test & Sig. & Decision \\
\hline 1 & $\begin{array}{l}\text { The categories of } \mathrm{H} 1-5 \text { Deliverables occur } \\
\text { with equal probabilities. }\end{array}$ & $\begin{array}{l}\text { One-Sample } \\
\text { Chi-Square Test }\end{array}$ & .000 & $\begin{array}{l}\text { Reject the null } \\
\text { hypothesis. }\end{array}$ \\
\hline 2 & $\begin{array}{l}\text { The categories of H1-6 Requested changes } \\
\text { occur with equal probabilities. }\end{array}$ & $\begin{array}{l}\text { One-Sample } \\
\text { Chi-Square Test }\end{array}$ & .000 & $\begin{array}{l}\text { Reject the null } \\
\text { hypothesis. }\end{array}$ \\
\hline 3 & $\begin{array}{l}\text { The categories of } \mathrm{H} 1-7 \text { Implemented change } \\
\text { requests occur with equal probabilities. }\end{array}$ & $\begin{array}{l}\text { One-Sample } \\
\text { Chi-Square Test }\end{array}$ & .000 & $\begin{array}{l}\text { Reject the null } \\
\text { hypothesis. }\end{array}$ \\
\hline 4 & $\begin{array}{l}\text { The categories of } \mathrm{H} 1-8 \text { Implemented } \\
\text { corrective actions occur with equal } \\
\text { probabilities. }\end{array}$ & $\begin{array}{l}\text { One-Sample } \\
\text { Chi-Square Test }\end{array}$ & .000 & $\begin{array}{l}\text { Reject the null } \\
\text { hypothesis. }\end{array}$ \\
\hline 5 & $\begin{array}{l}\text { The categories of } \mathrm{H} 1-9 \text { Implemented } \\
\text { preventive actions occur with equal } \\
\text { probabilities. }\end{array}$ & $\begin{array}{l}\text { One-Sample } \\
\text { Chi-Square Test }\end{array}$ & .000 & $\begin{array}{l}\text { Reject the null } \\
\text { hypothesis. }\end{array}$ \\
\hline 6 & $\begin{array}{l}\text { The categories of } \mathrm{H} 1-10 \text { Implemented defect } \\
\text { repair occur with equal probabilities. }\end{array}$ & $\begin{array}{l}\text { One-Sample } \\
\text { Chi-Square Test }\end{array}$ & .000 & $\begin{array}{l}\text { Reject the null } \\
\text { hypothesis. }\end{array}$ \\
\hline 7 & $\begin{array}{l}\text { The categories of } \mathrm{H} 1-11 \text { Work performance } \\
\text { information occur with equal probabilities. }\end{array}$ & $\begin{array}{l}\text { One-Sample } \\
\text { Chi-Square Test }\end{array}$ & .000 & $\begin{array}{l}\text { Reject the null } \\
\text { hypothesis. }\end{array}$ \\
\hline 8 & $\begin{array}{l}\text { The categories of H5-6 Recommended } \\
\text { corrective actions occur with equal } \\
\text { probabilities. }\end{array}$ & $\begin{array}{l}\text { One-Sample } \\
\text { Chi-Square Test }\end{array}$ & .000 & $\begin{array}{l}\text { Reject the null } \\
\text { hypothesis. }\end{array}$ \\
\hline 9 & $\begin{array}{l}\text { The categories of H5-7 Organizational process } \\
\text { assets occur with equal probabilities. }\end{array}$ & $\begin{array}{l}\text { One-Sample } \\
\text { Chi-Square Test }\end{array}$ & .000 & $\begin{array}{l}\text { Reject the null } \\
\text { hypothesis. }\end{array}$ \\
\hline 10 & $\begin{array}{l}\text { The categories of } \mathrm{H} 6-4 \text { Project staff } \\
\text { assignments occur with equal probabilities. }\end{array}$ & $\begin{array}{l}\text { One-Sample } \\
\text { Chi-Square Test }\end{array}$ & .000 & $\begin{array}{l}\text { Reject the null } \\
\text { hypothesis. }\end{array}$ \\
\hline 11 & $\begin{array}{l}\text { The categories of } \mathrm{H} 6-5 \text { Resource availability } \\
\text { occur with equal probabilities. }\end{array}$ & $\begin{array}{l}\text { One-Sample } \\
\text { Chi-Square Test }\end{array}$ & .000 & $\begin{array}{l}\text { Reject the null } \\
\text { hypothesis. }\end{array}$ \\
\hline 12 & $\begin{array}{l}\text { The categories of H6-6 Team performance } \\
\text { assessment occur with equal probabilities. }\end{array}$ & $\begin{array}{l}\text { One-Sample } \\
\text { Chi-Square Test }\end{array}$ & .000 & $\begin{array}{l}\text { Reject the null } \\
\text { hypothesis. }\end{array}$ \\
\hline 13 & $\begin{array}{l}\text { The categories of H9-7 Procurement } \\
\text { document package occur with equal } \\
\text { probabilities. }\end{array}$ & $\begin{array}{l}\text { One-Sample } \\
\text { Chi-Square Test }\end{array}$ & .000 & $\begin{array}{l}\text { Reject the null } \\
\text { hypothesis. }\end{array}$ \\
\hline 14 & $\begin{array}{l}\text { The categories of H9-8 Proposals occur with } \\
\text { equal probabilities. }\end{array}$ & $\begin{array}{l}\text { One-Sample } \\
\text { Chi-Square Test }\end{array}$ & .000 & $\begin{array}{l}\text { Reject the null } \\
\text { hypothesis. }\end{array}$ \\
\hline 15 & $\begin{array}{l}\text { The categories of H9-9 Selected sellers occur } \\
\text { with equal probabilities. }\end{array}$ & $\begin{array}{l}\text { One-Sample } \\
\text { Chi-Square Test }\end{array}$ & .000 & $\begin{array}{l}\text { Reject the null } \\
\text { hypothesis. }\end{array}$ \\
\hline 16 & $\begin{array}{l}\text { The categories of } \mathrm{H} 9-10 \text { Contract occur with } \\
\text { equal probabilities. }\end{array}$ & $\begin{array}{l}\text { One-Sample } \\
\text { Chi-Square Test }\end{array}$ & .000 & $\begin{array}{l}\text { Reject the null } \\
\text { hypothesis. }\end{array}$ \\
\hline 17 & $\begin{array}{l}\text { The categories of } \mathrm{H} 9-11 \text { Contract } \\
\text { management plan occur with equal } \\
\text { probabilities. }\end{array}$ & $\begin{array}{l}\text { One-Sample } \\
\text { Chi-Square Test }\end{array}$ & .000 & $\begin{array}{l}\text { Reject the null } \\
\text { hypothesis. }\end{array}$ \\
\hline 18 & $\begin{array}{l}\text { The categories of H9-12 Procurement } \\
\text { management plan (update) occur with equal } \\
\text { probabilities. }\end{array}$ & $\begin{array}{l}\text { One-Sample } \\
\text { Chi-Square Test }\end{array}$ & .000 & $\begin{array}{l}\text { Reject the null } \\
\text { hypothesis. }\end{array}$ \\
\hline
\end{tabular}




\section{Question 23: PM controlling and monitoring processes: contribution to project success}

A chi-square test of goodness-of-fit was performed to determine whether the agreement on how project management controlling and monitoring processes outputs contribute to project success was equally distributed. The level of agreement was not equally distributed in the sample (see Figure 31 and Table 17).

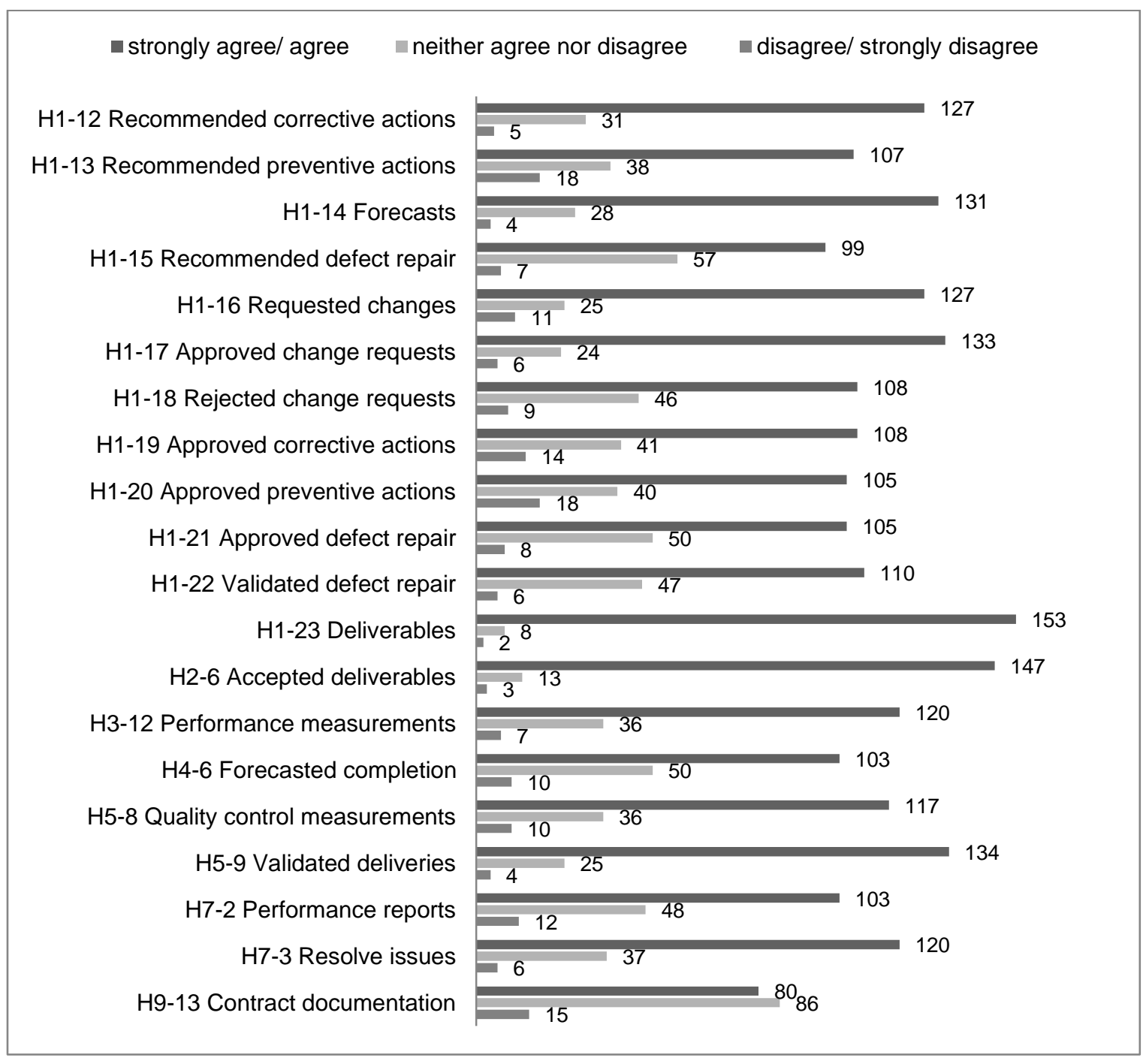

Figure 31. PM controlling and monitoring processes: chi-square test of goodness-of-fit 


\section{Table 17. PM controlling and monitoring processes: hypothesis test summary}

\begin{tabular}{|c|c|c|c|c|}
\hline \multicolumn{5}{|c|}{ Hypothesis Test Summary } \\
\hline & Null Hypothesis & Test & Sig. & Decision \\
\hline 1 & $\begin{array}{l}\text { The categories of } \mathrm{H} 1-12 \text { Recommended } \\
\text { corrective actions occur with equal probabilities. }\end{array}$ & $\begin{array}{l}\text { One-Sample } \\
\text { Chi-Square Test }\end{array}$ & .000 & $\begin{array}{l}\text { Reject the null } \\
\text { hypothesis. }\end{array}$ \\
\hline 2 & $\begin{array}{l}\text { The categories of } \mathrm{H} 1-13 \text { Recommended } \\
\text { preventive actions occur with equal probabilities. }\end{array}$ & $\begin{array}{l}\text { One-Sample } \\
\text { Chi-Square Test }\end{array}$ & .000 & $\begin{array}{l}\text { Reject the null } \\
\text { hypothesis. }\end{array}$ \\
\hline 3 & $\begin{array}{l}\text { The categories of } \mathrm{H} 1-14 \text { Forecasts occur with } \\
\text { equal probabilities. }\end{array}$ & $\begin{array}{l}\text { One-Sample } \\
\text { Chi-Square Test }\end{array}$ & .000 & $\begin{array}{l}\text { Reject the null } \\
\text { hypothesis. }\end{array}$ \\
\hline 4 & $\begin{array}{l}\text { The categories of } \mathrm{H} 1-15 \text { Recommended defect } \\
\text { repair occur with equal probabilities. }\end{array}$ & $\begin{array}{l}\text { One-Sample } \\
\text { Chi-Square Test }\end{array}$ & .000 & $\begin{array}{l}\text { Reject the null } \\
\text { hypothesis. }\end{array}$ \\
\hline 5 & $\begin{array}{l}\text { The categories of } \mathrm{H} 1-16 \text { Requested changes } \\
\text { occur with equal probabilities. }\end{array}$ & $\begin{array}{l}\text { One-Sample } \\
\text { Chi-Square Test }\end{array}$ & .000 & $\begin{array}{l}\text { Reject the null } \\
\text { hypothesis. }\end{array}$ \\
\hline 6 & $\begin{array}{l}\text { The categories of H1-17 Approved change } \\
\text { requests occur with equal probabilities. }\end{array}$ & $\begin{array}{l}\text { One-Sample } \\
\text { Chi-Square Test }\end{array}$ & .000 & $\begin{array}{l}\text { Reject the null } \\
\text { hypothesis. }\end{array}$ \\
\hline 7 & $\begin{array}{l}\text { The categories of } \mathrm{H} 1-18 \text { Rejected change } \\
\text { requests occur with equal probabilities. }\end{array}$ & $\begin{array}{l}\text { One-Sample } \\
\text { Chi-Square Test }\end{array}$ & .000 & $\begin{array}{l}\text { Reject the null } \\
\text { hypothesis. }\end{array}$ \\
\hline 8 & $\begin{array}{l}\text { The categories of } \mathrm{H} 1-19 \text { Approved corrective } \\
\text { actions occur with equal probabilities. }\end{array}$ & $\begin{array}{l}\text { One-Sample } \\
\text { Chi-Square Test }\end{array}$ & .000 & $\begin{array}{l}\text { Reject the null } \\
\text { hypothesis. }\end{array}$ \\
\hline 9 & $\begin{array}{l}\text { The categories of } \mathrm{H} 1-20 \text { Approved preventive } \\
\text { actions occur with equal probabilities. }\end{array}$ & $\begin{array}{l}\text { One-Sample } \\
\text { Chi-Square Test }\end{array}$ & .000 & $\begin{array}{l}\text { Reject the null } \\
\text { hypothesis. }\end{array}$ \\
\hline $\begin{array}{l}1 \\
0\end{array}$ & $\begin{array}{l}\text { The categories of } \mathrm{H} 1-21 \text { Approved defect repair } \\
\text { occur with equal probabilities. }\end{array}$ & $\begin{array}{l}\text { One-Sample } \\
\text { Chi-Square Test }\end{array}$ & .000 & $\begin{array}{l}\text { Reject the null } \\
\text { hypothesis. }\end{array}$ \\
\hline $\begin{array}{l}1 \\
1\end{array}$ & $\begin{array}{l}\text { The categories of } \mathrm{H} 1-22 \text { Validated defect repair } \\
\text { occur with equal probabilities. }\end{array}$ & $\begin{array}{l}\text { One-Sample } \\
\text { Chi-Square Test }\end{array}$ & .000 & $\begin{array}{l}\text { Reject the null } \\
\text { hypothesis. }\end{array}$ \\
\hline $\begin{array}{l}1 \\
2\end{array}$ & $\begin{array}{l}\text { The categories of H1-23 Deliverables occur with } \\
\text { equal probabilities. }\end{array}$ & $\begin{array}{l}\text { One-Sample } \\
\text { Chi-Square Test }\end{array}$ & .000 & $\begin{array}{l}\text { Reject the null } \\
\text { hypothesis. }\end{array}$ \\
\hline $\begin{array}{l}1 \\
3\end{array}$ & $\begin{array}{l}\text { The categories of } \mathrm{H} 2-6 \text { Accepted deliverables } \\
\text { occur with equal probabilities. }\end{array}$ & $\begin{array}{l}\text { One-Sample } \\
\text { Chi-Square Test }\end{array}$ & .000 & $\begin{array}{l}\text { Reject the null } \\
\text { hypothesis. }\end{array}$ \\
\hline $\begin{array}{l}1 \\
4\end{array}$ & $\begin{array}{l}\text { The categories of H3-12 Performance } \\
\text { measurements occur with equal probabilities. }\end{array}$ & $\begin{array}{l}\text { One-Sample } \\
\text { Chi-Square Test }\end{array}$ & .000 & $\begin{array}{l}\text { Reject the null } \\
\text { hypothesis. }\end{array}$ \\
\hline $\begin{array}{l}1 \\
5\end{array}$ & $\begin{array}{l}\text { The categories of H4-6 Forecasted completion } \\
\text { occur with equal probabilities. }\end{array}$ & $\begin{array}{l}\text { One-Sample } \\
\text { Chi-Square Test }\end{array}$ & .000 & $\begin{array}{l}\text { Reject the null } \\
\text { hypothesis. }\end{array}$ \\
\hline $\begin{array}{l}1 \\
6\end{array}$ & $\begin{array}{l}\text { The categories of H5-8 Quality control } \\
\text { measurements occur with equal probabilities. }\end{array}$ & $\begin{array}{l}\text { One-Sample } \\
\text { Chi-Square Test }\end{array}$ & .000 & $\begin{array}{l}\text { Reject the null } \\
\text { hypothesis. }\end{array}$ \\
\hline $\begin{array}{l}1 \\
7\end{array}$ & $\begin{array}{l}\text { The categories of H5-9 Validated deliverables } \\
\text { occur with equal probabilities. }\end{array}$ & $\begin{array}{l}\text { One-Sample } \\
\text { Chi-Square Test }\end{array}$ & .000 & $\begin{array}{l}\text { Reject the null } \\
\text { hypothesis. }\end{array}$ \\
\hline $\begin{array}{l}1 \\
8\end{array}$ & $\begin{array}{l}\text { The categories of H7-2 Performance report occur } \\
\text { with equal probabilities. }\end{array}$ & $\begin{array}{l}\text { One-Sample } \\
\text { Chi-Square Test }\end{array}$ & .000 & $\begin{array}{l}\text { Reject the null } \\
\text { hypothesis. }\end{array}$ \\
\hline $\begin{array}{l}1 \\
9\end{array}$ & $\begin{array}{l}\text { The categories of H7-3 Resolved issues occur } \\
\text { with equal probabilities. }\end{array}$ & $\begin{array}{l}\text { One-Sample } \\
\text { Chi-Square Test }\end{array}$ & .000 & $\begin{array}{l}\text { Reject the null } \\
\text { hypothesis. }\end{array}$ \\
\hline $\begin{array}{l}2 \\
0\end{array}$ & $\begin{array}{l}\text { The categories of H9-13 Contract documentation } \\
\text { occur with equal probabilities. }\end{array}$ & $\begin{array}{l}\text { One-Sample } \\
\text { Chi-Square Test }\end{array}$ & .000 & $\begin{array}{l}\text { Reject the null } \\
\text { hypothesis. }\end{array}$ \\
\hline
\end{tabular}




\section{Hypotheses testing}

\section{Hypothesis $\mathrm{H} 1$}

There is no significant relationship between long-term project success and project integration management.

The independent project management processes outputs are project charter, preliminary project scope statement, updates, project management plan, implemented change requests, implemented preventive actions, implemented defect repair, work performance information, recommended corrective actions, forecasts, recommended defect repair, approved change requests, rejected change requests, approved defect repair, and deliverables. The dependent project outcomes are sales, stakeholder satisfaction, user satisfaction, financial objectives, commercial benefit for contractors, sales, customer approval, and personal growth. The entire test summary is shown in Table 20. Due to the large number of tests, only few are described in this section. Further tests are shown in Appendices C and D.

A Fisher's exact test of independence was performed to examine whether there is a relationship between preliminary project scope statement and stakeholder satisfaction. The results revealed significant evidence of a relationship ( $p=.011,2$-sided). Moreover, 89 of the participants who did not consider stakeholder satisfaction as a project success criterion reported that preliminary project scope statement contributes to project success, while only 54 participants selected stakeholder satisfaction as a project success criterion (see 
Table 18). The strength of this association is represented by the coefficient Cramer's V (.236), which indicates a moderate relationship.

Table 18. Crosstab H1-2 Preliminary project scope statement * Stakeholder satisfaction

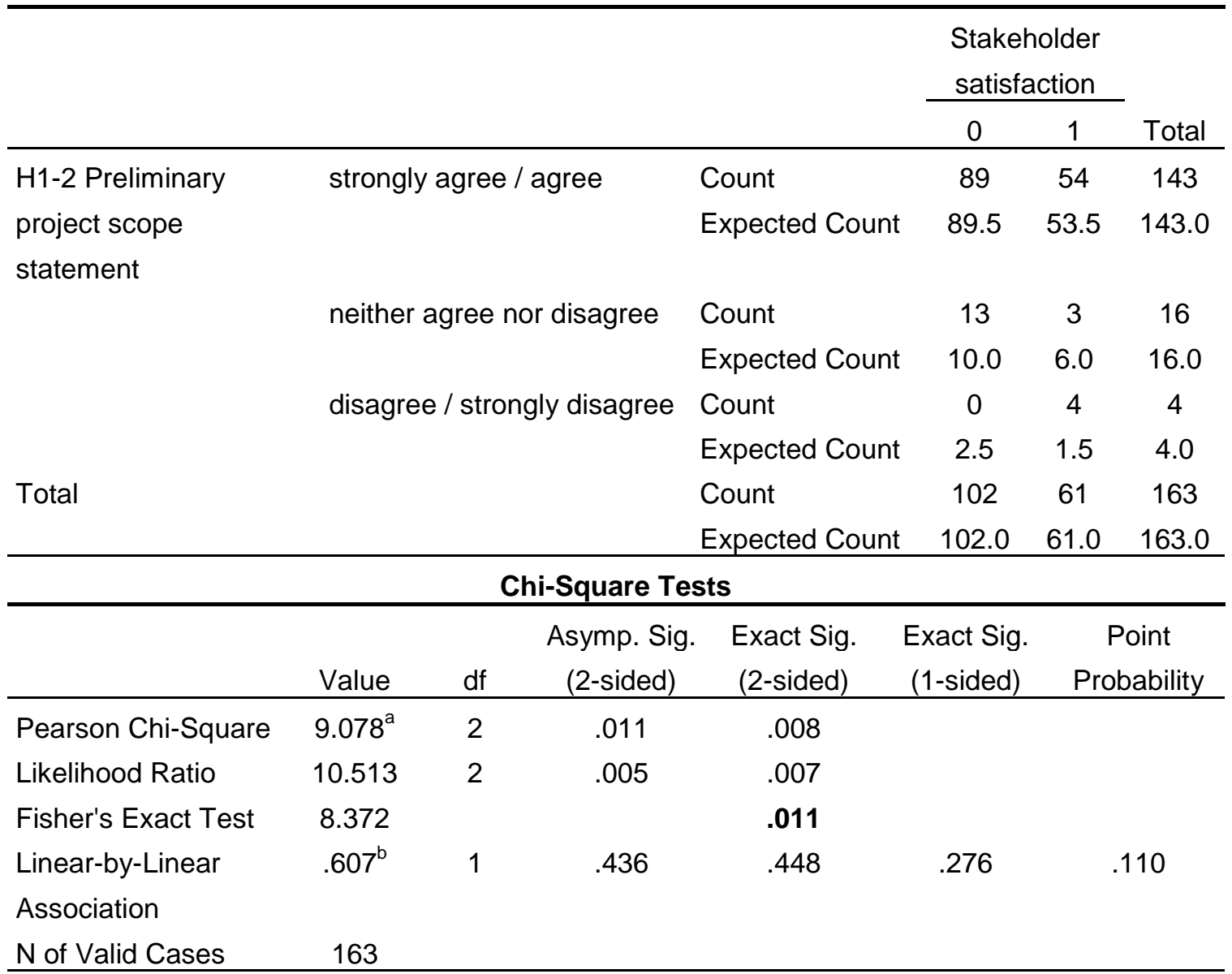

a. 2 cells (33.3\%) have expected count less than 5 . The minimum expected count is 1.50 .

b. The standardized statistic is .779 .

Symmetric Measures

\begin{tabular}{|c|c|c|c|c|}
\hline & & Value & Approx. Sig. & Exact Sig. \\
\hline \multirow[t]{2}{*}{ Nominal by Nominal } & Phi & .236 & .011 & .008 \\
\hline & Cramer's V & .236 & .011 & .008 \\
\hline \multicolumn{2}{|l|}{$\mathrm{N}$ of Valid Cases } & 163 & & \\
\hline \multirow{2}{*}{\multicolumn{2}{|c|}{ 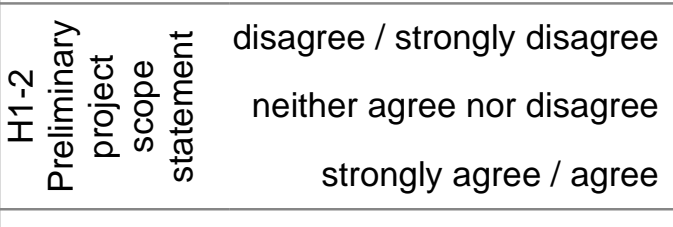 }} & & \multicolumn{2}{|c|}{$\begin{array}{c}\text { Stakeholder satisfaction } \\
\square 1=0\end{array}$} \\
\hline & & & 54 & \\
\hline & & 20 & 40 Count 60 & 100 \\
\hline
\end{tabular}


The second Fisher's exact test of independence was performed to examine whether there is a relationship between project management plan and stakeholder satisfaction. The results revealed significant evidence of a relationship ( $p=.040,2$-sided). Moreover, 90 of the participants who did not consider stakeholder satisfaction a project success criterion reported that project management plan contributes to project success, while only 47 participants selected stakeholder satisfaction as a project success criterion (see Table 19). The strength of this association is represented by the coefficient Cramer's V (.199), which indicates a weak relationship.

A shown in Table 20, the results of the tests revealed significant evidence of a relationship between the outputs of project integration management and long-term project success (i.e., project manager satisfaction, sales, stakeholder satisfaction, user satisfaction, financial objectives, customer approval, and personal growth). Chi-square values were greater than the critical value (5.991 by two degrees of freedom), and the p-values were less than .05 in both the chisquare and Fischer's exact tests. Therefore, the null hypothesis that there is no significant relationship between project integration management and long-term project success was rejected. 


\section{Table 19. Crosstab H1-4 Project management plan* Stakeholder satisfaction}

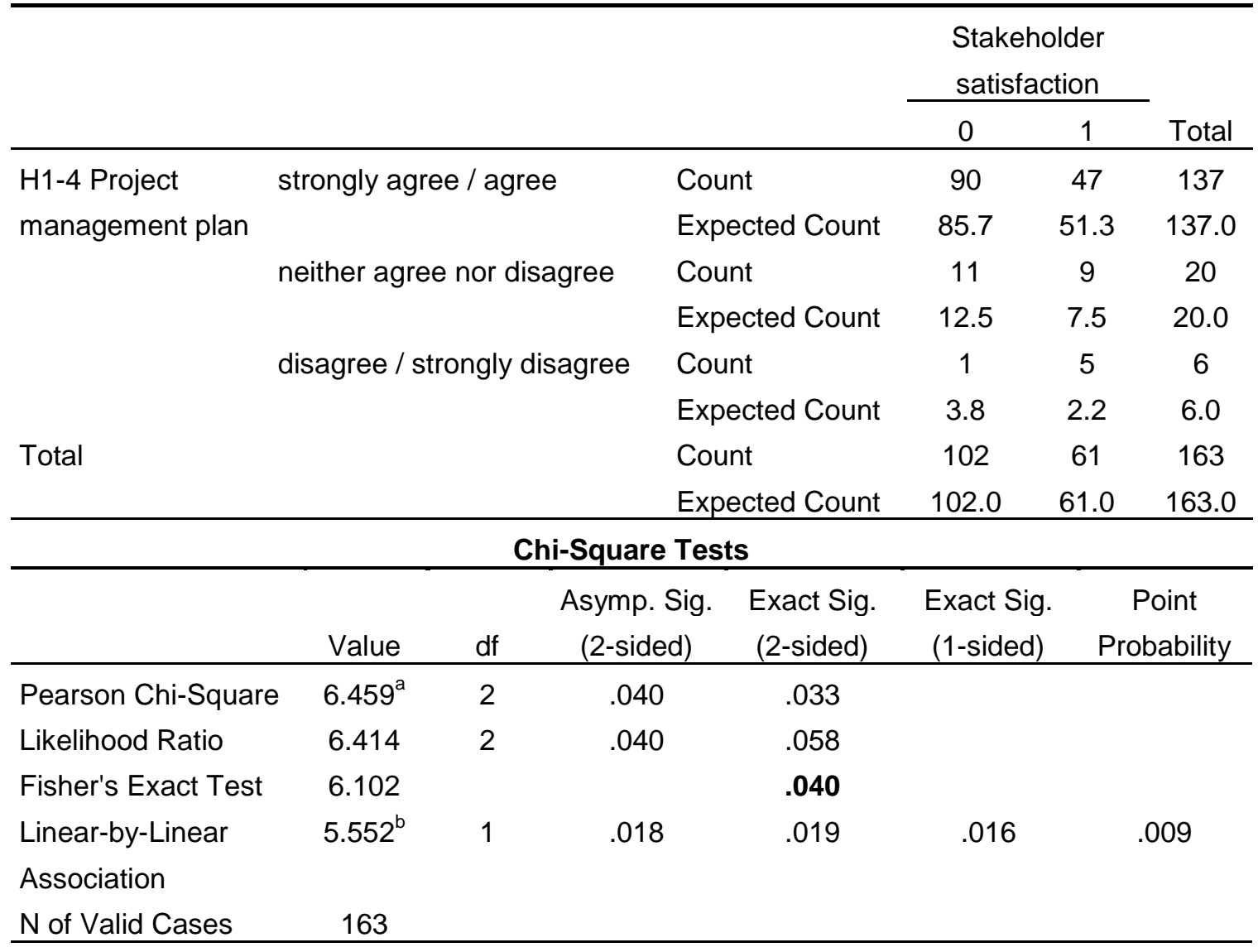

a. 2 cells (33.3\%) have expected count less than 5 . The minimum expected count is 2.25 .

b. The standardized statistic is 2.356 .

Symmetric Measures

\begin{tabular}{llccc}
\hline & & Value & Approx. Sig. & Exact Sig. \\
\hline Nominal by Nominal & Phi & .199 & .040 & .033 \\
& Cramer's V & .199 & .040 & .033 \\
N of Valid Cases & & 163 & & \\
\hline
\end{tabular}

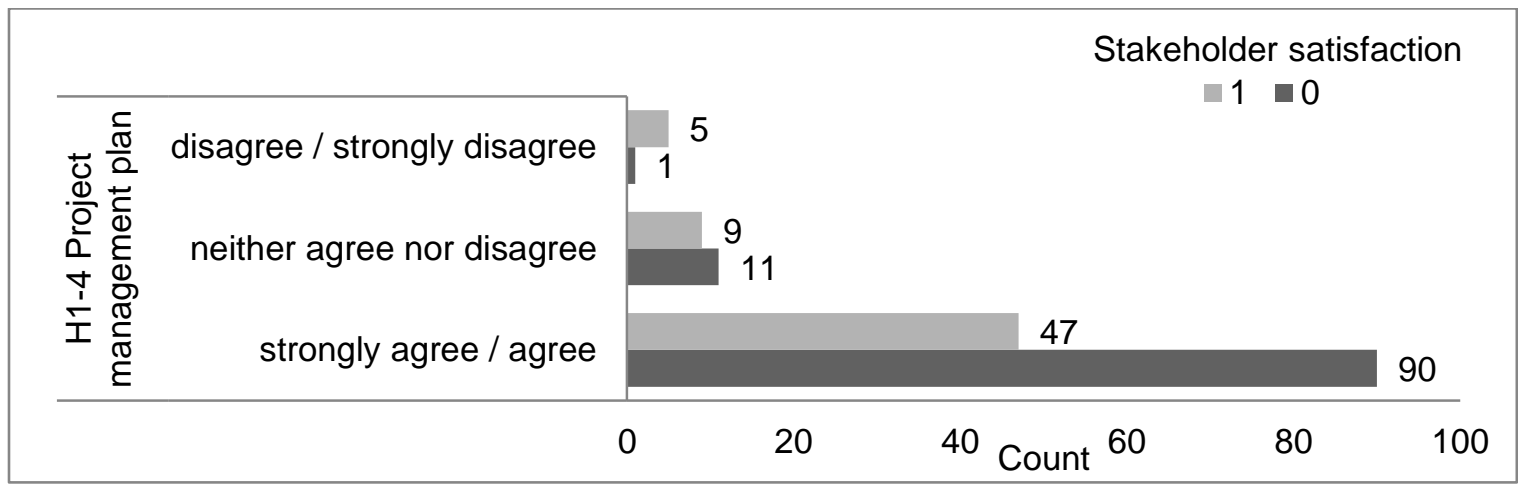




\section{Table 20. Summary hypothesis testing: $\mathrm{H} 1$ integration management}

\begin{tabular}{|c|c|c|c|}
\hline \multirow[b]{2}{*}{ Independent factors } & \multirow[b]{2}{*}{$\begin{array}{l}\text { Dependent project } \\
\text { outcomes }\end{array}$} & \multicolumn{2}{|l|}{ Independence Test } \\
\hline & & $\begin{array}{c}\text { Chi-Square Test } \\
(2 \text {-sided })\end{array}$ & $\begin{array}{c}\text { Fischer's } \\
\text { Exact Test } \\
\text { (2-sided) } \\
\end{array}$ \\
\hline \multirow[t]{2}{*}{ H1-1 Project charter } & Sales & & $p=.033$ \\
\hline & Financial objectives & & $p=.050$ \\
\hline $\begin{array}{l}\text { H1-2 Preliminary project } \\
\text { scope statement }\end{array}$ & Stakeholder satisfaction & & $p=.011$ \\
\hline H1-3 Updates & User satisfaction & & $p=.011$ \\
\hline $\begin{array}{l}\text { H1-4 Project } \\
\text { management plan }\end{array}$ & Stakeholder satisfaction & & $p=.040$ \\
\hline $\begin{array}{l}\text { H1-7 Implemented } \\
\text { change requests }\end{array}$ & $\begin{array}{l}\text { Scope } \\
\text { Commercial benefit for } \\
\text { contractors }\end{array}$ & $\chi^{2}(2, N=163)=6.460, p<.05$ & $p=.050$ \\
\hline $\begin{array}{l}\text { H1-9 Implemented } \\
\text { preventive actions }\end{array}$ & $\begin{array}{l}\text { Schedule } \\
\text { Financial objectives } \\
\text { Commercial benefit for } \\
\text { contractors }\end{array}$ & & $\begin{array}{l}p=.007 \\
p=.004 \\
p=.043\end{array}$ \\
\hline $\begin{array}{l}\text { H1-10 Implemented } \\
\text { defect repair }\end{array}$ & $\begin{array}{l}\text { Schedule } \\
\text { Sales }\end{array}$ & & $\begin{array}{l}p=.019 \\
p=.030\end{array}$ \\
\hline \multicolumn{4}{|l|}{ performance information } \\
\hline $\begin{array}{l}\text { H1-12 Recommended } \\
\text { corrective actions }\end{array}$ & Customer approval & & $p=.016$ \\
\hline H1-14 Forecasts & Performance objectives & & $p=.004$ \\
\hline $\begin{array}{l}\text { H1-15 Recommended } \\
\text { defect repair }\end{array}$ & Financial objectives & & $p=.024$ \\
\hline \multirow[t]{2}{*}{$\begin{array}{l}\text { H1-17 Approved change } \\
\text { requests }\end{array}$} & $\begin{array}{l}\text { Commercial benefit for } \\
\text { contractors }\end{array}$ & & $p=.036$ \\
\hline & Scope & & $p=.043$ \\
\hline \multirow[t]{2}{*}{$\begin{array}{l}\mathrm{H} 1-18 \text { Rejected change } \\
\text { requests }\end{array}$} & User satisfaction & $\chi^{2}(2, N=163)=6.490, p<.05$ & \\
\hline & Technical objectives & $\chi^{2}(2, N=163)=11.397, p<.05$ & \\
\hline $\begin{array}{l}\text { H1-21 Approved defect } \\
\text { repair }\end{array}$ & Personal growth & & $p=.049$ \\
\hline H1-23 Deliverables & $\begin{array}{l}\text { Commercial benefit for } \\
\text { contractors }\end{array}$ & & $p=.043$ \\
\hline
\end{tabular}




\section{Hypothesis $\mathrm{H} 2$}

There is no significant relationship between long-term project success and project scope management.

The independent project management processes output analyzed is the scope baseline. The dependent project outcomes are project team satisfaction and profitability.

A Fisher's exact test of independence was performed to examine whether there is a relationship between scope baseline and project team satisfaction. The results revealed significant evidence of a relationship ( $p=.045,2$-sided). Moreover, 114 of the participants who did not consider project team satisfaction a project success criterion reported that scope baseline contributes to project success, while only five participants selected project team satisfaction as a project success criterion (see Table 21) The strength of this association is represented by the coefficient Cramer's V (.209), which indicates a moderate relationship.

The second Fisher's exact test of independence was performed to examine whether there is a relationship between scope baseline and profitability. The results revealed significant evidence of a relationship ( $p=.039,2$-sided). Moreover, 102 of the participants who did not consider Profitability a project success criterion reported that scope baseline contributes to project success, while only 21 participants selected profitability as a project success criterion (see Table 22). The strength of this association is represented by the coefficient Cramer's V (.210), which indicates a moderate relationship. 
Table 21. Crosstab H2-5 Scope baseline * Project team satisfaction

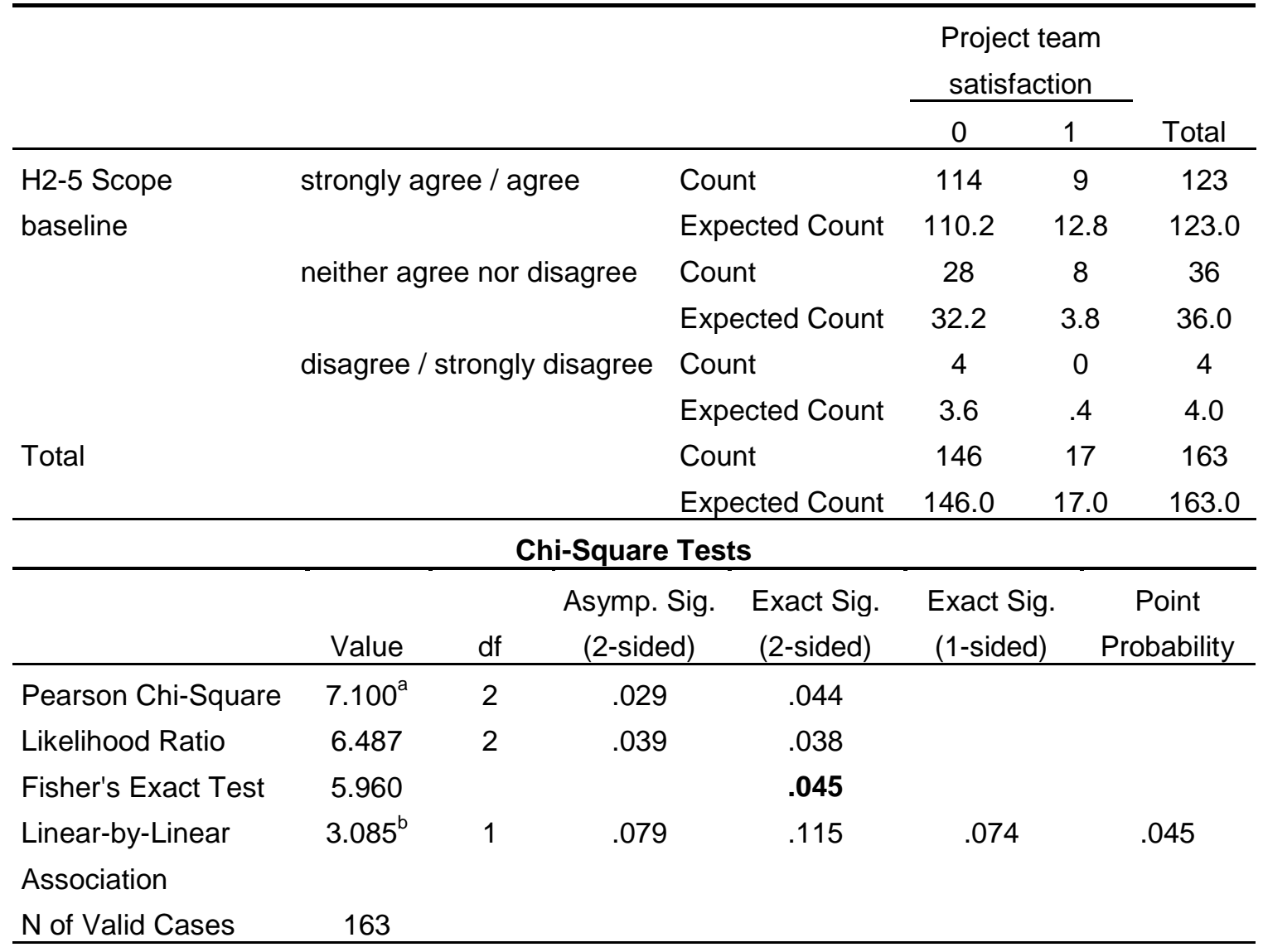

a. 3 cells $(50.0 \%)$ have expected count less than 5 . The minimum expected count is .42 .

b. The standardized statistic is 1.756 .

Symmetric Measures

\begin{tabular}{llccc}
\hline & & Value & Approx. Sig. & Exact Sig. \\
\hline Nominal by Nominal & Phi & .209 & .029 & .044 \\
& Cramer's V & .209 & .029 & .044 \\
N of Valid Cases & & 163 & & \\
\hline
\end{tabular}

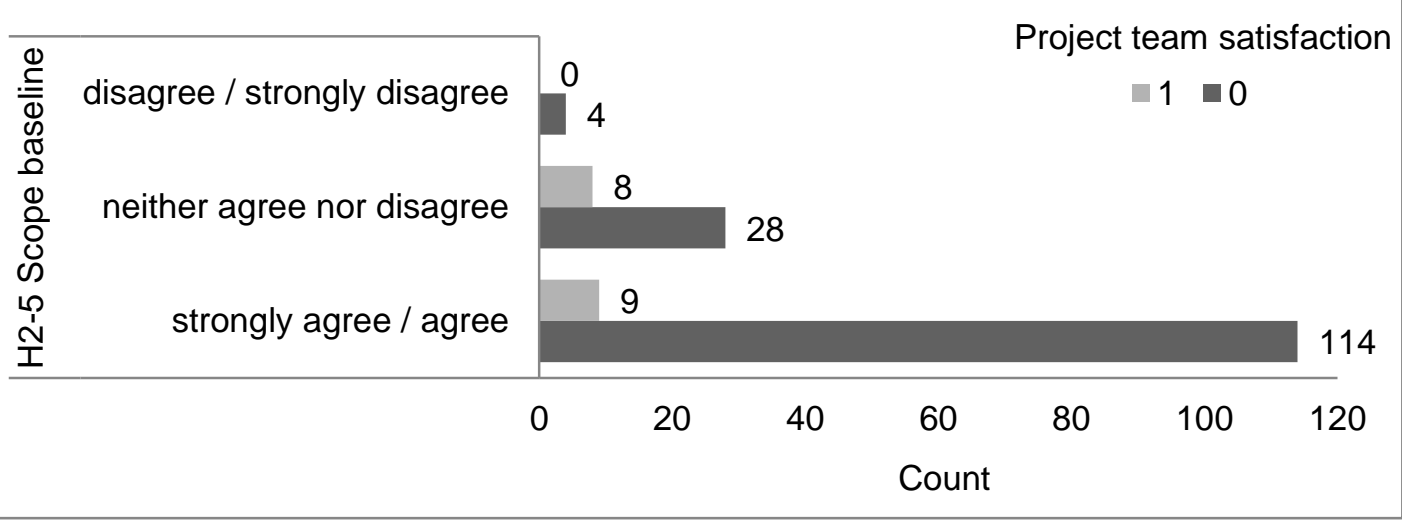


Table 22. Crosstab H2-5 Scope baseline * Profitability

\begin{tabular}{llcccc}
\hline & & \multicolumn{3}{c}{ Profitability } & \\
\cline { 3 - 4 } & & & 0 & 1 & Total \\
\hline H2-5 Scope & strongly agree / agree & Count & 102 & 21 & 123 \\
baseline & & Expected Count & 97.3 & 25.7 & 123.0 \\
& \multirow{3}{*}{ neither agree nor disagree } & Count & 23 & 13 & 36 \\
& & Expected Count & 28.5 & 7.5 & 36.0 \\
& \multirow{2}{*}{ disagree / strongly disagree } & Count & 4 & 0 & 4 \\
& & Expected Count & 3.2 & .8 & 4.0 \\
Total & & Count & 129 & 34 & 163 \\
& & Expected Count & 129.0 & 34.0 & 163.0 \\
\hline
\end{tabular}

\section{Chi-Square Tests}

\begin{tabular}{|c|c|c|c|c|c|c|}
\hline & Value & $\mathrm{df}$ & $\begin{array}{c}\text { Asymp. Sig. } \\
\text { (2-sided) }\end{array}$ & $\begin{array}{l}\text { Exact Sig } \\
\text { (2-sided) }\end{array}$ & $\begin{array}{l}\text { Exact Sig. } \\
\text { (1-sided) }\end{array}$ & $\begin{array}{c}\text { Point } \\
\text { Probability }\end{array}$ \\
\hline Pearson Chi-Square & $7.195^{\mathrm{a}}$ & 2 & .027 & .041 & & \\
\hline Likelihood Ratio & 7.414 & 2 & .025 & .023 & & \\
\hline Fisher's Exact Test & 6.190 & & & .039 & & \\
\hline Linear-by-Linear & $2.192^{b}$ & 1 & .139 & .173 & .102 & .051 \\
\hline \multicolumn{7}{|l|}{ Association } \\
\hline $\mathrm{N}$ of Valid Cases & 163 & & & & & \\
\hline
\end{tabular}

a. 2 cells (33.3\%) have expected count less than 5 . The minimum expected count is .83 .

b. The standardized statistic is 1.481 .

\section{Symmetric Measures}

\begin{tabular}{llccc}
\hline & & Value & Approx. Sig. & Exact Sig. \\
\hline Nominal by Nominal & Phi & .210 & .027 & .041 \\
& Cramer's V & .210 & .027 & .041 \\
N of Valid Cases & & 163 & & \\
\hline
\end{tabular}

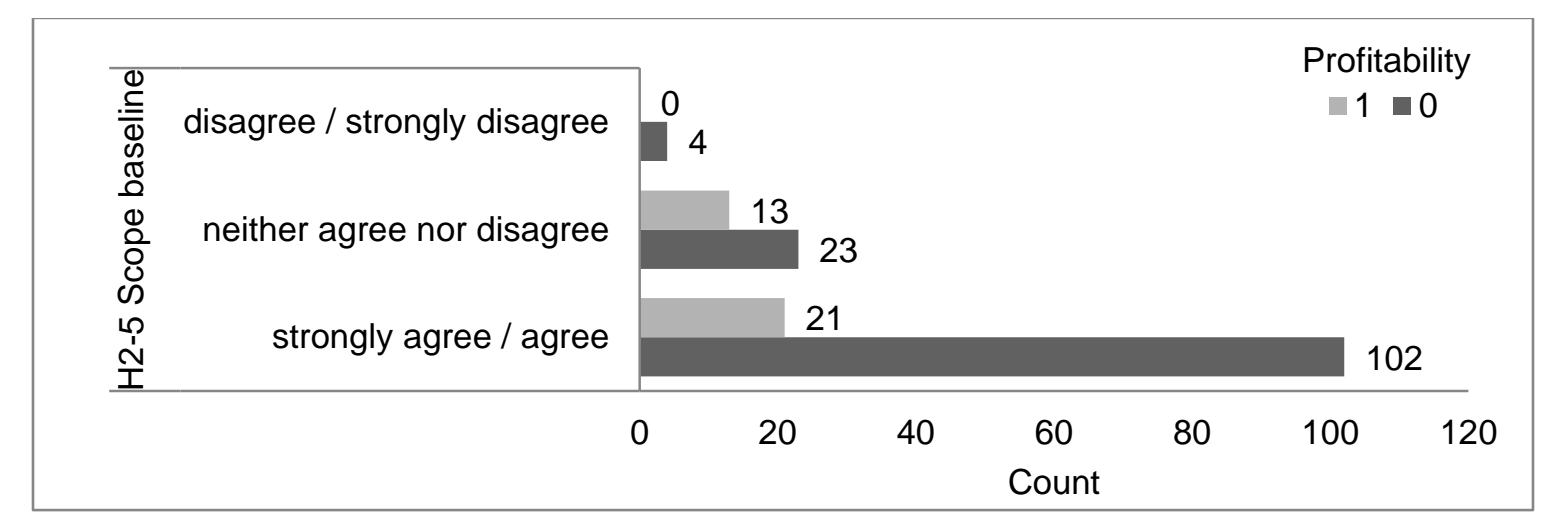


The results of the tests, shown in Table 23, revealed significant evidence of a relationship between the output of the project scope management (scope baseline) and long-term project success project (team satisfaction). The $p$-value in Fischer's exact test was less than .05. Therefore, the null hypothesis that there is no significant relationship between project scope management and long-term project success was rejected.

\section{Table 23. Summary hypothesis testing: $\mathrm{H} 2$ project scope management}

\begin{tabular}{llcc}
\hline & & \multicolumn{2}{c}{ Independence Test } \\
\cline { 3 - 4 } & & & Fischer's \\
Independent factors & Dependent project outcomes & Chi-Square Test & Exact Test \\
H2-5 Scope baseline & Project team satisfaction & & (2-sided) \\
\cline { 3 - 4 } & Profitability & $\mathrm{p}=.045$ \\
& & $\mathrm{p}=.039$ \\
\hline
\end{tabular}

\section{Hypothesis $\mathrm{H3}$}

There is significant no relationship between long-term project success and project time management.

The independent project management processes outputs analyzed are activity list, activity attributes, activity resource requirements, resource breakdown structure, resource calendar, and project schedule. The dependents project outcomes are customer satisfaction and sales.

The entire test summary is shown in Table 27. Due to the large number of tests, only few are described in this section. Further tests are shown in Appendices C and D. 
A Pearson chi-square test was conducted to examine whether there was a relationship between activity list and customer satisfaction. The results revealed a significant relationship (chi-square value $=10.216$, df $=2, p<.05$ ). A significantly larger proportion of the participants who had selected customer satisfaction as a project success criterion (81) reported that activity list contributes to project success, while only 47 participants did not consider customer satisfaction as a project success criterion (see Table 24). The strength of this association is represented by the coefficient Cramer's V (.250), which indicates a moderately strong relationship.

A second chi-square test was conducted to examine whether there was a relationship between resource breakdown structure and customer satisfaction. The results revealed a significant relationship (chi-square value $=6.820, \mathrm{df}=2, \mathrm{p}$ $<.05$ (see Table 25). The strength of this association is represented by the coefficient Cramer's V (.242), which indicates a moderate relationship.

Furthermore, a Fisher's exact test of independence was performed to examine whether there is a relationship between project schedule and customer satisfaction. The results revealed significant evidence of a relationship $(p=.002$, 2-sided) (see Table 26). The strength of this association is represented by the coefficient Cramer's V (.251), which indicates a moderately strong relationship. 
Table 24. Crosstab H3-1 Activity list * Customer satisfaction

\begin{tabular}{lllccc}
\hline & & \multicolumn{2}{c}{$\begin{array}{c}\text { Customer } \\
\text { satisfaction }\end{array}$} \\
\cline { 3 - 4 } & & 0 & 1 & Total \\
\hline \multirow{2}{*}{ H3-1 Activity list strongly agree / agree } & Count & 47 & 81 & 128 \\
& \multirow{2}{*}{ neither agree nor disagree } & Count & 53.4 & 74.6 & 128.0 \\
& & Expected Count & 11 & 12 & 23 \\
& \multirow{2}{*}{ disagree / strongly disagree } & Count & 10 & 2 & 12 \\
& & Expected Count & 5.0 & 7.0 & 12.0 \\
& & Count & 68 & 95 & 163 \\
& & Expected Count & 68.0 & 95.0 & 163.0 \\
\hline
\end{tabular}

\begin{tabular}{lcccccc}
\hline \multicolumn{7}{c}{ Chi-Square Tests } \\
\hline & Value & df & $\begin{array}{c}\text { Asymp. Sig. } \\
(2 \text {-sided })\end{array}$ & $\begin{array}{c}\text { Exact Sig. } \\
(2-\text {-sided })\end{array}$ & $\begin{array}{c}\text { Exact Sig. } \\
\text { (1-sided) }\end{array}$ & $\begin{array}{c}\text { Point } \\
\text { Probability }\end{array}$ \\
\hline Pearson Chi-Square & $\mathbf{1 0 . 2 1 6 ^ { \mathrm { a } }}$ & 2 & .006 & .005 & & \\
Likelihood Ratio & 10.513 & 2 & .005 & .006 & & \\
Fisher's Exact Test & 10.042 & & & .006 & .002 & .001 \\
Linear-by-Linear & $9.235^{\mathrm{b}}$ & 1 & .002 & .003 & & \\
Association & & & & & & \\
N of Valid Cases & 163 & 7 & & & \\
\hline
\end{tabular}

a. 0 cells $(0.0 \%)$ have expected count less than 5 . The minimum expected count is 5.01 .

b. The standardized statistic is -3.039 .

Symmetric Measures

\begin{tabular}{llccc}
\hline & & Value & Approx. Sig. & Exact Sig. \\
\hline Nominal by Nominal & Phi & .250 & .006 & .005 \\
& Cramer's V & .250 & .006 & .005 \\
N of Valid Cases & & 163 & & \\
\hline
\end{tabular}

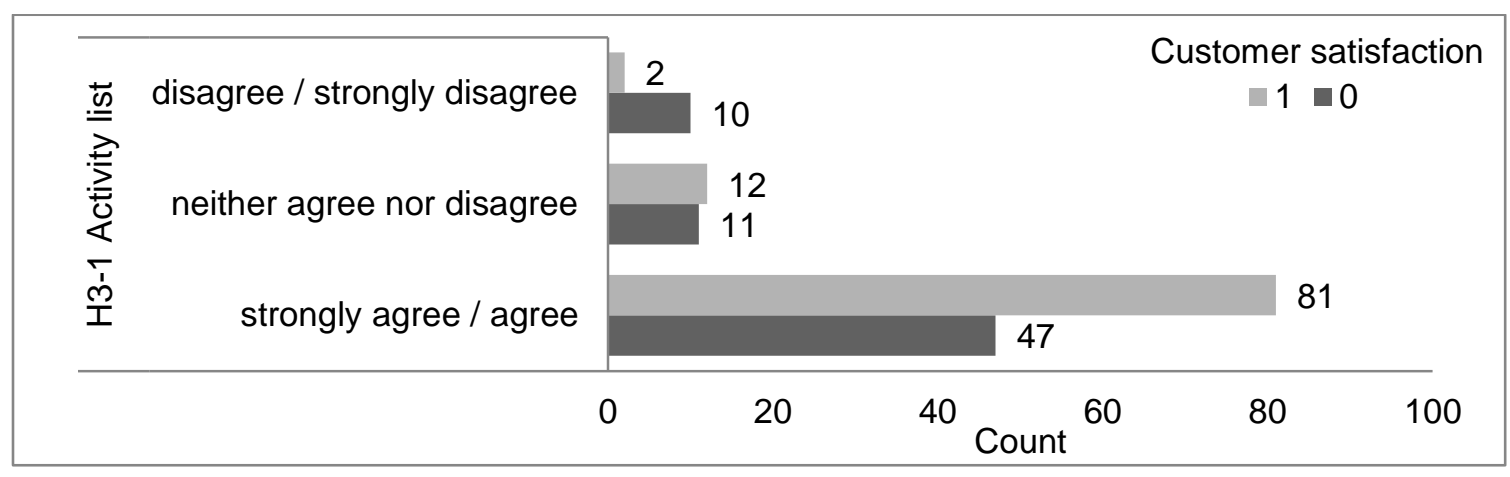




\section{Table 25. Crosstab H3-6 Resource breakdown structure * Customer satisfaction}

\begin{tabular}{lllccc}
\hline & & \multicolumn{3}{c}{ Customer satisfaction } & \\
\cline { 3 - 4 } & & & 0 & 1 & Total \\
\hline H3-6 Resource & \multirow{2}{*}{ strongly agree / agree } & Count & 27 & 57 & 84 \\
breakdown structure & \multirow{3}{*}{ neither agree nor disagree } & Expected Count & 35.0 & 49.0 & 84.0 \\
& & Count & 28 & 28 & 56 \\
& \multirow{2}{*}{ disagree / strongly disagree } & Expected Count & 23.4 & 32.6 & 56.0 \\
& & Count & 13 & 10 & 23 \\
& & Expected Count & 9.6 & 13.4 & 23.0 \\
Total & & Count & 68 & 95 & 163 \\
& & Expected Count & 68.0 & 95.0 & 163.0 \\
\hline
\end{tabular}

\section{Chi-Square Tests}

\begin{tabular}{|c|c|c|c|c|c|c|}
\hline & Value & $\mathrm{df}$ & $\begin{array}{c}\text { Asymp. Sig. } \\
\text { (2-sided) }\end{array}$ & $\begin{array}{c}\text { Exact Sig. } \\
\text { (2-sided) }\end{array}$ & $\begin{array}{c}\text { Exact Sig. } \\
\text { (1-sided) }\end{array}$ & $\begin{array}{c}\text { Point } \\
\text { Probability }\end{array}$ \\
\hline Pearson Chi-Square & $6.820^{\mathrm{a}}$ & 2 & .033 & .030 & & \\
\hline Likelihood Ratio & 6.854 & 2 & .032 & .033 & & \\
\hline Fisher's Exact Test & 6.819 & & & .031 & & \\
\hline Linear-by-Linear & $6.364^{b}$ & 1 & .012 & .015 & .008 & .004 \\
\hline \multicolumn{7}{|l|}{ Association } \\
\hline $\mathrm{N}$ of Valid Cases & 163 & & & & & \\
\hline
\end{tabular}

a. 0 cells $(0.0 \%)$ have expected count less than 5 . The minimum expected count is 9.60 .

b. The standardized statistic is -2.523 .

Symmetric Measures

\begin{tabular}{llccc}
\hline & & Value & Approx. Sig. & Exact Sig. \\
\hline Nominal by Nominal & Phi & .205 & .033 & .030 \\
& Cramer's V & .205 & .033 & .030 \\
N of Valid Cases & & 163 & & \\
\hline
\end{tabular}

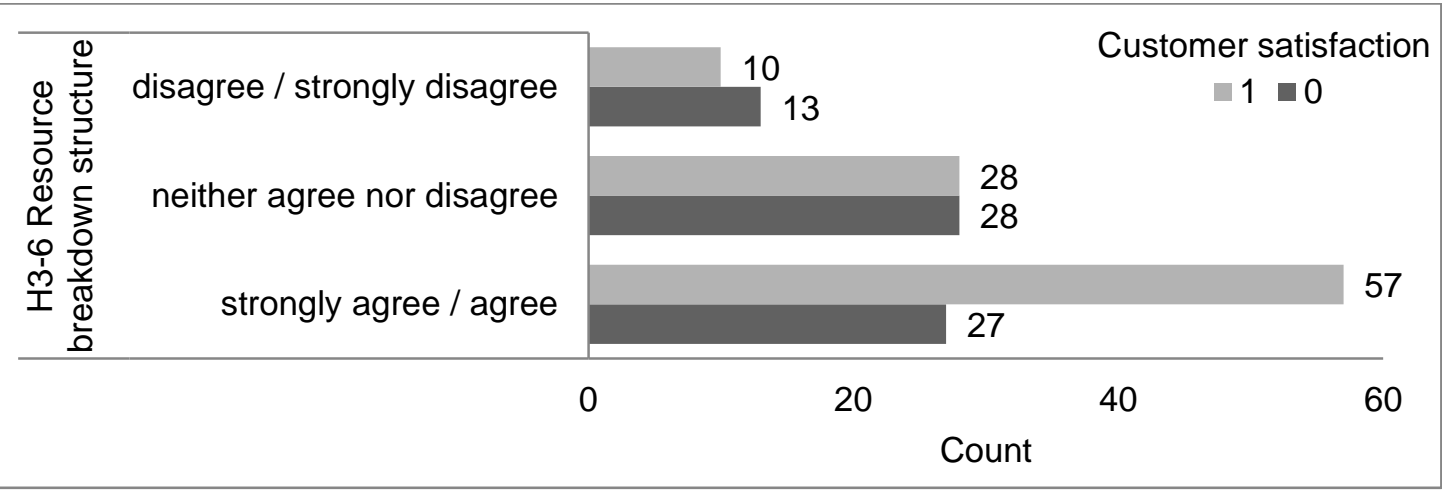


Table 26. Crosstab H3-9 Project schedule * Customer satisfaction

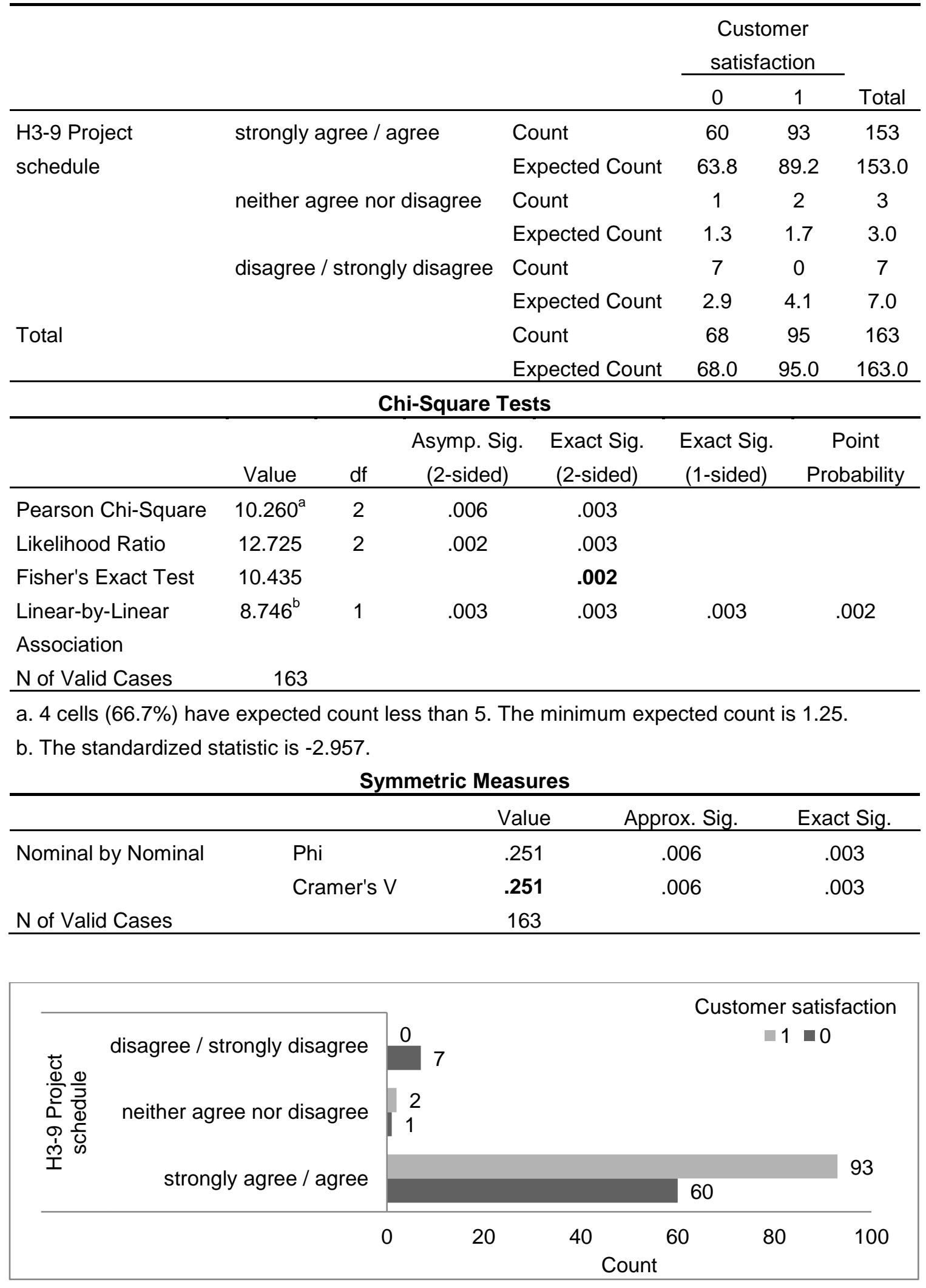


As can be seen in Table 27, the results of the tests revealed significant evidence of a relationship between the outputs of project time management and long-term project success (i.e., customer satisfaction, sales, stakeholder satisfaction, user satisfaction, financial objectives, and personal growth). Chisquare values were greater than the critical value ( 5.991 by two degrees of freedom), and the p-values were less than .05 in both the chi-square and Fischer's exact tests. Therefore, the null hypothesis that there is no significant relationship between project time management and long-term project success was rejected.

Table 27. Summary hypothesis testing; H3 project time management

\begin{tabular}{|c|c|c|c|}
\hline \multirow[b]{2}{*}{ Independent factors } & \multirow[b]{2}{*}{$\begin{array}{l}\text { Dependent project } \\
\text { outcomes }\end{array}$} & \multicolumn{2}{|l|}{ Independence Test } \\
\hline & & $\begin{array}{l}\text { Chi-Square Test } \\
\text { (2-sided) }\end{array}$ & $\begin{array}{c}\text { Fischer's } \\
\text { Exact Test } \\
\text { (2-sided) }\end{array}$ \\
\hline H3-1 Activity list & $\begin{array}{l}\text { Customer satisfaction } \\
\text { Sales }\end{array}$ & $\chi^{2}(2, N=163)=10.216, p<.05$ & $p=.038$ \\
\hline H3-2 Activity attributes & Sales & & $\mathrm{p}=.030$ \\
\hline $\begin{array}{l}\text { H3-5 Activity resource } \\
\text { requirements }\end{array}$ & Sales & & $p=.038$ \\
\hline \multirow{2}{*}{$\begin{array}{l}\text { H3-6 Resource } \\
\text { breakdown structure }\end{array}$} & Customer satisfaction & $\chi^{2}(2, N=163)=6.820, p<.05$ & \\
\hline & Sales & & $p=.008$ \\
\hline H3-7 Resource calendar & Performance objectives & $\chi^{2}(2, N=163)=7.150, p<.05$ & \\
\hline H3-9 Project schedule & Customer satisfaction & & $p=.002$ \\
\hline
\end{tabular}

\section{Hypothesis H4}

There is no significant relationship between long-term project success and project cost management. 
The independent project management processes outputs are activity cost estimates supporting detail and cost baseline. The dependent project outcomes are customer satisfaction, customer approval, and commercial benefit for customer.

The entire test summary is shown in Table 30. Due to the large number of tests, only few are described in this section. Further tests are shown in Appendices C and D.

A chi-square test was conducted to examine whether there was a relationship between activity cost estimates supporting detail and customer satisfaction. The results revealed a significant relationship (chi-square value $=$ 7.901, $\mathrm{df}=2, \mathrm{p}<.05)$. A significantly larger proportion of the participants who had selected customer satisfaction as a project success criterion (45) reported that activity cost estimates supporting detail contributes to project success, while only 18 participants did not consider customer satisfaction as a project success criterion (see Table 28). The strength of this association is represented by the coefficient Cramer's V (.220), which indicates a moderate relationship.

A further Pearson chi-square test was conducted to examine whether there was a relationship between cost baseline and customer satisfaction. The results revealed a significant relationship (chi-square value $=6.516$, df $=2, p<$ .05) (see Table 29). The strength of this association is represented by the coefficient Cramer's V (.200), which indicates a moderate relationship. 


\section{Table 28. Crosstab H4-2 Activity cost estimates supporting detail * Customer satisfaction}

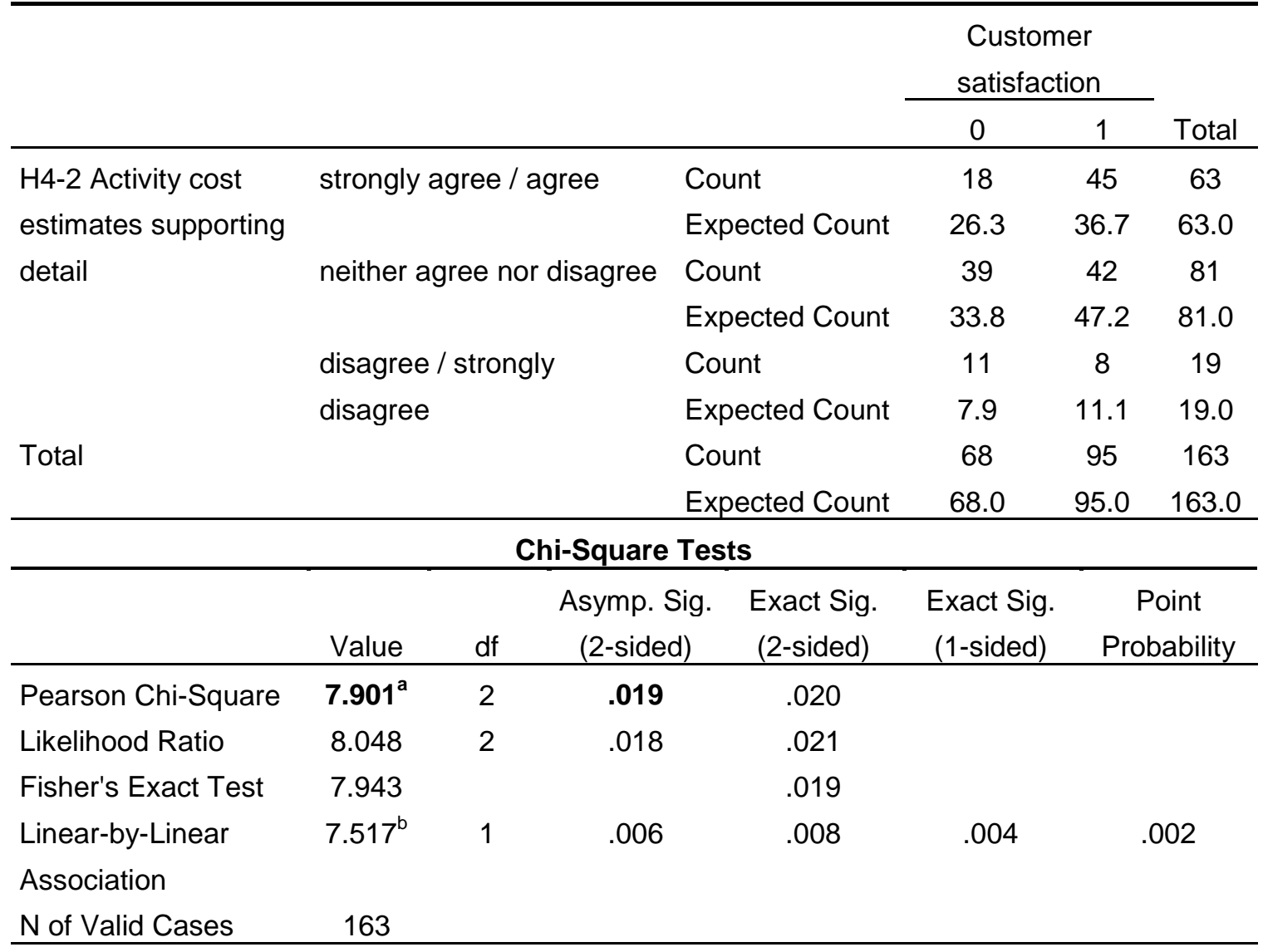

a. 0 cells $(0.0 \%)$ have expected count less than 5 . The minimum expected count is 7.93.

b. The standardized statistic is -2.742 .

Symmetric Measures

\begin{tabular}{llccc}
\hline & & Value & Approx. Sig. & Exact Sig. \\
\hline Nominal by Nominal & Phi & .220 & .019 & .020 \\
& Cramer's V & .220 & .019 & .020 \\
N of Valid Cases & & 163 & & \\
\hline
\end{tabular}

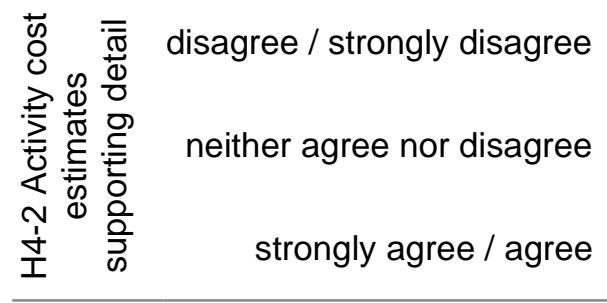

Customer satisfaction

$\square 1 \square 0$

11

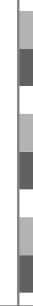

8
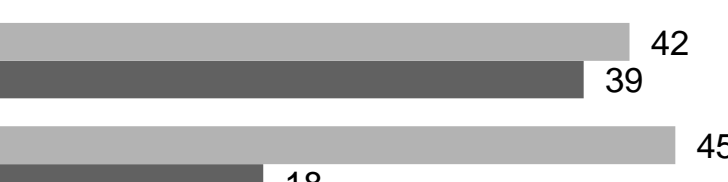

18

20 Count $30 \quad 40 \quad 50$


Table 29. Crosstab H4-4 Cost baseline * Customer satisfaction

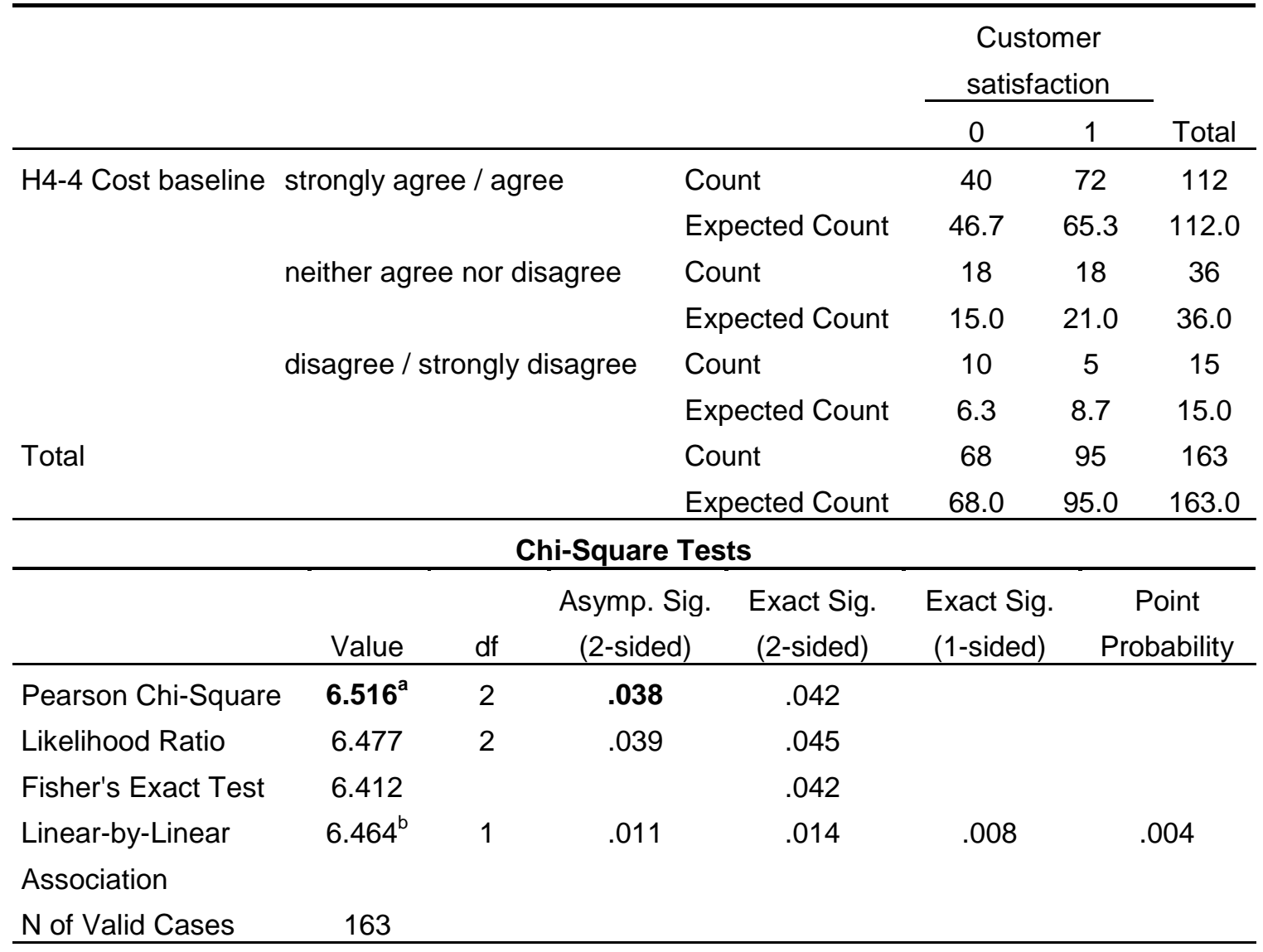

a. 0 cells $(0.0 \%)$ have expected count less than 5 . The minimum expected count is 6.26 .

b. The standardized statistic is -2.542 .

Symmetric Measures

\begin{tabular}{llccc}
\hline & & Value & Approx. Sig. & Exact Sig. \\
\hline Nominal by Nominal & Phi & .200 & .038 & .042 \\
& Cramer's V & .200 & .038 & .042 \\
N of Valid Cases & & 163 & & \\
\hline
\end{tabular}

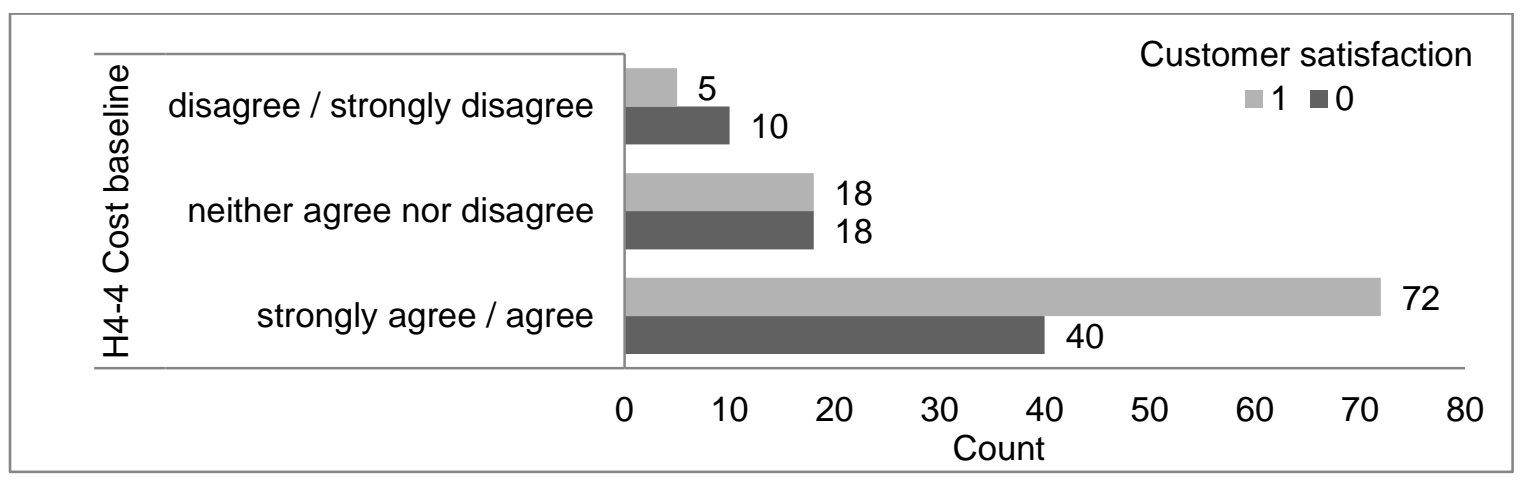


The results of the tests, presented in Table 30 , revealed significant evidence of a relationship between project cost management outputs (i.e., activity cost estimates supporting detail and cost baseline) and long-term project success (i.e., customer satisfaction and customer approval). Chi-square values were greater than the critical value ( 5.991 by two degrees of freedom), and the $p$ values were less than .05 in both the chi-square tests and Fischer's exact tests. Therefore, the null hypothesis that there is no significant relationship between project cost management and long-term project success was rejected.

\section{Table 30. Summary hypothesis testing; $\mathrm{H} 4$ project cost management}

\begin{tabular}{|c|c|c|c|}
\hline \multirow[b]{2}{*}{ Independent factors } & \multirow[b]{2}{*}{$\begin{array}{l}\text { Dependent project } \\
\text { outcomes }\end{array}$} & \multicolumn{2}{|l|}{ Independence Test } \\
\hline & & $\begin{array}{l}\text { Chi-Square Test } \\
\text { (2-sided) }\end{array}$ & $\begin{array}{l}\text { Fischer's } \\
\text { Exact Test } \\
\text { (2-sided) }\end{array}$ \\
\hline $\begin{array}{l}\text { H4-2 Activity cost } \\
\text { estimates supporting } \\
\text { detail }\end{array}$ & $\begin{array}{l}\text { Customer satisfaction } \\
\text { Customer approval }\end{array}$ & $\begin{array}{l}\chi^{2}(2, N=163)=7.901, p<.05 \\
\chi^{2}(2, N=163)=7.419, p<.05\end{array}$ & \\
\hline \multirow[t]{3}{*}{ H4-4 Cost baseline } & Customer satisfaction & $\chi^{2}(2, N=163)=6.516, p<.05$ & \\
\hline & $\begin{array}{l}\text { Commercial benefit for } \\
\text { customer }\end{array}$ & & $p=.019$ \\
\hline & Customer approval & $\chi^{2}(2, N=163)=7.635, p<.05$ & \\
\hline
\end{tabular}

\section{Hypothesis H5}

There is no significant relationship between long-term project success and project quality management.

The independent project management processes outputs are quality management plan, process improvement plan, recommended corrective actions, and quality control measurement. The dependent project outcomes are customer 
satisfaction, stakeholder satisfaction, strategic contribution of the project, and profitability.

The entire test summary is shown in Table 32. Due to the large number of tests only one test is described in this section. The remaining tests are shown in Appendices C and D.

A Pearson chi-square test was conducted to examine whether there was a relationship between quality management plan and customer satisfaction. The results revealed a significant relationship (chi-square value $=11.253, \mathrm{df}=2, \mathrm{p}<$ .05). A significantly larger proportion of the participants who had selected customer satisfaction as a project success criterion (75) reported that quality management plan contributes to project success, while only 37 participants did not consider customer satisfaction as a project success criterion (see Table 31). The strength of this association is represented by the coefficient Cramer's V (.263), which indicates a moderately strong relationship.

As shown in Table 32, the results of the tests revealed significant evidence of a relationship between project quality management outputs (i.e., quality management plan and recommended corrective actions) and long-term project success (i.e., stakeholder satisfaction, strategic contribution of the project, and profitability. The chi-square values were greater than the critical value (5.991 by two degrees of freedom), and the $p$-values were less than .05 . Therefore, the null hypothesis that there is no significant relationship between project quality management and long-term project success was rejected. 
Table 31. Crosstab H5-1 Quality management plan * Customer satisfaction

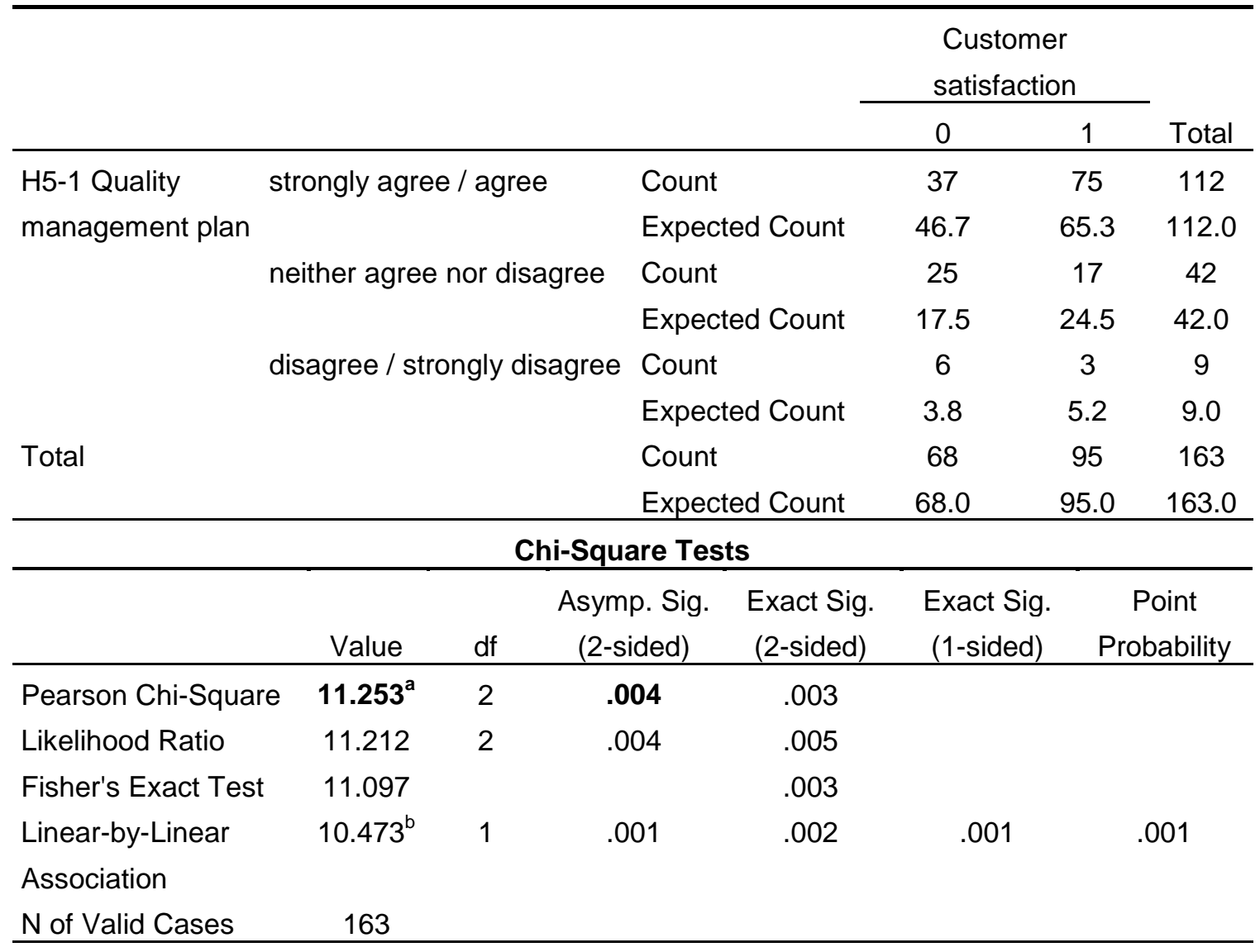

a. 1 cells $(16.7 \%)$ have expected count less than 5 . The minimum expected count is 3.75 .

b. The standardized statistic is -3.236 .

Symmetric Measures

\begin{tabular}{llccc}
\hline & & Value & Approx. Sig. & Exact Sig. \\
\hline Nominal by Nominal & Phi & .263 & .004 & .003 \\
& Cramer's V & .263 & .004 & .003 \\
N of Valid Cases & & 163 & & \\
\hline
\end{tabular}

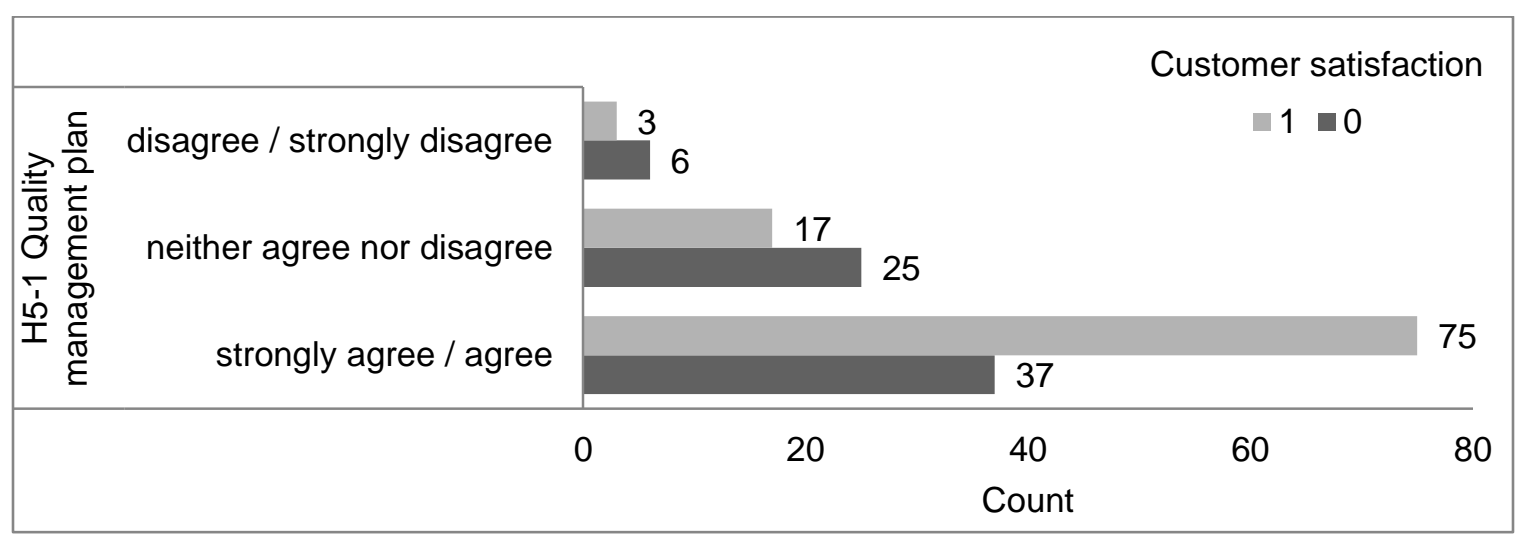


Table 32. Summary hypothesis testing: H5 project quality management

\begin{tabular}{|c|c|c|c|}
\hline \multirow[b]{2}{*}{ Independent factors } & \multirow[b]{2}{*}{$\begin{array}{l}\text { Dependent project } \\
\text { outcomes }\end{array}$} & \multicolumn{2}{|l|}{ Independence Test } \\
\hline & & $\begin{array}{c}\text { Chi-Square Test } \\
\text { (2-sided) }\end{array}$ & $\begin{array}{l}\text { Fischer's } \\
\text { Exact Test } \\
\text { (2-sided) }\end{array}$ \\
\hline $\begin{array}{l}\text { H5-1 Quality } \\
\text { management plan }\end{array}$ & $\begin{array}{l}\text { Customer satisfaction } \\
\text { Stakeholder satisfaction } \\
\text { Commercial benefit for } \\
\text { contractors }\end{array}$ & $\begin{array}{l}\chi^{2}(2, N=163)=11.253, p<.05 \\
\chi^{2}(2, N=163)=6.025, p<.05\end{array}$ & $p=.050$ \\
\hline $\begin{array}{l}\text { H5-4 Process } \\
\text { improvement plan }\end{array}$ & Customer satisfaction & $\chi^{2}(2, N=163)=5.987, p=.05$ & \\
\hline $\begin{array}{l}\text { H5-6 Recommended } \\
\text { corrective actions }\end{array}$ & $\begin{array}{l}\text { Strategic contribution of } \\
\text { the project } \\
\text { Profitability }\end{array}$ & $\begin{array}{l}\chi^{2}(2, N=163)=12.456, p<.05 \\
\chi^{2}(2, N=163)=6.668, p<.05\end{array}$ & \\
\hline $\begin{array}{l}\text { H5-8 Quality control } \\
\text { measurements }\end{array}$ & Scope & $\chi^{2}(2, N=163)=7.540, p<.05$ & \\
\hline
\end{tabular}

Hypothesis $\mathrm{H} 6$

There is no significant relationship between long-term project success and project human resource management.

The independent project management processes outputs are roles and responsibilities, staffing management plan, and resource availability. The dependent project outcomes are stakeholder satisfaction and user satisfaction.

A Fisher's exact test of independence was performed to examine whether there is a relationship between roles and responsibilities and stakeholder satisfaction. The results revealed significant evidence of a relationship $(p=.003$, 2-sided). Moreover, 96 of the participants who did not consider stakeholder satisfaction as a project success criterion reported that roles and responsibilities contributes to project success, while only 47 participants selected stakeholder satisfaction as a project success criterion (see Table 33) The strength of this 
association is represented by the coefficient Cramer's V (.256), which indicates a moderately strong relationship.

\section{Table 33. Crosstab H6-1 Roles and responsibilities * Stakeholder satisfaction}

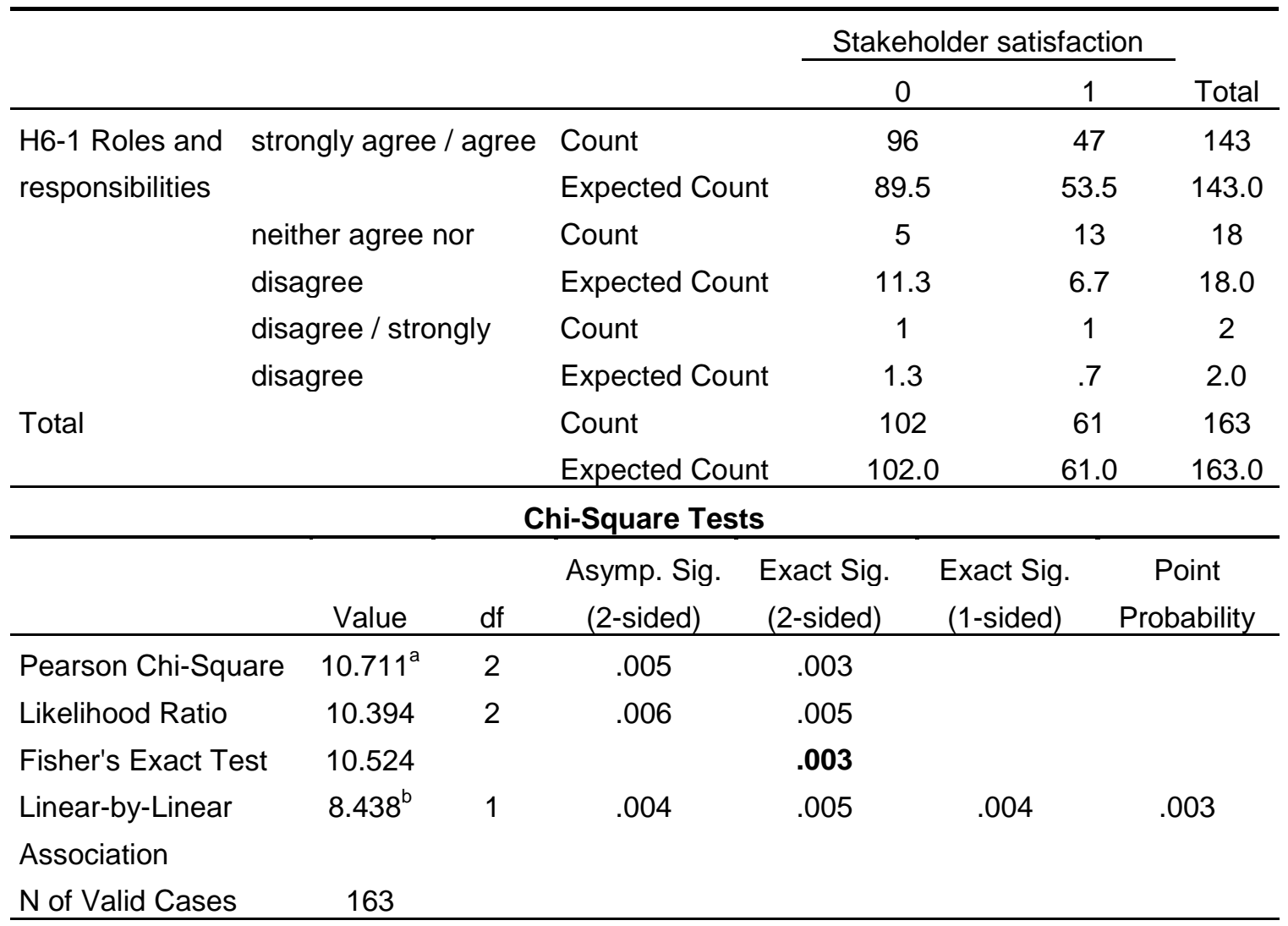

a. 2 cells (33.3\%) have expected count less than 5 . The minimum expected count is .75 .

b. The standardized statistic is 2.905 .

\section{Symmetric Measures}

\begin{tabular}{llccc}
\hline & & Value & Approx. Sig. & Exact Sig. \\
\hline Nominal by Nominal & Phi & .256 & .005 & .003 \\
& Cramer's V & .256 & .005 & .003 \\
N of Valid Cases & & 163 & & \\
\hline
\end{tabular}

\begin{tabular}{|c|c|c|c|c|c|}
\hline \multirow{3}{*}{$\begin{array}{c}\text { disagree / strongly disagree } \\
\text { neither agree nor disagree } \\
\text { strongly agree / agree }\end{array}$} & \multirow{2}{*}{\begin{tabular}{|l|l|l|}
1 & \\
1 & \\
& 5 & 13
\end{tabular}} & & \multicolumn{3}{|c|}{$\begin{array}{c}\text { Stakeholder satisfaction } \\
1 \\
1\end{array}$} \\
\hline & & & & & \\
\hline & \multicolumn{5}{|c|}{47} \\
\hline & 20 & ${ }^{40}$ Count & 60 & 80 & 100 \\
\hline
\end{tabular}


The results of the tests revealed significant evidence of a relationship between project human resource management outputs (i.e., roles and responsibilities and staffing management plan) and long-term project success (i.e., stakeholder and user satisfaction; see Table 34). The chi-square value was greater than the critical value (5.991 by two degrees of freedom), and the $\mathrm{p}$ values were less than .05 in both the chi-square and Fischer's exact tests. Therefore, the null hypothesis that there is no significant relationship between project human resource management and long-term project success was rejected.

Table 34. Summary hypothesis testing: H6 project human resource management

\begin{tabular}{llcc}
\hline & & \multicolumn{2}{c}{ Independence Test } \\
\cline { 3 - 4 } & Dependent project & Chi-Square Test \\
outcomes & (2-sided $)$ & $\begin{array}{c}\text { Fischer's } \\
\text { Exact Test } \\
\text { (2-sided) }\end{array}$ \\
\hline $\begin{array}{l}\text { Independent factors } \\
\text { responsibilities }\end{array}$ & Stakeholder satisfaction & $\mathrm{p}=.003$ \\
\hline $\begin{array}{l}\text { H6-3 Staffing } \\
\text { management plan }\end{array}$ & User satisfaction & $\chi^{2}(2, \mathrm{~N}=163)=7.894, \mathrm{p}<.05$ \\
\hline $\begin{array}{l}\text { H6-5 Resource } \\
\text { availability }\end{array}$ & Budget/Cost & $\mathrm{p}=.000$ \\
\hline
\end{tabular}

\section{$\underline{\text { Hypothesis } \mathrm{H} 7}$}

There is no significant relationship between long-term project success and project communication management.

The independent project management processes outputs are communication management plan, and resolved issues. The dependent project outcomes are customer satisfaction and personal growth. 
A chi-square test was conducted to examine whether there was a relationship between communication management plan and customer satisfaction. The results revealed a significant relationship (chi-square value $=$ $8.328, \mathrm{df}=2, \mathrm{p}<.05)$. A significantly larger proportion of the participants who had selected customer satisfaction as a project success criterion (81) reported that communication management plan contributes to project success, while only 45 participants did not consider customer satisfaction as a project success criterion (see Table 35). The strength of this association is represented by the coefficient Cramer's V (.226), which indicates a moderate relationship.

The results of the tests revealed significant evidence of a relationship between project communication management outputs (i.e., communication management plan and resolved issues) and long-term project success, customer satisfaction, and personal growth (see Table 36). The chi-square value was greater than the critical value (5.991 by two degrees of freedom), and the $p$ values were less than .05 in both the chi-square and Fischer's exact tests. Therefore, the null hypothesis that there is no significant relationship between project communication management and long-term project success was rejected. 


\section{Table 35. Crosstab H7-1 Communication management plan * Customer satisfaction}

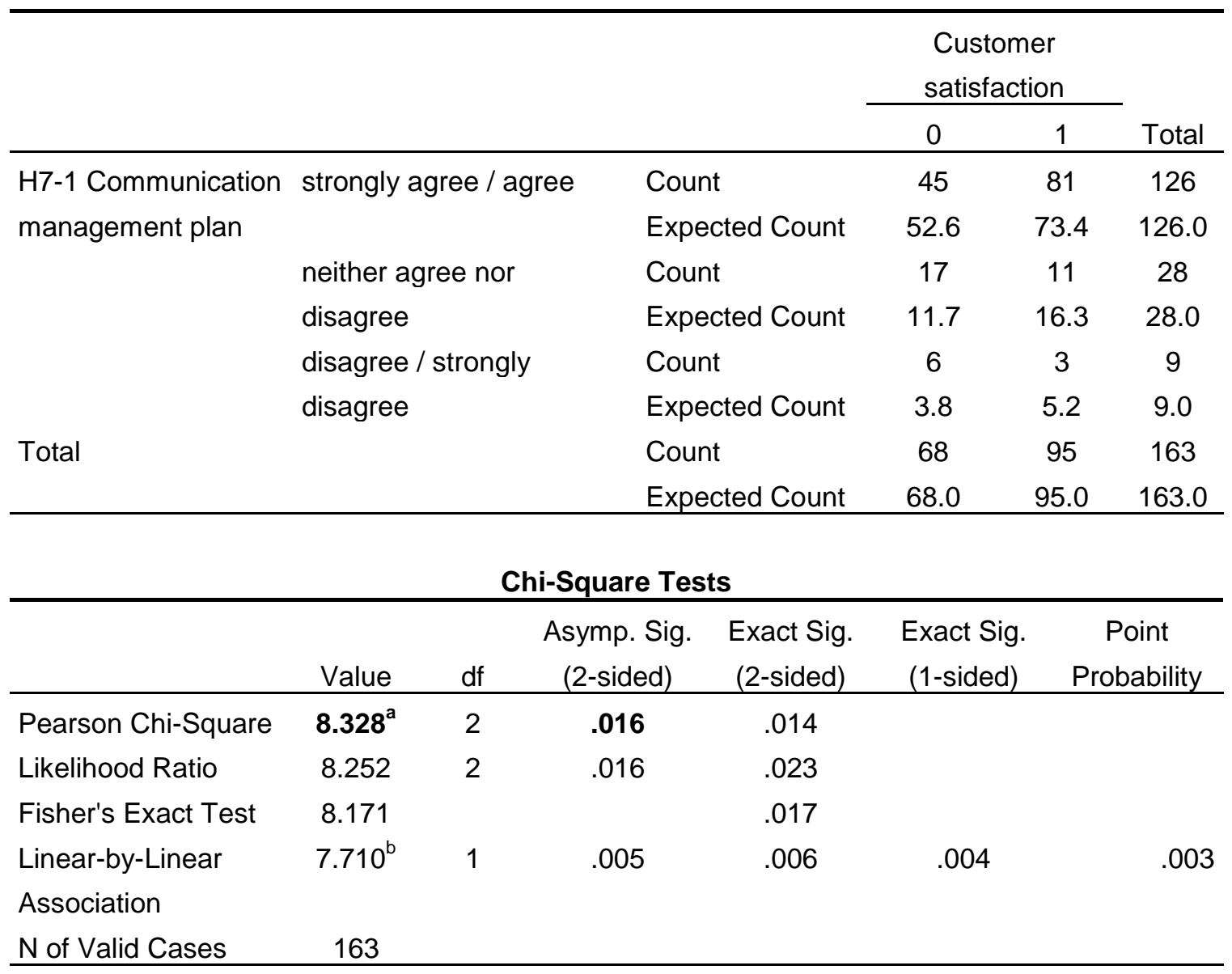

a. 1 cells $(16.7 \%)$ have expected count less than 5 . The minimum expected count is 3.75 .

b. The standardized statistic is -2.777 .

\begin{tabular}{llccc}
\hline \multicolumn{5}{c}{ Symmetric Measures } \\
\hline Nominal by Nominal & Phi & Value & Approx. Sig. & Exact Sig. \\
& Cramer's V & .226 & .016 & .014 \\
N of Valid Cases & & .226 & .016 & .014 \\
\hline
\end{tabular}

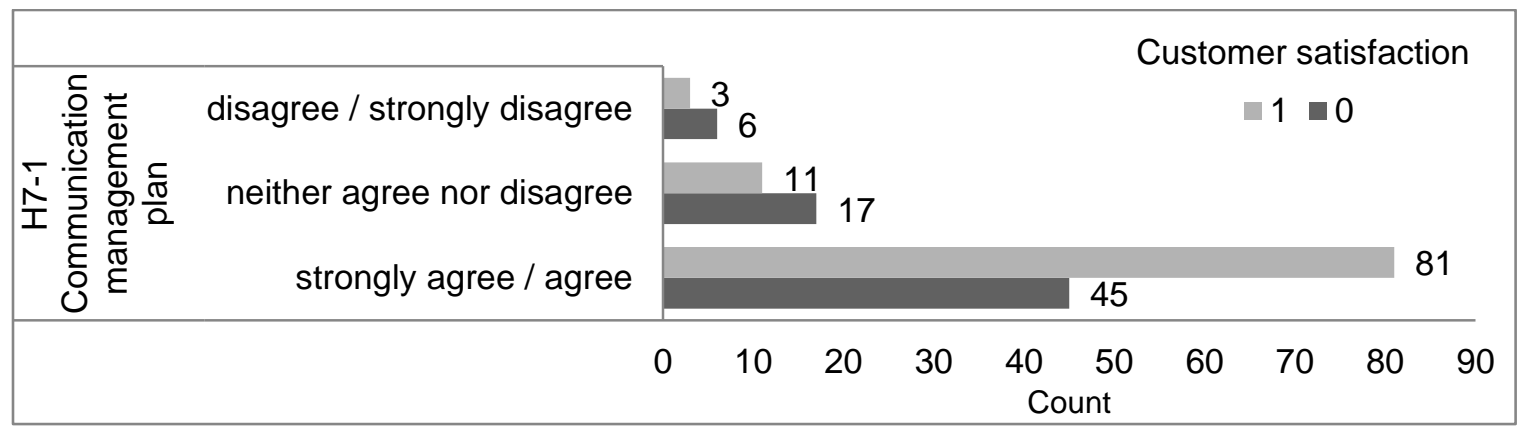




\section{Table 36. Summary hypothesis testing: $\mathrm{H} 7$ project communication management}

\begin{tabular}{llcc}
\hline & & \multicolumn{2}{c}{ Independence Test } \\
\cline { 3 - 4 } & Dependent project & Chi-Square Test & Fischer's \\
Independent factors & outcomes & $(2$-sided $)$ & $\begin{array}{c}\text { Exact Test } \\
(2 \text {-sided })\end{array}$ \\
\hline $\begin{array}{lll}\text { H7-1 Communication } \\
\text { management plan }\end{array}$ & Customer satisfaction & $\chi^{2}(2, \mathrm{~N}=163)=8.328, \mathrm{p}<.05$ & \\
\hline H7-3 Resolved issues & Personal growth & $\mathrm{p}=.037$ \\
\hline
\end{tabular}

\section{Hypothesis $\mathrm{H} 8$}

There is no significant relationship between long-term project success and project risk management.

The independent project management process outcome the risk management plan and the dependent project outcome is profitability.

A Pearson chi-square test was conducted to examine whether there was a relationship between risk management plan and profitability. The results revealed a significant relationship (chi-square value $=8.016, \mathrm{df}=2, \mathrm{p}<.05$ ). Moreover, 97 of the participants who did not consider profitability as a project success criterion reported that risk management plan contributes to project success, while only 33 participants selected user satisfaction as a project success criterion (see Table 37). The strength of this association is represented by the coefficient Cramer's V (.222), which indicates a moderate relationship. 
Table 37. Crosstab H8-1 Risk management plan * Profitability

\begin{tabular}{lllccc}
\hline & & & \multicolumn{2}{c}{ Profitability } & \\
\cline { 3 - 5 } & & & 0 & 1 & Total \\
\hline H8-1 Risk management & strongly agree / agree & Count & 97 & 33 & 130 \\
plan & & Expected Count & 102.9 & 27.1 & 130.0 \\
& neither agree nor & Count & 25 & 1 & 26 \\
& disagree & Expected Count & 20.6 & 5.4 & 26.0 \\
& disagree / strongly & Count & 7 & 0 & 7 \\
& disagree & Expected Count & 5.5 & 1.5 & 7.0 \\
Total & & Count & 129 & 34 & 163 \\
& & Expected Count & 129.0 & 34.0 & 163.0 \\
\hline
\end{tabular}

Chi-Square Tests

\begin{tabular}{|c|c|c|c|c|c|c|}
\hline & Value & df & $\begin{array}{c}\text { Asymp. Sig. } \\
\text { (2-sided) }\end{array}$ & $\begin{array}{c}\text { Exact Sig. } \\
\text { (2-sided) }\end{array}$ & $\begin{array}{c}\text { Exact Sig. } \\
\text { (1-sided) }\end{array}$ & $\begin{array}{c}\text { Point } \\
\text { Probability }\end{array}$ \\
\hline Pearson Chi-Square & $8.016^{a}$ & 2 & .018 & .019 & & \\
\hline Likelihood Ratio & 11.166 & 2 & .004 & .004 & & \\
\hline Fisher's Exact Test & 7.987 & & & .014 & & \\
\hline Linear-by-Linear & $7.348^{b}$ & 1 & .007 & .008 & .002 & .001 \\
\hline \multicolumn{7}{|l|}{ Association } \\
\hline $\mathrm{N}$ of Valid Cases & 163 & & & & & \\
\hline
\end{tabular}

a. 1 cells $(16.7 \%)$ have expected count less than 5 . The minimum expected count is 1.46 .

b. The standardized statistic is -2.711 .

Symmetric Measures

\begin{tabular}{llccc}
\hline & & Value & Approx. Sig. & Exact Sig. \\
\hline Nominal by Nominal & Phi & .222 & .018 & .019 \\
& Cramer's V & .222 & .018 & .019 \\
N of Valid Cases & & 163 & & \\
\hline
\end{tabular}

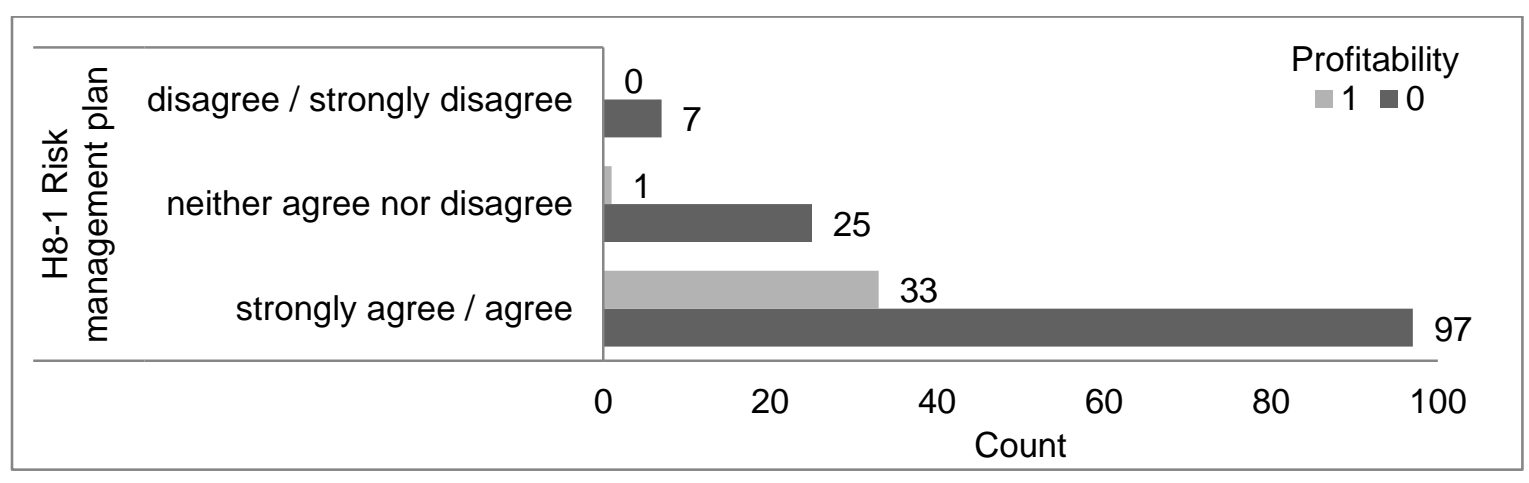


The result of the test, shown in Table 38, reveals significant evidence of a relationship between project risk management outputs (i.e., risk management plan) and long-term project success (i.e., profitability). The chi-square value was greater than the critical value (5.991 by two degrees of freedom), and the $p$-value was less than .05 . Therefore, the null hypothesis that there is no significant relationship between project risk management and long-term project success was rejected.

Table 38. Summary hypothesis testing: H8 project risk management

\begin{tabular}{llcc}
\hline & & \multicolumn{2}{c}{ Independence Test } \\
\cline { 3 - 4 } & Dependent project & Chi-Square Test & Fischer's \\
& outcome & $(2$-sided $)$ & (2-sided) \\
\hline Independent factor & Profitability & $\chi^{2}(2, \mathrm{~N}=163)=8.016, \mathrm{p}<.05$ & \\
\hline $\begin{array}{l}\text { H8-1 Risk management } \\
\text { plan }\end{array}$ & & & \\
\hline
\end{tabular}

Hypothesis $\mathrm{H} 9$

There is no significant relationship between long-term project success and project procurement management.

The independent project management processes outputs are procurement management plan, contract statement of work, make-or-buy decisions, procurement documents, supplier evaluation criteria, updates, procurement document package, proposals, selected sellers, contract, contract management plan, and contract documentation. 
The dependent project outcomes are customer satisfaction, stakeholder satisfaction, user satisfaction, commercial benefit for customer, project team satisfaction, commercial benefit for contractors, financial objectives, and strategic contribution of the project.

The entire test summary is shown in Table 44. Due to the large number of tests, only few are described in this section. Further tests are shown in Appendices C and D.

A chi-square test was conducted to examine whether there was a relationship between procurement management plan and customer satisfaction. The results revealed a significant relationship (chi-square value $=7.716, d f=2, p$ $<.05)$. A significantly larger proportion of the participants who had selected customer satisfaction as a project success criterion (53) reported that procurement management plan contributes to project success compared, while only 23 participants did not consider customer satisfaction as a project success criterion (see Table 39). The strength of this association is represented by the coefficient Cramer's V (.218), which indicates a moderate relationship.

A second chi-square test was conducted to examine whether there was a relationship between proposals and customer satisfaction. The results revealed a significant relationship (chi-square value $=10.845, \mathrm{df}=2, \mathrm{p}<.05$ ) (see Table 40). The strength of this association is represented by the coefficient Cramer's $V$ (.258), which indicates a moderately strong relationship. 


\section{Table 39. Crosstab H9-1 Procurement management plan * Customer satisfaction}

\begin{tabular}{|c|c|c|c|c|c|c|c|c|}
\hline & & & & & & \multicolumn{2}{|c|}{$\begin{array}{l}\text { Customer } \\
\text { satisfaction }\end{array}$} & \multirow[b]{2}{*}{ Total } \\
\hline & & & & & & 0 & 1 & \\
\hline \multirow{6}{*}{$\begin{array}{l}\text { H9-1 Procurement } \\
\text { management plan }\end{array}$} & \multicolumn{3}{|c|}{ strongly agree / agree } & \multicolumn{2}{|c|}{ Count } & 23 & 53 & 76 \\
\hline & & & & \multicolumn{2}{|c|}{ Expected Count } & 31.7 & 44.3 & 76.0 \\
\hline & neither a & ee $n$ & disagree & \multicolumn{2}{|c|}{ Count } & 35 & 32 & 67 \\
\hline & & & & \multicolumn{2}{|c|}{ Expected Count } & 28.0 & 39.0 & 67.0 \\
\hline & disagree & tron & disagree & \multicolumn{2}{|c|}{ Count } & 10 & 10 & 20 \\
\hline & & & & \multicolumn{2}{|c|}{ Expected Count } & 8.3 & 11.7 & 20.0 \\
\hline \multirow[t]{2}{*}{ Total } & & & & \multicolumn{2}{|c|}{ Count } & 68 & 95 & 163 \\
\hline & & & & \multicolumn{2}{|c|}{ Expected Count } & 68.0 & 95.0 & 163.0 \\
\hline \multicolumn{9}{|c|}{ Chi-Square Tests } \\
\hline & Value & $\mathrm{df}$ & \multicolumn{2}{|c|}{$\begin{array}{l}\text { Asymp. Sig. } \\
\text { (2-sided) }\end{array}$} & $\begin{array}{l}\text { Exact Sig. } \\
\text { (2-sided) }\end{array}$ & \multicolumn{2}{|c|}{$\begin{array}{l}\text { Exact Sig. } \\
\text { (1-sided) }\end{array}$} & $\begin{array}{c}\text { Point } \\
\text { Probability }\end{array}$ \\
\hline Pearson Chi-Square & $7.716^{\mathrm{a}}$ & 2 & \multicolumn{2}{|l|}{.021} & .019 & & & \\
\hline Likelihood Ratio & 7.812 & 2 & \multirow[t]{2}{*}{.020} & & .020 & & & \\
\hline Fisher's Exact Test & 7.761 & & & & .019 & & & \\
\hline Linear-by-Linear & $5.718^{b}$ & 1 & .017 & & .020 & .011 & & .005 \\
\hline \multicolumn{9}{|l|}{ Association } \\
\hline $\mathrm{N}$ of Valid Cases & 163 & & & & & & & \\
\hline
\end{tabular}

a. 0 cells $(0.0 \%)$ have expected count less than 5 . The minimum expected count is 8.34 .

b. The standardized statistic is -2.391 .

Symmetric Measures

\begin{tabular}{llccc}
\hline & & Value & Approx. Sig. & Exact Sig. \\
\hline Nominal by Nominal & Phi & .218 & .021 & .019 \\
& Cramer's V & .218 & .021 & .019 \\
N of Valid Cases & & 163.000 & & \\
\hline
\end{tabular}

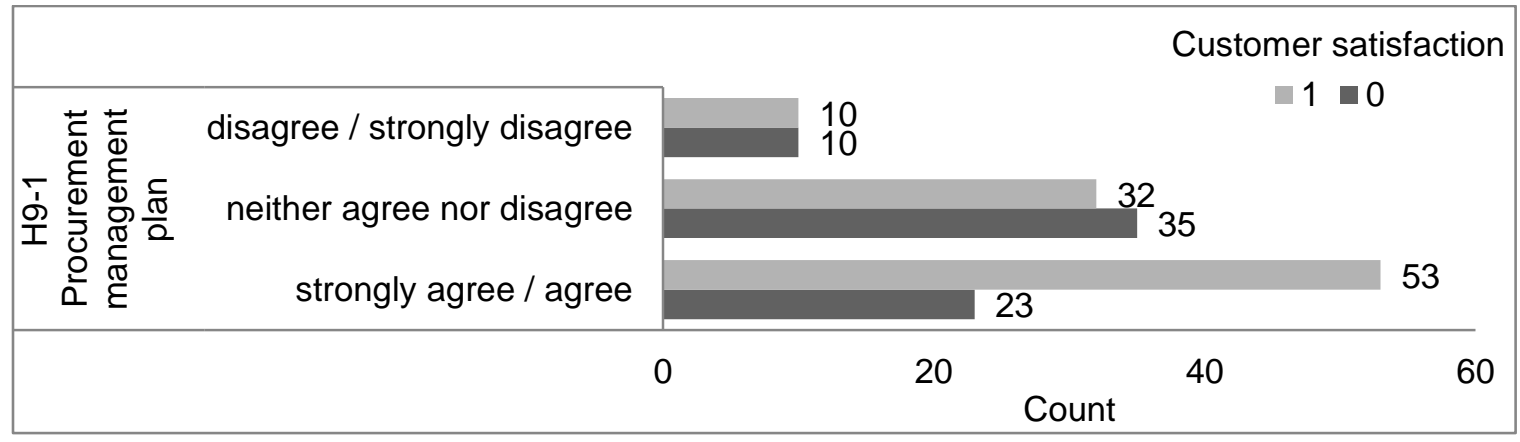


Table 40. Crosstab H9-8 Proposals * Customer satisfaction

\begin{tabular}{lllccc}
\hline & & \multicolumn{2}{c}{$\begin{array}{c}\text { Customer } \\
\text { satisfaction }\end{array}$} \\
\cline { 3 - 4 } & & 0 & 1 & Total \\
\hline \multirow{2}{*}{ H9-8 Proposals } & \multirow{2}{*}{ strongly agree / agree } & Count & 21 & 54 & 75 \\
& & Expected Count & 31.3 & 43.7 & 75.0 \\
& \multirow{2}{*}{ neither agree nor disagree } & Count & 39 & 33 & 72 \\
& \multirow{2}{*}{ disagree / strongly disagree } & Count & 30.0 & 42.0 & 72.0 \\
& & Expected Count & 6.7 & 9 & 16 \\
& & Count & 68 & 95 & 16.0 \\
& & & 68.0 & 95.0 & 163.0 \\
\hline
\end{tabular}

Chi-Square Tests

\begin{tabular}{lcccccc}
\hline & \multicolumn{7}{c}{$\begin{array}{c}\text { Asymp. Sig. } \\
\text { (2-sided) }\end{array}$} & $\begin{array}{c}\text { Exact Sig. } \\
\text { (2-sided) }\end{array}$ & $\begin{array}{c}\text { Exact Sig. } \\
\text { (1-sided) }\end{array}$ & $\begin{array}{c}\text { Point } \\
\text { Probability }\end{array}$ \\
\hline Pearson Chi-Square & $\mathbf{1 0 . 8 4 5 ^ { \mathrm { a } }}$ & 2 & .004 & .004 & & \\
Likelihood Ratio & 11.037 & 2 & .004 & .005 & & \\
Fisher's Exact Test & 10.942 & & & .004 & & .002 \\
Linear-by-Linear & $7.916^{\mathrm{b}}$ & 1 & .005 & .005 & .003 & \\
Association & & & & & & \\
N of Valid Cases & 163 & & & & & \\
\hline
\end{tabular}

a. 0 cells $(0.0 \%)$ have expected count less than 5 . The minimum expected count is 6.67.

b. The standardized statistic is $-2,814$.

\begin{tabular}{llccc}
\multicolumn{5}{c}{ Symmetric Measures } \\
\hline Nominal by Nominal & Phi & Value & Approx. Sig. & Exact Sig. \\
& Cramer's V & .258 & .004 & .004 \\
N of Valid Cases & & .258 & .004 & .004 \\
\hline
\end{tabular}

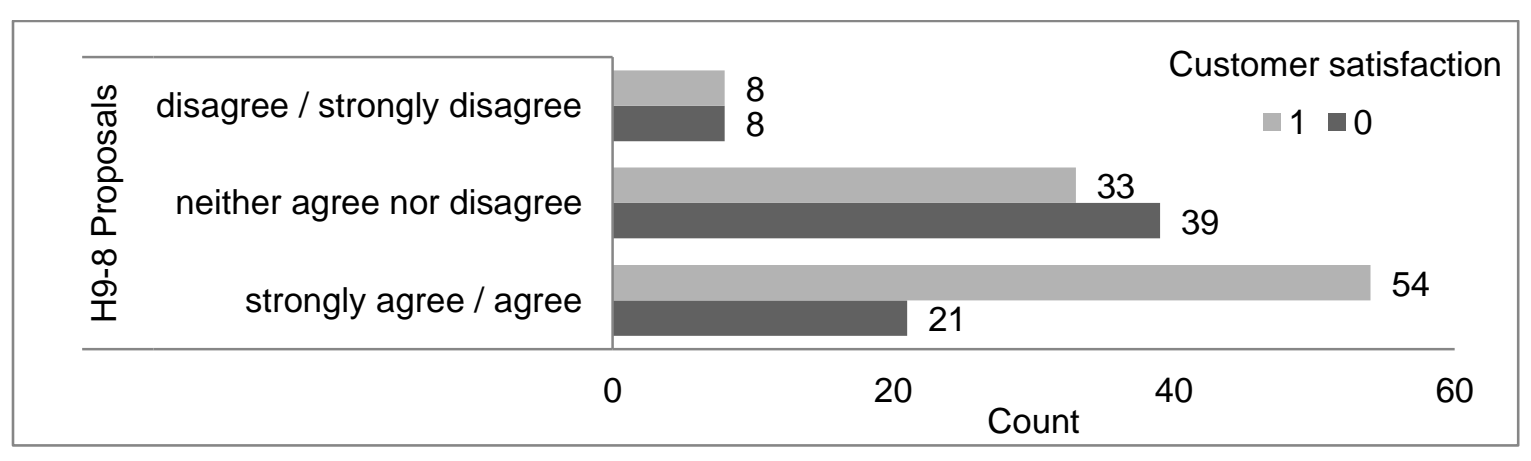


The third chi-square test was conducted to examine whether there was a relationship between selected sellers and customer satisfaction. The results revealed a significant relationship (chi-square value $=11.426$, df $=2, p<.05$ ). A significantly larger proportion of the participants who had selected customer satisfaction as a project success criterion (50) reported that selected sellers contribute to project success, while only 18 participants did not consider customer satisfaction as a project success criterion (see Table 41). The strength of this association is represented by the coefficient Cramer's V (.265), which indicates a moderately strong relationship.

The fourth chi-square test was conducted to examine whether there was a relationship between contract and customer satisfaction. The results revealed a significant relationship (chi-square value $=10.611, \mathrm{df}=2, \mathrm{p}<.05$ ). A significantly larger proportion of the participants who had selected customer satisfaction as a project success criterion (74) reported that contract contributes to project success, while only 39 participants did not consider customer satisfaction as a project success criterion (see Table 42). The strength of this association is represented by the coefficient Cramer's V (.255), which indicates a moderately strong relationship.

The fifth chi-square test was conducted to examine whether there was a relationship between contract management plan and customer satisfaction. The results revealed a significant relationship (chi-square value $=11.229, \mathrm{df}=2, \mathrm{p}<$ .05) (see Table 43). The strength of this association is represented by the coefficient Cramer's V (.262), which indicates a moderately strong relationship. 
Table 41. Crosstab H9-9 Selected sellers * Customer satisfaction

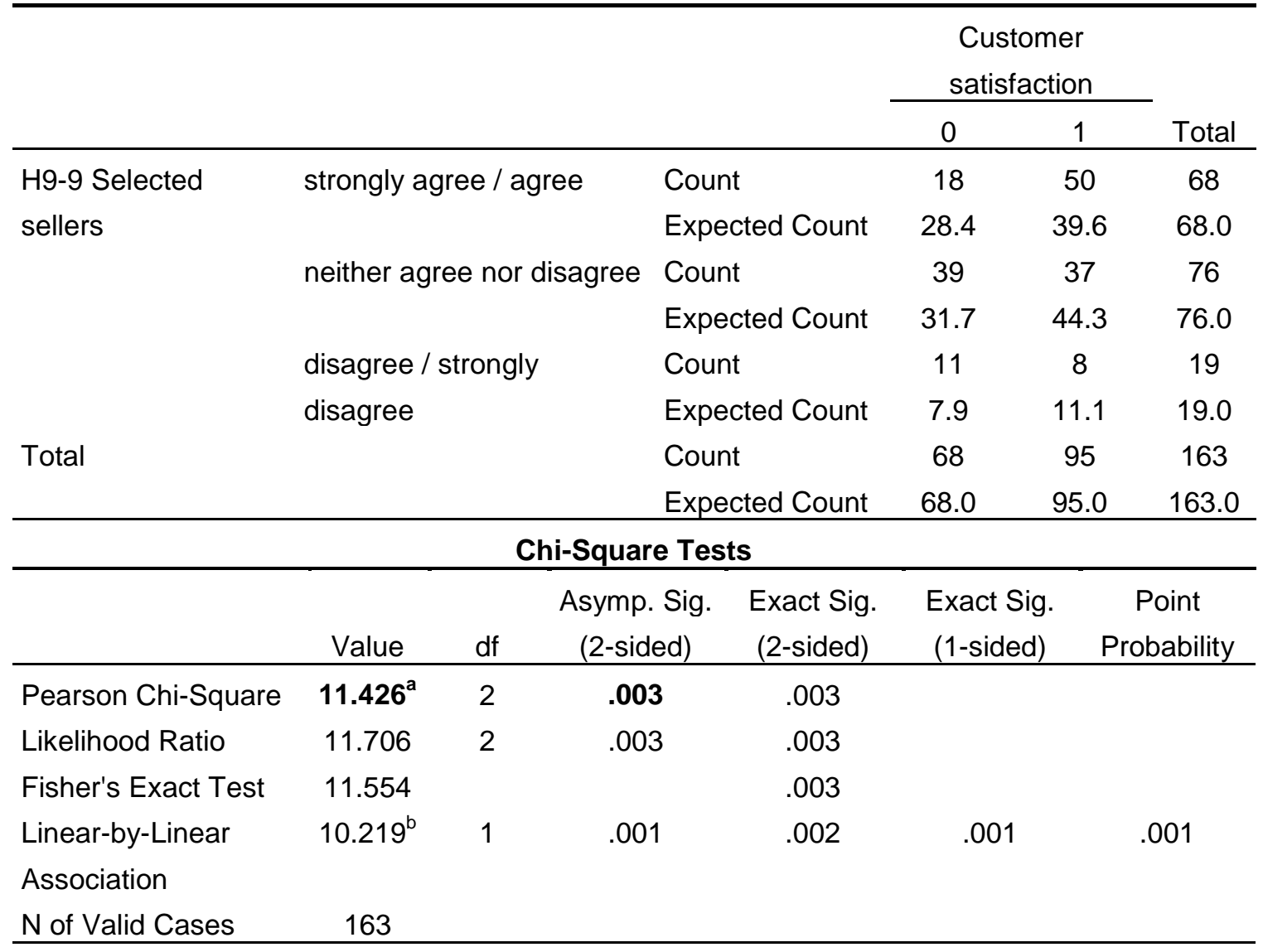

a. 0 cells $(0.0 \%)$ have expected count less than 5 . The minimum expected count is 7.93 .

b. The standardized statistic is -3.197 .

Symmetric Measures

\begin{tabular}{llccc}
\hline & & Value & Approx. Sig. & Exact Sig. \\
\hline Nominal by Nominal & Phi & .265 & .003 & .003 \\
& Cramer's V & .265 & .003 & .003 \\
N of Valid Cases & & 163 & & \\
\hline
\end{tabular}

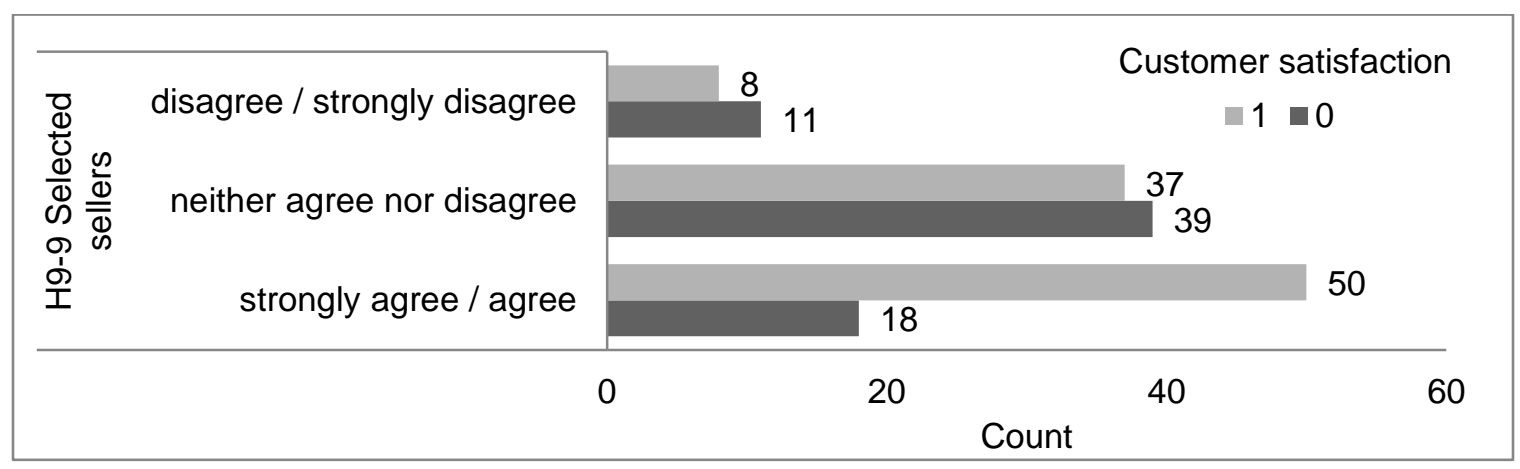




\section{Table 42. Crosstab H9-10 Contract * Customer satisfaction}

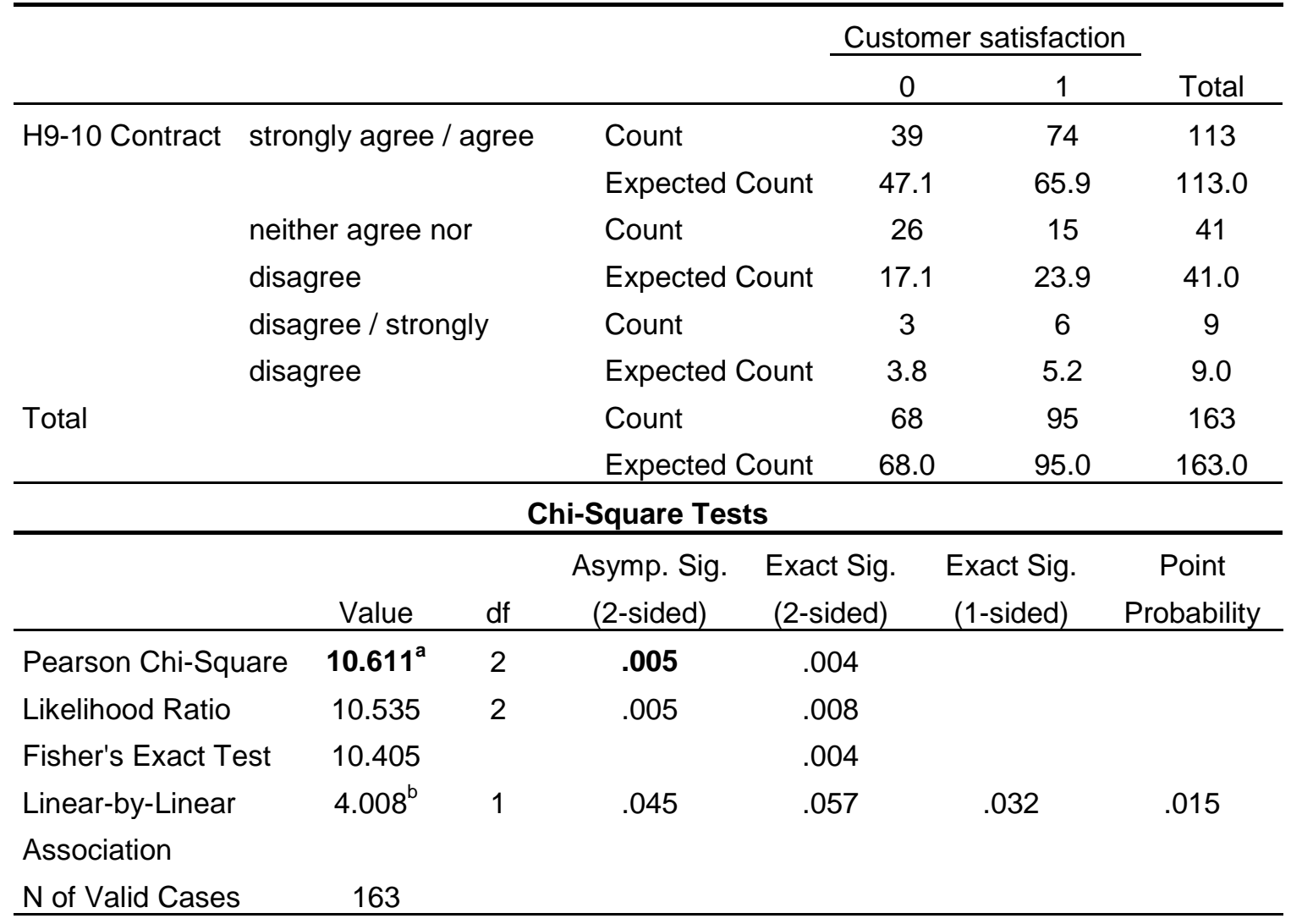

a. 1 cells $(16.7 \%)$ have expected count less than 5 . The minimum expected count is 3.75 .

b. The standardized statistic is -2.002 .

Symmetric Measures

\begin{tabular}{llccc}
\hline & & Value & Approx. Sig. & Exact Sig. \\
\hline Nominal by Nominal & Phi & .255 & .005 & .004 \\
& Cramer's V & .255 & .005 & .004 \\
N of Valid Cases & & 163 & & \\
\hline
\end{tabular}

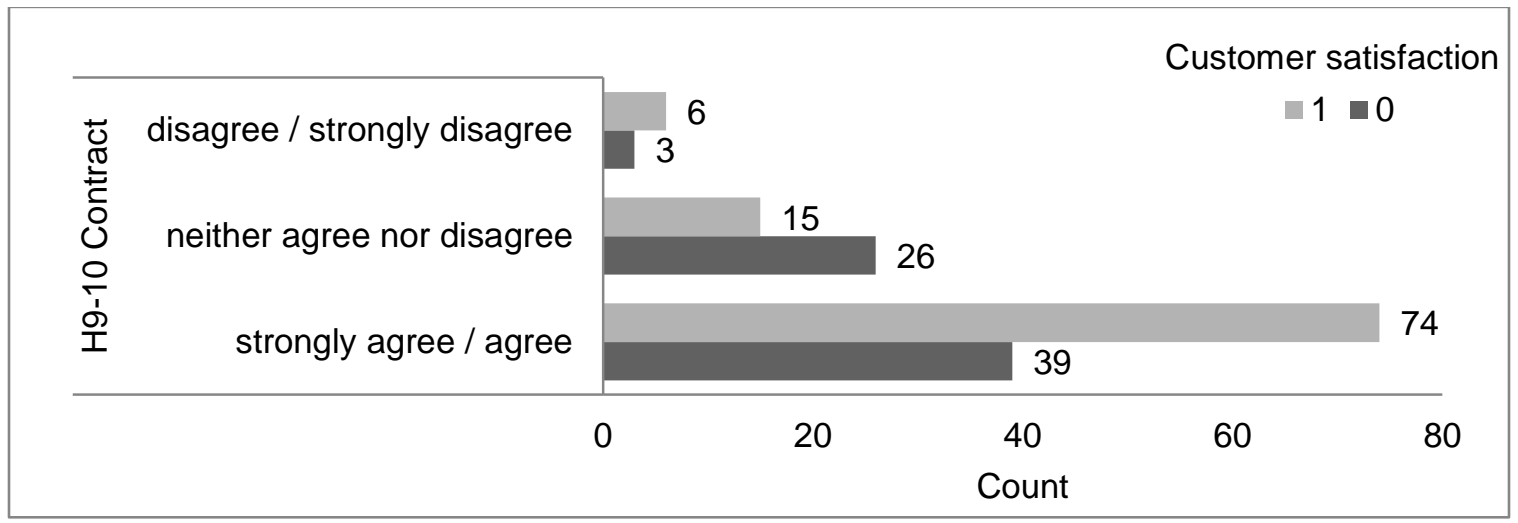




\section{Table 43. Crosstab H9-11 Contract management plan * Customer satisfaction}

\begin{tabular}{lllccc}
\hline & & & \multicolumn{2}{c}{$\begin{array}{c}\text { Customer } \\
\text { satisfaction }\end{array}$} \\
\cline { 4 - 5 } & & & 0 & 1 & Total \\
\hline H9-11 Contract & strongly agree / agree & Count & 18 & 49 & 67 \\
management plan & & Expected Count & 28.0 & 39.0 & 67.0 \\
& neither agree nor & Count & 39 & 32 & 71 \\
& disagree & Expected Count & 29.6 & 41.4 & 71.0 \\
& disagree / strongly & Count & 11 & 14 & 25 \\
& disagree & Expected Count & 10.4 & 14.6 & 25.0 \\
& & Count & 68 & 95 & 163 \\
& & Expected Count & 68.0 & 95.0 & 163.0 \\
\hline
\end{tabular}

\section{Chi-Square Tests}

\begin{tabular}{lcccccc}
\hline & Value & df & $\begin{array}{c}\text { Asymp. Sig. } \\
\text { (2-sided) }\end{array}$ & $\begin{array}{c}\text { Exact Sig. } \\
\text { (2-sided) }\end{array}$ & $\begin{array}{c}\text { Exact Sig. } \\
\text { (1-sided) }\end{array}$ & $\begin{array}{c}\text { Point } \\
\text { Probability }\end{array}$ \\
\hline Pearson Chi-Square & $\mathbf{1 1 . 2 2 9 ^ { \mathrm { a } }}$ & 2 & .004 & .003 & & \\
Likelihood Ratio & 11.464 & 2 & .003 & .004 & & \\
Fisher's Exact Test & 11.317 & & & .003 & & .006 \\
Linear-by-Linear & $5.574^{\mathrm{b}}$ & 1 & .018 & .019 & .012 & \\
Association & & & & & & \\
N of Valid Cases & 163 & & & & & \\
\hline
\end{tabular}

a. 0 cells $(0.0 \%)$ have expected count less than 5 . The minimum expected count is 10.43 .

b. The standardized statistic is -2.361 .

Symmetric Measures

\begin{tabular}{llccc}
\hline & & Value & Approx. Sig. & Exact Sig. \\
\hline Nominal by Nominal & Phi & .262 & .004 & .003 \\
& Cramer's V & .262 & .004 & .003 \\
N of Valid Cases & & 163 & & \\
\hline
\end{tabular}

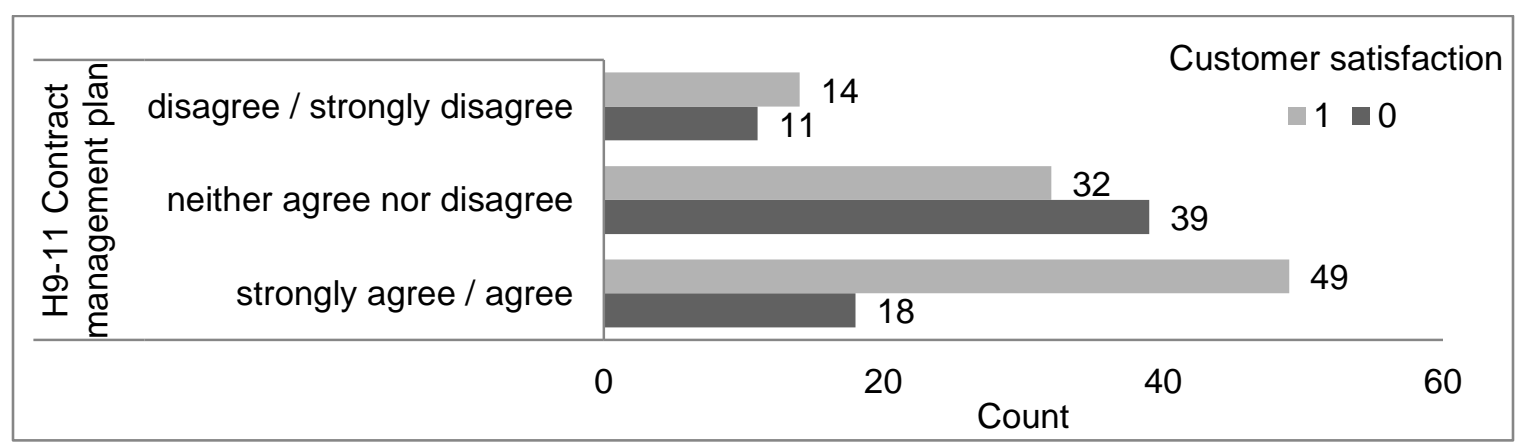




\section{Table 44. Summary hypothesis testing: H9 project procurement management}

\begin{tabular}{|c|c|c|c|}
\hline \multirow[b]{2}{*}{ Independent factors } & \multirow[b]{2}{*}{$\begin{array}{l}\text { Dependent project } \\
\text { outcomes }\end{array}$} & \multicolumn{2}{|l|}{ Independence Test } \\
\hline & & $\begin{array}{c}\text { Chi-Square Test } \\
\text { (2-sided) }\end{array}$ & $\begin{array}{l}\text { Fischer's } \\
\text { Exact Test } \\
\text { (2-sided) }\end{array}$ \\
\hline \multirow{2}{*}{$\begin{array}{l}\text { H9-1 Procurement } \\
\text { management plan }\end{array}$} & Customer satisfaction & $\chi^{2}(2, N=163)=7.716, p<.05$ & \\
\hline & Stakeholder satisfaction & $\chi^{2}(2, N=163)=10.768, p<.05$ & \\
\hline \multirow{2}{*}{$\begin{array}{l}\text { H9-2 Contract } \\
\text { statement of work }\end{array}$} & Technical objectives & $\chi^{2}(2, N=163)=9.852, p<.05$ & \\
\hline & Scope & $\chi^{2}(2, N=163)=8.986, p<.05$ & \\
\hline $\begin{array}{l}\text { H9-3 Make-or-buy } \\
\text { decisions }\end{array}$ & $\begin{array}{l}\text { Commercial benefit for } \\
\text { customer }\end{array}$ & $\chi^{2}(2, N=163)=7.304, p<.05$ & \\
\hline $\begin{array}{l}\text { H9-4 Procurement } \\
\text { documents }\end{array}$ & Project team satisfaction & $\chi^{2}(2, N=163)=7.673, p<.05$ & \\
\hline $\begin{array}{l}\text { H9-5 Supplier } \\
\text { evaluation criteria }\end{array}$ & Project team satisfaction & $\chi^{2}(2, N=163)=6.505, p<.05$ & \\
\hline H9-6 Updates & Performance objectives & $\chi^{2}(2, N=163)=9.347, p<.05$ & \\
\hline $\begin{array}{l}\text { H9-7 Procurement } \\
\text { document package }\end{array}$ & Scope & $\chi^{2}(2, N=163)=9.487, p<.05$ & \\
\hline \multirow[t]{2}{*}{ H9-8 Proposals } & Customer satisfaction & $\chi^{2}(2, N=163)=10.845, p<.05$ & \\
\hline & $\begin{array}{l}\text { Commercial benefit for } \\
\text { contractors }\end{array}$ & & $p=.026$ \\
\hline \multirow[t]{2}{*}{ H9-9 Selected sellers } & Customer satisfaction & $\chi^{2}(2, N=163)=11.426, p<.05$ & \\
\hline & Financial objectives & $\chi^{2}(2, N=163)=7.277, p<.05$ & \\
\hline H9-10 Contract & Customer satisfaction & $\chi^{2}(2, N=163)=10.611, p<.05$ & \\
\hline H9-11 Contract & Customer satisfaction & $\chi^{2}(2, N=163)=11.229, p<.05$ & \\
\hline management plan & User satisfaction & $\chi^{2}(2, N=163)=6.022, p<.05$ & \\
\hline \multirow{3}{*}{$\begin{array}{l}\text { H9-12 Procurement } \\
\text { management plan } \\
\text { (update) }\end{array}$} & Customer satisfaction & $\chi^{2}(2, N=163)=10.321, p<.05$ & \\
\hline & $\begin{array}{l}\text { Strategic contribution of } \\
\text { the project }\end{array}$ & $\chi^{2}(2, N=163)=6.307, p<.05$ & \\
\hline & $\begin{array}{l}\text { Commercial benefit for } \\
\text { customer }\end{array}$ & $\chi^{2}(2, N=163)=9.301, p<.05$ & \\
\hline $\begin{array}{l}\text { H9-13 Contract } \\
\text { documentation }\end{array}$ & $\begin{array}{l}\text { Strategic contribution of } \\
\text { the project }\end{array}$ & $\chi^{2}(2, N=163)=6.020, p<.05$ & \\
\hline
\end{tabular}


A shown in Table 44, the results of the tests revealed a significant relationship between project procurement management outputs (i.e., procurement management plan, procurement documents, supplier evaluation criteria, proposals, selected sellers, contract, , contract management plan, and contract documentation) and long-term project success (i.e., customer, stakeholder and project team satisfaction, financial objectives, strategic contribution of the project). The chi-square values were greater than the critical value ( 5.991 by two degrees of freedom), and the p-values were less than .05 in both the chi-square and Fischer's exact tests. Therefore, the null hypothesis that there is no significant relationship between project procurement management and long-term project success was rejected. 


\section{DISCUSSION OF RESULTS}

A total of 163 participants took the online survey. Eighty-nine percent are male and $11.0 \%$ female. Nearly six percent are between 20 and 30 years old, $36.8 \%$ are between 31 and 40 years old, $46 \%$ are between 41 and 50 years old, and $11.7 \%$ are older than 50 . Their work experience ranges from less than two years $(4.3 \%$ of total) to more than $20(25.2 \%)$, but all respondents $(100 \%)$ are involved in project work. Project management experience ranges from fewer than two years $(1.8 \%)$ to more than $20(6.1 \%)$. Nearly $87 \%$ earned a project management certification, 76.1\% earned the Project Management Professional (PMP) certification, 1.1\% earned the Program Management Professional (PgMP), 3.3\% earned the PMI Agile Certified Practitioner (PMI-ACP) SM, 1.1\% earned the PMI Risk Management Professional (PMI- RMP), and $0.6 \%$ earned the Certified Associate in Project Management (CAPM). Eighty-five percent are project managers, $4.9 \%$ are project coordinators, and $4.3 \%$ are project team members. Their projects comprise engineering (14.1\%), construction (1.8\%), information technology $(68.7 \%)$, enterprise resource planning $(4.9 \%)$, and infrastructure design and development (1.8\%). Nearly $10 \%$ of those projects took

an average of under six months $(9.8 \%)$, and $3.1 \%$ of them took more than 48 months. Approximately one half $(49.7 \%)$ are working on projects for external clients, $25.8 \%$ for internal clients, and $24.5 \%$ a combination of both. The sizes of 
the project teams range from fewer than five members (4.3\%) to more than 100 (4.9\%). The most common last project completion date was five years ago or less $(98.9 \%)$, followed by more than five years ago $(1.2 \%)$. The sizes of the project budgets range from less than $\$ 100,000$ (4.3\%) to more than $\$ 50$ million (1.8\%). Their business areas are computers/Information technology (24.5\%), construction (3.2\%), engineering (12.2\%), education (1.4\%), government $(5.5 \%)$, health care $(5.0 \%)$, manufacturing $(9.6 \%)$, software development $(15.4 \%)$, and telecommunications (15.6\%).

\section{Project Success Criteria:}

According to the survey, the top-nine criteria for judging project success are budget/cost $(79.8 \%)$, schedule $(73.0 \%)$, customer satisfaction (58.3), stakeholder satisfaction (37.4\%), scope (31.9\%), financial objectives $(30.1 \%)$, technical objectives (22.7\%), customer approval (20.9\%), and profitability (20.9\%). Schedule, budget/cost, scope, and technical objectives are short-term or past-oriented criteria (POC). The remaining criteria - customer and stakeholder satisfaction, financial objectives, customer approval, and profitability - are long-term or future-oriented criteria (FOC). These results reveal that five of the top-nine criteria for judging project success are long-term success criteria and four are short-term success criteria.

\section{Project Type and Project Success Criteria:}

The study reveals that the criteria used to judge project success are related to project type. For engineering projects, the top three project success 
criteria are budget/cost (82.6\% within this project type), schedule $(78.3 \%)$, and customer satisfaction (56.5). In construction projects, the criteria used are budget/cost (100\%), profitability (66.7\%), and schedule (33.3\%). In IT projects, the criteria used are budget/cost (80.4\%), schedule (75.9\%), and customer satisfaction (60.7\%).

\section{Project Size and Project Success Criteria:}

The results reveal that project success depends on project size. According to the survey, all project sizes use budget/cost as project success criteria. For projects of more than $\$ 50$ million, the scope, not the schedule, is considered the most important criterion of project success. Customer satisfaction is not used in projects of less than $\$ 100,000$. Stakeholder satisfaction is important for projects over $\$ 1$ million and less than $\$ 10$ million. 


\section{Table 45. Demographic characteristics of the respondents (1)}

\begin{tabular}{|c|c|c|c|}
\hline & & Frequency & Percent \\
\hline \multirow[t]{2}{*}{ Gender } & Male & 145 & 89.0 \\
\hline & Female & 18 & 11.0 \\
\hline \multirow[t]{4}{*}{ Age } & 20 - 30 years & 9 & 5.5 \\
\hline & $31-40$ years & 60 & 36.8 \\
\hline & $41-50$ years & 75 & 46.0 \\
\hline & Older than 50 years & 19 & 11.7 \\
\hline \multirow[t]{5}{*}{ Work experience } & Less than 2 years & 1 & .6 \\
\hline & 2 - 5 years & 7 & 4.3 \\
\hline & $6-10$ years & 30 & 18.4 \\
\hline & $11-20$ years & 84 & 51.5 \\
\hline & More than 20 years & 41 & 25.2 \\
\hline \multirow[t]{2}{*}{ Project work } & Yes & 163 & 100.0 \\
\hline & No & 0 & 0.0 \\
\hline \multirow[t]{2}{*}{ Last project completion } & Five years ago or less & 161 & 98.8 \\
\hline & More than five years ago & 2 & 1.2 \\
\hline \multirow[t]{5}{*}{ Size of project budgets } & Less than $\$ 100,000$ & 7 & 4.3 \\
\hline & More than $\$ 100,000$ - Less than $\$ 1$ million & 66 & 40.5 \\
\hline & $\begin{array}{l}\text { More than } \$ 1 \text { million - Less than } \$ 10 \\
\text { million }\end{array}$ & 67 & 41.1 \\
\hline & $\begin{array}{l}\text { More than } \$ 10 \text { million - Less than } \$ 50 \\
\text { million }\end{array}$ & 20 & 12.3 \\
\hline & More than $\$ 50$ million & 3 & 1.8 \\
\hline \multirow[t]{5}{*}{ Function of the project } & Project manager & 139 & 85.3 \\
\hline & Project coordinator & 8 & 4.9 \\
\hline & Project team member & 7 & 4.3 \\
\hline & Steering committee member & 1 & 6 \\
\hline & Advisor & 1 & .6 \\
\hline
\end{tabular}




\section{Table 46. Demographic characteristics of the respondents (2)}

\begin{tabular}{|c|c|c|c|}
\hline & & Frequency & Percent \\
\hline \multirow[t]{6}{*}{ Project type } & Engineering & 23 & 14.1 \\
\hline & Construction & 3 & 1.8 \\
\hline & Information technology & 112 & 68.7 \\
\hline & Enterprise resource planning & 8 & 4.9 \\
\hline & $\begin{array}{l}\text { Infrastructure design and } \\
\text { development }\end{array}$ & 3 & 1.8 \\
\hline & Other & 14 & 8.6 \\
\hline \multirow[t]{3}{*}{ Project purpose } & Internal client & 42 & 25.8 \\
\hline & External client & 81 & 49.7 \\
\hline & Both & 40 & 24.5 \\
\hline \multirow[t]{6}{*}{ Size of project teams } & Fewer than 5 & 7 & 4.3 \\
\hline & $5-10$ & 38 & 23.3 \\
\hline & $11-20$ & 46 & 28.2 \\
\hline & $21-50$ & 52 & 31.9 \\
\hline & $51-100$ & 12 & 7.4 \\
\hline & More than 100 & 8 & 4.9 \\
\hline \multirow[t]{6}{*}{ Project duration } & $1-6$ months & 16 & 9.8 \\
\hline & 7 - 12 months & 60 & 36.8 \\
\hline & 13 - 24 months & 63 & 38.7 \\
\hline & 25 - 36 months & 16 & 9.8 \\
\hline & 37 - 48 months & 3 & 1.8 \\
\hline & More than 48 months & 5 & 3.1 \\
\hline \multirow[t]{10}{*}{ Industry area ${ }^{a}$} & Computers / Information technology & 107 & 24.5 \\
\hline & Construction & 14 & 3.2 \\
\hline & Engineering & 53 & 12.2 \\
\hline & Education & 6 & 1.4 \\
\hline & Government & 24 & 5.5 \\
\hline & Health care & 22 & 5.0 \\
\hline & Manufacturing & 42 & 9.6 \\
\hline & Software development & 67 & 15.4 \\
\hline & Telecommunications & 68 & 15.6 \\
\hline & Other & 33 & 7.6 \\
\hline
\end{tabular}


Table 47. Demographic characteristics of the respondents (3)

\begin{tabular}{|c|c|c|c|}
\hline & & Frequency & Percent \\
\hline \multirow[t]{5}{*}{ PM experience } & Less than 2 years & 3 & 1.8 \\
\hline & 2 - 5 years & 29 & 17.8 \\
\hline & $6-10$ years & 62 & 38.0 \\
\hline & $11-20$ years & 59 & 36.2 \\
\hline & More than 20 years & 10 & 6.1 \\
\hline \multirow[t]{2}{*}{ PM certification } & Yes & 141 & 86.5 \\
\hline & No & 22 & 13.5 \\
\hline \multirow[t]{6}{*}{ PM certification type ${ }^{a}$} & $\begin{array}{l}\text { Certified Associate in Project Management } \\
\text { (CAPM) }\end{array}$ & 1 & 0.6 \\
\hline & Project Management Professional (PMP) & 137 & 76.1 \\
\hline & Program Management Professional (PgMP) & 2 & 1.1 \\
\hline & PMI Agile Certified Practitioner (PMI - ACP) SM & 6 & 3.3 \\
\hline & $\begin{array}{l}\text { PMI Risk Management Professional (PMI - } \\
\text { RMP) }\end{array}$ & 2 & 1.1 \\
\hline & Other & 32 & 17.8 \\
\hline \multirow[t]{7}{*}{ PM software used ${ }^{a}$} & Basecamp & 3 & 1.3 \\
\hline & Microsoft Project & 146 & 63.5 \\
\hline & Smartsheet & 4 & 1.7 \\
\hline & Projectplace & 7 & 3.0 \\
\hline & PLANTA Project & 2 & 0.9 \\
\hline & 2-plan & 2 & 0.9 \\
\hline & Other & 66 & 28.7 \\
\hline \multirow[t]{4}{*}{ Source of the software } & Commercial Software & 92 & 56.4 \\
\hline & Company's own Software & 12 & 7.4 \\
\hline & Combination of both & 56 & 34.4 \\
\hline & Other & 3 & 1.8 \\
\hline
\end{tabular}




\section{Relationship between project integration management and long-term}

\section{project success}

The results presented in Chapter Four reveal significant evidence of a relationship between project integration management and long-term project success.

Project charter - Sales: The project charter is a document authorizing a project within an organization and giving the project manager the necessary authority to assign project activities to human and/or technical resources. When the management officializes a project, all involved in that project feel comfortable because they face fewer problems than they would if they lacked a project charter; a charter lessens the potential for resistance to reduce the available resources necessary for a project. Projects are ranked in a project charter according to key commercial indicators. This ranking allows top management, stakeholders, sponsors, and project owners to prioritize projects. As a project charter includes product and service sales, activities could begin at this stage (i.e., project initiating). A charter's project ranking and key commercial indicators could have either a negative or positive affect on sales; thus, lower priority projects may have less sales than higher priority ones.

\section{Preliminary project scope and project Management plan - Stakeholder} satisfaction: A preliminary project scope statement defines a project's scope. It is used as an agreement between stakeholders about the project's scope and objectives. With this document, all stakeholders "speak the same language." A 
preliminary project scope statement setting out the project requirements and expectations, the criteria for measuring project success, and product or service objectives that are measurable, attainable, and realistic, which is then coordinated with a project management plan including all project planning documents, could contribute to stakeholder satisfaction.

Implemented preventive actions - Financial objectives: In order to reduce or eliminate project risks, a project team defines measures during the product or service development to prevent any non-conformities. The measures defined depend on the project team's experience. Simple and cheap solutions can sometimes be used to reduce or eliminate non-conformities, but actions required by the customer can be expensive or impact project profitability or financial objectives (e.g., if customers compel their suppliers to implement a $100 \%$ final visual check before delivering products, executed by three shifts every day during the product life cycle). Therefore, preventive actions could help firms achieve their financial objectives.

Forecasts - Performance objectives: Project managers regularly report project statuses to the project steering committee. These reports include the progress of the projects and forecasts. If the latter indicate that the performance objectives will not be achieved, further intervention from the management or project steering committee will be needed. Performance objectives that are definitely not attainable should be reviewed and updated with the project owner or customer; 
this can occur in product development projects, when the product fails to meet customer specifications because the test values or conditions were exaggerated. Therefore, forecasting could impact the performance objectives.

\section{Rejected change request - User satisfaction / Technical objectives:} Changes are common during the development phase of a product or service. Modifying the material of a product by drawing from another one with higher or lower material characteristics will impact the technical objectives. Changing the terms or conditions of a service could also contribute to either the satisfaction or dissatisfaction of the service users.

$\underline{\text { Relationship between project scope management and long-term project }}$

\section{success}

Scope baseline - Project team satisfaction / Profitability: Project managers track the progress of their projects by using baselines, one of which is the scope baseline, which measures how far a project is meeting its project scope objectives. Project teams are often faced with the unofficial enlargement of an approved project scope, which then requires additional human and technical resources. Such a circumstance could contribute to project team dissatisfaction and impact profitability. If the scope remains unchanged and the project team meets its scope baseline; however, the project should be achieved. 


\section{Relationship between Project Time Management and Long Term Project}

\section{$\underline{\text { Success }}$}

Activity list / Activity attributes / Activity resource requirement and RBS Customer satisfaction: The project customer pays the costs of product or service development as a lump-sum or amortized cost in the product or service unit price. The supplier must justify these costs by submitting a detailed breakdown based on an activity list that includes the work to be performed for the project, the resources needed for each activity, and the responsible people. The customer's purchasing department needs this detail to justify the costs internally. When the customer and supplier sign the contact for the development costs, it can be assumed that both parties to this contract (the purchasing department on the customer side and the sales department on the supplier side) are satisfied. Therefore, the activity list and related activity attributes, the activity resources, and the derived resources breakdown structure (RBS) could contribute to customer satisfaction during the negotiation phase and thus impact sales.

Resources calendar - Performance objectives: A resources calendar is created to show who (i.e., the human resources) or what (i.e., the technical resources) are assigned to which project activities and when. Human resources abilities differ from one person to another. An experienced design engineer needs less time to develop a product than an engineer with less experience. Technical equipment and resources also have different capacities, which could 
impact the completion date and thus the project schedule. Therefore, the resources calendar could influence the performance objectives.

Project schedule - Customer satisfaction: Using the project milestones submitted by the customer, the project manager builds in accordance with the project team and all involved parties (both internal and external) the project schedule, which includes a planned start and finish date for each activity to be performed. Activities are usually scheduled to meet the customer requirements set for each milestone. Thus, the finishing and milestone dates must be coherent. In later phases of the project, this schedule is used to show the progress of the project to the customer or steering committee; in this case, the schedule includes the percentage of work accomplished. Using a project schedule to show the customer that the project is in line with the time requirements and that the project's activities are all planned and its resources assigned could contribute to customer satisfaction.

Relationship between Project Cost Management and Long-term Project

\section{Success}

Activity costs estimates supporting detail - Customer satisfaction and approval: As mentioned, the customer pays the costs for development activities as a lump-sum or amortized cost in the product or service unit price. During the cost negotiation phase, the customer expects details about the estimated costs, such as a detailed breakdown and information or documents supporting the 
plausibility of the estimation. Once the customer is satisfied with the cost estimation, the development phase is commercially approved. Therefore, using activity cost estimates with supporting detail could contribute to customer satisfaction, the basis of a commercial partnership. If such satisfaction is achieved, the development cost should be approved.

Cost baseline - Customer approval: One of the baselines project managers use to track the progress of their projects is the cost baseline, which measures how a project is meeting its cost objectives. A project's target budget should be maintained. The project manager is responsible for optimizing activities that could push the project into cost overruns. Development budgets are sometimes agreed upon with the customer; the project manager must justify development cost overruns to the steering committee and the customer. Meeting the cost baseline could contribute to customer satisfaction and lead to cost underruns, to the commercial benefit of both customer and supplier. When the customer's cost expectations are met, there should be no obstacle to the approval of justified costs.

Relationship between Project Quality Management and Long-term Project

\section{Success}

Quality management plan - Customer and stakeholder satisfaction: Each customer expects his goods or services to be delivered in the right quantity, on time, and with the agreed quality. A quality management plan includes 
documents describing how the quality of goods is assured and controlled. These documents are created in the product development phase and used in the realization phase. They cover the whole realization process, from the inspection of raw materials to the final check before dispatch. Some automotive suppliers implement additional quality checks at the customer plant before the products hit the assembly lines to achieve a zero-reject rate (0 PPM); this is managed quality. A customer who receives only quality goods will never complain, and all stakeholders will be satisfied. Therefore, well-managed quality through comprehensive quality management contributes to customer and stakeholder satisfaction

Recommended corrective actions - Strategic contribution of the project: Continuous improvement is a goal-oriented activity within the quality system that helps organizations and manufacturing companies enhance the quality of their services or products. The outputs of the continuous improvement process are effective actions, either preventive or corrective, recommended for implementation. These actions could affect the entire organization and represent an overall improvement, which could then have a significant and strategic effect.

Relationship between Project HR Management and Long-term Project Success

Roles and responsibilities / Staffing management plan - Stakeholder and user satisfaction: It is useful to have lists describing everyone involved in a 
project, their roles (i.e., the project activities to be performed by each person), their decision-making authority, and their competencies. These lists show stakeholders the levels of skills and competencies required by the project and who is assigned to the project activities. A good fit is required between task and worker; sometimes, additional competencies must be acquired (e.g., through a staffing management plan), or the project will be put at risk. Therefore, defining the roles and responsibilities concerning project activities, combined with a staffing management plan, could contribute to stakeholder and user satisfaction.

Relationship between Project Communication Management and Long-term

\section{Project Success}

Communication management plan - Customer satisfaction: Communication in projects is key - communication in teams, in groups, between teams and groups, and through internal and external communication, such as with suppliers and customers. Project management comprises many processes, each receiving inputs and outputs. One output could be an input for another process. Therefore, inputs and outputs must be communicated throughout a project. A project communication plan defines communication types, when to communicate, who should communicate, and when the communication should take place (e.g., in monthly project steering committee meetings or meetings with customers). The format of the presentation and the topics are often standardized for all projects. Project managers report the status of their projects monthly, and the customer or steering committee ideally reacts appropriately when something goes wrong. 
Therefore, a communication management plan could contribute to customer satisfaction

\section{Relationship between Project Risk Management and Long-term Project}

\section{Success}

Risk management plan - Profitability: A risk management plan is a predefined procedure for evaluating the probability of events that could have a negative effect on project outcomes. The evaluation could be monthly, quarterly, or during each project phase. The risk evaluation should involve the entire project environment, customers, markets, suppliers, schedule, economics, human and technical resources, product, process, and quality. Project managers evaluate a list of categories in detail using a risk topology according to an internal scale similar to a Likert scale: 1 for no risk, 2 for low risk, 3 for moderate risk, 4 for high risk, and 5 for very high risk. Management support is required in high and very high-risk cases. When a customer changes the scope of an ongoing new product development project, the development time may be increased as a result, possibly requiring additional resources and delaying the product's market entry. Either result could have a negative effect on project profitability. Thus, managing risk in preventive and proactive ways is required. 


\section{Relationship between Project Procurement Management and Long-term}

\section{Project Success}

A supplier could also be a customer at the same time. Suppliers can be customers of sub-suppliers, thus enjoying a customer/supplier relationship involving management by a supplier management team on one side or customer management on the other from first contact (i.e., in a project-related request for a quotation), throughout all project phases and during product or service realization, until the contract closure (i.e., end of the product or service life cycle).

\section{Procurement management plan / Procurement documents / Supplier} evaluation, Supplier selection - Customer, stakeholder, and project team satisfaction: A procurement management plan is a company's structured method of defining and establishing the steps required for managing purchases and acquisitions in a project. The procurement management plan ensures that suppliers or sub-suppliers are following the customer's or end-user's policies. Supplier or sub-supplier problems regarding quality, deliveries, or commercial issues concern stakeholders, who must spend much time and effort solving the problems. Thus, managing suppliers and sub-suppliers effectively using a procurement management plan that complies with customer needs and evaluates, selects, and rewards suppliers and sub-suppliers who are competitive in terms of cost and quality could contribute to customer, stakeholder, and project team satisfaction. 
Make-or-buy-decisions - Commercial benefit for customer: Projects follow make-or-buy procedures to define which services, products, components, or systems must be acquired externally. Decisions are taken after the signature of the contract with the customer, project sponsor, or end-user (if any). These decisions are cost- , quality-, or capacity-oriented. Cost-oriented decisions can impact the business position of a project positively. The decision whether to make molding tools and stamped or molded sub-components in Germany or in low-cost countries like Slovakia or Romania is significant for a project's financial objectives. Customers may request cost or price reductions. Therefore, a make or buy decisions could benefit both the customer and the supplier. 


\section{CONCLUSIONS AND FUTURE RESEARCH}

This dissertation set out to investigate the role that the project management body of knowledge plays in helping organizations and companies to improve the resulting project outcomes and achieving predetermined shortand long-term project success. In this final chapter the following will be reviewed and / or discussed: the research contributions of this dissertation, the directions for future research, implications and finally the framework.

One of the more significant findings to emerge from this study is from the top-nine used criteria for judging project success five of them are long-term success criteria and four are short-term success criteria. Profitability could be considered, as strategic objectives, that projects tend to achieve. Therefore, this finding confirms the suggestion of Cleland (1986) to consider project success of two views: 1) the fulfillment of predetermined technical requirements an time and within budget, and 2) the achievement of the Strategic objectives. The second major finding was that project success depends on project type and project size, therefore the emphasis of the project success criteria is different for different project types. For construction projects, the top-three project success criteria are budget/cost, profitability, and schedule. For engineering and information technology projects, the emphasis is different, thus budget/cost, schedule and customer satisfaction. However, customer satisfaction is not used for judging 
projects of size less than $\$ 100,000$. It seems also that the schedule it not the focus of project of the size more than $\$ 50$ million.

These findings confirm the observation of McCoy (1986) that there is no generally accepted definition for project success and that there is neither a generally accepted definition for project success nor guidelines to measure.

The study has gone some way towards enhancing our understanding of the project management body of knowledge represented in the nine knowledge areas and the related project management process groups. The empirical findings in this study contribute to existing knowledge in project success criteria and project success factors by providing an operational link between these factors, outputs of the project management groups, to the project outcomes or project measurement criteria. The present study confirms previous findings that confirmed the role of project management in achieving long-term project success and contradicts those studies stating that the role of project management is limited to the controlling of cost, budget and scope.

Although the study has successfully demonstrated that the project management body of knowledge contributes to both short-term and long-term project success, and that the project success depends on the type and size of the project to be judged, it has certain limitations in terms of the perspective of different functions in the project management filed. The sample was representative in term of Knowledge and experience in the project management field. A large proportion of the participants are project managers, who are familiar with the project management processes, but the question regarding which criteria 
are used to judge project success and which factors contribute that success, the sample would tend to miss a representative proportion of participants who are project team members, project committee members, etc. ... in order investigate the interdependence between the function on the project and the perspective regarding the success measurement. As stated by Freeman and Beale (1992), "an architect may consider success in terms of aesthetic appearance, an engineer in terms technical competence, an accountant in terms of dollars spent under budget, and chief executive officers rate their success in the stock market". The population from which the sample was drawn does not constitute a homogeneous group, therefore a stratified sampling technique will be recommended for further research in order to obtain a representative sample. The strata could be formed on the basis on relevant common characteristics like: (a) function on the project; (b) project type; (c) industry; and (d) project budget.

\section{Contributions}

To the best of our knowledge, this study is the first one investigating the relationships between all outputs of the project management body of knowledge processes and the project success. Nine knowledge areas (integration management, scope management, time management, cost management, quality management, communication management, risk management, human resources management, and procurement management), and four project management process groups (initiating, planning, executing, monitoring, and controlling) have been investigated. 


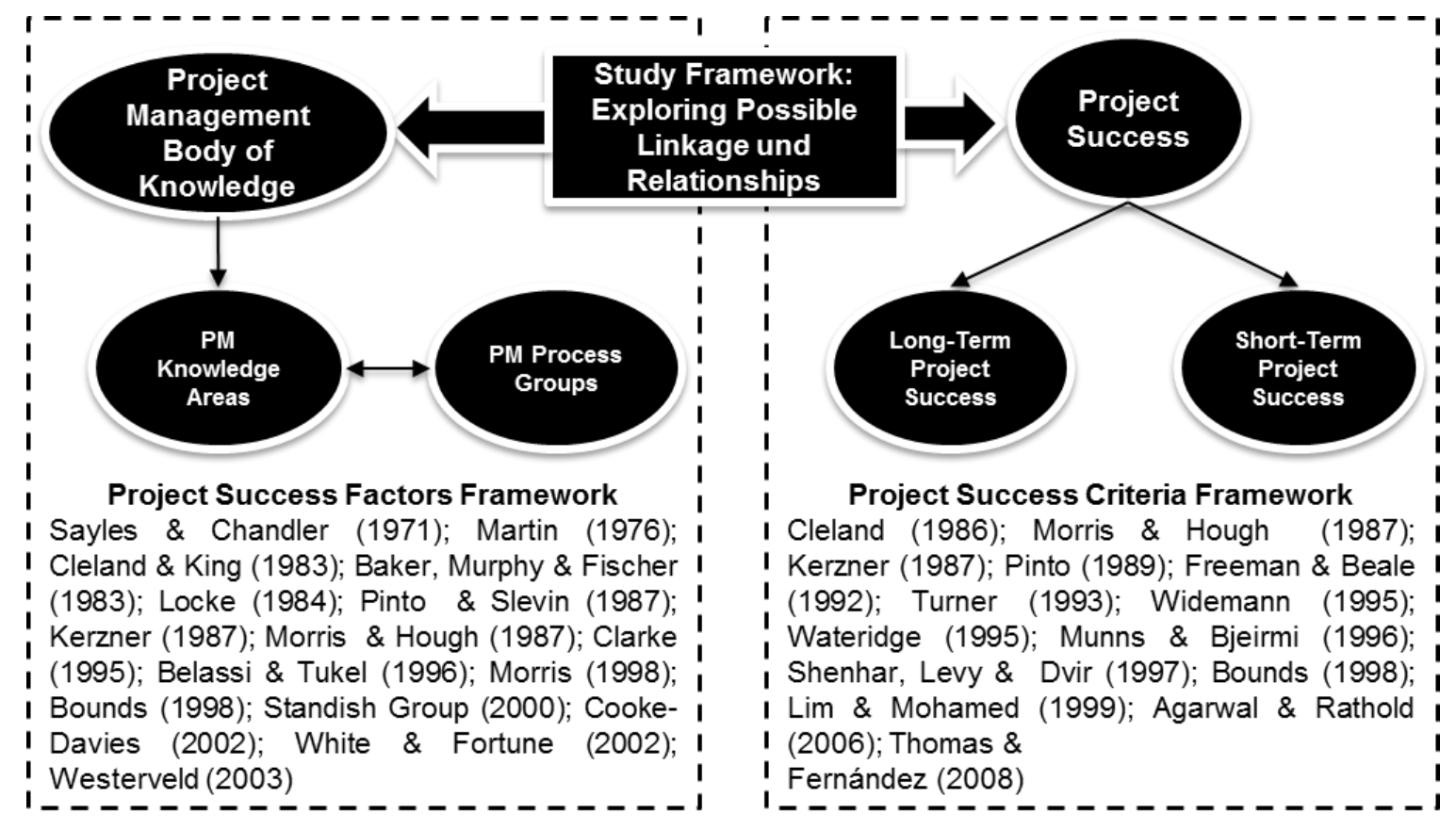

\section{Figure 32. Study Framework}

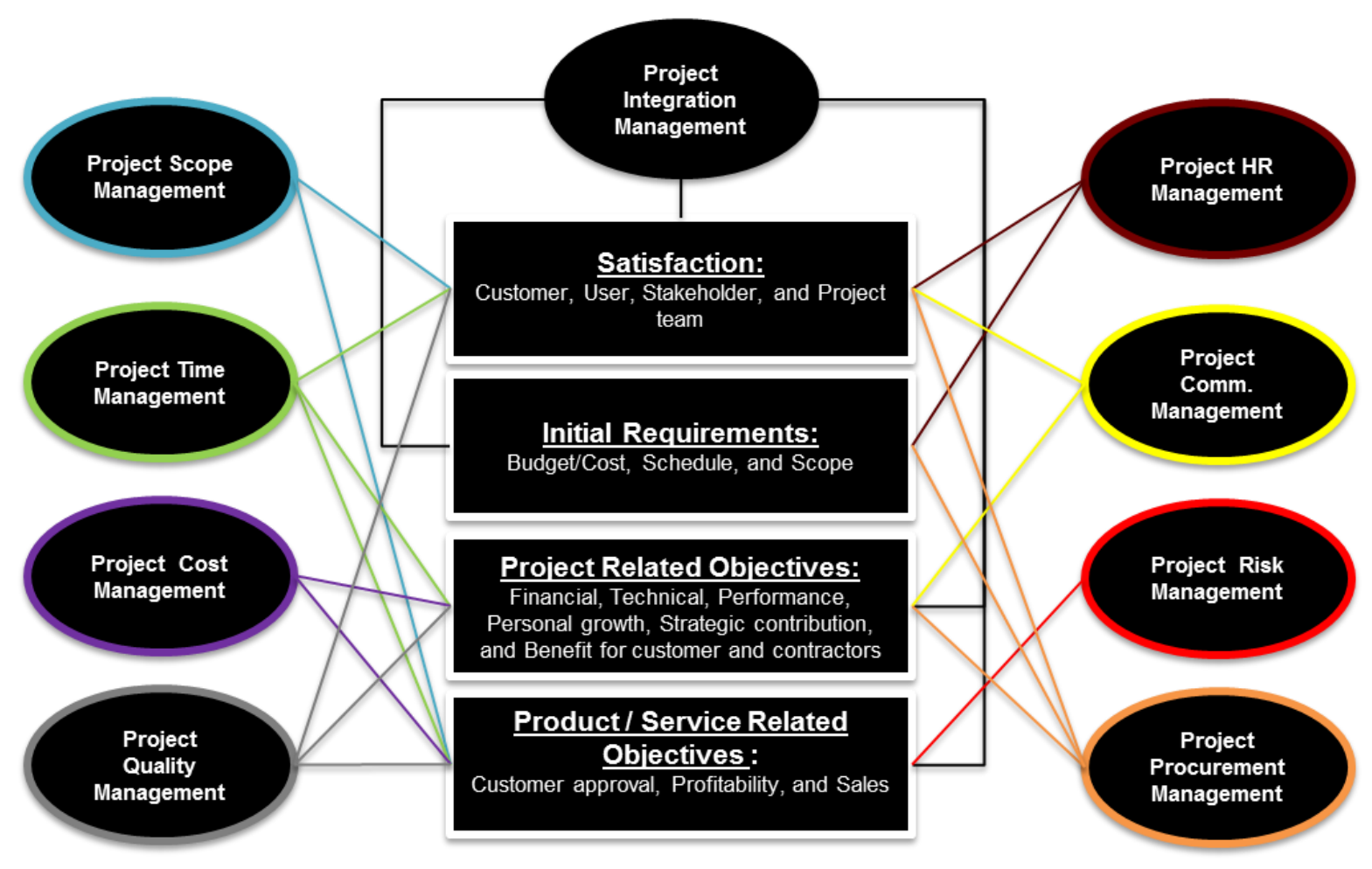

Figure 33 Framework Results 
- Favorably empirical contributions that consist of new findings based on systematically observed data and provide new data to reveal formerly unknown insights about the project management body of knowledge and its relation to short- and long- term success.

- Methodological contribution that support practitioners analyzing and improving the project outcomes by using the theory of constraints as problem solving process. It provides an organized and structured view, how to deal systematically with undesired project outcomes. As example this process was applied to customer satisfaction (see. Section Methodological Framework)

- A general classification of the top nine used criteria for judging project success, (1) budget/cost, (2) schedule, (3) customer satisfaction, (4) stakeholder satisfaction, (5) scope, (6) financial objectives, (7) technical objectives, (8) customer approval, and (9) profitability. This classification provides an organized overview of short-term and long-term criteria for measuring the project outcomes.

- A specific classification of the top three criteria used to judge project success in relation to project type. For engineering and information technology projects, the top three project success criteria are (1) budget/cost, (2) schedule, and (3) customer satisfaction. In construction projects, the criteria used are (1) budget/cost, (2) profitability, and (3) schedule.

- The top criterion used to judge project success in relation to project size. All project sizes use budget/cost as project success criteria. For projects of more 
than $\$ 50$ million, the scope, not the schedule, is considered the most important criterion of project success. Customer satisfaction is not used in projects of less than $\$ 100,000$. Stakeholder satisfaction is important for projects over $\$ 1$ million and less than $\$ 10$ million.

\section{Future research}

Further research needs to examine more closely the links between project selection criteria and project success criteria. Another possible area of future research would be to investigate which elements and processes of the project management body of knowledge are implemented and used in companies and organizations with the objective to explore the relationship between their project success rate and those implemented processes.

\section{Implications}

The findings of this study have a number of important implications for future practice and therefore several courses of action will be recommended. Project success criteria should be defined at the beginning of each project and should be logically linked to criteria used during the project selection and the factors that contribute that success. The results of this research support also integrating a set of project success criteria that are valid for all projects, thus General Project Success Criteria (GPSC), and project related success criteria, which are specific to each project (SPSC, specific project success criteria). General Project Success Criteria could be e.g. budget/ cost, schedule, scope, 
technical performance, etc... and Specific Project Success Criteria could include such criteria such like market share, strategic contribution of the project.

\section{Methodological Framework}

Doubtless, delivering projects on time, within budget, and within the predefined scope remains the basic requirement for business and represents just an "entrance card" into the market. In order to be competitive and achieve longterm success with projects linked to the company's or organization's strategy; however, the abovementioned three project achievements are not enough. Achieving more advantages requires a structured project management that considers projects in their entirety - from project selection to the end of the product or service life cycle. This is only realizable if long-term project measurement criteria are implemented and reported continuously. Based on the findings of this study and the researcher's experience in project management, the following are recommended:

- Develop a set of project selection criteria that enable management and support during the decision-making process about which projects should be realized.

- Make sure that the entire organization understands the project selection criteria.

- Have a project portfolio in the organization and make it known. It helps to have a one-page (minimum) description of two project selection criteria that 
can be used to justify the prioritization of one project or project groups over others.

- Make the project prioritization known in your organization in order to avoid resources conflicts.

- Develop a set of criteria supporting project success judgments. It will outline what should be achieved and when at the beginning of each project. The criteria should be understandable by the project team and manager and contain short-term and long-term criteria linked to the organization's strategy and long-term goals. The criteria should consider projects in their entirety and not only criteria like budget, cost, schedule, and scope.

- Make a logical link between the project selection and project success criteria.

- Identify which factors could contribute to the achievement of project success, measured by the project success criteria, and link the project success factors to the project success criteria. The findings of this study could be used as an orientation.

- Implement, execute, and manage the factors that contribute to project success.

- Develop a set of criteria by which to judge the risk in the entire project environment - including customers, markets, suppliers, schedules, economics, human and technical resources, products, processes, and quality - and make sure that the project team and project manager are familiar with the risk evaluation and report. 
- "Educate" your customers and support them in defining their expectations, and try to meet their unwritten expectations.

- Transform the informal communication between the development teams (i.e., customer and supplier) into a formal communication; any minor or major changes required by the customer or supplier should be evaluated technically and economically.

- "Educate" your customers and suppliers about your internal policies.

- Steering committee meetings should be decision meetings and not only informal meetings.

- Train your staff in project management and inter-personal skills, and train your project manager in leadership.

The following framework demonstrates the theory of constraints as problem solving process applied to customer satisfaction (example) (see Figure 32).

\section{What to change?}

- Identification of the core conflict that is responsible for the undesired project outcomes.

The undesired effect in this case is the dissatisfaction of the customer. Possible causes could be the quality, the availability, reliability and the plausibility of one or more of following project management process outputs:

H3-01 Activity list: output of activity definition process - Project time management 
H3-06 Resource breakdown structure: output of activity resource estimating process - Project time management

H3-09 Project schedule: output of schedule development process - Project time management

H4-02 Activity cost estimates supporting detail: output of cost estimating process

- Project cost management

H4-04 Cost baseline: output of cost budgeting process - Project cost management

H5-01 Quality management plan: output of quality planning process - Project quality management

H7-01 Communication management plan: output of communications planning process - Project communication management

H9-01 Procurement management plan: output of plan purchases and acquisitions process - Project procurement management

H9-08 Proposals: output of request seller responses process - Project procurement management

H9-09 Selected sellers: output of select sellers process - Project procurement management - Project procurement management

H9-10 Contract: output of select sellers process - Project procurement management

H9-11 Contract management plan: output of select sellers process - Project procurement management 
- Build a current reality tree that describes the non-conformities of the outputs mentioned above and their link to the customer dissatisfaction.

\section{What to change to?}

- Identification of actions to improve the quality, availability, reliability and the plausibility of the outputs. Process und human resources related actions.

- Construct a Future Reality Tree that lays out the complete solution that:

$\checkmark$ Resolves the undesired project outcome (customer dissatisfaction) by making its opposite, the desired project outcome (customer satisfaction).

$\checkmark$ Ensures alignment with the project and organization objectives.

$\checkmark$ Ensures that no new negative side-effects (Negative Branches) will occur from implementing the solution.

$\checkmark$ Leverages the existing TOC applications that are needed to make the solution work, and

\section{How to cause the change?}

- Build a Tactical Objectives Map that charts the overall course for getting from the current reality to the future reality, where the solution is fully implemented.

- Create detailed task interdependency diagram, using Transition Trees (TRTs) when necessary to flesh out crucial actions.

- Transform action plans into a complete project network that can be effectively managed 


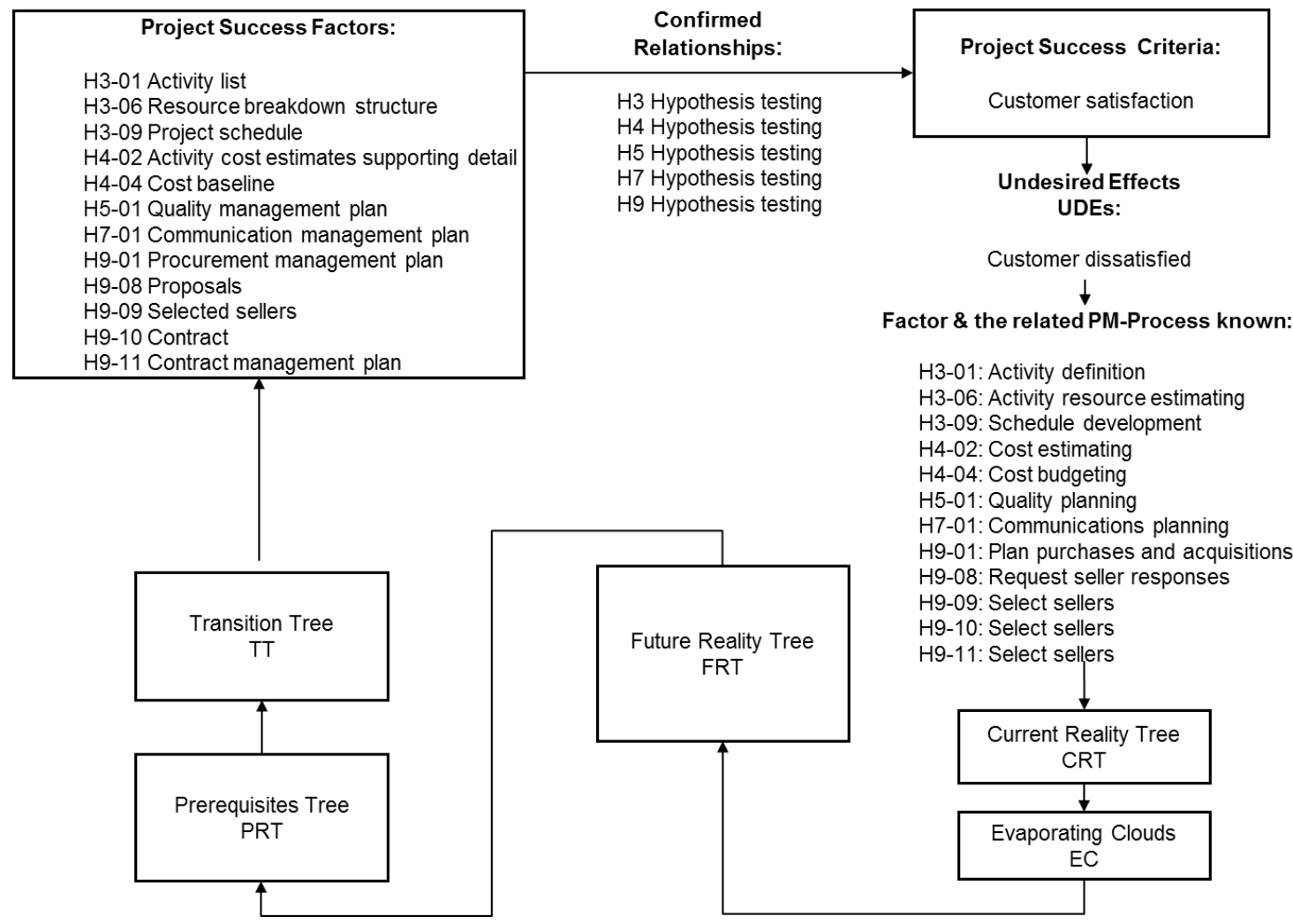

Figure 34. Theory of constraints applied to customer satisfaction 


\section{REFERENCES}

Abeyasinghe, M. C. L., Greenwood, D. J., \& Johansen, D. E. (2001). An efficient method for scheduling construction projects with resources constraints. International Journal of Project Management, 19, 29-45.

Agarwal, N., \& Rathold, U. (2006). Defining "success" for software projects: An exploratory revelation. International Journal of Project Management, 24, 358-370.

Ahlemann, F., El Arbi, F., Kaiser, M. G., \& Heck, A. (2012). A process framework for theoretically grounded prescriptive research in the project management field. International Journal of Project Management doi:10.1016/j.ijproman.2012.03.008.

Anderson, D. K., \& Merna, T. (2003). Project management strategy - project management represented as a process based set of management domains and the consequences for project management strategy. International Journal of Project Management, 21(7), 387-393.

Andersen, E. S., Grude, K. V., Haug, T., (2009). Goal directed project management. London: Kogan Page.

Atkinson, R. (1999). Project management: cost, time and quality, two best guesses and phenomenon, its time to accept other success criteria. International Journal of Project Management, 17(6), 337-342.

Baccarini, D. (1999). The logical framework method for defining project success. Project Management Journal, 30(4), 25-32.

Baker, B., Murphy, D. C., \& Fischer, D. (1983). Factors affecting project success. Project Management Handbook. New York: Van Nostrand Reinhold Co.

Belassi, W., \& Tukel, O. I. (1996). A new framework for determining critical success/failure factors in projects. International Journal of Project Management, 14(3), 141-151.

Bounds, G. (1998). The last word on project management. Institute of Industrial Engineers Solutions, 30(11), 41-43. 
Clarke, A. (1999). A practical use of key success factors to improve the effectiveness of project management. International Journal of Project Management, 17(3), 139-145.

Cleland, D. I. (1986). Measuring success: The owner's viewpoint. Proceedings of the 18th Annual Seminar/Symposium (S. 6-12). Montreal, Canada: Upper Darby, PA: Project Management Institute.

Cleland, D. I., \& King, W. R. (1983). Systems Analysis and Project Management. Columbus, OH: McGraw-Hill.

Cooke-Davies, T. (2002). The "real" success factors on projects. International Journal of Project Management, 20, 185-190.

Cooper, D. F. (1976). Heuristics for scheduling resource-constrained projects: An experimental investigation. Management Science, 22 (11), 1186-1194.

Dettmer, H. (1997). Goldratt's theory of constraints: A systems approach to continuous improvement. Milwaukee, WI: ASQC Quality Press.

Duncan, W. R. (April 1999). Back to basics: charters, chains, and challenges. PM Network Magazine.

Freeman, M., \& Beale, P. (1992). Measuring project success. Project Management Journal, 23(1), 8-17.

Goldratt, E. M. (1990). What is this thing called Theory of Constraints and how should it be implemented. New York: North River Press.

Goldratt, E. M. (1994). It's Not Luck. Great Barrington, MA: North River Press.

Goldratt, E. M. (1997). Critical Chain. Great Barrington, MA: North River Press.

Goldratt, E. M., \& Cox, J. (2004). The goal: A process of ongoing improvement. Great Barrington, MA: North River Press.

Hab, G., \& Wagner, R. (2006). Projektmanagement in der Automobilindustrie Effizientes Management von Fahrzeugprojekten entlang der Wertschöpfungskette. Augsburg, Germany: Gabler.

Hyväri, I. (2006). Success of projects in different organizational conditions. Project Management Journal, 37(4), 31-41.

Jugdev, K., \& Müller, R. (2005). A retrospective look at our evolving understanding of project success. Project Management Journal, 36(4), 1931. 
Jyh-Bin, Y. (2007). How the critical chain scheduling method is working for construction projects. Cost Engineering, 49(4), 25-32.

Kerzner, H. (1987). In search of excellence in project management. Journal of System Management, 38(2), 30-40.

Kerzner, H. (1998). In search of excellence in project management: Successful practices in high performance organizations. New York: Van Nostrand Reinhold.

Kothari, C. R. (2004). Research methodology: Methods and techniques. New Delhi, India: New Age International.

Lim, C. S., \& Mohamed, M. Z. (1999). Criteria for project success: an exploratory reexamination. International Journal of Project Management, 17(4), 243248.

Locke, D. (1984). Project management. New York: St. Martins Press.

Martin, C. C. (1976). Project management. New York: Amaco.

McCoy, F. A. (1986). Measuring success: Establishing and maintaining a baseline. PMI Annual Seminar \& Symposium. Montreal, Canada.

Morris, P. W. (1988). Managing project interfaces: key points for project success. In D. I. Cleland, \& W. R. King, (Eds.), Project management handbook (pp. 16-55). New York: Van Nostrand-Reinhold.

Morris, P. W., \& Hough, G. H. (1987). The anatomy of major projects. A study of the reality of project management. London: John Wiley.

Munns, A. K., \& Bjeirmi, B. F. (1996). The role of project management in achieving project success. International Journal of Project Management, 14(2), 81-87.

Newbold, R. C. (1998). Project management in the fast lane: Applying the Theory of Constraints. Boca Raton, FL: St. Lucie Press.

Packendorff, J. (1995). Inquiring into the temporary organization: New directions for project management research. Scandinavian Journal of Management, 11(4), 319-334.

Pinto, J. K., \& Slevin, D. (1987). Critical factors in successful project implementation. IEEE Transactions on Engineering Management, 34, 2227. 
Pinto, J. K., \& Slevin, D. (1989). Critical success factors in R\&D projects. Research Technology Management, 32(1), 31-35.

Project Management Institute (2004). A Guide to The Project Management Body of Knowledge (PMBOK Guide). Project Management Institute, Inc.

Remenyi, D., \& Sherwood-Smith, M. (1999). Maximaize information systems value by continuous participative evaluation. Log. Information Management, 12, 14-31.

Sayles, L. R., \& Chandler, M. K. (1971). Managing large systems. New York: Harper and Row.

Scheinkopf, L. (1999). Thinking for a change: Putting the TOC thinking processes to use. Boca Raton, FL: St. Lucie Press.

Schragenheim, E., \& Dettmer, H. W. (1991). Buffer management: A diagnostic tool for production control. Production and Inventory Management Journal, 32(2), 74-79.

Selltiz, C., Wrightsman, L. S., Cook, S. W., \& the Society for the Psychological Study of Social Issues. (1962). Research methods in social science. Austin, TX: Holt, Rinehart, \& Winston.

Shenhar, A., Levy, O., \& Dvir, D. (1997). Mapping the dimensions of project success. Project Management Journal, 28(2), 5-13.

Sherman, D. G., Cole, A. J., \& Boardman, J. T. (1996). Assisting cultural reform in a projects-based company using Systemigrams. International Journal of Project Management, 14(1), 23-30.

Shou, Y., \& Yeo, K. T. (2000). Estimation of project buffers in critical chain project management. ICMIT, S. 162-167.

Söderlund, J. (2004). Building theories of project management: Past research, questions for the future. International Journal of Project Management, 22, $183-11$.

Steiner, G. A. (1969). Top Management Planning. New York: MacMillian.

The Standish Group. (2009). CHAOS Summary 2009: The 10 Laws of Chaos. Boston, MA: The Standish Group International, Inc.

Thomas, G., \& Fernández, W. (2008). Success in IT projects: A matter definition? International Journal of Project Management, 26, 733-742. 
Turner, J. R. (1993). The handbook of project based management.London: McGraw-Hill.

Wateridge, J. (1995). IT-projects: A basis for success. International Journal of Project Management, 13(3), 169-172.

Watson, K. J., Blackstone, J. H., \& Gardiner, S. C. (2007). The evolution of a management philosophy: The theory of constraints. Journal of Operations Management, 25, 387-402.

Westervald, E. (2003). The Project Excellence Model: Linking success criteria and critical success factors. International Journal of Project Management, $21,411-418$.

Wiest, J. D. (1967). A heuristic model for scheduling large projects with limited resources. Management Science, 13(6), 539-377.

White, D., \& Fortune, J. (2002). Current partice in project management: An empirical study. International Journal of Project Management, 20, 1-11.

Wideman, R. M. (1995). Criteria for a project management body of knowledge. International Journal of Project Management, 13(2), 71-75. 


\title{
APPENDIX A: SURVEY QUESTIONNAIRE
}

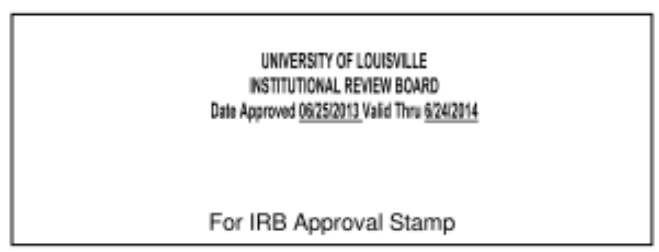

\author{
Project Management and its Relation to Long-Term Project Success: An Empirically Based Theoretical \\ Framework
}

Date: June $12^{\text {th }}, 2013$

Dear PMI-Members (German Chapters)

You are being invited to participate in a research study by answering the attached survey about the project management body of knowledge and the project success. There are no known risks for your participation in this research study. The information collected may not benefit you directly. The information learned in this study may be helpful to others. The information you provide will be analyzed to identify those elements of the project management body of knowledge that contribute to project success and those criteria that are often used to judge project success. Your completed survey will be stored at Qualtrics.com. The survey will take approximately $15 \mathrm{~min}-20 \mathrm{~min}$ time to complete.

Individuals from the Department of the Institutional Review Board (IRB), the Human Subjects Protection Program Office (HSPPO), and other regulatory agencies may inspect these records. In all other respects, however, the data will be held in confidence to the extent permitted by law. Should the data be published, your identity will not be disclosed.

Taking part in this study is voluntary. By completing this survey you agree to take part in this research study. You do not have to answer any questions that make you uncomfortable. You may choose not to take part at all. If you decide to be in this study you may stop taking part at any time. If you decide not to be in this study or if you stop taking part at any time, you will not lose any benefits for which you may qualify.

If you have any questions, concerns, or complaints about the research study, please contact: Youssef Ait Boudlal, 0049176367444 04; Professor Dr. Gerald W. Evans, 0015028520143.

If you have any questions about your rights as a research subject, you may call the Human Subjects Protection Program Office at (502) 852-5188. You can discuss any questions about your rights as a research subject, in private, with a member of the Institutional Review Board (IRB). You may also call this number if you have other questions about the research, and you cannot reach the research staff, or want to talk to someone else. The IRB is an independent committee made up of people from the University community, staff of the institutions, as well as people from the community not connected with these institutions. The IRB has reviewed this research study.

If you have concerns or complaints about the research or research staff and you do not wish to give your name, you may call 1-877-852-1167. This is a 24 hour hot line answered by people who do not work at the University of Louisville.

Sincerely,

Youssef Ait Boudlal

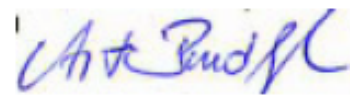

Prof. Dr. Gerald W. Evan

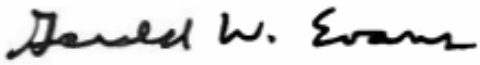


Introduction:

Preamble Consent

Question 1: Please indicate your gender:

O Male (1)

○ Female (2)

Question 2: Please indicate your age group:

○ 20 - 30 years (1)

○ 31 - 40 years $(2)$

○ 41 - 50 years $(3)$

- Older than 50 years (4)

Question 3: How many total years' work experience do you have?

O Less than 2 years (1)

○ 2 - 5 years (2)

○ 6 - 10 years $(3)$

- 11 - 20 years $(4)$

o More than 20 years (5)

Question 4: Have you been involved in project work?

○ Yes (1)

○ No (2)

If No Is Selected, then skip to "Did you earn a Project Management Certification"

Question 5: If yes, when was your last project completed?

O Five years ago or less (1)

- More than five years ago (2) 
Question 6: Average size project budgets you have worked with:

O Less than $\$ 100,000$ (1)

- More than $\$ 100,000$ - Less than $\$ 1$ million (2)

- More than $\$ 1$ million - Less than $\$ 10$ million (3)

- More than $\$ 10$ million - Less than $\$ 50$ million (4)

o More than $\$ 50$ million (5)

Question 7: What was your function on the project?

○ Project manager (1)

- Project coordinator (2)

○ Project team member (3)

- Customer / User (4)

O Sponsor (5)

○ Steering committee member (6)

○ Advisor (7)

O Administrative support (8)

o Other (9)

Question 8: Which of the following best describes the project with which you were/are involved?

○ Engineering (1)

o Construction (2)

O Information technology (3)

- Enterprise resource planning (4)

- Infrastructure design and development (5)

o Other (6) 
Question 9: This project was primarily to serve the needs of an:

O Internal client (1)

o External client (2)

o Both (3)

Question 10: Approximate size of project teams with which you have worked:

O Fewer than $5(1)$

o 5 - $10(2)$

- $11-20(3)$

○ $21-50(4)$

- $51-100(5)$

o More than $100(6)$

Question 11: Average duration of projects on which you have worked

- Less than a month (1)

o 1 - 6 months (2)

o 7 - 12 months (3)

○ 13 - 24 months (4)

- 25 - 36 months (5)

○ 37 - 48 months (6)

o More than 48 months (7) 
Question 12: In what industry are/were of projects have you worked on (check all that apply):

O Computers / Information technology (1)

○ Construction (2)

○ Engineering (3)

○ Education (4)

o Government (5)

o Health care (6)

○ Manufacturing (7)

o Software development (8)

o Telecommunications (9)

o Other (10)

Question 13: How many years of project management experience do you have?

- Less than 2 years (1)

○ 2 - 5 years (2)

○ 6 - 10 years $(3)$

- $11-20$ years $(4)$

o More than 20 years (5)

\section{Question 14: Did you earn a Project Management Certification?}
○ Yes (1)
o No (2)

Answer: If Did "you earn a Project Management Certification?" Yes is selected 
Question 15: If yes, which type? (Please check all that apply)

- Certified Associate in Project Management (CAPM) (1)

- Project Management Professional (PMP) (2)

- Program Management Professional (PgMP) (3)

- PMI Agile Certified Practitioner (PMI - ACP) SM (4)

- PMI Risk Management Professional (PMI - RMP) (5)

o PMI Scheduling Professional (PMI - SP) (6)

- OPM3 Professional Certification (7)

○ Other (8)

Question 16: Which Project Management Software do you normally use? (Please check all that apply)

○ Basecamp (1)

- Copper Project (2)

○ 5 PM (3)

○ Microsoft Project (4)

O Smartsheet (5)

○ Projectplace (6)

- Ace Project (7)

- PLANTA Project (8)

○ 2-plan (9)

o Others (10)

Question 17: Which of the following best describes the Project Management Software you are using?

- Commercial Software (1)

o Company's own Software (2)

- Combination of both (3)

o Other (4) 
Question 18: According to your experience, which criteria are used most often to judge project success?

○ Budget/Cost (1)

- Schedule (2)

○ Customer satisfaction (3)

○ User satisfaction (4)

O Stakeholder satisfaction (5)

o Project team satisfaction (6)

- Strategic contribution of the project (7)

○ Financial objectives (8)

o Technical objectives (9)

o Performance objectives (10)

- Commercial benefit for contractors (11)

- Commercial benefit for customer (12)

o Scope (13)

o Personal growth (14)

o Customer approval (15)

○ Profitability (16)

o Sales (17)

o Other (18)

Question 19: Please indicate the occurrence frequency of the following possible symptoms at your organization:

\begin{tabular}{|c|c|c|c|c|c|}
\hline & $\begin{array}{l}\text { Rarely } \\
\text { or } \\
\text { never } \\
\text { occurs } \\
\text { (1) }\end{array}$ & $\begin{array}{l}\text { Sometimes } \\
\text { occurs } \\
\text { (2) }\end{array}$ & $\begin{array}{l}\text { Often } \\
\text { occurs } \\
(3)\end{array}$ & $\begin{array}{c}\text { Usually } \\
\text { occurs } \\
(4)\end{array}$ & $\begin{array}{c}\text { Almost } \\
\text { always } \\
\text { occurs } \\
\text { (5) }\end{array}$ \\
\hline $\begin{array}{l}\text { Customers change their minds as to a project's scope, } \\
\text { schedule, or specifications during the project (1) }\end{array}$ & 0 & 0 & 0 & 0 & 0 \\
\hline $\begin{array}{l}\text { Customer projects are mostly the "half-baked" ideas they } \\
\text { would like us to work on (2) }\end{array}$ & 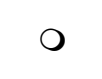 & 0 & O & 0 & 0 \\
\hline $\begin{array}{l}\text { Necessary things (e.g., Info, specs, materials, authorization, } \\
\text { etc.) are not available when needed ( } 3 \text { ) }\end{array}$ & $\mathrm{O}$ & O & 0 & 0 & $\mathrm{O}$ \\
\hline $\begin{array}{c}\text { There is a shortage of skilled people and resources for our } \\
\text { projects (4) }\end{array}$ & 0 & 0 & 0 & O & 0 \\
\hline
\end{tabular}


Some tasks can only be done by a few (key) individuals (or resources) (5)

Some resources (or processes) are critical bottlenecks (limited capacity) that hurt the entire operation (6)

Rules, procedures, and company policies hold projects back, rather than help (7)

Significant, risky, and/or unsupportable assumptions are made by project teams (8)

People are judged, rewarded, or punished based upon our project measurement and reporting systems (9)

People do not understand our project measurement and reporting systems (10)

Project measurement and reporting systems are poorly designed (11)

There is a lack of accountability (12)

Unrelated cost (ie. non-project costs, overhead, other projects,...) are allocated to a project (13)

Project plans and cost estimates are "played with" until they lose any basis in reality and/or believability (14)

There is a lack of teamwork (co-operation) within project teams (15)

Project teams that under-utilize their resources will soon find those resources re-assigned elsewhere (16)

There is a lack of teamwork (co-operation) between different project teams (17)

There is a lack of teamwork (co-operation) between a project team and other non-project groups (18)

People try to look busy when they really not (19)

Work expands to fill the time available to our project workers (20)

People delay and/or procrastinate the starting of critical tasks

There are discussions, frustrations and/or disagreements about the priority of different projects (22)

People work on non-priority tasks while priority tasks sit waiting for them to start or restart (23)

"Student syndrome" (given extra time, a person will spend it on other, personally important priorities until the sensed risk is intolerable) is alive and well in our projects (24)

Murphy's Law (given two equally probable outcomes, you will always get the undesired outcome: i.e., "Things go wrong") is alive and well in our projects (25)

The goals of leadership team, project managers and people are major source of conflict (26)

The conflicts among leadership team, project managers and people always result in win/win (27)

Our leadership team does not fully understand what is causing these symptoms to occur (28)

Our leadership team is not sure if practical, and economically viable solutions or alternatives may exist (29)

Our leadership team has apathy, ignorance, inability, indifference, or disregard towards the symptoms and their effects on our projects, customers, and the project team members (30)

The planned deliverables (scope, cost, quality) form a project fall short of expectations (31)

Projects are significantly late (late enough to cause complaints 


\section{Question 20: The following outputs of the PM Initiating Processes contribute to project success:}

\begin{tabular}{|c|c|c|c|c|c|}
\hline & $\begin{array}{c}\text { Strongly agree } \\
(1)\end{array}$ & $\begin{array}{c}\text { Agree } \\
(2)\end{array}$ & $\begin{array}{c}\text { Neither Agree nor } \\
\text { Disagree (3) }\end{array}$ & $\begin{array}{c}\text { Disagree } \\
(4)\end{array}$ & $\begin{array}{c}\text { Strongly } \\
\text { Disagree (5) }\end{array}$ \\
\hline $\begin{array}{c}\text { Project charter (1) } \\
\text { Preliminary project scope } \\
\text { statement (2) }\end{array}$ & 0 & 0 & 0 & 0 & 0 \\
Updates (3) & 0 & 0 & 0 & 0 & 0 \\
\hline
\end{tabular}

\section{Question 21: The following outputs of the PM Planning Processes contribute to project success:}

\begin{tabular}{|c|c|c|c|c|c|}
\hline & $\begin{array}{l}\text { Strongly } \\
\text { agree (1) }\end{array}$ & Agree (2) & $\begin{array}{c}\text { Neither Agree } \\
\text { nor Disagree } \\
\text { (3) }\end{array}$ & Disagree (4) & $\begin{array}{c}\text { Strongly } \\
\text { Disagree (5) }\end{array}$ \\
\hline Project Management plan (1) & $\mathrm{O}$ & $\mathrm{O}$ & $\mathrm{O}$ & $\mathrm{O}$ & $\mathrm{O}$ \\
\hline Project scope management plan (2) & $\mathrm{O}$ & $\mathrm{O}$ & $\mathrm{O}$ & $\mathrm{O}$ & O \\
\hline Project scope statement (3) & O & $\mathrm{O}$ & O & $\mathrm{O}$ & $\mathrm{O}$ \\
\hline Work breakdown structure (4) & $\mathrm{O}$ & $\mathrm{O}$ & $\bigcirc$ & $\mathrm{O}$ & $\bigcirc$ \\
\hline WBS dictionary (5) & $\mathrm{O}$ & $\mathrm{O}$ & $\mathrm{O}$ & $\mathrm{O}$ & $\mathrm{O}$ \\
\hline Scope baseline (6) & $\mathrm{O}$ & $\mathrm{O}$ & $\mathrm{O}$ & O & $\mathrm{O}$ \\
\hline Activity list (7) & $\mathrm{O}$ & $\mathrm{O}$ & $\mathrm{O}$ & $\mathrm{O}$ & $\mathrm{O}$ \\
\hline Activity attributes (8) & O & O & ○ & O & ○ \\
\hline Milestones list (9) & $\mathrm{O}$ & $\mathrm{O}$ & $\mathrm{O}$ & $\mathrm{O}$ & $\mathrm{O}$ \\
\hline Project schedule network diagram (10) & $\mathrm{O}$ & $\mathrm{O}$ & O & $\mathrm{O}$ & $\mathrm{O}$ \\
\hline Activity resources requirements (11) & $\mathrm{O}$ & $\mathrm{O}$ & $\mathrm{O}$ & $\mathrm{O}$ & $\mathrm{O}$ \\
\hline Resource breakdown structure (12) & $\mathrm{O}$ & $\mathrm{O}$ & ○ & $\mathrm{O}$ & $\bigcirc$ \\
\hline Resource calendar (13) & O & O & O & O & O \\
\hline Activity duration estimates (14) & $\mathrm{O}$ & $\mathrm{O}$ & $\mathrm{O}$ & $\mathrm{O}$ & $\mathrm{O}$ \\
\hline Project schedule (15) & O & $\mathrm{O}$ & $\bigcirc$ & $\mathrm{O}$ & $\mathrm{O}$ \\
\hline Schedule model data (16) & ○ & O & ○ & O & O \\
\hline Schedule baseline (17) & $\mathrm{O}$ & $\mathrm{O}$ & O & $\mathrm{O}$ & $\mathrm{O}$ \\
\hline Activity cost estimates (18) & $\mathrm{O}$ & $\mathrm{O}$ & O & $\mathrm{O}$ & O \\
\hline $\begin{array}{l}\text { Activity cost estimates supporting detail } \\
\text { (19) }\end{array}$ & $\mathrm{O}$ & $\bigcirc$ & O & $\mathrm{O}$ & $\mathrm{O}$ \\
\hline Cost management plan (20) & $\bigcirc$ & $\mathrm{O}$ & $\bigcirc$ & $\mathrm{O}$ & $\bigcirc$ \\
\hline Cost baseline (21) & $\mathrm{O}$ & $\mathrm{O}$ & $\mathrm{O}$ & $\mathrm{O}$ & $\mathrm{O}$ \\
\hline Project funding requirements (22) & $\mathrm{O}$ & $\mathrm{O}$ & O & O & O \\
\hline Quality management plan (23) & $\mathrm{O}$ & $\mathrm{O}$ & $\mathrm{O}$ & $\mathrm{O}$ & $\mathrm{O}$ \\
\hline Quality metrics (24) & O & O & O & $\mathrm{O}$ & $\mathrm{O}$ \\
\hline
\end{tabular}




\begin{tabular}{|c|c|c|c|c|c|}
\hline Quality checklists (25) & $\mathrm{O}$ & $\mathrm{O}$ & $\mathrm{O}$ & $\mathrm{O}$ & $\mathrm{O}$ \\
\hline Process improvement plan (26) & $\mathrm{O}$ & $\mathrm{O}$ & O & $\mathrm{O}$ & $\mathrm{O}$ \\
\hline Quality baseline (27) & $\mathrm{O}$ & $\mathrm{O}$ & $\mathrm{O}$ & $\mathrm{O}$ & $\mathrm{O}$ \\
\hline Roles and responsibilities (28) & $\mathrm{O}$ & $\mathrm{O}$ & $\mathrm{O}$ & $\mathrm{O}$ & O \\
\hline Project organization chart (29) & 0 & 0 & 0 & 0 & 0 \\
\hline Staffing management plan (30) & 0 & 0 & 0 & 0 & 0 \\
\hline Communication management plan (31) & 0 & 0 & 0 & 0 & 0 \\
\hline Risk management plan (32) & 0 & 0 & 0 & 0 & 0 \\
\hline Risk register (33) & 0 & 0 & 0 & 0 & 0 \\
\hline Risk-related contractual agreements (34) & $\mathrm{O}$ & $\mathrm{O}$ & $\mathrm{O}$ & O & O \\
\hline Procurement management plan (35) & 0 & 0 & 0 & 0 & 0 \\
\hline Contract statement of work (36) & $\mathrm{O}$ & $\mathrm{O}$ & $\mathrm{O}$ & $\mathrm{O}$ & O \\
\hline Make-or-buy decisions (37) & 0 & 0 & 0 & 0 & 0 \\
\hline Procurement documents (38) & O & $\mathrm{O}$ & $\mathrm{O}$ & $\mathrm{O}$ & O \\
\hline Supplier evaluation criteria (39) & 0 & 0 & 0 & 0 & 0 \\
\hline Updates (40) & 0 & 0 & 0 & $\mathrm{O}$ & O \\
\hline
\end{tabular}

\section{Question 22: The following outputs of the PM Executing Processes contribute to project success:}

\begin{tabular}{|c|c|c|c|c|c|}
\hline & $\begin{array}{l}\text { Strongly agree } \\
\text { (1) }\end{array}$ & Agree (2) & $\begin{array}{c}\text { Neither Agree } \\
\text { nor Disagree } \\
\text { (3) }\end{array}$ & Disagree (4) & $\begin{array}{c}\text { Strongly } \\
\text { Disagree (5) }\end{array}$ \\
\hline Deliverables (1) & 0 & 0 & 0 & 0 & 0 \\
\hline Requested changes (2) & 0 & 0 & 0 & 0 & 0 \\
\hline Implemented change requests (3) & O & O & O & O & O \\
\hline Implemented corrective actions (4) & 0 & 0 & 0 & 0 & 0 \\
\hline Implemented preventive actions (5) & O & O & O & $\mathrm{O}$ & O \\
\hline Implemented defect repair (6) & 0 & 0 & 0 & 0 & 0 \\
\hline Work performance information (7) & O & O & O & O & O \\
\hline $\begin{array}{l}\text { Recommended corrective actions } \\
\text { (8) }\end{array}$ & O & 0 & 0 & O & 0 \\
\hline Organizational process assets (9) & $\mathrm{O}$ & 0 & 0 & 0 & 0 \\
\hline Project staff assignments (10) & 0 & 0 & 0 & 0 & 0 \\
\hline Resource availability (11) & O & O & O & $\mathrm{O}$ & 0 \\
\hline $\begin{array}{l}\text { Team performance assessment } \\
\text { (12) }\end{array}$ & 0 & 0 & 0 & 0 & 0 \\
\hline Qualified sellers list (13) & 0 & 0 & $\mathrm{O}$ & 0 & O \\
\hline $\begin{array}{l}\text { Procurement document package } \\
\qquad(14)\end{array}$ & $\mathrm{O}$ & O & $\mathrm{O}$ & $\mathrm{O}$ & $\mathrm{O}$ \\
\hline Proposals (15) & O & O & O & $\mathrm{O}$ & O \\
\hline Selected sellers (16) & 0 & 0 & $\mathrm{O}$ & 0 & 0 \\
\hline Contract (17) & $\mathrm{O}$ & O & O & $\mathrm{O}$ & $\mathrm{O}$ \\
\hline Contract management plan (18) & $\mathrm{O}$ & O & $\mathrm{O}$ & $\mathrm{O}$ & O \\
\hline $\begin{array}{l}\text { Procurement management plan } \\
\text { (19) }\end{array}$ & O & O & O & O & $\mathrm{O}$ \\
\hline
\end{tabular}


Question 23: The following outputs of the PM Monitoring and Controlling Processes contribute to project success:

\begin{tabular}{|c|c|c|c|c|c|}
\hline & $\begin{array}{l}\text { Strongly } \\
\text { agree } \\
\text { (1) }\end{array}$ & $\begin{array}{c}\text { Agree } \\
(2)\end{array}$ & $\begin{array}{l}\text { Neither } \\
\text { Agree nor } \\
\text { Disagree } \\
\text { (3) }\end{array}$ & $\begin{array}{c}\text { Disagree } \\
\text { (4) }\end{array}$ & $\begin{array}{c}\text { Strongly } \\
\text { Disagree } \\
\text { (5) }\end{array}$ \\
\hline Recommended corrective actions ( 1 ) & O & O & $\mathrm{O}$ & O & O \\
\hline Recommended preventive actions (2) & O & O & O & O & O \\
\hline Forecasts (3) & O & O & O & O & O \\
\hline Recommended defect repair (4) & O & O & O & O & O \\
\hline Requested changes (5) & O & O & O & O & O \\
\hline Approved change requests (6) & O & O & O & O & O \\
\hline Rejected change requests ( 7 ) & O & O & O & O & O \\
\hline Approved corrective actions (8) & $\mathrm{O}$ & O & $\mathrm{O}$ & O & $\mathrm{O}$ \\
\hline Approved preventive actions (9) & O & $\mathrm{O}$ & O & O & O \\
\hline Approved defect repair (10) & O & O & O & O & O \\
\hline Validated defect repair (11) & O & O & O & O & O \\
\hline Deliverables (12) & O & O & O & O & O \\
\hline Accepted deliverables (13) & O & O & O & O & O \\
\hline Performance measurements (14) & O & O & O & O & O \\
\hline Forecasted completion (15) & O & O & O & O & O \\
\hline Quality control measurements (16) & O & O & O & O & O \\
\hline Validated deliverables (17) & O & $\mathrm{O}$ & O & O & O \\
\hline Performance report (18) & $\mathrm{O}$ & O & $\mathrm{O}$ & O & $\mathrm{O}$ \\
\hline Resolved issues (19) & O & $\mathrm{O}$ & $\mathrm{O}$ & O & $\mathrm{O}$ \\
\hline Contract documentation (20) & 0 & 0 & 0 & 0 & 0 \\
\hline
\end{tabular}




\section{APPENDIX B: RAW DATA}

Gender of the respondents

\begin{tabular}{llcccc}
\hline & & Frequency & Percent & Valid Percent & Cumulative Percent \\
\hline \multirow{2}{*}{ Valid } & Male & 145 & 89.0 & 89.0 & 89.0 \\
& Female & 18 & 11.0 & 11.0 & 100.0 \\
& Total & 163 & 100.0 & 100.0 & \\
\hline
\end{tabular}

Age of the respondents

\begin{tabular}{llcccc}
\hline & & Frequency & Percent & Valid Percent & Cumulative Percent \\
\hline \multirow{2}{*}{ Valid } & $20-30$ years & 9 & 5.5 & 5.5 & 5.5 \\
& $31-40$ years & 60 & 36.8 & 36.8 & 42.3 \\
& $41-50$ years & 75 & 46.0 & 46.0 & 88.3 \\
Older than 50 years & 19 & 11.7 & 11.7 & 100.0 \\
Total & 163 & 100.0 & 100.0 & \\
\hline
\end{tabular}

\section{Work experience}

\begin{tabular}{llcccc}
\hline & Frequency & Percent & Valid Percent & Cumulative Percent \\
\hline Valid & Less than 2 years & 1 & .6 & .6 & .6 \\
& 2 - 5 years & 7 & 4.3 & 4.3 & 4.9 \\
6 - 10 years & 30 & 18.4 & 18.4 & 23.3 \\
11 - 20 years & 84 & 51.5 & 51.5 & 74.8 \\
More than 20 years & 41 & 25.2 & 25.2 & 100.0 \\
Total & 163 & 100.0 & 100.0 & \\
\hline
\end{tabular}

\section{Project work}

\begin{tabular}{cccccc}
\hline & & Frequency & Percent & Valid Percent & Cumulative Percent \\
\hline Valid & Yes & 163 & 100.0 & 100.0 & 100.0 \\
\hline
\end{tabular}

Last project completion

\begin{tabular}{llcccc}
\hline & Frequency & Percent & Valid Percent & Cumulative Percent \\
\hline Valid & Five years ago or less & 161 & 98.8 & 98.8 & 98.8 \\
& $\begin{array}{l}\text { More than five years } \\
\text { ago }\end{array}$ & 2 & 1.2 & 1.2 & 100.0 \\
$\quad$ Total & 163 & 100.0 & 100.0 & \\
\hline
\end{tabular}




\section{Size of project budgets}

\begin{tabular}{lccccc}
\hline & & & \multicolumn{2}{c}{ Valid } & Cumulative \\
& Frequency & Percent & Percent & Percent \\
\hline Valid Less than $\$ 100,000$ & 7 & 4.3 & 4.3 & 4.3 \\
More than $\$ 100,000$ - Less than $\$ 1$ million & 66 & 40.5 & 40.5 & 44.8 \\
$\quad$ More than $\$ 1$ million - Less than $\$ 10$ million & 67 & 41.1 & 41.1 & 85.9 \\
More than $\$ 10$ million - Less than $\$ 50$ & 20 & 12.3 & 12.3 & 98.2 \\
$\quad$ million & 3 & 1.8 & 1.8 & 100.0 \\
$\quad$ More than $\$ 50$ million & 163 & 100.0 & 100.0 & \\
$\quad$ Total & & & & \\
\hline
\end{tabular}

\section{Function on the project}

\begin{tabular}{llcccc}
\hline & & & & Cumulative \\
& & Frequency & Percent & Valid Percent & \begin{tabular}{c} 
Percent \\
\hline Valid
\end{tabular} \\
\cline { 2 - 5 } & Project manager & 139 & 85.3 & 85.3 & 85.3 \\
& Project coordinator & 8 & 4.9 & 4.9 & 90.2 \\
& Project team member & 7 & 4.3 & 4.3 & 94.5 \\
Steering committee & 1 & .6 & .6 & 95.1 \\
member & 1 & .6 & .6 & 95.7 \\
Advisor & 7 & 4.3 & 4.3 & 100.0 \\
Other & 163 & 100.0 & 100.0 & \\
Total & & & & \\
\hline
\end{tabular}

\section{Project type}

\begin{tabular}{lcccc}
\hline & & & & Cumulative \\
& Frequency & Percent & Valid Percent & Percent \\
\hline Valid Engineering & 23 & 14.1 & 14.1 & 14.1 \\
Construction & 3 & 1.8 & 1.8 & 16.0 \\
Information technology & 112 & 68.7 & 68.7 & 84.7 \\
Enterprise resource planning & 8 & 4.9 & 4.9 & 89.6 \\
Infrastructure design and & 3 & 1.8 & 1.8 & 91.4 \\
development & 14 & 8.6 & 8.6 & 100.0 \\
Other & 163 & 100.0 & 100.0 & \\
Total & & &
\end{tabular}




\section{Project purpose}

\begin{tabular}{llcccc}
\hline & & Frequency & Percent & Valid Percent & Cumulative Percent \\
\hline \multirow{2}{*}{ Valid } & Internal client & 42 & 25.8 & 25.8 & 25.8 \\
& External client & 81 & 49.7 & 49.7 & 75.5 \\
& Both & 40 & 24.5 & 24.5 & 100.0 \\
Total & 163 & 100.0 & 100.0 & \\
\hline
\end{tabular}

\section{$\underline{\text { Size of project teams }}$}

\begin{tabular}{llcccc}
\hline & Frequency & Percent & Valid Percent & Cumulative Percent \\
\hline Valid & Fewer than 5 & 7 & 4.3 & 4.3 & 4.3 \\
& $5-10$ & 38 & 23.3 & 23.3 & 27.6 \\
$11-20$ & 46 & 28.2 & 28.2 & 55.8 \\
$21-50$ & 52 & 31.9 & 31.9 & 87.7 \\
$51-100$ & 12 & 7.4 & 7.4 & 95.1 \\
More than 100 & 8 & 4.9 & 4.9 & 100.0 \\
Total & 163 & 100.0 & 100.0 & \\
\hline
\end{tabular}

\section{Project duration}

\begin{tabular}{llcccc}
\hline & & & Valid & \\
& & Frequency & Percent & Percent & Cumulative Percent \\
\hline Valid & $1-6$ months & 16 & 9.8 & 9.8 & 9.8 \\
& $7-12$ months & 60 & 36.8 & 36.8 & 46.6 \\
& $13-24$ months & 63 & 38.7 & 38.7 & 85.3 \\
$25-36$ months & 16 & 9.8 & 9.8 & 95.1 \\
37 - 48 months & 3 & 1.8 & 1.8 & 96.9 \\
More than 48 months & 5 & 3.1 & 3.1 & 100.0 \\
Total & 163 & 100.0 & 100.0 & \\
\hline
\end{tabular}


$\underline{\text { Industry area }}$

\begin{tabular}{|c|c|c|c|c|}
\hline & & \multicolumn{2}{|c|}{ Responses } & \multirow[b]{2}{*}{ Percent of Cases } \\
\hline & & $\mathrm{N}$ & Percent & \\
\hline \multirow{11}{*}{$\begin{array}{l}\text { Industry } \\
\text { area }^{\mathrm{a}}\end{array}$} & Computers / Information & 107 & 24.5 & 65.6 \\
\hline & technology & & & \\
\hline & Construction & 14 & 3.2 & 8.6 \\
\hline & Engineering & 53 & 12.2 & 32.5 \\
\hline & Education & 6 & 1.4 & 3.7 \\
\hline & Government & 24 & 5.5 & 14.7 \\
\hline & Health care & 22 & 5.0 & 13.5 \\
\hline & Manufacturing & 42 & 9.6 & 25.8 \\
\hline & Software development & 67 & 15.4 & 41.1 \\
\hline & Telecommunications & 68 & 15.6 & 41.7 \\
\hline & Other & 33 & 7.6 & 20.2 \\
\hline Total & & 436 & 100.0 & 267.5 \\
\hline
\end{tabular}

a. Dichotomy group tabulated at value 1 .

\section{Project management experience}

\begin{tabular}{llcccc}
\hline & & Frequency & Percent & Valid Percent & Cumulative Percent \\
\hline Valid & Less than 2 years & 3 & 1.8 & 1.8 & 1.8 \\
& 2 - 5 years & 29 & 17.8 & 17.8 & 19.6 \\
6 - 10 years & 62 & 38.0 & 38.0 & 57.7 \\
11 - 20 years & 59 & 36.2 & 36.2 & 93.9 \\
More than 20 years & 10 & 6.1 & 6.1 & 100.0 \\
Total & 163 & 100.0 & 100.0 & \\
\hline
\end{tabular}

\section{PM certification}

\begin{tabular}{|c|c|c|c|c|c|}
\hline & & Frequency & Percent & Valid Percent & $\begin{array}{c}\text { Cumulative } \\
\text { Percent }\end{array}$ \\
\hline \multirow[t]{3}{*}{ Valid } & Yes & 141 & 86.5 & 86.5 & 86.5 \\
\hline & No & 22 & 13.5 & 13.5 & 100.0 \\
\hline & Total & 163 & 100.0 & 100.0 & \\
\hline
\end{tabular}




\section{PM certification type}

\begin{tabular}{|c|c|c|c|c|}
\hline & & \multicolumn{2}{|c|}{ Responses } & \multirow{2}{*}{$\begin{array}{l}\text { Percent } \\
\text { of Cases }\end{array}$} \\
\hline & & $\mathrm{N}$ & Percent & \\
\hline \multirow[t]{7}{*}{ Certification $^{a}$} & $\begin{array}{l}\text { Certified Associate in Project Management } \\
\text { (CAPM) }\end{array}$ & 1 & 0.6 & 0.7 \\
\hline & Project Management Professional (PMP) & 137 & 76.1 & 97.2 \\
\hline & Program Management Professional (PgMP) & 2 & 1.1 & 1.4 \\
\hline & PMI Agile Certified Practitioner (PMI - ACP) & 6 & 3.3 & 4.3 \\
\hline & SM & & & \\
\hline & $\begin{array}{l}\text { PMI Risk Management Professional (PMI - } \\
\text { RMP) }\end{array}$ & 2 & 1.1 & 1.4 \\
\hline & Other & 32 & 17.8 & 22.7 \\
\hline Total & & 180 & 100.0 & 127.7 \\
\hline
\end{tabular}

a. Dichotomy group tabulated at value 1 .

\section{PM software used}

\begin{tabular}{llccc}
\hline & & \multicolumn{2}{c}{ Responses } & \\
\cline { 3 - 4 } & & $\mathrm{N}$ & Percent & Percent of Cases \\
\hline PM-Software $^{\mathrm{a}}$ & Basecamp & 3 & 1.3 & 1.8 \\
& Microsoft Project & 146 & 63.5 & 89.6 \\
& Smartsheet & 4 & 1.7 & 2.5 \\
& Projectplace & 7 & 3.0 & 4.3 \\
& PLANTA Project & 2 & 0.9 & 1.2 \\
& 2-plan & 2 & 0.9 & 1.2 \\
& Other & 66 & 28.7 & 40.5 \\
& & 230 & 100.0 & 141.1 \\
\hline
\end{tabular}

a. Dichotomy group tabulated at value 1 .

\section{Source of the used PM software}

\begin{tabular}{|c|c|c|c|c|c|}
\hline & & Frequency & Percent & Valid Percent & $\begin{array}{c}\text { Cumulative } \\
\text { Percent }\end{array}$ \\
\hline \multirow[t]{5}{*}{ Valid } & Commercial Software & 92 & 56.4 & 56.4 & 56.4 \\
\hline & Company's own Software & 12 & 7.4 & 7.4 & 63.8 \\
\hline & Combination of both & 56 & 34.4 & 34.4 & 98.2 \\
\hline & Other & 3 & 1.8 & 1.8 & 100.0 \\
\hline & Total & 163 & 100.0 & 100.0 & \\
\hline
\end{tabular}




\section{Poject success criteria}

\begin{tabular}{llccc}
\hline & & \multicolumn{2}{c}{ Responses } & \multicolumn{2}{c}{ Percent of } \\
& & $N$ & Percent & Cases \\
\hline Project success criteria $^{a}$ & Budget/Cost & 130 & 17.7 & 79.8 \\
& Schedule & 119 & 16.2 & 73.0 \\
& Customer satisfaction & 95 & 12.9 & 58.3 \\
& User satisfaction & 25 & 3.4 & 15.3 \\
& Stakeholder satisfaction & 61 & 8.3 & 37.4 \\
& Project team satisfaction & 17 & 2.3 & 10.4 \\
& Strategic contribution of the project & 20 & 2.7 & 12.3 \\
& Financial objectives & 49 & 6.7 & 30.1 \\
& Technical objectives & 37 & 5.0 & 22.7 \\
& Performance objectives & 33 & 4.5 & 20.2 \\
& Commercial benefit for contractors & 3 & 0.4 & 1.8 \\
& Commercial benefit for customer & 15 & 2.0 & 9.2 \\
& Scope & 52 & 7.1 & 31.9 \\
& Personal growth & 1 & 0.1 & 0.6 \\
Customer approval & 34 & 4.6 & 20.9 \\
Total & 34 & 4.6 & 20.9 \\
& Profitability & 9 & 1.2 & 5.5 \\
Sales & 2 & 0.3 & 1.2 \\
& Other & 736 & 100.0 & 451.5 \\
\hline
\end{tabular}

a. Dichotomy group tabulated at value 1 . 


\section{Project success criteria: hypothesis test summary}

\begin{tabular}{|c|c|c|c|c|}
\hline & Null Hypothesis & Test & Sig. & Decision \\
\hline 1 & The categories of Budget/Cost occur with equal probabilities. & $\begin{array}{l}\text { One-Sample Chi- } \\
\text { Square Test }\end{array}$ &, 000 & $\begin{array}{l}\text { Reject the null } \\
\text { hypothesis. }\end{array}$ \\
\hline 2 & The categories of Schedule occur with equal probabilities. & $\begin{array}{l}\text { One-Sample Chi- } \\
\text { Square Test }\end{array}$ &, 000 & $\begin{array}{l}\text { Reject the null } \\
\text { hypothesis. }\end{array}$ \\
\hline 3 & The categories of Customer satisfaction occur with equal probabilities. & $\begin{array}{l}\text { One-Sample Chi- } \\
\text { Square Test }\end{array}$ & ,034 & $\begin{array}{l}\text { Reject the null } \\
\text { hypothesis. }\end{array}$ \\
\hline 4 & The categories of User satisfaction occur with equal probabilities. & $\begin{array}{l}\text { One-Sample Chi- } \\
\text { Square Test }\end{array}$ &, 000 & $\begin{array}{l}\text { Reject the null } \\
\text { hypothesis. }\end{array}$ \\
\hline 5 & The categories of Stakeholder satisfaction occur with equal probabilities. & $\begin{array}{l}\text { One-Sample Chi- } \\
\text { Square Test }\end{array}$ & ,001 & $\begin{array}{l}\text { Reject the null } \\
\text { hypothesis. }\end{array}$ \\
\hline 6 & The categories of Project team satisfaction occur with equal probabilities. & $\begin{array}{l}\text { One-Sample Chi- } \\
\text { Square Test }\end{array}$ &, 000 & $\begin{array}{l}\text { Reject the null } \\
\text { hypothesis. }\end{array}$ \\
\hline 7 & $\begin{array}{l}\text { The categories of Strategic contribution of the project occur with equal } \\
\text { probabilities. }\end{array}$ & $\begin{array}{l}\text { One-Sample Chi- } \\
\text { Square Test }\end{array}$ & 000 & $\begin{array}{l}\text { Reject the null } \\
\text { hypothesis. }\end{array}$ \\
\hline 8 & The categories of Financial objectives occur with equal probabilities. & $\begin{array}{l}\text { One-Sample Chi- } \\
\text { Square Test }\end{array}$ &, 000 & $\begin{array}{l}\text { Reject the null } \\
\text { hypothesis. }\end{array}$ \\
\hline 9 & The categories of Technical objectives occur with equal probabilities. & $\begin{array}{l}\text { One-Sample Chi- } \\
\text { Square Test }\end{array}$ & 000 & $\begin{array}{l}\text { Reject the null } \\
\text { hypothesis. }\end{array}$ \\
\hline 10 & The categories of Performance objectives occur with equal probabilities. & $\begin{array}{l}\text { One-Sample Chi- } \\
\text { Square Test }\end{array}$ &, 000 & $\begin{array}{l}\text { Reject the null } \\
\text { hypothesis. }\end{array}$ \\
\hline 11 & $\begin{array}{l}\text { The categories of Commercial benefit for contractors occur with equal } \\
\text { probabilities. }\end{array}$ & $\begin{array}{l}\text { One-Sample Chi- } \\
\text { Square Test }\end{array}$ &, 000 & $\begin{array}{l}\text { Reject the null } \\
\text { hypothesis. }\end{array}$ \\
\hline 12 & $\begin{array}{l}\text { The categories of Commercial benefit for customer occur with equal } \\
\text { probabilities. }\end{array}$ & $\begin{array}{l}\text { One-Sample Chi- } \\
\text { Square Test }\end{array}$ &, 000 & $\begin{array}{l}\text { Reject the null } \\
\text { hypothesis. }\end{array}$ \\
\hline 13 & The categories of Scope occur with equal probabilities. & $\begin{array}{l}\text { One-Sample Chi- } \\
\text { Square Test }\end{array}$ &, 000 & $\begin{array}{l}\text { Reject the null } \\
\text { hypothesis. }\end{array}$ \\
\hline 14 & The categories of Personal growth occur with equal probabilities. & $\begin{array}{l}\text { One-Sample Chi- } \\
\text { Square Test }\end{array}$ &, 000 & $\begin{array}{l}\text { Reject the null } \\
\text { hypothesis. }\end{array}$ \\
\hline 15 & The categories of Customer approval occur with equal probabilities. & $\begin{array}{l}\text { One-Sample Chi- } \\
\text { Square Test }\end{array}$ &, 000 & $\begin{array}{l}\text { Reject the null } \\
\text { hypothesis. }\end{array}$ \\
\hline 16 & The categories of Profitability occur with equal probabilities. & $\begin{array}{l}\text { One-Sample Chi- } \\
\text { Square Test }\end{array}$ &, 000 & $\begin{array}{l}\text { Reject the null } \\
\text { hypothesis. }\end{array}$ \\
\hline 17 & The categories of Sales occur with equal probabilities. & $\begin{array}{l}\text { One-Sample Chi- } \\
\text { Square Test }\end{array}$ &, 000 & $\begin{array}{l}\text { Reject the null } \\
\text { hypothesis. }\end{array}$ \\
\hline
\end{tabular}




\section{$\underline{\text { Rotated Component Matrix }}$}

Rotated Component Matrix ${ }^{\mathrm{a}}$

\begin{tabular}{|c|c|c|c|c|c|c|c|c|c|c|}
\hline \multirow[b]{2}{*}{ Rotated Component Matrix } & \multicolumn{10}{|c|}{ Component } \\
\hline & 1 & 2 & 3 & 4 & 5 & 6 & 7 & 8 & 9 & 10 \\
\hline $\begin{array}{l}\text { Customers change their minds as to a project's } \\
\text { scope, schedule, or specifications during the project }\end{array}$ & .096 & -.037 & .199 & -.097 & .196 & .570 & .014 & .013 & .403 & -.187 \\
\hline $\begin{array}{l}\text { Customer projects are mostly the "half-baked" ideas } \\
\text { they would like us to work on }\end{array}$ & .135 & .191 & .071 & .015 & .011 & .753 & .036 & .054 & .077 & .036 \\
\hline $\begin{array}{l}\text { Necessary things (e.g., Info, specs, materials, } \\
\text { authorization, etc.) are not available when needed }\end{array}$ & .083 & .070 & .114 & .202 & .110 & .672 & .175 & .166 & -.211 & .073 \\
\hline $\begin{array}{l}\text { There is a shortage of skilled people and resources } \\
\text { for our projects }\end{array}$ & .000 & .088 & .093 & .287 & -.077 & .114 & .485 & .473 & .045 & -.300 \\
\hline $\begin{array}{l}\text { Some tasks can only be done by a few (key) } \\
\text { individuals (or resources) }\end{array}$ & .073 & .106 & -.054 & -.060 & .104 & .060 & .840 & .033 & .205 & -.033 \\
\hline $\begin{array}{l}\text { Some resources (or processes) are critical } \\
\text { bottlenecks (limited capacity) that hurt the entire } \\
\text { operation }\end{array}$ & .235 & .007 & .122 & .032 & .165 & .102 & .794 & -.072 & -.055 & .095 \\
\hline $\begin{array}{l}\text { Rules, procedures, and company policies hold } \\
\text { projects back, rather than help }\end{array}$ & .016 & .376 & .017 & .058 & .369 & .242 & .118 & -.092 & .248 & .176 \\
\hline $\begin{array}{l}\text { Significant, risky, and/or unsupportable assumptions } \\
\text { are made by project teams }\end{array}$ & .122 & .355 & -.078 & .543 & .056 & .350 & -.075 & -.015 & .018 & -.043 \\
\hline $\begin{array}{l}\text { People are judged, rewarded, or punished based } \\
\text { upon our project measurement and reporting systems }\end{array}$ & -.007 & .055 & -.017 & .108 & -.113 & -.003 & .142 & .141 & .809 & .003 \\
\hline $\begin{array}{l}\text { People do not understand our project measurement } \\
\text { and reporting systems }\end{array}$ & .222 & .631 & .040 & -.093 & .135 & .062 & .062 & .126 & .065 & -.109 \\
\hline $\begin{array}{l}\text { Project measurement and reporting systems are } \\
\text { poorly designed }\end{array}$ & .106 & .751 & .301 & .008 & .026 & .117 & .052 & .141 & -.130 & -.011 \\
\hline There is a lack of accountability & .369 & .521 & .225 & .097 & .287 & .035 & -.055 & .011 & -.068 & .034 \\
\hline $\begin{array}{l}\text { Unrelated cost (ie. non-project costs, overhead, other } \\
\text { projects,...) are allocated to a project }\end{array}$ & -.007 & .588 & -.016 & .422 & .027 & .056 & .043 & -.129 & .211 & -.029 \\
\hline $\begin{array}{l}\text { Project plans and cost estimates are "played with" } \\
\text { until they lose any basis in reality and/or believability }\end{array}$ & .229 & .449 & .247 & .180 & .240 & .379 & .239 & -.129 & -.112 & -.073 \\
\hline $\begin{array}{l}\text { There is a lack of teamwork (co-operation) within } \\
\text { project teams }\end{array}$ & .422 & -.107 & .244 & .247 & .343 & .071 & -.077 & -.007 & .359 & .019 \\
\hline $\begin{array}{l}\text { Project teams that under-utilize their resources will } \\
\text { soon find those resources re-assigned elsewhere }\end{array}$ & .147 & .066 & .068 & .063 & .225 & .145 & -.062 & .792 & .147 & .104 \\
\hline $\begin{array}{l}\text { There is a lack of teamwork (co-operation) between } \\
\text { different project teams }\end{array}$ & .332 & -.017 & .133 & .604 & .185 & -.063 & .075 & .254 & .185 & .086 \\
\hline
\end{tabular}




\begin{tabular}{|c|c|c|c|c|c|c|c|c|c|c|}
\hline $\begin{array}{l}\text { There is a lack of teamwork (co-operation) between a } \\
\text { project team and other non-project groups }\end{array}$ & .265 & .063 & .087 & .688 & .098 & -.001 & .091 & .146 & -.038 & .163 \\
\hline People try to look busy when they really not & .706 & .056 & .062 & .157 & -.020 & .229 & .116 & .128 & -.041 & .102 \\
\hline $\begin{array}{l}\text { Work expands to fill the time available to our project } \\
\text { workers }\end{array}$ & .665 & .205 & .105 & .038 & 021 & .112 & .160 & 243 & -.059 & 193 \\
\hline $\begin{array}{l}\text { People delay and/or procrastinate the starting of } \\
\text { critical tasks }\end{array}$ & .643 & .152 & .064 & .276 & .293 & .129 & .048 & -.160 & .052 & -.050 \\
\hline $\begin{array}{l}\text { There are discussions, frustrations and/or } \\
\text { disagreements about the priority of different projects }\end{array}$ & .546 & .116 & .083 & .140 & .277 & -.003 & .094 & .265 & .016 & -.251 \\
\hline $\begin{array}{l}\text { People work on non-priority tasks while priority tasks } \\
\text { sit waiting for them to start or restart }\end{array}$ & .587 & .312 & -.025 & .249 & .294 & -.009 & .211 & -.158 & .031 & -.044 \\
\hline $\begin{array}{l}\text { "Student syndrome" (given extra time, a person will } \\
\text { spend it on other, personally important priorities until } \\
\text { the sensed risk is intolerable) is alive and well in our } \\
\text { projects }\end{array}$ & .654 & .081 & .251 & .089 & .027 & .023 & .001 & .,017 & .056 & -.107 \\
\hline $\begin{array}{l}\text { Murphy's Law (given two equally probable outcomes, } \\
\text { you will always get the undesired outcome: i.e., } \\
\text { "Things go wrong") is alive and well in our projects }\end{array}$ & .226 & -.090 & .380 & .522 & .247 & .031 & -.075 & -.099 & -.003 & -.118 \\
\hline $\begin{array}{l}\text { The goals of leadership team, project managers and } \\
\text { people are major source of conflict }\end{array}$ & .109 & .057 & .263 & .494 & .278 & .171 & -.037 & -.031 & .121 & -.324 \\
\hline $\begin{array}{l}\text { The conflicts among leadership team, project } \\
\text { managers and people always result in win/win }\end{array}$ & .004 & -.061 & .029 & .041 & -.060 & .024 & .000 & .042 & .002 & .868 \\
\hline $\begin{array}{l}\text { Our leadership team does not fully understand what } \\
\text { is causing these symptoms to occur }\end{array}$ & .123 & .003 & .809 & .110 & .005 & .001 & .071 & .082 & .073 & -.027 \\
\hline $\begin{array}{l}\text { Our leadership team is not sure if practical, and } \\
\text { economically viable solutions or alternatives may } \\
\text { exist }\end{array}$ & .089 & .302 & .656 & .159 & .220 & .172 & .123 & -.037 & .059 & .117 \\
\hline $\begin{array}{l}\text { Our leadership team has apathy, ignorance, inability, } \\
\text { indifference, or disregard towards the symptoms and } \\
\text { their effects on our projects, customers, and the } \\
\text { project team members }\end{array}$ & .177 & .265 & .715 & .011 & .078 & .158 & -.074 & .053 & -.071 & .001 \\
\hline $\begin{array}{l}\text { The planned deliverables (scope, cost, quality) form a } \\
\text { project fall short of expectations }\end{array}$ & .177 & -.009 & .401 & .145 & .525 & .199 & .126 & .171 & -.082 & -.127 \\
\hline $\begin{array}{l}\text { Projects are significantly late (late enough to cause } \\
\text { complaints or dis-satisfaction) }\end{array}$ & .247 & .191 & .069 & .141 & .651 & .072 & .129 & .026 & -.063 & -.144 \\
\hline $\begin{array}{l}\text { Projects are over-budget in person-hrs consumed, } \\
\text { and/or costs }\end{array}$ & .044 & .164 & .068 & .151 & .768 & .042 & .083 & .154 & -.021 & .031 \\
\hline
\end{tabular}

Extraction Method: Principal Component Analysis.

Rotation Method: Varimax with Kaiser Normalization. 


\section{PM planning processes}

\begin{tabular}{|c|c|c|c|c|}
\hline & $\begin{array}{c}\text { strongly agree/ } \\
\text { agree }\end{array}$ & $\begin{array}{r}\text { neither agree } \\
\text { nor disagree }\end{array}$ & $\begin{array}{c}\text { disagree/ } \\
\text { strongly disagree }\end{array}$ & Total \\
\hline H1-4 Project management plan & 137 & 20 & 6 & 163 \\
\hline H2-1 Project scope management plan & 122 & 33 & 8 & 163 \\
\hline H2-2 Project scope statement & 144 & 12 & 7 & 163 \\
\hline H2-3 Work breakdown structure & 137 & 14 & 12 & 163 \\
\hline H2-4 WBS dictionary & 73 & 63 & 27 & 163 \\
\hline H2-5 Scope baseline & 123 & 36 & 4 & 163 \\
\hline H3-1 Activity list & 128 & 23 & 12 & 163 \\
\hline H3-2 Activity attributes & 70 & 68 & 25 & 163 \\
\hline H3-3 Milestones list & 142 & 15 & 6 & 163 \\
\hline H3-4 Project schedule network diagrams & 85 & 52 & 26 & 163 \\
\hline H3-5 Activity resource requirements & 93 & 55 & 15 & 163 \\
\hline H3-6 Resource breakdown structure & 84 & 56 & 23 & 163 \\
\hline H3-7 Resource calendar & 101 & 46 & 16 & 163 \\
\hline H3-8 Activity duration estimates & 124 & 31 & 8 & 163 \\
\hline H3-9 Project schedule & 153 & 3 & 7 & 163 \\
\hline H3-10 Schedule model data & 41 & 95 & 27 & 163 \\
\hline H3-11 Schedule baseline & 105 & 42 & 16 & 163 \\
\hline H4-1 Activity cost estimates & 116 & 33 & 14 & 163 \\
\hline H4-2 Activity cost est. supporting detail & 63 & 81 & 19 & 163 \\
\hline H4-3 Cost management plan & 107 & 43 & 13 & 163 \\
\hline H4-4 Cost baseline & 112 & 36 & 15 & 163 \\
\hline H4-5 Project funding requirements & 83 & 62 & 18 & 163 \\
\hline H5-1 Quality management plan & 112 & 42 & 9 & 163 \\
\hline H5-2 Quality metrics & 99 & 53 & 11 & 163 \\
\hline H5-3 Quality checklists & 111 & 44 & 8 & 163 \\
\hline H5-4 Process improvement plan & 66 & 78 & 19 & 163 \\
\hline H5-5 Quality baseline & 81 & 67 & 15 & 163 \\
\hline H6-1 Roles and responsibilities & 143 & 18 & 2 & 163 \\
\hline H6-2 Project organization chart & 129 & 27 & 7 & 163 \\
\hline H6-3 Stuffing management plan & 100 & 49 & 14 & 163 \\
\hline H7-1 Communication management plan & 126 & 28 & 9 & 163 \\
\hline H8-1 Risk management plan & 130 & 26 & 7 & 163 \\
\hline H8-2 Risk register & 126 & 29 & 8 & 163 \\
\hline H8-3 Risk-related contractual agreements & 95 & 55 & 13 & 163 \\
\hline H9-1 Procurement management plan & 76 & 67 & 20 & 163 \\
\hline H9-2 Contract statement of work & 102 & 51 & 10 & 163 \\
\hline H9-3 Make-or-buy decisions & 83 & 57 & 23 & 163 \\
\hline H9-4 Procurement documents & 77 & 70 & 16 & 163 \\
\hline H9-5 Supplier evaluation criteria & 77 & 66 & 20 & 163 \\
\hline H9-6 Updates & 119 & 32 & 12 & 163 \\
\hline
\end{tabular}




\section{PM-executing processes}

\begin{tabular}{lcccc}
\hline & $\begin{array}{c}\text { strongly } \\
\text { agree/ } \\
\text { agree }\end{array}$ & $\begin{array}{c}\text { neither } \\
\text { agree } \\
\text { nor disagree }\end{array}$ & $\begin{array}{c}\text { disagree/ } \\
\text { strongly } \\
\text { disagree }\end{array}$ & Total \\
\hline H1-5 Deliverables & 159 & 4 & 0 & 163 \\
H1-6 Requested changes & 135 & 18 & 10 & 163 \\
H1-7 Implemented change requests & 130 & 25 & 8 & 163 \\
H1-8 Implemented corrective actions & 126 & 34 & 3 & 163 \\
H1-9 Implemented preventive actions & 121 & 38 & 4 & 163 \\
H1-10 Implemented defect repair & 118 & 40 & 5 & 163 \\
H1-11 Work performance information & 99 & 50 & 14 & 163 \\
H5-6 Recommended corrective actions & 96 & 56 & 9 & 163 \\
H5-7 Organizational process assets & 77 & 70 & 16 & 163 \\
H6-4 Project staff assignments & 107 & 49 & 7 & 163 \\
H6-5 Resource availability & 145 & 17 & 1 & 163 \\
H6-6 Team performance assessment & 72 & 75 & 16 & 163 \\
H9-6 Qualified sellers list & 59 & 78 & 26 & 163 \\
H9-7 Procurement document package & 49 & 85 & 29 & 163 \\
H9-8 Proposals & 75 & 72 & 16 & 163 \\
H9-9 Selected sellers & 68 & 76 & 19 & 163 \\
H9-10 Contract & 113 & 41 & 9 & 163 \\
H9-11 Contract management plan & 67 & 71 & 25 & 163 \\
H9-12 Procurement management plan (up.) & 67 & 73 & 23 & 163 \\
\hline
\end{tabular}




\section{PM controlling and monitoring processes}

\begin{tabular}{lcccc}
\hline & neither & disagree/ & \\
& $\begin{array}{c}\text { strongly } \\
\text { agree/ agree }\end{array}$ & $\begin{array}{c}\text { agree } \\
\text { nor disagree }\end{array}$ & $\begin{array}{c}\text { strongly } \\
\text { disagree }\end{array}$ & Total \\
\hline H1-12 Recommended corrective actions & 127 & 31 & 5 & 163 \\
H1-13 Recommended preventive actions & 107 & 38 & 18 & 163 \\
H1-14 Forecasts & 131 & 28 & 4 & 163 \\
H1-15 Recommended defect repair & 99 & 57 & 7 & 163 \\
H1-16 Requested changes & 127 & 25 & 11 & 163 \\
H1-17 Approved change requests & 133 & 24 & 6 & 163 \\
H1-18 Rejected change requests & 108 & 46 & 9 & 163 \\
H1-19 Approved corrective actions & 108 & 41 & 14 & 163 \\
H1-20 Approved preventive actions & 105 & 40 & 18 & 163 \\
H1-21 Approved defect repair & 105 & 50 & 8 & 163 \\
H1-22 Validated defect repair & 110 & 47 & 6 & 163 \\
H1-23 Deliverables & 153 & 8 & 2 & 163 \\
H2-6 Accepted deliverables & 147 & 13 & 3 & 163 \\
H3-12 Performance measurements & 120 & 36 & 7 & 163 \\
H4-6 Forecasted completion & 103 & 50 & 10 & 163 \\
H5-8 Quality control measurements & 117 & 36 & 10 & 163 \\
H5-9 Validated deliveries & 134 & 25 & 4 & 163 \\
H7-2 Performance reports & 103 & 48 & 12 & 163 \\
H7-3 Resolved issues & 120 & 37 & 6 & 163 \\
H9-13 Contract documentation & 80 & 86 & 15 & 163 \\
\hline
\end{tabular}




\section{APPENDIX C: CROSSTABULATIONS}

\section{Crosstab H1-1 Project charter * Financial objectives}

\begin{tabular}{|c|c|c|c|c|c|}
\hline & & & \multicolumn{2}{|c|}{$\begin{array}{l}\text { Financial } \\
\text { objectives }\end{array}$} & \multirow[b]{2}{*}{ Total } \\
\hline & & & 0 & 1 & \\
\hline \multirow[t]{6}{*}{ H1-1 Project charter } & strongly agree / agree & Count & 102 & 42 & 144 \\
\hline & & Expected Count & 100.7 & 43.3 & 144.0 \\
\hline & neither agree nor disagree & Count & 11 & 3 & 14 \\
\hline & & Expected Count & 9.8 & 4.2 & 14.0 \\
\hline & disagree / strongly disagree & Count & 1 & 4 & 5 \\
\hline & & Expected Count & 3.5 & 1.5 & 5.0 \\
\hline \multirow[t]{2}{*}{ Total } & & Count & 114 & 49 & 163 \\
\hline & & Expected Count & 114.0 & 49.0 & 163.0 \\
\hline
\end{tabular}

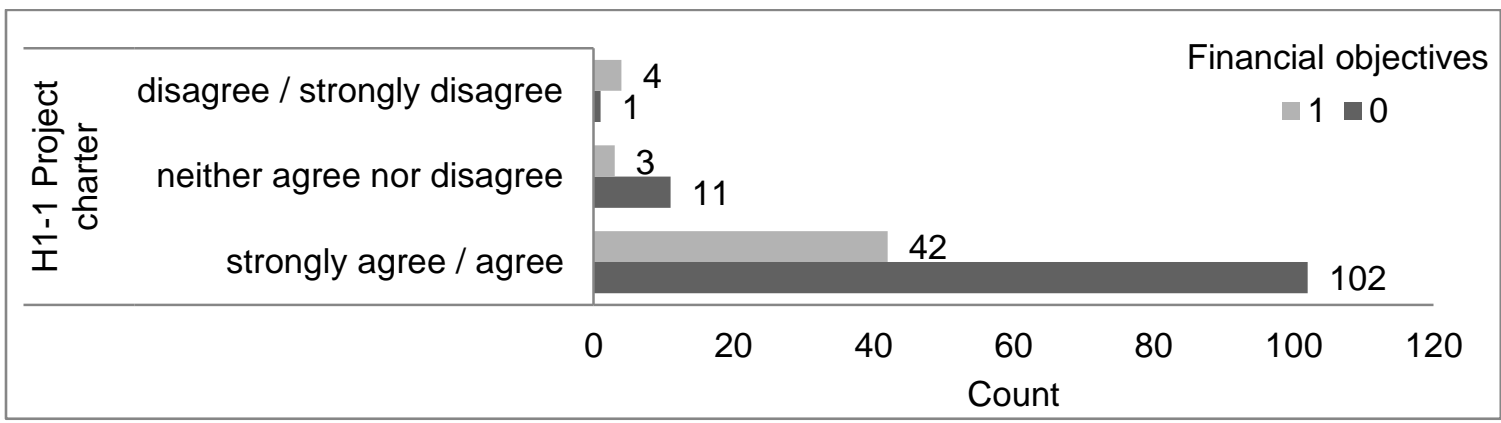

\section{Chi-Square Tests}

\begin{tabular}{|c|c|c|c|c|c|c|}
\hline & Value & df & $\begin{array}{c}\text { Asymp. Sig. } \\
\text { (2-sided) }\end{array}$ & $\begin{array}{c}\text { Exact Sig. } \\
\text { (2-sided) }\end{array}$ & $\begin{array}{c}\text { Exact Sig. } \\
\text { (1-sided) }\end{array}$ & $\begin{array}{c}\text { Point } \\
\text { Probability }\end{array}$ \\
\hline Pearson Chi-Square & $6.482^{\mathrm{a}}$ & 2 & .039 & .039 & & \\
\hline Likelihood Ratio & 5.911 & 2 & .052 & .071 & & \\
\hline Fisher's Exact Test & 5.628 & & & .050 & & \\
\hline Linear-by-Linear & $2.223^{b}$ & 1 & .136 & .167 & .102 & .051 \\
\hline \multicolumn{7}{|l|}{ Association } \\
\hline $\mathrm{N}$ of Valid Cases & 163 & & & & & \\
\hline
\end{tabular}

a. 3 cells $(50.0 \%)$ have expected count less than 5 . The minimum expected count is 1.50 .

b. The standardized statistic is 1.491 .

Symmetric Measures

\begin{tabular}{llccc}
\hline & & Value & Approx. Sig. & Exact Sig. \\
\hline Nominal by Nominal & Phi & .199 & .039 & .039 \\
& Cramer's V & .199 & .039 & .039 \\
N of Valid Cases & & 163 & & \\
\hline
\end{tabular}




\section{Crosstab H1-1 Project charter * Sales}

\begin{tabular}{lllccc}
\hline & & \multicolumn{3}{c}{ Sales } & \\
\cline { 3 - 4 } & & & 0 & 1 & Total \\
\hline H1-1 Project charter & strongly agree / agree & Count & 137 & 7 & 144 \\
& & Expected Count & 136.0 & 8.0 & 144.0 \\
& \multirow{2}{*}{ neither agree nor disagree } & Count & 14 & 0 & 14 \\
& & Expected Count & 13.2 & .8 & 14.0 \\
& \multirow{2}{*}{ disagree / strongly disagree } & Count & 3 & 2 & 5 \\
& & Expected Count & 4.7 & .3 & 5.0 \\
Total & & Count & 154 & 9 & 163 \\
& & Expected Count & 154.0 & 9.0 & 163.0 \\
\hline
\end{tabular}

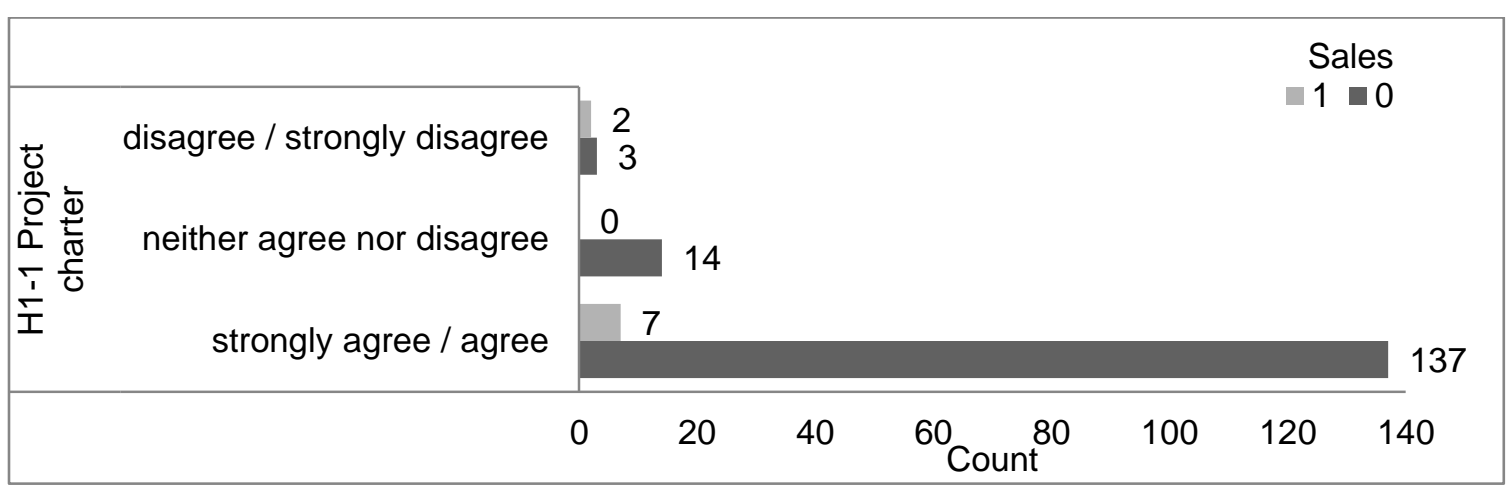

Chi-Square Tests

\begin{tabular}{|c|c|c|c|c|c|c|}
\hline & Value & $\mathrm{df}$ & $\begin{array}{c}\text { Asymp. Sig. } \\
\text { (2-sided) }\end{array}$ & $\begin{array}{c}\text { Exact Sig. } \\
\text { (2-sided) }\end{array}$ & $\begin{array}{c}\text { Exact Sig. } \\
\text { (1-sided) }\end{array}$ & $\begin{array}{c}\text { Point } \\
\text { Probability }\end{array}$ \\
\hline Pearson Chi-Square & $12.333^{\mathrm{a}}$ & 2 & .002 & .020 & & \\
\hline Likelihood Ratio & 6.912 & 2 & .032 & .020 & & \\
\hline Fisher's Exact Test & 6.905 & & & .033 & & \\
\hline Linear-by-Linear & $4.474^{\mathrm{b}}$ & 1 & .034 & .062 & .062 & .043 \\
\hline \multicolumn{7}{|l|}{ Association } \\
\hline $\mathrm{N}$ of Valid Cases & 163 & & & & & \\
\hline
\end{tabular}

a. 3 cells $(50.0 \%)$ have expected count less than 5 . The minimum expected count is 28 .

b. The standardized statistic is 2.115 .

Symmetric Measures

\begin{tabular}{llccc}
\hline & & Value & Approx. Sig. & Exact Sig. \\
\hline Nominal by Nominal & Phi & .275 & .002 & .020 \\
& Cramer's V & .275 & .002 & .020 \\
N of Valid Cases & & 163 & & \\
\hline
\end{tabular}




\section{Crosstab H1-3 Updates * User satisfaction}

\begin{tabular}{lllccc}
\hline & & \multicolumn{2}{c}{ User satisfaction } & \\
\cline { 3 - 4 } & & & 0 & 1 & Total \\
\hline H1-3 Updates & strongly agree / agree & Count & 101 & 24 & 125 \\
& & Expected Count & 105.8 & 19.2 & 125.0 \\
& \multirow{2}{*}{ neither agree nor disagree } & Count & 30 & 0 & 30 \\
& & Expected Count & 25.4 & 4.6 & 30.0 \\
& disagree / strongly & Count & 7 & 1 & 8 \\
& disagree & Expected Count & 6.8 & 1.2 & 8.0 \\
& & Count & 138 & 25 & 163 \\
& & Expected Count & 138.0 & 25.0 & 163.0 \\
\hline
\end{tabular}

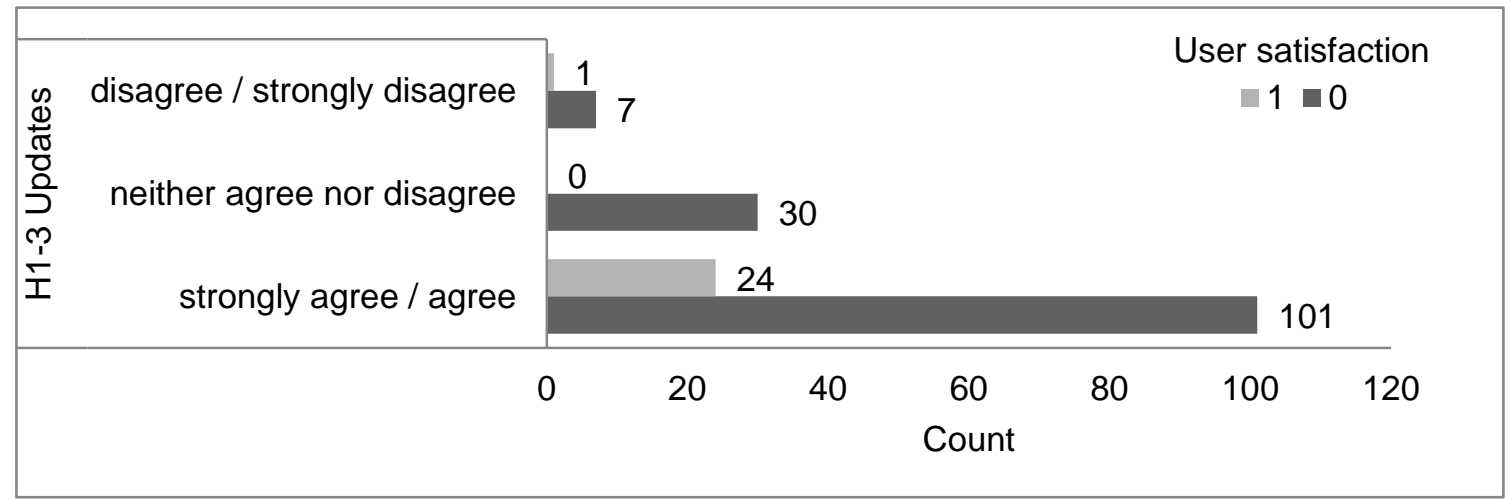

\section{Chi-Square Tests}

\begin{tabular}{lcccccc}
\hline & Value & df & $\begin{array}{c}\text { Asymp. Sig. } \\
\text { (2-sided) }\end{array}$ & $\begin{array}{c}\text { Exact Sig. } \\
(2 \text {-sided) }\end{array}$ & $\begin{array}{c}\text { Exact Sig. } \\
(1 \text {-sided })\end{array}$ & $\begin{array}{c}\text { Point } \\
\text { Probability }\end{array}$ \\
\hline Pearson Chi-Square & $6.921^{\mathrm{a}}$ & 2 & .031 & .038 & & \\
Likelihood Ratio & 11.391 & 2 & .003 & .004 & & \\
Fisher's Exact Test & 8.365 & & & .011 & & \\
Linear-by-Linear & $3.990^{\mathrm{b}}$ & 1 & .046 & .046 & .025 & .019 \\
Association & & & & & & \\
N of Valid Cases & 163 & & & & & \\
\hline
\end{tabular}

a. 2 cells (33.3\%) have expected count less than 5 . The minimum expected count is 1.23 .

b. The standardized statistic is -1.998 .

Symmetric Measures

\begin{tabular}{llccc}
\hline & & Value & Approx. Sig. & Exact Sig. \\
\hline Nominal by Nominal & Phi & .206 & .031 & .038 \\
& Cramer's V & .206 & .031 & .038 \\
N of Valid Cases & & 163 & & \\
\hline
\end{tabular}


Crosstab H1-7 Implemented change requests * Commercial benefit for contractors

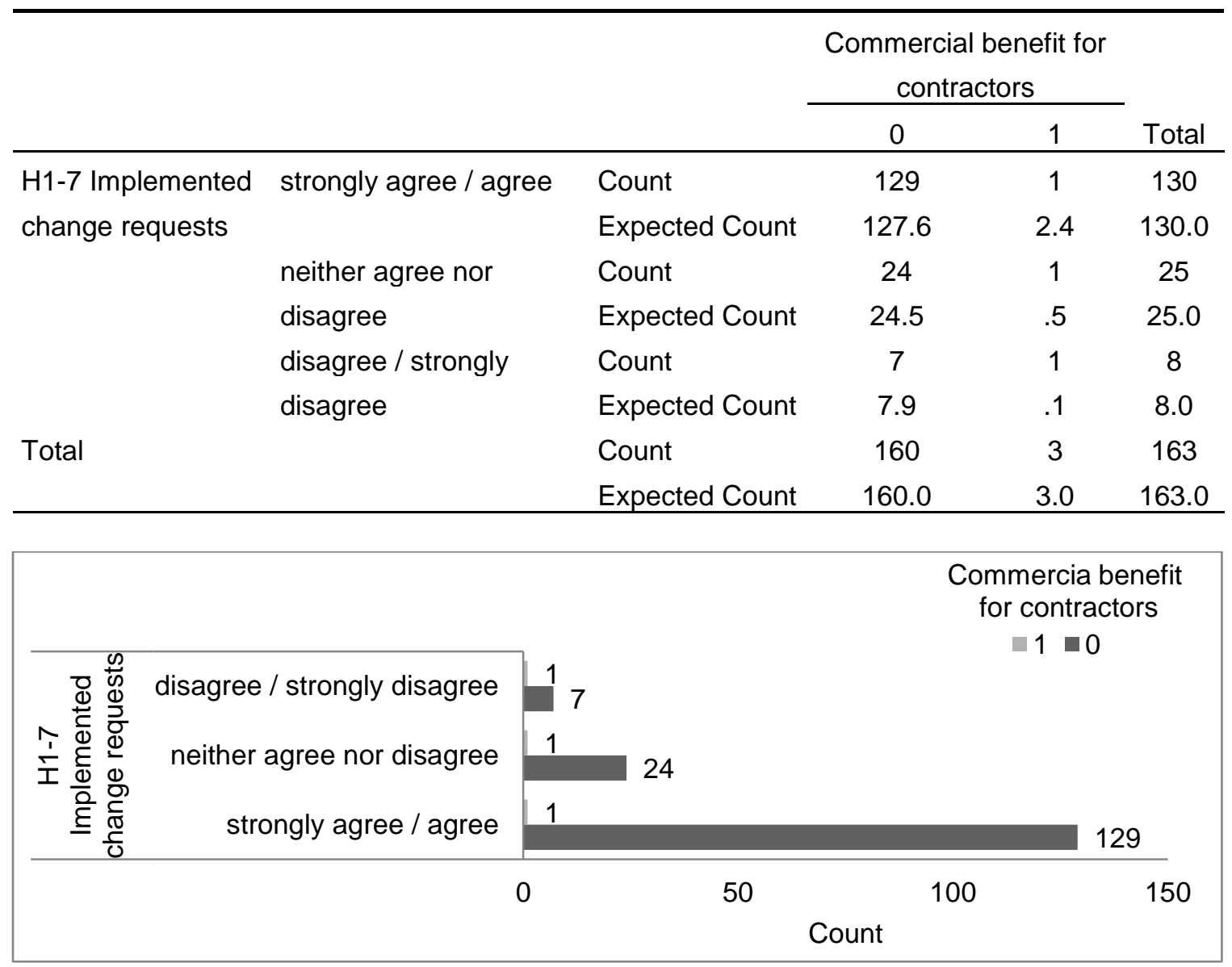

\section{Chi-Square Tests}

\begin{tabular}{lcccccc}
\hline & Value & df & $\begin{array}{c}\text { Asymp. Sig. } \\
\text { (2-sided) }\end{array}$ & $\begin{array}{c}\text { Exact Sig. } \\
(2 \text {-sided })\end{array}$ & $\begin{array}{c}\text { Exact Sig. } \\
(1-\text {-sided })\end{array}$ & $\begin{array}{c}\text { Point } \\
\text { Probability }\end{array}$ \\
\hline Pearson Chi-Square & $6.503^{\mathrm{a}}$ & 2 & .039 & .050 & & \\
Likelihood Ratio & 3.762 & 2 & .152 & .105 & & \\
Fisher's Exact Test & 5.890 & & & .050 & & \\
Linear-by-Linear & $5.941^{\mathrm{b}}$ & 1 & .015 & .050 & .050 & .040 \\
Association & & & & & & \\
N of Valid Cases & 163 & & & & & \\
\hline
\end{tabular}

a. 3 cells $(50.0 \%)$ have expected count less than 5 . The minimum expected count is .15 .

b. The standardized statistic is 2.437 .

Symmetric Measures

\begin{tabular}{llccc}
\hline & & Value & Approx. Sig. & Exact Sig. \\
\hline Nominal by Nominal & Phi & .200 & .039 & .050 \\
& Cramer's V & .200 & .039 & .050 \\
N of Valid Cases & & 163 & & \\
\hline
\end{tabular}


Crosstab H1-7 Implemented change requests * Scope

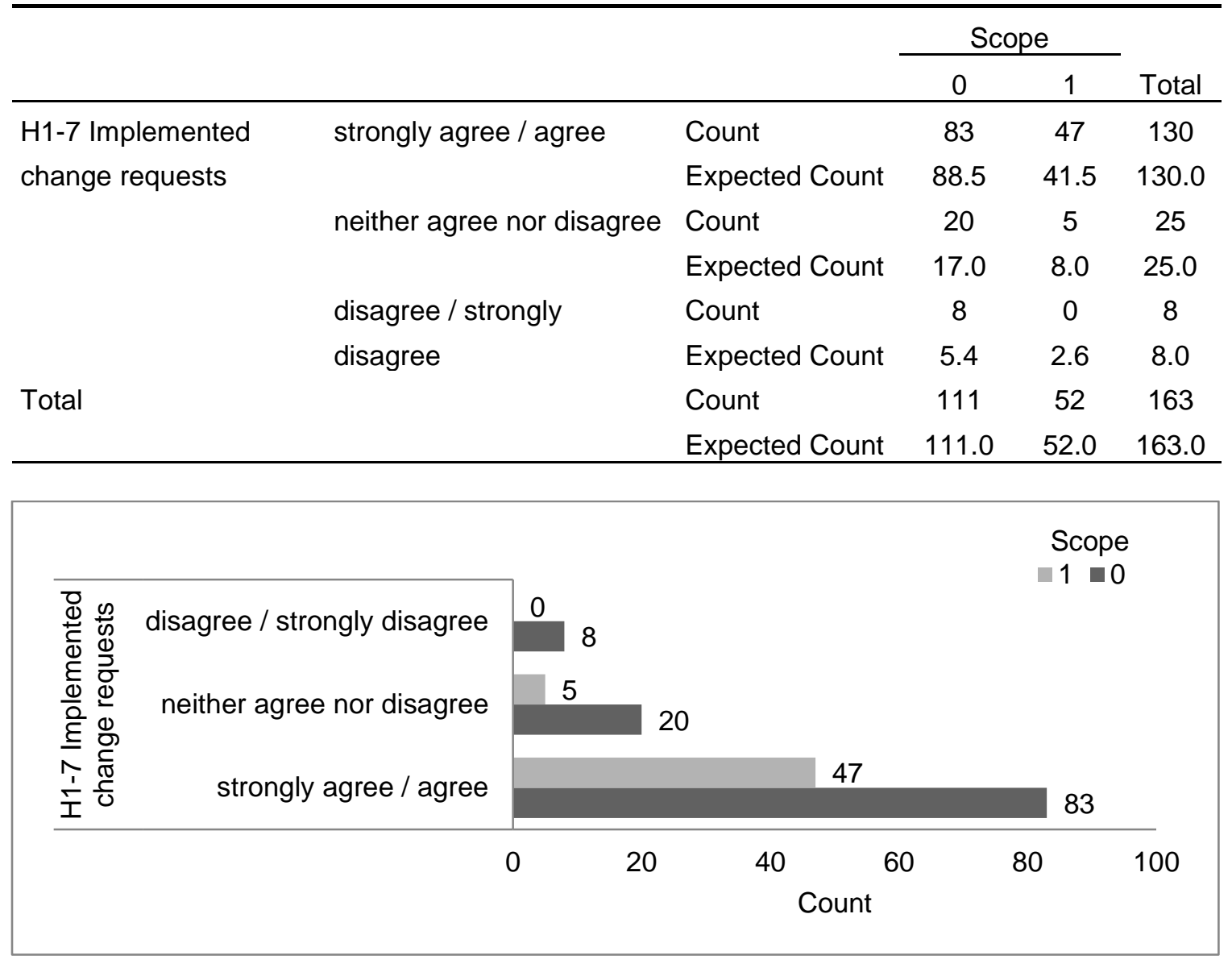

Chi-Square Tests

\begin{tabular}{lcccccc}
\hline & \multicolumn{7}{c}{$\begin{array}{c}\text { Asymp. Sig. } \\
\text { Value }\end{array}$} & $\begin{array}{c}\text { Exact Sig. } \\
\text { (2-sided) }\end{array}$ & $\begin{array}{c}\text { Exact Sig. } \\
(2 \text {-sided })\end{array}$ & $\begin{array}{c}\text { Point } \\
(1-s i d e d)\end{array}$ & Probability \\
\hline Pearson Chi-Square & $\mathbf{6 . 4 6 0 ^ { \mathrm { a } }}$ & 2 & .040 & .037 & & \\
Likelihood Ratio & 8.980 & 2 & .011 & .016 & & \\
Fisher's Exact Test & 6.380 & & & .037 & & .004 \\
Linear-by-Linear & $6.397^{\mathrm{b}}$ & 1 & .011 & .011 & .006 & \\
Association & & & & & & \\
N of Valid Cases & 163 & & & & & \\
\hline
\end{tabular}

a. 1 cells $(16.7 \%)$ have expected count less than 5 . The minimum expected count is 2.55 .

b. The standardized statistic is -2.529 .

Symmetric Measures

\begin{tabular}{llccc}
\hline & & Value & Approx. Sig. & Exact Sig. \\
\hline Nominal by Nominal & Phi & .199 & .040 & .037 \\
& Cramer's V & .199 & .040 & .037 \\
N of Valid Cases & & 163 & & \\
\hline
\end{tabular}




\section{Crosstab H1-9 Implemented preventive actions * Schedule}

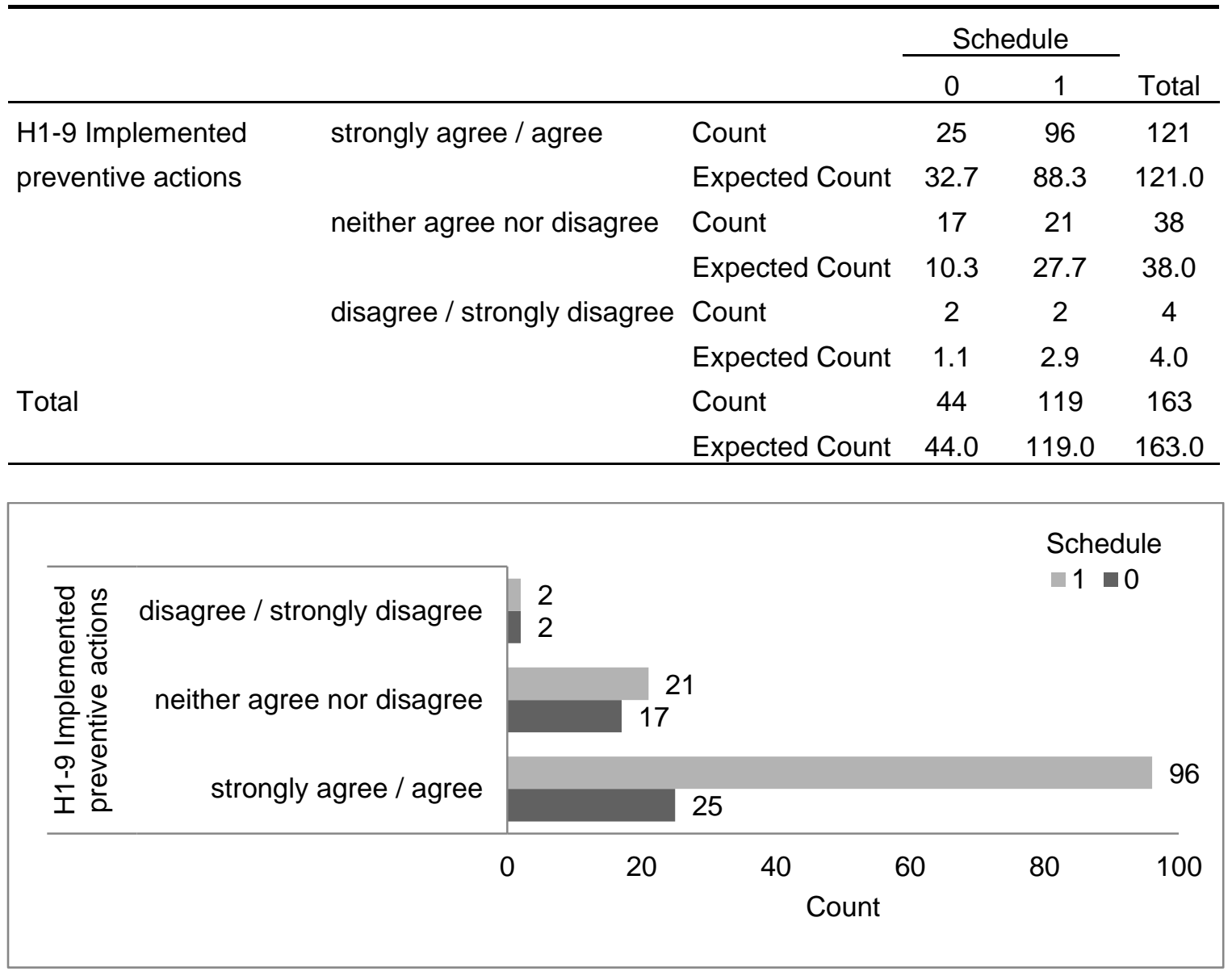

Chi-Square Tests

\begin{tabular}{lcccccc}
\hline & Value & df & $\begin{array}{c}\text { Asymp. Sig. } \\
\text { (2-sided) }\end{array}$ & $\begin{array}{c}\text { Exact Sig. } \\
(2 \text {-sided) }\end{array}$ & $\begin{array}{c}\text { Exact Sig. } \\
\text { (1-sided) }\end{array}$ & $\begin{array}{c}\text { Point } \\
\text { Probability }\end{array}$ \\
\hline Pearson Chi-Square & $9.607^{\mathrm{a}}$ & 2 & .008 & .009 & & \\
Likelihood Ratio & 9.037 & 2 & .011 & .012 & & \\
Fisher's Exact Test & 9.458 & & & .007 & & \\
Linear-by-Linear & $9.057^{\mathrm{b}}$ & 1 & .003 & .003 & .003 & .002 \\
Association & & & & & & \\
N of Valid Cases & 163 & & & & & \\
\hline
\end{tabular}

a. 2 cells (33.3\%) have expected count less than 5 . The minimum expected count is 1.08 .

b. The standardized statistic is -3.009 .

Symmetric Measures

\begin{tabular}{llccc}
\hline & & Value & Approx. Sig. & Exact Sig. \\
\hline Nominal by Nominal & Phi & .243 & .008 & .009 \\
& Cramer's V & .243 & .008 & .009 \\
N of Valid Cases & & 163 & & \\
\hline
\end{tabular}




\begin{tabular}{lllccc}
\hline & & & \multicolumn{2}{c}{ Financial } \\
& & & \multicolumn{2}{c}{ objectives } \\
\cline { 3 - 5 } & & & 0 & 1 & Total \\
\hline H1-9 Implemented & \multirow{2}{*}{ strongly agree / agree } & Count & 78 & 43 & 121 \\
preventive actions & & Expected Count & 84.6 & 36.4 & 121.0 \\
& \multirow{2}{*}{ neither agree nor disagree } & Count & 34 & 4 & 38 \\
& & Expected Count & 26.6 & 11.4 & 38.0 \\
& \multirow{3}{*}{ disagree / strongly disagree } & Count & 2 & 2 & 4 \\
& & Expected Count & 2.8 & 1.2 & 4.0 \\
& & Count & 114 & 49 & 163 \\
& & Expected Count & 114.0 & 49.0 & 163.0 \\
\hline
\end{tabular}

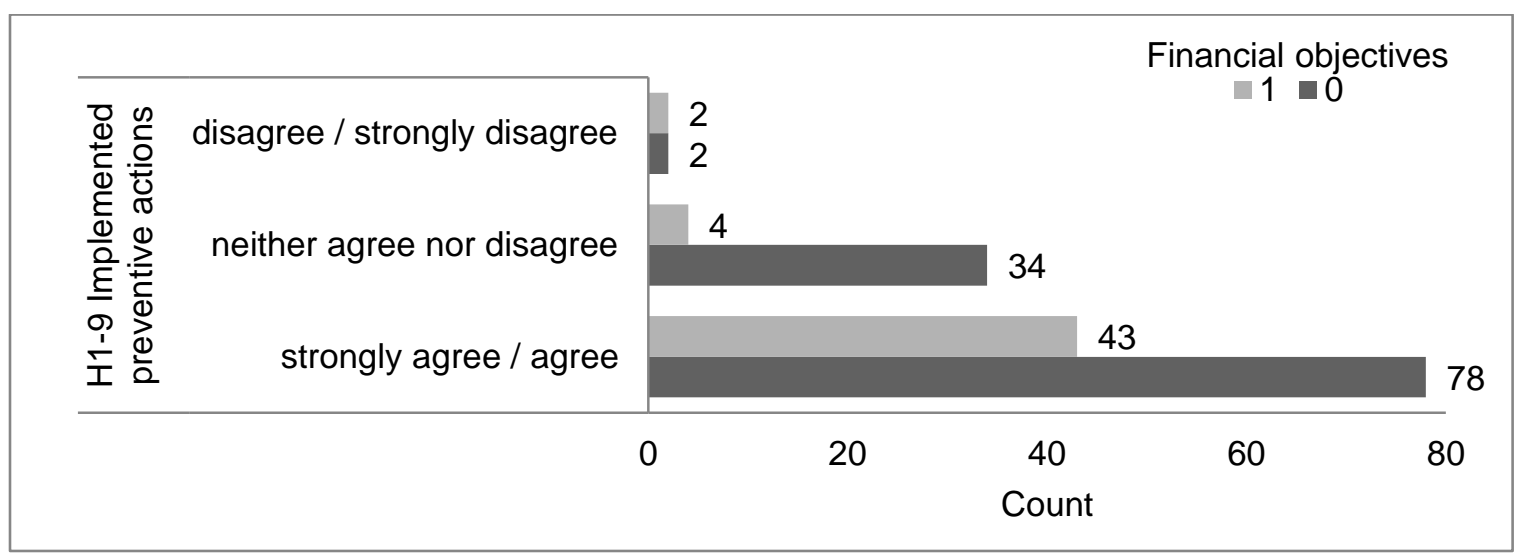

\section{Chi-Square Tests}

\begin{tabular}{lcccccc}
\hline & \multicolumn{7}{c}{$\begin{array}{c}\text { Asymp. Sig. } \\
\text { (2-sided) }\end{array}$} & $\begin{array}{c}\text { Exact Sig. } \\
\text { (2-sided) }\end{array}$ & $\begin{array}{c}\text { Exact Sig. } \\
\text { (1-sided) }\end{array}$ & $\begin{array}{c}\text { Point } \\
\text { Probability }\end{array}$ \\
\hline Pearson Chi-Square & $9.379^{\mathrm{a}}$ & 2 & .009 & .012 & & \\
Likelihood Ratio & 10.721 & 2 & .005 & .006 & & \\
Fisher's Exact Test & 10.343 & & & .004 & & .019 \\
Linear-by-Linear & $3.915^{\mathrm{b}}$ & 1 & .048 & .060 & .031 & \\
Association & & & & & & \\
N of Valid Cases & 163 & & & & & \\
\hline
\end{tabular}

a. 2 cells (33.3\%) have expected count less than 5 . The minimum expected count is 1.20 .

b. The standardized statistic is -1.979 .

Symmetric Measures

\begin{tabular}{llccc}
\hline & & Value & Approx. Sig. & Exact Sig. \\
\hline Nominal by Nominal & Phi & .240 & .009 & .012 \\
& Cramer's V & .240 & .009 & .012 \\
N of Valid Cases & & 163 & & \\
\hline
\end{tabular}


Crosstab H1-9 Implemented preventive actions * Commercial benefit for contractors

\begin{tabular}{|c|c|c|c|c|c|}
\hline & & & \multicolumn{2}{|c|}{$\begin{array}{l}\text { Commercial } \\
\text { benefit for } \\
\text { contractors }\end{array}$} & \multirow[b]{2}{*}{ Total } \\
\hline & & & 0 & 1 & \\
\hline \multirow{6}{*}{$\begin{array}{l}\text { H1-9 Implemented } \\
\text { preventive actions }\end{array}$} & strongly agree / agree & Count & 120 & 1 & 121 \\
\hline & & Expected Count & 118.8 & 2.2 & 121.0 \\
\hline & neither agree nor disagree & Count & 37 & 1 & 38 \\
\hline & & Expected Count & 37.3 & .7 & 38.0 \\
\hline & disagree / strongly & Count & 3 & 1 & 4 \\
\hline & disagree & Expected Count & 3.9 & .1 & 4.0 \\
\hline \multirow[t]{2}{*}{ Total } & & Count & 160 & 3 & 163 \\
\hline & & Expected Count & 160.0 & 3.0 & 163.0 \\
\hline
\end{tabular}

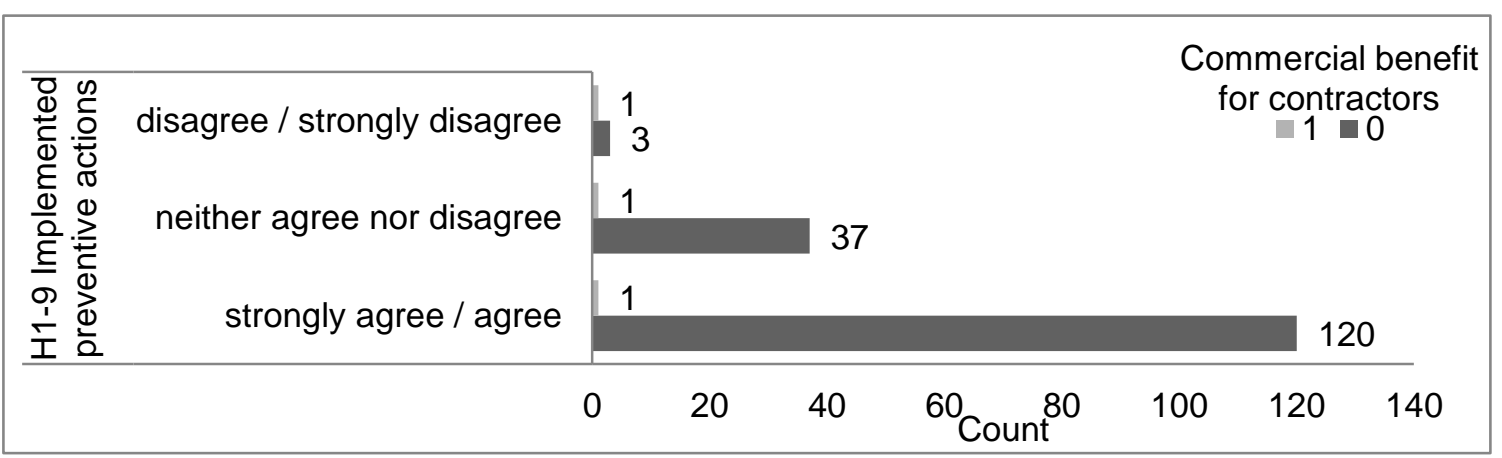

Chi-Square Tests

\begin{tabular}{|c|c|c|c|c|c|c|}
\hline & Value & $\mathrm{df}$ & $\begin{array}{c}\text { Asymp. Sig. } \\
\text { (2-sided) }\end{array}$ & $\begin{array}{c}\text { Exact Sig. } \\
\text { (2-sided) }\end{array}$ & $\begin{array}{c}\text { Exact Sig. } \\
(1 \text {-sided })\end{array}$ & $\begin{array}{c}\text { Point } \\
\text { Probability }\end{array}$ \\
\hline Pearson Chi-Square & $12.696^{\mathrm{a}}$ & 2 & .002 & .031 & & \\
\hline Likelihood Ratio & 4.585 & 2 & .101 & .084 & & \\
\hline Fisher's Exact Test & 6.928 & & & .043 & & \\
\hline Linear-by-Linear & $6.219^{b}$ & 1 & .013 & .043 & .043 & .038 \\
\hline \multicolumn{7}{|l|}{ Association } \\
\hline $\mathrm{N}$ of Valid Cases & 163 & & & & & \\
\hline
\end{tabular}

a. 4 cells $(66.7 \%)$ have expected count less than 5 . The minimum expected count is .07 .

b. The standardized statistic is 2.494 .

Symmetric Measures

\begin{tabular}{llccc}
\hline & & Value & Approx. Sig. & Exact Sig. \\
\hline Nominal by Nominal & Phi & .279 & .002 & .031 \\
& Cramer's V & .279 & .002 & .031 \\
N of Valid Cases & & 163 & & \\
\hline
\end{tabular}




\section{Crosstab H1-10 Implemented defect repair * Schedule}

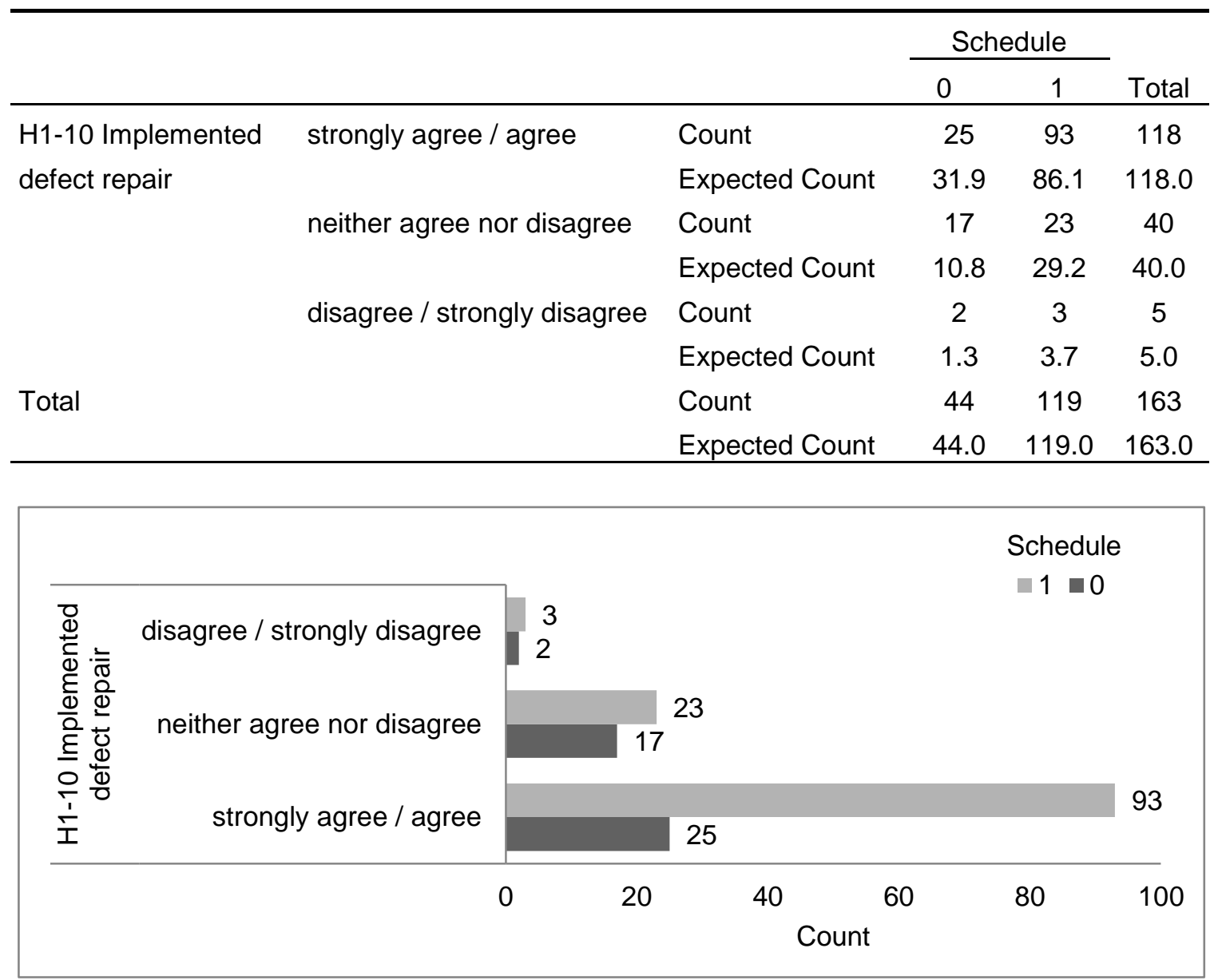

\section{Chi-Square Tests}

\begin{tabular}{lcccccc}
\hline & \multicolumn{7}{c}{$\begin{array}{c}\text { Asymp. Sig. } \\
\text { (2-sided) }\end{array}$} & $\begin{array}{c}\text { Exact Sig. } \\
(2 \text {-sided })\end{array}$ & $\begin{array}{c}\text { Exact Sig. } \\
\text { (1-sided) }\end{array}$ & $\begin{array}{c}\text { Point } \\
\text { Probability }\end{array}$ \\
\hline Pearson Chi-Square & $7.329^{\mathrm{a}}$ & 2 & .026 & .034 & & \\
Likelihood Ratio & 6.970 & 2 & .031 & .027 & & \\
Fisher's Exact Test & 7.337 & & & .019 & & \\
Linear-by-Linear & $6.357^{\mathrm{b}}$ & 1 & .012 & .013 & .011 & .006 \\
Association & & & & & & \\
N of Valid Cases & 163 & & & & & \\
\hline
\end{tabular}

a. 2 cells (33.3\%) have expected count less than 5 . The minimum expected count is 1.35 .

b. The standardized statistic is -2.521 .

Symmetric Measures

\begin{tabular}{llccc}
\hline & & Value & Approx. Sig. & Exact Sig. \\
\hline Nominal by Nominal & Phi & .212 & .026 & .034 \\
& Cramer's V & .212 & .026 & .034 \\
N of Valid Cases & & 163 & & \\
\hline
\end{tabular}




\section{Crosstab H1-10 Implemented defect repair * Sales}

\begin{tabular}{lllccc}
\hline & & & \multicolumn{2}{c}{ Sales } & \\
\cline { 3 - 5 } & & & 0 & 1 & Total \\
\hline H1-10 Implemented & \multirow{2}{*}{ strongly agree / agree } & Count & 112 & 6 & 118 \\
& & Expected Count & 111.5 & 6.5 & 118.0 \\
& neither agree nor disagree & Count & 39 & 1 & 40 \\
& & Expected Count & 37.8 & 2.2 & 40.0 \\
& disagree / strongly & Count & 3 & 2 & 5 \\
Total & disagree & Expected Count & 4.7 & .3 & 5.0 \\
& & Count & 154 & 9 & 163 \\
& & Expected Count & 154.0 & 9.0 & 163.0 \\
\hline
\end{tabular}

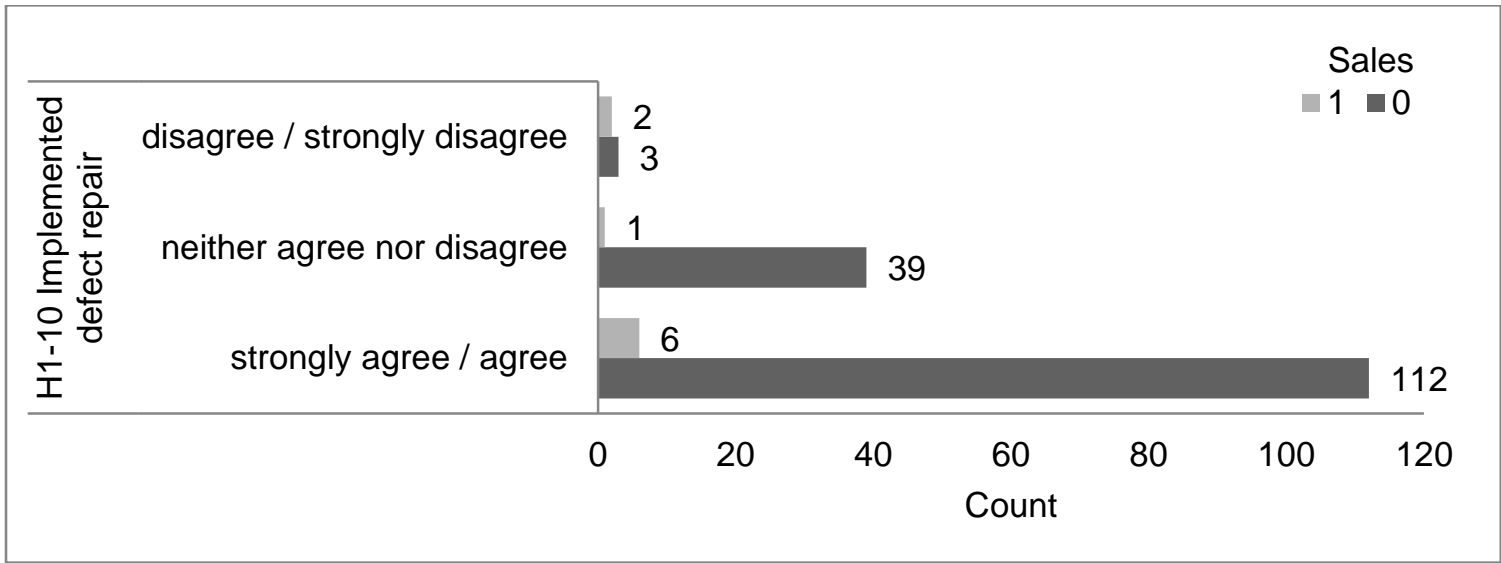

Chi-Square Tests

\begin{tabular}{lcccccc}
\hline & Value & df & $\begin{array}{c}\text { Asymp. Sig. } \\
(2 \text {-sided })\end{array}$ & $\begin{array}{c}\text { Exact Sig. } \\
(2 \text {-sided })\end{array}$ & $\begin{array}{c}\text { Exact Sig. } \\
(1 \text {-sided })\end{array}$ & $\begin{array}{c}\text { Point } \\
\text { Probability }\end{array}$ \\
\hline Pearson Chi-Square & $12.137^{\mathrm{a}}$ & 2 & .002 & .019 & & \\
Likelihood Ratio & 6.112 & 2 & .047 & .050 & & \\
Fisher's Exact Test & 7.076 & & & .030 & & \\
Linear-by-Linear & $2.139^{\mathrm{b}}$ & 1 & .144 & .180 & .130 & .084 \\
Association & & & & & & \\
N of Valid Cases & 163 & & & & & \\
\hline
\end{tabular}

a. 3 cells $(50.0 \%)$ have expected count less than 5 . The minimum expected count is 28 .

b. The standardized statistic is 1.463 .

Symmetric Measures

\begin{tabular}{llccc}
\hline & & Value & Approx. Sig. & Exact Sig. \\
\hline Nominal by Nominal & Phi & .273 & .002 & .019 \\
& Cramer's V & .273 & .002 & .019 \\
N of Valid Cases & & 163 & & \\
\hline
\end{tabular}




\section{Crosstab H1-11 Work performance information * Sales}

\begin{tabular}{lllccc}
\hline & & & \multicolumn{2}{c}{ Sales } & \\
\cline { 4 - 5 } & & & 0 & 1 & Total \\
\hline H1-11 Work & strongly agree / & Count & 92 & 7 & 99 \\
performance & agree & Expected Count & 93.5 & 5.5 & 99.0 \\
information & neither agree nor & Count & 50 & 0 & 50 \\
& disagree & Expected Count & 47.2 & 2.8 & 50.0 \\
& disagree / strongly & Count & 12 & 2 & 14 \\
& disagree & Expected Count & 13.2 & .8 & 14.0 \\
Total & & Count & 154 & 9 & 163 \\
& & Expected Count & 154.0 & 9.0 & 163.0 \\
\hline
\end{tabular}

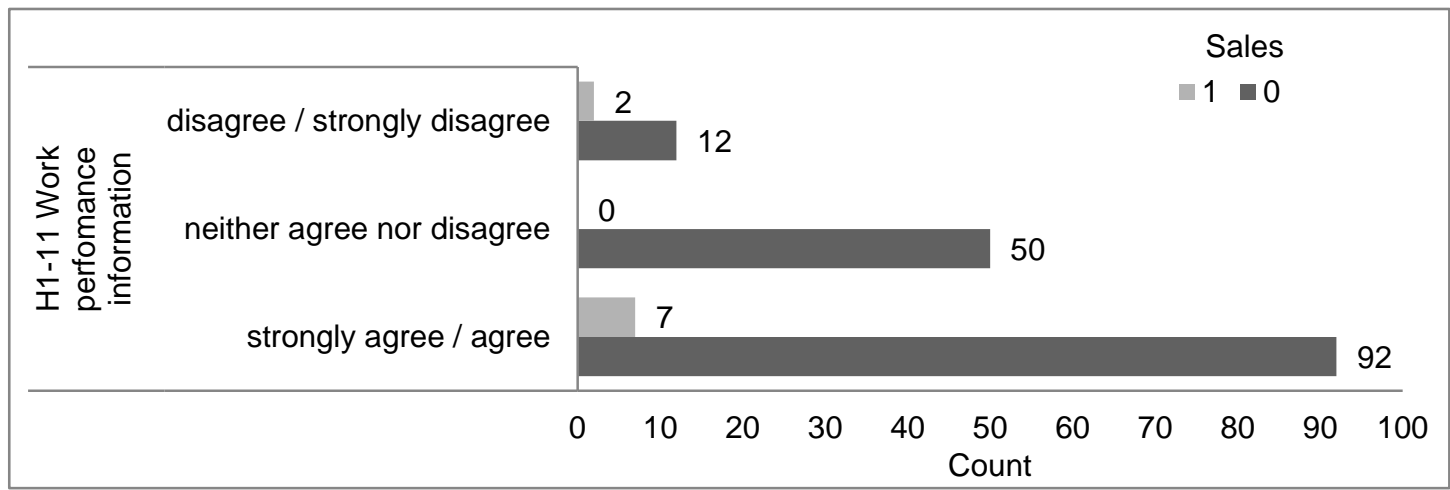

\section{Chi-Square Tests}

Asymp.

Sig. (2- Exact Sig. Exact Sig. Point

\begin{tabular}{lcccccc} 
& Value & df & sided) & (2-sided) & (1-sided) & Probability \\
\hline Pearson Chi-Square & $5.439^{\mathrm{a}}$ & 2 & .066 & .079 & & \\
Likelihood Ratio & 7.566 & 2 & .023 & .030 & & \\
Fisher's Exact Test & 5.943 & & & .046 & & \\
Linear-by-Linear & $.026^{\mathrm{b}}$ & 1 & .872 & 1.000 & .0561 & .207 \\
Association & & & & & & \\
N of Valid Cases & 163 & & & & & \\
\hline
\end{tabular}

a. 2 cells (33.3\%) have expected count less than 5 . The minimum expected count is .77 .

b. The standardized statistic is -.162 .

Symmetric Measures

\begin{tabular}{llccc}
\hline & & Value & Approx. Sig. & Exact Sig. \\
\hline Nominal by Nominal & Phi & .183 & .066 & .079 \\
& Cramer's V & .183 & .066 & .079 \\
N of Valid Cases & & 163 & & \\
\hline
\end{tabular}


Crosstab H1-12 Recommended corrective actions * Customer approval

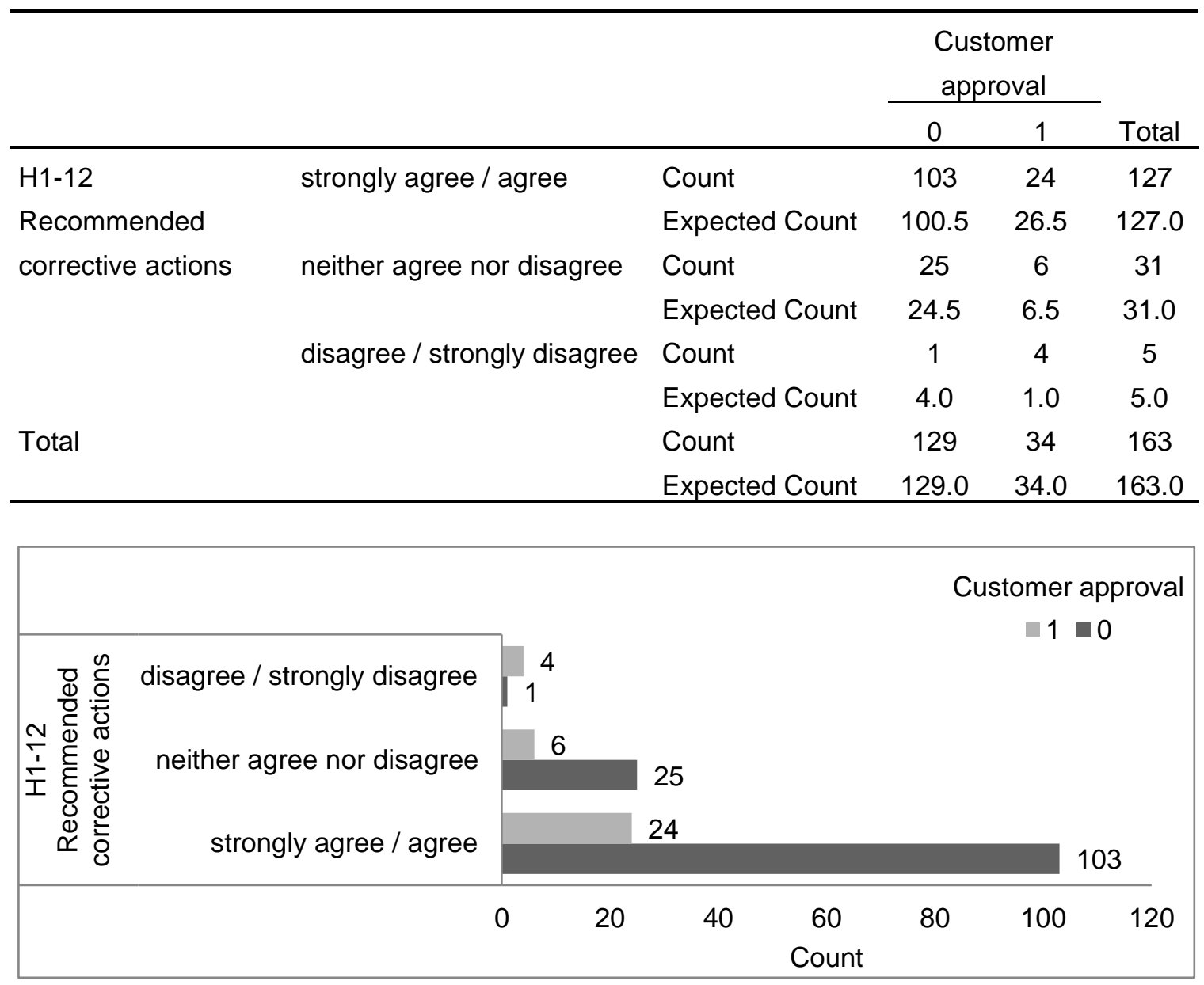

Chi-Square Tests

\begin{tabular}{lcccccc}
\hline & Value & df & $\begin{array}{c}\text { Asymp. Sig. } \\
(2 \text {-sided })\end{array}$ & $\begin{array}{c}\text { Exact Sig. } \\
(2-\text {-sided })\end{array}$ & $\begin{array}{c}\text { Exact Sig. } \\
(1 \text {-sided })\end{array}$ & $\begin{array}{c}\text { Point } \\
\text { Probability }\end{array}$ \\
\hline Pearson Chi-Square & $10.932^{\mathrm{a}}$ & 2 & .004 & .009 & & \\
Likelihood Ratio & 8.349 & 2 & .015 & .021 & & \\
Fisher's Exact Test & 8.389 & & & .016 & & \\
Linear-by-Linear & $4.392^{\mathrm{b}}$ & 1 & .036 & .051 & .033 & .019 \\
Association & & & & & & \\
N of Valid Cases & 163 & & & & & \\
\hline
\end{tabular}

a. 2 cells (33.3\%) have expected count less than 5 . The minimum expected count is 1.04 .

b. The standardized statistic is 2.096 .

Symmetric Measures

\begin{tabular}{llccc}
\hline & & Value & Approx. Sig. & Exact Sig. \\
\hline Nominal by Nominal & Phi & .259 & .004 & .009 \\
& Cramer's V & .259 & .004 & .009 \\
N of Valid Cases & & 163 & & \\
\hline
\end{tabular}




\section{Crosstab H1-14 Forecasts * Performance objectives}

\begin{tabular}{lllccc}
\hline & & \multicolumn{2}{c}{$\begin{array}{c}\text { Performance } \\
\text { objectives }\end{array}$} \\
\cline { 3 - 4 } & & 0 & 1 & Total \\
\hline \multirow{2}{*}{ H1-14 Forecasts } & strongly agree / agree & Count & 99 & 32 & 131 \\
& & Expected Count & 104.5 & 26.5 & 131.0 \\
& \multirow{2}{*}{ neither agree nor disagree } & Count & 28 & 0 & 28 \\
& \multirow{2}{*}{ disagree / strongly disagree } & Count & 3.7 & 28.0 \\
& & Expected Count & 3.2 & .8 & 4 \\
& & Count & 130 & 33 & 163 \\
Total & & Expected Count & 130.0 & 33.0 & 163.0 \\
\hline
\end{tabular}

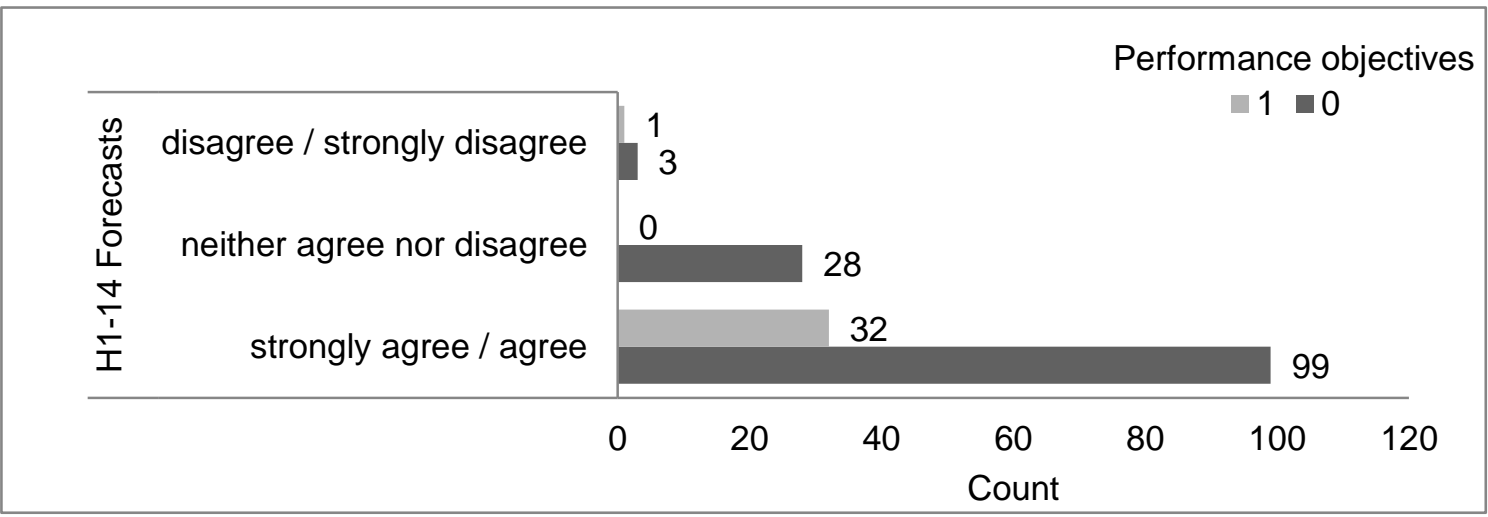

\section{Chi-Square Tests}

\begin{tabular}{lcccccc}
\hline & Value & df & $\begin{array}{c}\text { Asymp. Sig. } \\
\text { (2-sided) }\end{array}$ & $\begin{array}{c}\text { Exact Sig. } \\
(2 \text {-sided) }\end{array}$ & $\begin{array}{c}\text { Exact Sig. } \\
\text { (1-sided) }\end{array}$ & $\begin{array}{c}\text { Point } \\
\text { Probability }\end{array}$ \\
\hline Pearson Chi-Square & $8.583^{\mathrm{a}}$ & 2 & .014 & .013 & & \\
Likelihood Ratio & 14.075 & 2 & .001 & .002 & & \\
Fisher's Exact Test & 11.188 & & & .004 & & \\
Linear-by-Linear & $4.775^{\mathrm{b}}$ & 1 & .029 & .035 & .015 & .012 \\
Association & & & & & & \\
N of Valid Cases & 163 & & & & & \\
\hline
\end{tabular}

a. 2 cells $(33.3 \%)$ have expected count less than 5 . The minimum expected count is .81 .

b. The standardized statistic is -2.185 .

Symmetric Measures

\begin{tabular}{llccc}
\hline & & Value & Approx. Sig. & Exact Sig. \\
\hline Nominal by Nominal & Phi & .229 & .014 & .013 \\
& Cramer's V & .229 & .014 & .013 \\
N of Valid Cases & & 163 & & \\
\hline
\end{tabular}




\section{Crosstab H1-15 Recommended defect repair * Financial objectives}

\begin{tabular}{lllccc}
\hline & & & \multicolumn{2}{c}{$\begin{array}{c}\text { Financial } \\
\text { objectives }\end{array}$} \\
\cline { 3 - 4 } & & & 0 & 1 & Total \\
\hline H1-15 Recommended & strongly agree / agree & Count & 62 & 37 & 99 \\
defect repair & & Expected Count & 69.2 & 29.8 & 99.0 \\
& neither agree nor disagree & Count & 47 & 10 & 57 \\
& & Expected Count & 39.9 & 17.1 & 57.0 \\
& disagree / strongly & Count & 5 & 2 & 7 \\
Total & disagree & Expected Count & 4.9 & 2.1 & 7.0 \\
& & Count & 114 & 49 & 163 \\
& & Expected Count & 114.0 & 49.0 & 163.0 \\
\hline
\end{tabular}

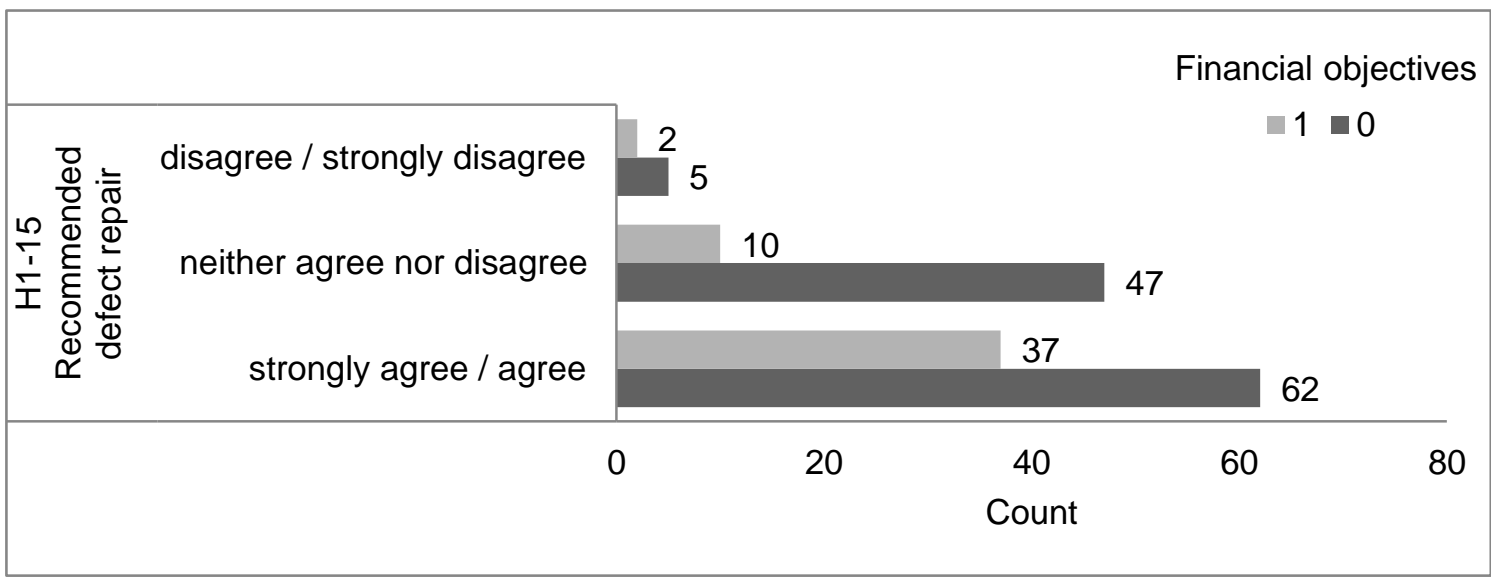

\section{Chi-Square Tests}

\begin{tabular}{lcccccc}
\hline & \multicolumn{7}{c}{$\begin{array}{c}\text { Asymp. Sig. } \\
\text { (2-sided) }\end{array}$} & $\begin{array}{c}\text { Exact Sig. } \\
(2 \text {-sided) }\end{array}$ & $\begin{array}{c}\text { Exact Sig. } \\
\text { (1-sided) }\end{array}$ & $\begin{array}{c}\text { Point } \\
\text { Probability }\end{array}$ \\
\hline Pearson Chi-Square & $6.773^{\mathrm{a}}$ & 2 & .034 & .027 & & \\
Likelihood Ratio & 7.132 & 2 & .028 & .035 & & \\
Fisher's Exact Test & 6.947 & & & .024 & & \\
Linear-by-Linear & $4.714^{\mathrm{b}}$ & 1 & .030 & .037 & .019 & .011 \\
Association & & & & & & \\
N of Valid Cases & 163 & & & & & \\
\hline
\end{tabular}

a. 2 cells $(33.3 \%)$ have expected count less than 5 . The minimum expected count is 2.10 .

b. The standardized statistic is $-2,171$.

Symmetric Measures

\begin{tabular}{llccc}
\hline & & Value & Approx. Sig. & Exact Sig. \\
\hline Nominal by Nominal & Phi & .204 & .034 & .027 \\
& Cramer's V & .204 & .034 & .027 \\
N of Valid Cases & & 163 & & \\
\hline
\end{tabular}




\begin{tabular}{lllccc}
\hline & & & \multicolumn{2}{c}{$\begin{array}{c}\text { Commercial benefit } \\
\text { for contractors }\end{array}$} & \\
\cline { 3 - 5 } & & & 0 & 1 & Total \\
\hline H1-17 Approved & strongly agree / & Count & 132 & 1 & 133 \\
change requests & agree & Expected Count & 130.6 & 2.4 & 133.0 \\
& neither agree nor & Count & 23 & 1 & 24 \\
& disagree & Expected Count & 23.6 & .4 & 24.0 \\
& disagree / strongly & Count & 5 & 1 & 6 \\
& disagree & Expected Count & 5.9 & .1 & 6.0 \\
& & Count & 160 & 3 & 163 \\
Total & & Expected Count & 160.0 & 3.0 & 163.0 \\
\hline
\end{tabular}

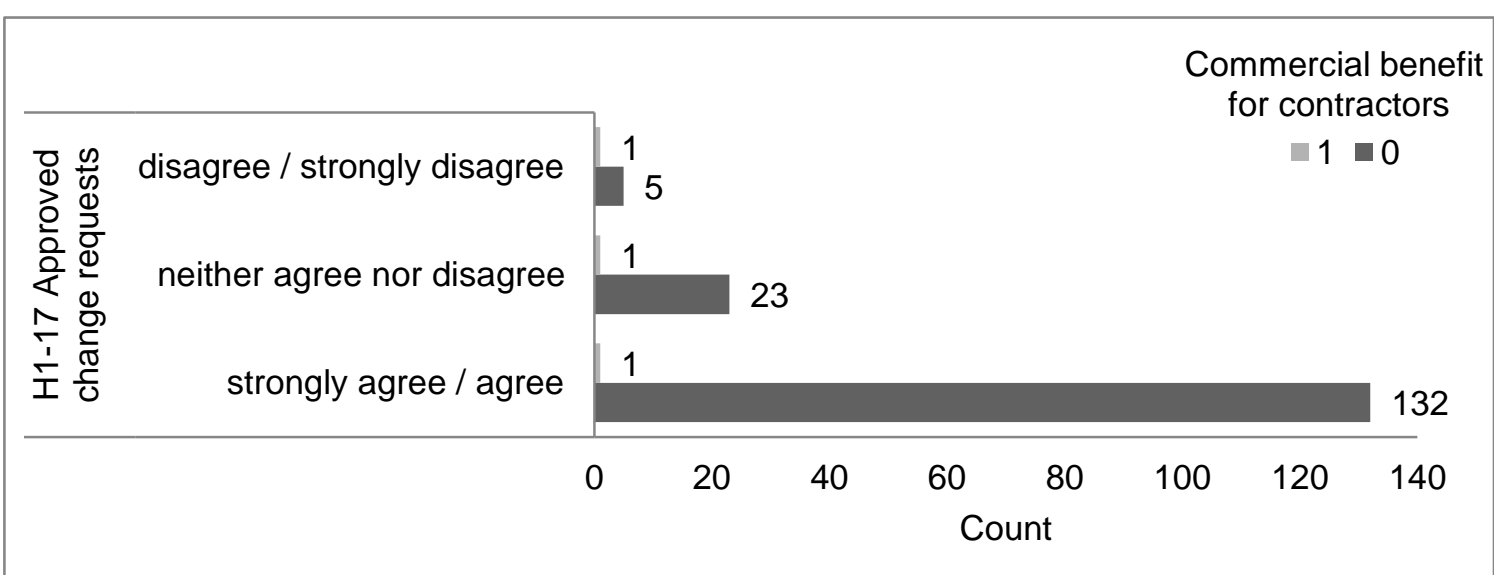

\section{Chi-Square Tests}

\begin{tabular}{lcccccc}
\hline & Value & df & $\begin{array}{c}\text { Asymp. Sig. } \\
(2 \text {-sided })\end{array}$ & $\begin{array}{c}\text { Exact Sig. } \\
(2 \text {-sided })\end{array}$ & $\begin{array}{c}\text { Exact Sig. } \\
(1 \text {-sided })\end{array}$ & $\begin{array}{c}\text { Point } \\
\text { Probability }\end{array}$ \\
\hline Pearson Chi-Square & $8,892^{\mathrm{a}}$ & 2 & .012 & .036 & & \\
Likelihood Ratio & 4,422 & 2 & .110 & .036 & & \\
Fisher's Exact Test & 6,807 & & & .036 & & \\
Linear-by-Linear & $7,505^{\mathrm{b}}$ & 1 & .006 & .036 & .036 & .030 \\
Association & & & & & & \\
N of Valid Cases & 163 & & & & & \\
\hline
\end{tabular}

a. 3 cells $(50.0 \%)$ have expected count less than 5 . The minimum expected count is .11 .

b. The standardized statistic is 2,740 .

Symmetric Measures

\begin{tabular}{llccc}
\hline & & Value & Approx. Sig. & Exact Sig. \\
\hline Nominal by Nominal & Phi & .234 & .012 & .036 \\
& Cramer's V & .234 & .012 & .036 \\
N of Valid Cases & & 163 & & \\
\hline
\end{tabular}


Crosstab H1-17 Approved change request * Scope

\begin{tabular}{lllccc}
\hline & & & \multicolumn{3}{c}{ Scope } \\
\cline { 3 - 5 } & & & 0 & 1 & Total \\
\hline H1-17 Approved & strongly agree / agree & Count & 85 & 48 & 133 \\
change requests & & Expected Count & 90.6 & 42.4 & 133.0 \\
& neither agree nor disagree & Count & 20 & 4 & 24 \\
& & Expected Count & 16.3 & 7.7 & 24.0 \\
& disagree / strongly & Count & 6 & 0 & 6 \\
Total & disagree & Expected Count & 4.1 & 1.9 & 6.0 \\
& & Count & 111 & 52 & 163 \\
& & Expected Count & 111.0 & 52.0 & 163.0 \\
\hline
\end{tabular}

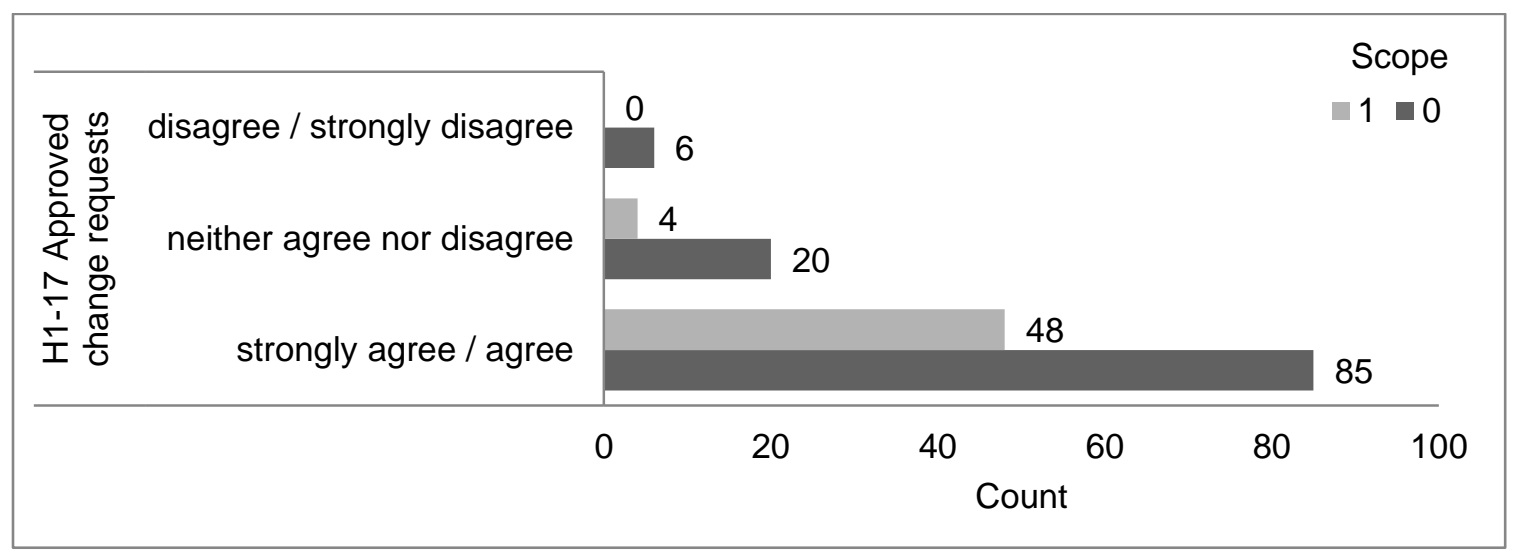

Chi-Square Tests

\begin{tabular}{lcccccc}
\hline & \multicolumn{7}{c}{$\begin{array}{c}\text { Asymp. Sig. } \\
\text { (2-sided) }\end{array}$} & $\begin{array}{c}\text { Exact Sig. } \\
\text { (2-sided) }\end{array}$ & $\begin{array}{c}\text { Exact Sig. } \\
\text { (1-sided) }\end{array}$ & $\begin{array}{c}\text { Point } \\
\text { Probability }\end{array}$ \\
\hline Pearson Chi-Square & $6.449^{\mathrm{a}}$ & 2 & .040 & .043 & & \\
Likelihood Ratio & 8.544 & 2 & .014 & .017 & & \\
Fisher's Exact Test & 6.097 & & & .043 & & \\
Linear-by-Linear & $6.399^{\mathrm{b}}$ & 1 & .011 & .016 & .006 & .004 \\
Association & & & & & & \\
N of Valid Cases & 163 & & & & & \\
\hline
\end{tabular}

a. 2 cells (33.3\%) have expected count less than 5 . The minimum expected count is 1.91 .

b. The standardized statistic is -2.530 .

Symmetric Measures

\begin{tabular}{llccc}
\hline & & Value & Approx. Sig. & Exact Sig. \\
\hline Nominal by Nominal & Phi & .199 & .040 & .043 \\
& Cramer's V & .199 & .040 & .043 \\
N of Valid Cases & & 163 & & \\
\hline
\end{tabular}




\begin{tabular}{lllccc}
\hline & & & \multicolumn{2}{c}{ User } \\
& & & \multicolumn{2}{c}{ satisfaction } & \\
\cline { 3 - 4 } & & & 0 & 1 & Total \\
\hline H1-18 Rejected & strongly agree / agree & Count & 86 & 22 & 108 \\
change requests & & Expected Count & 91.4 & 16.6 & 108.0 \\
& \multirow{2}{*}{ neither agree nor disagree } & Count & 43 & 3 & 46 \\
& \multirow{3}{*}{ disagree / strongly disagree } & Count & 9 & 0 & 9 \\
& & Expected Count & 7.6 & 1.4 & 9.0 \\
& & Count & 138 & 25 & 163 \\
Total & & Expected Count & 138.0 & 25.0 & 163.0 \\
\hline
\end{tabular}

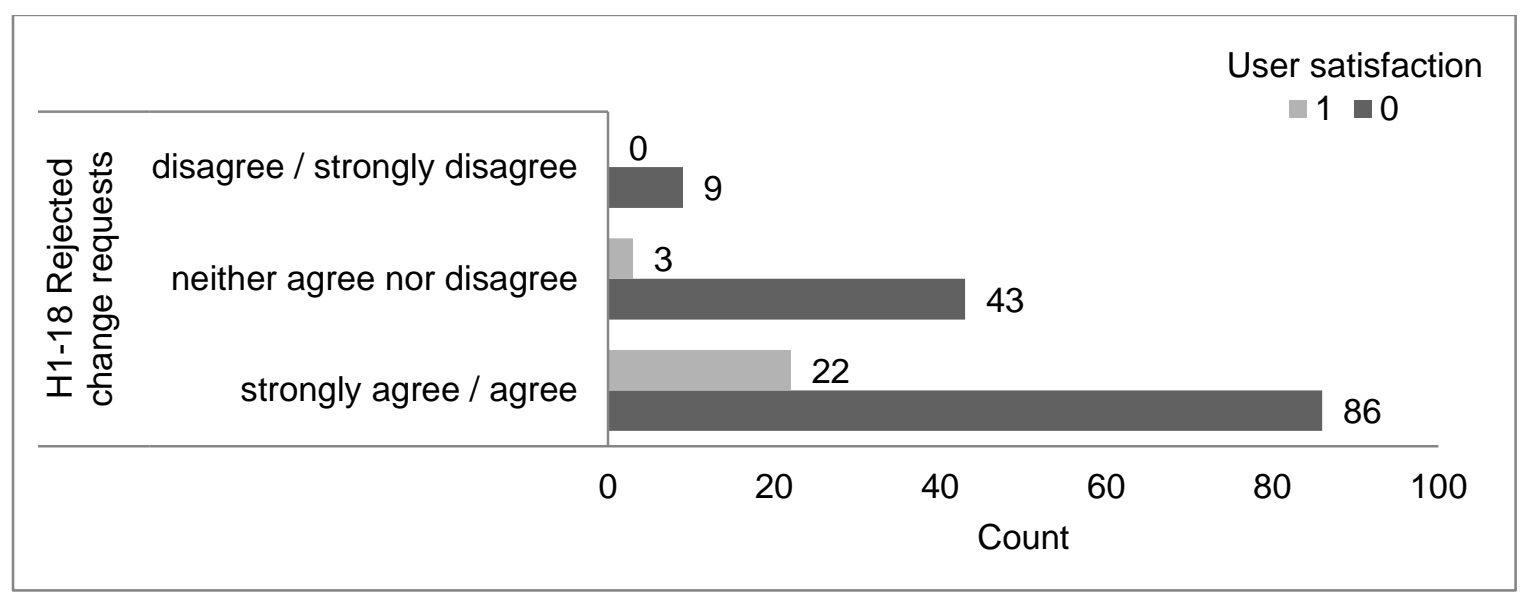

\section{Chi-Square Tests}

\begin{tabular}{|c|c|c|c|c|c|c|}
\hline & Value & df & $\begin{array}{c}\text { Asymp. Sig. } \\
\text { (2-sided) }\end{array}$ & $\begin{array}{c}\text { Exact Sig. } \\
\text { (2-sided) }\end{array}$ & $\begin{array}{c}\text { Exact Sig. } \\
\text { (1-sided) }\end{array}$ & $\begin{array}{c}\text { Point } \\
\text { Probability }\end{array}$ \\
\hline Pearson Chi-Square & $6.490^{\mathrm{a}}$ & 2 & .039 & .047 & & \\
\hline Likelihood Ratio & 8.330 & 2 & .016 & .017 & & \\
\hline Fisher's Exact Test & 5.859 & & & .040 & & \\
\hline Linear-by-Linear & $6.252^{b}$ & 1 & .012 & .015 & .006 & .004 \\
\hline \multicolumn{7}{|l|}{ Association } \\
\hline $\mathrm{N}$ of Valid Cases & 163 & & & & & \\
\hline
\end{tabular}

a. 1 cells (16.7\%) have expected count less than 5 . The minimum expected count is 1.38 .

b. The standardized statistic is -2.500 .

Symmetric Measures

\begin{tabular}{llccc}
\hline & & Value & Approx. Sig. & Exact Sig. \\
\hline Nominal by Nominal & Phi & .200 & .039 & .047 \\
& Cramer's V & .200 & .039 & .047 \\
N of Valid Cases & & 163 & & \\
\hline
\end{tabular}




\begin{tabular}{lllccc}
\hline & & & \multicolumn{2}{c}{ Technical } \\
& & & \multicolumn{2}{c}{ objectives } & \\
\cline { 3 - 4 } & & & 0 & 1 & Total \\
\hline H1-18 Rejected change & strongly agree / agree & Count & 84 & 24 & 108 \\
requests & & Expected Count & 83.5 & 24.5 & 108.0 \\
& neither agree nor disagree & Count & 39 & 7 & 46 \\
& & Expected Count & 35.6 & 10.4 & 46.0 \\
& disagree / strongly & Count & 3 & 6 & 9 \\
Total & disagree & Expected Count & 7.0 & 2.0 & 9.0 \\
& & Count & 126 & 37 & 163 \\
& & Expected Count & 126.0 & 37.0 & 163.0 \\
\hline
\end{tabular}

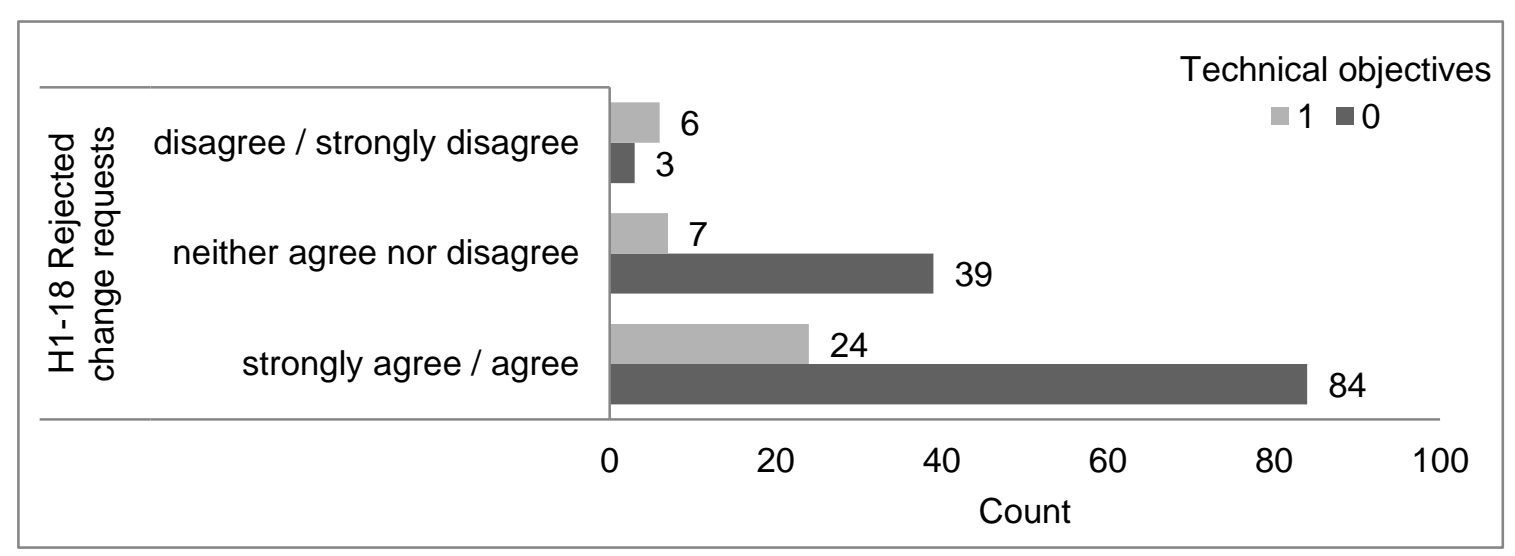

Chi-Square Tests

\begin{tabular}{lcccccc}
\hline & \multicolumn{7}{c}{$\begin{array}{c}\text { Asymp. Sig. } \\
\text { (2-sided) }\end{array}$} & $\begin{array}{c}\text { Exact Sig. } \\
(2-\text {-sided })\end{array}$ & $\begin{array}{c}\text { Exact Sig. } \\
\text { (1-sided) }\end{array}$ & $\begin{array}{c}\text { Point } \\
\text { Probability }\end{array}$ \\
\hline Pearson Chi-Square & $\mathbf{1 1 . 3 9 7 ^ { \mathrm { a } }}$ & 2 & .003 & .004 & & \\
Likelihood Ratio & 9.503 & 2 & .009 & .007 & & \\
Fisher's Exact Test & 9.509 & & & .006 & & .046 \\
Linear-by-Linear & $1.992^{\mathrm{b}}$ & 1 & .158 & .206 & .107 & \\
Association & & & & & & \\
N of Valid Cases & 163 & & & & & \\
\hline
\end{tabular}

a. 1 cells $(16.7 \%)$ have expected count less than 5 . The minimum expected count is 2.04 .

b. The standardized statistic is 1.411 .

Symmetric Measures

\begin{tabular}{llccc}
\hline & & Value & Approx. Sig. & Exact Sig. \\
\hline Nominal by Nominal & Phi & .264 & .003 & .004 \\
& Cramer's V & .264 & .003 & .004 \\
N of Valid Cases & & 163 & & \\
\hline
\end{tabular}




\begin{tabular}{lllccc}
\hline & & \multicolumn{2}{c}{$\begin{array}{c}\text { Personal } \\
\text { growth }\end{array}$} \\
\cline { 3 - 4 } & & & 0 & 1 & Total \\
\hline H1-21 Approved & strongly agree / agree & Count & 105 & 0 & 105 \\
defect repair & & Expected Count & 104.4 & .6 & 105.0 \\
& \multirow{2}{*}{ neither agree nor disagree } & Count & 50 & 0 & 50 \\
& & Expected Count & 49.7 & .3 & 50.0 \\
& \multirow{2}{*}{ disagree / strongly disagree } & Count & 7 & 1 & 8 \\
& & Expected Count & 8.0 & .0 & 8.0 \\
& & Count & 162 & 1 & 163 \\
& & Expected Count & 162.0 & 1.0 & 163.0 \\
\hline
\end{tabular}

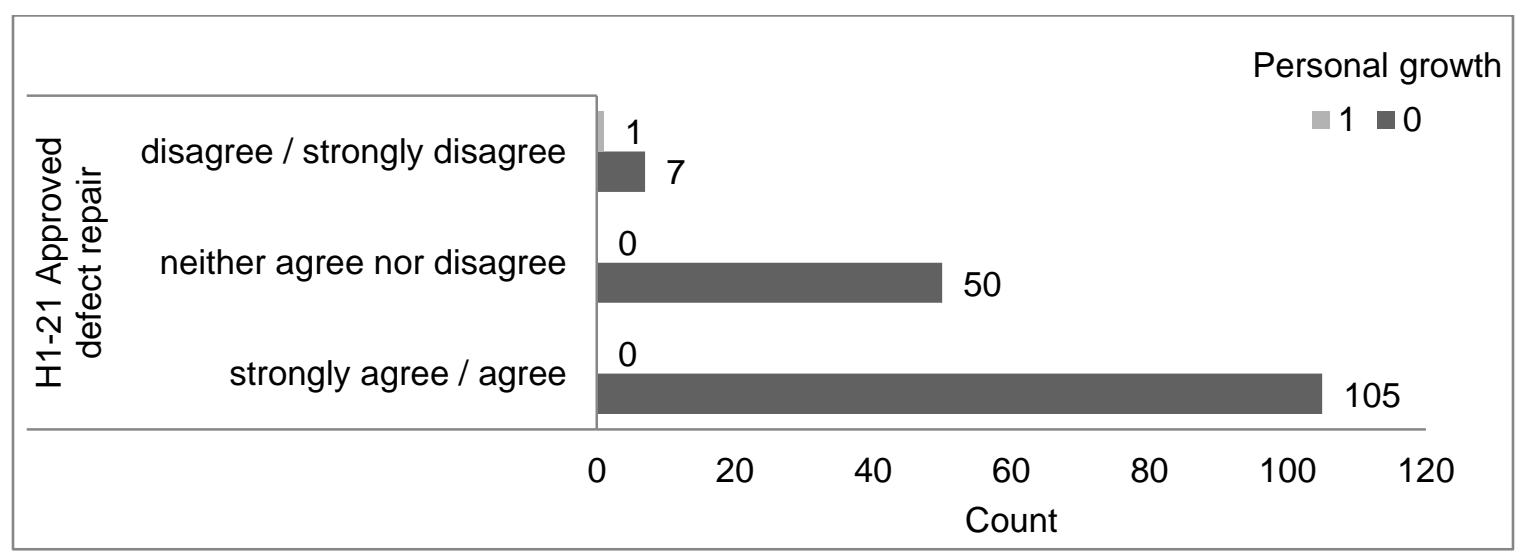

Chi-Square Tests

\begin{tabular}{lcccccc}
\hline & Value & df & $\begin{array}{c}\text { Asymp. Sig. } \\
\text { (2-sided) }\end{array}$ & $\begin{array}{c}\text { Exact Sig. } \\
(2 \text {-sided })\end{array}$ & $\begin{array}{c}\text { Exact Sig. } \\
\text { (1-sided) }\end{array}$ & $\begin{array}{c}\text { Point } \\
\text { Probability }\end{array}$ \\
\hline Pearson Chi-Square & $19.495^{\mathrm{a}}$ & 2 & .000 & .049 & & \\
Likelihood Ratio & 6.153 & 2 & .046 & .049 & & \\
Fisher's Exact Test & 7.001 & & & .049 & & \\
Linear-by-Linear & $7.503^{\mathrm{b}}$ & 1 & .006 & .049 & .049 & .049 \\
Association & & & & & & \\
N of Valid Cases & 163 & & & & & \\
\hline
\end{tabular}

a. 3 cells $(50.0 \%)$ have expected count less than 5 . The minimum expected count is .05 .

b. The standardized statistic is 2.739 .

Symmetric Measures

\begin{tabular}{llccc}
\hline & & Value & Approx. Sig. & Exact Sig. \\
\hline Nominal by Nominal & Phi & .346 & .000 & .049 \\
& Cramer's V & .346 & .000 & .049 \\
N of Valid Cases & & 163 & & \\
\hline
\end{tabular}




\section{Crosstab H1-23 Deliverables * Commercial benefit for contractors}

\begin{tabular}{|c|c|c|c|c|c|}
\hline & & & \multicolumn{2}{|c|}{$\begin{array}{c}\text { Commercial } \\
\text { benefit for } \\
\text { contractors }\end{array}$} & \multirow[b]{2}{*}{ Total } \\
\hline & & & 0 & 1 & \\
\hline $\mathrm{H} 1-23$ & strongly agree / agree & Count & 151 & 2 & 153 \\
\hline \multirow[t]{5}{*}{ Deliverables } & & Expected Count & 150.2 & 2.8 & 153.0 \\
\hline & neither agree nor disagree & Count & 8 & 0 & 8 \\
\hline & & Expected Count & 7.9 & .1 & 8.0 \\
\hline & disagree / strongly disagree & Count & 1 & 1 & 2 \\
\hline & & Expected Count & 2.0 & .0 & 2,0 \\
\hline \multirow[t]{2}{*}{ Total } & & Count & 160 & 3 & 163 \\
\hline & & Expected Count & 160.0 & 3.0 & 163.0 \\
\hline
\end{tabular}

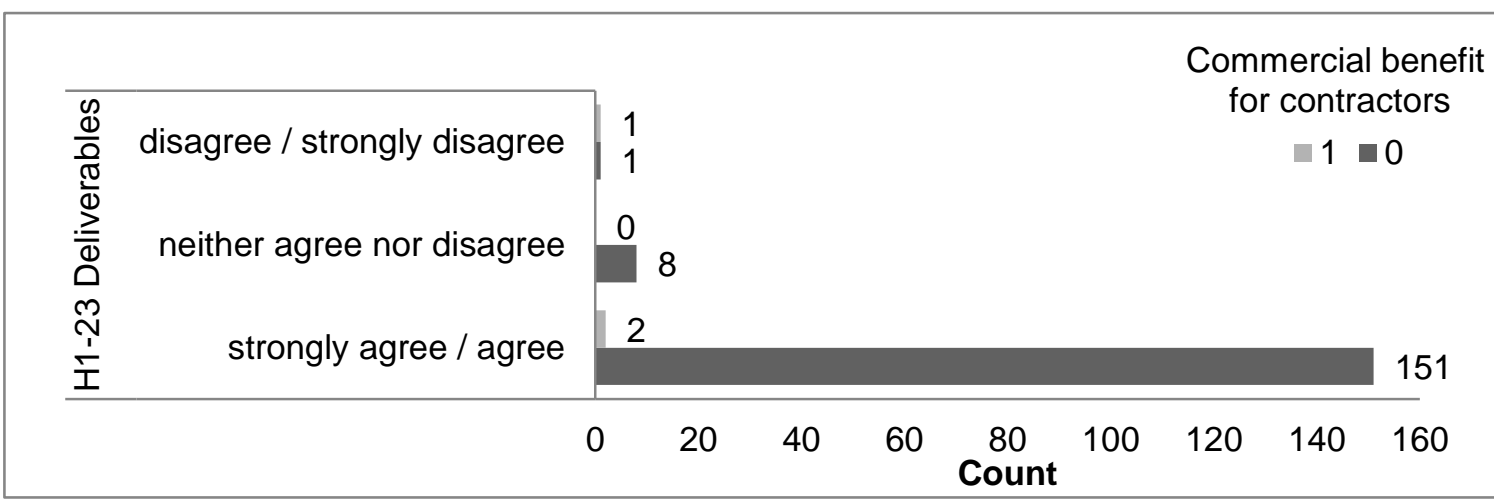

\section{Chi-Square Tests}

\begin{tabular}{lcccccc}
\hline & Value & df & $\begin{array}{c}\text { Asymp. Sig. } \\
(2 \text {-sided })\end{array}$ & $\begin{array}{c}\text { Exact Sig. } \\
(2 \text {-sided })\end{array}$ & $\begin{array}{c}\text { Exact Sig. } \\
(1 \text {-sided })\end{array}$ & $\begin{array}{c}\text { Point } \\
\text { Probability }\end{array}$ \\
\hline Pearson Chi-Square & $26.067^{\mathrm{a}}$ & 2 & .000 & .037 & & \\
Likelihood Ratio & 5.820 & 2 & .054 & .043 & & \\
Fisher's Exact Test & 8.476 & & & .043 & & \\
Linear-by-Linear & $11.519^{\mathrm{b}}$ & 1 & .001 & .043 & .043 & .039 \\
Association & & & & & & \\
N of Valid Cases & 163 & & & & & \\
\hline
\end{tabular}
a. 4 cells $(66.7 \%)$ have expected count less than 5 . The minimum expected count is .04 .

b. The standardized statistic is 3.394 .

Symmetric Measures

\begin{tabular}{llccc}
\hline & & Value & Approx. Sig. & Exact Sig. \\
\hline Nominal by Nominal & Phi & .400 & .000 & .037 \\
& Cramer's V & .400 & .000 & .037 \\
N of Valid Cases & & 163 & & \\
\hline
\end{tabular}


Crosstab H3-1 Activity list * Sales

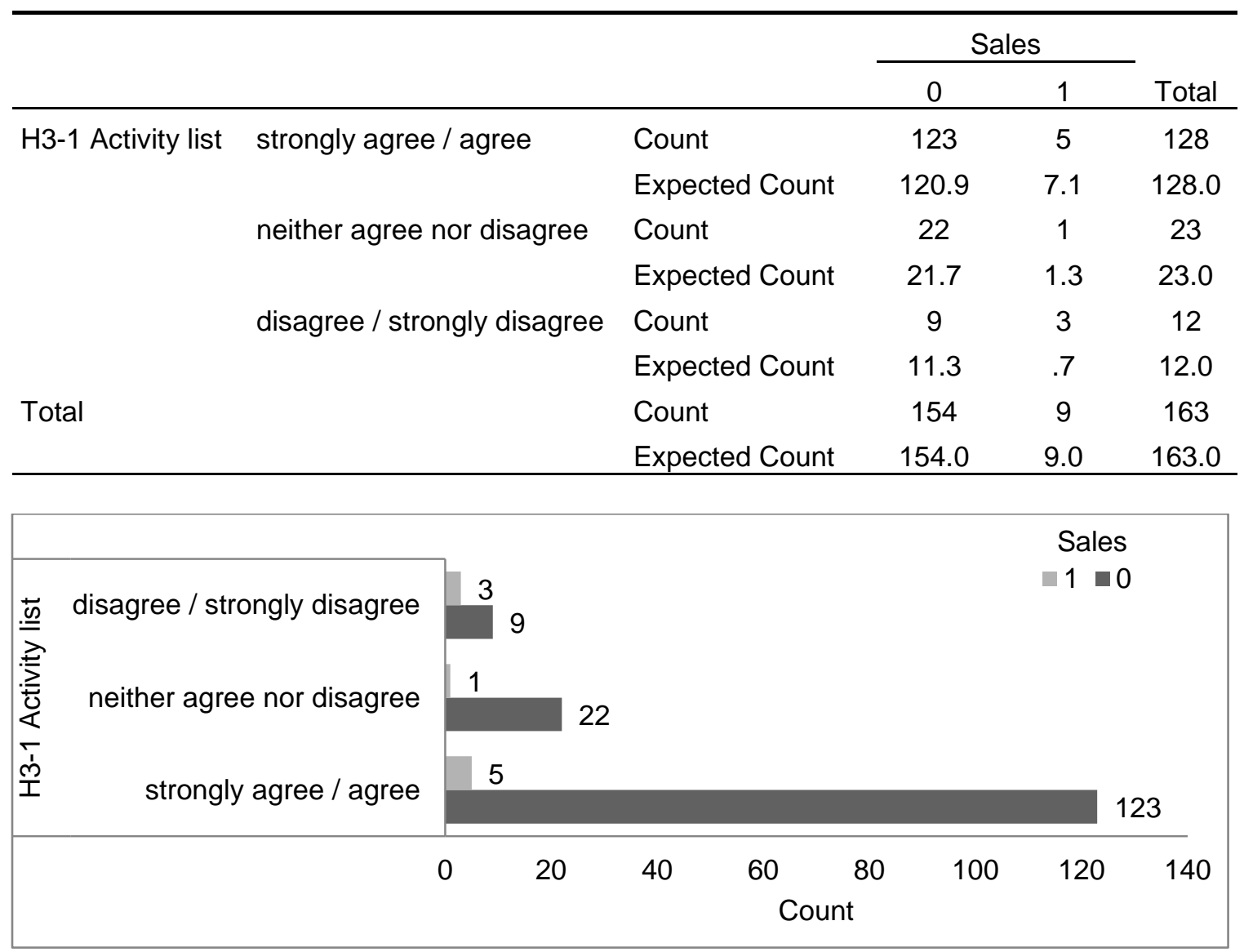

Chi-Square Tests

\begin{tabular}{lcccccc}
\hline & \multicolumn{7}{c}{$\begin{array}{c}\text { Asymp. Sig. } \\
\text { (2-sided) }\end{array}$} & $\begin{array}{c}\text { Exact Sig. } \\
(2 \text {-sided })\end{array}$ & $\begin{array}{c}\text { Exact Sig. } \\
\text { (1-sided) }\end{array}$ & $\begin{array}{c}\text { Point } \\
\text { Probability }\end{array}$ \\
\hline Pearson Chi-Square & $9.429^{\mathrm{a}}$ & 2 & .009 & .024 & & \\
Likelihood Ratio & 5.680 & 2 & .058 & .044 & & \\
Fisher's Exact Test & 6.641 & & & .038 & & \\
Linear-by-Linear & $6.435^{\mathrm{b}}$ & 1 & .011 & .022 & .022 & .015 \\
Association & & & & & & \\
N of Valid Cases & 163 & & & & & \\
\hline
\end{tabular}

a. 2 cells (33.3\%) have expected count less than 5 . The minimum expected count is .66 .

b. The standardized statistic is 2.537 .

Symmetric Measures

\begin{tabular}{|c|c|c|c|c|}
\hline & & Value & Approx. Sig. & Exact Sig. \\
\hline \multirow[t]{2}{*}{ Nominal by Nominal } & Phi & .241 & .009 & .024 \\
\hline & Cramer's V & .241 & .009 & .024 \\
\hline $\mathrm{N}$ of Valid Cases & & 163 & & \\
\hline
\end{tabular}


Crosstab H3-2 Activity attributes * Sales

\begin{tabular}{lllccc}
\hline & & \multicolumn{3}{c}{ Sales } & \\
\cline { 3 - 4 } & & & 0 & 1 & Total \\
\hline H3-2 Activity & \multirow{2}{*}{ strongly agree / agree } & Count & 66 & 4 & 70 \\
attributes & \multirow{3}{*}{ neither agree nor disagree } & Expected Count & 66.1 & 3.9 & 70.0 \\
& & Count & 67 & 1 & 68 \\
& \multirow{2}{*}{ disagree / strongly disagree } & Expected Count & 64.2 & 3.8 & 68.0 \\
& & Count & 21 & 4 & 25 \\
& & Expected Count & 23.6 & 1.4 & 25.0 \\
Total & & Count & 154 & 9 & 163 \\
& & Expected Count & 154.0 & 9.0 & 163.0 \\
\hline
\end{tabular}

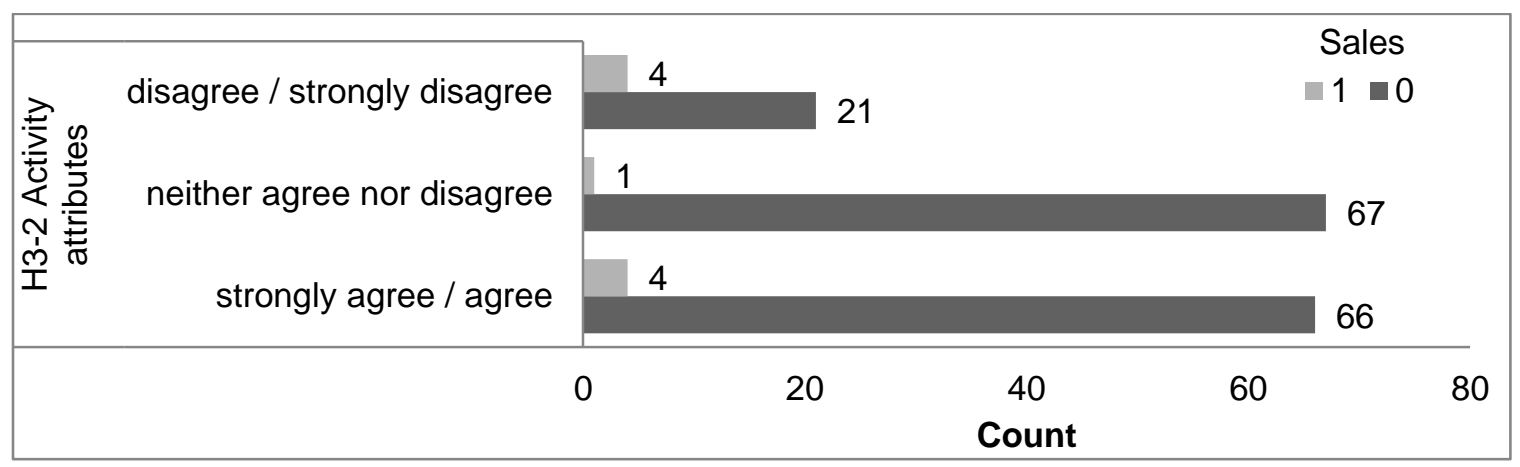

Chi-Square Tests

\begin{tabular}{|c|c|c|c|c|c|c|}
\hline & Value & $\mathrm{df}$ & $\begin{array}{c}\text { Asymp. Sig. } \\
\text { (2-sided) }\end{array}$ & $\begin{array}{c}\text { Exact Sig. } \\
\text { (2-sided) }\end{array}$ & $\begin{array}{l}\text { Exact Sig. } \\
\text { (1-sided) }\end{array}$ & $\begin{array}{c}\text { Point } \\
\text { Probability }\end{array}$ \\
\hline Pearson Chi-Square & $7.406^{\mathrm{a}}$ & 2 & .025 & .026 & & \\
\hline Likelihood Ratio & 6.559 & 2 & .038 & .031 & & \\
\hline Fisher's Exact Test & 6.485 & & & .031 & & \\
\hline $\begin{array}{l}\text { Linear-by-Linear } \\
\text { Association }\end{array}$ & $1.424^{b}$ & 1 & .233 & .338 & .170 & .092 \\
\hline $\mathrm{N}$ of Valid Cases & 163 & & & & & \\
\hline
\end{tabular}

a. 3 cells $(50.0 \%)$ have expected count less than 5 . The minimum expected count is 1.38 .

b. The standardized statistic is 1.193 .

Symmetric Measures

\begin{tabular}{llccc}
\hline & & Value & Approx. Sig. & Exact Sig. \\
\hline Nominal by Nominal & Phi & .213 & .025 & .026 \\
& Cramer's V & .213 & .025 & .026 \\
N of Valid Cases & & 163 & & \\
\hline
\end{tabular}


Crosstab H3-5 Activity resources requirements * Sales

\begin{tabular}{|c|c|c|c|c|c|}
\hline & & & \multicolumn{2}{|c|}{ Sales } & \multirow[b]{2}{*}{ Total } \\
\hline & & & 0 & 1 & \\
\hline H3-5 Activity resources & strongly agree / agree & Count & 88 & 5 & 93 \\
\hline \multirow[t]{5}{*}{ requirements } & & Expected Count & 87.9 & 5.1 & 93.0 \\
\hline & neither agree nor disagree & Count & 54 & 1 & 55 \\
\hline & & Expected Count & 52.0 & 3.0 & 55.0 \\
\hline & Disagree / strongly & Count & 12 & 3 & 15 \\
\hline & disagree & Expected Count & 14.2 & .8 & 15.0 \\
\hline \multirow[t]{2}{*}{ Total } & & Count & 154 & 9 & 163 \\
\hline & & Expected Count & 154.0 & 9.0 & 163.0 \\
\hline
\end{tabular}

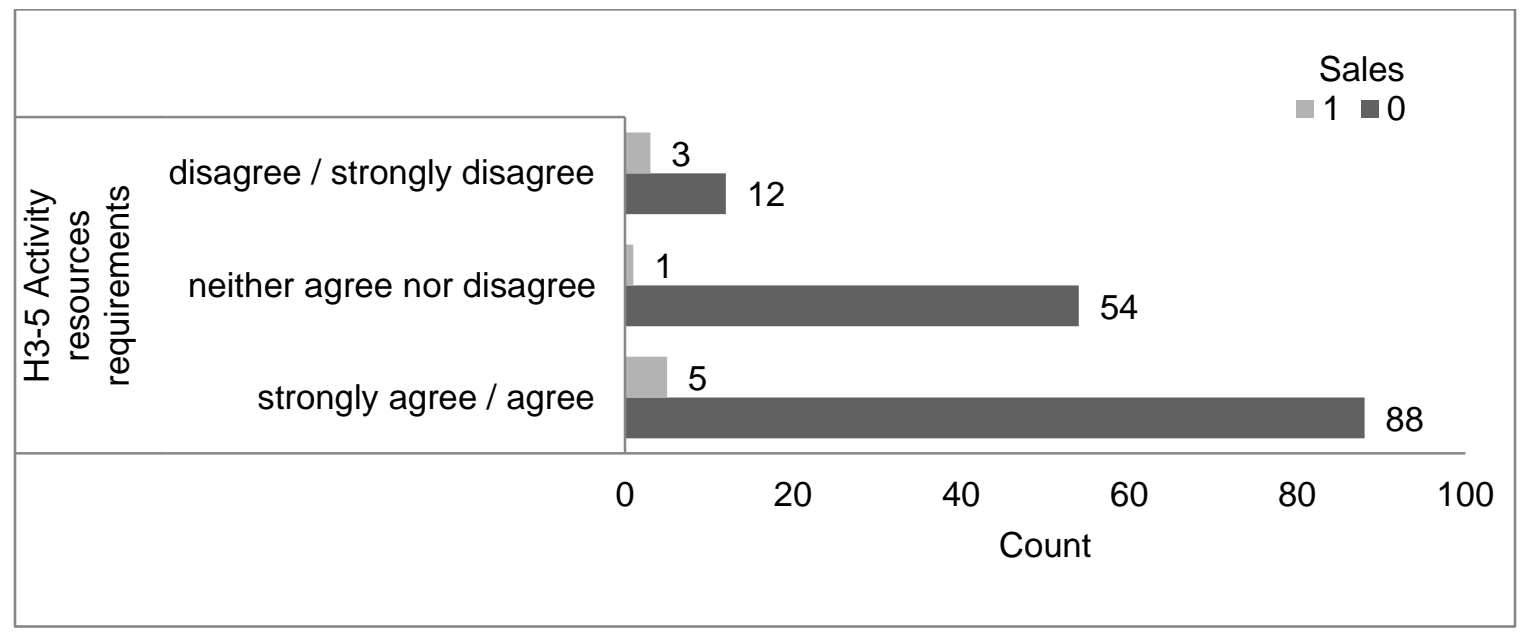

\section{Chi-Square Tests}

\begin{tabular}{lcccccc}
\hline & Value & df & $\begin{array}{c}\text { Asymp. Sig. } \\
(2-\text { sided })\end{array}$ & $\begin{array}{c}\text { Exact Sig. } \\
(2-\text { sided })\end{array}$ & $\begin{array}{c}\text { Exact Sig. } \\
\text { (1-sided) }\end{array}$ & $\begin{array}{c}\text { Point } \\
\text { Probability }\end{array}$ \\
\hline Pearson Chi-Square & $7.477^{\mathrm{a}}$ & 2 & .024 & .027 & & \\
Likelihood Ratio & 5.665 & 2 & .059 & .047 & & \\
Fisher's Exact Test & 5.923 & & & .038 & & .095 \\
Linear-by-Linear & $1.434^{\mathrm{b}}$ & 1 & .231 & .297 & .173 & \\
Association & & & & & & \\
N of Valid Cases & 163 & & & & & \\
\hline
\end{tabular}

a. 2 cells $(33.3 \%)$ have expected count less than 5 . The minimum expected count is .83 .

b. The standardized statistic is 1.198 .

Symmetric Measures

\begin{tabular}{llccc}
\hline & & Value & Approx. Sig. & Exact Sig. \\
\hline Nominal by Nominal & Phi & .214 & .024 & .027 \\
& Cramer's V & .214 & .024 & .027 \\
N of Valid Cases & & 163 & & \\
\hline
\end{tabular}


Crosstab H3-6 Resource breakdown structure * Sales

\begin{tabular}{lllccc}
\hline & & & \multicolumn{3}{c}{ Sales } \\
\cline { 3 - 5 } & & & 0 & 1 & Total \\
\hline H3-6 Resource & strongly agree / agree & Count & 79 & 5 & 84 \\
breakdown structure & & Expected Count & 79.4 & 4.6 & 84.0 \\
& \multirow{2}{*}{ neither agree nor disagree } & Count & 56 & 0 & 56 \\
& & Expected Count & 52.9 & 3.1 & 56.0 \\
& disagree / strongly & Count & 19 & 4 & 23 \\
& disagree & Expected Count & 21.7 & 1.3 & 23.0 \\
& & Count & 154 & 9 & 163 \\
& & Expected Count & 154.0 & 9.0 & 163.0 \\
\hline
\end{tabular}

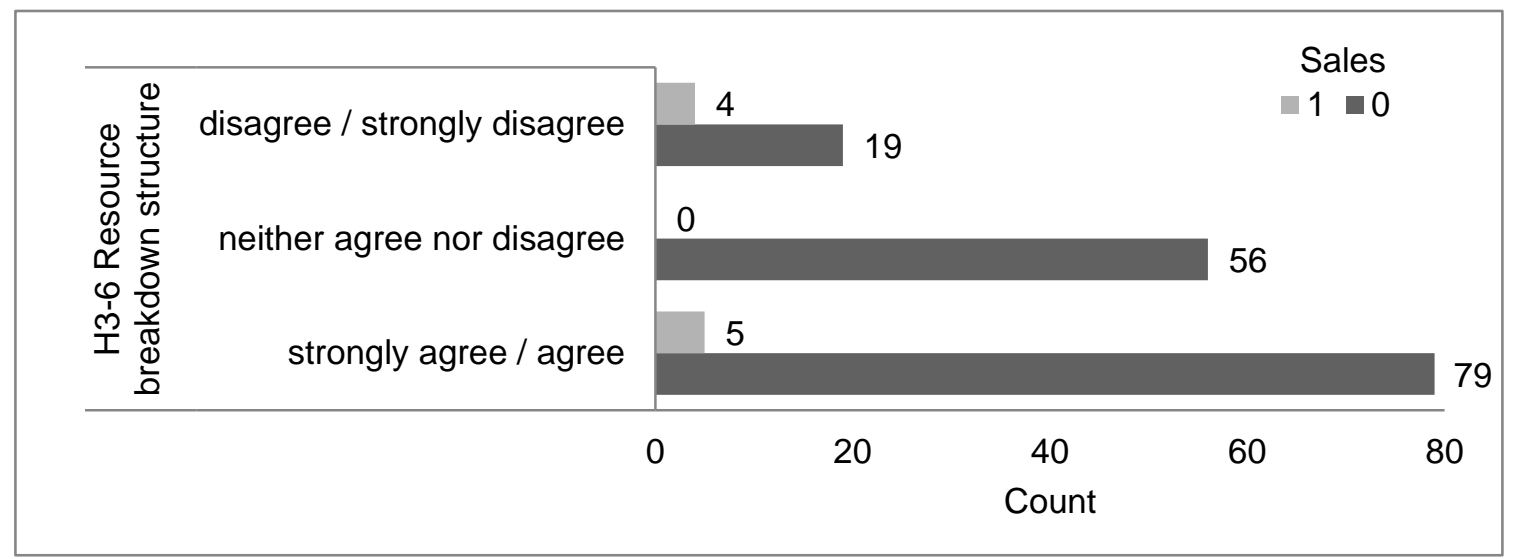

\section{Chi-Square Tests}

\begin{tabular}{lcccccc}
\hline & Value & df & $\begin{array}{c}\text { Asymp. Sig. } \\
\text { (2-sided) }\end{array}$ & $\begin{array}{c}\text { Exact Sig. } \\
(2 \text {-sided })\end{array}$ & $\begin{array}{c}\text { Exact Sig. } \\
\text { (1-sided) }\end{array}$ & $\begin{array}{c}\text { Point } \\
\text { Probability }\end{array}$ \\
\hline Pearson Chi-Square & $9.515^{\mathrm{a}}$ & 2 & .009 & .008 & & \\
Likelihood Ratio & 10.467 & 2 & .005 & .006 & & \\
Fisher's Exact Test & 8.699 & & & .008 & & \\
Linear-by-Linear & $1.269^{\mathrm{b}}$ & 1 & .260 & .342 & .186 & .096 \\
Association & & & & & & \\
N of Valid Cases & 163 & & & & & \\
\hline
\end{tabular}

a. 3 cells $(50.0 \%)$ have expected count less than 5 . The minimum expected count is 1.27.

b. The standardized statistic is 1.127 .

Symmetric Measures

\begin{tabular}{llccc}
\hline & & Value & Approx. Sig. & Exact Sig. \\
\hline Nominal by Nominal & Phi & .242 & .009 & .008 \\
& Cramer's V & .242 & .009 & .008 \\
N of Valid Cases & & 163 & & \\
\hline
\end{tabular}




\begin{tabular}{|c|c|c|c|c|c|}
\hline & & & \multicolumn{2}{|c|}{$\begin{array}{c}\text { Performance } \\
\text { objectives }\end{array}$} & \multirow[b]{2}{*}{ Total } \\
\hline & & & 0 & 1 & \\
\hline \multirow[t]{6}{*}{ H3-7 Resource calendar } & strongly agree / agree & Count & 78 & 23 & 101 \\
\hline & & Expected Count & 80.6 & 20.4 & 101.0 \\
\hline & neither agree nor disagree & Count & 42 & 4 & 46 \\
\hline & & Expected Count & 36.7 & 9.3 & 46.0 \\
\hline & disagree / strongly disagree & Count & 10 & 6 & 16 \\
\hline & & Expected Count & 12.8 & 3.2 & 16.0 \\
\hline \multirow[t]{2}{*}{ Total } & & Count & 130 & 33 & 163 \\
\hline & & Expected Count & 130.0 & 33.0 & 163.0 \\
\hline
\end{tabular}

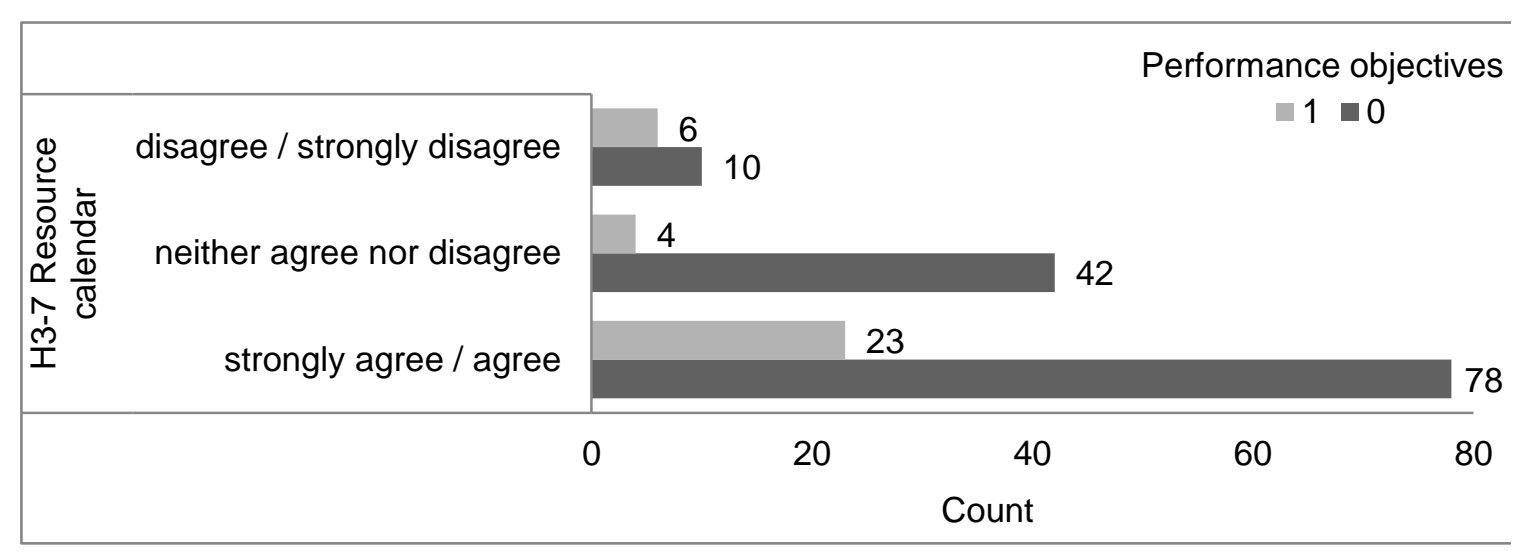

Chi-Square Tests

\begin{tabular}{|c|c|c|c|c|c|c|}
\hline & Value & $\mathrm{df}$ & $\begin{array}{c}\text { Asymp. Sig. } \\
\text { (2-sided) }\end{array}$ & $\begin{array}{c}\text { Exact Sig. } \\
\text { (2-sided) }\end{array}$ & $\begin{array}{l}\text { Exact Sig. } \\
\text { (1-sided) }\end{array}$ & $\begin{array}{c}\text { Point } \\
\text { Probability }\end{array}$ \\
\hline Pearson Chi-Square & $7.150^{\mathrm{a}}$ & 2 & .028 & .023 & & \\
\hline Likelihood Ratio & 7.509 & 2 & .023 & .042 & & \\
\hline Fisher's Exact Test & 7.335 & & & .022 & & \\
\hline Linear-by-Linear & $.004^{b}$ & 1 & .952 & 1.000 & .525 & .115 \\
\hline \multicolumn{7}{|l|}{ Association } \\
\hline $\mathrm{N}$ of Valid Cases & 163 & & & & & \\
\hline
\end{tabular}

a. 1 cells $(16.7 \%)$ have expected count less than 5 . The minimum expected count is 3.24 .

b. The standardized statistic is .061 .

Symmetric Measures

\begin{tabular}{llccc}
\hline & & Value & Approx. Sig. & Exact Sig. \\
\hline Nominal by Nominal & Phi & .209 & .028 & .023 \\
& Cramer's V & .209 & .028 & .023 \\
N of Valid Cases & & 163 & & \\
\hline
\end{tabular}


Crosstab H4-2 Activity cost estimates supporting detail * Customer approval

\begin{tabular}{lllccc}
\hline & & & \multicolumn{2}{c}{$\begin{array}{c}\text { Customer } \\
\text { approval }\end{array}$} \\
\cline { 3 - 5 } & & & 0 & 1 & Total \\
\hline H4-2 Activity cost & strongly agree / agree & Count & 43 & 20 & 63 \\
estimates supporting & & Expected Count & 49.9 & 13.1 & 63.0 \\
detail & neither agree nor disagree & Count & 70 & 11 & 81 \\
& & Expected Count & 64.1 & 16.9 & 81.0 \\
& \multirow{2}{*}{ disagree / strongly disagree } & Count & 16 & 3 & 19 \\
& & Expected Count & 15.0 & 4.0 & 19.0 \\
Total & & Count & 129 & 34 & 163 \\
& & Expected Count & 129.0 & 34.0 & 163.0 \\
\hline
\end{tabular}

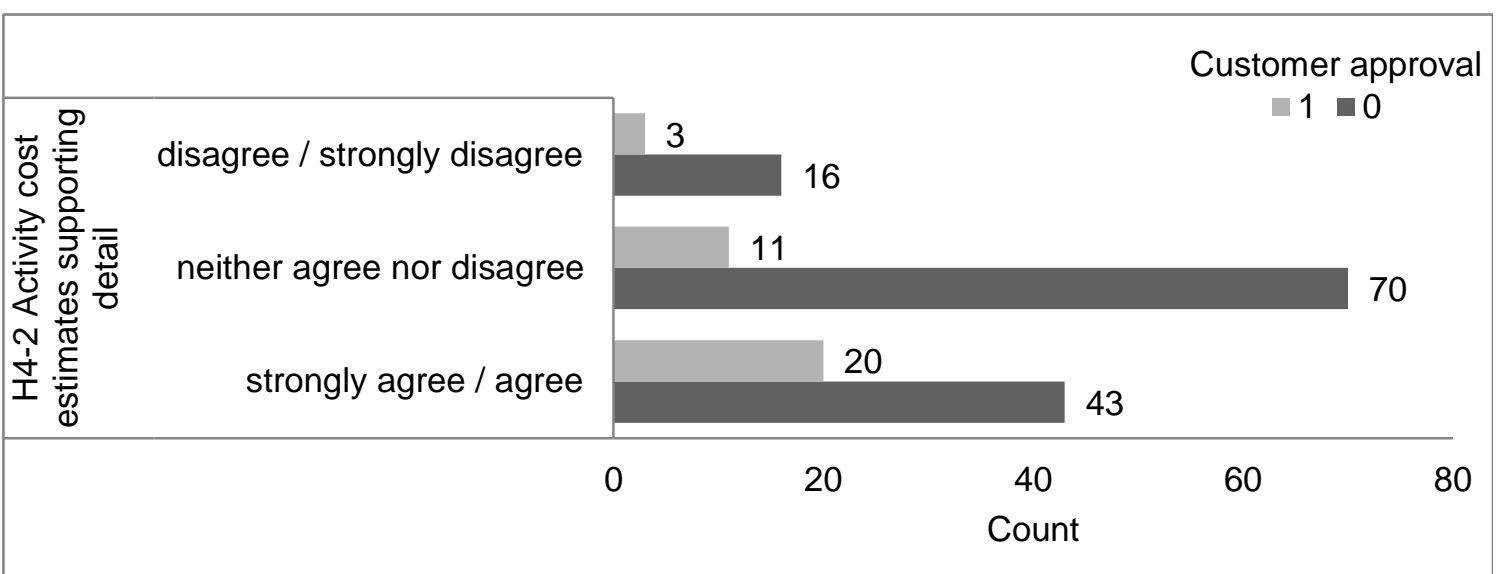

\section{Chi-Square Tests}

\begin{tabular}{lcccccc}
\hline & \multicolumn{7}{c}{$\begin{array}{c}\text { Asymp. Sig. } \\
\text { (2-sided) }\end{array}$} & $\begin{array}{c}\text { Exact Sig. } \\
(2 \text {-sided })\end{array}$ & $\begin{array}{c}\text { Exact Sig. } \\
\text { (1-sided) }\end{array}$ & $\begin{array}{c}\text { Point } \\
\text { Probability }\end{array}$ \\
\hline Pearson Chi-Square & $7.419^{\mathrm{a}}$ & 2 & .024 & .024 & & \\
Likelihood Ratio & 7.264 & 2 & .026 & .037 & & \\
Fisher's Exact Test & 7.055 & & & .029 & & \\
Linear-by-Linear & $5.253^{\mathrm{b}}$ & 1 & .022 & .027 & .014 & .008 \\
Association & & & & & & \\
N of Valid Cases & 163 & & & & & \\
\hline
\end{tabular}

a. 1 cells $(16.7 \%)$ have expected count less than 5 . The minimum expected count is 3.96 .

b. The standardized statistic is -2.292 .

Symmetric Measures

\begin{tabular}{llccc}
\hline & & Value & Approx. Sig. & Exact Sig. \\
\hline Nominal by Nominal & Phi & .213 & .024 & .024 \\
& Cramer's V & .213 & .024 & .024 \\
N of Valid Cases & & 163 & & \\
\hline
\end{tabular}


Crosstab H4-4 Cost baseline * Commercial benefit for customer

\begin{tabular}{lllccc}
\hline & & \multicolumn{2}{c}{$\begin{array}{c}\text { Commercial benefit } \\
\text { for customer }\end{array}$} \\
\cline { 3 - 4 } & & & 0 & 1 & Total \\
\hline H4-4 Cost & strongly agree / agree & Count & 97 & 15 & 112 \\
baseline & & Expected Count & 101.7 & 10.3 & 112.0 \\
& neither agree nor disagree & Count & 36 & 0 & 36 \\
& & Expected Count & 32.7 & 3.3 & 36.0 \\
& \multirow{2}{*}{ disagree / strongly disagree } & Count & 15 & 0 & 15 \\
& & Expected Count & 13.6 & 1.4 & 15.0 \\
& & Count & 148 & 15 & 163 \\
& & Expected Count & 148.0 & 15.0 & 163.0 \\
\hline
\end{tabular}

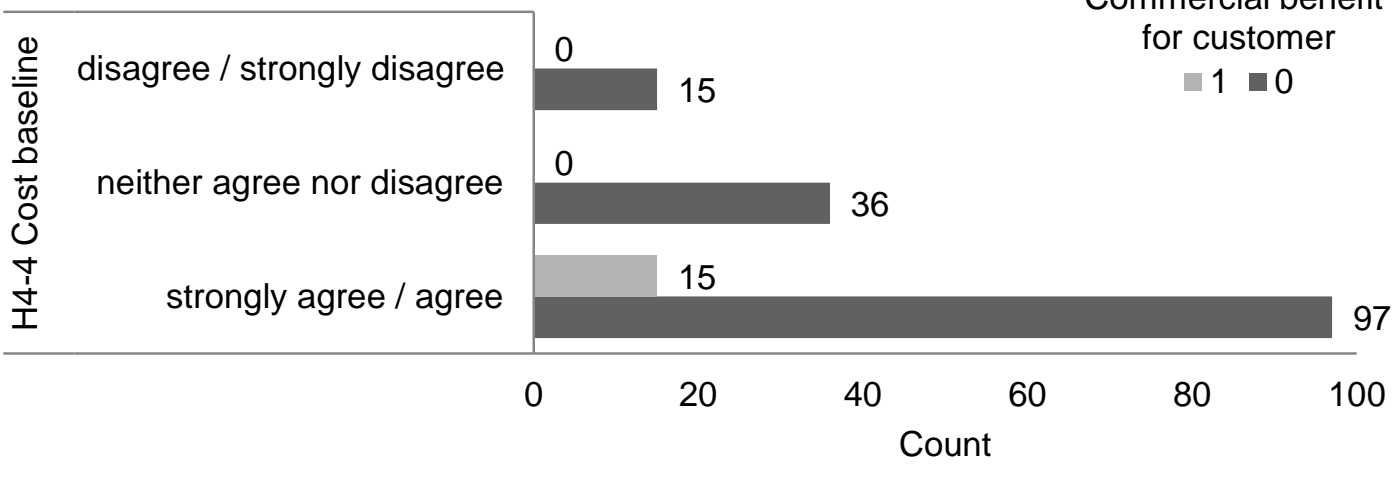

\section{Chi-Square Tests}

\begin{tabular}{lcccccc}
\hline & Value & df & $\begin{array}{c}\text { Asymp. Sig. } \\
\text { (2-sided) }\end{array}$ & $\begin{array}{c}\text { Exact Sig. } \\
(2 \text {-sided) }\end{array}$ & $\begin{array}{c}\text { Exact Sig. } \\
\text { (1-sided) }\end{array}$ & $\begin{array}{c}\text { Point } \\
\text { Probability }\end{array}$ \\
\hline Pearson Chi-Square & $7.523^{\mathrm{a}}$ & 2 & .023 & .019 & & \\
Likelihood Ratio & 11.938 & 2 & .003 & .005 & & \\
Fisher's Exact Test & 7.263 & & & .019 & & \\
Linear-by-Linear & $6.334^{\mathrm{b}}$ & 1 & .012 & .009 & .003 & .003 \\
Association & & & & & & \\
\hline $\mathrm{N}$ of Valid Cases & 163 & & & & &
\end{tabular}

a. 2 cells (33.3\%) have expected count less than 5 . The minimum expected count is 1.38 .

b. The standardized statistic is -2.517 .

Symmetric Measures

\begin{tabular}{llccc}
\hline & & Value & Approx. Sig. & Exact Sig. \\
\hline Nominal by Nominal & Phi & .215 & .023 & .019 \\
& Cramer's V & .215 & .023 & .019 \\
N of Valid Cases & & 163 & & \\
\hline
\end{tabular}




\begin{tabular}{lllccc}
\hline & & \multicolumn{2}{c}{$\begin{array}{c}\text { Customer } \\
\text { approval }\end{array}$} \\
\cline { 3 - 4 } & & 0 & 1 & Total \\
\hline \multirow{2}{*}{ H4-4 Cost baseline } & strongly agree / agree & Count & 82 & 30 & 112 \\
& & Expected Count & 88.6 & 23.4 & 112.0 \\
& \multirow{2}{*}{ neither agree nor disagree } & Count & 33 & 3 & 36 \\
& & Expected Count & 28.5 & 7.5 & 36.0 \\
& \multirow{3}{*}{ disagree / strongly disagree } & Count & 14 & 1 & 15 \\
& & Expected Count & 11.9 & 3.1 & 15.0 \\
& & Count & 129 & 34 & 163 \\
& & Expected Count & 129.0 & 34.0 & 163.0 \\
\hline
\end{tabular}

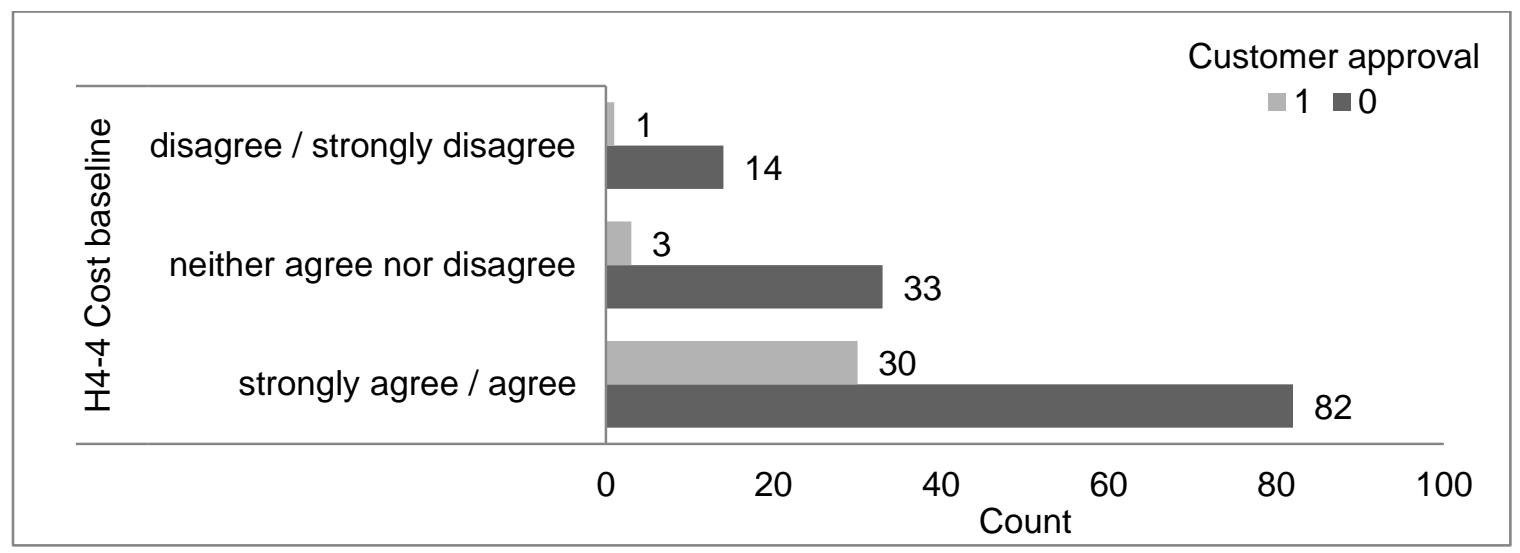

\begin{tabular}{|c|c|c|c|c|c|c|}
\hline \multicolumn{7}{|c|}{ Chi-Square Tests } \\
\hline & Value & df & $\begin{array}{c}\text { Asymp. Sig. } \\
\text { (2-sided) }\end{array}$ & $\begin{array}{c}\text { Exact Sig. } \\
\text { (2-sided) }\end{array}$ & $\begin{array}{c}\text { Exact Sig. } \\
\text { (1-sided) }\end{array}$ & $\begin{array}{c}\text { Point } \\
\text { Probability }\end{array}$ \\
\hline Pearson Chi-Square & $7.635^{a}$ & 2 & .022 & .018 & & \\
\hline Likelihood Ratio & 8.768 & 2 & .012 & .017 & & \\
\hline Fisher's Exact Test & 7.414 & & & .020 & & \\
\hline $\begin{array}{l}\text { Linear-by-Linear } \\
\text { Association }\end{array}$ & $6.679^{b}$ & 1 & .010 & .011 & .004 & .003 \\
\hline $\mathrm{N}$ of Valid Cases & 163 & & & & & \\
\hline
\end{tabular}

a. 1 cells (16.7\%) have expected count less than 5 . The minimum expected count is 3.13 .

b. The standardized statistic is -2.584 .

Symmetric Measures

\begin{tabular}{llccc}
\hline & & Value & Approx. Sig. & Exact Sig. \\
\hline Nominal by Nominal & Phi & .216 & .022 & .018 \\
& Cramer's V & .216 & .022 & .018 \\
N of Valid Cases & & 163 & & \\
\hline
\end{tabular}




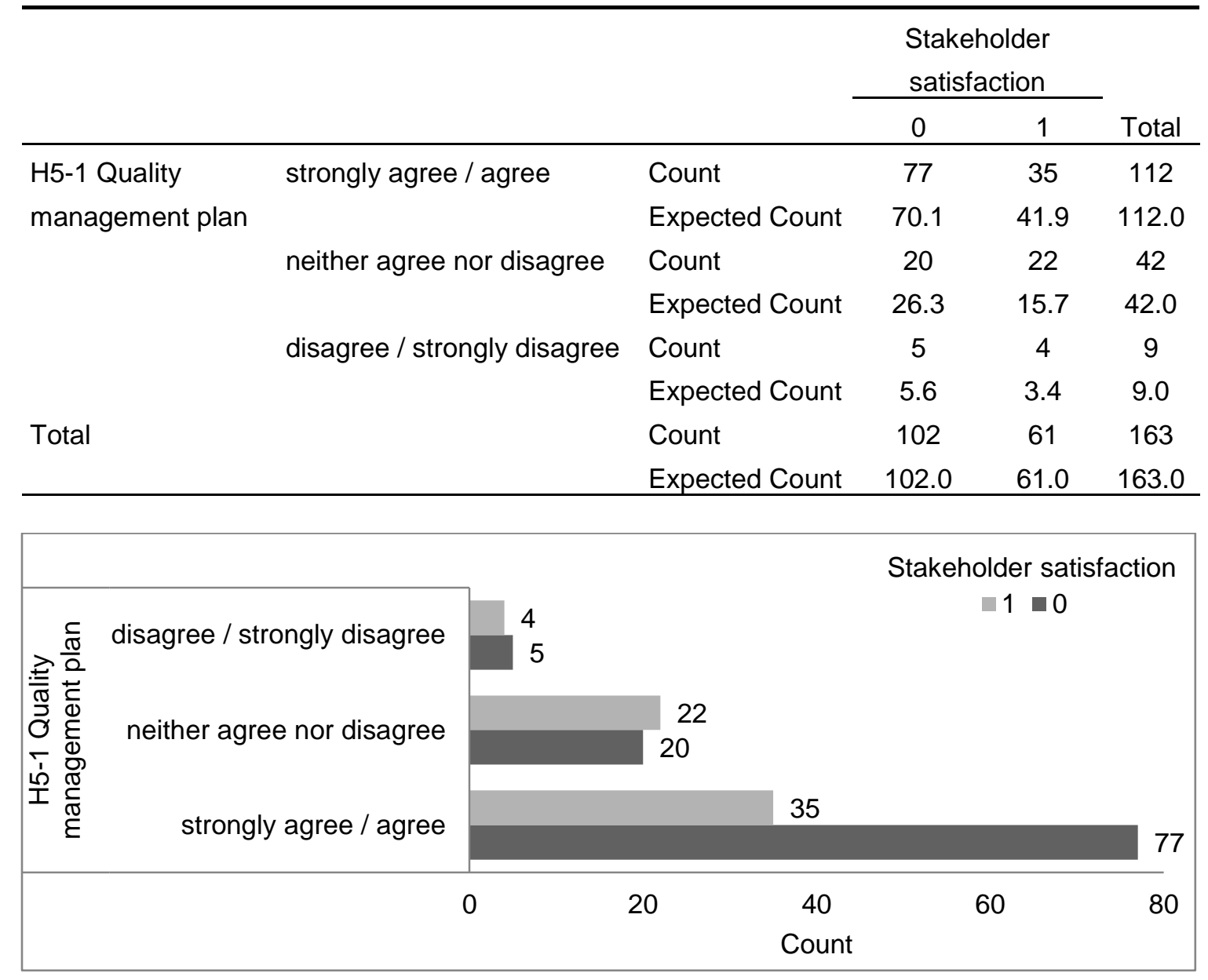

\section{Chi-Square Tests}

\begin{tabular}{|c|c|c|c|c|c|c|}
\hline & Value & $\mathrm{df}$ & $\begin{array}{c}\text { Asymp. Sig. } \\
\text { (2-sided) }\end{array}$ & $\begin{array}{c}\text { Exact Sig. } \\
\text { (2-sided) }\end{array}$ & $\begin{array}{c}\text { Exact Sig. } \\
\text { (1-sided) }\end{array}$ & $\begin{array}{c}\text { Point } \\
\text { Probability }\end{array}$ \\
\hline Pearson Chi-Square & $6.025^{\mathrm{a}}$ & 2 & .049 & .049 & & \\
\hline Likelihood Ratio & 5.924 & 2 & .052 & .060 & & \\
\hline Fisher's Exact Test & 6.024 & & & .053 & & \\
\hline Linear-by-Linear & $4.322^{b}$ & 1 & .038 & .039 & .027 & .013 \\
\hline \multicolumn{7}{|l|}{ Association } \\
\hline $\mathrm{N}$ of Valid Cases & 163 & & & & & \\
\hline
\end{tabular}

a. 1 cells (16.7\%) have expected count less than 5 . The minimum expected count is 3.37 .

b. The standardized statistic is 2.079 .

Symmetric Measures

\begin{tabular}{llrrr}
\hline & & \multicolumn{1}{c}{ Value } & Approx. Sig. & Exact Sig. \\
\hline Nominal by Nominal & Phi & .192 & .049 & .049 \\
& Cramer's V & .192 & .049 & .049 \\
N of Valid Cases & & 163.000 & & \\
\hline
\end{tabular}




\section{Crosstab H5-1 Quality management plan * Commercial benefit for customer}

\begin{tabular}{lllccc}
\hline & & & \multicolumn{2}{c}{$\begin{array}{c}\text { Commercial benefit } \\
\text { for customer }\end{array}$} \\
\cline { 3 - 5 } & & & 0 & 1 & Total \\
\hline H5-1 Quality & strongly agree / agree & Count & 105 & 7 & 112 \\
management plan & & Expected Count & 101.7 & 10.3 & 112.0 \\
& neither agree nor & Count & 34 & 8 & 42 \\
& disagree & Expected Count & 38.1 & 3.9 & 42.0 \\
& disagree / strongly & Count & 9 & 0 & 9 \\
& disagree & Expected Count & 8.2 & .8 & 9.0 \\
& & Count & 148 & 15 & 163 \\
& & Expected Count & 148.0 & 15.0 & 163.0 \\
\hline
\end{tabular}

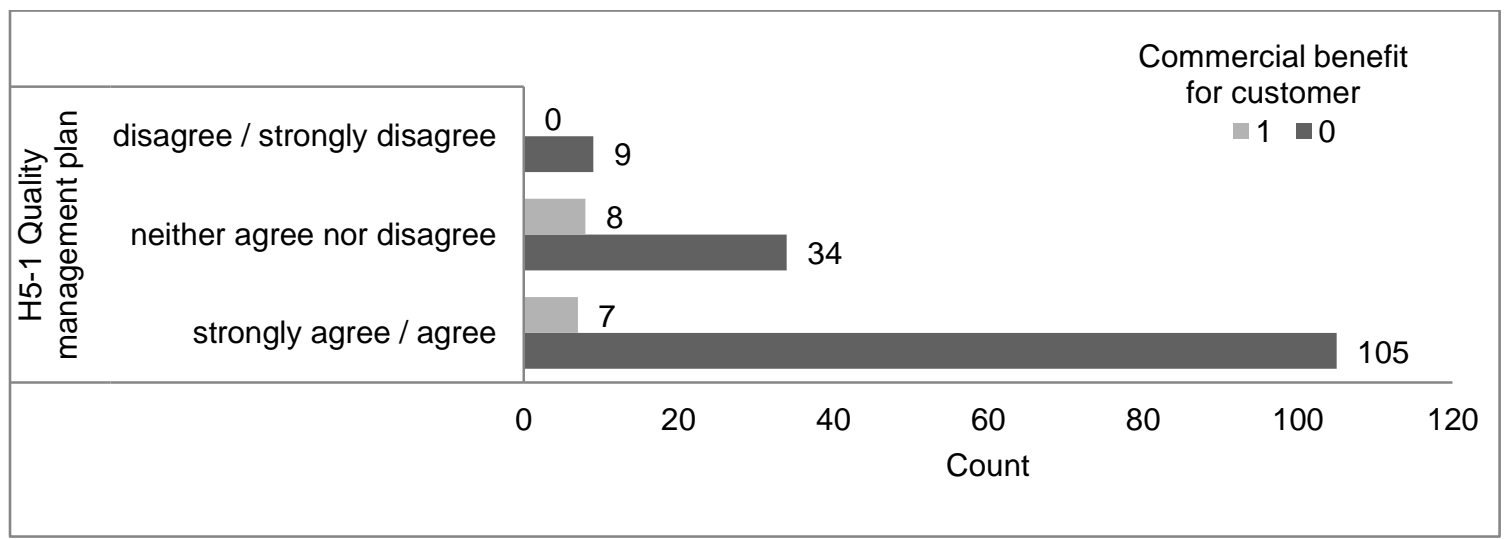

\section{Chi-Square Tests}

\begin{tabular}{lcccccc}
\hline & \multicolumn{7}{c}{$\begin{array}{c}\text { Asymp. Sig. } \\
\text { (2-sided) }\end{array}$} & $\begin{array}{c}\text { Exact Sig. } \\
\text { (2-sided) }\end{array}$ & $\begin{array}{c}\text { Exact Sig. } \\
\text { (1-sided) }\end{array}$ & $\begin{array}{c}\text { Point } \\
\text { Probability }\end{array}$ \\
\hline Pearson Chi-Square & $6.953^{\mathrm{a}}$ & 2 & .031 & .036 & & \\
Likelihood Ratio & 6.876 & 2 & .032 & .030 & & \\
Fisher's Exact Test & 5.616 & & & .050 & & .088 \\
Linear-by-Linear & $1.307^{\mathrm{b}}$ & 1 & .253 & .357 & .179 & \\
Association & & & & & & \\
N of Valid Cases & 163 & & & & & \\
\hline
\end{tabular}

a. 2 cells (33.3\%) have expected count less than 5 . The minimum expected count is .83 .

b. The standardized statistic is 1.143 .

Symmetric Measures

\begin{tabular}{llrrr}
\hline & & \multicolumn{1}{l}{ Value } & \multicolumn{1}{c}{ Approx. Sig. } & \multicolumn{1}{c}{ Exact Sig. } \\
\hline Nominal by Nominal & Phi & .207 & .031 & .036 \\
& Cramer's V & .207 & .031 & .036 \\
N of Valid Cases & & 163.000 & & \\
\hline
\end{tabular}




\section{Crosstab H5-4 Process improvement plan * Customer satisfaction}

\begin{tabular}{lllccc}
\hline & & \multicolumn{2}{c}{$\begin{array}{c}\text { Customer } \\
\text { satisfaction }\end{array}$} \\
\cline { 3 - 4 } & & & 0 & 1 & Total \\
\hline H5-4 Process & strongly agree / agree & Count & 20 & 46 & 66 \\
improvement plan & & Expected Count & 27.5 & 38.5 & 66.0 \\
& \multirow{2}{*}{ neither agree nor disagree } & Count & 39 & 39 & 78 \\
& & Expected Count & 32.5 & 45.5 & 78.0 \\
& \multirow{2}{*}{ disagree / strongly disagree } & Count & 9 & 10 & 19 \\
& & Expected Count & 7.9 & 11.1 & 19.0 \\
Total & & Count & 68 & 95 & 163 \\
& & Expected Count & 68.0 & 95.0 & 163.0 \\
\hline
\end{tabular}

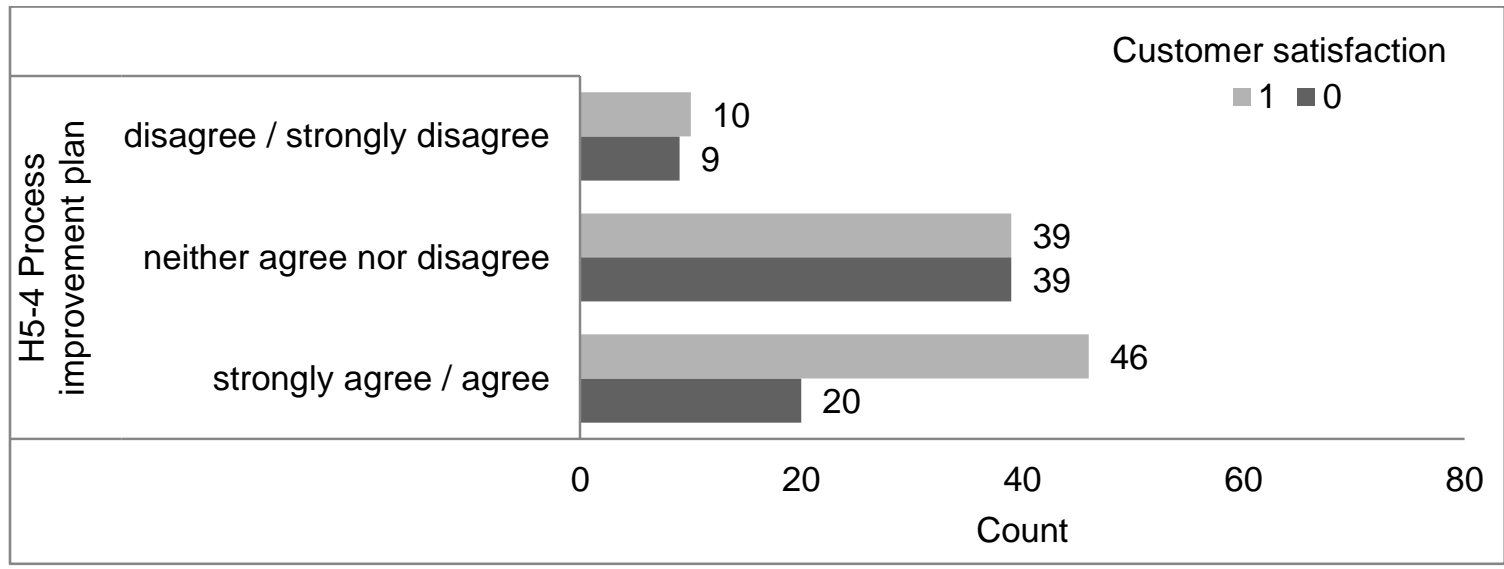

\section{Chi-Square Tests}

\begin{tabular}{lcccccc}
\hline & Value & df & $\begin{array}{c}\text { Asymp. Sig. } \\
(2 \text {-sided })\end{array}$ & $\begin{array}{c}\text { Exact Sig. } \\
(2 \text {-sided })\end{array}$ & $\begin{array}{c}\text { Exact Sig. } \\
\text { (1-sided) }\end{array}$ & $\begin{array}{c}\text { Point } \\
\text { Probability }\end{array}$ \\
\hline Pearson Chi-Square & $\mathbf{5 . 9 8 7 ^ { \mathrm { a } }}$ & 2 & .050 & .053 & & \\
Likelihood Ratio & 6.085 & 2 & .048 & .056 & & \\
Fisher's Exact Test & 6.036 & & & .053 & & \\
Linear-by-Linear & $4.239^{\mathrm{b}}$ & 1 & .040 & .042 & .026 & .012 \\
Association & & & & & & \\
N of Valid Cases & 163 & & & & & \\
\hline
\end{tabular}

a. 0 cells $(.0 \%)$ have expected count less than 5 . The minimum expected count is 7.93 .

b. The standardized statistic is -2.059 .

Symmetric Measures

\begin{tabular}{llrrr}
\hline & & \multicolumn{1}{c}{ Value } & Approx. Sig. & Exact Sig. \\
\hline Nominal by Nominal & Phi & .192 & .050 & .053 \\
& Cramer's V & .192 & .050 & .053 \\
N of Valid Cases & & 163.000 & & \\
\hline
\end{tabular}


Crosstab H5-6 Recommended corrective actions * Strategic contribution to the project

\begin{tabular}{lllccc}
\hline & & \multicolumn{2}{c}{$\begin{array}{c}\text { Strategic contribution } \\
\text { of the project }\end{array}$} \\
\cline { 3 - 5 } & & & 0 & 1 & Total \\
\hline H5-6 Recommended & strongly agree / agree & Count & 79 & 19 & 98 \\
corrective actions & & Expected Count & 86.0 & 12.0 & 98.0 \\
& neither agree nor & Count & 56 & 0 & 56 \\
& disagree & Expected Count & 49.1 & 6.9 & 56.0 \\
& disagree / strongly & Count & 8 & 1 & 9 \\
& disagree & Expected Count & 7.9 & 1.1 & 9.0 \\
& & Count & 143 & 20 & 163 \\
& & Expected Count & 143.0 & 20.0 & 163.0 \\
\hline
\end{tabular}

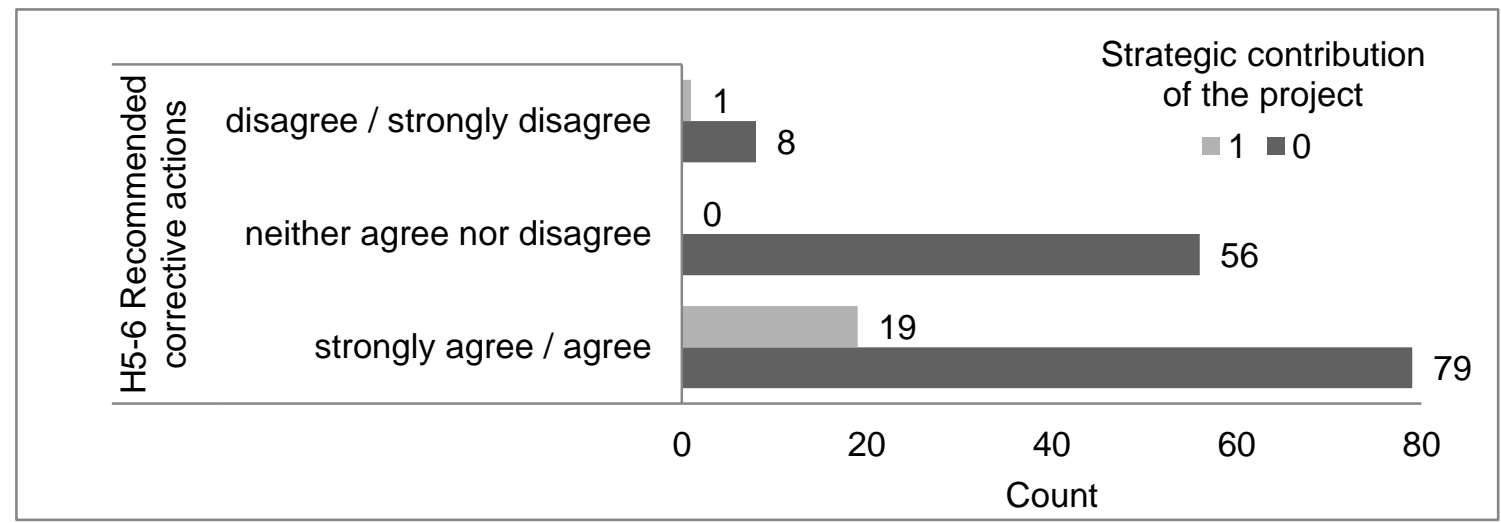

Chi-Square Tests

\begin{tabular}{lcccccc}
\hline & Value & df & $\begin{array}{c}\text { Asymp. Sig. } \\
\text { (2-sided) }\end{array}$ & $\begin{array}{c}\text { Exact Sig. } \\
(2 \text {-sided })\end{array}$ & $\begin{array}{c}\text { Exact Sig. } \\
\text { (1-sided) }\end{array}$ & $\begin{array}{c}\text { Point } \\
\text { Probability }\end{array}$ \\
\hline Pearson Chi-Square & $\mathbf{1 2 . 4 5 6 ^ { \mathrm { a } }}$ & 2 & .002 & .003 & & \\
Likelihood Ratio & 18.689 & 2 & .000 & .000 & & \\
Fisher's Exact Test & 15.506 & & & .000 & & \\
Linear-by-Linear & $7.924^{\mathrm{b}}$ & 1 & .005 & .004 & .002 & .002 \\
Association & & & & & & \\
N of Valid Cases & 163 & & & & & \\
\hline
\end{tabular}

a. 1 cells $(16.7 \%)$ have expected count less than 5 . The minimum expected count is 1.10 .

b. The standardized statistic is -2.815 .

\section{Symmetric Measures}

\begin{tabular}{llccc}
\hline & & Value & Approx. Sig. & Exact Sig. \\
\hline Nominal by Nominal & Phi & .276 & .002 & .003 \\
& Cramer's V & .276 & .002 & .003 \\
N of Valid Cases & & 163 & & \\
\hline
\end{tabular}




\section{Crosstab H5-6 Recommended corrective actions * Profitability}

\begin{tabular}{lllccc}
\hline & & & \multicolumn{2}{c}{ Profitability } & \\
\cline { 3 - 5 } & & & 0 & 1 & Total \\
\hline H5-6 Recommended & \multirow{2}{*}{ strongly agree / agree } & Count & 71 & 27 & 98 \\
& & Expected Count & 77.6 & 20.4 & 98.0 \\
& \multirow{2}{*}{ neither agree nor disagree } & Count & 50 & 6 & 56 \\
& & Expected Count & 44.3 & 11.7 & 56.0 \\
& \multirow{2}{*}{ disagree / strongly disagree } & Count & 8 & 1 & 9 \\
& & Expected Count & 7.1 & 1.9 & 9.0 \\
& & Count & 129 & 34 & 163 \\
& & Expected Count & 129.0 & 34.0 & 163.0 \\
\hline
\end{tabular}

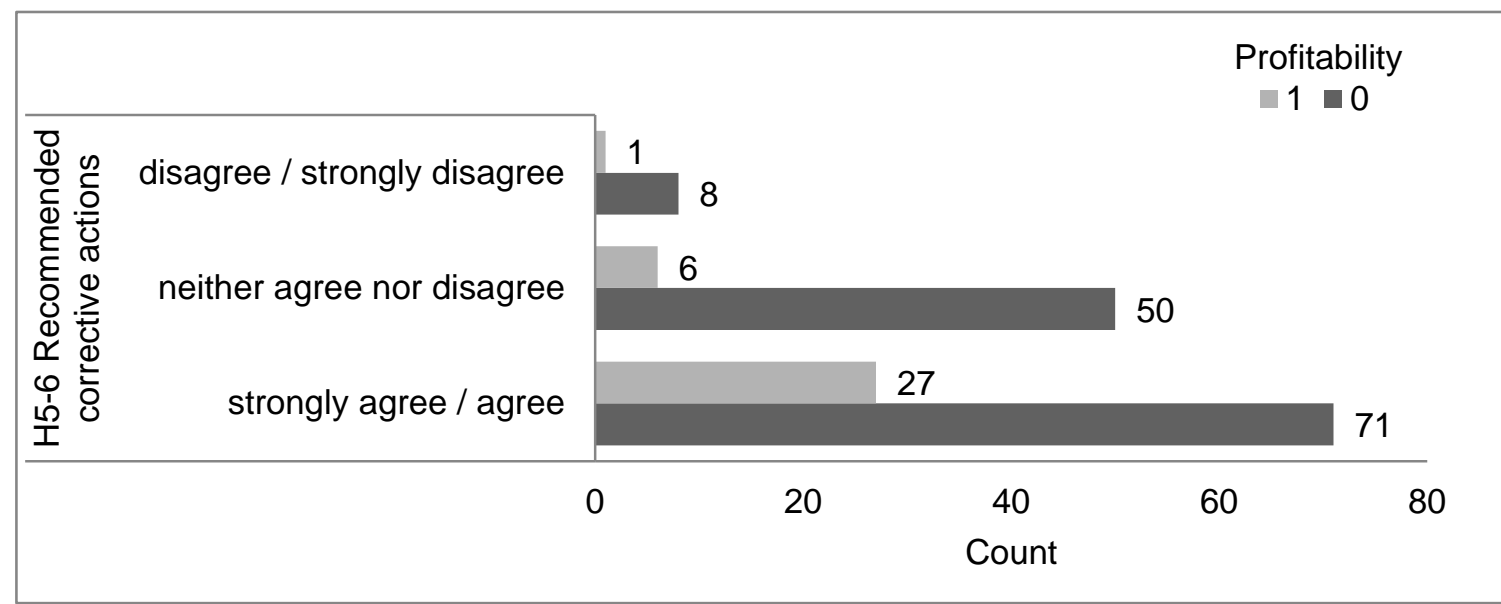

\section{Chi-Square Tests}

\begin{tabular}{lcccccc}
\hline & \multicolumn{1}{c}{ Asymp. Sig. } & $\begin{array}{c}\text { Exact Sig. } \\
\text { (2-sided) }\end{array}$ & $\begin{array}{c}\text { Exact Sig. } \\
(1 \text {-sided) }\end{array}$ & $\begin{array}{c}\text { Point } \\
\text { Probability }\end{array}$ \\
\hline Pearson Chi-Square & $\mathbf{6 . 6 6 8 ^ { \mathrm { a } }}$ & 2 & .036 & .042 & & \\
Likelihood Ratio & 7.146 & 2 & .028 & .031 & & \\
Fisher's Exact Test & 6.470 & & & .031 & & \\
Linear-by-Linear & $5.699^{\mathrm{b}}$ & 1 & .017 & .023 & .010 & .006 \\
Association & & & & & & \\
N of Valid Cases & 163 & & & & & \\
\hline
\end{tabular}

a. 1 cells $(16.7 \%)$ have expected count less than 5 . The minimum expected count is 1.88 .

b. The standardized statistic is -2.387 .

Symmetric Measures

\begin{tabular}{llccc}
\hline & & Value & Approx. Sig. & Exact Sig. \\
\hline Nominal by Nominal & Phi & .202 & .036 & .042 \\
& Cramer's V & .202 & .036 & .042 \\
N of Valid Cases & & 163 & & \\
\hline
\end{tabular}


Crosstab H5-8 Quality control measurements * Scope

\begin{tabular}{lllccc}
\hline & & & \multicolumn{2}{c}{ Scope } & \\
\cline { 3 - 5 } & & & 0 & 1 & Total \\
\hline H5-8 Quality control & \multirow{2}{*}{ strongly agree / agree } & Count & 81 & 36 & 117 \\
measurements & & Expected Count & 79.7 & 37.3 & 117.0 \\
& \multirow{2}{*}{ neither agree nor disagree } & Count & 27 & 9 & 36 \\
& \multirow{2}{*}{ disagree / strongly disagree } & Count & 3 & 7 & 10 \\
& & Expected Count & 6.8 & 3.2 & 10.0 \\
& & Count & 111 & 52 & 163 \\
Total & & Expected Count & 111.0 & 52.0 & 163.0 \\
\hline
\end{tabular}

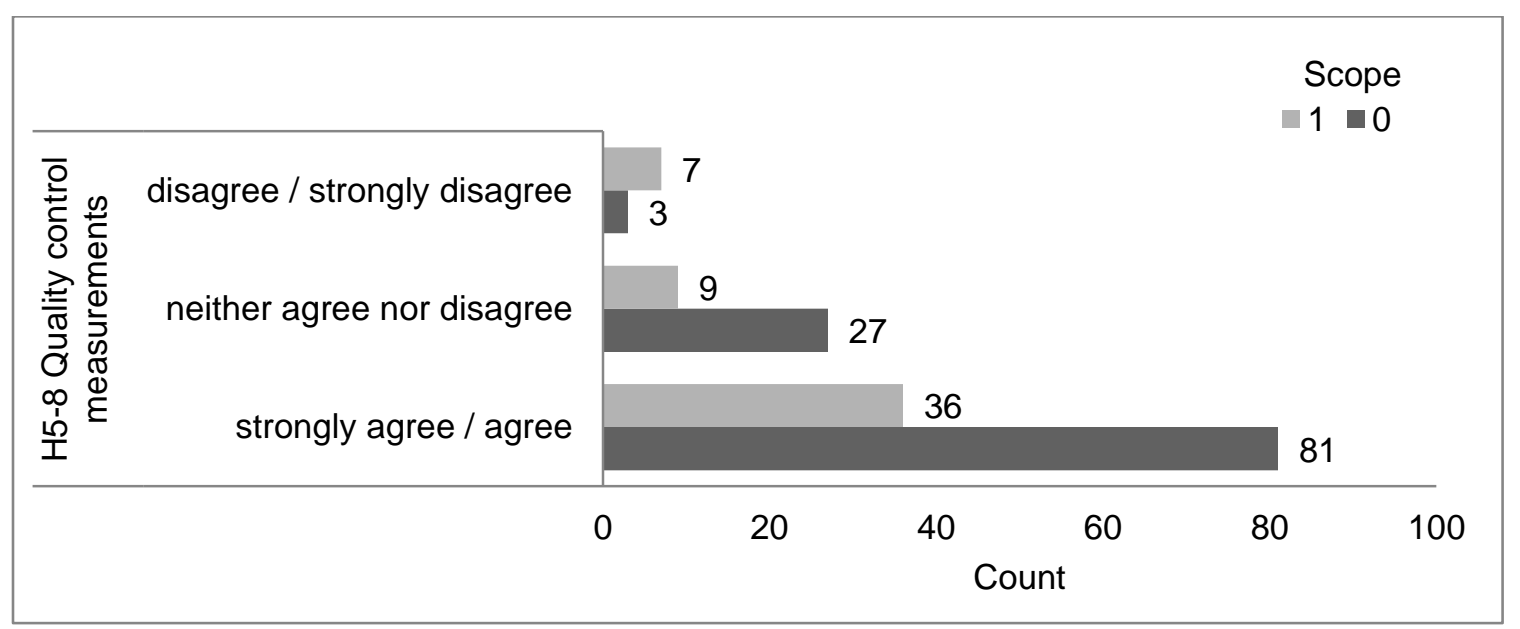

\section{Chi-Square Tests}

\begin{tabular}{|c|c|c|c|c|c|c|}
\hline & Value & df & $\begin{array}{c}\text { Asymp. Sig. } \\
\text { (2-sided) }\end{array}$ & $\begin{array}{l}\text { Exact Sig. } \\
\text { (2-sided) }\end{array}$ & $\begin{array}{l}\text { Exact Sig. } \\
\text { (1-sided) }\end{array}$ & $\begin{array}{c}\text { Point } \\
\text { Probability }\end{array}$ \\
\hline Pearson Chi-Square & $7.540^{\mathrm{a}}$ & 2 & .023 & .021 & & \\
\hline Likelihood Ratio & 6.978 & 2 & .031 & .043 & & \\
\hline Fisher's Exact Test & 6.861 & & & .028 & & \\
\hline Linear-by-Linear & $2.125^{\mathrm{b}}$ & 1 & .145 & .157 & .096 & .039 \\
\hline \multicolumn{7}{|l|}{ Association } \\
\hline $\mathrm{N}$ of Valid Cases & 163 & & & & & \\
\hline
\end{tabular}

a. 1 cells $(16.7 \%)$ have expected count less than 5 . The minimum expected count is 3.19 .

b. The standardized statistic is 1.458 .

Symmetric Measures

\begin{tabular}{llccc}
\hline & & Value & Approx. Sig. & Exact Sig. \\
\hline Nominal by Nominal & Phi & .215 & .023 & .021 \\
& Cramer's V & .215 & .023 & .021 \\
N of Valid Cases & & 163 & & \\
\hline
\end{tabular}




\begin{tabular}{lllccc}
\hline & & & \multicolumn{2}{c}{ User } \\
& & & \multicolumn{2}{c}{ satisfaction } & \\
\cline { 3 - 5 } & & & 0 & 1 & Total \\
\hline H6-3 Staffing & strongly agree / agree & Count & 83 & 17 & 100 \\
management plan & & Expected Count & 84.7 & 15.3 & 100.0 \\
& \multirow{2}{*}{ neither agree nor disagree } & Count & 46 & 3 & 49 \\
& & Expected Count & 41.5 & 7.5 & 49.0 \\
& \multirow{2}{*}{ disagree / strongly disagree } & Count & 9 & 5 & 14 \\
& & Expected Count & 11.9 & 2.1 & 14.0 \\
& & Count & 138 & 25 & 163 \\
& & Expected Count & 138.0 & 25.0 & 163.0 \\
\hline
\end{tabular}

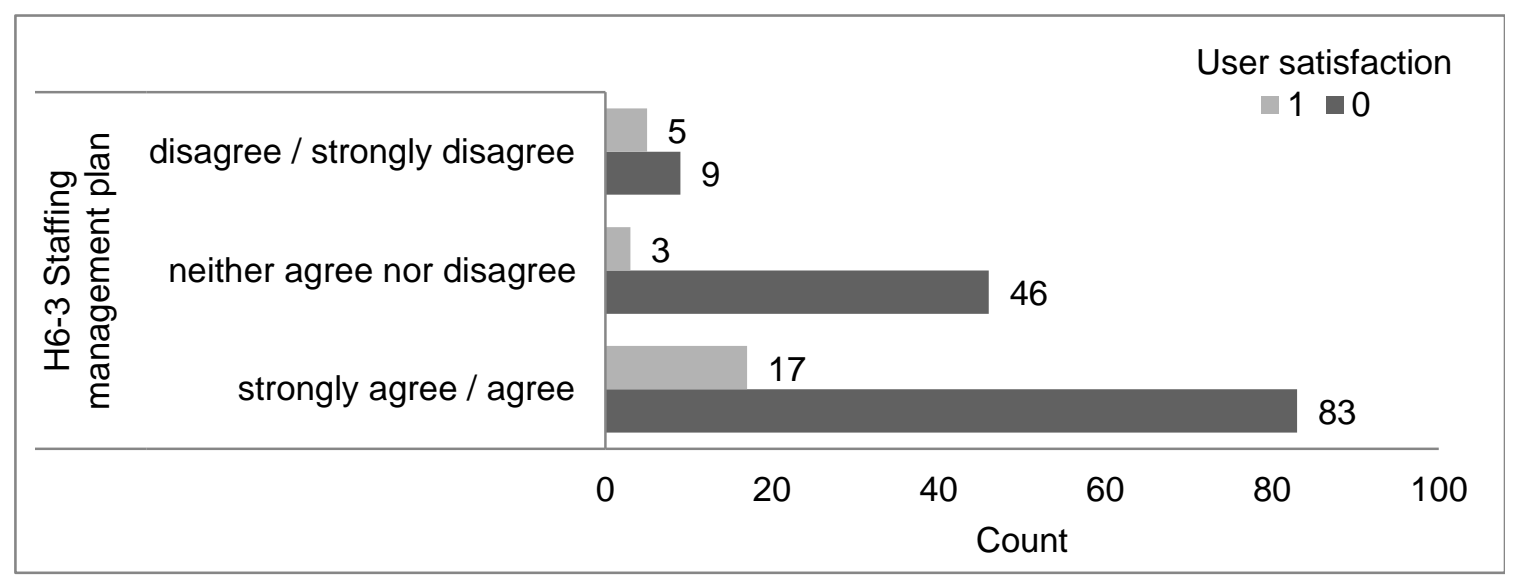

Chi-Square Tests

\begin{tabular}{lcccccc}
\hline & \multicolumn{7}{c}{$\begin{array}{c}\text { Asymp. Sig. } \\
\text { (2-sided) }\end{array}$} & $\begin{array}{c}\text { Exact Sig. } \\
\text { (2-sided) }\end{array}$ & $\begin{array}{c}\text { Exact Sig. } \\
\text { (1-sided) }\end{array}$ & $\begin{array}{c}\text { Point } \\
\text { Probability }\end{array}$ \\
\hline Pearson Chi-Square & $7.894^{\mathrm{a}}$ & 2 & .019 & .021 & & \\
Likelihood Ratio & 7.699 & 2 & .021 & .024 & & \\
Fisher's Exact Test & 7.635 & & & .018 & & \\
Linear-by-Linear & $.158^{\mathrm{b}}$ & 1 & .691 & .739 & .399 & .119 \\
Association & & & & & & \\
N of Valid Cases & 163 & & & & & \\
\hline
\end{tabular}

a. 1 cells $(16.7 \%)$ have expected count less than 5 . The minimum expected count is 2.15 .

b. The standardized statistic is .397 .

Symmetric Measures

\begin{tabular}{llccc}
\hline & & Value & Approx. Sig. & Exact Sig. \\
\hline Nominal by Nominal & Phi & .220 & .019 & .021 \\
& Cramer's V & .220 & .019 & .021 \\
N of Valid Cases & & 163.000 & & \\
\hline
\end{tabular}




\section{Crosstab H6-5 Resource availability * Budget/Cost}

\begin{tabular}{llcccc}
\hline & & & \multicolumn{2}{c}{ Budget/Cost } & \\
\cline { 3 - 4 } & & & 0 & 1 & Total \\
\hline H6-5 Resource & strongly agree / agree & Count & 23 & 122 & 145 \\
availability & \multirow{2}{*}{ neither agree nor disagree } & Count & 10 & 7 & 17 \\
& & Expected Count & 29.4 & 115.6 & 145.0 \\
& \multirow{2}{*}{ disagree / strongly disagree } & Count & 3.4 & 13.6 & 17.0 \\
& & 0 & 1 & 1 \\
& & Expected Count & .2 & .8 & 1.0 \\
Total & & 33 & 130 & 163 \\
& & Count & 33.0 & 130.0 & 163.0 \\
\hline
\end{tabular}

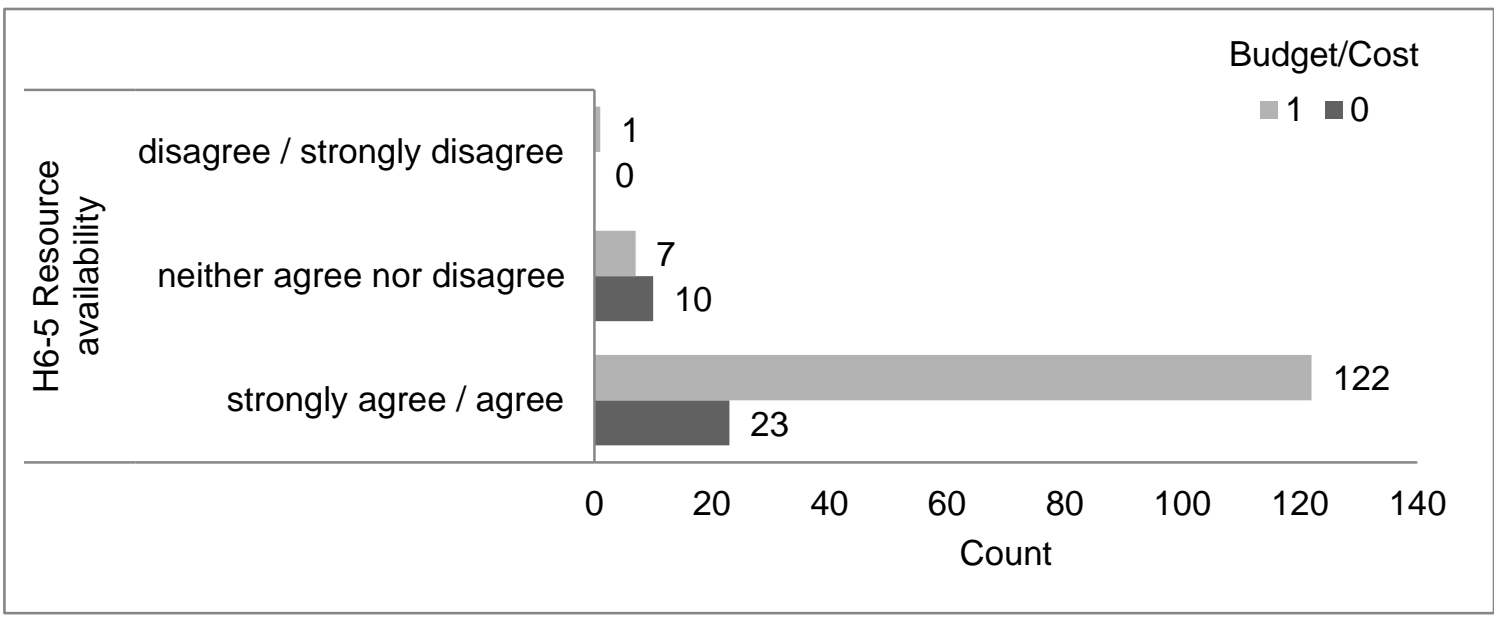

Chi-Square Tests

\begin{tabular}{lcccccc}
\hline & Value & df & $\begin{array}{c}\text { Asymp. Sig. } \\
\text { (2-sided) }\end{array}$ & $\begin{array}{c}\text { Exact Sig. } \\
(2-\text {-sided })\end{array}$ & $\begin{array}{c}\text { Exact Sig. } \\
(1-s i d e d)\end{array}$ & $\begin{array}{c}\text { Point } \\
\text { Probability }\end{array}$ \\
\hline Pearson Chi-Square & $17.649^{\mathrm{a}}$ & 2 & .000 & .000 & & \\
Likelihood Ratio & 14.360 & 2 & .001 & .000 & & \\
Fisher's Exact Test & 14.594 & & & .000 & & \\
Linear-by-Linear & $12.407^{\mathrm{b}}$ & 1 & .000 & .002 & .002 & .001 \\
Association & & & & & & \\
N of Valid Cases & 163 & & & & & \\
\hline
\end{tabular}

a. 3 cells $(50.0 \%)$ have expected count less than 5 . The minimum expected count is .20 .

b. The standardized statistic is -3.522 .

Symmetric Measures

\begin{tabular}{llccc}
\hline & & Value & Approx. Sig. & Exact Sig. \\
\hline Nominal by Nominal & Phi & .329 & .000 & .000 \\
& Cramer's V & .329 & .000 & .000 \\
N of Valid Cases & & 163 & & \\
\hline
\end{tabular}


Crosstab H7-3 Resolved issues * Personal growth

\begin{tabular}{llcccc}
\hline & & & \multicolumn{2}{c}{ Personal growth } & \\
\cline { 3 - 4 } & & & 0 & 1 & Total \\
\hline H7-3 Resolved & \multirow{2}{*}{ strongly agree / agree } & Count & 120 & 0 & 120 \\
issues & & Expected Count & 119.3 & .7 & 120.0 \\
& \multirow{2}{*}{ neither agree nor disagree } & Count & 37 & 0 & 37 \\
& & Expected Count & 36.8 & .2 & 37.0 \\
& \multirow{2}{*}{ disagree / strongly disagree } & Count & 5 & 1 & 6 \\
& & Expected Count & 6.0 & .0 & 6.0 \\
& & Count & 162 & 1 & 163 \\
& & Expected Count & 162.0 & 1.0 & 163.0 \\
\hline
\end{tabular}

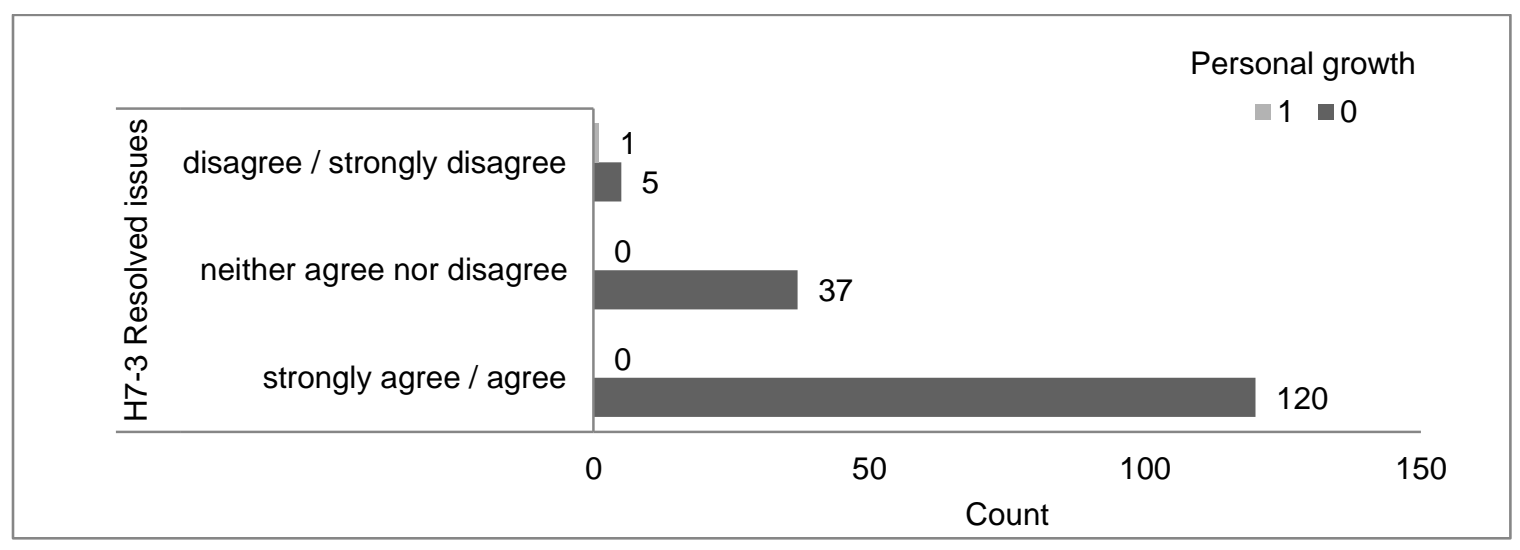

Chi-Square Tests

\begin{tabular}{|c|c|c|c|c|c|c|}
\hline & Value & $\mathrm{df}$ & $\begin{array}{c}\text { Asymp. Sig. } \\
\text { (2-sided) }\end{array}$ & $\begin{array}{l}\text { Exact Sig. } \\
\text { (2-sided) }\end{array}$ & $\begin{array}{c}\text { Exact Sig. } \\
\text { (1-sided) }\end{array}$ & $\begin{array}{c}\text { Point } \\
\text { Probability }\end{array}$ \\
\hline Pearson Chi-Square & $26.328^{a}$ & 2 & .000 & .037 & & \\
\hline Likelihood Ratio & 6.775 & 2 & .034 & .037 & & \\
\hline Fisher's Exact Test & 8.032 & & & .037 & & \\
\hline Linear-by-Linear & $10.174^{b}$ & 1 & .001 & .037 & .037 & .037 \\
\hline \multicolumn{7}{|l|}{ Association } \\
\hline $\mathrm{N}$ of Valid Cases & 163 & & & & & \\
\hline
\end{tabular}

a. 3 cells $(50.0 \%)$ have expected count less than 5 . The minimum expected count is .04 .

b. The standardized statistic is 3.190 .

Symmetric Measures

\begin{tabular}{llccc}
\hline & & Value & Approx. Sig. & Exact Sig. \\
\hline Nominal by Nominal & Phi & .402 & .000 & .037 \\
& Cramer's V & .402 & .000 & .037 \\
N of Valid Cases & & 163 & & \\
\hline
\end{tabular}


Crosstab H9-1 Procurement management plan * Stakeholder satisfaction

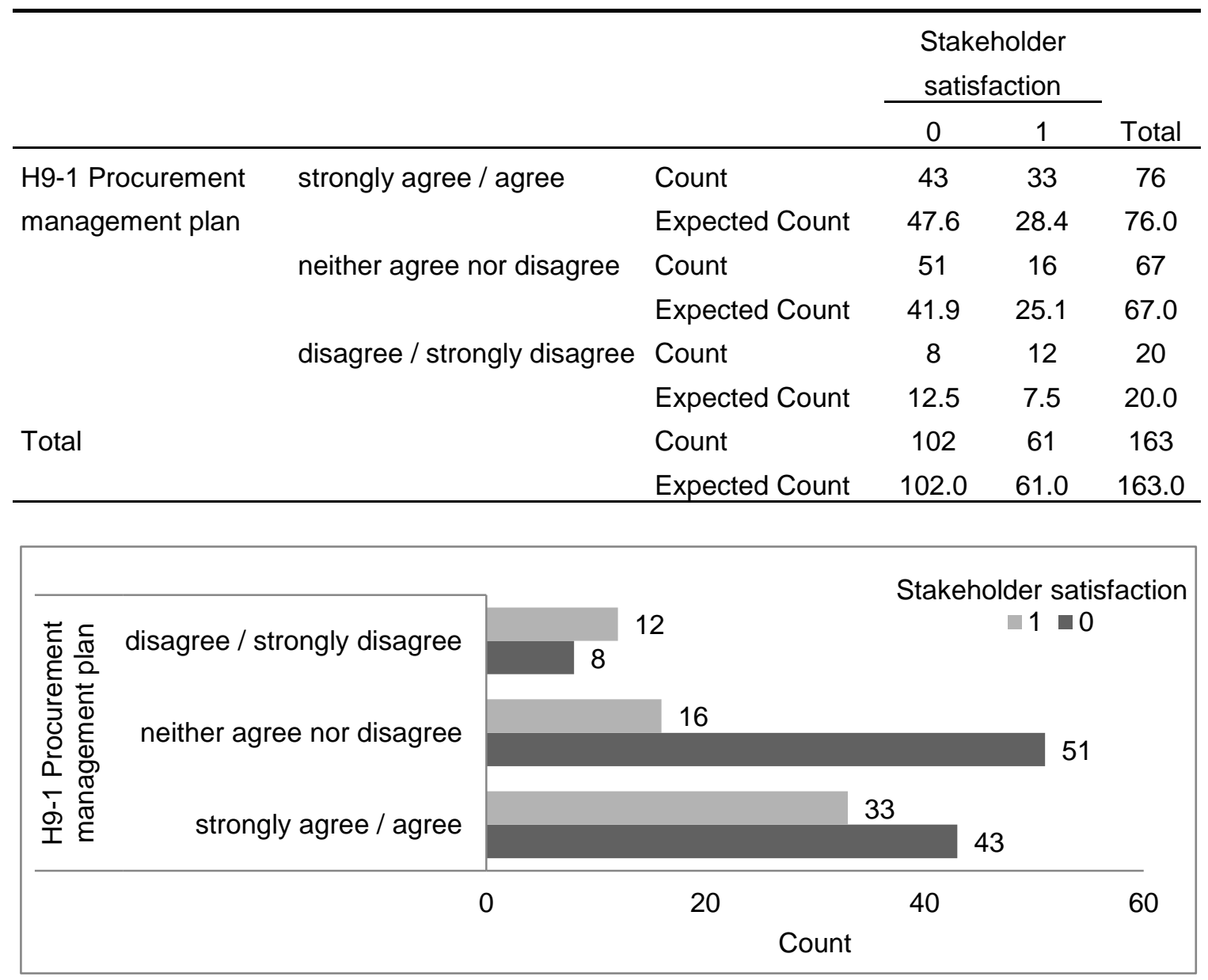

Chi-Square Tests

\begin{tabular}{lcccccc}
\hline & Value & df & $\begin{array}{c}\text { Asymp. Sig. } \\
\text { (2-sided) }\end{array}$ & $\begin{array}{c}\text { Exact Sig. } \\
\text { (2-sided) }\end{array}$ & $\begin{array}{c}\text { Exact Sig. } \\
\text { (1-sided) }\end{array}$ & $\begin{array}{c}\text { Point } \\
\text { Probability }\end{array}$ \\
\hline Pearson Chi-Square & $\mathbf{1 0 . 7 6 \mathbf { 8 } ^ { \mathrm { a } }}$ & 2 & .005 & .004 & & \\
Likelihood Ratio & 10.923 & 2 & .004 & .005 & & \\
Fisher's Exact Test & 10.783 & & & .005 & & .093 \\
Linear-by-Linear & $.000^{\mathrm{b}}$ & 1 & .992 & 1.000 & .544 & \\
Association & & & & & & \\
N of Valid Cases & 163 & & & & & \\
\hline
\end{tabular}

a. 0 cells $(0.0 \%)$ have expected count less than 5 . The minimum expected count is 7.48 .

b. The standardized statistic is -.010 .

Symmetric Measures

\begin{tabular}{llccc}
\hline & & Value & Approx. Sig. & Exact Sig. \\
\hline Nominal by Nominal & Phi & .257 & .005 & .004 \\
& Cramer's V & .257 & .005 & .004 \\
N of Valid Cases & & 163 & & \\
\hline
\end{tabular}




\section{Crosstab H9-2 Contract statement of work * Technical Objectives}

\begin{tabular}{lllccc}
\hline & & & \multicolumn{2}{c}{ Technical objectives } & \\
\cline { 3 - 4 } & & & 0 & 1 & Total \\
\hline H9-2 Contract & strongly agree / agree & Count & 71 & 31 & 102 \\
statement of work & & Expected Count & 78.8 & 23.2 & 102.0 \\
& \multirow{2}{*}{ neither agree nor disagree } & Count & 45 & 6 & 51 \\
& & Expected Count & 39.4 & 11.6 & 51.0 \\
& disagree / strongly & Count & 10 & 0 & 10 \\
& disagree & Expected Count & 7.7 & 2.3 & 10.0 \\
Total & & Count & 126 & 37 & 163 \\
& & Expected Count & 126.0 & 37.0 & 163.0 \\
\hline
\end{tabular}

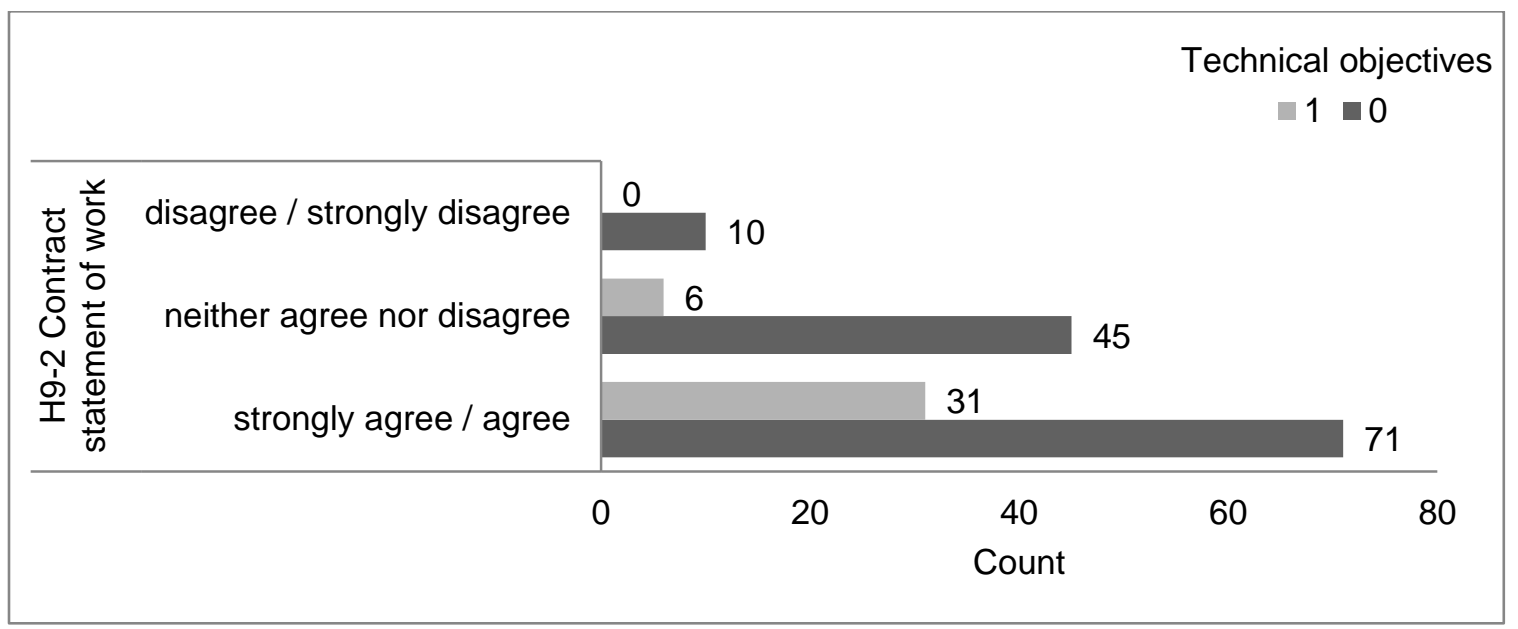

\section{Chi-Square Tests}

\begin{tabular}{lcccccc}
\hline & \multicolumn{7}{c}{$\begin{array}{c}\text { Asymp. Sig. } \\
\text { Value }\end{array}$} & $\begin{array}{c}\text { Exact Sig. } \\
\text { (2-sided) }\end{array}$ & $\begin{array}{c}\text { Exact Sig. } \\
(2 \text {-sided })\end{array}$ & $\begin{array}{c}\text { Point } \\
\text { (1-sided) }\end{array}$ & Probability \\
\hline Pearson Chi-Square & $9.852^{\mathrm{a}}$ & 2 & .007 & .007 & & \\
Likelihood Ratio & 12.379 & 2 & .002 & .002 & & \\
Fisher's Exact Test & 9.671 & & & .006 & & \\
Linear-by-Linear & $9.650^{\mathrm{b}}$ & 1 & .002 & .002 & .001 & .001 \\
Association & & & & & & \\
N of Valid Cases & 163 & & & & & \\
\hline
\end{tabular}

a. 1 cells $(16.7 \%)$ have expected count less than 5 . The minimum expected count is 2.27.

b. The standardized statistic is -3.106 .

Symmetric Measures

\begin{tabular}{llccc}
\hline & & Value & Approx. Sig. & Exact Sig. \\
\hline Nominal by Nominal & Phi & .246 & .007 & .007 \\
& Cramer's V & .246 & .007 & .007 \\
N of Valid Cases & & 163 & & \\
\hline
\end{tabular}


Crosstab H9-2 Contract statement of work * Scope

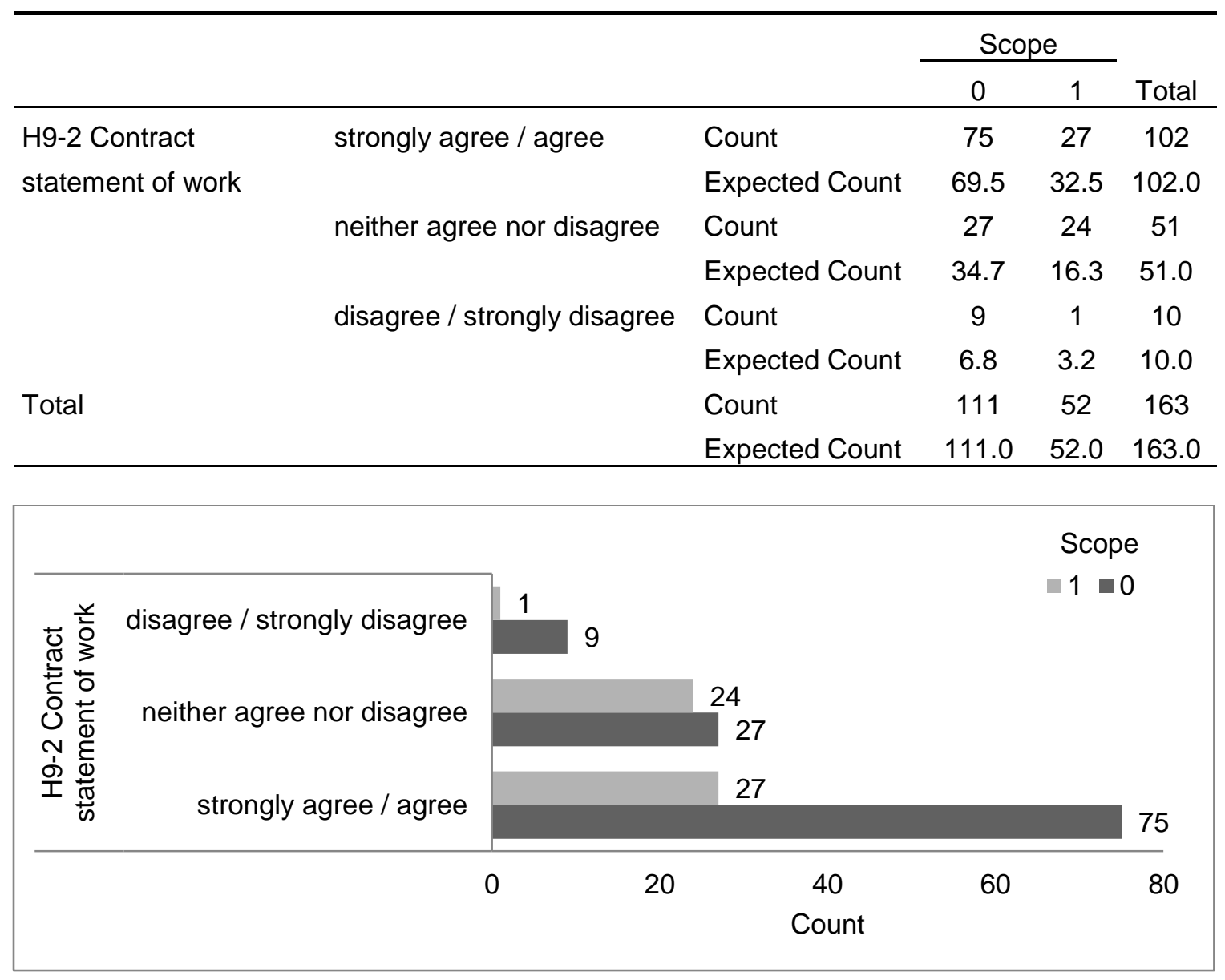

Chi-Square Tests

\begin{tabular}{lcccccc}
\hline & Value & df & $\begin{array}{c}\text { Asymp. Sig. } \\
(2 \text {-sided })\end{array}$ & $\begin{array}{c}\text { Exact Sig. } \\
(2 \text {-sided })\end{array}$ & $\begin{array}{c}\text { Exact Sig. } \\
(1-\text {-sided })\end{array}$ & $\begin{array}{c}\text { Point } \\
\text { Probability }\end{array}$ \\
\hline Pearson Chi-Square & $\mathbf{8 . 9 8 6 ^ { \mathrm { a } }}$ & 2 & .011 & .011 & & \\
Likelihood Ratio & 9.195 & 2 & .010 & .014 & & \\
Fisher's Exact Test & 8.518 & & & .012 & & \\
Linear-by-Linear & $.854^{\mathrm{b}}$ & 1 & .355 & .408 & .215 & .070 \\
Association & & & & & & \\
N of Valid Cases & 163 & & & & & \\
\hline
\end{tabular}

a. 1 cells (16.7\%) have expected count less than 5 . The minimum expected count is 3.19 .

b. The standardized statistic is .924 .

Symmetric Measures

\begin{tabular}{llccc}
\hline & & Value & Approx. Sig. & Exact Sig. \\
\hline Nominal by Nominal & Phi & .235 & .011 & .011 \\
& Cramer's V & .235 & .011 & .011 \\
N of Valid Cases & & 163.000 & & \\
\hline
\end{tabular}


Crosstab H9-3 Make-or-buy decisions * Commercial benefit for customer

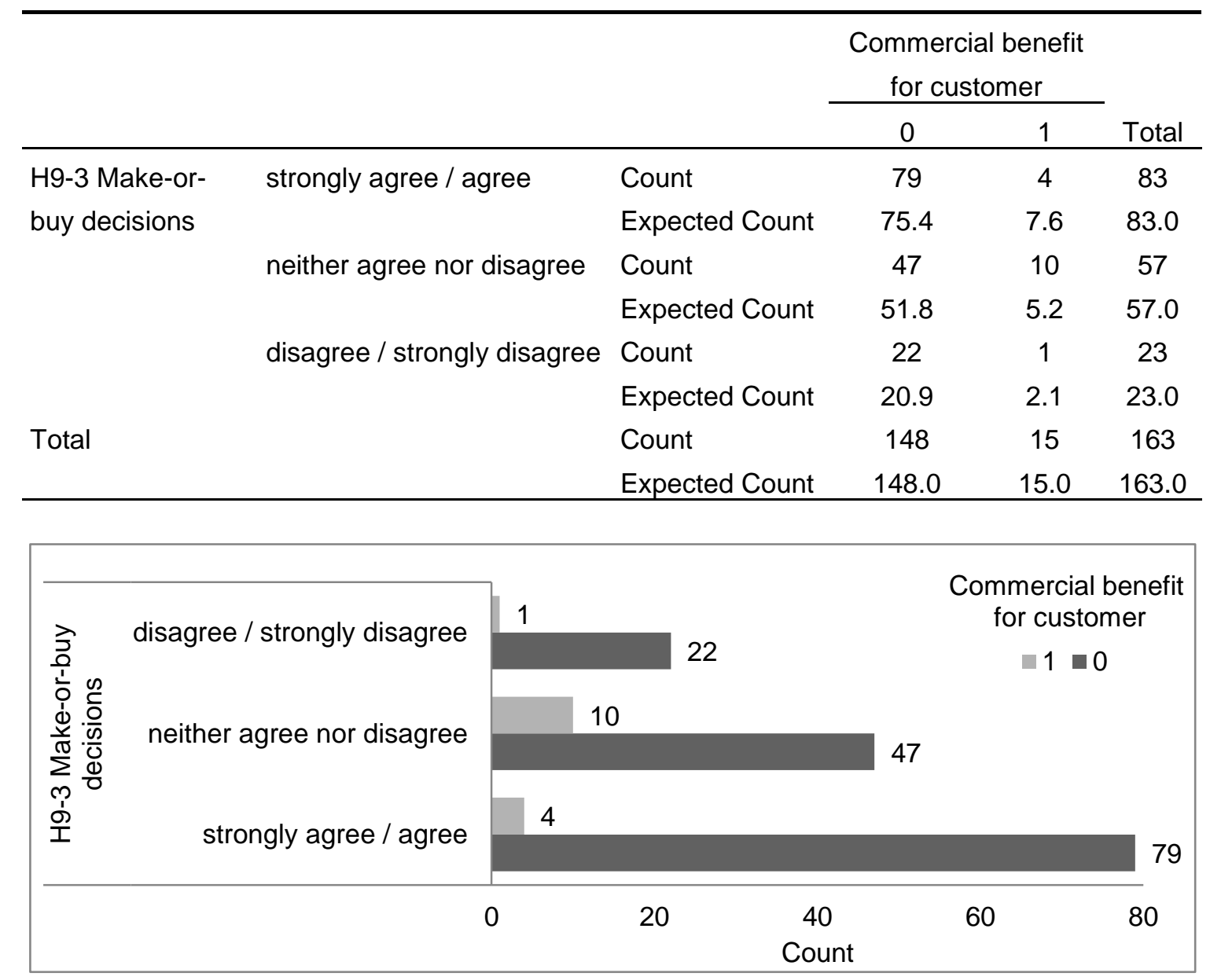

Chi-Square Tests

\begin{tabular}{lcccccc}
\hline & Value & df & $\begin{array}{c}\text { Asymp. Sig. } \\
\text { (2-sided) }\end{array}$ & $\begin{array}{c}\text { Exact Sig. } \\
\text { (2-sided) }\end{array}$ & $\begin{array}{c}\text { Exact Sig. } \\
\text { (1-sided) }\end{array}$ & $\begin{array}{c}\text { Point } \\
\text { Probability }\end{array}$ \\
\hline Pearson Chi-Square & $\mathbf{7 . 3 0 4 ^ { \mathrm { a } }}$ & 2 & .026 & .025 & & \\
Likelihood Ratio & 6.913 & 2 & .032 & .042 & & \\
Fisher's Exact Test & 6.374 & & & .037 & & .092 \\
Linear-by-Linear & $.901^{\mathrm{b}}$ & 1 & .342 & .351 & .221 & \\
Association & & & & & & \\
N of Valid Cases & 163 & & & & & \\
\hline
\end{tabular}

a. 1 cells $(16.7 \%)$ have expected count less than 5 . The minimum expected count is 2.12 .

b. The standardized statistic is .949 .

\begin{tabular}{llccc}
\hline \multicolumn{5}{c}{ Symmetric Measures } \\
\hline Nominal by Nominal & Phi & Value & Approx. Sig. & Exact Sig. \\
& Cramer's V & .212 & .026 & .025 \\
N of Valid Cases & & .212 & .026 & .025 \\
\hline
\end{tabular}




\section{Crosstab H9-4 Procurement documents * Project team satisfaction}

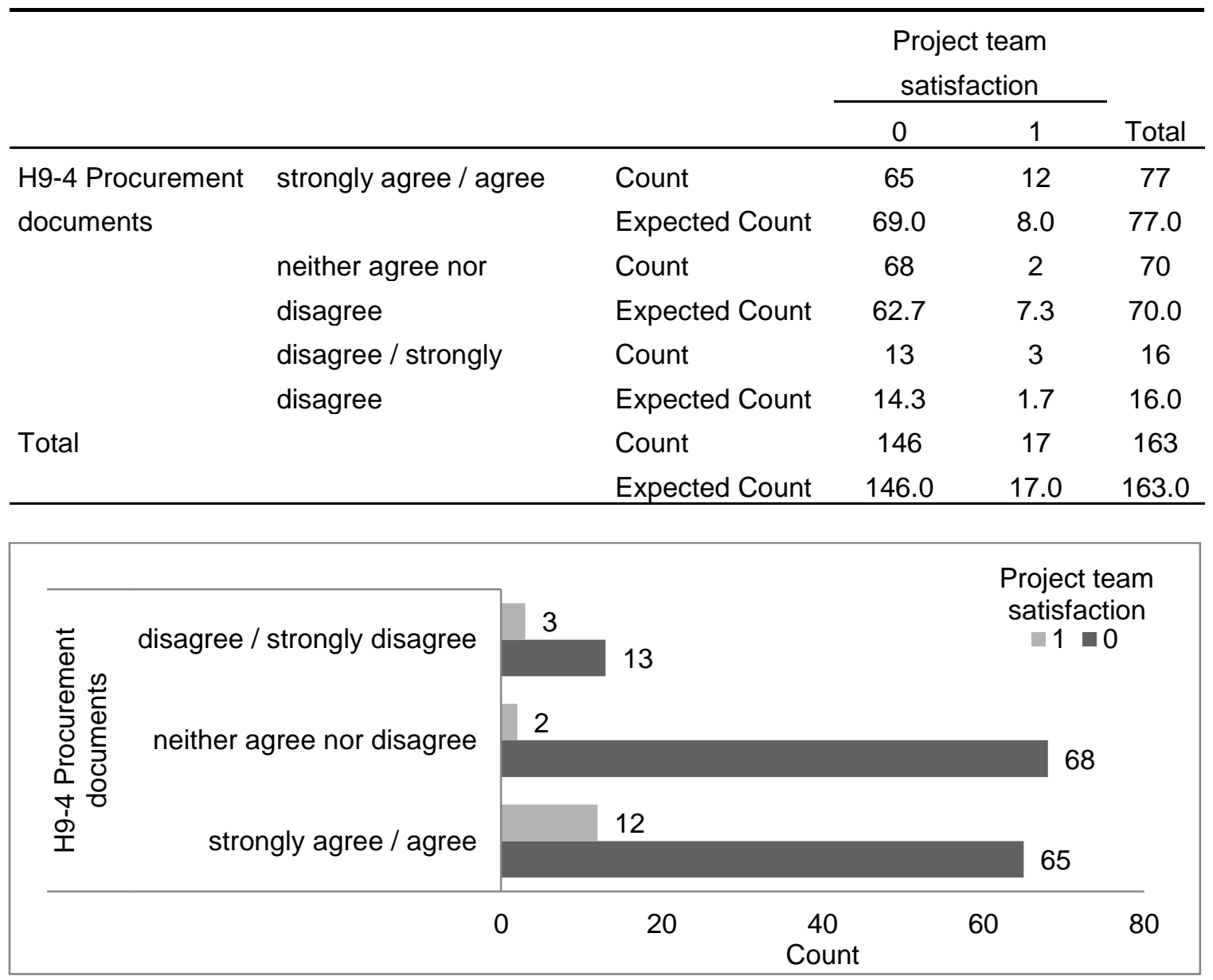

Chi-Square Tests

\begin{tabular}{lcccccc}
\hline & Value & df & $\begin{array}{c}\text { Asymp. Sig. } \\
\text { (2-sided) }\end{array}$ & $\begin{array}{c}\text { Exact Sig. } \\
(2-\text {-sided })\end{array}$ & $\begin{array}{c}\text { Exact Sig. } \\
\text { (1-sided) }\end{array}$ & $\begin{array}{c}\text { Point } \\
\text { Probability }\end{array}$ \\
\hline Pearson Chi-Square & $7.673^{\mathrm{a}}$ & 2 & .022 & .025 & & \\
Likelihood Ratio & 8.776 & 2 & .012 & .013 & & \\
Fisher's Exact Test & 8.539 & & & .009 & & \\
Linear-by-Linear & $1.055^{\mathrm{b}}$ & 1 & .304 & .338 & .205 & .096 \\
Association & & & & & & \\
N of Valid Cases & 163 & & & & & \\
\hline
\end{tabular}

a. 1 cells (16.7\%) have expected count less than 5 . The minimum expected count is 1.67 .

b. The standardized statistic is -1.027 .

Symmetric Measures

\begin{tabular}{llccc}
\hline & & Value & Approx. Sig. & Exact Sig. \\
\hline Nominal by Nominal & Phi & .217 & .022 & .025 \\
& Cramer's V & .217 & .022 & .025 \\
N of Valid Cases & & 163 & & \\
\hline
\end{tabular}




\section{Crosstab H9-5 Supplier evaluation criteria * Project team satisfaction}

\begin{tabular}{lllccc}
\hline & & & \multicolumn{2}{c}{ Project team } & \\
& & & \multicolumn{2}{c}{ satisfaction } & \\
\cline { 3 - 5 } & & & 0 & 1 & Total \\
\hline H9-5 Supplier & \multirow{2}{*}{ strongly agree / agree } & Count & 65 & 12 & 77 \\
evaluation criteria & & Expected Count & 69.0 & 8.0 & 77.0 \\
& \multirow{2}{*}{ neither agree nor disagree } & Count & 64 & 2 & 66 \\
& & Expected Count & 59.1 & 6.9 & 66.0 \\
& \multirow{2}{*}{ disagree / strongly disagree } & Count & 17 & 3 & 20 \\
& & Expected Count & 17.9 & 2.1 & 20.0 \\
& & Count & 146 & 17 & 163 \\
& & & 146.0 & 17.0 & 163.0 \\
\hline
\end{tabular}

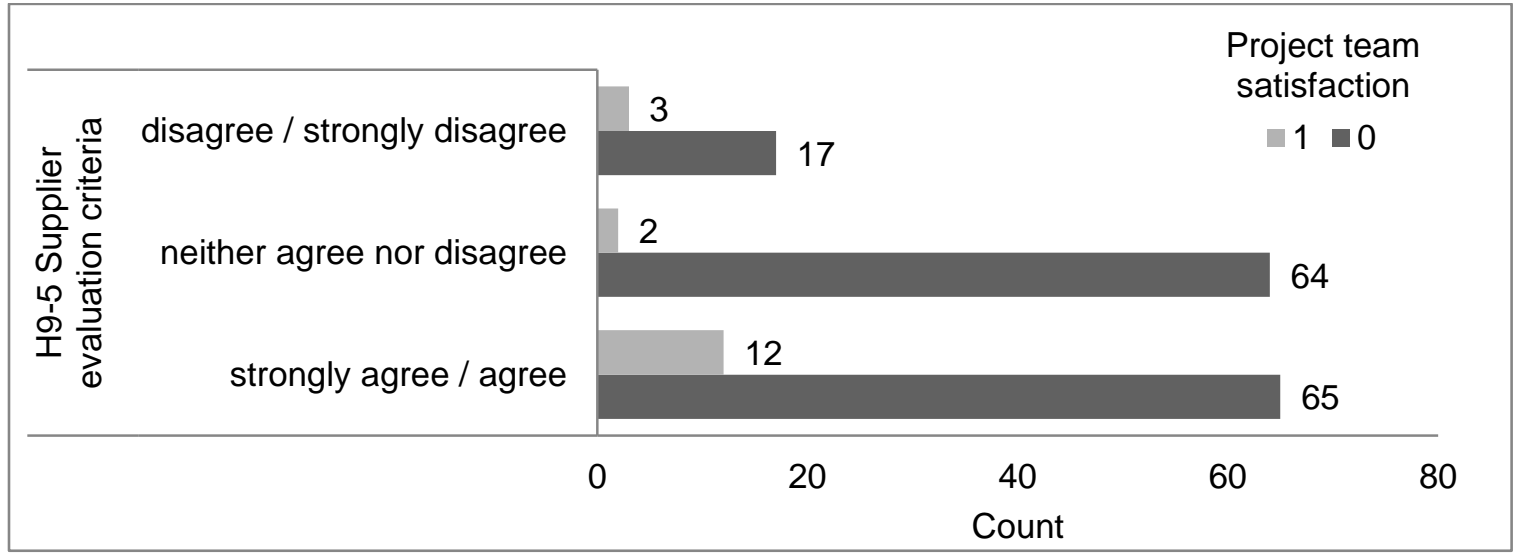

\section{Chi-Square Tests}

\begin{tabular}{|c|c|c|c|c|c|c|}
\hline & Value & $\mathrm{df}$ & $\begin{array}{c}\text { Asymp. Sig. } \\
\text { (2-sided) }\end{array}$ & $\begin{array}{c}\text { Exact Sig. } \\
\text { (2-sided) }\end{array}$ & $\begin{array}{c}\text { Exact Sig. } \\
\text { (1-sided) }\end{array}$ & $\begin{array}{c}\text { Point } \\
\text { Probability }\end{array}$ \\
\hline Pearson Chi-Square & $6.506^{\mathrm{a}}$ & 2 & .039 & .041 & & \\
\hline Likelihood Ratio & 7.549 & 2 & .023 & .022 & & \\
\hline Fisher's Exact Test & 7.190 & & & .025 & & \\
\hline Linear-by-Linear & $1.289^{b}$ & 1 & .256 & .274 & .172 & .082 \\
\hline \multicolumn{7}{|l|}{ Association } \\
\hline $\mathrm{N}$ of Valid Cases & 163 & & & & & \\
\hline
\end{tabular}
a. 1 cells $(16.7 \%)$ have expected count less than 5 . The minimum expected count is 2.09 .

b. The standardized statistic is -1.135 .

Symmetric Measures

\begin{tabular}{llccc}
\hline & & Value & Approx. Sig. & Exact Sig. \\
\hline Nominal by Nominal & Phi & .200 & .039 & .041 \\
& Cramer's V & .200 & .039 & .041 \\
N of Valid Cases & & 163 & & \\
\hline
\end{tabular}




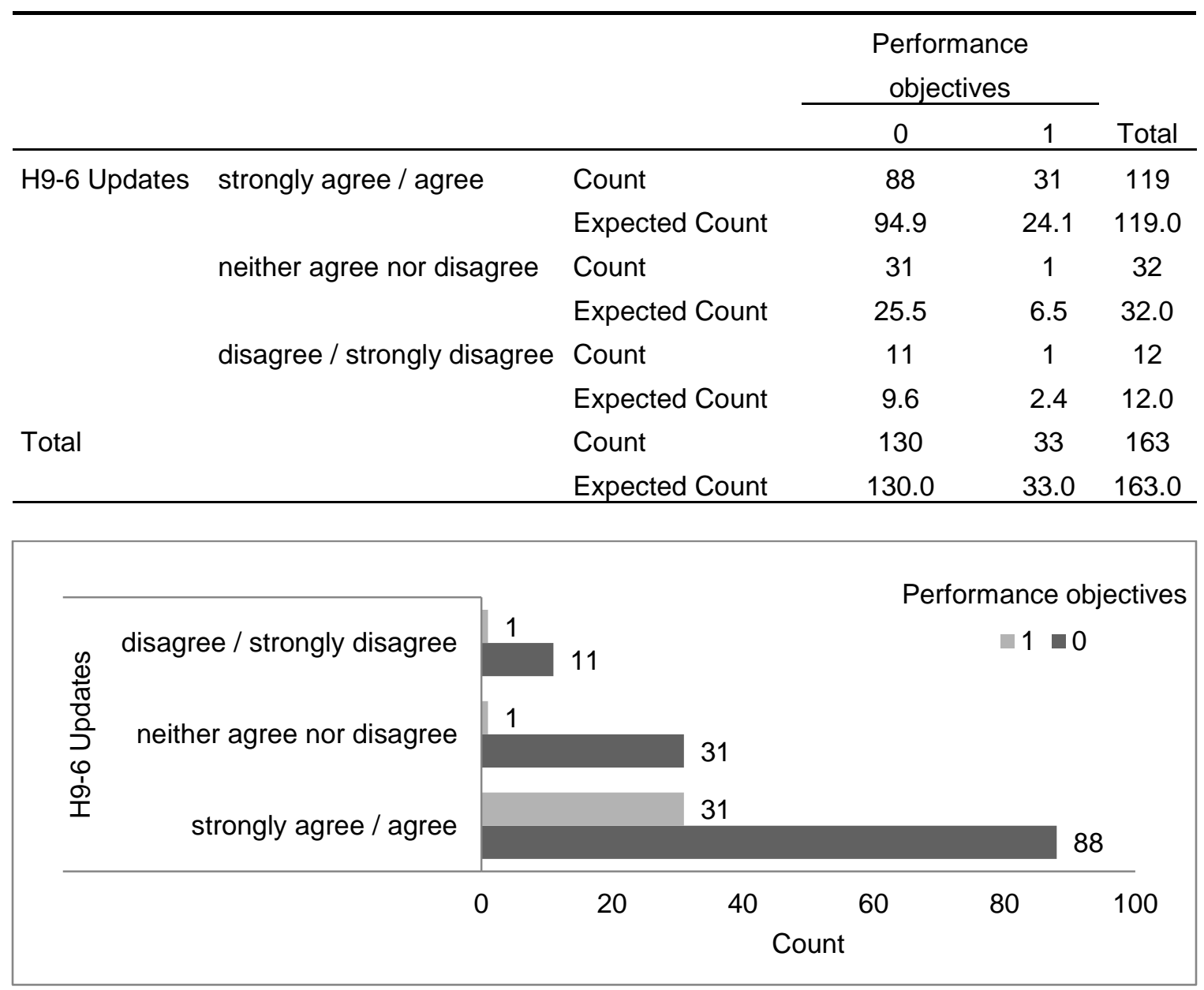

\begin{tabular}{lcccccc} 
& \multicolumn{7}{c}{ Chi-Square Tests } \\
& Value & df & $\begin{array}{c}\text { Asymp. Sig. } \\
(2-\text {-sided) }\end{array}$ & $\begin{array}{c}\text { Exact Sig. } \\
(2-s i d e d)\end{array}$ & $\begin{array}{c}\text { Exact Sig. } \\
\text { (1-sided) }\end{array}$ & $\begin{array}{c}\text { Point } \\
\text { Probability }\end{array}$ \\
\hline Pearson Chi-Square & $\mathbf{9 . 3 4 7 ^ { \mathrm { a } }}$ & 2 & .009 & .010 & & \\
Likelihood Ratio & 11.937 & 2 & .003 & .003 & & \\
Fisher's Exact Test & 10.018 & & & .004 & .002 \\
Linear-by-Linear & $7.042^{\mathrm{b}}$ & 1 & .008 & .009 & .003 & \\
Association & & & & & & \\
N of Valid Cases & 163 & & & & & \\
\hline
\end{tabular}

a. 1 cells $(16,7 \%)$ have expected count less than 5 . The minimum expected count is 2,43 .

b. The standardized statistic is $-2,654$.

Symmetric Measures

\begin{tabular}{llccc}
\hline & & Value & Approx. Sig. & Exact Sig. \\
\hline Nominal by Nominal & Phi & .239 & .009 & .010 \\
& Cramer's V & .239 & .009 & .010 \\
N of Valid Cases & & 163 & & \\
\hline
\end{tabular}


Crosstab H9-7 Procurement document package * Scope

\begin{tabular}{|c|c|c|c|c|c|}
\hline & & & \multicolumn{2}{|c|}{ Scope } & \multirow[b]{2}{*}{ Total } \\
\hline & & & 0 & 1 & \\
\hline H9-7 Procurement & strongly agree / agree & Count & 38 & 11 & 49 \\
\hline \multirow[t]{5}{*}{ document package } & & Expected Count & 33.4 & 15.6 & 49.0 \\
\hline & neither agree nor disagree & Count & 60 & 25 & 85 \\
\hline & & Expected Count & 57.9 & 27.1 & 85.0 \\
\hline & disagree / strongly & Count & 13 & 16 & 29 \\
\hline & disagree & Expected Count & 19.7 & 9.3 & 29.0 \\
\hline \multirow[t]{2}{*}{ Total } & & Count & 111 & 52 & 163 \\
\hline & & Expected Count & 111.0 & 52.0 & 163.0 \\
\hline
\end{tabular}

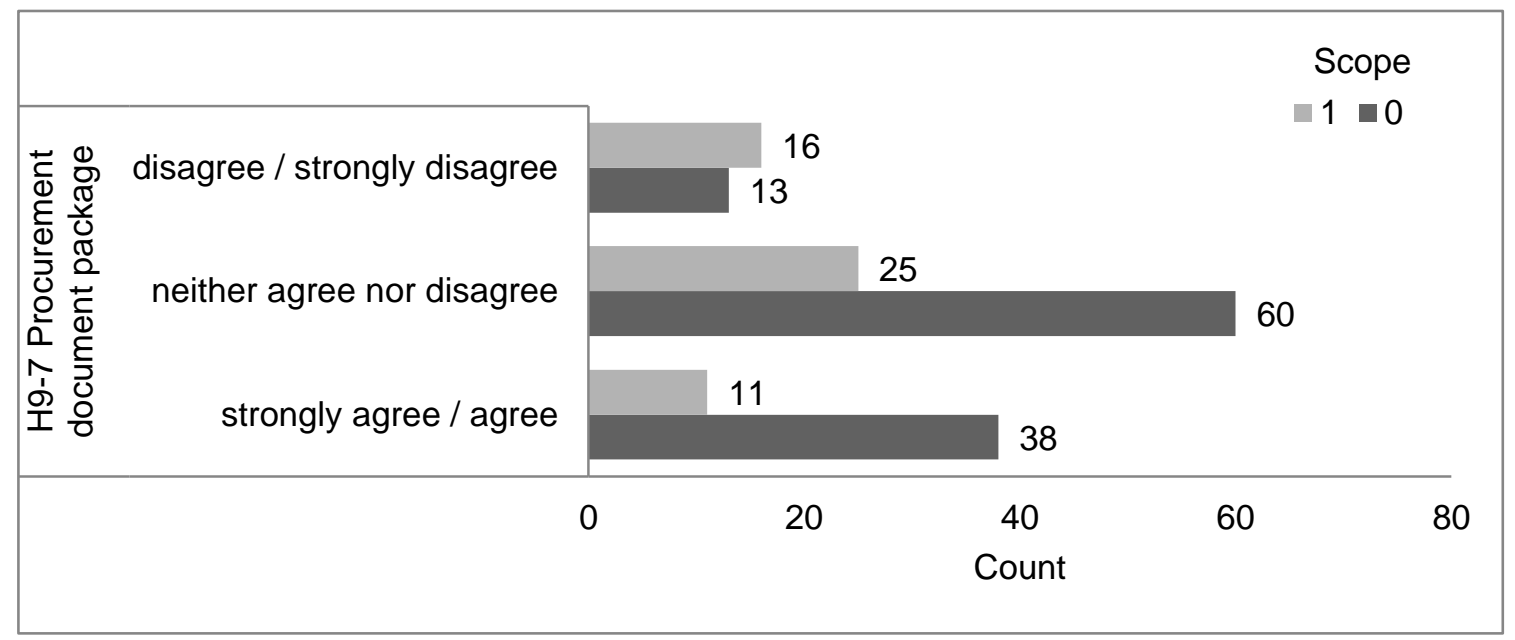

\section{Chi-Square Tests}

\begin{tabular}{lcccccc}
\hline & \multicolumn{7}{c}{$\begin{array}{c}\text { Asymp. Sig. } \\
\text { (2-sided) }\end{array}$} & $\begin{array}{c}\text { Exact Sig. } \\
\text { (2-sided) }\end{array}$ & $\begin{array}{c}\text { Exact Sig. } \\
\text { 1-sided) }\end{array}$ & $\begin{array}{c}\text { Point } \\
\text { Probability }\end{array}$ \\
\hline Pearson Chi-Square & $\mathbf{9 . 4 8 7 ^ { \mathrm { a } }}$ & 2 & .009 & .009 & & \\
Likelihood Ratio & 9.052 & 2 & .011 & .012 & & \\
Fisher's Exact Test & 8.952 & & & .011 & & .002 \\
Linear-by-Linear & $7.843^{\mathrm{b}}$ & 1 & .005 & .006 & .004 & \\
Association & & & & & & \\
N of Valid Cases & 163 & & & & & \\
\hline
\end{tabular}

a. 0 cells $(0.0 \%)$ have expected count less than 5 . The minimum expected count is 9.25 .

b. The standardized statistic is 2.801 .

Symmetric Measures

\begin{tabular}{llccc}
\hline & & Value & Approx. Sig. & Exact Sig. \\
\hline Nominal by Nominal & Phi & .241 & .009 & .009 \\
& Cramer's V & .241 & .009 & .009 \\
N of Valid Cases & & 163 & & \\
\hline
\end{tabular}




\begin{tabular}{lllccc}
\hline & & \multicolumn{2}{c}{$\begin{array}{c}\text { Commercial benefit } \\
\text { for contractors }\end{array}$} \\
\cline { 3 - 5 } & & & 0 & 1 & Total \\
\hline H9-8 Proposals & \multirow{2}{*}{ strongly agree / agree } & Count & 74 & 1 & 75 \\
& & Expected Count & 73.6 & 1.4 & 75.0 \\
& \multirow{2}{*}{ neither agree nor disagree } & Count & 72 & 0 & 72 \\
& & Expected Count & 70.7 & 1.3 & 72.0 \\
& disagree / strongly & Count & 14 & 2 & 16 \\
& disagree & Expected Count & 15.7 & .3 & 16.0 \\
& & Count & 160 & 3 & 163 \\
& & Expected Count & 160.0 & 3.0 & 163.0 \\
\hline
\end{tabular}

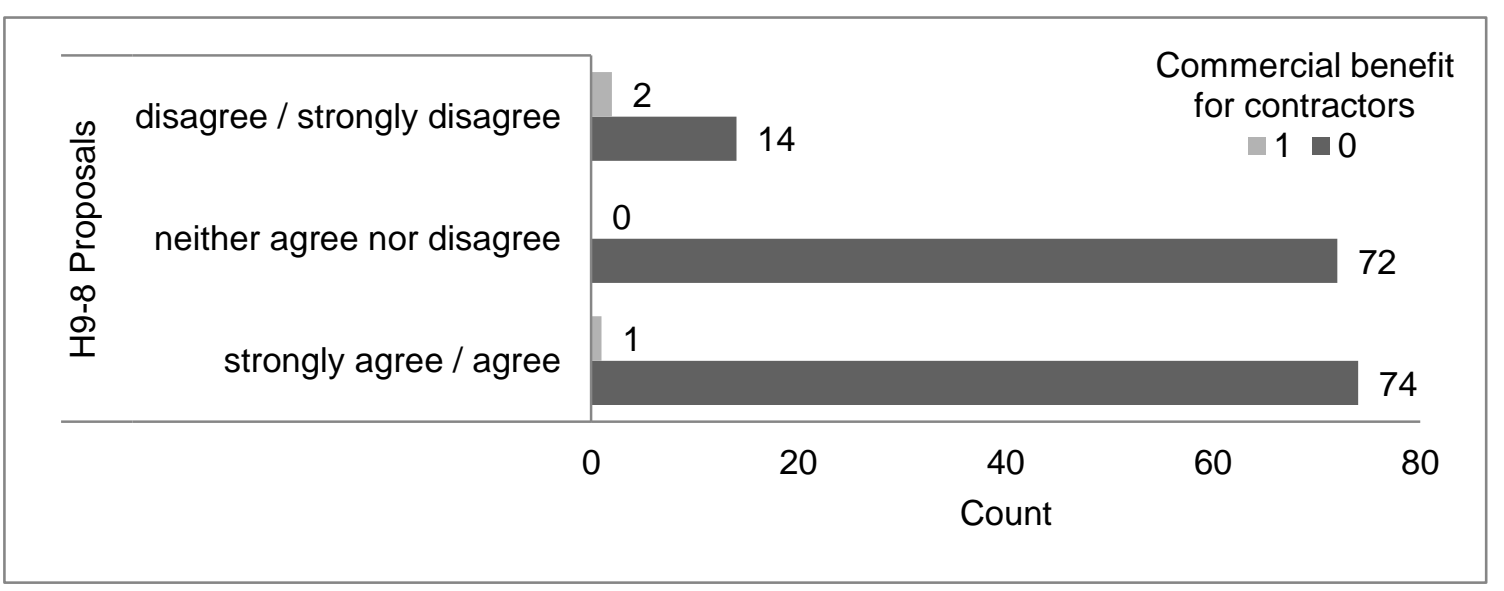

\section{Chi-Square Tests}

\begin{tabular}{lcccccc}
\hline & Value & df & $\begin{array}{c}\text { Asymp. Sig. } \\
\text { (2-sided) }\end{array}$ & $\begin{array}{c}\text { Exact Sig. } \\
(2-s i d e d)\end{array}$ & $\begin{array}{c}\text { Exact Sig. } \\
\text { (1-sided) }\end{array}$ & $\begin{array}{c}\text { Point } \\
\text { Probability }\end{array}$ \\
\hline Pearson Chi-Square & $11.520^{\mathrm{a}}$ & 2 & .003 & .026 & & \\
Likelihood Ratio & 7.237 & 2 & .027 & .026 & & \\
Fisher's Exact Test & 6.811 & & & .026 & & .070 \\
Linear-by-Linear & $3.437^{\mathrm{b}}$ & 1 & .064 & .083 & .083 & \\
Association & & & & & & \\
N of Valid Cases & 163 & & & & & \\
\hline
\end{tabular}

a. 3 cells $(50.0 \%)$ have expected count less than 5 . The minimum expected count is 29 .

b. The standardized statistic is 1.854 .

Symmetric Measures

\begin{tabular}{llccc}
\hline & & Value & Approx. Sig. & Exact Sig. \\
\hline Nominal by Nominal & Phi & .266 & .003 & .026 \\
& Cramer's V & .266 & .003 & .026 \\
N of Valid Cases & & 163 & & \\
\hline
\end{tabular}


Crosstab H9-11 Contract management plan * User satisfaction

\begin{tabular}{lllccc}
\hline & & & \multicolumn{2}{c}{ User satisfaction } & \\
\cline { 3 - 4 } & & & 0 & 1 & Total \\
\hline H9-11 Contract & strongly agree / agree & Count & 55 & 12 & 67 \\
management plan & & Expected Count & 56.7 & 10.3 & 67.0 \\
& neither agree nor & Count & 65 & 6 & 71 \\
& disagree & Expected Count & 60.1 & 10.9 & 71.0 \\
& disagree / strongly & Count & 18 & 7 & 25 \\
& disagree & Expected Count & 21.2 & 3.8 & 25.0 \\
& & Count & 138 & 25 & 163 \\
& & Expected Count & 138.0 & 25.0 & 163.0 \\
\hline
\end{tabular}

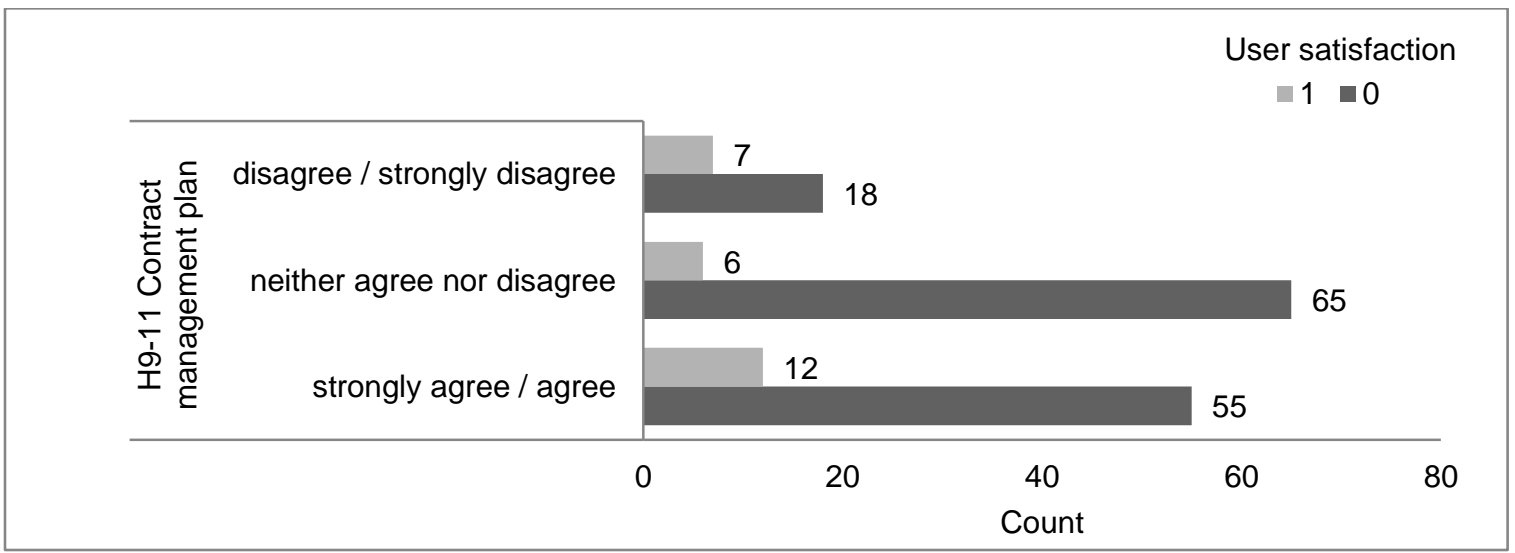

\section{Chi-Square Tests}

\begin{tabular}{|c|c|c|c|c|c|c|}
\hline & Value & df & $\begin{array}{c}\text { Asymp. Sig. } \\
\text { (2-sided) }\end{array}$ & $\begin{array}{l}\text { Exact Sig. } \\
\text { (2-sided) }\end{array}$ & $\begin{array}{c}\text { Exact Sig. } \\
\text { (1-sided) }\end{array}$ & $\begin{array}{c}\text { Point } \\
\text { Probability } \\
\end{array}$ \\
\hline Pearson Chi-Square & $6.022^{a}$ & 2 & .049 & .052 & & \\
\hline Likelihood Ratio & 5.936 & 2 & .051 & .058 & & \\
\hline Fisher's Exact Test & 6.044 & & & .050 & & \\
\hline Linear-by-Linear & $.196^{b}$ & 1 & .658 & .759 & .383 & .109 \\
\hline \multicolumn{7}{|l|}{ Association } \\
\hline $\mathrm{N}$ of Valid Cases & 163 & & & & & \\
\hline
\end{tabular}

a. 1 cells $(16.7 \%)$ have expected count less than 5 . The minimum expected count is 3.83 .

b. The standardized statistic is .443 .

Symmetric Measures

\begin{tabular}{llccc}
\hline & & Value & Approx. Sig. & Exact Sig. \\
\hline Nominal by Nominal & Phi & .192 & .049 & .052 \\
& Cramer's V & .192 & .049 & .052 \\
N of Valid Cases & & 163 & & \\
\hline
\end{tabular}


Crosstab H9-12 Procurement management plan (update) * Customer satisfaction

\begin{tabular}{lllccc}
\hline & & & & & \\
& & & \multicolumn{2}{c}{ Customer satisfaction } & \\
\cline { 3 - 5 } & & & 0 & 1 & Total \\
\hline H9-12 Procurement & strongly agree / agree & Count & 18 & 49 & 67 \\
management plan & & Expected Count & 28.0 & 39.0 & 67.0 \\
(update) & neither agree nor & Count & 38 & 35 & 73 \\
& disagree & Expected Count & 30.5 & 42.5 & 73.0 \\
& disagree / strongly & Count & 12 & 11 & 23 \\
& disagree & Expected Count & 9.6 & 13.4 & 23.0 \\
Total & & Count & 68 & 95 & 163 \\
& & Expected Count & 68.0 & 95.0 & 163.0 \\
\hline
\end{tabular}

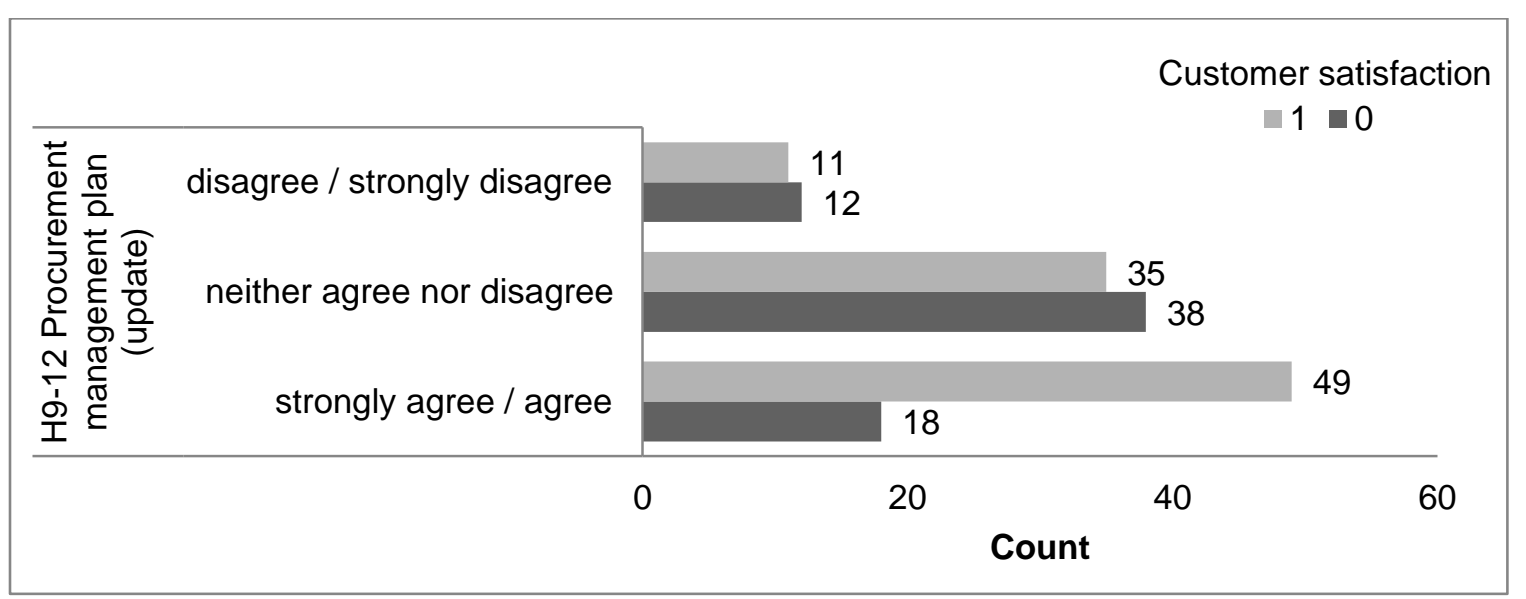

Chi-Square Tests

\begin{tabular}{lcccccc}
\hline & Value & df & $\begin{array}{c}\text { Asymp. Sig. } \\
\text { (2-sided) }\end{array}$ & $\begin{array}{c}\text { Exact Sig. } \\
(2-s i d e d)\end{array}$ & $\begin{array}{c}\text { Exact Sig. } \\
\text { (1-sided) }\end{array}$ & $\begin{array}{c}\text { Point } \\
\text { Probability }\end{array}$ \\
\hline Pearson Chi-Square & $\mathbf{1 0 . 3 2 1 ^ { \mathrm { a } }}$ & 2 & .006 & .005 & & \\
Likelihood Ratio & 10.578 & 2 & .005 & .006 & & \\
Fisher's Exact Test & 10.453 & & & .005 & & .002 \\
Linear-by-Linear & $7.988^{\mathrm{b}}$ & 1 & .005 & .006 & .003 & \\
Association & & & & & & \\
N of Valid Cases & 163 & & & & & \\
\hline
\end{tabular}

a. 0 cells $(0.0 \%)$ have expected count less than 5 . The minimum expected count is 9.60 .

b. The standardized statistic is -2.826 .

Symmetric Measures

\begin{tabular}{llccc}
\hline & & Value & Approx. Sig. & Exact Sig. \\
\hline Nominal by Nominal & Phi & .252 & .006 & .005 \\
& Cramer's V & .252 & .006 & .005 \\
N of Valid Cases & & 163 & & \\
\hline
\end{tabular}


Crosstab H9-12 Procurement management plan (update) * Strategic contribution of the project

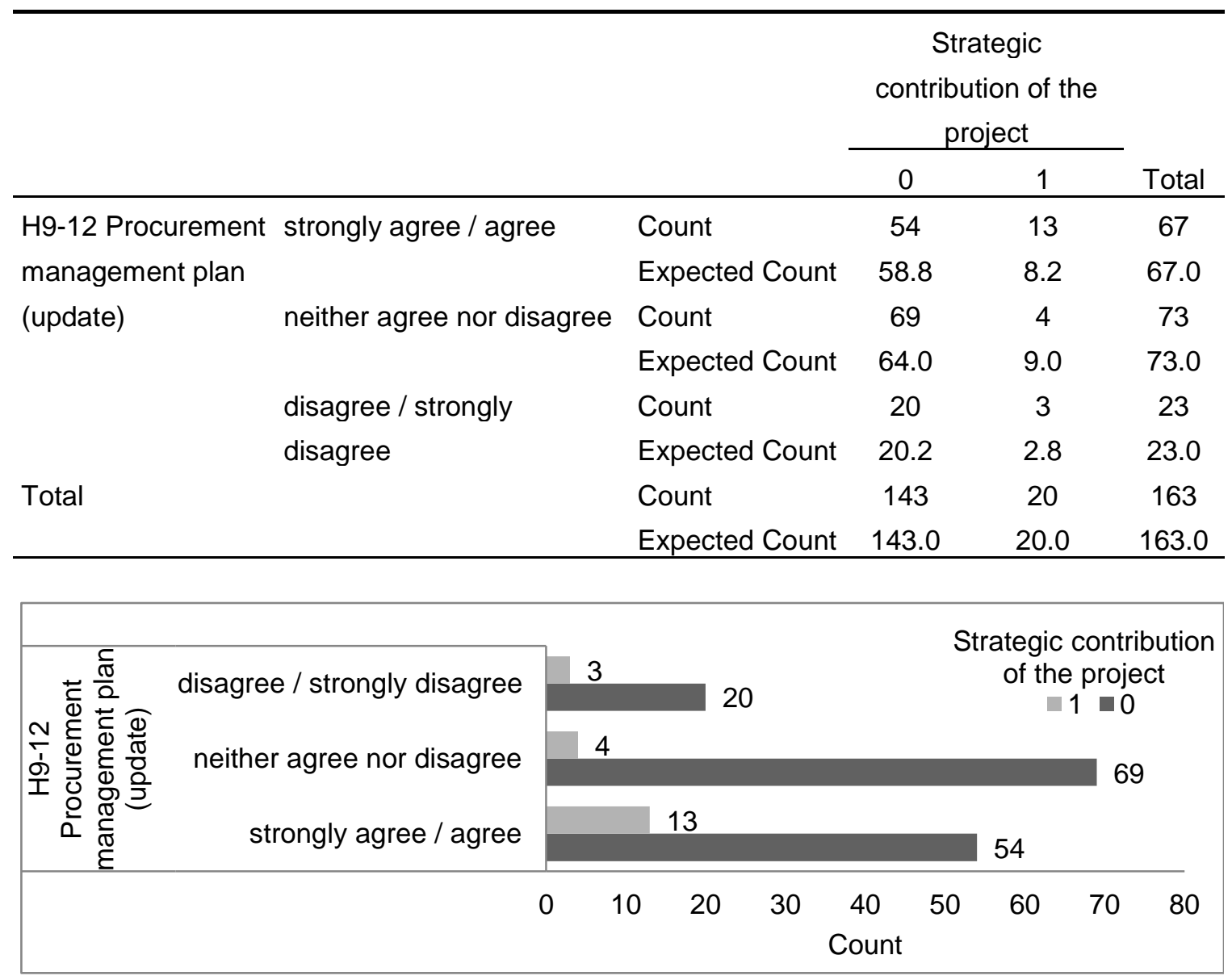

\begin{tabular}{lcccccc}
\hline \multicolumn{7}{c}{ Chi-Square Tests } \\
& Value & df & $\begin{array}{c}\text { Asymp. Sig. } \\
(2-\text {-sided })\end{array}$ & $\begin{array}{c}\text { Exact Sig. } \\
(2-\text {-sided })\end{array}$ & $\begin{array}{c}\text { Exact Sig. } \\
(1-\text {-sided })\end{array}$ & $\begin{array}{c}\text { Point } \\
\text { Probability }\end{array}$ \\
\hline Pearson Chi-Square & $\mathbf{6 . 3 0 7 ^ { \mathrm { a } }}$ & 2 & .043 & .037 & & \\
Likelihood Ratio & 6.608 & 2 & .037 & .052 & & \\
Fisher's Exact Test & 6.405 & & & .039 & .040 \\
Linear-by-Linear & $2.502^{\mathrm{b}}$ & 1 & .114 & .124 & .077 & \\
Association & & & & & & \\
N of Valid Cases & 163 & & & & & \\
\hline
\end{tabular}

a. 1 cells $(16.7 \%)$ have expected count less than 5 . The minimum expected count is 2.82 .

b. The standardized statistic is $-1,582$.

Symmetric Measures

\begin{tabular}{llccc}
\hline & & Value & Approx. Sig. & Exact Sig. \\
\hline Nominal by Nominal & Phi & .197 & .043 & .037 \\
& Cramer's V & .197 & .043 & .037 \\
N of Valid Cases & & 163 & & \\
\hline
\end{tabular}


Crosstab H9-12 Procurement management plan (update) * Commercial benefit for customer

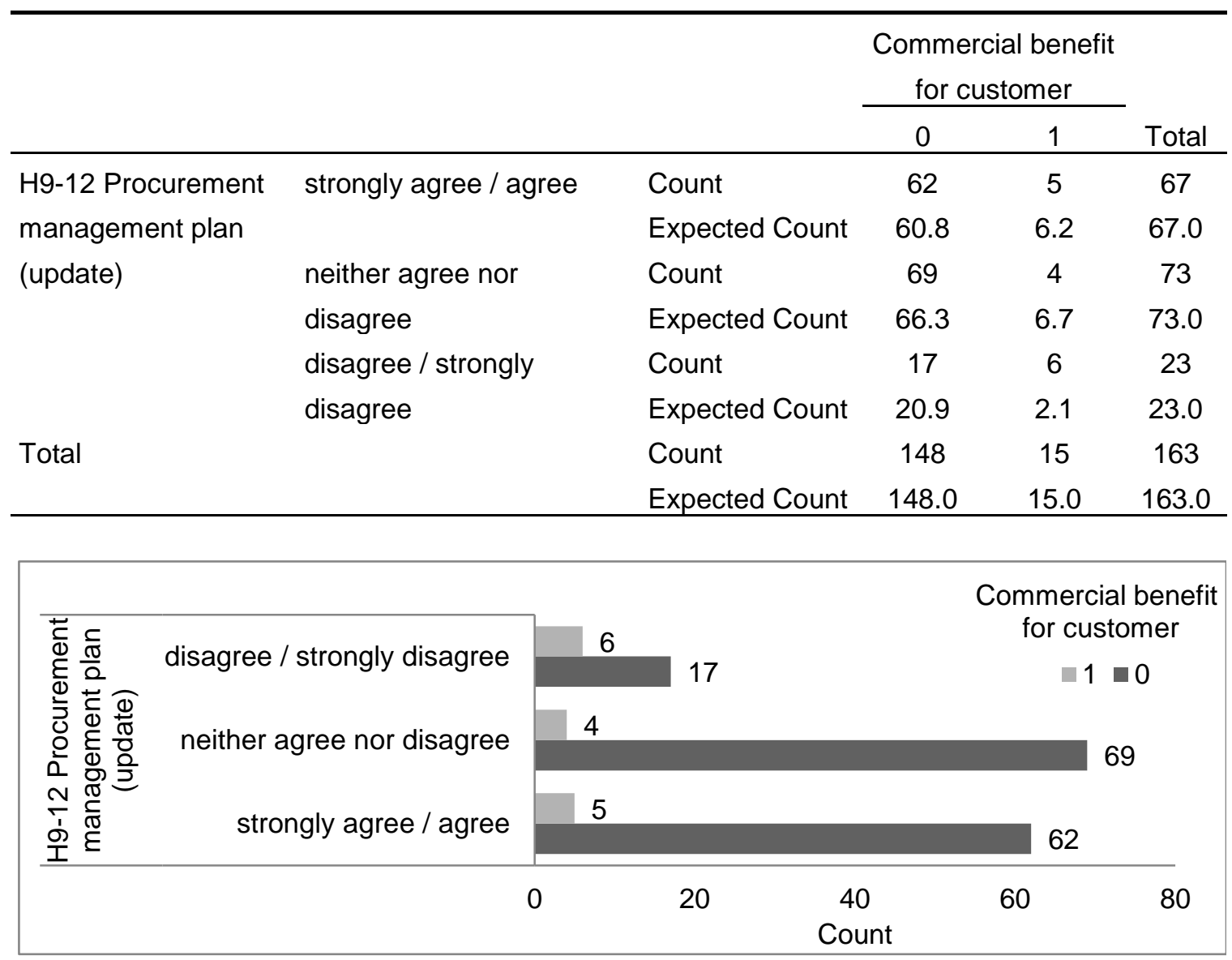

\section{Chi-Square Tests}

\begin{tabular}{|c|c|c|c|c|c|c|}
\hline & Value & df & $\begin{array}{c}\text { Asymp. Sig. } \\
\text { (2-sided) }\end{array}$ & $\begin{array}{c}\text { Exact Sig. } \\
\text { (2-sided) }\end{array}$ & $\begin{array}{c}\text { Exact Sig. } \\
\text { (1-sided) }\end{array}$ & $\begin{array}{c}\text { Point } \\
\text { Probability }\end{array}$ \\
\hline Pearson Chi-Square & $9.301^{a}$ & 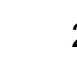 & .010 & .011 & & \\
\hline Likelihood Ratio & 7.164 & 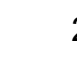 & .028 & .036 & & \\
\hline Fisher's Exact Test & 7.426 & & & .021 & & \\
\hline Linear-by-Linear & $3.881^{b}$ & & .049 & .053 & .040 & .023 \\
\hline \multicolumn{7}{|l|}{ Association } \\
\hline $\mathrm{N}$ of Valid Cases & 163 & & & & & \\
\hline
\end{tabular}

a. 1 cells $(16.7 \%)$ have expected count less than 5 . The minimum expected count is 2.12 .

b. The standardized statistic is 1.970 .

Symmetric Measures

\begin{tabular}{llccc}
\hline & & Value & Approx. Sig. & Exact Sig. \\
\hline Nominal by Nominal & Phi & .239 & .010 & .011 \\
& Cramer's V & .239 & .010 & .011 \\
N of Valid Cases & & 163 & & \\
\hline
\end{tabular}




\begin{tabular}{lllccc}
\hline & & & \multicolumn{2}{c}{$\begin{array}{c}\text { Strategic contribution } \\
\text { of the project }\end{array}$} \\
\cline { 3 - 5 } & & & 0 & 1 & Total \\
\hline H9-13 Contract & strongly agree / agree & Count & 68 & 12 & 80 \\
documentation & & Expected Count & 70.2 & 9.8 & 80.0 \\
& neither agree nor disagree & Count & 64 & 4 & 68 \\
& & Expected Count & 59.7 & 8.3 & 68.0 \\
& disagree / strongly & Count & 11 & 4 & 15 \\
& disagree & Expected Count & 13.2 & 1.8 & 15.0 \\
& & Count & 143 & 20 & 163 \\
& & Expected Count & 143.0 & 20.0 & 163. \\
& & & & & 0 \\
\hline
\end{tabular}

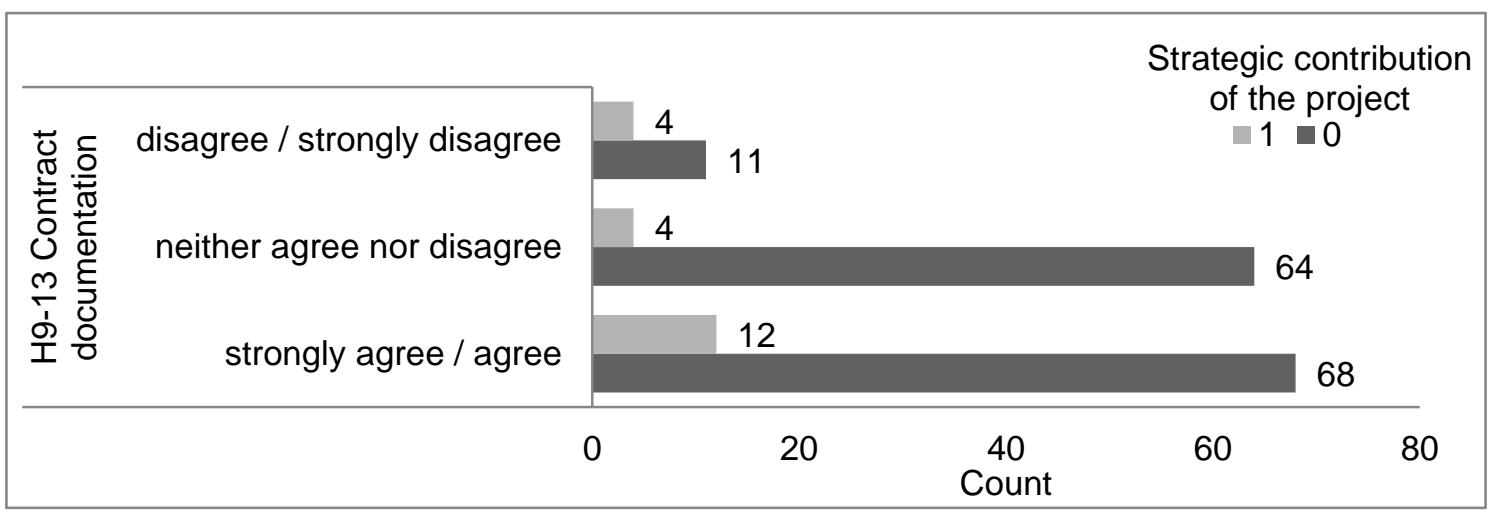

Chi-Square Tests

\begin{tabular}{|c|c|c|c|c|c|c|}
\hline & Value & $\mathrm{df}$ & $\begin{array}{c}\text { Asymp. Sig. } \\
\text { (2-sided) }\end{array}$ & $\begin{array}{c}\text { Exact Sig. } \\
\text { (2-sided) }\end{array}$ & $\begin{array}{c}\text { Exact Sig. } \\
(1 \text {-sided })\end{array}$ & $\begin{array}{c}\text { Point } \\
\text { Probability }\end{array}$ \\
\hline Pearson Chi-Square & $6.020^{\mathrm{a}}$ & 2 & .049 & .051 & & \\
\hline Likelihood Ratio & 5.903 & 2 & .052 & .062 & & \\
\hline Fisher's Exact Test & 6.098 & & & .033 & & \\
\hline Linear-by-Linear & $.000^{b}$ & 1 & .993 & 1.000 & .576 & .145 \\
\hline \multicolumn{7}{|l|}{ Association } \\
\hline N of Valid Cases & 163 & & & & & \\
\hline
\end{tabular}

a. 1 cells $(16.7 \%)$ have expected count less than 5 . The minimum expected count is 1.84 .

b. The standardized statistic is -.009 .

\begin{tabular}{llccc}
\multicolumn{5}{c}{ Symmetric Measures } \\
\hline Nominal by Nominal & Phi & Value & Approx. Sig. & Exact Sig. \\
& Cramer's V & .192 & .049 & .051 \\
N of Valid Cases & & .192 & .049 & .051 \\
\hline
\end{tabular}




\section{APPENDIX D: $p$ - AND CHI-SQUARE VALUES OF ALL TESTS}

\begin{tabular}{|c|c|c|}
\hline \multirow[b]{3}{*}{ Independent factors } & \multicolumn{2}{|c|}{ Independence Test } \\
\hline & \multicolumn{2}{|c|}{$\begin{array}{c}\text { Dependent project outcome: } \\
\text { Budget/Cost }\end{array}$} \\
\hline & $\begin{array}{c}\text { Chi-Square Test } \\
\text { (2-sided })\end{array}$ & $\begin{array}{c}\text { Fischer's } \\
\text { Exact Test } \\
\text { (2-sided) }\end{array}$ \\
\hline $\mathrm{H} 1-1$ Project charter & & $p=.430$ \\
\hline H1-2 Preliminary project scope statement & & $p=.223$ \\
\hline H1-3 Updates & $\chi^{2}(2, N=163)=.374, p=.830$ & \\
\hline H1-4 Project management plan & & $p=.218$ \\
\hline H1-5 Deliverables & & $p=.583$ \\
\hline H1-6 Requested changes & & $p=.792$ \\
\hline $\mathrm{H} 1-7$ Implemented change requests & $\chi^{2}(2, N=163)=2.271, p=.321$ & \\
\hline H1-8 Implemented corrective actions & & $p=.275$ \\
\hline H1-9 Implemented preventive actions & & $p=.105$ \\
\hline H1-10 Implemented defect repair & & $p=.061$ \\
\hline H1-11 Work performance information & $\chi^{2}(2, N=163)=2.192, p=.334$ & \\
\hline H1-12 Recommended corrective actions & & $p=.177$ \\
\hline H1-13 Recommended preventive actions & $\chi^{2}(2, N=163)=2.335, p=.311$ & \\
\hline H1-14 Forecasts & & $p=.917$ \\
\hline H1-15 Recommended defect repair & $\chi^{2}(2, N=163)=1.537, p=.464$ & \\
\hline H1-16 Requested changes & $\chi^{2}(2, N=163)=1.803, p=.406$ & \\
\hline H1-17 Approved change requests & & $p=.834$ \\
\hline H1-18 Rejected change requests & $\chi^{2}(2, N=163)=2.669, p=.263$ & \\
\hline H1-19 Approved corrective actions & $\chi^{2}(2, N=163)=.648, p=.723$ & \\
\hline H1-20 Approved preventive actions & $\chi^{2}(2, N=163)=1.747, p=.417$ & \\
\hline H1-21 Approved defect repair & $\chi^{2}(2, N=163)=.827, p=.661$ & \\
\hline H1-22 Validated defect repair & & $p=.473$ \\
\hline H1-23 Deliverables & & $p=.289$ \\
\hline
\end{tabular}




\begin{tabular}{|c|c|c|}
\hline \multirow[b]{3}{*}{ Independent factors } & \multicolumn{2}{|c|}{ Independence Test } \\
\hline & \multicolumn{2}{|c|}{$\begin{array}{c}\text { Dependent project outcome: } \\
\text { Schedule }\end{array}$} \\
\hline & $\begin{array}{c}\text { Chi-Square Test } \\
\text { (2-sided) }\end{array}$ & $\begin{array}{c}\text { Fischer's } \\
\text { Exact Test } \\
\text { (2-sided) }\end{array}$ \\
\hline H1-1 Project charter & & $p=.296$ \\
\hline H1-2 Preliminary project scope statement & & $p=.401$ \\
\hline H1-3 Updates & $\chi^{2}(2, N=163)=5.885, p=.053$ & \\
\hline H1-4 Project management plan & & $p=.678$ \\
\hline H1-5 Deliverables & & $p=1.000$ \\
\hline H1-6 Requested changes & & $p=1.000$ \\
\hline H1-7 Implemented change requests & $\chi^{2}(2, N=163)=1.101, p=.577$ & \\
\hline H1-8 Implemented corrective actions & & $p=.406$ \\
\hline H1-9 Implemented preventive actions & & $p=.007$ \\
\hline H1-10 Implemented defect repair & & $p=.019$ \\
\hline H1-11 Work performance information & $\chi^{2}(2, N=163)=.592, p=.744$ & \\
\hline H1-12 Recommended corrective actions & & $p=.060$ \\
\hline H1-13 Recommended preventive actions & $\chi^{2}(2, N=163)=1.404, p=.496$ & \\
\hline H1-14 Forecasts & & $p=.455$ \\
\hline H1-15 Recommended defect repair & $\chi^{2}(2, N=163)=3.047, p=.218$ & \\
\hline H1-16 Requested changes & $\chi^{2}(2, N=163)=2.787, p=.248$ & \\
\hline H1-17 Approved change requests & & $p=.400$ \\
\hline H1-18 Rejected change requests & $\chi^{2}(2, N=163)=1.058, p=.589$ & \\
\hline H1-19 Approved corrective actions & $\chi^{2}(2, N=163)=2.742, p=.254$ & \\
\hline H1-20 Approved preventive actions & $\chi^{2}(2, N=163)=2.580, p=.275$ & \\
\hline H1-21 Approved defect repair & $\chi^{2}(2, N=163)=2.986, p=.225$ & \\
\hline H1-22 Validated defect repair & & $p=.114$ \\
\hline H1-23 Deliverables & & $p=.832$ \\
\hline
\end{tabular}




\begin{tabular}{|c|c|c|}
\hline \multirow[b]{3}{*}{ Independent factors } & \multicolumn{2}{|c|}{ Independence Test } \\
\hline & \multicolumn{2}{|c|}{$\begin{array}{c}\text { Dependent project outcome: } \\
\text { Customer satisfaction }\end{array}$} \\
\hline & $\begin{array}{c}\text { Chi-Square Test } \\
\text { (2-sided) }\end{array}$ & $\begin{array}{c}\text { Fischer's } \\
\text { Exact Test } \\
\text { (2-sided) }\end{array}$ \\
\hline H1-1 Project charter & & $p=.270$ \\
\hline H1-2 Preliminary project scope statement & & $p=1.000$ \\
\hline H1-3 Updates & & $p=.720$ \\
\hline H1-4 Project management plan & & $p=.183$ \\
\hline H1-5 Deliverables & & $p=1.000$ \\
\hline H1-6 Requested changes & $\chi^{2}(2, N=163)=5.188, p=.075$ & \\
\hline H1-7 Implemented change requests & & $p=.703$ \\
\hline H1-8 Implemented corrective actions & & $p=.083$ \\
\hline H1-9 Implemented preventive actions & & $p=.310$ \\
\hline H1-10 Implemented defect repair & & $p=.140$ \\
\hline H1-11 Work performance information & $\chi^{2}(2, N=163)=.013, p=.994$ & \\
\hline H1-12 Recommended corrective actions & & $p=.944$ \\
\hline H1-13 Recommended preventive actions & $\chi^{2}(2, N=163)=5.592, p=.061$ & \\
\hline H1-14 Forecasts & & $p=.676$ \\
\hline H1-15 Recommended defect repair & & $p=.564$ \\
\hline H1-16 Requested changes & $\chi^{2}(2, N=163)=2.345, p=.310$ & \\
\hline H1-17 Approved change requests & & $p=.844$ \\
\hline H1-18 Rejected change requests & $\chi^{2}(2, N=163)=1.357, p=.507$ & \\
\hline H1-19 Approved corrective actions & $\chi^{2}(2, N=163)=3.639, p=.162$ & \\
\hline H1-20 Approved preventive actions & $\chi^{2}(2, N=163)=3.204, p=.201$ & \\
\hline H1-21 Approved defect repair & & $p=.925$ \\
\hline H1-22 Validated defect repair & & $p=.835$ \\
\hline H1-23 Deliverables & & $p=.863$ \\
\hline
\end{tabular}




\begin{tabular}{|c|c|c|}
\hline \multirow[b]{3}{*}{ Independent factors } & \multicolumn{2}{|c|}{ Independence Test } \\
\hline & \multicolumn{2}{|c|}{$\begin{array}{c}\text { Dependent project outcome: } \\
\text { User satisfaction }\end{array}$} \\
\hline & $\begin{array}{c}\text { Chi-Square Test } \\
\text { (2-sided) } \\
\end{array}$ & $\begin{array}{c}\text { Fischer's } \\
\text { Exact Test } \\
\text { (2-sided) }\end{array}$ \\
\hline H1-1 Project charter & & $p=1.000$ \\
\hline H1-2 Preliminary project scope statement & & $p=.434$ \\
\hline H1-3 Updates & & $p=.011$ \\
\hline H1-4 Project management plan & & $p=.247$ \\
\hline H1-5 Deliverables & & $p=1.000$ \\
\hline H1-6 Requested changes & & $p=.131$ \\
\hline H1-7 Implemented change requests & & $p=.754$ \\
\hline H1-8 Implemented corrective actions & & $p=.435$ \\
\hline H1-9 Implemented preventive actions & & $p=1.000$ \\
\hline H1-10 Implemented defect repair & & $p=.485$ \\
\hline H1-11 Work performance information & $\chi^{2}(2, N=163)=3.090, p=$ & \\
\hline H1-12 Recommended corrective actions & & $p=.822$ \\
\hline H1-13 Recommended preventive actions & $\chi^{2}(2, N=163)=1.514, p=$ & \\
\hline H1-14 Forecasts & & $p=.088$ \\
\hline H1-15 Recommended defect repair & $\chi^{2}(2, N=163)=3.453, p=$ & \\
\hline H1-16 Requested changes & & $p=.236$ \\
\hline H1-17 Approved change requests & & $p=1.000$ \\
\hline H1-18 Rejected change requests & $\chi^{2}(2, \mathrm{~N}=163)=6.490, \mathrm{p}$ & \\
\hline H1-19 Approved corrective actions & $\chi^{2}(2, N=163)=1.531, p=$ & \\
\hline H1-20 Approved preventive actions & $\chi^{2}(2, N=163)=1.166, p=$ & \\
\hline H1-21 Approved defect repair & $\chi^{2}(2, N=163)=5.363, p=$ & \\
\hline H1-22 Validated defect repair & $\chi^{2}(2, N=163)=2.380, p=$ & \\
\hline H1-23 Deliverables & & $p=.542$ \\
\hline
\end{tabular}




\begin{tabular}{|c|c|c|}
\hline \multirow[b]{3}{*}{ Independent factors } & \multicolumn{2}{|c|}{ Independence Test } \\
\hline & \multicolumn{2}{|c|}{$\begin{array}{c}\text { Dependent project outcome: } \\
\text { Stakeholder satisfaction }\end{array}$} \\
\hline & $\begin{array}{c}\text { Chi-Square Test } \\
\text { (2-sided) }\end{array}$ & $\begin{array}{c}\text { Fischer's } \\
\text { Exact Test } \\
\text { (2-sided) }\end{array}$ \\
\hline H1-1 Project charter & & $p=.398$ \\
\hline H1-2 Preliminary project scope statement & & $p=.011$ \\
\hline H1-3 Updates & $\chi^{2}(2, N=163)=2.264, p=.322$ & \\
\hline H1-4 Project management plan & & $p=.040$ \\
\hline H1-5 Deliverables & & $p=.630$ \\
\hline H1-6 Requested changes & $\chi^{2}(2, N=163)=4.434, p=.109$ & \\
\hline H1-7 Implemented change requests & $\chi^{2}(2, N=163)=1.844, p=.398$ & \\
\hline H1-8 Implemented corrective actions & & $p=.238$ \\
\hline H1-9 Implemented preventive actions & & $p=.187$ \\
\hline H1-10 Implemented defect repair & & $p=.615$ \\
\hline H1-11 Work performance information & $\chi^{2}(2, N=163)=1.021, p=.600$ & \\
\hline H1-12 Recommended corrective actions & & $p=.888$ \\
\hline H1-13 Recommended preventive actions & $\chi^{2}(2, N=163)=1.032, p=.597$ & \\
\hline H1-14 Forecasts & & $p=.280$ \\
\hline H1-15 Recommended defect repair & & $p=.601$ \\
\hline H1-16 Requested changes & $\chi^{2}(2, N=163)=1.003, p=.605$ & \\
\hline H1-17 Approved change requests & & $p=1.000$ \\
\hline H1-18 Rejected change requests & $\chi^{2}(2, N=163)=.744, p=.689$ & \\
\hline H1-19 Approved corrective actions & $\chi^{2}(2, N=163)=1.548, p=.461$ & \\
\hline H1-20 Approved preventive actions & $\chi^{2}(2, N=163)=1.688, p=.430$ & \\
\hline H1-21 Approved defect repair & $\chi^{2}(2, N=163)=.369, p=.832$ & \\
\hline H1-22 Validated defect repair & & $p=.596$ \\
\hline H1-23 Deliverables & & $p=.539$ \\
\hline
\end{tabular}




\begin{tabular}{|c|c|c|}
\hline \multirow[b]{3}{*}{ Independent factors } & \multicolumn{2}{|c|}{ Independence Test } \\
\hline & \multicolumn{2}{|c|}{$\begin{array}{c}\text { Dependent project outcome: } \\
\text { Project team satisfaction }\end{array}$} \\
\hline & $\begin{array}{c}\text { Chi-Square Test } \\
\text { (2-sided) }\end{array}$ & $\begin{array}{c}\text { Fischer's } \\
\text { Exact Test } \\
\text { (2-sided) }\end{array}$ \\
\hline H1-1 Project charter & & $p=.637$ \\
\hline H1-2 Preliminary project scope statement & & $p=1.000$ \\
\hline H1-3 Updates & & $p=.401$ \\
\hline H1-4 Project management plan & & $p=.846$ \\
\hline H1-5 Deliverables & & $p=1.000$ \\
\hline H1-6 Requested changes & & $p=.312$ \\
\hline H1-7 Implemented change requests & & $p=.509$ \\
\hline H1-8 Implemented corrective actions & & $p=.366$ \\
\hline H1-9 Implemented preventive actions & & $p=.514$ \\
\hline H1-10 Implemented defect repair & & $p=1.000$ \\
\hline H1-11 Work performance information & $\chi^{2}(2, N=163)=4.140, p=.126$ & \\
\hline H1-12 Recommended corrective actions & & $p=.377$ \\
\hline H1-13 Recommended preventive actions & & $p=.083$ \\
\hline H1-14 Forecasts & & $p=.087$ \\
\hline H1-15 Recommended defect repair & $\chi^{2}(2, N=163)=2.645, p=.266$ & \\
\hline H1-16 Requested changes & & $p=.099$ \\
\hline H1-17 Approved change requests & & $p=.731$ \\
\hline H1-18 Rejected change requests & & $p=.482$ \\
\hline H1-19 Approved corrective actions & & $p=1.000$ \\
\hline H1-20 Approved preventive actions & & $p=.927$ \\
\hline H1-21 Approved defect repair & $\chi^{2}(2, N=163)=1.107, p=.575$ & \\
\hline H1-22 Validated defect repair & & $p=.888$ \\
\hline H1-23 Deliverables & & $p=.679$ \\
\hline
\end{tabular}




\begin{tabular}{|c|c|c|}
\hline \multirow[b]{3}{*}{ Independent factors } & \multicolumn{2}{|c|}{ Independence Test } \\
\hline & \multicolumn{2}{|c|}{$\begin{array}{l}\text { Dependent project outcome: } \\
\text { Strategic contribution of the project }\end{array}$} \\
\hline & $\begin{array}{c}\text { Chi-Square Test } \\
\text { (2-sided) }\end{array}$ & $\begin{array}{c}\text { Fischer's } \\
\text { Exact Test } \\
\text { (2-sided) }\end{array}$ \\
\hline H1-1 Project charter & & $p=1.000$ \\
\hline H1-2 Preliminary project scope statement & & $p=.820$ \\
\hline H1-3 Updates & & $p=.657$ \\
\hline H1-4 Project management plan & & $p=.875$ \\
\hline H1-5 Deliverables & & $p=1.000$ \\
\hline H1-6 Requested changes & & $p=.707$ \\
\hline H1-7 Implemented change requests & & $p=.636$ \\
\hline H1-8 Implemented corrective actions & & $p=1.000$ \\
\hline H1-9 Implemented preventive actions & & $p=.490$ \\
\hline H1-10 Implemented defect repair & & $p=.695$ \\
\hline H1-11 Work performance information & $\chi^{2}(2, N=163)=1.222, p=.543$ & \\
\hline H1-12 Recommended corrective actions & & $p=.371$ \\
\hline H1-13 Recommended preventive actions & & $p=.672$ \\
\hline H1-14 Forecasts & & $p=.856$ \\
\hline H1-15 Recommended defect repair & $\chi^{2}(2, N=163)=2.429, p=.297$ & \\
\hline H1-16 Requested changes & & $p=.613$ \\
\hline H1-17 Approved change requests & & $p=.584$ \\
\hline H1-18 Rejected change requests & $\chi^{2}(2, N=163)=0.042, p=.979$ & \\
\hline H1-19 Approved corrective actions & $\chi^{2}(2, N=163)=2.219, p=.330$ & \\
\hline H1-20 Approved preventive actions & & $p=.672$ \\
\hline H1-21 Approved defect repair & $\chi^{2}(2, N=163)=2.586, p=.274$ & \\
\hline H1-22 Validated defect repair & $\chi^{2}(2, N=163)=4.491, p=.106$ & \\
\hline H1-23 Deliverables & & $p=1.000$ \\
\hline
\end{tabular}




\begin{tabular}{|c|c|c|}
\hline \multirow[b]{3}{*}{ Independent factors } & \multicolumn{2}{|c|}{ Independence Test } \\
\hline & \multicolumn{2}{|c|}{$\begin{array}{c}\text { Dependent project outcome: } \\
\text { Financial objectives }\end{array}$} \\
\hline & $\begin{array}{c}\text { Chi-Square Test } \\
\text { (2-sided) }\end{array}$ & $\begin{array}{c}\text { Fischer's } \\
\text { Exact Test } \\
\text { (2-sided) }\end{array}$ \\
\hline H1-1 Project charter & & $p=.050$ \\
\hline H1-2 Preliminary project scope statement & & $p=.194$ \\
\hline H1-3 Updates & $\chi^{2}(2, N=163)=0.104, p=.949$ & \\
\hline H1-4 Project management plan & & $p=.333$ \\
\hline H1-5 Deliverables & & $p=.317$ \\
\hline H1-6 Requested changes & $\chi^{2}(2, N=163)=0.051, p=.975$ & \\
\hline H1-7 Implemented change requests & $\chi^{2}(2, N=163)=0.678, p=.712$ & \\
\hline H1-8 Implemented corrective actions & & $p=.379$ \\
\hline H1-9 Implemented preventive actions & & $p=.004$ \\
\hline H1-10 Implemented defect repair & & $p=.158$ \\
\hline H1-11 Work performance information & $\chi^{2}(2, N=163)=0.190, p=.910$ & \\
\hline H1-12 Recommended corrective actions & & $p=.720$ \\
\hline H1-13 Recommended preventive actions & $\chi^{2}(2, N=163)=1.916, p=.384$ & \\
\hline H1-14 Forecasts & & $p=.106$ \\
\hline H1-15 Recommended defect repair & & $p=.024$ \\
\hline H1-16 Requested changes & $\chi^{2}(2, N=163)=5.513, p=.064$ & \\
\hline H1-17 Approved change requests & & $p=.937$ \\
\hline H1-18 Rejected change requests & $\chi^{2}(2, N=163)=1.816, p=.403$ & \\
\hline H1-19 Approved corrective actions & $\chi^{2}(2, N=163)=.612, p=.736$ & \\
\hline H1-20 Approved preventive actions & $\chi^{2}(2, N=163)=2.505, p=.286$ & \\
\hline H1-21 Approved defect repair & $\chi^{2}(2, N=163)=2.534, p=.282$ & \\
\hline H1-22 Validated defect repair & & $p=.475$ \\
\hline H1-23 Deliverables & & $p=.487$ \\
\hline
\end{tabular}




\begin{tabular}{|c|c|c|}
\hline \multirow[b]{3}{*}{ Independent factors } & \multicolumn{2}{|l|}{ Independence Test } \\
\hline & \multicolumn{2}{|c|}{$\begin{array}{c}\text { Dependent project outcome: } \\
\text { Technical objectives }\end{array}$} \\
\hline & $\begin{array}{c}\text { Chi-Square Test } \\
(2 \text {-sided }) \\
\end{array}$ & $\begin{array}{c}\text { Fischer's } \\
\text { Exact Test } \\
\text { (2-sided) }\end{array}$ \\
\hline H1-1 Project charter & & $p=.059$ \\
\hline H1-2 Preliminary project scope statement & & $p=1.000$ \\
\hline H1-3 Updates & $\chi^{2}(2, N=163)=2.636, p=.268$ & \\
\hline H1-4 Project management plan & & $p=.917$ \\
\hline H1-5 Deliverables & & $p=.575$ \\
\hline H1-6 Requested changes & & $p=.261$ \\
\hline H1-7 Implemented change requests & $\chi^{2}(2, N=163)=.676, p=.713$ & \\
\hline H1-8 Implemented corrective actions & & $p=.621$ \\
\hline H1-9 Implemented preventive actions & & $p=.202$ \\
\hline H1-10 Implemented defect repair & & $p=.326$ \\
\hline $\mathrm{H} 1-11$ Work performance information & $\chi^{2}(2, N=163)=2.313, p=.315$ & \\
\hline H1-12 Recommended corrective actions & & $p=.124$ \\
\hline H1-13 Recommended preventive actions & $\chi^{2}(2, N=163)=4.761, p=.093$ & \\
\hline H1-14 Forecasts & & $p=.474$ \\
\hline H1-15 Recommended defect repair & $\chi^{2}(2, N=163)=3.014, p=.222$ & \\
\hline H1-16 Requested changes & $\chi^{2}(2, N=163)=1.974, p=.373$ & \\
\hline H1-17 Approved change requests & & $p=.347$ \\
\hline H1-18 Rejected change requests & $\chi^{2}(2, N=163)=11.397, p=.003$ & \\
\hline H1-19 Approved corrective actions & $\chi^{2}(2, N=163)=2.174, p=.337$ & \\
\hline H1-20 Approved preventive actions & $\chi^{2}(2, N=163)=.873, p=.646$ & \\
\hline H1-21 Approved defect repair & $\chi^{2}(2, N=163)=2.695, p=.260$ & \\
\hline H1-22 Validated defect repair & & $p=1.000$ \\
\hline H1-23 Deliverables & & $\mathrm{p}=.811$ \\
\hline
\end{tabular}




\begin{tabular}{|c|c|c|}
\hline \multirow[b]{3}{*}{ Independent factors } & \multicolumn{2}{|c|}{ Independence Test } \\
\hline & \multicolumn{2}{|c|}{$\begin{array}{c}\text { Dependent project outcome: } \\
\text { Performances objectives }\end{array}$} \\
\hline & $\begin{array}{c}\text { Chi-Square Test } \\
\text { (2-sided) }\end{array}$ & $\begin{array}{c}\text { Fischer's } \\
\text { Exact Test } \\
\text { (2-sided) }\end{array}$ \\
\hline H1-1 Project charter & & $p=.430$ \\
\hline H1-2 Preliminary project scope statement & & $p=1.000$ \\
\hline H1-3 Updates & $\chi^{2}(2, N=163)=4.814, p=.090$ & \\
\hline H1-4 Project management plan & & $p=.529$ \\
\hline H1-5 Deliverables & & $p=.583$ \\
\hline H1-6 Requested changes & & $p=.447$ \\
\hline H1-7 Implemented change requests & $\chi^{2}(2, N=163)=.320, p=.852$ & \\
\hline H1-8 Implemented corrective actions & & $p=.817$ \\
\hline H1-9 Implemented preventive actions & & $p=1.000$ \\
\hline H1-10 Implemented defect repair & & $p=.734$ \\
\hline H1-11 Work performance information & $\chi^{2}(2, N=163)=.014, p=.993$ & \\
\hline H1-12 Recommended corrective actions & & $p=.105$ \\
\hline H1-13 Recommended preventive actions & $\chi^{2}(2, N=163)=2.402, p=.301$ & \\
\hline H1-14 Forecasts & & $p=.004$ \\
\hline H1-15 Recommended defect repair & $\chi^{2}(2, N=163)=1.241, p=.538$ & \\
\hline H1-16 Requested changes & $\chi^{2}(2, N=163)=4.173, p=.124$ & \\
\hline H1-17 Approved change requests & & $p=.335$ \\
\hline H1-18 Rejected change requests & $\chi^{2}(2, N=163)=.320, p=.849$ & \\
\hline H1-19 Approved corrective actions & $\chi^{2}(2, N=163)=1.764, p=.414$ & \\
\hline H1-20 Approved preventive actions & $\chi^{2}(2, N=163)=1.268, p=.530$ & \\
\hline H1-21 Approved defect repair & $\chi^{2}(2, N=163)=.849, p=.654$ & \\
\hline H1-22 Validated defect repair & & $p=.550$ \\
\hline H1-23 Deliverables & & $p=.289$ \\
\hline
\end{tabular}




\begin{tabular}{|c|c|c|}
\hline \multirow[b]{3}{*}{ Independent factors } & \multicolumn{2}{|c|}{ Independence Test } \\
\hline & \multicolumn{2}{|c|}{$\begin{array}{c}\text { Dependent project outcome: } \\
\text { Commercial benefit for contractors }\end{array}$} \\
\hline & $\begin{array}{c}\text { Chi-Square Test } \\
\text { (2-sided) } \\
\end{array}$ & $\begin{array}{c}\text { Fischer's } \\
\text { Exact Test } \\
\text { (2-sided) }\end{array}$ \\
\hline H1-1 Project charter & & $p=1.000$ \\
\hline H1-2 Preliminary project scope statement & & $p=1.000$ \\
\hline H1-3 Updates & & $\mathrm{p}=.552$ \\
\hline H1-4 Project management plan & & $p=.145$ \\
\hline H1-5 Deliverables & & $p=1.000$ \\
\hline H1-6 Requested changes & & $p=.434$ \\
\hline H1-7 Implemented change requests & & $p=.050$ \\
\hline H1-8 Implemented corrective actions & & $\mathrm{p}=.541$ \\
\hline H1-9 Implemented preventive actions & & $p=.043$ \\
\hline H1-10 Implemented defect repair & & $p=.055$ \\
\hline H1-11 Work performance information & & $p=.167$ \\
\hline H1-12 Recommended corrective actions & & $p=.096$ \\
\hline H1-13 Recommended preventive actions & & $p=1.000$ \\
\hline H1-14 Forecasts & & $p=1.000$ \\
\hline H1-15 Recommended defect repair & & $p=1.000$ \\
\hline H1-16 Requested changes & & $p=.530$ \\
\hline H1-17 Approved change requests & & $p=.036$ \\
\hline $\mathrm{H} 1-18$ Rejected change requests & & $p=1.000$ \\
\hline H1-19 Approved corrective actions & & $p=1.000$ \\
\hline H1-20 Approved preventive actions & & $\mathrm{p}=.173$ \\
\hline H1-21 Approved defect repair & & $p=.350$ \\
\hline H1-22 Validated defect repair & & $p=.079$ \\
\hline H1-23 Deliverables & & $p=.043$ \\
\hline
\end{tabular}




\begin{tabular}{|c|c|c|}
\hline \multirow[b]{3}{*}{ Independent factors } & \multicolumn{2}{|c|}{ Independence Test } \\
\hline & \multicolumn{2}{|c|}{$\begin{array}{c}\text { Dependent project outcome: } \\
\text { Commercial benefit for customer }\end{array}$} \\
\hline & $\begin{array}{c}\text { Chi-Square Test } \\
(2 \text {-sided })\end{array}$ & $\begin{array}{c}\text { Fischer's } \\
\text { Exact Test } \\
\text { (2-sided) }\end{array}$ \\
\hline H1-1 Project charter & & $p=.468$ \\
\hline H1-2 Preliminary project scope statement & & $p=.571$ \\
\hline H1-3 Updates & & $p=.576$ \\
\hline H1-4 Project management plan & & $p=.673$ \\
\hline H1-5 Deliverables & & $p=1.000$ \\
\hline H1-6 Requested changes & & $p=.636$ \\
\hline H1-7 Implemented change requests & & $p=1.000$ \\
\hline H1-8 Implemented corrective actions & & $p=.806$ \\
\hline H1-9 Implemented preventive actions & & $p=1.000$ \\
\hline H1-10 Implemented defect repair & & $p=.854$ \\
\hline H1-11 Work performance information & & $p=.649$ \\
\hline H1-12 Recommended corrective actions & & $p=.575$ \\
\hline H1-13 Recommended preventive actions & & $p=.922$ \\
\hline H1-14 Forecasts & & $p=.644$ \\
\hline H1-15 Recommended defect repair & $\chi^{2}(2, N=163)=.830, p=.660$ & \\
\hline H1-16 Requested changes & & $p=1.000$ \\
\hline H1-17 Approved change requests & & $p=.706$ \\
\hline H1-18 Rejected change requests & & $p=.642$ \\
\hline H1-19 Approved corrective actions & & $p=1.000$ \\
\hline H1-20 Approved preventive actions & & $p=.704$ \\
\hline H1-21 Approved defect repair & & $p=.361$ \\
\hline H1-22 Validated defect repair & & $p=.259$ \\
\hline H1-23 Deliverables & & $p=1.000$ \\
\hline
\end{tabular}




\begin{tabular}{|c|c|c|}
\hline \multirow[b]{3}{*}{ Independent factors } & \multicolumn{2}{|c|}{ Independence Test } \\
\hline & \multicolumn{2}{|c|}{$\begin{array}{c}\text { Dependent project outcome: } \\
\text { Scope }\end{array}$} \\
\hline & $\begin{array}{c}\text { Chi-Square Test } \\
\text { (2-sided) }\end{array}$ & $\begin{array}{c}\text { Fischer's } \\
\text { Exact Test } \\
\text { (2-sided) }\end{array}$ \\
\hline H1-1 Project charter & & $p=.529$ \\
\hline H1-2 Preliminary project scope statement & & $p=.235$ \\
\hline H1-3 Updates & $\chi^{2}(2, N=163)=5.728, p=.057$ & \\
\hline H1-4 Project management plan & & $p=.759$ \\
\hline H1-5 Deliverables & & $p=1.000$ \\
\hline H1-6 Requested changes & $\chi^{2}(2, N=163)=2.642, p=.267$ & \\
\hline H1-7 Implemented change requests & $\chi^{2}(2, N=163)=6.460, p=.040$ & \\
\hline H1-8 Implemented corrective actions & & $p=.735$ \\
\hline H1-9 Implemented preventive actions & & $p=.429$ \\
\hline H1-10 Implemented defect repair & & $p=.519$ \\
\hline H1-11 Work performance information & $\chi^{2}(2, N=163)=1.238, p=.539$ & \\
\hline H1-12 Recommended corrective actions & & $p=.594$ \\
\hline H1-13 Recommended preventive actions & $\chi^{2}(2, N=163)=0.902, p=.637$ & \\
\hline H1-14 Forecasts & & $p=.450$ \\
\hline H1-15 Recommended defect repair & & $p=.501$ \\
\hline H1-16 Requested changes & $\chi^{2}(2, N=163)=2.112, p=.348$ & \\
\hline H1-17 Approved change requests & & $p=.043$ \\
\hline H1-18 Rejected change requests & $\chi^{2}(2, N=163)=3.388, p=.184$ & \\
\hline H1-19 Approved corrective actions & $\chi^{2}(2, N=163)=2.653, p=.265$ & \\
\hline H1-20 Approved preventive actions & $\chi^{2}(2, N=163)=2.542, p=.281$ & \\
\hline H1-21 Approved defect repair & $\chi^{2}(2, N=163)=2.918, p=.232$ & \\
\hline H1-22 Validated defect repair & & $p=.059$ \\
\hline H1-23 Deliverables & & $p=.075$ \\
\hline
\end{tabular}




\begin{tabular}{|c|c|c|}
\hline \multirow[b]{3}{*}{ Independent factors } & \multicolumn{2}{|c|}{ Independence Test } \\
\hline & \multicolumn{2}{|c|}{$\begin{array}{c}\text { Dependent project outcome: } \\
\text { Personal growth }\end{array}$} \\
\hline & $\begin{array}{c}\text { Chi-Square Test } \\
\text { (2-sided) }\end{array}$ & $\begin{array}{c}\text { Fischer's } \\
\text { Exact Test } \\
\text { (2-sided) }\end{array}$ \\
\hline H1-1 Project charter & & $p=.117$ \\
\hline H1-2 Preliminary project scope statement & & $p=1.000$ \\
\hline H1-3 Updates & & $p=1.000$ \\
\hline H1-4 Project management plan & & $p=1.000$ \\
\hline H1-5 Deliverables & & $p=1.000$ \\
\hline H1-6 Requested changes & & $p=.172$ \\
\hline H1-7 Implemented change requests & & $p=1.000$ \\
\hline H1-8 Implemented corrective actions & & $p=.227$ \\
\hline H1-9 Implemented preventive actions & & $p=1.000$ \\
\hline H1-10 Implemented defect repair & & $p=1.000$ \\
\hline H1-11 Work performance information & & $p=1.000$ \\
\hline H1-12 Recommended corrective actions & & $p=1.000$ \\
\hline H1-13 Recommended preventive actions & & $p=1.000$ \\
\hline H1-14 Forecasts & & $p=1.000$ \\
\hline H1-15 Recommended defect repair & & $p=.393$ \\
\hline H1-16 Requested changes & & $p=1.000$ \\
\hline H1-17 Approved change requests & & $p=1.000$ \\
\hline H1-18 Rejected change requests & & $p=1.000$ \\
\hline H1-19 Approved corrective actions & & $p=1.000$ \\
\hline H1-20 Approved preventive actions & & $p=1.000$ \\
\hline H1-21 Approved defect repair & & $p=.049$ \\
\hline H1-22 Validated defect repair & & $p=1.000$ \\
\hline H1-23 Deliverables & & $p=1.000$ \\
\hline
\end{tabular}




\begin{tabular}{|c|c|c|}
\hline \multirow[b]{3}{*}{ Independent factors } & \multirow{2}{*}{\multicolumn{2}{|c|}{$\begin{array}{c}\text { Independence Test } \\
\text { Dependent project outcome: } \\
\text { Customer approval } \\
\end{array}$}} \\
\hline & & \\
\hline & $\begin{array}{c}\text { Chi-Square Test } \\
\text { (2-sided) }\end{array}$ & $\begin{array}{l}\text { Fischer's } \\
\text { Exact Test } \\
\text { (2-sided) } \\
\end{array}$ \\
\hline H1-1 Project charter & & $p=.789$ \\
\hline $\mathrm{H} 1-2$ Preliminary project scope statement & & $p=.617$ \\
\hline H1-3 Updates & $\chi^{2}(2, N=163)=2.641, p=.267$ & \\
\hline H1-4 Project management plan & & $p=.438$ \\
\hline H1-5 Deliverables & & $p=.581$ \\
\hline H1-6 Requested changes & & $p=.178$ \\
\hline H1-7 Implemented change requests & $\chi^{2}(2, N=163)=1.700, p=.427$ & \\
\hline H1-8 Implemented corrective actions & & $p=.122$ \\
\hline H1-9 Implemented preventive actions & & $p=.334$ \\
\hline H1-10 Implemented defect repair & & $p=.392$ \\
\hline H1-11 Work performance information & $\chi^{2}(2, N=163)=.553, p=.759$ & \\
\hline H1-12 Recommended corrective actions & & $p=.016$ \\
\hline H1-13 Recommended preventive actions & $\chi^{2}(2, N=163)=.219, p=.896$ & \\
\hline H1-14 Forecasts & & $p=.619$ \\
\hline H1-15 Recommended defect repair & $\chi^{2}(2, N=163)=.900, p=.637$ & \\
\hline H1-16 Requested changes & $\chi^{2}(2, N=163)=.071, p=.965$ & \\
\hline H1-17 Approved change requests & & $p=.713$ \\
\hline H1-18 Rejected change requests & $\chi^{2}(2, N=163)=2.762, p=.251$ & \\
\hline H1-19 Approved corrective actions & $\chi^{2}(2, N=163)=1.747, p=.418$ & \\
\hline H1-20 Approved preventive actions & $\chi^{2}(2, N=163)=1.863, p=.394$ & \\
\hline H1-21 Approved defect repair & $\chi^{2}(2, N=163)=2.732, p=.255$ & \\
\hline H1-22 Validated defect repair & & $p=.259$ \\
\hline H1-23 Deliverables & & $p=.151$ \\
\hline
\end{tabular}




\begin{tabular}{|c|c|c|}
\hline \multirow[b]{3}{*}{ Independent factors } & \multicolumn{2}{|c|}{ Independence Test } \\
\hline & \multicolumn{2}{|c|}{$\begin{array}{c}\text { Dependent project outcome: } \\
\text { Profitability } \\
\end{array}$} \\
\hline & $\begin{array}{c}\text { Chi-Square Test } \\
\text { (2-sided) }\end{array}$ & $\begin{array}{c}\text { Fischer's } \\
\text { Exact Test } \\
\text { (2-sided) }\end{array}$ \\
\hline H1-1 Project charter & & $p=.559$ \\
\hline $\mathrm{H} 1-2$ Preliminary project scope statement & & $p=.796$ \\
\hline H1-3 Updates & $\chi^{2}(2, N=163)=2.066, p=.356$ & \\
\hline H1-4 Project management plan & & $p=.693$ \\
\hline H1-5 Deliverables & & $p=1.000$ \\
\hline H1-6 Requested changes & & $p=.458$ \\
\hline H1-7 Implemented change requests & $\chi^{2}(2, N=163)=1.437, p=.488$ & \\
\hline H1-8 Implemented corrective actions & & $p=.668$ \\
\hline H1-9 Implemented preventive actions & & $p=.398$ \\
\hline H1-10 Implemented defect repair & & $p=.052$ \\
\hline $\mathrm{H} 1-11$ Work performance information & $\chi^{2}(2, N=163)=.068, p=.967$ & \\
\hline H1-12 Recommended corrective actions & & $p=.844$ \\
\hline H1-13 Recommended preventive actions & $\chi^{2}(2, N=163)=.488, p=.783$ & \\
\hline H1-14 Forecasts & & $p=.836$ \\
\hline H1-15 Recommended defect repair & $\chi^{2}(2, N=163)=.340, p=.844$ & \\
\hline H1-16 Requested changes & $\chi^{2}(2, N=163)=1.581, p=.454$ & \\
\hline H1-17 Approved change requests & & $p=.057$ \\
\hline H1-18 Rejected change requests & $\chi^{2}(2, N=163)=1.196, p=.550$ & \\
\hline H1-19 Approved corrective actions & $\chi^{2}(2, N=163)=.409, p=.815$ & \\
\hline H1-20 Approved preventive actions & $\chi^{2}(2, N=163)=1.863, p=.394$ & \\
\hline H1-21 Approved defect repair & $\chi^{2}(2, N=163)=1.348, p=.510$ & \\
\hline H1-22 Validated defect repair & & $p=.870$ \\
\hline H1-23 Deliverables & & $p=1.000$ \\
\hline
\end{tabular}




\begin{tabular}{|c|c|c|}
\hline \multirow[b]{3}{*}{ Independent factors } & \multicolumn{2}{|c|}{ Independence Test } \\
\hline & \multicolumn{2}{|c|}{$\begin{array}{c}\text { Dependent project outcome: } \\
\text { Sales }\end{array}$} \\
\hline & $\begin{array}{c}\text { Chi-Square Test } \\
\text { (2-sided) }\end{array}$ & $\begin{array}{c}\text { Fischer's } \\
\text { Exact Test } \\
\text { (2-sided) }\end{array}$ \\
\hline H1-1 Project charter & & $p=.033$ \\
\hline H1-2 Preliminary project scope statement & & $p=.244$ \\
\hline H1-3 Updates & & $p=.678$ \\
\hline H1-4 Project management plan & & $p=.253$ \\
\hline H1-5 Deliverables & & $p=1.000$ \\
\hline H1-6 Requested changes & & $p=.777$ \\
\hline $\mathrm{H} 1-7$ Implemented change requests & & $p=.197$ \\
\hline H1-8 Implemented corrective actions & & $p=.057$ \\
\hline H1-9 Implemented preventive actions & & $p=.173$ \\
\hline H1-10 Implemented defect repair & & $p=.030$ \\
\hline H1-11 Work performance information & & $p=.046$ \\
\hline H1-12 Recommended corrective actions & & $p=1.000$ \\
\hline H1-13 Recommended preventive actions & & $p=.872$ \\
\hline H1-14 Forecasts & & $p=.493$ \\
\hline H1-15 Recommended defect repair & & $p=1.000$ \\
\hline H1-16 Requested changes & & $p=.525$ \\
\hline H1-17 Approved change requests & & $p=1.000$ \\
\hline H1-18 Rejected change requests & & $p=.104$ \\
\hline H1-19 Approved corrective actions & & $p=1.000$ \\
\hline H1-20 Approved preventive actions & & $p=.433$ \\
\hline H1-21 Approved defect repair & & $p=.668$ \\
\hline H1-22 Validated defect repair & & $p=.806$ \\
\hline H1-23 Deliverables & & $p=1.000$ \\
\hline
\end{tabular}




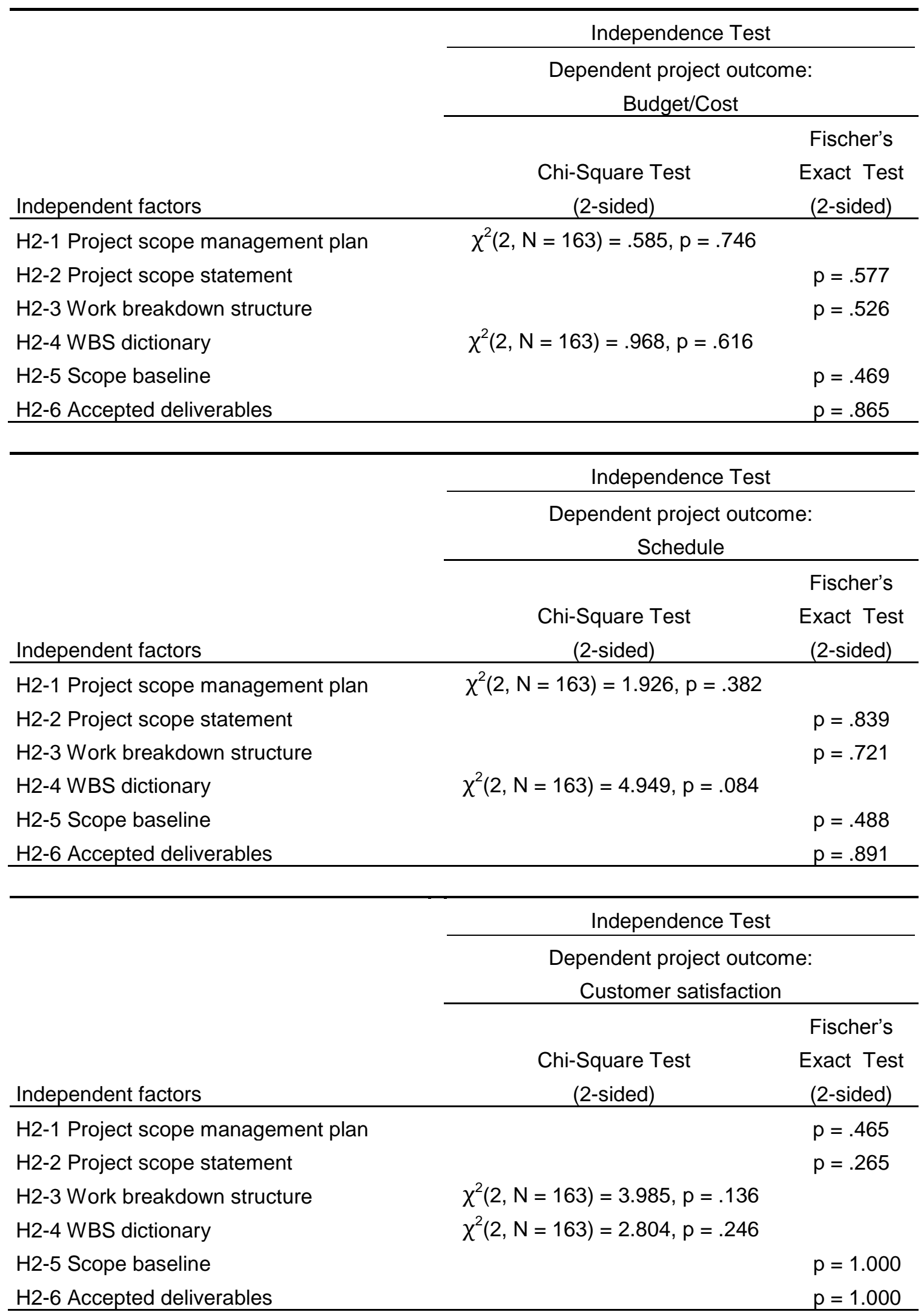




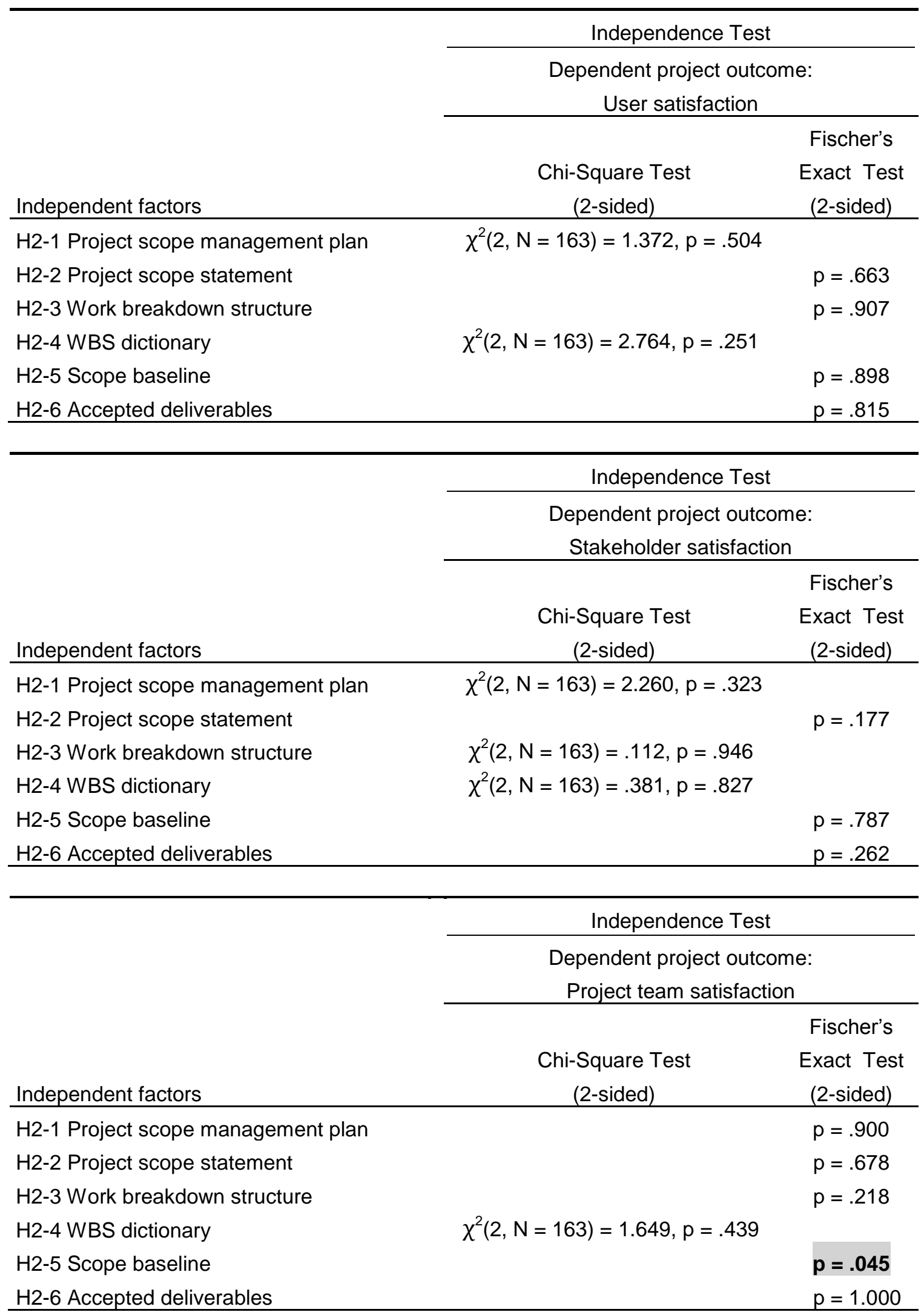




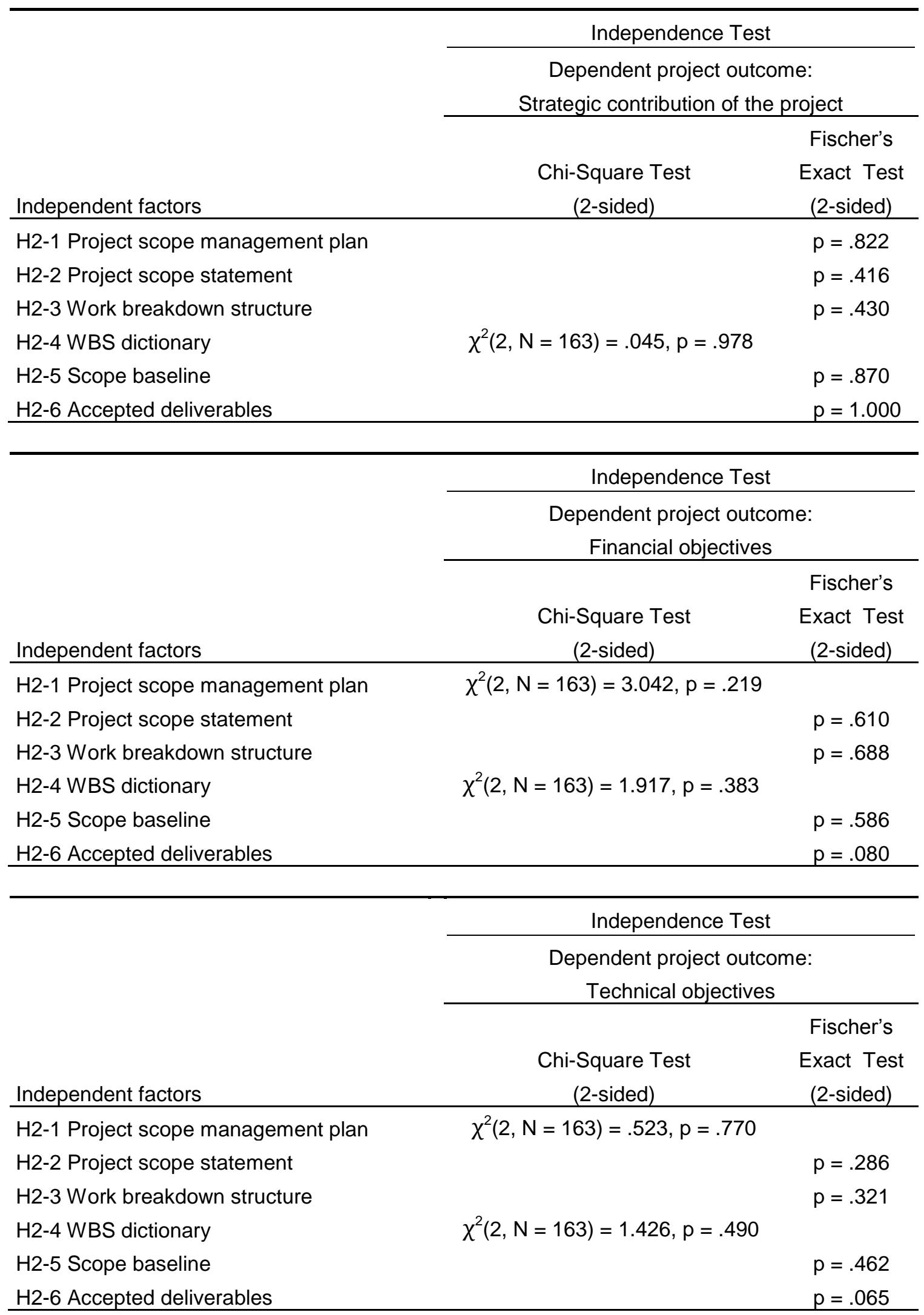




\begin{tabular}{|c|c|c|}
\hline \multirow[b]{3}{*}{ Independent factors } & \multicolumn{2}{|c|}{ Independence Test } \\
\hline & \multicolumn{2}{|c|}{$\begin{array}{c}\text { Dependent project outcome: } \\
\text { Performance objectives }\end{array}$} \\
\hline & $\begin{array}{c}\text { Chi-Square Test } \\
\text { (2-sided) }\end{array}$ & $\begin{array}{c}\text { Fischer's } \\
\text { Exact Test } \\
\text { (2-sided) }\end{array}$ \\
\hline H2-1 Project scope management plan & \multicolumn{2}{|c|}{$\chi^{2}(2, N=163)=.470, p=.791$} \\
\hline H2-2 Project scope statement & & $p=.577$ \\
\hline H2-3 Work breakdown structure & & $p=.159$ \\
\hline H2-4 WBS dictionary & \multicolumn{2}{|c|}{$\chi^{2}(2, N=163)=4.082, p=.130$} \\
\hline H2-5 Scope baseline & \multicolumn{2}{|r|}{$p=.099$} \\
\hline H2-6 Accepted deliverables & \multicolumn{2}{|r|}{$p=.096$} \\
\hline & \multicolumn{2}{|c|}{ Independence Test } \\
\hline & \multicolumn{2}{|c|}{$\begin{array}{c}\text { Dependent project outcome: } \\
\text { Commercial benefit for contractors }\end{array}$} \\
\hline Independent factors & $\begin{array}{c}\text { Chi-Square Test } \\
\text { (2-sided) }\end{array}$ & $\begin{array}{c}\text { Fischer's } \\
\text { Exact Test } \\
\text { (2-sided) }\end{array}$ \\
\hline H2-1 Project scope management plan & & $p=.583$ \\
\hline H2-2 Project scope statement & & $p=.138$ \\
\hline H2-3 Work breakdown structure & & $p=.408$ \\
\hline H2-4 WBS dictionary & & $p=.565$ \\
\hline H2-5 Scope baseline & & $p=.082$ \\
\hline \multirow[t]{4}{*}{ H2-6 Accepted deliverables } & & $\mathrm{p}=.071$ \\
\hline & \multicolumn{2}{|c|}{ Independence Test } \\
\hline & \multicolumn{2}{|c|}{$\begin{array}{c}\text { Dependent project outcome: } \\
\text { Commercial benefit for customer }\end{array}$} \\
\hline & $\begin{array}{l}\text { Chi-Square Test } \\
(2-\text { sided }) \\
\end{array}$ & $\begin{array}{c}\text { Fischer's } \\
\text { Exact Test } \\
\text { (2-sided) }\end{array}$ \\
\hline H2-1 Project scope management plan & \multirow{6}{*}{$\chi^{2}(2, N=163)=.210, p=$} & $p=.683$ \\
\hline H2-2 Project scope statement & & $p=.513$ \\
\hline H2-3 Work breakdown structure & & $p=.638$ \\
\hline H2-4 WBS dictionary & & \\
\hline H2-5 Scope baseline & & $p=.548$ \\
\hline H2-6 Accepted deliverables & & $p=.711$ \\
\hline
\end{tabular}




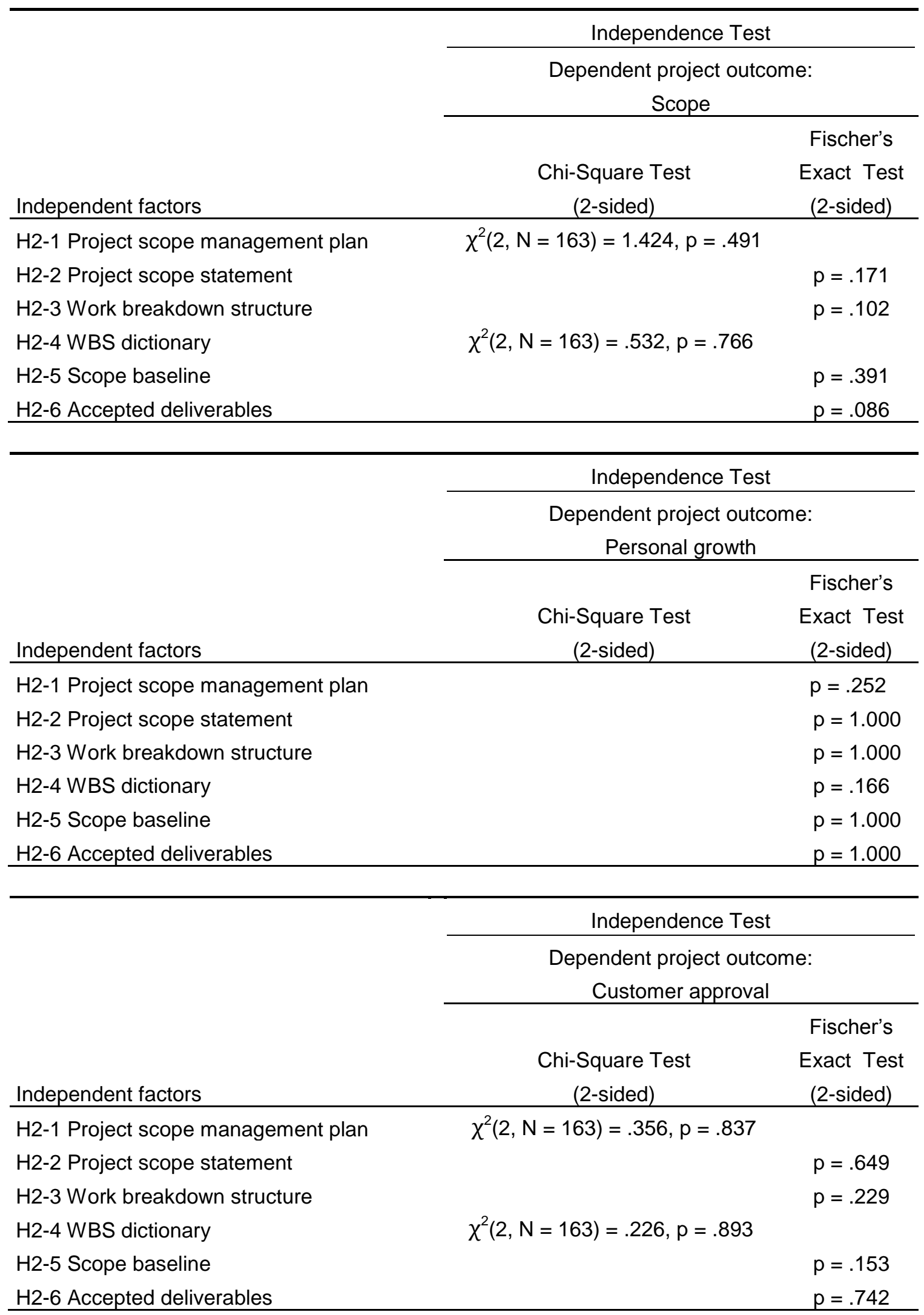




\begin{tabular}{|c|c|c|}
\hline \multirow[b]{3}{*}{ Independent factors } & \multicolumn{2}{|c|}{ Independence Test } \\
\hline & \multicolumn{2}{|c|}{$\begin{array}{c}\text { Dependent project outcome: } \\
\text { Profitability }\end{array}$} \\
\hline & $\begin{array}{l}\text { Chi-Square Test } \\
\text { (2-sided) }\end{array}$ & $\begin{array}{l}\text { Fischer's } \\
\text { Exact Test } \\
\text { (2-sided) }\end{array}$ \\
\hline H2-1 Project scope management plan & $\chi^{2}(2, N=163)=.601, p=$ & \\
\hline H2-2 Project scope statement & & $p=.178$ \\
\hline H2-3 Work breakdown structure & & $p=.623$ \\
\hline H2-4 WBS dictionary & $\chi^{2}(2, N=163)=.476, p=$ & \\
\hline H2-5 Scope baseline & & $p=.039$ \\
\hline \multirow[t]{3}{*}{ H2-6 Accepted deliverables } & & $\mathrm{p}=.447$ \\
\hline & \multicolumn{2}{|c|}{ Independence Test } \\
\hline & \multicolumn{2}{|c|}{$\begin{array}{c}\text { Dependent project outcome: } \\
\text { Sales }\end{array}$} \\
\hline Independent factors & $\begin{array}{c}\text { Chi-Square Test } \\
\text { (2-sided) }\end{array}$ & $\begin{array}{l}\text { Fischer's } \\
\text { Exact Test } \\
\text { (2-sided) }\end{array}$ \\
\hline H2-1 Project scope management plan & & $p=.238$ \\
\hline H2-2 Project scope statement & & $p=.429$ \\
\hline H2-3 Work breakdown structure & & $p=.604$ \\
\hline H2-4 WBS dictionary & & $p=.588$ \\
\hline H2-5 Scope baseline & & $p=.076$ \\
\hline H2-6 Accepted deliverables & & $p=1.000$ \\
\hline
\end{tabular}




\begin{tabular}{|c|c|c|}
\hline \multirow[b]{3}{*}{ Independent factors } & \multicolumn{2}{|c|}{ Independence Test } \\
\hline & \multicolumn{2}{|c|}{$\begin{array}{c}\text { Dependent project outcome: } \\
\text { Budget/Cost }\end{array}$} \\
\hline & $\begin{array}{c}\text { Chi-Square Test } \\
\text { (2-sided) }\end{array}$ & $\begin{array}{c}\text { Fischer's } \\
\text { Exact Test } \\
\text { (2-sided) }\end{array}$ \\
\hline H3-1 Activity list & & $p=.822$ \\
\hline H3-2 Activity attributes & $\chi^{2}(2, N=163)=1.106, p=.575$ & \\
\hline H3-3 Milestone list & & $p=.426$ \\
\hline H3-4 Project schedule network diagrams & $\chi^{2}(2, N=163)=.095, p=.953$ & \\
\hline H3-5 Activity resource requirements & $\chi^{2}(2, N=163)=.431, p=.806$ & \\
\hline H3-6 Resource breakdown structure & $\chi^{2}(2, N=163)=5.510, p=.064$ & \\
\hline H3-7 Resource calendar & $\chi^{2}(2, N=163)=.249, p=.883$ & \\
\hline H3-8 Activity duration estimates & $\chi^{2}(2, N=163)=3.799, p=.150$ & \\
\hline H3-9 Project schedule & & $p=.815$ \\
\hline H3-10 Schedule model data & $\chi^{2}(2, N=163)=.827, p=.661$ & \\
\hline H3-11 Schedule baseline & $\chi^{2}(2, N=163)=1.331, p=.514$ & \\
\hline H3-12 Performance measurements & $\chi^{2}(2, N=163)=1.352, p=.509$ & \\
\hline & Independence $\mathrm{TC}$ & \\
\hline & $\begin{array}{c}\text { Dependent project ou } \\
\text { Schedule } \\
\end{array}$ & \\
\hline Independent factors & $\begin{array}{c}\text { Chi-Square Test } \\
\text { (2-sided) }\end{array}$ & $\begin{array}{c}\text { Fischer's } \\
\text { Exact Test } \\
\text { (2-sided) }\end{array}$ \\
\hline H3-1 Activity list & $\chi^{2}(2, N=163)=.796, p=.672$ & \\
\hline H3-2 Activity attributes & $\chi^{2}(2, N=163)=.572, p=.751$ & \\
\hline H3-3 Milestone list & & $p=.640$ \\
\hline H3-4 Project schedule network diagrams & $\chi^{2}(2, N=163)=1.164, p=.559$ & \\
\hline H3-5 Activity resource requirements & $\chi^{2}(2, N=163)=.373, p=.830$ & \\
\hline H3-6 Resource breakdown structure & $\chi^{2}(2, N=163)=2.675, p=.262$ & \\
\hline H3-7 Resource calendar & $\chi^{2}(2, N=163)=.405, p=.817$ & \\
\hline H3-8 Activity duration estimates & $\chi^{2}(2, N=163)=.091, p=.956$ & \\
\hline H3-9 Project schedule & $\chi^{2}(2, N=163)=.073, p=.964$ & \\
\hline H3-10 Schedule model data & $\chi^{2}(2, N=163)=.023, p=.989$ & \\
\hline H3-11 Schedule baseline & $\chi^{2}(2, N=163)=.091, p=.956$ & \\
\hline H3-12 Performance measurements & $\chi^{2}(2, N=163)=.534, p=.766$ & \\
\hline
\end{tabular}




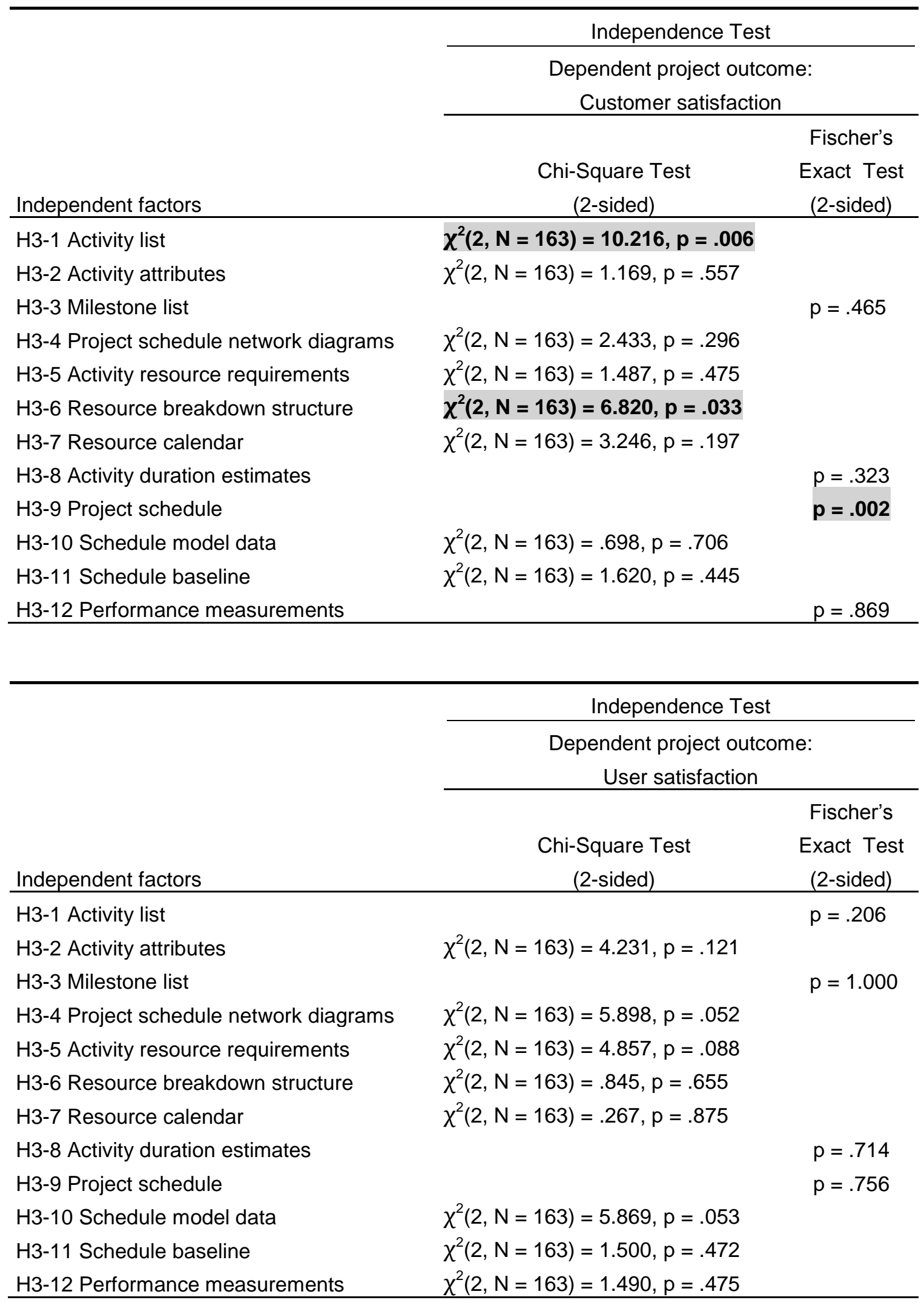




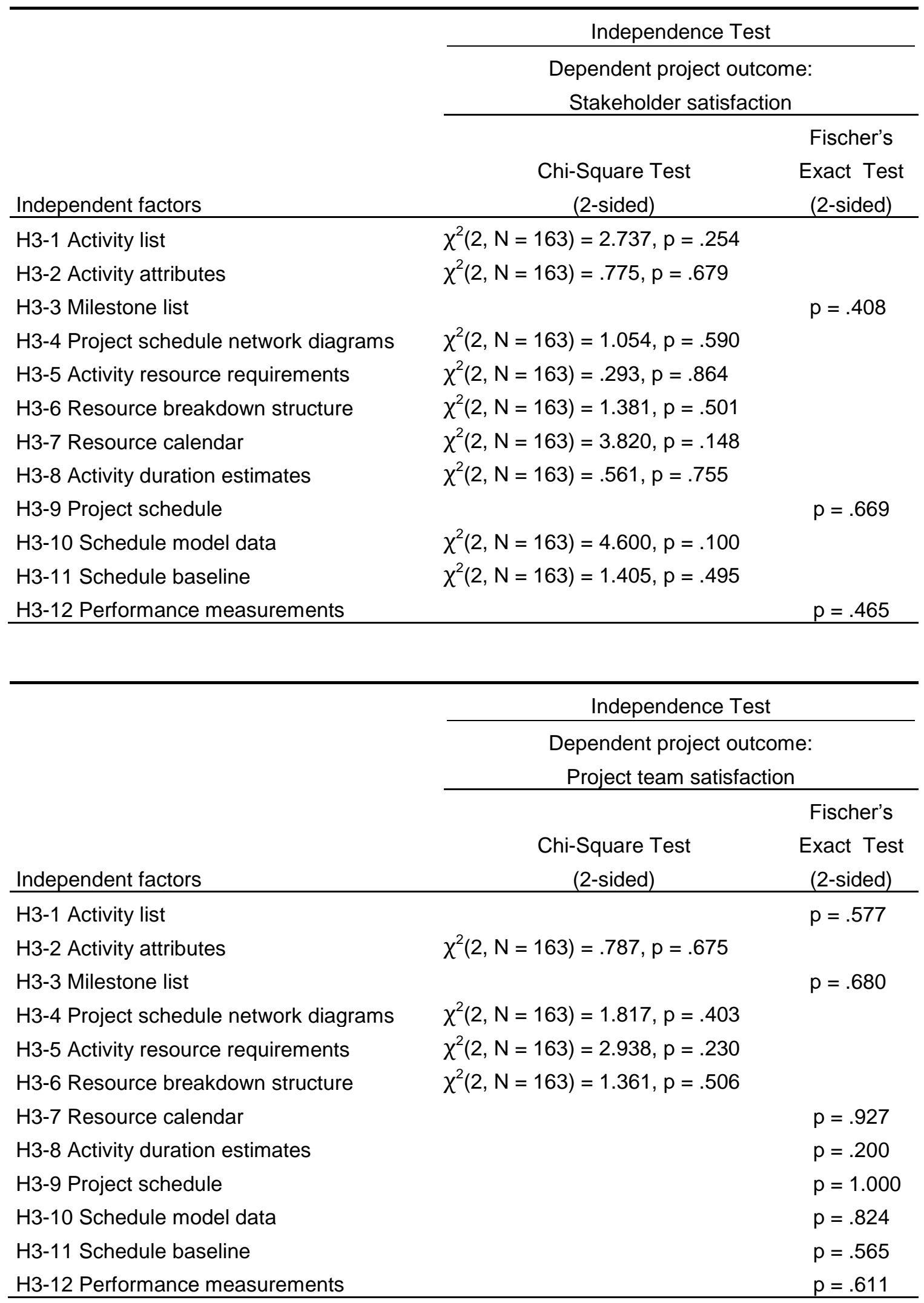




\begin{tabular}{|c|c|c|}
\hline \multirow[b]{3}{*}{ Independent factors } & \multicolumn{2}{|c|}{ Independence Test } \\
\hline & \multicolumn{2}{|c|}{$\begin{array}{l}\text { Dependent project outcome: } \\
\text { Strategic contribution of the project }\end{array}$} \\
\hline & $\begin{array}{c}\text { Chi-Square Test } \\
(2 \text {-sided })\end{array}$ & $\begin{array}{c}\text { Fischer's } \\
\text { Exact Test } \\
\text { (2-sided) }\end{array}$ \\
\hline H3-1 Activity list & & $p=1.000$ \\
\hline H3-2 Activity attributes & $\chi^{2}(2, N=163)=2.622, p=.270$ & \\
\hline H3-3 Milestone list & & $p=.863$ \\
\hline H3-4 Project schedule network diagrams & $\chi^{2}(2, N=163)=4.831, p=.089$ & \\
\hline H3-5 Activity resource requirements & $\chi^{2}(2, N=163)=1.623, p=.444$ & \\
\hline H3-6 Resource breakdown structure & $\chi^{2}(2, N=163)=.026, p=.987$ & \\
\hline H3-7 Resource calendar & $\chi^{2}(2, N=163)=.119, p=.942$ & \\
\hline H3-8 Activity duration estimates & & $p=1.000$ \\
\hline H3-9 Project schedule & & $p=.729$ \\
\hline H3-10 Schedule model data & $\chi^{2}(2, N=163)=5.853, p=.054$ & \\
\hline H3-11 Schedule baseline & $\chi^{2}(2, N=163)=2.529, p=.282$ & \\
\hline H3-12 Performance measurements & & $p=.909$ \\
\hline & Independence $\mathrm{TC}$ & \\
\hline & $\begin{array}{r}\text { Dependent project ou } \\
\text { Financial objectiv }\end{array}$ & \\
\hline Independent factors & $\begin{array}{l}\text { Chi-Square Test } \\
\text { (2-sided) }\end{array}$ & $\begin{array}{c}\text { Fischer's } \\
\text { Exact Test } \\
\text { (2-sided) }\end{array}$ \\
\hline H3-1 Activity list & $\chi^{2}(2, N=163)=3.690, p=.158$ & \\
\hline H3-2 Activity attributes & $\chi^{2}(2, N=163)=.456, p=.796$ & \\
\hline H3-3 Milestone list & $\chi^{2}(2, N=163)=1.413, p=.493$ & \\
\hline H3-4 Project schedule network diagrams & $\chi^{2}(2, N=163)=.786, p=.675$ & \\
\hline H3-5 Activity resource requirements & $\chi^{2}(2, N=163)=3.160, p=.206$ & \\
\hline H3-6 Resource breakdown structure & $\chi^{2}(2, N=163)=.460, p=.794$ & \\
\hline H3-7 Resource calendar & $\chi^{2}(2, N=163)=3.986, p=.136$ & \\
\hline H3-8 Activity duration estimates & $\chi^{2}(2, N=163)=.229, p=.892$ & \\
\hline H3-9 Project schedule & & $p=.453$ \\
\hline H3-10 Schedule model data & $\chi^{2}(2, N=163)=1.586, p=.452$ & \\
\hline H3-11 Schedule baseline & $\chi^{2}(2, N=163)=.219, p=.896$ & \\
\hline H3-12 Performance measurements & & $p=.208$ \\
\hline
\end{tabular}




\begin{tabular}{|c|c|c|}
\hline \multirow[b]{3}{*}{ Independent factors } & \multicolumn{2}{|c|}{ Independence Test } \\
\hline & \multicolumn{2}{|c|}{$\begin{array}{c}\text { Dependent project outcome: } \\
\text { Technical objectives }\end{array}$} \\
\hline & $\begin{array}{c}\text { Chi-Square Test } \\
\text { (2-sided) }\end{array}$ & $\begin{array}{c}\text { Fischer's } \\
\text { Exact Test } \\
\text { (2-sided) }\end{array}$ \\
\hline H3-1 Activity list & $\chi^{2}(2, N=163)=3.922, p=.141$ & \\
\hline H3-2 Activity attributes & $\chi^{2}(2, N=163)=2.435, p=.296$ & \\
\hline H3-3 Milestone list & & $p=.129$ \\
\hline H3-4 Project schedule network diagrams & $\chi^{2}(2, N=163)=.440, p=.801$ & \\
\hline H3-5 Activity resource requirements & $\chi^{2}(2, N=163)=5.356, p=.069$ & \\
\hline H3-6 Resource breakdown structure & $\chi^{2}(2, N=163)=2.570, p=.277$ & \\
\hline H3-7 Resource calendar & $\chi^{2}(2, N=163)=3.278, p=.194$ & \\
\hline H3-8 Activity duration estimates & $\chi^{2}(2, N=163)=3.702, p=.157$ & \\
\hline H3-9 Project schedule & & $p=.845$ \\
\hline H3-10 Schedule model data & $\chi^{2}(2, N=163)=2.969, p=.227$ & \\
\hline H3-11 Schedule baseline & $\chi^{2}(2, N=163)=2.751, p=.253$ & \\
\hline H3-12 Performance measurements & $\chi^{2}(2, N=163)=2.635, p=.268$ & \\
\hline & Independence $\mathrm{TC}$ & \\
\hline & $\begin{array}{r}\text { Dependent project ou } \\
\text { Performance objec } \\
\end{array}$ & \\
\hline Independent factors & $\begin{array}{c}\text { Chi-Square Test } \\
\text { (2-sided) }\end{array}$ & $\begin{array}{c}\text { Fischer's } \\
\text { Exact Test } \\
\text { (2-sided) }\end{array}$ \\
\hline H3-1 Activity list & & $p=.637$ \\
\hline H3-2 Activity attributes & $\chi^{2}(2, N=163)=.345, p=.842$ & \\
\hline H3-3 Milestone list & & $p=.377$ \\
\hline H3-4 Project schedule network diagrams & $\chi^{2}(2, N=163)=.095, p=.953$ & \\
\hline H3-5 Activity resource requirements & $\chi^{2}(2, N=163)=1.804, p=.406$ & \\
\hline H3-6 Resource breakdown structure & $\chi^{2}(2, N=163)=2.524, p=.283$ & \\
\hline H3-7 Resource calendar & $\chi^{2}(2, N=163)=7.150, p=.028$ & \\
\hline H3-8 Activity duration estimates & $\chi^{2}(2, N=163)=1.801, p=.406$ & \\
\hline H3-9 Project schedule & & $p=.815$ \\
\hline H3-10 Schedule model data & $\chi^{2}(2, N=163)=.102, p=.950$ & \\
\hline H3-11 Schedule baseline & $\chi^{2}(2, N=163)=.092, p=.955$ & \\
\hline H3-12 Performance measurements & $\chi^{2}(2, N=163)=1.890, p=.389$ & \\
\hline
\end{tabular}




\begin{tabular}{|c|c|c|}
\hline \multirow[b]{3}{*}{ Independent factors } & \multicolumn{2}{|c|}{ Independence Test } \\
\hline & \multicolumn{2}{|c|}{$\begin{array}{c}\text { Dependent project outcome: } \\
\text { Commercial benefit for contractors }\end{array}$} \\
\hline & $\begin{array}{l}\text { Chi-Square Test } \\
\text { (2-sided) }\end{array}$ & $\begin{array}{c}\text { Fischer's } \\
\text { Exact Test } \\
\text { (2-sided) }\end{array}$ \\
\hline H3-1 Activity list & & $p=.518$ \\
\hline H3-2 Activity attributes & & $p=1.000$ \\
\hline H3-3 Milestone list & & $p=.129$ \\
\hline H3-4 Project schedule network diagrams & & $p=.417$ \\
\hline H3-5 Activity resource requirements & & $p=.290$ \\
\hline H3-6 Resource breakdown structure & & $p=1.000$ \\
\hline H3-7 Resource calendar & & $p=.672$ \\
\hline H3-8 Activity duration estimates & & $p=1.000$ \\
\hline H3-9 Project schedule & & $p=1.000$ \\
\hline H3-10 Schedule model data & & $p=.228$ \\
\hline H3-11 Schedule baseline & & $p=.284$ \\
\hline \multirow[t]{4}{*}{ H3-12 Performance measurements } & & $p=.134$ \\
\hline & \multicolumn{2}{|c|}{ Independence Test } \\
\hline & \multicolumn{2}{|c|}{$\begin{array}{l}\text { Dependent project outcome: } \\
\text { Commercial benefit for customer }\end{array}$} \\
\hline & $\begin{array}{l}\text { Chi-Square Test } \\
\text { (2-sided) }\end{array}$ & $\begin{array}{c}\text { Fischer's } \\
\text { Exact Test } \\
\text { (2-sided) }\end{array}$ \\
\hline H3-1 Activity list & & $p=.222$ \\
\hline H3-2 Activity attributes & $\chi^{2}(2, N=163)=.737, p=.692$ & \\
\hline H3-3 Milestone list & & $p=.516$ \\
\hline H3-4 Project schedule network diagrams & & $p=1.000$ \\
\hline H3-5 Activity resource requirements & $\chi^{2}(2, N=163)=.347, p=.841$ & \\
\hline H3-6 Resource breakdown structure & $\chi^{2}(2, N=163)=.812, p=.666$ & \\
\hline H3-7 Resource calendar & & $p=.294$ \\
\hline H3-8 Activity duration estimates & & $p=1.000$ \\
\hline H3-9 Project schedule & & $p=1.000$ \\
\hline H3-10 Schedule model data & & $p=.867$ \\
\hline H3-11 Schedule baseline & & $p=.374$ \\
\hline H3-12 Performance measurements & & $p=.108$ \\
\hline
\end{tabular}




\begin{tabular}{|c|c|c|}
\hline \multirow[b]{3}{*}{ Independent factors } & \multicolumn{2}{|c|}{ Independence Test } \\
\hline & \multicolumn{2}{|c|}{$\begin{array}{l}\text { Dependent project outcome: } \\
\text { Scope }\end{array}$} \\
\hline & $\begin{array}{c}\text { Chi-Square Test } \\
\text { (2-sided) }\end{array}$ & $\begin{array}{c}\text { Fischer's } \\
\text { Exact Test } \\
\text { (2-sided) }\end{array}$ \\
\hline H3-1 Activity list & $\chi^{2}(2, N=163)=1.717, p=.424$ & \\
\hline H3-2 Activity attributes & $\chi^{2}(2, N=163)=4.503, p=.105$ & \\
\hline H3-3 Milestone list & & $p=.274$ \\
\hline H3-4 Project schedule network diagrams & $\chi^{2}(2, N=163)=.970, p=.616$ & \\
\hline H3-5 Activity resource requirements & $\chi^{2}(2, N=163)=1.875, p=.392$ & \\
\hline H3-6 Resource breakdown structure & $\chi^{2}(2, N=163)=3.175, p=.204$ & \\
\hline H3-7 Resource calendar & $\chi^{2}(2, N=163)=5.282, p=.071$ & \\
\hline H3-8 Activity duration estimates & $\chi^{2}(2, N=163)=.927, p=.629$ & \\
\hline H3-9 Project schedule & & $p=1.000$ \\
\hline H3-10 Schedule model data & $\chi^{2}(2, N=163)=4.024, p=.134$ & \\
\hline H3-11 Schedule baseline & $\chi^{2}(2, N=163)=3.868, p=.145$ & \\
\hline H3-12 Performance measurements & & $p=.949$ \\
\hline
\end{tabular}

\begin{tabular}{lcc}
\hline & \multicolumn{2}{c}{ Independence Test } \\
\cline { 2 - 3 } & \multicolumn{2}{c}{$\begin{array}{c}\text { Dependent project outcome: } \\
\text { Personal growth }\end{array}$} \\
\cline { 2 - 3 } & \multicolumn{2}{c}{ Fischer's } \\
& Chi-Square Test & Exact Test \\
Independent factors & (2-sided) & $p=1.000$ \\
H3-1 Activity list & $p=.153$ \\
H3-2 Activity attributes & $p=1.000$ \\
H3-3 Milestone list & $p=.160$ \\
H3-4 Project schedule network diagrams & $p=.429$ \\
H3-5 Activity resource requirements & $p=1.000$ \\
H3-6 Resource breakdown structure & $p=1.000$ \\
H3-7 Resource calendar & $p=1.000$ \\
H3-8 Activity duration estimates & $p=1.000$ \\
H3-9 Project schedule & $p=1.000$ \\
H3-10 Schedule model data & $p=1.000$ \\
H3-11 Schedule baseline & $p=1.000$ \\
H3-12 Performance measurements & & \\
\hline
\end{tabular}




\begin{tabular}{|c|c|c|}
\hline \multirow[b]{3}{*}{ Independent factors } & \multicolumn{2}{|c|}{ Independence Test } \\
\hline & \multicolumn{2}{|c|}{$\begin{array}{c}\text { Dependent project outcome: } \\
\text { Customer approval }\end{array}$} \\
\hline & $\begin{array}{c}\text { Chi-Square Test } \\
\text { (2-sided) }\end{array}$ & $\begin{array}{c}\text { Fischer's } \\
\text { Exact Test } \\
\text { (2-sided) }\end{array}$ \\
\hline H3-1 Activity list & & $p=.565$ \\
\hline H3-2 Activity attributes & $\chi^{2}(2, N=163)=2.967, p=.227$ & \\
\hline H3-3 Milestone list & & $p=.811$ \\
\hline H3-4 Project schedule network diagrams & $\chi^{2}(2, N=163)=3.065, p=.216$ & \\
\hline H3-5 Activity resource requirements & $\chi^{2}(2, N=163)=2.222, p=.200$ & \\
\hline H3-6 Resource breakdown structure & $\chi^{2}(2, N=163)=1.020, p=.601$ & \\
\hline H3-7 Resource calendar & $\chi^{2}(2, N=163)=2.631, p=.268$ & \\
\hline H3-8 Activity duration estimates & $\chi^{2}(2, N=163)=3.009, p=.222$ & \\
\hline H3-9 Project schedule & & $p=.419$ \\
\hline H3-10 Schedule model data & $\chi^{2}(2, N=163)=1.953, p=.377$ & \\
\hline H3-11 Schedule baseline & $\chi^{2}(2, N=163)=2.745, p=.253$ & \\
\hline H3-12 Performance measurements & $\chi^{2}(2, N=163)=4.320, p=.115$ & \\
\hline & Independence T & \\
\hline & $\begin{array}{r}\text { Dependent project ou } \\
\text { Profitability } \\
\end{array}$ & \\
\hline Independent factors & $\begin{array}{l}\text { Chi-Square Test } \\
\text { (2-sided) }\end{array}$ & $\begin{array}{l}\text { Fischer's } \\
\text { Exact Test } \\
\text { (2-sided) }\end{array}$ \\
\hline H3-1 Activity list & & $p=.379$ \\
\hline H3-2 Activity attributes & $\chi^{2}(2, N=163)=4.303, p=.116$ & \\
\hline H3-3 Milestone list & & $p=.897$ \\
\hline H3-4 Project schedule network diagrams & $\chi^{2}(2, N=163)=.806, p=.668$ & \\
\hline H3-5 Activity resource requirements & $\chi^{2}(2, N=163)=.569, p=.752$ & \\
\hline H3-6 Resource breakdown structure & $\chi^{2}(2, N=163)=4.091, p=.129$ & \\
\hline H3-7 Resource calendar & $\chi^{2}(2, N=163)=2.673, p=.263$ & \\
\hline H3-8 Activity duration estimates & $\chi^{2}(2, N=163)=.404, p=.801$ & \\
\hline H3-9 Project schedule & & $p=.533$ \\
\hline H3-10 Schedule model data & $\chi^{2}(2, N=163)=.102, p=.950$ & \\
\hline H3-11 Schedule baseline & $\chi^{2}(2, N=163)=.312, p=.856$ & \\
\hline H3-12 Performance measurements & $\chi^{2}(2, N=163)=.296, p=.862$ & \\
\hline
\end{tabular}




\begin{tabular}{lcc}
\hline & \multicolumn{2}{c}{ Independence Test } \\
\cline { 2 - 3 } & \multicolumn{2}{c}{ Dependent project outcome: } \\
\cline { 2 - 3 } & \multicolumn{2}{c}{ Sales } \\
\cline { 2 - 3 } Independent factors & Fischer's \\
\hline H3-1 Activity list & Exact Test \\
H3-2 Activity attributes & (2-sided) & -sided) \\
H3-3 Milestone list & $p=.038$ \\
H3-4 Project schedule network diagrams & $p=.031$ \\
H3-5 Activity resource requirements & $p=.210$ \\
H3-6 Resource breakdown structure & $p=.084$ \\
H3-7 Resource calendar & $p=.038$ \\
H3-8 Activity duration estimates & $p=.008$ \\
H3-9 Project schedule & $p=.064$ \\
H3-10 Schedule model data & $p=.397$ \\
H3-11 Schedule baseline & $p=.443$ \\
H3-12 Performance measurements & $p=.567$ \\
\hline
\end{tabular}




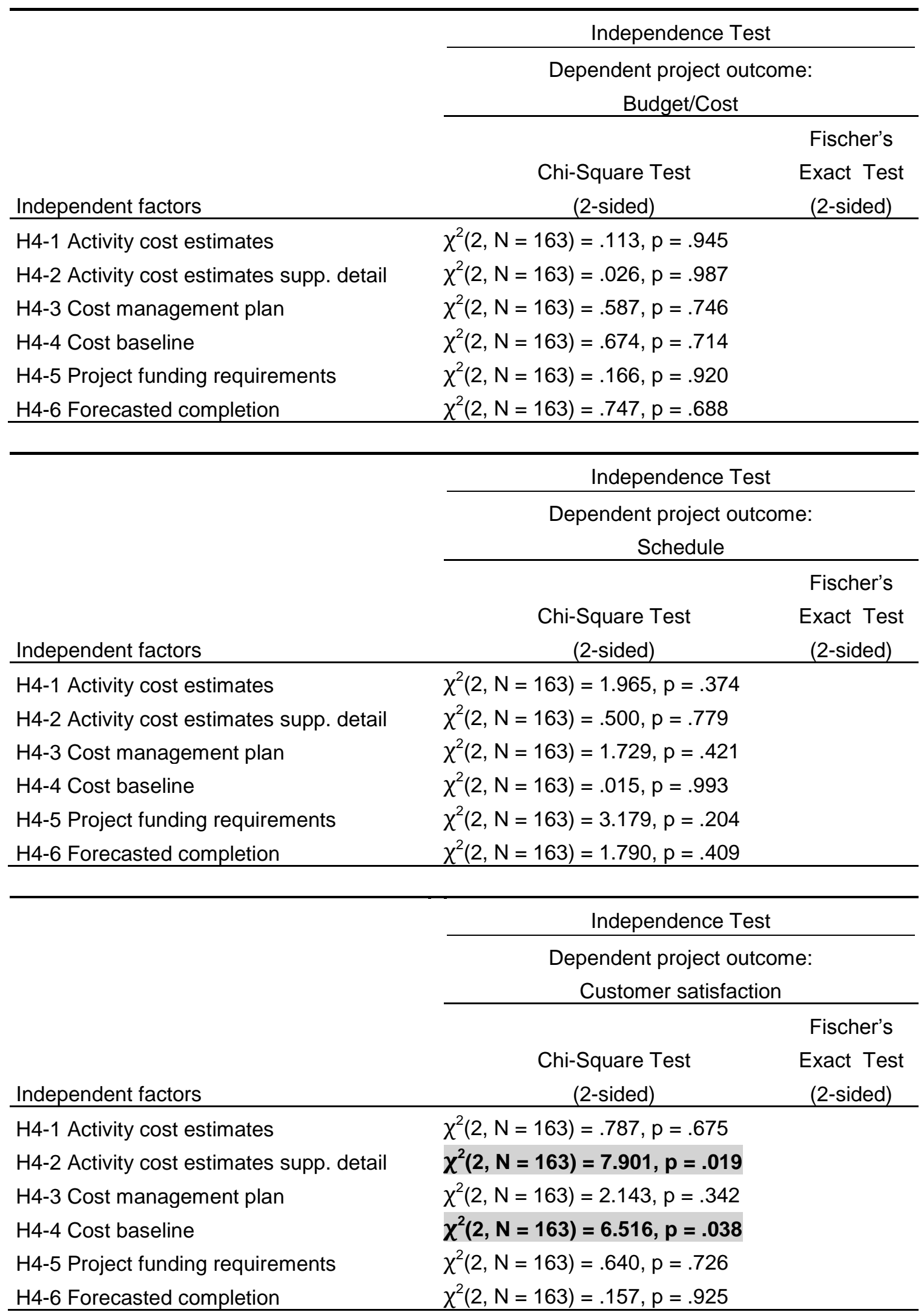




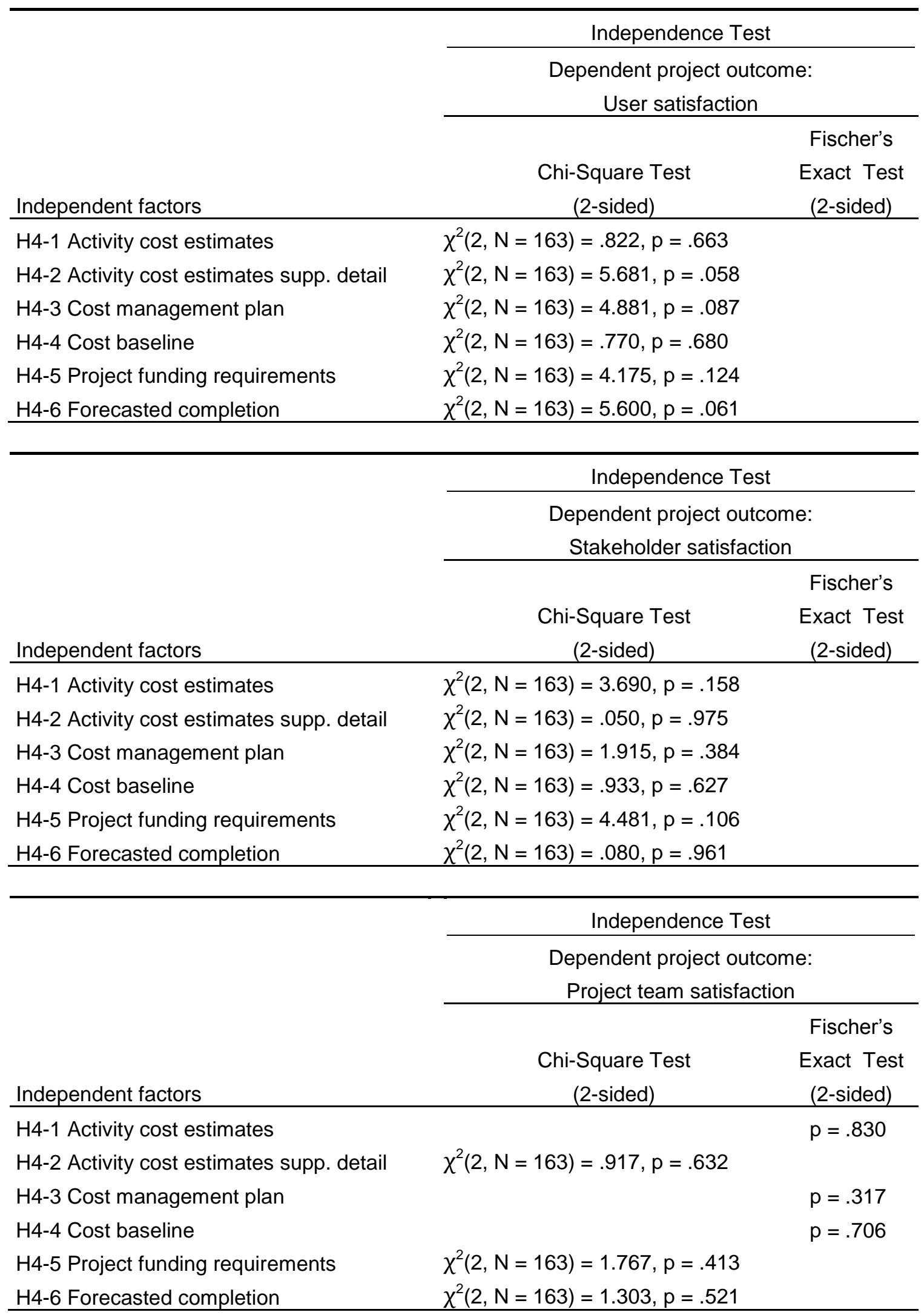




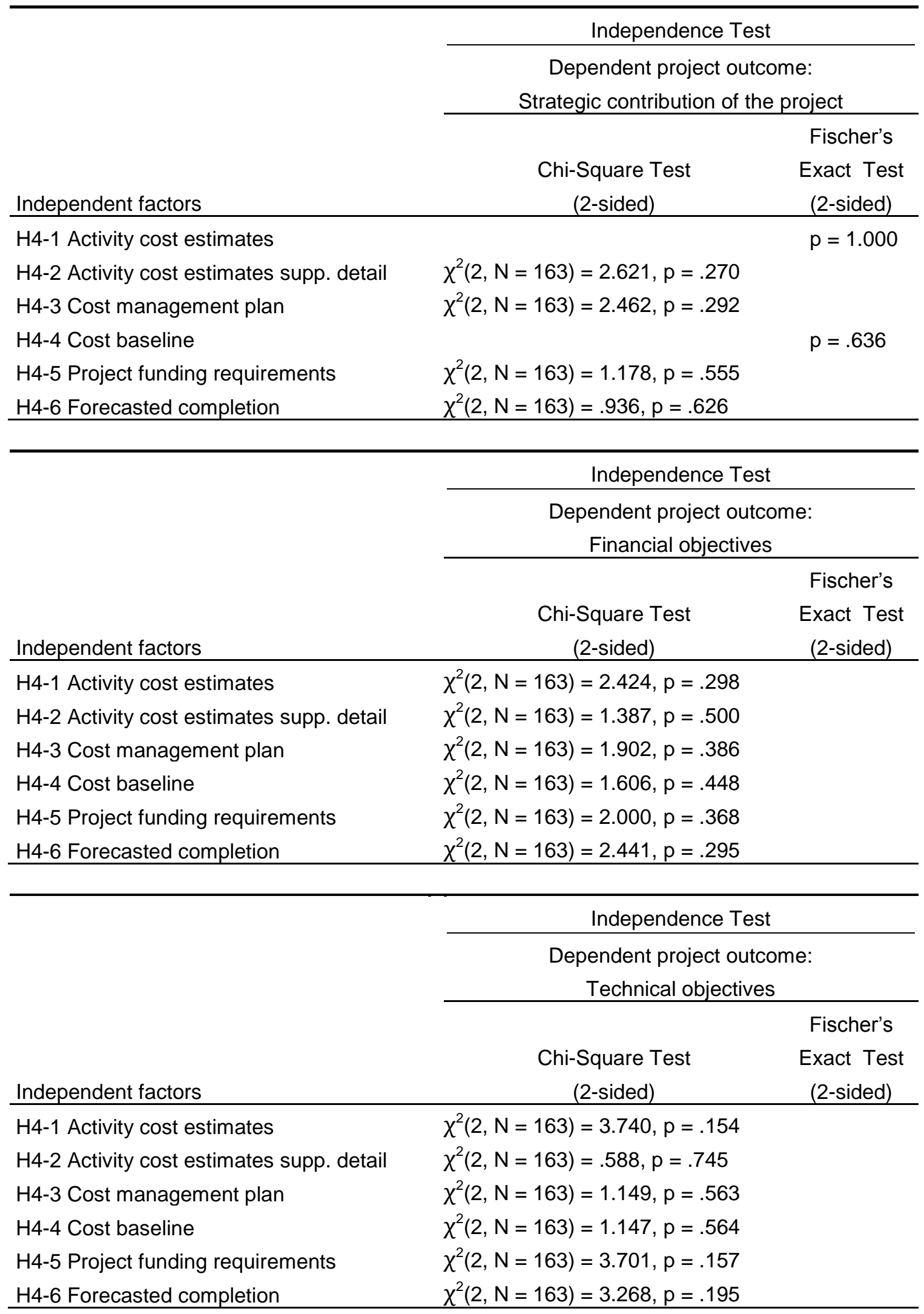




\begin{tabular}{|c|c|c|}
\hline \multirow[b]{3}{*}{ Independent factors } & \multicolumn{2}{|c|}{ Independence Test } \\
\hline & \multicolumn{2}{|c|}{$\begin{array}{l}\text { Dependent project outcome: } \\
\text { Performance objectives }\end{array}$} \\
\hline & $\begin{array}{c}\text { Chi-Square Test } \\
(2 \text {-sided })\end{array}$ & $\begin{array}{c}\text { Fischer's } \\
\text { Exact Test } \\
\text { (2-sided) }\end{array}$ \\
\hline H4-1 Activity cost estimates & \multicolumn{2}{|l|}{$\chi^{2}(2, N=163)=1.351, p=.509$} \\
\hline H4-2 Activity cost estimates supp. detail & \multicolumn{2}{|l|}{$\chi^{2}(2, N=163)=3.259, p=.196$} \\
\hline H4-3 Cost management plan & \multicolumn{2}{|l|}{$\chi^{2}(2, N=163)=.365, p=.833$} \\
\hline H4-4 Cost baseline & \multicolumn{2}{|l|}{$\chi^{2}(2, N=163)=.555, p=.758$} \\
\hline H4-5 Project funding requirements & \multicolumn{2}{|l|}{$\chi^{2}(2, N=163)=1.054, p=.590$} \\
\hline H4-6 Forecasted completion & \multicolumn{2}{|l|}{$\chi^{2}(2, N=163)=1.227, p=.542$} \\
\hline & \multicolumn{2}{|c|}{ Independence Test } \\
\hline & \multicolumn{2}{|c|}{$\begin{array}{c}\text { Dependent project outcome: } \\
\text { Commercial benefit for contractors }\end{array}$} \\
\hline Independent factors & $\begin{array}{l}\text { Chi-Square Test } \\
\text { (2-sided) }\end{array}$ & $\begin{array}{c}\text { Fischer's } \\
\text { Exact Test } \\
\text { (2-sided) }\end{array}$ \\
\hline H4-1 Activity cost estimates & & $p=.332$ \\
\hline H4-2 Activity cost estimates supp. detail & & $p=1.000$ \\
\hline H4-3 Cost management plan & & $p=.656$ \\
\hline H4-4 Cost baseline & & $p=1.000$ \\
\hline H4-5 Project funding requirements & & $p=.481$ \\
\hline \multirow[t]{4}{*}{ H4-6 Forecasted completion } & & $p=1.000$ \\
\hline & \multicolumn{2}{|c|}{ Independence Test } \\
\hline & \multicolumn{2}{|c|}{$\begin{array}{c}\text { Dependent project outcome: } \\
\text { Commercial benefit for customer }\end{array}$} \\
\hline & $\begin{array}{l}\text { Chi-Square Test } \\
\text { (2-sided) }\end{array}$ & $\begin{array}{c}\text { Fischer's } \\
\text { Exact Test } \\
\text { (2-sided) }\end{array}$ \\
\hline H4-1 Activity cost estimates & & $p=.607$ \\
\hline H4-2 Activity cost estimates supp. detail & $\chi^{2}(2, N=163)=2.878, p=.237$ & \\
\hline H4-3 Cost management plan & & $p=1.000$ \\
\hline H4-4 Cost baseline & & $p=.019$ \\
\hline H4-5 Project funding requirements & $\chi^{2}(2, N=163)=2.167, p=.338$ & \\
\hline H4-6 Forecasted completion & & $p=.373$ \\
\hline
\end{tabular}




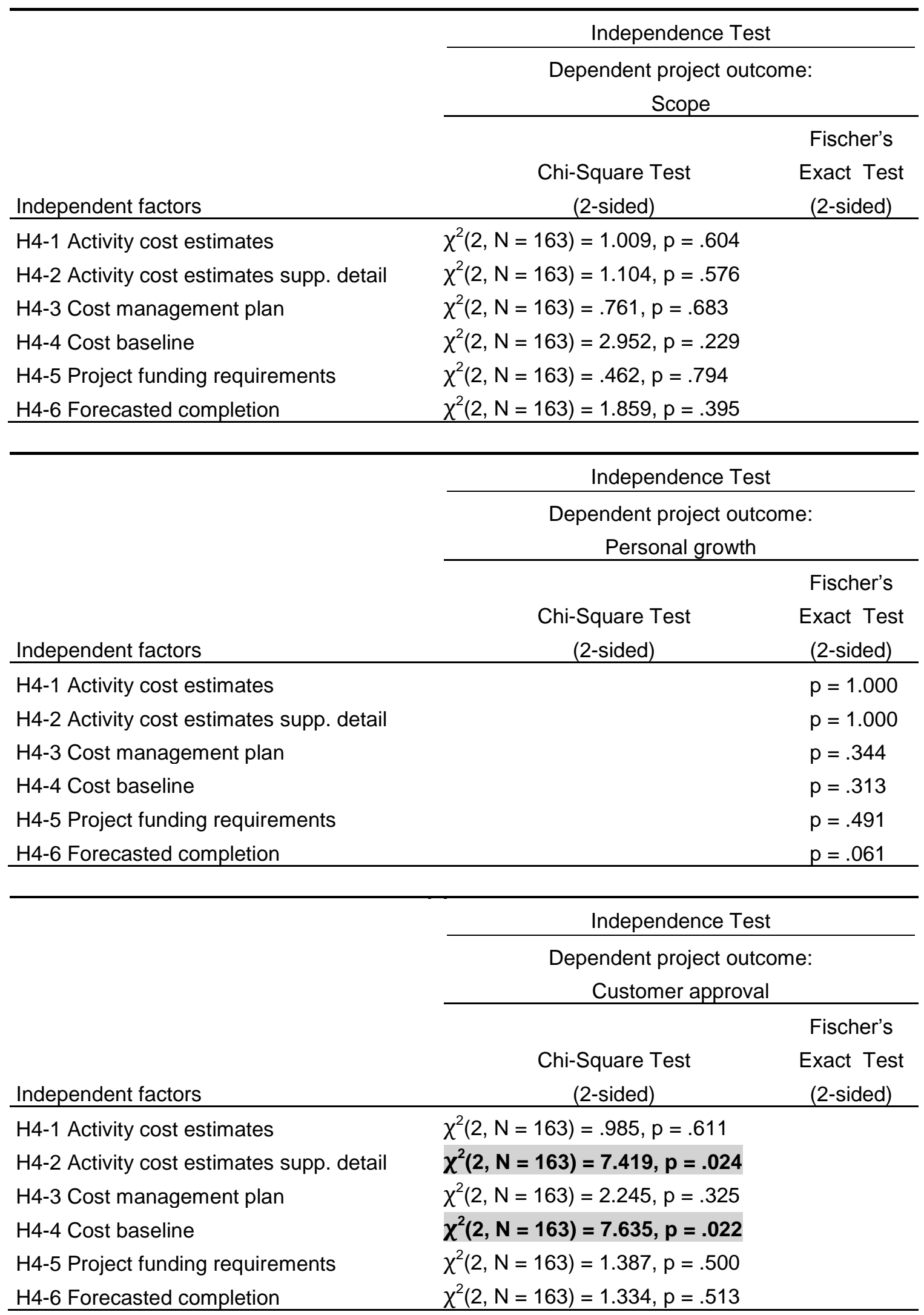




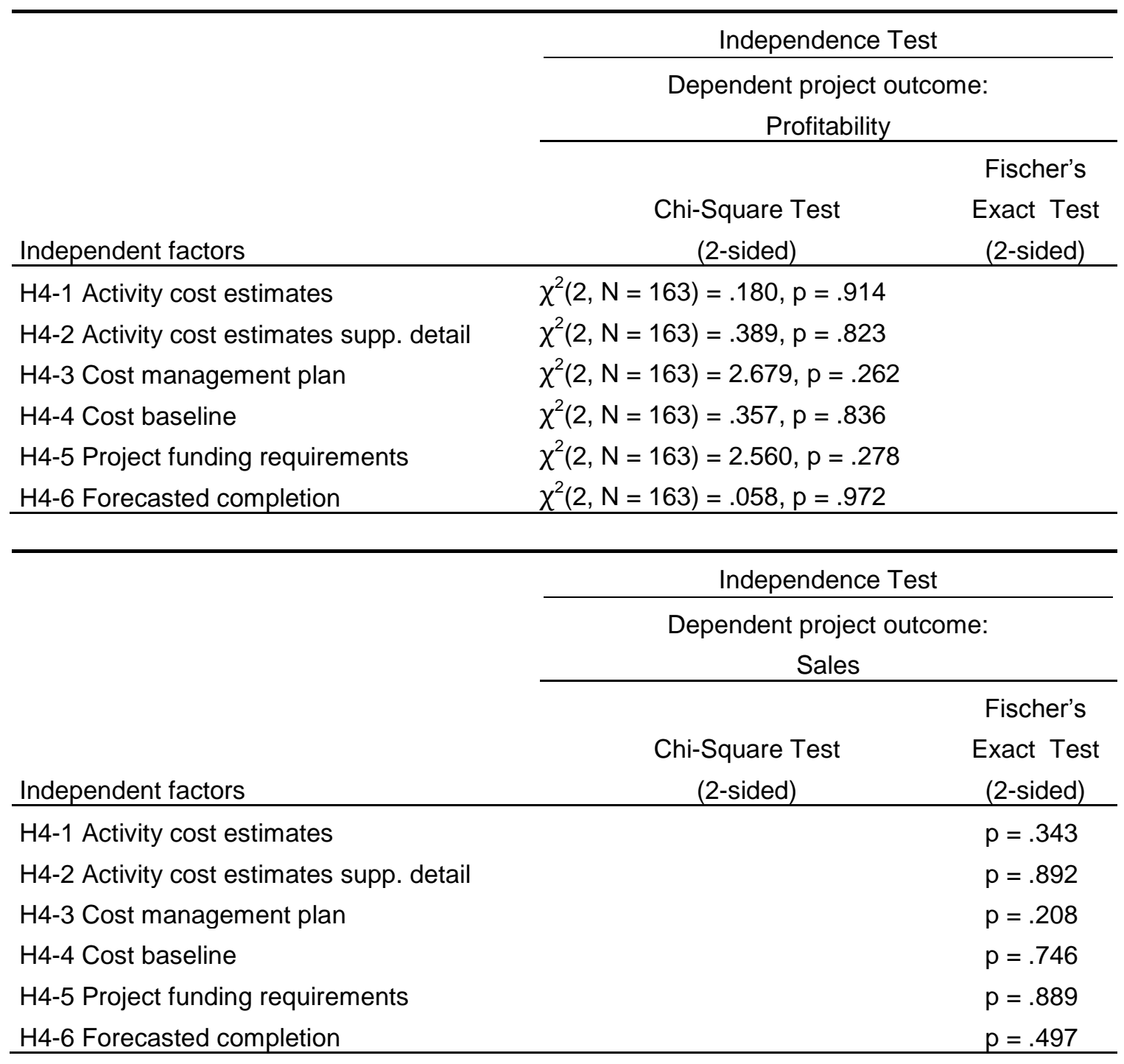




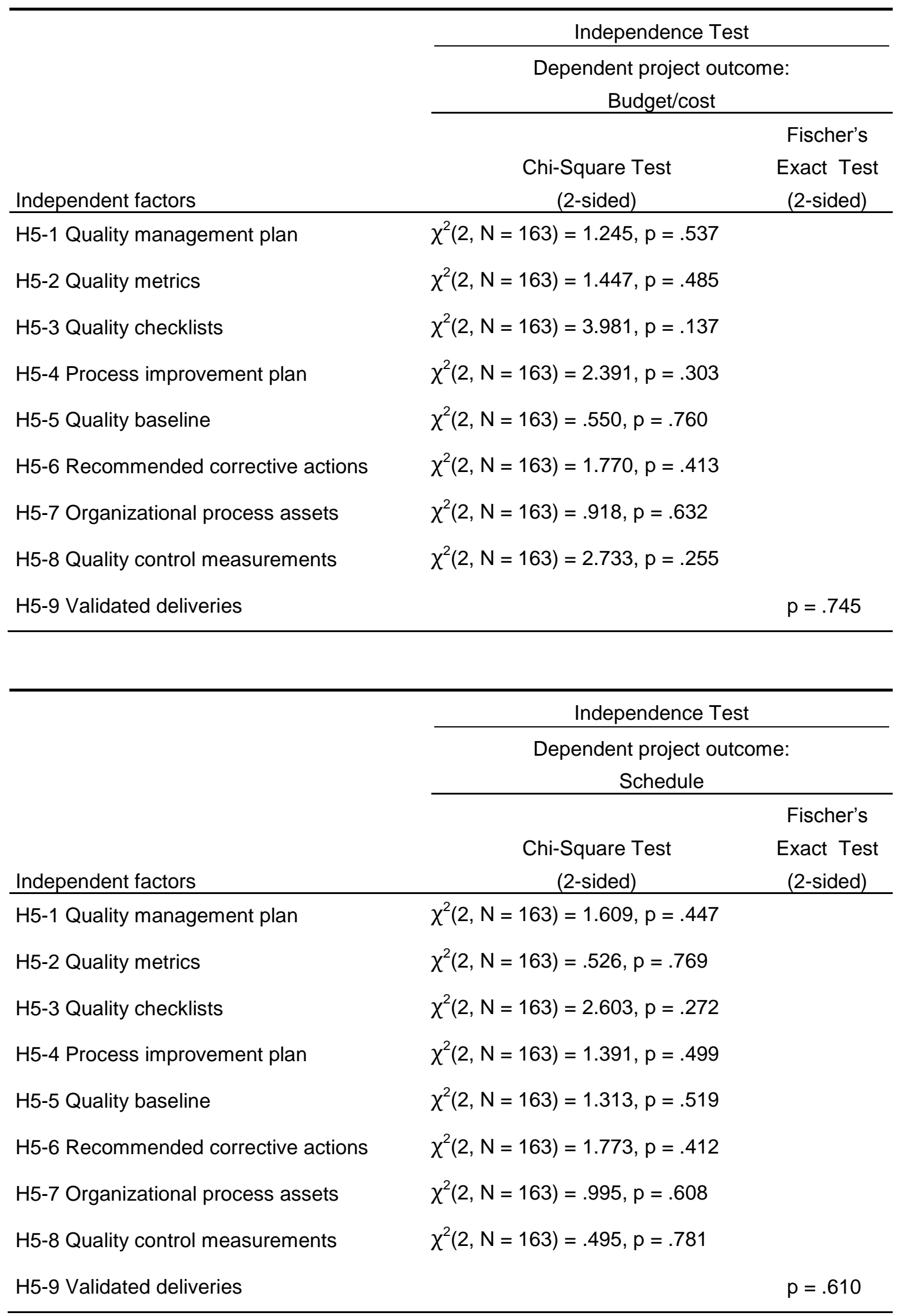




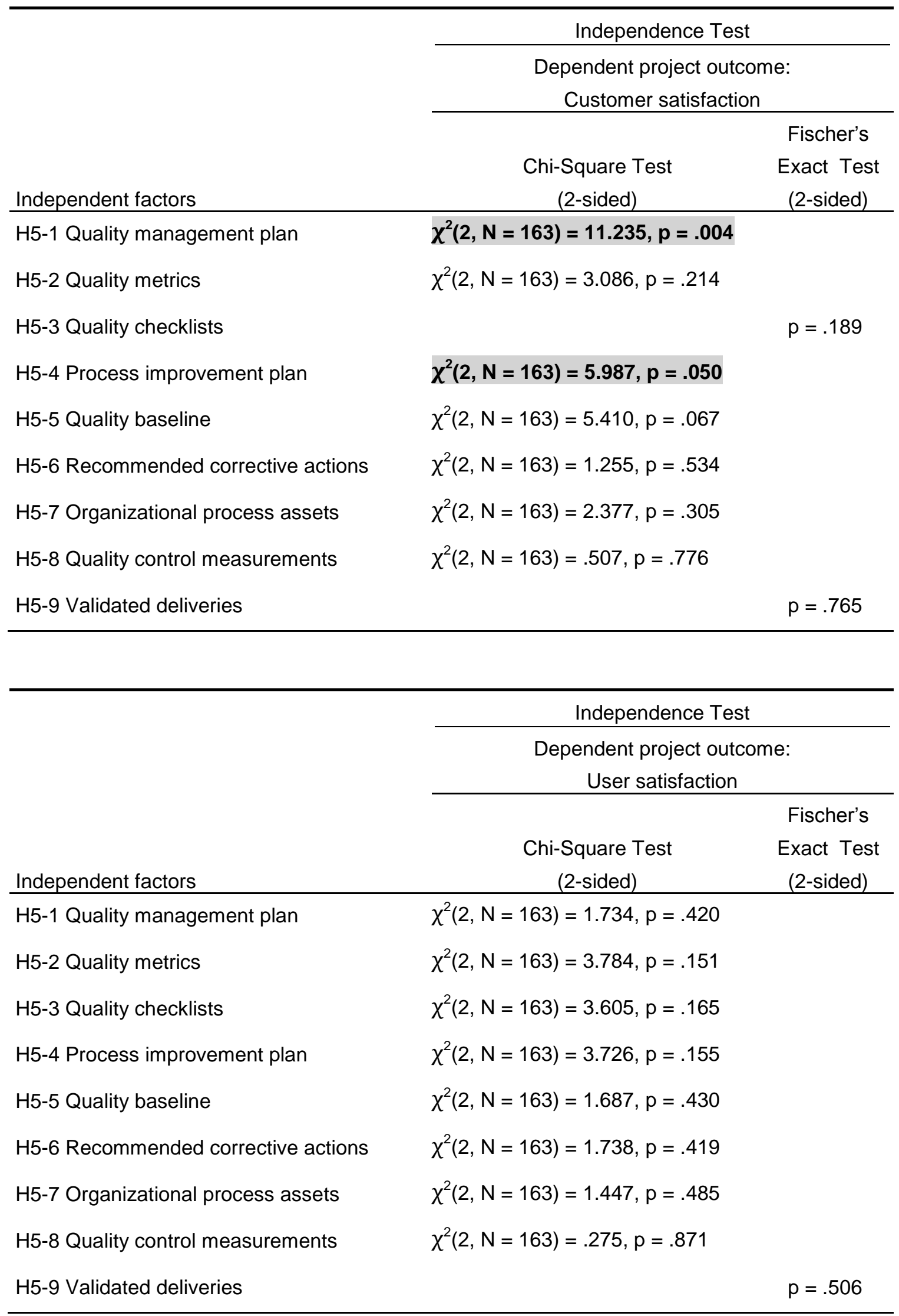




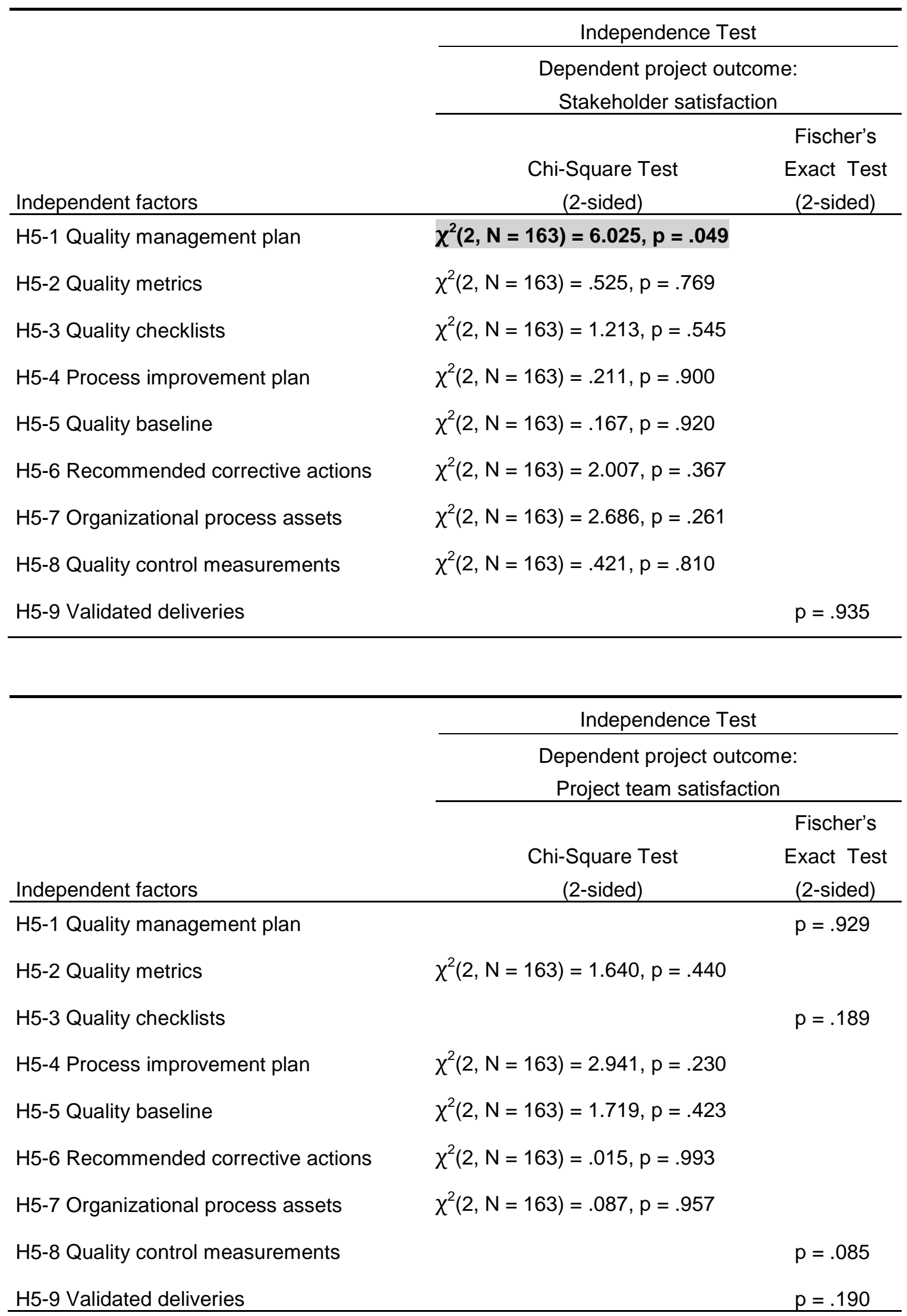




\begin{tabular}{|c|c|c|}
\hline \multirow[b]{3}{*}{ Independent factors } & \multicolumn{2}{|c|}{ Independence Test } \\
\hline & \multicolumn{2}{|c|}{$\begin{array}{c}\text { Dependent project outcome: } \\
\text { Strategic contribution of the project }\end{array}$} \\
\hline & $\begin{array}{c}\text { Chi-Square Test } \\
\text { (2-sided) } \\
\end{array}$ & $\begin{array}{c}\text { Fischer's } \\
\text { Exact Test } \\
\text { (2-sided) }\end{array}$ \\
\hline H5-1 Quality management plan & \multicolumn{2}{|c|}{$\chi^{2}(2, N=163)=.022, p=.989$} \\
\hline H5-2 Quality metrics & \multicolumn{2}{|c|}{$\chi^{2}(2, N=163)=2.698, p=.259$} \\
\hline H5-3 Quality checklists & \multicolumn{2}{|c|}{$\chi^{2}(2, N=163)=1.689, p=.430$} \\
\hline H5-4 Process improvement plan & \multicolumn{2}{|c|}{$\chi^{2}(2, N=163)=.857, p=.652$} \\
\hline H5-5 Quality baseline & \multicolumn{2}{|c|}{$\chi^{2}(2, N=163)=1.040, p=.595$} \\
\hline H5-6 Recommended corrective actions & \multicolumn{2}{|c|}{$\chi^{2}(2, N=163)=12.456, p=.002$} \\
\hline H5-7 Organizational process assets & \multicolumn{2}{|c|}{$\chi^{2}(2, N=163)=1.119, p=.210$} \\
\hline H5-8 Quality control measurements & \multirow{2}{*}{\multicolumn{2}{|c|}{$p=.054$}} \\
\hline \multicolumn{2}{|l|}{ H5-9 Validated deliveries } & \\
\hline \multirow[b]{3}{*}{ Independent factors } & \multicolumn{2}{|c|}{ Independence Test } \\
\hline & \multicolumn{2}{|c|}{$\begin{array}{l}\text { Dependent project outcome: } \\
\text { Financial objectives }\end{array}$} \\
\hline & $\begin{array}{c}\text { Chi-Square Test } \\
\text { (2-sided) }\end{array}$ & $\begin{array}{c}\text { Fischer's } \\
\text { Exact Test } \\
\text { (2-sided) }\end{array}$ \\
\hline H5-1 Quality management plan & \multicolumn{2}{|c|}{$\chi^{2}(2, N=163)=.793, p=.673$} \\
\hline H5-2 Quality metrics & \multicolumn{2}{|c|}{$\chi^{2}(2, N=163)=5.559, p=.062$} \\
\hline H5-3 Quality checklists & \multicolumn{2}{|c|}{$\chi^{2}(2, N=163)=1.788, p=.409$} \\
\hline H5-4 Process improvement plan & \multicolumn{2}{|c|}{$\chi^{2}(2, N=163)=1.476, p=.478$} \\
\hline H5-5 Quality baseline & \multicolumn{2}{|c|}{$\chi^{2}(2, N=163)=.194, p=.908$} \\
\hline H5-6 Recommended corrective actions & \multicolumn{2}{|c|}{$\chi^{2}(2, N=163)=.447, p=.800$} \\
\hline H5-7 Organizational process assets & \multicolumn{2}{|c|}{$\chi^{2}(2, N=163)=1.081, p=.582$} \\
\hline H5-8 Quality control measurements & \multicolumn{2}{|c|}{$\chi^{2}(2, N=163)=1.377, p=.502$} \\
\hline H5-9 Validated deliveries & & $p=.351$ \\
\hline
\end{tabular}




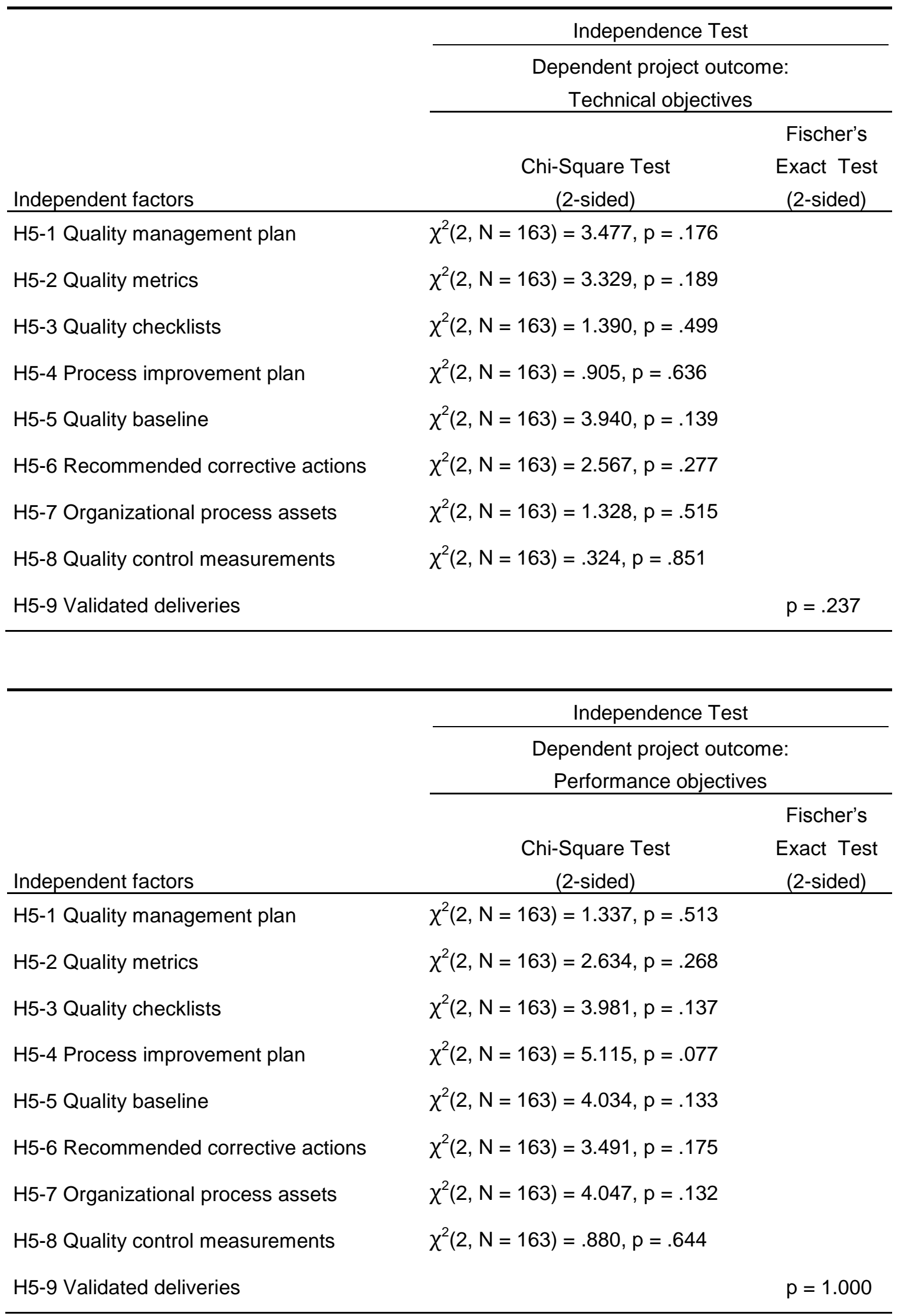




\begin{tabular}{lcc}
\hline & \multicolumn{2}{c}{ Independence Test } \\
\cline { 2 - 3 } & \multicolumn{2}{c}{$\begin{array}{c}\text { Dependent project outcome: } \\
\text { Commercial benefit for contractors }\end{array}$} \\
\cline { 2 - 3 } Independent factors & $\begin{array}{c}\text { Fischer's } \\
\text { Exact Test } \\
\text { H5-1 Quality management plan }\end{array}$ & $\mathrm{p}=.174$ \\
H5-2 Quality metrics & $\mathrm{p}=.142$ \\
H5-3 Quality checklists & $\mathrm{p}=.160$ \\
H5-4 Process improvement plan & $\mathrm{p}=.720$ \\
H5-5 Quality baseline & $\mathrm{p}=.206$ \\
H5-6 Recommended corrective actions & $\mathrm{p}=1.000$ \\
H5-7 Organizational process assets & $\mathrm{p}=.448$ \\
H5-8 Quality control measurements & $\mathrm{p}=.633$ \\
H5-9 Validated deliveries & $\mathrm{p}=1.000$ \\
\hline
\end{tabular}

\begin{tabular}{|c|c|c|}
\hline \multirow[b]{3}{*}{ Independent factors } & \multicolumn{2}{|c|}{ Independence Test } \\
\hline & \multicolumn{2}{|c|}{$\begin{array}{c}\text { Dependent project outcome: } \\
\text { Commercial benefit for customer }\end{array}$} \\
\hline & $\begin{array}{c}\text { Chi-Square Test } \\
\text { (2-sided) }\end{array}$ & $\begin{array}{c}\text { Fischer's } \\
\text { Exact Test } \\
\text { (2-sided) }\end{array}$ \\
\hline H5-1 Quality management plan & & $p=.050$ \\
\hline H5-2 Quality metrics & & $p=.825$ \\
\hline H5-3 Quality checklists & & $p=1.000$ \\
\hline H5-4 Process improvement plan & $\chi^{2}(2, N=163)=3.209, p=.201$ & \\
\hline H5-5 Quality baseline & $\chi^{2}(2, N=163)=1.689, p=.430$ & \\
\hline H5-6 Recommended corrective actions & $\chi^{2}(2, N=163)=1.035, p=.596$ & \\
\hline H5-7 Organizational process assets & $\chi^{2}(2, N=163)=.221, p=.895$ & \\
\hline H5-8 Quality control measurements & & $p=.718$ \\
\hline H5-9 Validated deliveries & & $p=1.000$ \\
\hline
\end{tabular}




\begin{tabular}{|c|c|c|}
\hline \multirow[b]{3}{*}{ Independent factors } & \multicolumn{2}{|c|}{ Independence Test } \\
\hline & \multicolumn{2}{|c|}{$\begin{array}{l}\text { Dependent project outcome: } \\
\text { Scope }\end{array}$} \\
\hline & $\begin{array}{c}\text { Chi-Square Test } \\
(2 \text {-sided }) \\
\end{array}$ & $\begin{array}{c}\text { Fischer's } \\
\text { Exact Test } \\
\text { (2-sided) }\end{array}$ \\
\hline H5-1 Quality management plan & $\chi^{2}(2, N=163)=1.897, p=.387$ & \\
\hline H5-2 Quality metrics & $\chi^{2}(2, N=163)=.605, p=.739$ & \\
\hline H5-3 Quality checklists & $\chi^{2}(2, N=163)=2.565, p=.277$ & \\
\hline H5-4 Process improvement plan & $\chi^{2}(2, N=163)=1.294, p=.524$ & \\
\hline H5-5 Quality baseline & $\chi^{2}(2, N=163)=.081, p=.960$ & \\
\hline H5-6 Recommended corrective actions & $\chi^{2}(2, N=163)=1.719, p=.423$ & \\
\hline H5-7 Organizational process assets & $\chi^{2}(2, N=163)=1.648, p=.439$ & \\
\hline H5-8 Quality control measurements & $\chi^{2}(2, N=163)=7.540, p=.023$ & \\
\hline H5-9 Validated deliveries & & $p=.506$ \\
\hline
\end{tabular}

\begin{tabular}{lcc}
\hline & \multicolumn{2}{c}{ Independence Test } \\
\cline { 2 - 3 } & \multicolumn{2}{c}{$\begin{array}{c}\text { Dependent project outcome: } \\
\text { Personal growth }\end{array}$} \\
\cline { 2 - 3 } & \multicolumn{2}{c}{ Chi-Square Test } \\
(2-sided) & $\begin{array}{c}\text { Exact Test } \\
\text { Independent factors }\end{array}$ & $\mathrm{p}=.313$ \\
H5-1 Quality management plan & $\mathrm{p}=1.000$ \\
H5-2 Quality metrics & $\mathrm{p}=.319$ \\
H5-3 Quality checklists & $\mathrm{p}=.117$ \\
H5-4 Process improvement plan & $\mathrm{p}=.503$ \\
H5-5 Quality baseline & $\mathrm{p}=1.000$ \\
H5-6 Recommended corrective actions & $\mathrm{p}=.528$ \\
H5-7 Organizational process assets & $\mathrm{p}=1.000$ \\
H5-8 Quality control measurements & $\mathrm{p}=1.000$ \\
\hline H5-9 Validated deliveries & &
\end{tabular}




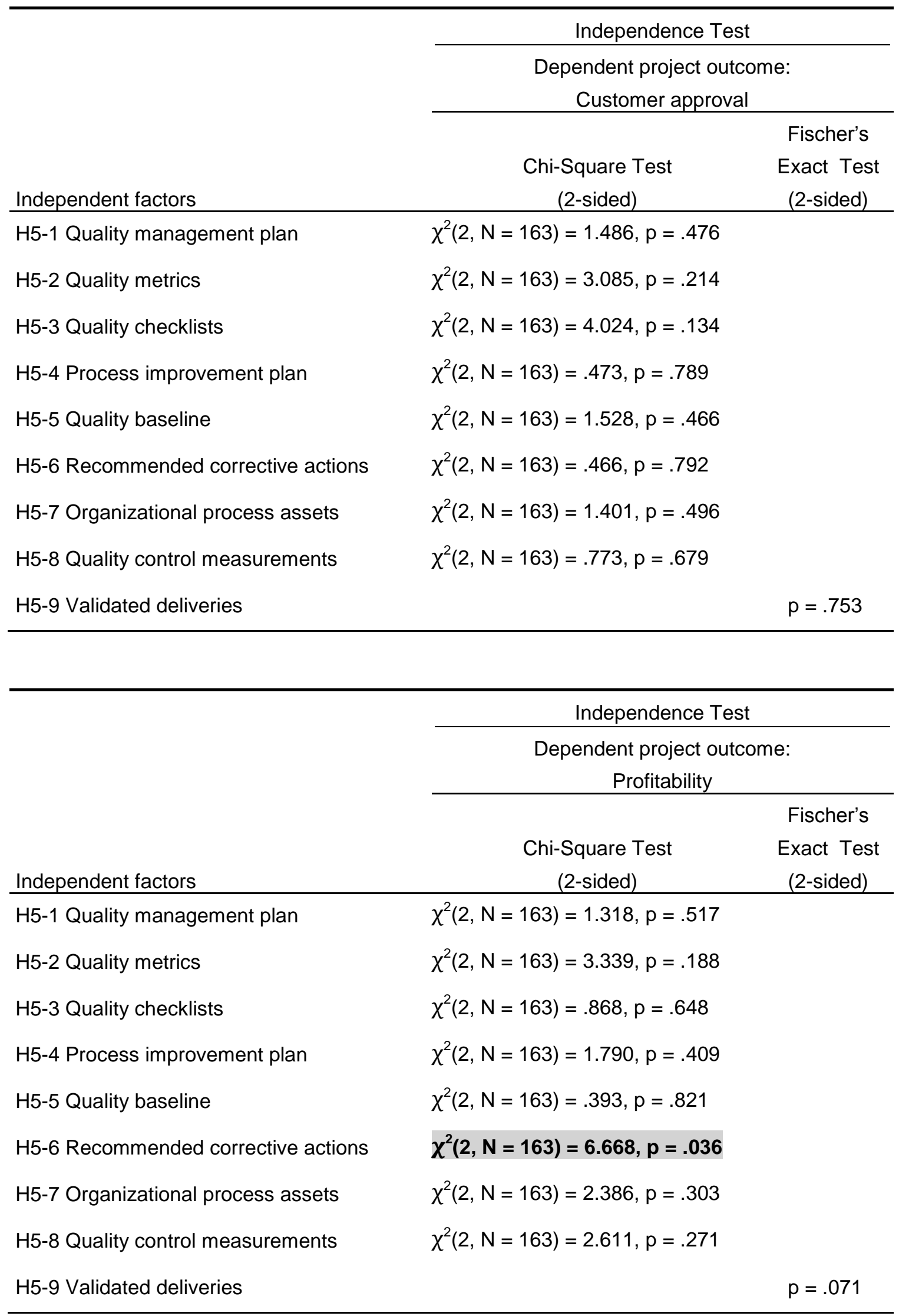




\begin{tabular}{lcc}
\hline & \multicolumn{2}{c}{ Independence Test } \\
\cline { 2 - 3 } & \multicolumn{2}{c}{ Dependent project outcome: } \\
\cline { 2 - 3 } & \multicolumn{2}{c}{ Sales } \\
Independent factors & Chi-Square Test \\
(2-sided) & Exach Test \\
H5-1 Quality management plan & (2-sided) \\
H5-2 Quality metrics & $\mathrm{p}=.218$ \\
H5-3 Quality checklists & $\mathrm{p}=.621$ \\
H5-4 Process improvement plan & $\mathrm{p}=.351$ \\
H5-5 Quality baseline & $\mathrm{p}=.494$ \\
H5-6 Recommended corrective actions & $\mathrm{p}=.890$ \\
H5-7 Organizational process assets & $\mathrm{p}=.697$ \\
H5-8 Quality control measurements & $\mathrm{p}=1.000$ \\
H5-9 Validated deliveries & $\mathrm{p}=.286$ \\
\hline
\end{tabular}




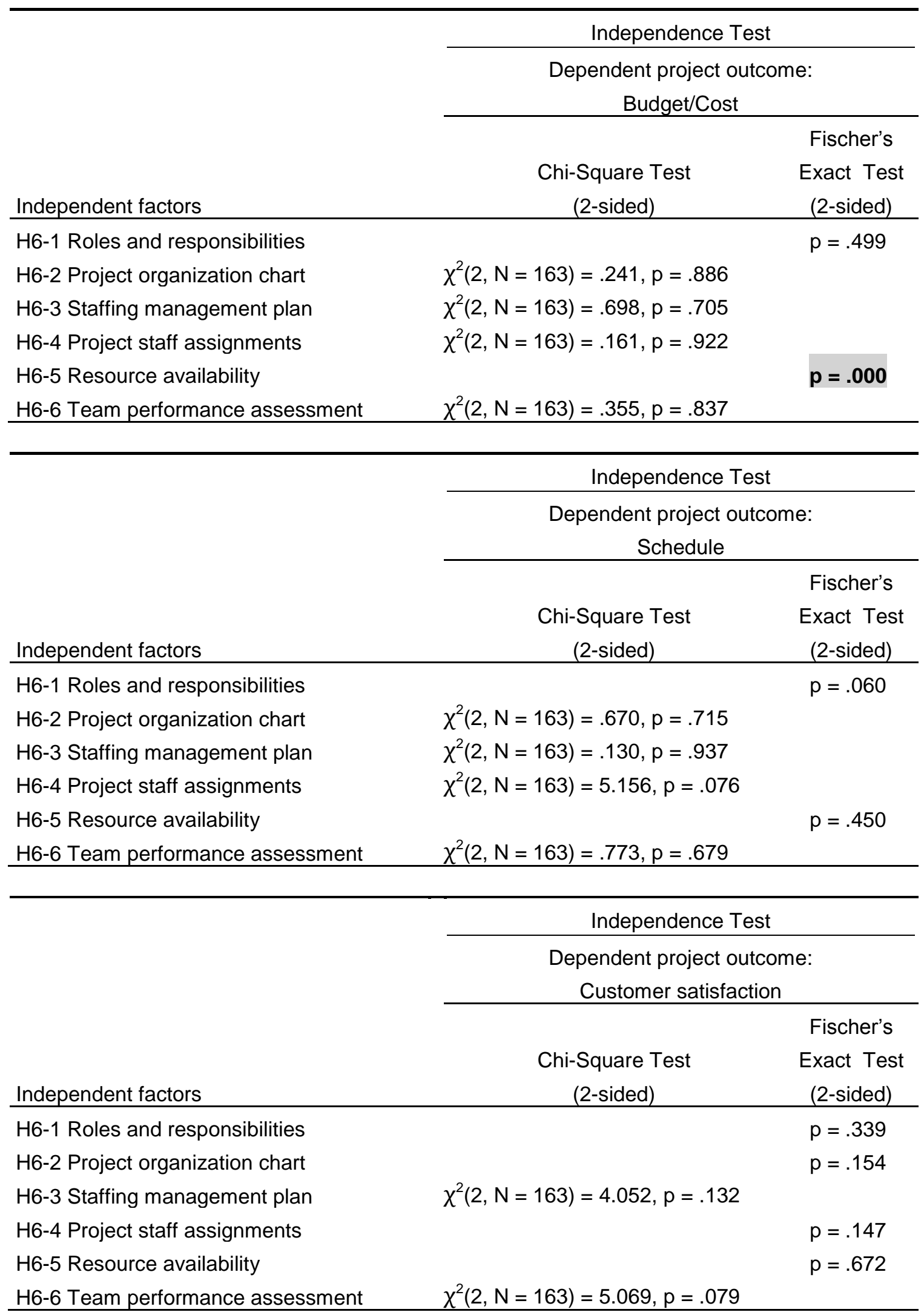




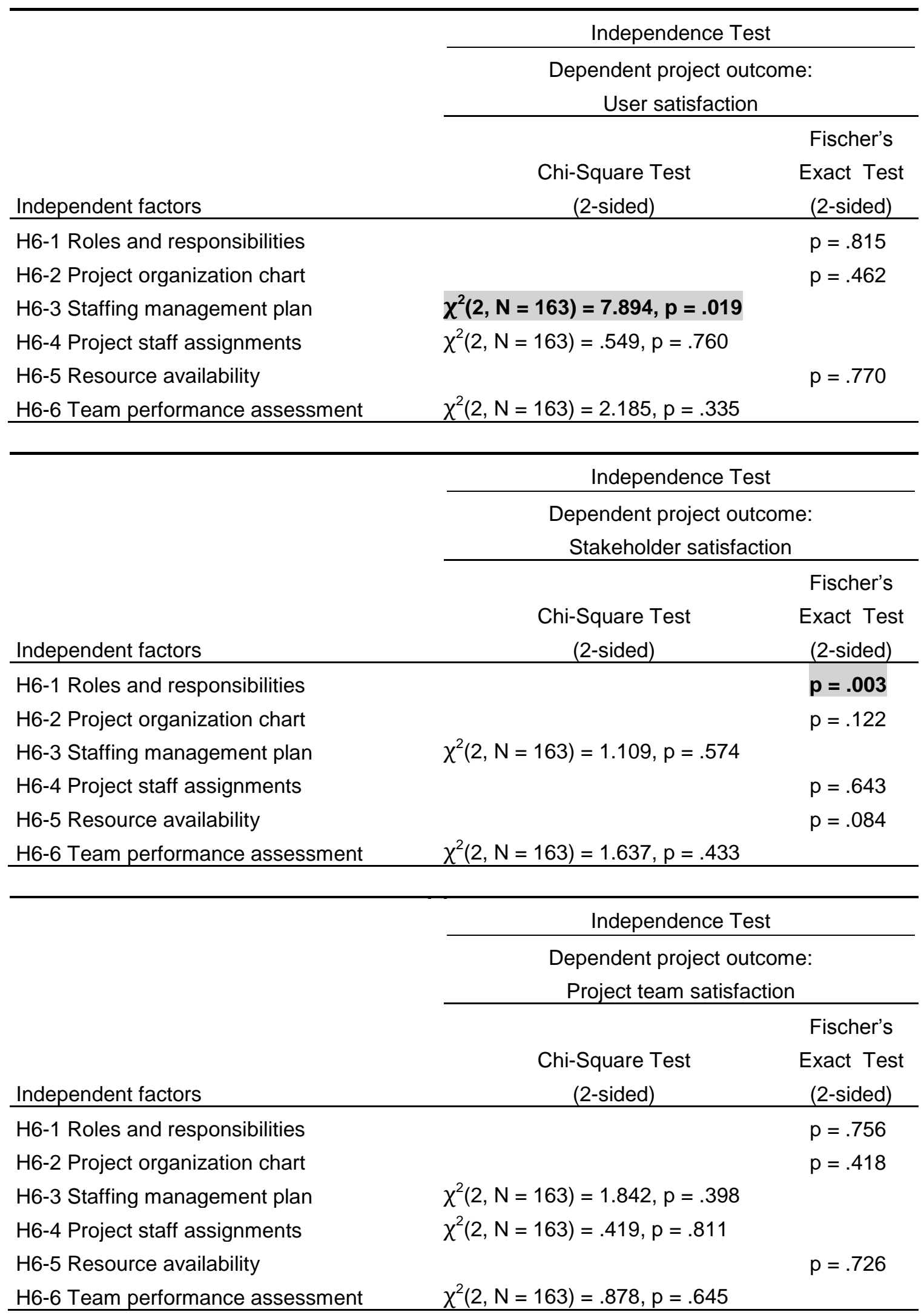




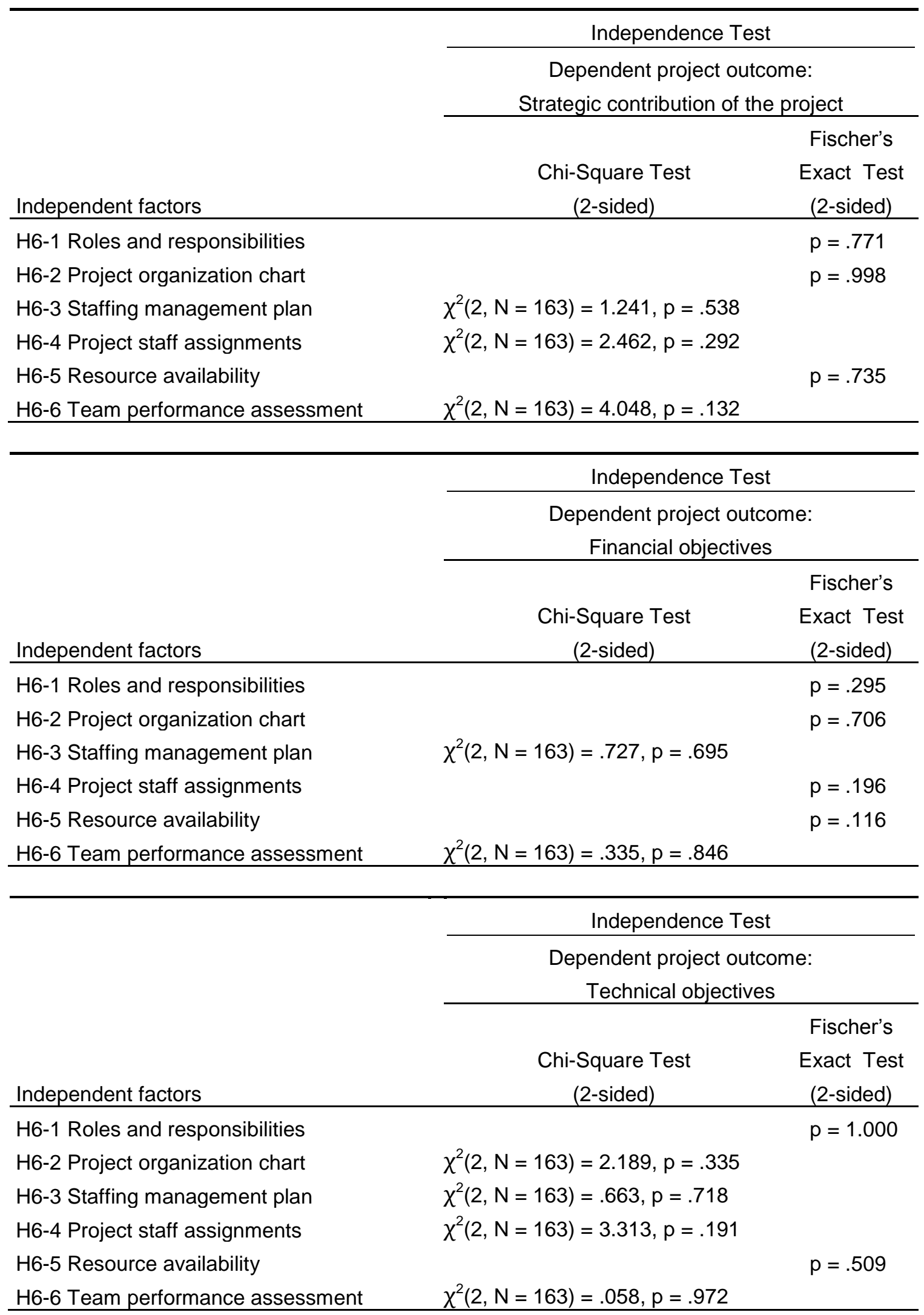




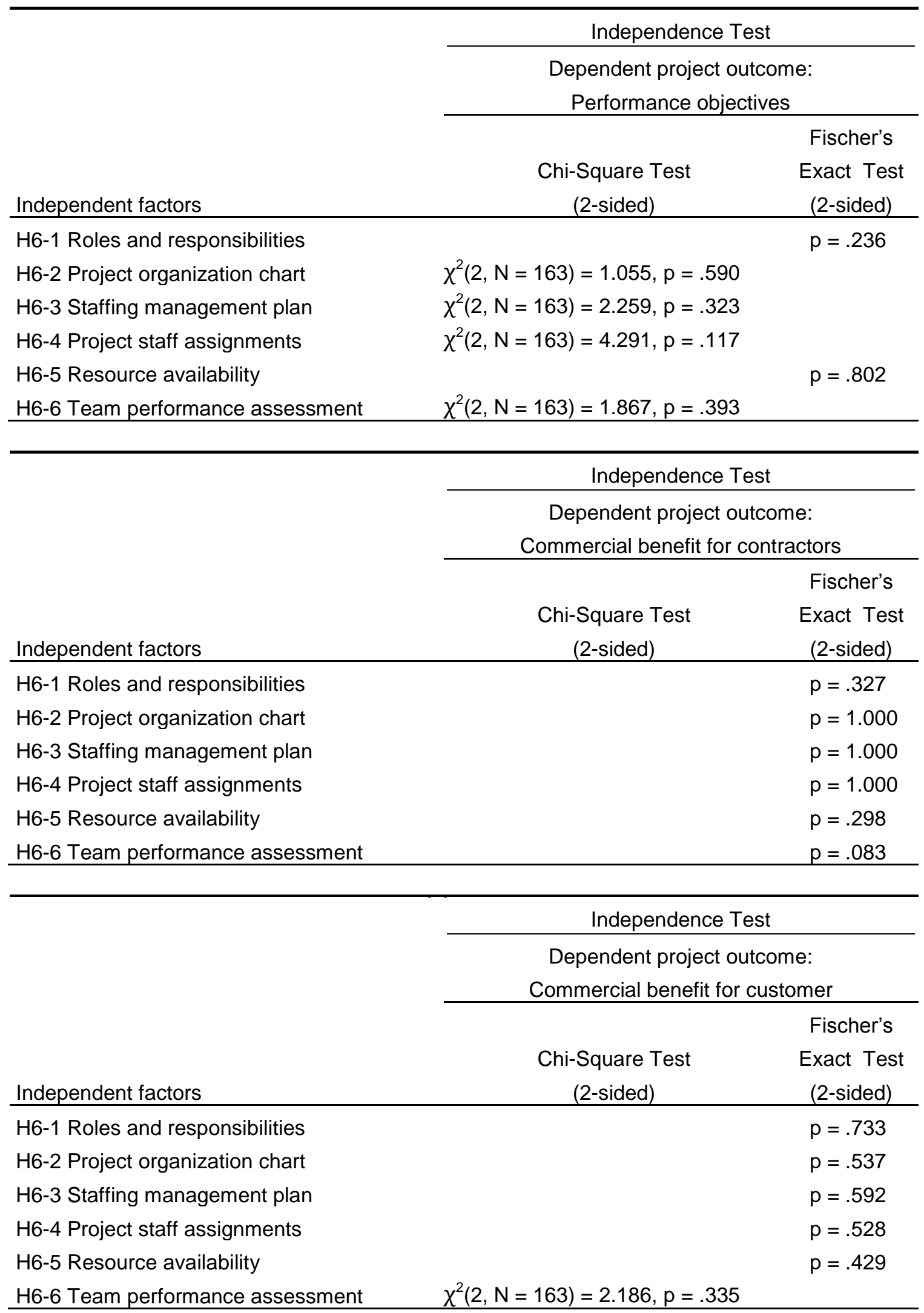




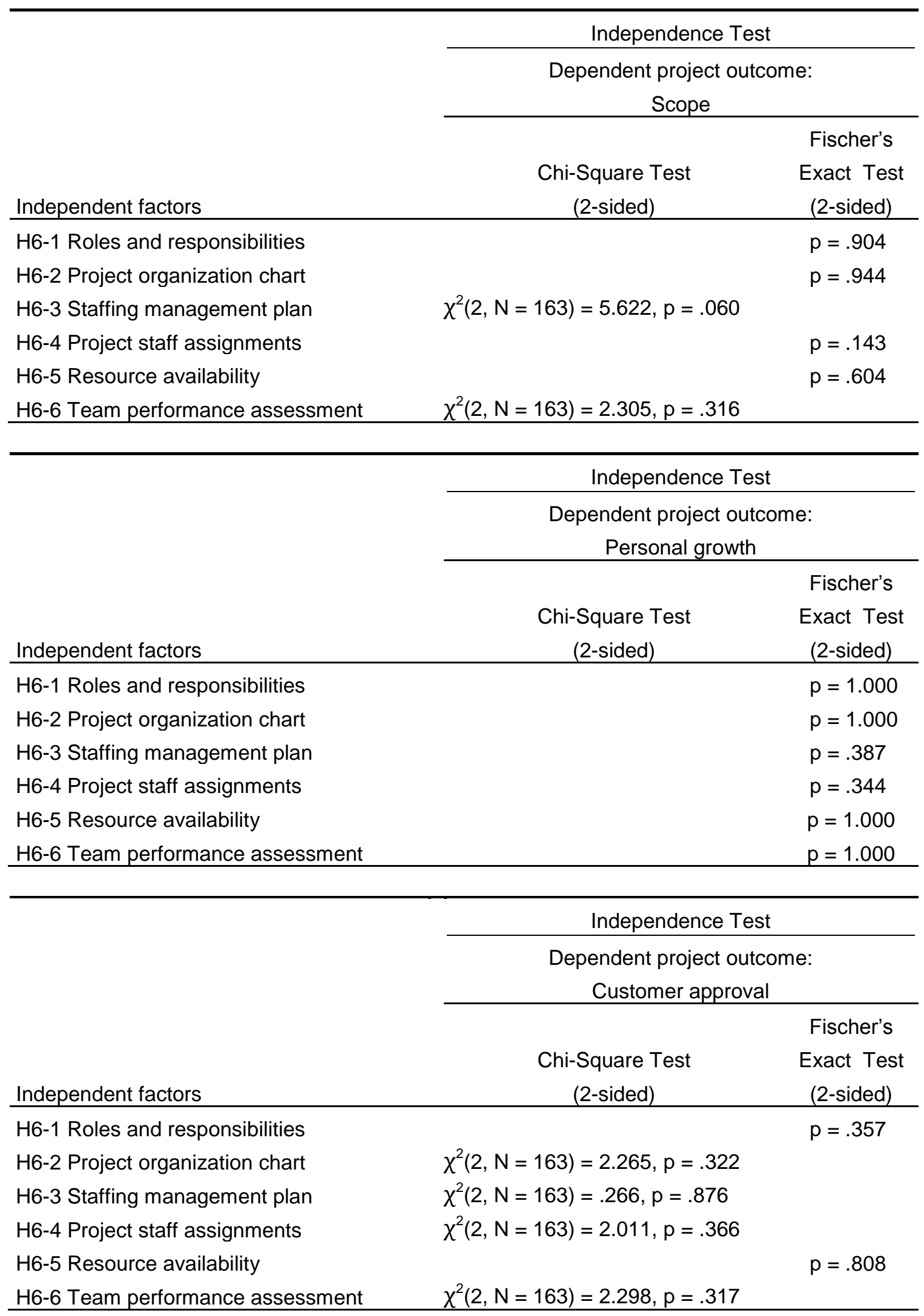




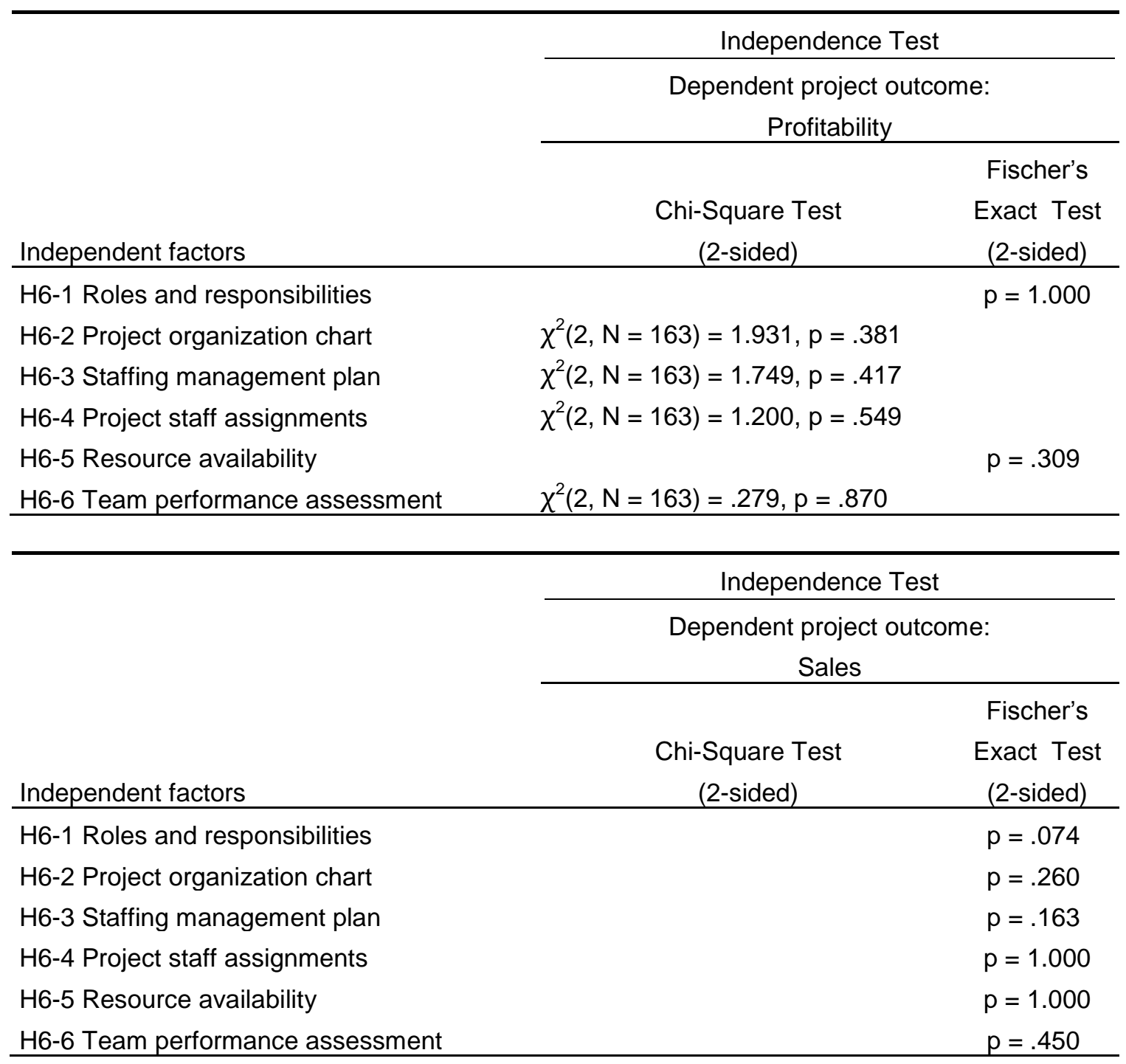




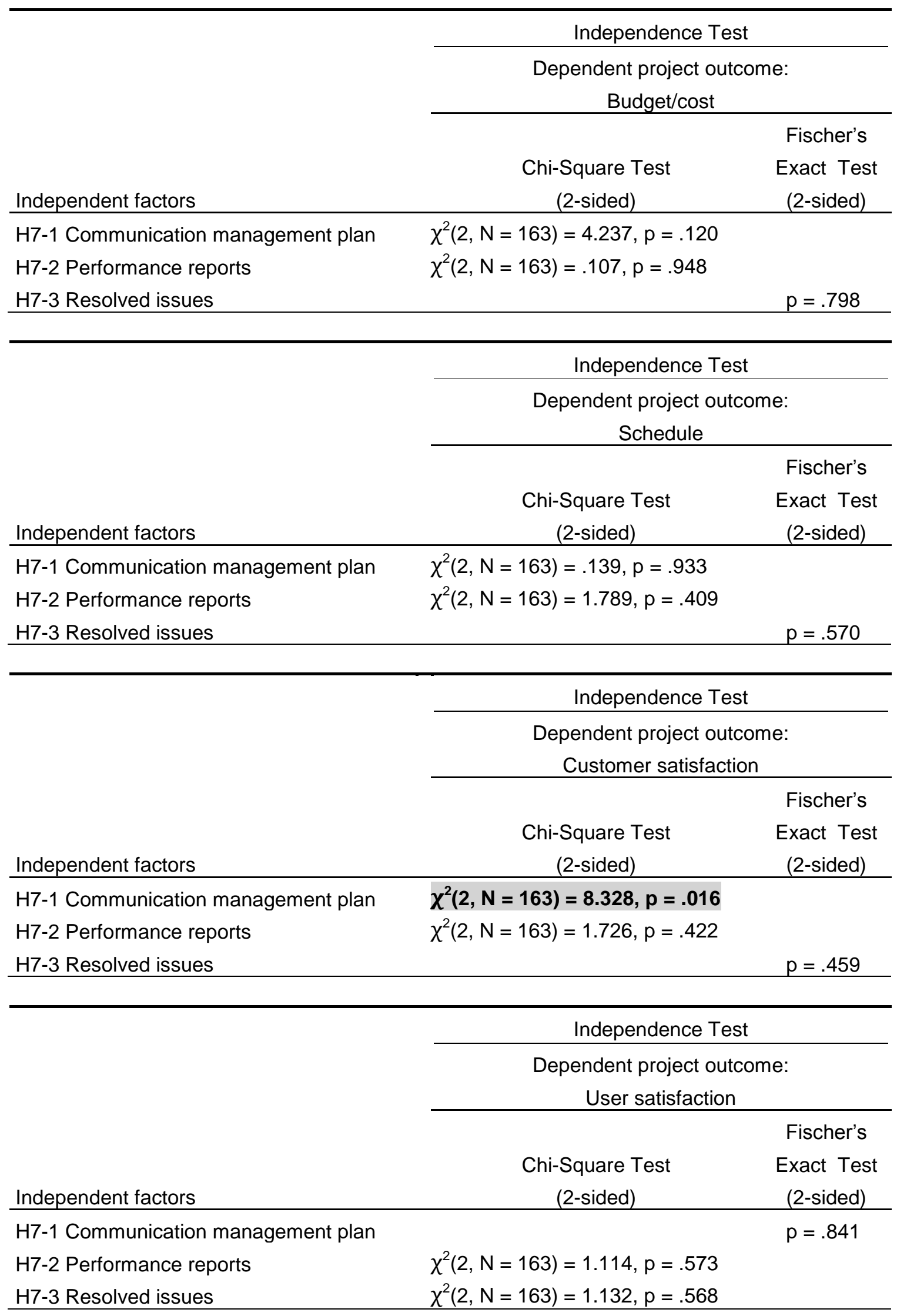




\begin{tabular}{|c|c|c|}
\hline \multirow[b]{3}{*}{ Independent factors } & \multicolumn{2}{|c|}{ Independence Test } \\
\hline & \multicolumn{2}{|c|}{$\begin{array}{c}\text { Dependent project outcome: } \\
\text { Stakeholder satisfaction }\end{array}$} \\
\hline & $\begin{array}{c}\text { Chi-Square Test } \\
\text { (2-sided) }\end{array}$ & $\begin{array}{c}\text { Fischer's } \\
\text { Exact Test } \\
\text { (2-sided) }\end{array}$ \\
\hline H7-1 Communication management plan & $\chi^{2}(2, N=163)=2.818, p=.244$ & \\
\hline H7-2 Performance reports & $\chi^{2}(2, N=163)=1.123, p=.570$ & \\
\hline \multirow[t]{4}{*}{ H7-3 Resolved issues } & & $p=.186$ \\
\hline & Independence Tt & \\
\hline & $\begin{array}{r}\text { Dependent project ou } \\
\text { Project team satisfa }\end{array}$ & \\
\hline & $\begin{array}{l}\text { Chi-Square Test } \\
\text { (2-sided) }\end{array}$ & $\begin{array}{c}\text { Fischer's } \\
\text { Exact Test } \\
\text { (2-sided) }\end{array}$ \\
\hline $\begin{array}{l}\text { H7-1 Communication management plan } \\
\text { H7-2 Performance reports }\end{array}$ & $\chi^{2}(2, N=163)=.063, p=.969$ & $p=.474$ \\
\hline \multirow[t]{4}{*}{ H7-3 Resolved issues } & & $p=.588$ \\
\hline & Independence Tt & \\
\hline & $\begin{array}{l}\text { Dependent project ou } \\
\text { Strategic contribution of }\end{array}$ & roject \\
\hline & $\begin{array}{l}\text { Chi-Square Test } \\
\text { (2-sided) }\end{array}$ & $\begin{array}{c}\text { Fischer's } \\
\text { Exact Test } \\
\text { (2-sided) }\end{array}$ \\
\hline $\begin{array}{l}\text { H7-1 Communication management plan } \\
\text { H7-2 Performance reports }\end{array}$ & H7-1 Communication management plan & $p=.739$ \\
\hline \multirow[t]{4}{*}{ H7-3 Resolved issues } & & $p=.904$ \\
\hline & Independence $\mathrm{T} \epsilon$ & \\
\hline & $\begin{array}{l}\text { Dependent project ou } \\
\text { Financial objectiv }\end{array}$ & \\
\hline & $\begin{array}{l}\text { Chi-Square Test } \\
\text { (2-sided) }\end{array}$ & $\begin{array}{c}\text { Fischer's } \\
\text { Exact Test } \\
\text { (2-sided) }\end{array}$ \\
\hline H7-1 Communication management plan & $\chi^{2}(2, N=163)=1.643, p=.440$ & \\
\hline H7-2 Performance reports & $\chi^{2}(2, N=163)=1.157, p=.561$ & \\
\hline H7-3 Resolved issues & & $p=.799$ \\
\hline
\end{tabular}




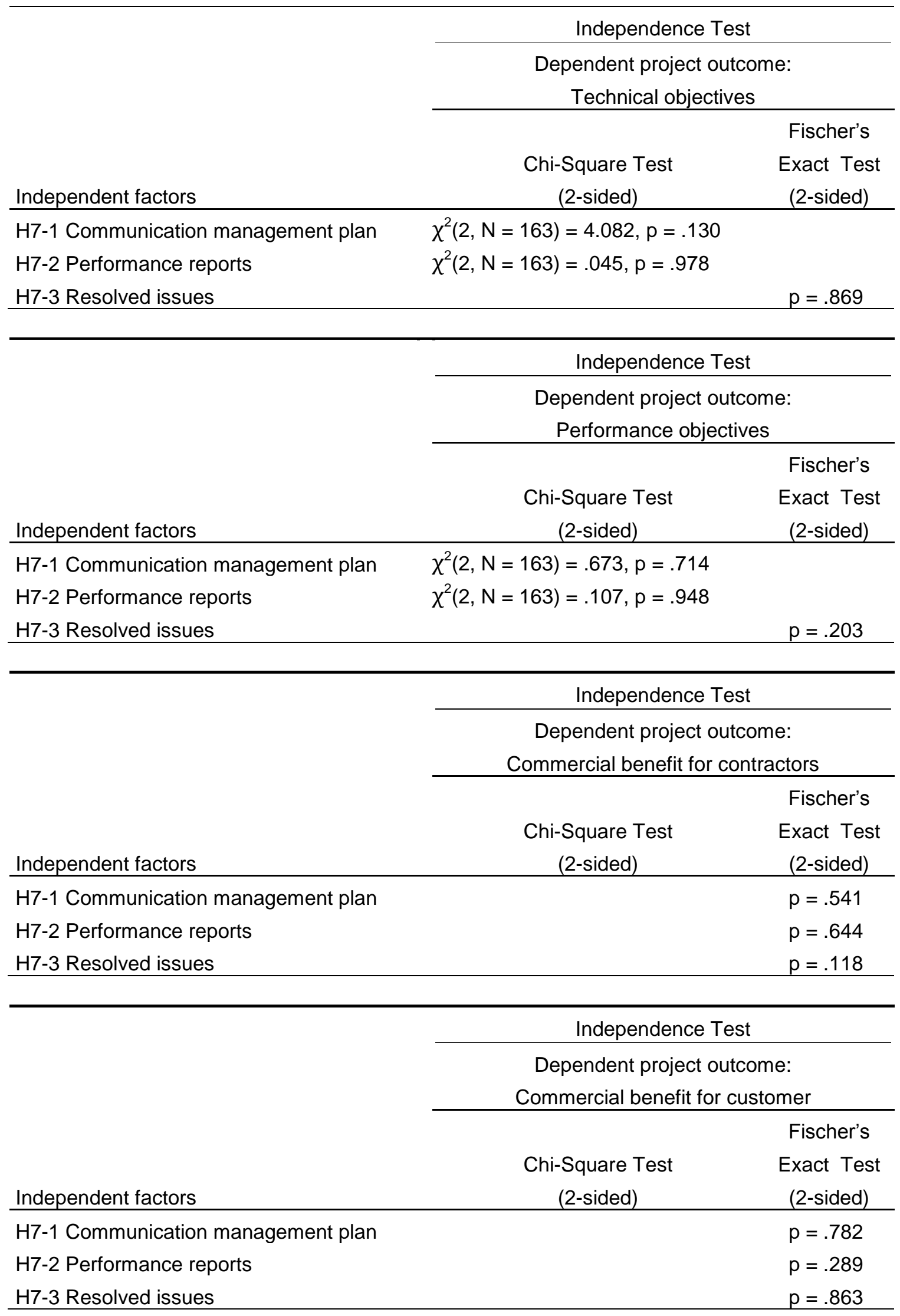




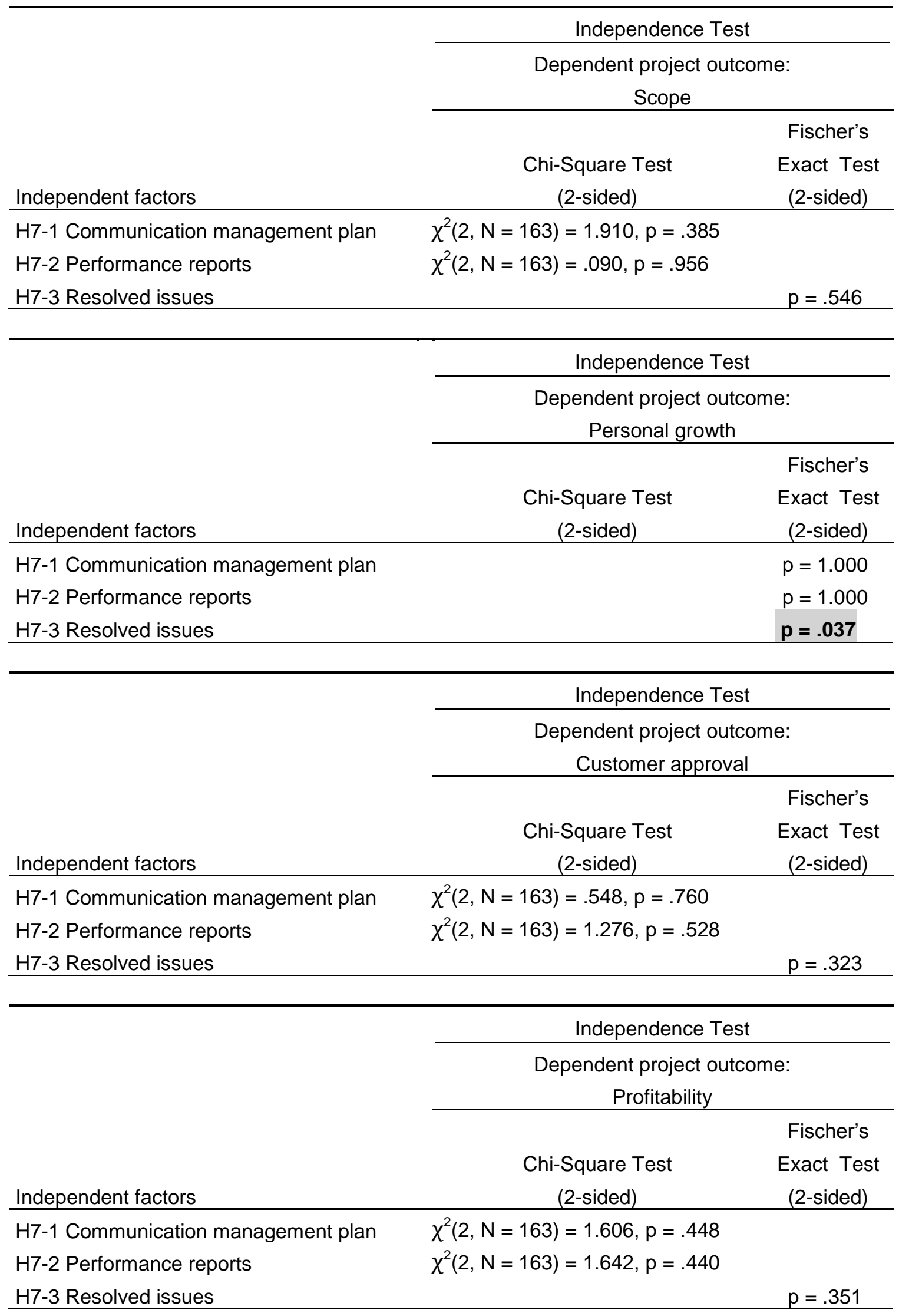




\begin{tabular}{lcc}
\hline & \multicolumn{2}{c}{ Independence Test } \\
\cline { 2 - 3 } & \multicolumn{2}{c}{ Dependent project outcome: } \\
& \multicolumn{2}{c}{ Sales } \\
\cline { 2 - 3 } & Chi-Square Test & Fischer's \\
Exact Test & $(2$-sided $)$ \\
\hline H7-1 Communication management plan & $(2$-sided $)$ & $\mathrm{p}=.625$ \\
H7-2 Performance reports & & $\mathrm{p}=.527$ \\
H7-3 Resolved issues & $\mathrm{p}=1.000$ \\
\hline
\end{tabular}




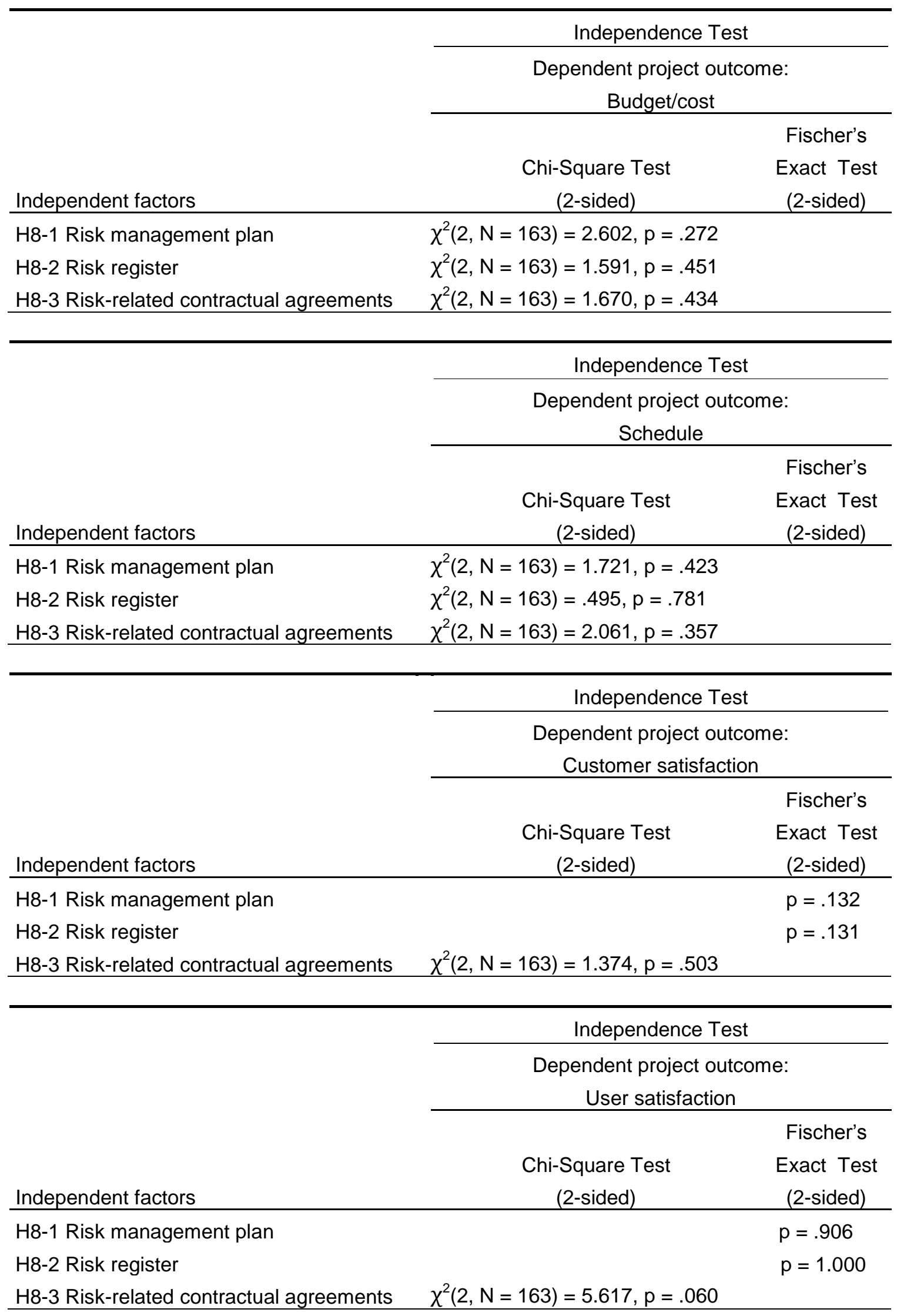




\begin{tabular}{|c|c|c|}
\hline \multirow[b]{3}{*}{ Independent factors } & \multicolumn{2}{|c|}{ Independence Test } \\
\hline & \multicolumn{2}{|c|}{$\begin{array}{c}\text { Dependent project outcome: } \\
\text { Stakeholder satisfaction }\end{array}$} \\
\hline & $\begin{array}{c}\text { Chi-Square Test } \\
\text { (2-sided) }\end{array}$ & $\begin{array}{c}\text { Fischer's } \\
\text { Exact Test } \\
\text { (2-sided) }\end{array}$ \\
\hline H8-1 Risk management plan & & $p=.149$ \\
\hline H8-2 Risk register & \multicolumn{2}{|l|}{$\chi^{2}(2, N=163)=.589, p=.745$} \\
\hline H8-3 Risk-related contractual agreements & \multicolumn{2}{|l|}{$\chi^{2}(2, N=163)=2.526, p=.283$} \\
\hline & \multicolumn{2}{|c|}{ Independence Test } \\
\hline & \multicolumn{2}{|c|}{$\begin{array}{c}\text { Dependent project outcome: } \\
\text { Project team satisfaction }\end{array}$} \\
\hline Independent factors & $\begin{array}{l}\text { Chi-Square Test } \\
\text { (2-sided) }\end{array}$ & $\begin{array}{c}\text { Fischer's } \\
\text { Exact Test } \\
\text { (2-sided) }\end{array}$ \\
\hline H8-1 Risk management plan & & $p=.767$ \\
\hline H8-2 Risk register & & $p=.526$ \\
\hline H8-3 Risk-related contractual agreements & \multicolumn{2}{|l|}{$\chi^{2}(2, N=163)=1.184, p=.553$} \\
\hline & \multicolumn{2}{|c|}{ Independence Test } \\
\hline & \multicolumn{2}{|c|}{$\begin{array}{l}\text { Dependent project outcome: } \\
\text { Strategic contribution of the project }\end{array}$} \\
\hline Independent factors & $\begin{array}{l}\text { Chi-Square Test } \\
\text { (2-sided })\end{array}$ & $\begin{array}{c}\text { Fischer's } \\
\text { Exact Test } \\
\text { (2-sided) }\end{array}$ \\
\hline H8-1 Risk management plan & & $p=.897$ \\
\hline H8-2 Risk register & & $p=.811$ \\
\hline H8-3 Risk-related contractual agreements & \multicolumn{2}{|l|}{$\chi^{2}(2, N=163)=.560, p=.756$} \\
\hline & \multicolumn{2}{|c|}{ Independence Test } \\
\hline & \multicolumn{2}{|c|}{$\begin{array}{l}\text { Dependent project outcome: } \\
\text { Financial objectives }\end{array}$} \\
\hline Independent factors & $\begin{array}{l}\text { Chi-Square Test } \\
\text { (2-sided) }\end{array}$ & $\begin{array}{c}\text { Fischer's } \\
\text { Exact Test } \\
\text { (2-sided) }\end{array}$ \\
\hline H8-1 Risk management plan & \multirow{3}{*}{\multicolumn{2}{|c|}{$\begin{array}{l}\chi^{2}(2, N=163)=1.428, p=.490 \\
\chi^{2}(2, N=163)=2.768, p=.251\end{array}$}} \\
\hline H8-2 Risk register & & \\
\hline H8-3 Risk-related contractual agreements & & \\
\hline
\end{tabular}




\begin{tabular}{|c|c|c|}
\hline \multirow[b]{3}{*}{ Independent factors } & \multicolumn{2}{|c|}{ Independence Test } \\
\hline & \multicolumn{2}{|c|}{$\begin{array}{c}\text { Dependent project outcome: } \\
\text { Technical objectives }\end{array}$} \\
\hline & $\begin{array}{c}\text { Chi-Square Test } \\
(2 \text {-sided })\end{array}$ & $\begin{array}{c}\text { Fischer's } \\
\text { Exact Test } \\
\text { (2-sided) }\end{array}$ \\
\hline H8-1 Risk management plan & $\chi^{2}(2, N=163)=2.155, p=.340$ & \\
\hline H8-2 Risk register & $\chi^{2}(2, N=163)=2.472, p=.291$ & \\
\hline \multirow[t]{3}{*}{ H8-3 Risk-related contractual agreements } & $\chi^{2}(2, N=163)=1.918, p=.383$ & \\
\hline & \multicolumn{2}{|c|}{ Independence Test } \\
\hline & \multicolumn{2}{|c|}{$\begin{array}{c}\text { Dependent project outcome: } \\
\text { Performance objectives }\end{array}$} \\
\hline Independent factors & $\begin{array}{l}\text { Chi-Square Test } \\
(2-\text { sided })\end{array}$ & $\begin{array}{c}\text { Fischer's } \\
\text { Exact Test } \\
\text { (2-sided) }\end{array}$ \\
\hline H8-1 Risk management plan & \multicolumn{2}{|l|}{$\chi^{2}(2, N=163)=.669, p=.716$} \\
\hline H8-2 Risk register & \multicolumn{2}{|l|}{$\chi^{2}(2, N=163)=.128, p=.938$} \\
\hline H8-3 Risk-related contractual agreements & \multicolumn{2}{|l|}{$\chi^{2}(2, N=163)=.539, p=.764$} \\
\hline \multirow[b]{3}{*}{ Independent factors } & \multicolumn{2}{|c|}{ Independence Test } \\
\hline & \multicolumn{2}{|c|}{$\begin{array}{c}\text { Dependent project outcome: } \\
\text { Commercial benefit for contractors }\end{array}$} \\
\hline & $\begin{array}{l}\text { Chi-Square Test } \\
\text { (2-sided) }\end{array}$ & $\begin{array}{c}\text { Fischer's } \\
\text { Exact Test } \\
\text { (2-sided) }\end{array}$ \\
\hline H8-1 Risk management plan & & $p=.495$ \\
\hline H8-2 Risk register & & $p=.541$ \\
\hline \multirow[t]{4}{*}{ H8-3 Risk-related contractual agreements } & & $p=.454$ \\
\hline & Independence T & \\
\hline & $\begin{array}{l}\text { Dependent project o } \\
\text { Commercial benefit for }\end{array}$ & le: \\
\hline & $\begin{array}{c}\text { Chi-Square Test } \\
\text { (2-sided) }\end{array}$ & $\begin{array}{c}\text { Fischer's } \\
\text { Exact Test } \\
\text { (2-sided) }\end{array}$ \\
\hline H8-1 Risk management plan & & $p=.858$ \\
\hline H8-2 Risk register & & $p=1.000$ \\
\hline H8-3 Risk-related contractual agreements & $\chi^{2}(2, N=163)=.848, p=.654$ & \\
\hline
\end{tabular}




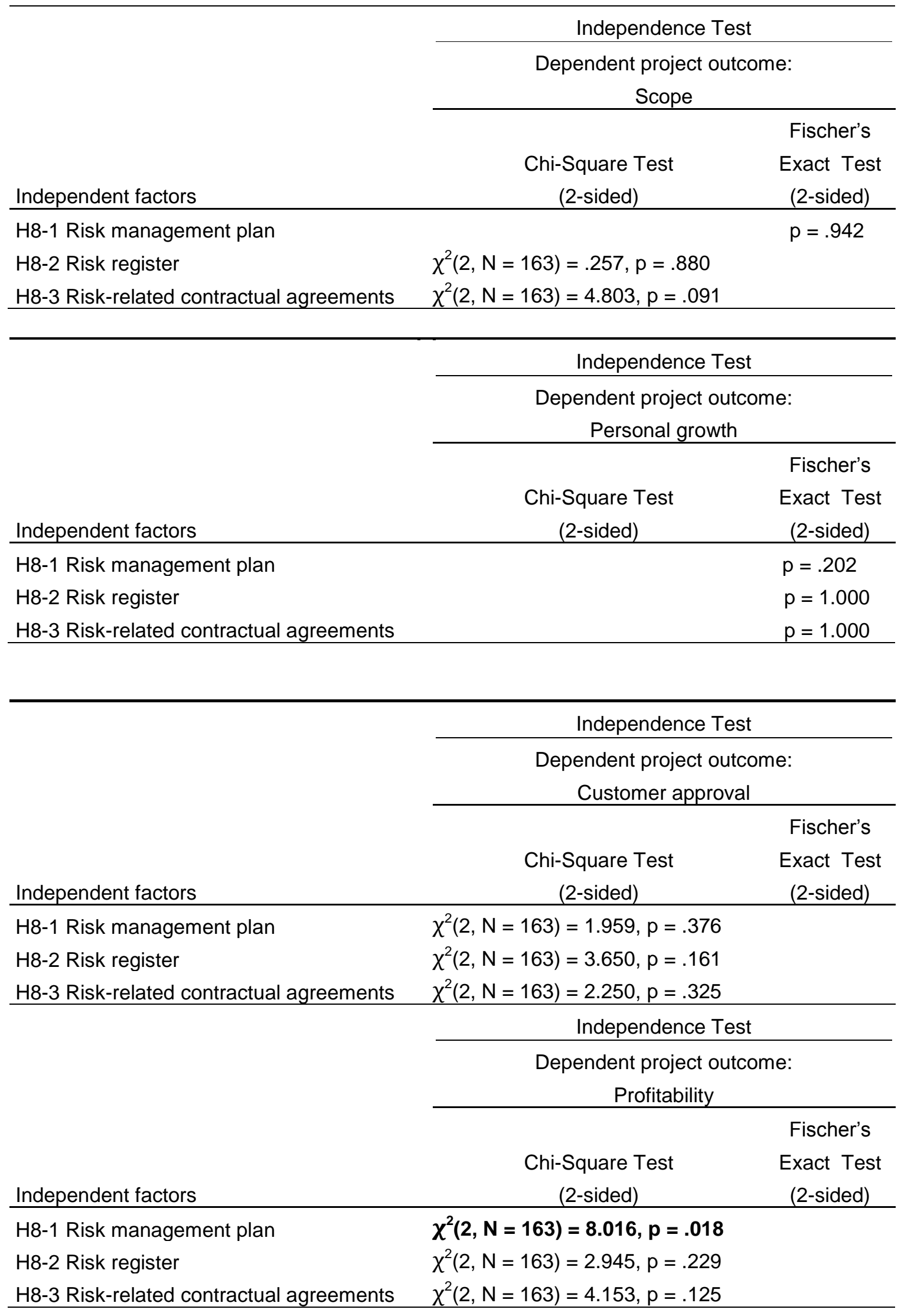




\begin{tabular}{lcc}
\hline & \multicolumn{2}{c}{ Independence Test } \\
\cline { 2 - 3 } & \multicolumn{2}{c}{ Dependent project outcome: } \\
\cline { 2 - 3 } & \multicolumn{2}{c}{ Sales } \\
\cline { 2 - 3 } & Chi-Square Test & Fischer's \\
Independent factors & Exact Test \\
H8-1 Risk management plan & & $\mathrm{p}=.449$ \\
H8-2 Risk register & & $\mathrm{p}=.302$ \\
H8-3 Risk-related contractual agreements & $\mathrm{p}=.206$ \\
\hline
\end{tabular}




\begin{tabular}{|c|c|c|}
\hline \multirow[b]{3}{*}{ Independent factors } & \multicolumn{2}{|c|}{ Independence Test } \\
\hline & \multicolumn{2}{|c|}{ Dependent project outcome: Budget/Cost } \\
\hline & $\begin{array}{c}\text { Chi-Square Test } \\
(2 \text {-sided })\end{array}$ & $\begin{array}{c}\text { Fischer's } \\
\text { Exact Test } \\
\text { (2-sided) }\end{array}$ \\
\hline H9-1 Procurement management plan & \multicolumn{2}{|l|}{$\chi^{2}(2, N=163)=.454, p=.797$} \\
\hline H9-2 Contract statement of work & \multicolumn{2}{|l|}{$\chi^{2}(2, N=163)=1.296, p=.523$} \\
\hline H9-3 Make-or-buy decisions & \multicolumn{2}{|l|}{$\chi^{2}(2, N=163)=.506, p=.776$} \\
\hline H9-4 Procurement documents & \multicolumn{2}{|l|}{$\chi^{2}(2, N=163)=3.395, p=.183$} \\
\hline H9-5 Supplier evaluation criteria & \multicolumn{2}{|l|}{$\chi^{2}(2, N=163)=1.756, p=.416$} \\
\hline H9-6 Updates & \multicolumn{2}{|l|}{$\chi^{2}(2, N=163)=1.553, p=.460$} \\
\hline H9-7 Procurement documents package & \multicolumn{2}{|l|}{$\chi^{2}(2, N=163)=.313, p=.855$} \\
\hline H9-8 Proposals & \multicolumn{2}{|l|}{$\chi^{2}(2, N=163)=.312, p=.855$} \\
\hline H9-9 Selected sellers & \multicolumn{2}{|l|}{$\chi^{2}(2, N=163)=1.343, p=.511$} \\
\hline H9-10 Contract & \multicolumn{2}{|l|}{$\chi^{2}(2, N=163)=1.845, p=.398$} \\
\hline H9-11 Contract management plan & \multicolumn{2}{|l|}{$\chi^{2}(2, N=163)=.401, p=.819$} \\
\hline H9-12 Procurement management plan (up) & \multicolumn{2}{|l|}{$\chi^{2}(2, N=163)=.772, p=.680$} \\
\hline H9-13 Contract documentation & \multicolumn{2}{|l|}{$\chi^{2}(2, N=163)=.440, p=.803$} \\
\hline \multirow[b]{3}{*}{ Independent factors } & \multicolumn{2}{|c|}{ Independence Test } \\
\hline & \multicolumn{2}{|c|}{ Dependent project outcome: Schedule } \\
\hline & $\begin{array}{c}\text { Chi-Square Test } \\
\text { (2-sided) }\end{array}$ & $\begin{array}{c}\text { Fischer's } \\
\text { Exact Test } \\
\text { (2-sided) }\end{array}$ \\
\hline H9-1 Procurement management plan & \multicolumn{2}{|l|}{$\chi^{2}(2, N=163)=3.373, p=.152$} \\
\hline H9-2 Contract statement of work & \multicolumn{2}{|l|}{$\chi^{2}(2, N=163)=2.861, p=.239$} \\
\hline H9-3 Make-or-buy decisions & \multicolumn{2}{|l|}{$\chi^{2}(2, N=163)=4.314, p=.116$} \\
\hline H9-4 Procurement documents & \multicolumn{2}{|l|}{$\chi^{2}(2, N=163)=.188, p=.910$} \\
\hline H9-5 Supplier evaluation criteria & \multicolumn{2}{|l|}{$\chi^{2}(2, N=163)=.146, p=.930$} \\
\hline H9-6 Updates & \multicolumn{2}{|l|}{$\chi^{2}(2, N=163)=2.021, p=.364$} \\
\hline H9-7 Procurement documents package & \multicolumn{2}{|l|}{$\chi^{2}(2, N=163)=1.083, p=.582$} \\
\hline H9-8 Proposals & \multicolumn{2}{|l|}{$\chi^{2}(2, N=163)=2.579, p=.275$} \\
\hline H9-9 Selected sellers & \multicolumn{2}{|l|}{$\chi^{2}(2, N=163)=.356, p=.837$} \\
\hline H9-10 Contract & \multicolumn{2}{|l|}{$\chi^{2}(2, N=163)=1.493, p=.474$} \\
\hline H9-11 Contract management plan & \multicolumn{2}{|l|}{$\chi^{2}(2, N=163)=1.312, p=.519$} \\
\hline H9-12 Procurement management plan (up) & \multicolumn{2}{|l|}{$\chi^{2}(2, N=163)=2.228, p=.328$} \\
\hline H9-13 Contract documentation & \multicolumn{2}{|l|}{$\chi^{2}(2, N=163)=.596, p=.742$} \\
\hline
\end{tabular}




\begin{tabular}{|c|c|c|}
\hline \multirow[b]{3}{*}{ Independent factors } & \multicolumn{2}{|c|}{ Independence Test } \\
\hline & \multicolumn{2}{|c|}{ Dependent project outcome: Customer satisfaction } \\
\hline & $\begin{array}{c}\text { Chi-Square Test } \\
(2-\text { sided })\end{array}$ & $\begin{array}{c}\text { Fischer's } \\
\text { Exact Test } \\
\text { (2-sided) }\end{array}$ \\
\hline H9-1 Procurement management plan & \multicolumn{2}{|l|}{$\chi^{2}(2, N=163)=7.716, p=.021$} \\
\hline H9-2 Contract statement of work & \multicolumn{2}{|l|}{$\chi^{2}(2, N=163)=5.131, p=.077$} \\
\hline H9-3 Make-or-buy decisions & \multicolumn{2}{|l|}{$\chi^{2}(2, N=163)=1.379, p=.502$} \\
\hline H9-4 Procurement documents & \multicolumn{2}{|l|}{$\chi^{2}(2, N=163)=5.452, p=.065$} \\
\hline H9-5 Supplier evaluation criteria & \multicolumn{2}{|l|}{$\chi^{2}(2, N=163)=3.953, p=.139$} \\
\hline H9-6 Updates & \multicolumn{2}{|l|}{$\chi^{2}(2, N=163)=.486, p=.784$} \\
\hline H9-7 Procurement documents package & \multicolumn{2}{|l|}{$\chi^{2}(2, N=163)=5.554, p=.062$} \\
\hline H9-8 Proposals & \multicolumn{2}{|l|}{$\chi^{2}(2, N=163)=10.845, p=.004$} \\
\hline H9-9 Selected sellers & \multicolumn{2}{|l|}{$\chi^{2}(2, N=163)=11.426, p=.003$} \\
\hline H9-10 Contract & \multicolumn{2}{|l|}{$\chi^{2}(2, N=163)=10.611, p=.005$} \\
\hline H9-11 Contract management plan & \multicolumn{2}{|l|}{$\chi^{2}(2, N=163)=11.229, p=.004$} \\
\hline H9-12 Procurement management plan (up) & \multicolumn{2}{|l|}{$\chi^{2}(2, N=163)=10.321, p=.006$} \\
\hline H9-13 Contract documentation & \multicolumn{2}{|l|}{$\chi^{2}(2, N=163)=2.272, p=.321$} \\
\hline \multirow[b]{3}{*}{ Independent factors } & \multicolumn{2}{|c|}{ Independence Test } \\
\hline & \multicolumn{2}{|c|}{ Dependent project outcome: User satisfaction } \\
\hline & $\begin{array}{c}\text { Chi-Square Test } \\
(2 \text {-sided })\end{array}$ & $\begin{array}{c}\text { Fischer's } \\
\text { Exact Test } \\
\text { (2-sided) }\end{array}$ \\
\hline H9-1 Procurement management plan & \multicolumn{2}{|l|}{$\chi^{2}(2, N=163)=2.368, p=.306$} \\
\hline H9-2 Contract statement of work & \multicolumn{2}{|l|}{$\chi^{2}(2, N=163)=1.955, p=.376$} \\
\hline H9-3 Make-or-buy decisions & \multicolumn{2}{|l|}{$\chi^{2}(2, N=163)=.109, p=.947$} \\
\hline H9-4 Procurement documents & \multicolumn{2}{|l|}{$\chi^{2}(2, N=163)=.911, p=.634$} \\
\hline H9-5 Supplier evaluation criteria & \multicolumn{2}{|l|}{$\chi^{2}(2, N=163)=.007, p=1.000$} \\
\hline H9-6 Updates & & $p=.646$ \\
\hline H9-7 Procurement documents package & \multicolumn{2}{|l|}{$\chi^{2}(2, N=163)=1.399, p=.497$} \\
\hline H9-8 Proposals & \multicolumn{2}{|l|}{$\chi^{2}(2, N=163)=3.924, p=.141$} \\
\hline H9-9 Selected sellers & \multicolumn{2}{|l|}{$\chi^{2}(2, N=163)=1.466, p=.480$} \\
\hline H9-10 Contract & \multicolumn{2}{|l|}{$\chi^{2}(2, N=163)=1.502, p=.472$} \\
\hline H9-11 Contract management plan & \multicolumn{2}{|l|}{$\chi^{2}(2, N=163)=6.022, p=.049$} \\
\hline H9-12 Procurement management plan (up) & \multicolumn{2}{|l|}{$\chi^{2}(2, N=163)=5.168, p=.075$} \\
\hline H9-13 Contract documentation & \multicolumn{2}{|l|}{$\chi^{2}(2, N=163)=1.432, p=.489$} \\
\hline
\end{tabular}




\begin{tabular}{|c|c|c|}
\hline \multirow[b]{3}{*}{ Independent factors } & \multicolumn{2}{|c|}{ Independence Test } \\
\hline & \multicolumn{2}{|c|}{$\begin{array}{l}\text { Dependent project outcome: Stakeholder } \\
\text { satisfaction }\end{array}$} \\
\hline & $\begin{array}{l}\text { Chi-Square Test } \\
\text { (2-sided) }\end{array}$ & $\begin{array}{c}\text { Fischer's Exact } \\
\text { Test (2-sided) }\end{array}$ \\
\hline H9-1 Procurement management plan & \multicolumn{2}{|l|}{$\chi^{2}(2, N=163)=10.768, p=.005$} \\
\hline H9-2 Contract statement of work & \multicolumn{2}{|l|}{$\chi^{2}(2, N=163)=.156, p=.925$} \\
\hline H9-3 Make-or-buy decisions & \multicolumn{2}{|l|}{$\chi^{2}(2, N=163)=4.995, p=.082$} \\
\hline H9-4 Procurement documents & \multicolumn{2}{|l|}{$\chi^{2}(2, N=163)=1.910, p=.385$} \\
\hline H9-5 Supplier evaluation criteria & \multicolumn{2}{|l|}{$\chi^{2}(2, N=163)=.502, p=.778$} \\
\hline H9-6 Updates & \multicolumn{2}{|l|}{$\chi^{2}(2, N=163)=.870, p=.647$} \\
\hline H9-7 Procurement documents package & \multicolumn{2}{|l|}{$\chi^{2}(2, N=163)=.237, p=.888$} \\
\hline H9-8 Proposals & \multicolumn{2}{|l|}{$\chi^{2}(2, N=163)=2.273, p=.321$} \\
\hline H9-9 Selected sellers & \multicolumn{2}{|l|}{$\chi^{2}(2, N=163)=.426, p=.808$} \\
\hline H9-10 Contract & \multicolumn{2}{|l|}{$\chi^{2}(2, N=163)=.205, p=.903$} \\
\hline H9-11 Contract management plan & \multicolumn{2}{|l|}{$\chi^{2}(2, N=163)=3.579, p=.167$} \\
\hline H9-12 Procurement management plan (up) & \multicolumn{2}{|l|}{$\chi^{2}(2, N=163)=4.381, p=.112$} \\
\hline H9-13 Contract documentation & \multicolumn{2}{|l|}{$\chi^{2}(2, N=163)=.607, p=.738$} \\
\hline \multirow[b]{3}{*}{ Independent factors } & \multicolumn{2}{|c|}{ Independence Test } \\
\hline & \multicolumn{2}{|c|}{$\begin{array}{l}\text { Dependent project outcome: Project team } \\
\text { satisfaction } \\
\end{array}$} \\
\hline & $\begin{array}{l}\text { Chi-Square Test } \\
\text { (2-sided) }\end{array}$ & $\begin{array}{c}\text { Fischer's Exact } \\
\text { Test (2-sided) }\end{array}$ \\
\hline H9-1 Procurement management plan & \multicolumn{2}{|l|}{$\chi^{2}(2, N=163)=2.593, p=.273$} \\
\hline H9-2 Contract statement of work & \multicolumn{2}{|l|}{$\chi^{2}(2, N=163)=1.275, p=.528$} \\
\hline H9-3 Make-or-buy decisions & \multicolumn{2}{|l|}{$\chi^{2}(2, N=163)=.474, p=.789$} \\
\hline H9-4 Procurement documents & \multicolumn{2}{|l|}{$\chi^{2}(2, N=163)=7.673, p=.022$} \\
\hline H9-5 Supplier evaluation criteria & \multicolumn{2}{|l|}{$\chi^{2}(2, N=163)=6.506, p=.039$} \\
\hline H9-6 Updates & & $p=.319$ \\
\hline H9-7 Procurement documents package & \multicolumn{2}{|l|}{$\chi^{2}(2, N=163)=.962, p=.618$} \\
\hline H9-8 Proposals & \multicolumn{2}{|l|}{$\chi^{2}(2, N=163)=1.529, p=.466$} \\
\hline H9-9 Selected sellers & \multicolumn{2}{|l|}{$\chi^{2}(2, N=163)=2.538, p=.281$} \\
\hline H9-10 Contract & & $p=.095$ \\
\hline H9-11 Contract management plan & \multicolumn{2}{|l|}{$\chi^{2}(2, N=163)=1.585, p=.453$} \\
\hline H9-12 Procurement management plan (up) & \multicolumn{2}{|l|}{$\chi^{2}(2, N=163)=1.817, p=.403$} \\
\hline H9-13 Contract documentation & \multicolumn{2}{|l|}{$\chi^{2}(2, N=163)=4.938, p=.085$} \\
\hline
\end{tabular}




\begin{tabular}{|c|c|c|}
\hline \multirow[b]{3}{*}{ Independent factors } & \multicolumn{2}{|c|}{ Independence Test } \\
\hline & \multicolumn{2}{|c|}{$\begin{array}{c}\text { Dependent project outcome: Strategic contribution } \\
\text { of the project }\end{array}$} \\
\hline & $\begin{array}{l}\text { Chi-Square Test } \\
\text { (2-sided) }\end{array}$ & $\begin{array}{c}\text { Fischer's Exact } \\
\text { Test (2-sided) }\end{array}$ \\
\hline H9-1 Procurement management plan & \multicolumn{2}{|l|}{$\chi^{2}(2, N=163)=1.122, p=.571$} \\
\hline H9-2 Contract statement of work & \multicolumn{2}{|l|}{$\chi^{2}(2, N=163)=1.611, p=.447$} \\
\hline H9-3 Make-or-buy decisions & \multicolumn{2}{|l|}{$\chi^{2}(2, N=163)=1.580, p=.454$} \\
\hline H9-4 Procurement documents & \multicolumn{2}{|l|}{$\chi^{2}(2, N=163)=1.676, p=.433$} \\
\hline H9-5 Supplier evaluation criteria & \multicolumn{2}{|l|}{$\chi^{2}(2, N=163)=1.274, p=.529$} \\
\hline H9-6 Updates & & $p=.916$ \\
\hline H9-7 Procurement documents package & \multicolumn{2}{|l|}{$\chi^{2}(2, N=163)=.471, p=.790$} \\
\hline H9-8 Proposals & \multicolumn{2}{|l|}{$\chi^{2}(2, N=163)=3.491, p=.175$} \\
\hline H9-9 Selected sellers & \multicolumn{2}{|l|}{$\chi^{2}(2, N=163)=1.254, p=.534$} \\
\hline H9-10 Contract & \multicolumn{2}{|l|}{$\chi^{2}(2, N=163)=2.900, p=.235$} \\
\hline H9-11 Contract management plan & \multicolumn{2}{|l|}{$\chi^{2}(2, N=163)=3.784, p=.151$} \\
\hline H9-12 Procurement management plan (up) & \multicolumn{2}{|l|}{$\chi^{2}(2, N=163)=6.307, p=.043$} \\
\hline H9-13 Contract documentation & \multicolumn{2}{|l|}{$\chi^{2}(2, N=163)=6.020, p=.049$} \\
\hline \multirow[b]{3}{*}{ Independent factors } & \multicolumn{2}{|c|}{ Independence Test } \\
\hline & \multicolumn{2}{|c|}{ Dependent project outcome: Financial objectives } \\
\hline & $\begin{array}{l}\text { Chi-Square Test } \\
\text { (2-sided) }\end{array}$ & $\begin{array}{l}\text { Fischer's Exact } \\
\text { Test (2-sided) }\end{array}$ \\
\hline H9-1 Procurement management plan & \multicolumn{2}{|l|}{$\chi^{2}(2, N=163)=2.297, p=.317$} \\
\hline H9-2 Contract statement of work & \multicolumn{2}{|l|}{$\chi^{2}(2, N=163)=2.599, p=.273$} \\
\hline H9-3 Make-or-buy decisions & \multicolumn{2}{|l|}{$\chi^{2}(2, N=163)=.172, p=.918$} \\
\hline H9-4 Procurement documents & \multicolumn{2}{|l|}{$\chi^{2}(2, N=163)=.130, p=.937$} \\
\hline H9-5 Supplier evaluation criteria & \multicolumn{2}{|l|}{$\chi^{2}(2, N=163)=1.084, p=.582$} \\
\hline H9-6 Updates & \multicolumn{2}{|l|}{$\chi^{2}(2, N=163)=1.114, p=.573$} \\
\hline H9-7 Procurement documents package & \multicolumn{2}{|l|}{$\chi^{2}(2, N=163)=2.560, p=.278$} \\
\hline H9-8 Proposals & \multicolumn{2}{|l|}{$\chi^{2}(2, N=163)=.263, p=.877$} \\
\hline H9-9 Selected sellers & \multicolumn{2}{|l|}{$\chi^{2}(2, N=163)=7.277, p=.026$} \\
\hline H9-10 Contract & \multicolumn{2}{|l|}{$\chi^{2}(2, N=163)=3.885, p=.143$} \\
\hline H9-11 Contract management plan & \multicolumn{2}{|l|}{$\chi^{2}(2, N=163)=2.366, p=.306$} \\
\hline H9-12 Procurement management plan (up) & \multicolumn{2}{|l|}{$\chi^{2}(2, N=163)=1.147, p=.564$} \\
\hline H9-13 Contract documentation & \multicolumn{2}{|l|}{$\chi^{2}(2, N=163)=2.245, p=.326$} \\
\hline
\end{tabular}




\begin{tabular}{|c|c|c|}
\hline \multirow[b]{3}{*}{ Independent factors } & \multicolumn{2}{|c|}{ Independence Test } \\
\hline & \multicolumn{2}{|c|}{ Dependent project outcome: Technical objectives } \\
\hline & $\begin{array}{c}\text { Chi-Square Test } \\
\text { (2-sided) } \\
\end{array}$ & $\begin{array}{l}\text { Fischer's Exact } \\
\text { Test (2-sided) } \\
\end{array}$ \\
\hline H9-1 Procurement management plan & \multicolumn{2}{|c|}{$\chi^{2}(2, N=163)=5.192, p=.075$} \\
\hline H9-2 Contract statement of work & \multicolumn{2}{|c|}{$\chi^{2}(2, N=163)=9.852, p=.007$} \\
\hline H9-3 Make-or-buy decisions & \multicolumn{2}{|c|}{$\chi^{2}(2, N=163)=3.913, p=.141$} \\
\hline H9-4 Procurement documents & \multicolumn{2}{|c|}{$\chi^{2}(2, N=163)=4.345, p=.114$} \\
\hline H9-5 Supplier evaluation criteria & \multicolumn{2}{|c|}{$\chi^{2}(2, N=163)=.847, p=.655$} \\
\hline H9-6 Updates & \multicolumn{2}{|c|}{$\chi^{2}(2, N=163)=1.555, p=.460$} \\
\hline H9-7 Procurement documents package & \multicolumn{2}{|c|}{$\chi^{2}(2, N=163)=.589, p=.745$} \\
\hline H9-8 Proposals & \multicolumn{2}{|c|}{$\chi^{2}(2, N=163)=.263, p=.877$} \\
\hline H9-9 Selected sellers & \multicolumn{2}{|c|}{$\chi^{2}(2, N=163)=4.992, p=.082$} \\
\hline H9-10 Contract & \multicolumn{2}{|c|}{$\chi^{2}(2, N=163)=4.337, p=.114$} \\
\hline H9-11 Contract management plan & \multicolumn{2}{|c|}{$\chi^{2}(2, N=163)=3.417, p=.181$} \\
\hline H9-12 Procurement management plan (up) & \multicolumn{2}{|c|}{$\chi^{2}(2, N=163)=3.596, p=.166$} \\
\hline H9-13 Contract documentation & \multicolumn{2}{|c|}{$\chi^{2}(2, N=163)=.129, p=.938$} \\
\hline \multirow[b]{3}{*}{ Independent factors } & \multicolumn{2}{|c|}{ Independence Test } \\
\hline & \multicolumn{2}{|c|}{$\begin{array}{l}\text { Dependent project outcome: Performance } \\
\text { objectives }\end{array}$} \\
\hline & $\begin{array}{l}\text { Chi-Square Test } \\
\text { (2-sided) } \\
\end{array}$ & $\begin{array}{l}\text { Fischer's Exact } \\
\text { Test (2-sided) } \\
\end{array}$ \\
\hline H9-1 Procurement management plan & \multicolumn{2}{|c|}{$\chi^{2}(2, N=163)=3.661, p=.160$} \\
\hline H9-2 Contract statement of work & \multicolumn{2}{|c|}{$\chi^{2}(2, N=163)=.506, p=.776$} \\
\hline H9-3 Make-or-buy decisions & \multicolumn{2}{|c|}{$\chi^{2}(2, N=163)=2.183, p=.336$} \\
\hline H9-4 Procurement documents & \multicolumn{2}{|c|}{$\chi^{2}(2, N=163)=2.700, p=.259$} \\
\hline H9-5 Supplier evaluation criteria & \multicolumn{2}{|c|}{$\chi^{2}(2, N=163)=.320, p=.852$} \\
\hline H9-6 Updates & \multicolumn{2}{|c|}{$\chi^{2}(2, N=163)=9.347, p=.009$} \\
\hline H9-7 Procurement documents package & \multicolumn{2}{|c|}{$\chi^{2}(2, N=163)=1.716, p=.424$} \\
\hline H9-8 Proposals & \multicolumn{2}{|c|}{$\chi^{2}(2, N=163)=1.826, p=.401$} \\
\hline H9-9 Selected sellers & \multicolumn{2}{|c|}{$\chi^{2}(2, N=163)=2.585, p=.275$} \\
\hline H9-10 Contract & \multicolumn{2}{|c|}{$\chi^{2}(2, N=163)=.548, p=.760$} \\
\hline H9-11 Contract management plan & \multicolumn{2}{|c|}{$\chi^{2}(2, N=163)=2.085, p=.353$} \\
\hline H9-12 Procurement management plan (up) & \multicolumn{2}{|c|}{$\chi^{2}(2, N=163)=1.339, p=.512$} \\
\hline H9-13 Contract documentation & \multicolumn{2}{|c|}{$\chi^{2}(2, N=163)=.008, p=.996$} \\
\hline
\end{tabular}




\begin{tabular}{|c|c|c|}
\hline \multirow[b]{3}{*}{ Independent factors } & \multicolumn{2}{|c|}{ Independence Test } \\
\hline & \multicolumn{2}{|c|}{$\begin{array}{l}\text { Dependent project outcome: Commercial benefit } \\
\text { for contractors }\end{array}$} \\
\hline & $\begin{array}{l}\text { Chi-Square Test } \\
\text { (2-sided) }\end{array}$ & $\begin{array}{c}\text { Fischer's Exact } \\
\text { Test (2-sided) }\end{array}$ \\
\hline H9-1 Procurement management plan & & $p=1.000$ \\
\hline H9-2 Contract statement of work & & $p=.130$ \\
\hline H9-3 Make-or-buy decisions & & $p=.539$ \\
\hline H9-4 Procurement documents & & $p=.146$ \\
\hline H9-5 Supplier evaluation criteria & & $p=1.000$ \\
\hline H9-6 Updates & & $p=.296$ \\
\hline H9-7 Procurement documents package & & $p=.437$ \\
\hline H9-8 Proposals & & $p=.026$ \\
\hline H9-9 Selected sellers & & $p=.168$ \\
\hline H9-10 Contract & & $p=.173$ \\
\hline H9-11 Contract management plan & & $p=.543$ \\
\hline H9-12 Procurement management plan (up) & & $p=.524$ \\
\hline \multirow[t]{4}{*}{ H9-13 Contract documentation } & & $p=.138$ \\
\hline & \multicolumn{2}{|c|}{ Independence Test } \\
\hline & \multicolumn{2}{|c|}{$\begin{array}{c}\text { Dependent project outcome: Commercial benefit } \\
\text { for customer }\end{array}$} \\
\hline & $\begin{array}{l}\text { Chi-Square Test } \\
\text { (2-sided) }\end{array}$ & $\begin{array}{l}\text { Fischer's Exact } \\
\text { Test (2-sided) }\end{array}$ \\
\hline H9-1 Procurement management plan & $\chi^{2}(2, N=163)=1.802, p=.406$ & \\
\hline H9-2 Contract statement of work & & $p=.174$ \\
\hline H9-3 Make-or-buy decisions & $\chi^{2}(2, N=163)=7.304, p=.026$ & \\
\hline H9-4 Procurement documents & $\chi^{2}(2, N=163)=3.641, p=.162$ & \\
\hline H9-5 Supplier evaluation criteria & $\chi^{2}(2, N=163)=.354, p=.838$ & \\
\hline H9-6 Updates & & $p=.206$ \\
\hline H9-7 Procurement documents package & & $p=.170$ \\
\hline H9-8 Proposals & $\chi^{2}(2, N=163)=3.925, p=.141$ & \\
\hline H9-9 Selected sellers & $\chi^{2}(2, N=163)=4.822, p=.090$ & \\
\hline H9-10 Contract & & $p=.119$ \\
\hline H9-11 Contract management plan & $\chi^{2}(2, N=163)=4.575, p=.102$ & \\
\hline H9-12 Procurement management plan (up) & $\chi^{2}(2, N=163)=9.301, p=.010$ & \\
\hline H9-13 Contract documentation & $\chi^{2}(2, N=163)=.681, p=.711$ & \\
\hline
\end{tabular}




\begin{tabular}{|c|c|c|}
\hline \multirow[b]{3}{*}{ Independent factors } & \multicolumn{2}{|c|}{ Independence Test } \\
\hline & \multicolumn{2}{|c|}{ Dependent project outcome: Scope } \\
\hline & $\begin{array}{c}\text { Chi-Square Test } \\
\text { (2-sided) }\end{array}$ & $\begin{array}{c}\text { Fischer's Exact } \\
\text { Test (2-sided) }\end{array}$ \\
\hline H9-1 Procurement management plan & \multicolumn{2}{|c|}{$\chi^{2}(2, N=163)=1.200, p=.549$} \\
\hline H9-2 Contract statement of work & \multicolumn{2}{|c|}{$\chi^{2}(2, N=163)=8.986, p=.011$} \\
\hline H9-3 Make-or-buy decisions & \multicolumn{2}{|c|}{$\chi^{2}(2, N=163)=1.375, p=.503$} \\
\hline H9-4 Procurement documents & \multicolumn{2}{|c|}{$\chi^{2}(2, N=163)=.965, p=.617$} \\
\hline H9-5 Supplier evaluation criteria & \multicolumn{2}{|c|}{$\chi^{2}(2, N=163)=1.627, p=.443$} \\
\hline H9-6 Updates & \multicolumn{2}{|c|}{$\chi^{2}(2, N=163)=2.439, p=.295$} \\
\hline H9-7 Procurement documents package & \multicolumn{2}{|c|}{$\chi^{2}(2, N=163)=9.487, p=.009$} \\
\hline H9-8 Proposals & \multicolumn{2}{|c|}{$\chi^{2}(2, N=163)=1.020, p=.600$} \\
\hline H9-9 Selected sellers & \multicolumn{2}{|c|}{$\chi^{2}(2, N=163)=.951, p=.621$} \\
\hline H9-10 Contract & \multicolumn{2}{|c|}{$\chi^{2}(2, N=163)=.918, p=.632$} \\
\hline H9-11 Contract management plan & \multicolumn{2}{|c|}{$\chi^{2}(2, N=163)=.248, p=.883$} \\
\hline H9-12 Procurement management plan (up) & \multicolumn{2}{|c|}{$\chi^{2}(2, N=163)=1.653, p=.438$} \\
\hline H9-13 Contract documentation & \multicolumn{2}{|c|}{$\chi^{2}(2, N=163)=1.295, p=.523$} \\
\hline \multirow[b]{3}{*}{ Independent factors } & \multicolumn{2}{|c|}{ Independence Test } \\
\hline & \multicolumn{2}{|c|}{ Dependent project outcome: Personal growth } \\
\hline & $\begin{array}{c}\text { Chi-Square Test } \\
\text { (2-sided) }\end{array}$ & $\begin{array}{c}\text { Fischer's Exact } \\
\text { Test (2-sided) }\end{array}$ \\
\hline H9-1 Procurement management plan & & $p=1.000$ \\
\hline H9-2 Contract statement of work & & $p=.374$ \\
\hline H9-3 Make-or-buy decisions & & $p=1.000$ \\
\hline H9-4 Procurement documents & & $p=1.000$ \\
\hline H9-5 Supplier evaluation criteria & & $p=1.000$ \\
\hline H9-6 Updates & & $p=1.000$ \\
\hline H9-7 Procurement documents package & & $p=.178$ \\
\hline H9-8 Proposals & & $p=1.000$ \\
\hline H9-9 Selected sellers & & $p=1.000$ \\
\hline H9-10 Contract & & $p=1.000$ \\
\hline H9-11 Contract management plan & & $p=.153$ \\
\hline H9-12 Procurement management plan (up) & & $p=.141$ \\
\hline H9-13 Contract documentation & & $p=.509$ \\
\hline
\end{tabular}




\begin{tabular}{|c|c|c|}
\hline \multirow[b]{3}{*}{ Independent factors } & \multicolumn{2}{|c|}{ Independence Test } \\
\hline & \multicolumn{2}{|c|}{ Dependent project outcome: Customer approval } \\
\hline & $\begin{array}{c}\text { Chi-Square Test } \\
\text { (2-sided) }\end{array}$ & $\begin{array}{c}\text { Fischer's Exact } \\
\text { Test (2-sided) }\end{array}$ \\
\hline H9-1 Procurement management plan & \multicolumn{2}{|l|}{$\chi^{2}(2, N=163)=.869, p=.647$} \\
\hline H9-2 Contract statement of work & \multicolumn{2}{|l|}{$\chi^{2}(2, N=163)=1.034, p=.596$} \\
\hline H9-3 Make-or-buy decisions & \multicolumn{2}{|l|}{$\chi^{2}(2, N=163)=.508, p=.776$} \\
\hline H9-4 Procurement documents & \multicolumn{2}{|l|}{$\chi^{2}(2, N=163)=1.578, p=.454$} \\
\hline H9-5 Supplier evaluation criteria & \multicolumn{2}{|l|}{$\chi^{2}(2, N=163)=2.162, p=.339$} \\
\hline H9-6 Updates & \multicolumn{2}{|l|}{$\chi^{2}(2, N=163)=3.195, p=.202$} \\
\hline H9-7 Procurement documents package & \multicolumn{2}{|l|}{$\chi^{2}(2, N=163)=2.448, p=.294$} \\
\hline H9-8 Proposals & \multicolumn{2}{|l|}{$\chi^{2}(2, N=163)=1.213, p=.545$} \\
\hline H9-9 Selected sellers & \multicolumn{2}{|l|}{$\chi^{2}(2, N=163)=2.242, p=.326$} \\
\hline H9-10 Contract & \multicolumn{2}{|l|}{$\chi^{2}(2, N=163)=1.920, p=.383$} \\
\hline H9-11 Contract management plan & \multicolumn{2}{|l|}{$\chi^{2}(2, N=163)=1.464, p=.481$} \\
\hline H9-12 Procurement management plan (up) & \multicolumn{2}{|l|}{$\chi^{2}(2, N=163)=4.675, p=.097$} \\
\hline H9-13 Contract documentation & \multicolumn{2}{|l|}{$\chi^{2}(2, N=163)=2.238, p=.327$} \\
\hline \multirow[b]{3}{*}{ Independent factors } & \multicolumn{2}{|c|}{ Independence Test } \\
\hline & \multicolumn{2}{|c|}{ Dependent project outcome: Profitability } \\
\hline & $\begin{array}{c}\text { Chi-Square Test } \\
\text { (2-sided) }\end{array}$ & $\begin{array}{c}\text { Fischer's Exact } \\
\text { Test (2-sided) }\end{array}$ \\
\hline H9-1 Procurement management plan & \multicolumn{2}{|l|}{$\chi^{2}(2, N=163)=.869, p=.647$} \\
\hline H9-2 Contract statement of work & \multicolumn{2}{|l|}{$\chi^{2}(2, N=163)=2.400, p=.301$} \\
\hline H9-3 Make-or-buy decisions & \multicolumn{2}{|l|}{$\chi^{2}(2, N=163)=2.047, p=.359$} \\
\hline H9-4 Procurement documents & \multicolumn{2}{|l|}{$\chi^{2}(2, N=163)=1.269, p=.530$} \\
\hline H9-5 Supplier evaluation criteria & \multicolumn{2}{|l|}{$\chi^{2}(2, N=163)=1.784, p=.410$} \\
\hline H9-6 Updates & \multicolumn{2}{|l|}{$\chi^{2}(2, N=163)=.495, p=.781$} \\
\hline H9-7 Procurement documents package & \multicolumn{2}{|l|}{$\chi^{2}(2, N=163)=.477, p=.788$} \\
\hline H9-8 Proposals & \multicolumn{2}{|l|}{$\chi^{2}(2, N=163)=1.719, p=.423$} \\
\hline H9-9 Selected sellers & \multicolumn{2}{|l|}{$\chi^{2}(2, N=163)=2.232, p=.328$} \\
\hline H9-10 Contract & \multicolumn{2}{|l|}{$\chi^{2}(2, N=163)=.476, p=.788$} \\
\hline H9-11 Contract management plan & \multicolumn{2}{|l|}{$\chi^{2}(2, N=163)=.456, p=.796$} \\
\hline H9-12 Procurement management plan (up) & \multicolumn{2}{|l|}{$\chi^{2}(2, N=163)=.783, p=.676$} \\
\hline H9-13 Contract documentation & \multicolumn{2}{|l|}{$\chi^{2}(2, N=163)=1.147, p=.564$} \\
\hline
\end{tabular}




\begin{tabular}{lcc}
\hline & \multicolumn{2}{c}{ Independence Test } \\
\cline { 2 - 3 } & \multicolumn{2}{c}{ Dependent project outcome: Sales } \\
\cline { 2 - 3 } Independent factors & $\begin{array}{c}\text { Chi-Square Test } \\
\text { (2-sided) }\end{array}$ & $\begin{array}{c}\text { Fischer's Exact } \\
\text { Test (2-sided) }\end{array}$ \\
\hline H9-1 Procurement management plan & $\mathrm{p}=.566$ \\
H9-2 Contract statement of work & $\mathrm{p}=.498$ \\
H9-3 Make-or-buy decisions & $\mathrm{p}=1.000$ \\
H9-4 Procurement documents & $\mathrm{p}=.599$ \\
H9-5 Supplier evaluation criteria & $\mathrm{p}=.891$ \\
H9-6 Updates & $\mathrm{p}=.704$ \\
H9-7 Procurement documents package & $\mathrm{p}=.479$ \\
H9-8 Proposals & $\mathrm{p}=.391$ \\
H9-9 Selected sellers & $\mathrm{p}=.150$ \\
H9-10 Contract & $\mathrm{p}=.371$ \\
H9-11 Contract management plan & $\mathrm{p}=.653$ \\
H9-12 Procurement management plan (up) & $\mathrm{p}=1.000$ \\
H9-13 Contract documentation & $\mathrm{p}=.681$ \\
\hline
\end{tabular}


CURRICULUM VITA

NAME:

Youssef Ait Boudlal

ADDRESS

Industriestraße 13

53721 Siegburg, Germany

DOB:

Marrakesh, Morocco - May 09, 1969

EDUCATION:

University of Louisville, 2014

Ph.D. Industrial Engineering

University of Applied Science Berlin, 2005

M.S. Industrial Engineering

University of Applied Science Bielefeld, 1999

Dipl. -Ing. (FH) Mechanical Engineering

PROFESSIONAL CAREER
ConEM Consulting (since 2011)

Owner

C2 Consulting GmbH (2007 - 2010)

Consultant

Lear Corporation GmbH (2004 - 2007)

Project Manager France

Invenio Engineering Services GmbH (2001 - 2003)

Project Manager

Porsche Eng. Services GmbH (1999 - 2001)

Design Engineer 